UNIVERSIDADE DE SÃO PAULO

FACULDADE DE ARQUITETURA E URBANISMO

MANOELA ROSSINETTI RUFINONI

PRESERVAÇÃO E RESTAURO URBANO

Teoria e Prática de Intervenção em

Sítios Industriais de Interesse Cultural

SÃo PAULO

2009 
MANOELA ROSSINETTI RUFINONI

\section{PRESERVAÇÃO E RESTAURO URBANO \\ Teoria e Prática de Intervenção em \\ Sítios Industriais de Interesse Cultural}

Tese apresentada à Faculdade de Arquitetura e Urbanismo da Universidade de São Paulo para obtenção do título de doutor.

Área de concentração: História e Fundamentos da Arquitetura e do Urbanismo

Orientadora: Prof. Dr ${ }^{\mathrm{a}}$. Beatriz Mugayar Kühl

\section{São Paulo}

2009 
AUTORIZO A REPRODUÇÃO E DIVULGAÇÃO TOTAL OU PARCIAL DESTE TRABALHO, POR QUALQUER MEIO CONVENCIONAL OU ELETRÔNICO, PARA FINS DE ESTUDO E PESQUISA, DESDE QUE CITADA A FONTE.

E-MAIL: mrr@usp.br

Rufinoni, Manoela Rossinetti

R923p Preservação e restauro urbano: teoria e prática de intervenção em sítios industriais de interesse cultural / Manoela Rossinetti Rufinoni. - São Paulo, 2009. 336 p. : il.

Tese (Doutorado - Área de Concentração: História e Fundamentos da Arquitetura e do Urbanismo) - FAUUSP.

Orientadora: Beatriz Mugayar Kühl

1.Edifícios industriais - Preservação - Restauração - São Paulo (SP) 2.Patrimônio cultural I.Título

CDU 72.025.3 
A elaboração desta pesquisa contou com a contribuição de diversos profissionais e instituições ao longo de quatro anos de trabalho. Gostaria de manifestar meus sinceros agradecimentos a todos os professores, colaboradores e amigos que me acompanharam neste percurso.

Agradeço, inicialmente, à Professora Beatriz Mugayar Kühl, pela orientação lúcida, instigante e objetiva, pela confiança em meu trabalho e pelo constante incentivo ao desenvolvimento do tema, desde a dissertação de mestrado.

Ao Conselho Nacional de Desenvolvimento Científico e Tecnológico, agradeço pelas bolsas concedidas, uma institucional por intermédio da FAUUSP e outra na modalidade "doutorado sanduíche" no exterior, auxílios de fundamental importância para o desenvolvimento desta tese.

Aos Professores Benedito Lima de Toledo e Heloísa Barbuy agradeço pelos comentários e sugestões fornecidas na banca de qualificação. Vários professores demonstraram interesse pelo tema da pesquisa e foram valiosos colaboradores, como Maria Lúcia Bressan Pinheiro, Fernanda Fernandes e José Pedro de Oliveira, docentes que me acompanharam nos estágios do Programa de Aperfeiçoamento de Ensino, bem como os professores das disciplinas cursadas no doutorado, cujos questionamentos impulsionaram a busca por diferenciadas abordagens investigativas: Professores Philip Oliver Gunn (in memorian), Ana Lucia Duarte Lanna e Paulo César Garcez Marins.

Agradeço aos docentes da Università degli Studi di Roma "La Sapienza”, instituição que me acolheu durante o estágio de pesquisas na Itália, especialmente ao Professor Giovanni Carbonara, orientador no exterior, que demonstrou grande interesse pelo objeto de estudo e forneceu valiosas indicações que contribuíram sobremaneira para o prosseguimento das análises. À Professora Maria Piera Sette, pela oportunidade de cursar como ouvinte a sua disciplina na Scuola di Specializzazione in Restauro e pelas suas pertinentes sugestões. Ainda na Sapienza, agradeço à Professora Simona Salvo e a Beatrice 
Vivio, pelas indicações bibliográficas e pelo imprescindível apoio pessoal, acadêmico e operacional.

Durante o estágio no exterior, devo agradecimentos pelas entrevistas e pelas sugestões a Jukka Jokilehto, no ICCROM, bem como a Paolo Torsello e Roberto Bobbio, professores da Università degli Studi di Genova, que me receberam com atenção e forneceram importantes indicações bibliográficas e informações sobre o processo de revitalização na área portuária. Agradeço ainda ao Professor José Manuel Lopes Cordeiro, da Universidade do Minho, pelo interesse demonstrado e pelas discussões sobre a preservação do patrimônio industrial.

Ainda no exterior, agradeço aos companheiros de pesquisa Letícia Leitão e Alfredo Tagliavia, pelas longas e instigantes conversas sobre os rumos da vida acadêmica e sobre nossos próprios objetos de estudo - ocasião em que muitos tópicos puderam ser redirecionados. Agradeço também às presenças acolhedoras das amigas Pedrina, Lia e Roseli, companheiras em diferentes momentos (e percursos) em Roma.

No prosseguimento dos estudos em São Paulo, agradeço aos arquitetos do Departamento de Patrimônio Histórico da PMSP, sempre interessados pelo tema e muito prestativos todas as vezes que necessitei de informações: Walter Pires, Mirthes Baffi, Andrea Tourinho, Lia Mayumi, Dalva Thomaz, Sueli de Bem, Geni Sugai, Ana Clara Giannecchini, Lara Melo Souza, Lícia Mara de Oliveira. Na Secretaria de Planejamento, agradeço ao arquiteto Pedro Sales, pelas importantes informações e fotos da Diagonal Sul, tão gentilmente fornecidas, e, no CONDEPHAAT, a Marly Rodrigues, pelo interesse e apoio constantes à pesquisa.

Aos amigos da pós-graduação, Amanda Vasques, Ana Paula Farah, Antonio Soukef Junior, Claudia dos Reis e Cunha, Cristina Pereira de Araújo, José Hermes Pereira, Rita de Cássia Francisco, Roseli d'Elboux e Sabrina Fontenele, agradeço pelas proveitosas conversas sobre nossos objetos de estudo, indicações bibliográficas, sugestões de caminhos investigativos e toda sorte de incentivos pessoais e profissionais, difíceis de enumerar.

Devo ainda agradecimentos especiais a Luzia Adario Rossinetti, Priscila Rufinoni e Roseli d'Elboux, pelo apoio profissional e pessoal e pelas leituras atentas e criteriosas. E Everal R. Vergílio da Silva, pelo companheirismo e dedicação ao longo de todo o percurso da tese. 
INTRODUÇÃO

PARTE I A PRESERVAÇÃo URBANA e o contraponto da cidade industrial

CAPÍTULO 1 A MATURAÇÃO DO CONCEITO DE PATRIMÔNIO URBANO

Os espaços da indústria impulsionam o debate

Interpolações em um texto

Ambiente, monumento, valor: conceitos em formação 30

As contribuições da nascente disciplina do urbanismo

CAPÍTULO 2 O PATRIMÔNIO URBANO EM CENA: PRESERVAÇÃO E INTERVENÇÃO 80

Reflexões sobre a relação 'antigo-novo'

A dimensão urbana da preservação e do restauro

Os documentos internacionais e a expansão do patrimônio cultural

PARTE II O RESTAURO URBANO e o espaço industrial como artefato cultural A Operação Urbana Diagonal Sul em São Paulo

CAPÍtulo 3 PRESERVAÇÃO E RESTAURO DO PATRIMÔNIO URBANO-INDUSTRIAL

As especificidades do patrimônio industrial e a escala urbana

Preservação urbana e patrimônio industrial: desafios e perspectivas

Intervenções urbanas em sítios industriais de interesse cultural

A preservação do patrimônio urbano-industrial paulistano:

A Operação Urbana Diagonal Sul

CONSIDERAÇões FinAIS 


\section{ILUSTRAÇÕES}

No Título

Pág

01 Modificações sucessivas na Praça da Catedral de Milão, Itália. Situação em 1730, 1818, 194040 e 1960.

02 Exemplo de 'saneamento' implantado por meio de intervenções consideradas limitadas. Plano de expropriação e esquema de loteamento projetado por Charles Van Mierlo, 1889.

03 Imagem reproduzida em estudos sobre estética urbana para ressaltar as questões envolvidas na transformação desordenada das cidades

04 O bairro do Renascimento, em Roma. Intervenção proposta segundo o método do 86 'desadensamento construtivo'.

05 Ilustração empregada por Giovannoni em Vecchie Città.

06 Sítios industriais no bairro Ostiense, Roma, Itália. Os sítios destacados (e áreas envoltórias) 215 integram o Projeto Urbano Ostiense-Marconi.

07 Novo pólo dos Museus do Capitólio na Central Elétrica Montemartini (Musei Capitolini 218 Centrale Montemartini), vista da sala das máquinas. Projeto de adaptação realizado em 1997.

08 Antigo Matadouro do Testaccio, Roma. À esquerda, pavilhões ocupados pelo MACRO, 218 Museu de Arte Contemporânea de Roma. À direita, vista geral do conjunto arquitetônico.

09 a. Mercados Gerais de Roma. Configuração original: pavilhões e espaços externos para venda 222 de produtos.

b. Situação em 2007, após o início das demolições. Edifícios remanescentes.

10 a. Mercados Gerais. Antigo pavilhão para venda de carnes e ovos. Projeto original.

b. Vista interna do pavilhão.

c. Vista externa, situação em 2006.

11 Mercados Gerais. Antigo pavilhão para venda de peixe. Situação em 2006.

2 Vista geral dos Mercados a partir da linha do metrô. Em primeiro plano, pavilhões demolidos em 2007. Ao fundo, estruturas do Gasômetro.

13 Mercados Gerais. Início das demolições em 2007.

14 Revitalização dos Mercados Gerais. Perspectiva eletrônica do projeto de Rem Koolhaas.

5 a. Revitalização dos Mercados Gerais, projeto de Rem Koolhaas. Elevação via Ostiense

b. Elevação lateral esquerda

16 Proposta de intervenção no conjunto de armazéns da Federação Consórcios Agrários de Roma, também localizado no bairro Ostiense.

17 Sítio industrial Mira Lanza. O projeto de intervenção prevê demolições parciais e inserção de novos edifícios: salas de teatro, casa para estudantes, um parque público e um hotel.

18 Porto Histórico de Genova. Em destaque, área onde se concentram os principais projetos de revitalização já executados ou em andamento.

19 Porto de Genova. Indicação dos galpões industriais adaptados para novos usos e das áreas em processo de revitalização.

20 Vista geral do Porto Antigo. Em primeiro plano, o edifício longitudinal dos antigos Armazéns do Algodão. Ao fundo, as intervenções de Renzo Piano.

21 Vista geral do Porto. Em primeiro plano, a Praça de Eventos e os mastros que sustentam o Bigo, elevador panorâmico, projeto de Renzo Piano. Ao fundo, a cidade antiga.

22 a. Vista geral da Darsena. Situação em 2002, antes da demolição dos grandes silos na Ponte Parodi.

b. Demolição dos silos na Ponte Parodi, 2002.

23 a. Vista geral do Porto, 2007.

b. Espaços públicos criados na Expo 92.

24 a. Antigo Armazém do Algodão adaptado para novos usos, 2007.

b. Arredores do Armazém. Os antigos guindastes do porto foram conservados.

c. Em primeiro plano, bloco de serviços construído na primeira etapa da revitalização.

d. Adaptação dos espaços internos do armazém.

25 a. Museu do Mar e da Navegação, na Darsena. Projeto do arquiteto espanhol Guillermo Vázquez Consuegra, 2007.

b. O projeto de Consuegra, vencedor de concurso realizado em 2000 , substituiu a antiga fachada por uma pele de alumínio e vidro e evidenciou as estruturas originais de pedra. 
c. Museu do Mar. Detalhe das antigas estruturas em arco.

Armazéns do Instituto Náutico, na Darsena, 2007.

27 a. Faculdade de Economia e Comércio instalada em antigos galpões, ao lado do Museu do Mar. 236 Projeto de adaptação do arquiteto italiano Aldo Rizzo, 2007.

b. Faculdade de Economia e Comércio instalada em antigos galpões.

28 Silos de concreto armado, atribuídos a Hennebique. Atualmente abandonados, 2007.

29 O 'cone' de Portman. Projeto da década de 1980 para a revitalização do Porto. O edifício e 239 anexos abrigariam diversos usos: marina, hotel, comércio, restaurantes e escritórios.

30 Entrada da estação San Giorgio do metrô. Parte da estrutura de pedra das antigas plataformas portuárias foi deixada à vista, 2007.

31 Antigos armazéns 'cortados' na década de 1960 para dar passagem à via elevada, 2007. 240

32 Planície de Coroglio, bairro Bagnoli, Nápoles. Mapeamento das futuras intervenções segundo 246 o PUE. A área demarcada como n.1 será destinada ao Parque Urbano.

33 Vista aérea: Coroglio-Bagnoli. Em destaque, sítio industrial objeto das futuras intervenções. 246 Em vermelho, primeira etapa das obras.

34 a. Artefatos industriais que serão adaptados para novas funções no parque. Edifício da Aciaria 247 construído na década de 1960, abrigará a Cidade da Música e um restaurante panorâmico.

b. Alto-forno construído na década de 1950, futuro Museu do Trabalho.

c. Central de resfriamento de água construída nos anos 1980, deverá transformar-se em Aquário e Centro de Exposições sobre o Mar.

35 a. Oficina mecânica construída em 1910. Será transformada em sede de um instituto de pesquisas.

b. Cais Norte recentemente recuperado como passeio público. Ao fundo, as grandes estruturas do sítio industrial marcam a paisagem, sobretudo a grande chaminé e o alto-forno.

36 a. Parque Urbano de Bagnoli. Projeto do escritório Insula Arquitetura e coordenado por Francesco Cellini. Em destaque, a primeira etapa das obras.

b. Primeira etapa das obras. Os caminhos do parque procuram seguir a seqüência da produção siderúrgica, permitindo um percurso didático.

c. Perspectiva eletrônica do parque. Ao fundo, as gigantescas estruturas do alto-forno.

d. Perspectiva eletrônica. À esquerda, a central de resfriamento de água. À direita, uma das chaminés.

e. Parque Urbano de Bagnoli. Corte AA'.

f. Parque Urbano de Bagnoli. Corte DD'.

37 a. Operações urbanas em São Paulo. Em amarelo, operações vigentes; em laranja, operações 254 propostas no PDE 2002. Círculo em destaque: OUDS.

b. Perímetro da Operação Urbana Diagonal Sul, São Paulo.

38 Sobreposição da OUDS sobre planta da cidade de São Paulo em 1914, com demarcação das principais fábricas catalogadas nesta data.

39 Sobreposição da OUDS sobre planta da cidade de São Paulo em 1930. Urbanização consolidada em grande parte do perímetro.

40 Delimitação da Operação Urbana Diagonal Sul.

41 Levantamento do uso predominante por quadra na OUDS.

42 Proposta inicial de demarcação das áreas sujeitas ao direito de preempção, segundo o Plano 262 Regional Mooca.

43 a. Projeto de ampliação dos Armazéns Ernesto de Castro, elevação principal.

b. Armazéns Ernesto de Castro, vista da rua André de Leão, 2003.

44 a. Armazéns de Elias Calfat. (Armazéns Piratininga). Projeto de Victor Dubugras. Planta de 1916, corte e detalhe estrutural.

b. Planta de 1918, elevações e corte.

c. Elevações segundo projeto de 1918 .

d. Elevações segundo projeto de 1918.

e. Acesso ao conjunto industrial, via interna, 2005.

f. Detalhe das venezianas nas aberturas do frontão, 2005

g. Detalhe da estrutura de ferro fundido, 2005.

45 a. Tecelagem de Seda Ítalo-Brasileira. Edifício do refeitório e almoxarifado, 1936.

b. Tecelagem de Seda Ítalo-Brasileira. Perspectiva do reservatório, 1936.

46 a. Ford Motors Company. Vista geral na década de 1950.

b. Ford Motors Company. Acesso principal.

47 a. Projeto de armazéns em terreno adjacente à Cia. Jardim de Cafés Finos, 1943-44. 
b. Companhia Jardim de Cafés Finos, 1943. Vista da avenida do Estado antes da construção da via elevada.

c. Companhia Jardim de Cafés Finos, 1943.

48 a. Arno Indústria e Comércio, corte longitudinal e transversal, 1953.

b. Construção da cobertura metálica.

49 Manufatura de Brinquedos Estrela, vista geral do conjunto arquitetônico e detalhe da fachada, 268 década de 1950.

50 a. Lion S.A. Engenharia e Importação, 1954. Elevação do prédio da administração e do 269 armazém de peças e elevação principal.

b. Perspectiva do projeto aprovado.

51 Projeto de Vilanova Artigas para a Cia. União de Refinadores, 1943-44.

52 a. Edifícios e sítios industriais identificados até o momento nos bairros do Pari e Brás.

b. Edifícios e sítios industriais identificados até o momento no bairro da Mooca e parte da Vila Prudente e Ipiranga.

53 Rua Borges de Figueiredo. Mapa anexo à Resolução de Tombamento.

54 Conjunto industrial tombado na Rua Borges de Figueiredo. Oficinas Casa Vanorden, 2004.

Conjunto industrial Grandes Moinhos Minetti Gamba, 2004.

59 Rua João Antônio de Oliveira em 2003. Metalúrgica Piratininga e residências adjacentes 274 demolidas em 2006.

60 Rua Borges de Figueiredo. À esquerda, galpões industriais tombados em 2007. À direita, 274 edifício construído no local da antiga Metalúrgica, 2008.

61 a. Fábrica de Estopas na rua Marina Crespi, construída na década de 1910. Situação em 2004.

b. Demolição, entre 2004 e 2005.

c. Situação em 2008.Torres residenciais já construídas. Parte da fachada foi mantida como pórtico de acesso.

d. Detalhe de um dos frontões remanescentes.

e. Descaracterização da paisagem. Vista da rua da Mooca, 2008.

f. Aspectos da paisagem local. Residências nas imediações da rua Marina Crespi, 2008.

62 a. Cotonifício Crespi. Obras de adaptação para o novo uso. Demolições no edifício da fiação. 277

b. Demolição das lajes do primeiro pavimento, 2004.

c. Após o término das obras. Junção entre a estrutura de aço original e a nova construção de pré-moldados de concreto, 2005.

d. Conjunto arquitetônico do Cotonifício Crespi. Situação em 2001.

e. Situação em 2004, após as demolições para a inserção do hipermercado.

f. Vista da esquina entre a rua dos Trilhos e a rua Taquari. Situação em 2001.

g. Mesmo ângulo. Situação após o término das obras, em 2004.

63 Vista do eixo industrial ao longo da estrada de ferro. Em primeiro plano, cruzamento entre o viaduto Pacheco Chaves, início da rua dos Patriotas e a avenida do Estado, Ipiranga.

64 Possíveis cenários para a nova ocupação dos corredores metropolitanos. Desenhos da década de 1970.

65 São Paulo Tower, edifício de 108 andares que seria implantado no bairro do Pari. Proposta de 286 1999.

Arredores da São Paulo Tower, aspectos da paisagem preexistente. Da esquerda para a direita: Moinho Matarazzo, Tecelagem Mariangela e residências tradicionais do bairro, 2006.

66 a. Proposta de revitalização de um trecho da Diagonal Sul entre os viadutos Grande São Paulo e 288 São Carlos. Plano geral.

b. Perspectiva eletrônica: marquise e torres de $200 \mathrm{~m}$ de altura.

c. Detalhamento da proposta.

67 Projeto de Reurbanização Mooca / Ipiranga, entre o viaduto Grande São Paulo e a rua da 291 Mooca. Plano Geral e perspectivas eletrônicas. 
CONDEPHAAT - Conselho de Defesa do Patrimônio Histórico, Arqueológico e Turístico do Estado de São Paulo

CONPRESP - Conselho Municipal de Preservação do Patrimônio Histórico, Cultural e Ambiental da Cidade de São Paulo

DPH-PMSP - Departamento do Patrimônio Histórico da Secretaria da Cultura da Prefeitura Municipal de São Paulo

EMURB - Empresa Municipal de Urbanização

ICOMOS - International Council on Monuments and Sites

ICCROM - International Centre for the Study of the Preservation and Restoration of Cultural Property

IPHAN - Instituto do Patrimônio Histórico e Artístico Nacional

OUDS - Operação Urbana Diagonal Sul

PAEP - Pesquisa da Atividade Econômica Paulista

PDE - Plano Diretor Estratégico

PREM - Plano Regional Estratégico Mooca

RFFSA - Rede Ferroviária Federal Sociedade Anônima

SEADE - Fundação Sistema Estadual de Análise de Dados

SEMPLA-PMSP - Secretaria do Planejamento da Prefeitura Municipal de São Paulo SPR - São Paulo Railway

TICCIH - The International Committee for the Conservation of Industrial Heritage UNESCO - United Nations Educational, Scientific and Cultural Organization ZEPEC - Zonas Especiais de Preservação Cultural 
As intervenções em antigos sítios industriais geralmente são guiadas pela caracterização desses espaços como reservas de terreno disponível para novos usos, a despeito de suas preexistências históricas, estéticas e memoriais. A partir dessa constatação, a presente pesquisa discute a aplicabilidade dos princípios teóricos da preservação e do restauro na prática de intervenções no patrimônio urbano industrial. $\mathrm{Na}$ primeira parte do estudo, são evidenciados os percursos investigativos e cognitivos que concorreram para o amadurecimento de conceitos, teorias e princípios em torno da preservação e do restauro do patrimônio urbano. Na segunda parte, são abordados os principais problemas enfrentados no tratamento dos sítios industriais de interesse cultural e analisados alguns casos de intervenção, com o intuito de discutir os motivos que dificultam a aplicação prática dos princípios anteriormente evidenciados e sugerir caminhos para a condução criteriosa de futuros projetos, a exemplo da Operação Urbana Diagonal Sul, em São Paulo.

Palavras-chave: patrimônio urbano, preservação, restauração, arquitetura industrial

\begin{abstract}
Interventions in urban industrial heritage with cultural interest usually are made under the wrong assumption that those spaces are characterized as spare ground available for new uses, in spite of their historical, aesthetic and memorial pre-existence. From that fact, this research discuss the appliance of the theoretical principles of preservation and restoration in the practice of intervention in this heritage. The first part of this study shows the investigative and cognitive ways that concurred to the developing of concepts, theories and principles surrounding restoration and preservation of urban heritage. The second part takes on the major existing problems when dealing with industrial sites and analyses some intervention cases, in order to discuss the reasons that make difficult the appliance of the previously showed principles, and also suggests ways of achieving criteria for the conduct of future projects, like the urban project Diagonal Sul, in São Paulo, Brazil.
\end{abstract}

Key words: urban heritage, preservation, restoration, industrial architecture. 
A presente pesquisa analisa a teoria e a prática da preservação e do restauro urbano com enfoque para as especificidades teórico-operacionais envolvidas no tratamento de sítios urbanos industriais de interesse cultural. Dessa forma, a partir do aprofundamento teórico, objetivamos verificar a aplicabilidade dos princípios do restauro urbano na intervenção prática em exemplares do patrimônio industrial. Evidenciaremos, ao longo desse percurso investigativo, os caminhos e aprofundamentos necessários para fundamentar tais intervenções, respeitando as especificidades desse patrimônio e buscando a necessária integração entre a preservação dessas estruturas, os instrumentos de planejamento e as demandas de desenvolvimento urbano.

A questão das antigas áreas urbanas industriais desativadas ou subutilizadas e dos novos cenários a serem buscados para a sua valorização são temas que vêm assumindo significativa representatividade no panorama das políticas de desenvolvimento urbano em diversos países e em diferentes escalas. De fato, essas extensas áreas - principalmente quando localizadas em regiões estratégicas de grandes cidades - , não poderiam passar despercebidas frente à atual dinâmica de transformação urbana contínua e acelerada que tanto conhecemos, notadamente em cidades como São Paulo. Além da localização geralmente privilegiada, essas antigas áreas industriais representam reservas potenciais de terreno urbano ocioso, degradado e de baixo custo; um considerável conjunto de vantagens para a implementação de novos empreendimentos e que vem despertando, naturalmente, a atenção de diversos setores envolvidos na produção e transformação da cidade. As propostas projetuais advindas dessa demanda, contudo, evidenciam estratégias de apropriação urbana bastante agressivas, repercussões diretas dos modos e métodos predominantes de produção da cidade contemporânea. Além do mercado imobiliário privado, também o poder público tem demonstrado interesse nessas áreas e em seu evidente potencial fundiário e econômico para o desenvolvimento de grandes projetos urbanos.

Essa realidade tem sido observada no tratamento dos sítios industriais existentes ao longo da área encampada pela Operação Urbana Diagonal Sul, em São Paulo. O 
perímetro delimitado pela Prefeitura como área estratégica para a realização de futuros projetos urbanos percorre o eixo da ferrovia Santos-Jundiaí desde as proximidades do bairro do Pari até a divisa com a cidade de São Caetano do Sul. Ao longo desse trajeto que atravessa vários bairros e perfaz cerca de dois mil hectares encontramos diversos edifícios fabris, galpões, espaços produtivos, pátios de manobras, vilas operárias; conjuntos construídos e espaços urbanos cuja configuração fora condicionada pela presença marcante da atividade industrial entre o final do século XIX e meados da década de 1960, quando as indústrias de maior porte começaram a deixar a região. Nesse perímetro marcado por extensas áreas subutilizadas, por vezes degradadas e abandonadas, a municipalidade pretende promover transformações revitalizadoras com o intuito de dinamizar a região e criar instrumentos de valorização, objetivo central das chamadas operações urbanas ${ }^{1}$, instrumento previsto em lei federal e cujas áreas a serem trabalhadas na cidade de São Paulo foram recentemente demarcadas pelo último plano diretor. ${ }^{2}$

Não obstante as questões econômicas e estratégias naturalmente envolvidas na atuação sobre áreas urbanas de grandes dimensões e visivelmente degradadas, uma particularidade essencial tem sido deixada para segundo plano nas discussões sobre a atuação renovadora em antigas áreas industriais desocupadas: a caracterização de grande parte desses edifícios e sítios industriais como patrimônio cultural. A postura de diversas propostas advindas dessas discussões - inclusive para alguns trechos da Diagonal Sul - , parece não reconhecer os atributos documentais, estéticos e memoriais das preexistências industriais, dos conjuntos ali construídos que evidenciam traçados urbanos, massas edificadas, percursos e cotidianidades de inegável importância na configuração de paisagens únicas. Em um cenário de grandes oportunidades de transformação urbana, essas estratificações históricas e as urbanidades e paisagens por elas geradas, acabam por ser obscurecidas ou até mesmo apagadas por completo.

O reconhecimento dos valores das paisagens urbanas, a sua caracterização como bem cultural e a preocupação com a sua tutela - aquisições conceituais que derivam do amadurecimento das discussões sobre a preservação, sobre o restauro, e sobre a própria

\footnotetext{
${ }^{1}$ BRASIL. Lei n. 10257, de 10 de julho de 2001. Estatuto da Cidade. Seção X, art. 32, §1 ${ }^{\text {. }}$ "Considera-se operação urbana consorciada o conjunto de intervenções e medidas coordenadas pelo Poder Público Municipal, com a participação dos proprietários, moradores, usuários permanentes e investidores privados, com o objetivo de alcançar em uma área transformações urbanísticas estruturais, melhorias sociais e valorização ambiental." (Grifo nosso).

${ }^{2}$ SÃO PAULO (Cidade). Lei no . 13430, de 13 de setembro de 2002. Plano Diretor Estratégico do Município de São Paulo. Consultar em especial: Seção VII, art. 225 e Mapa n ${ }^{\circ} 9$ que integra a mesma Lei.
} 
compreensão do que configura um patrimônio cultural - , são temas que vêm se desenvolvendo desde longa data, com contribuições advindas também do campo do urbanismo. O processo contínuo de aprofundamento desse debate abriu caminho para a valorização de artefatos até então considerados 'menores', como a chamada arquitetura de base, conjuntos arquitetônicos e paisagens construídas que passaram a ser reconhecidas por suas especiais qualidades compositivas, contexto interpretativo que nos permite abarcar muitos exemplares do patrimônio industrial. Tais conquistas conceituais impulsionaram a compreensão dos tecidos urbanos e das massas edificadas como elementos que definem a 'literatura arquitetônica' ${ }^{3}$ de uma dada região, como artefatos dotados de especificidades que os qualificam como bens culturais que merecem ser valorizados e tutelados. E assim entendidos, esses espaços urbanos e conjuntos construídos passaram a requerer um conjunto complexo de medidas para o seu tratamento e preservação; medidas a serem pautadas pelos pressupostos e princípios da teoria do restauro.

Essa expansão do conceito de patrimônio cultural, contexto no qual se inserem muitos exemplares do patrimônio industrial, representa um dos grandes temas do debate contemporâneo sobre a preservação e o restauro dos bens culturais. Como toda ação modificadora em um bem cultural pressupõe o reconhecimento e entendimento prévio de suas especificidades como premissa para fundamentar qualquer proposta, a valorização de artefatos cada vez mais complexos tem nos colocado diante de grandes desafios interpretativos e operacionais. No caso do patrimônio urbano industrial, a diversidade e complexidade de edifícios e espaços que o compõem representam uma série de dificuldades para uma correta apreensão de suas especificidades, ponto de partida para respaldar uma intervenção coerente e consciente de seus valores culturais. A grande extensão das áreas envolvidas, o correto entendimento das relações travadas entre espaços construídos, codificações sociais e expressividades estéticas, a devida apreensão de suas características evolutivas, composição formal e integração com o entorno, são alguns dos principais desafios na análise do patrimônio urbano industrial, além, é claro, da própria dificuldade inicial de defender a sua caracterização como bem cultural e da pressão especulativa a que freqüentemente está sujeito.

$\mathrm{O}$ entendimento do valor cultural dos conjuntos arquitetônicos e urbanos e os princípios teóricos que devem reger a atuação sobre os mesmos (e sobre quaisquer bens

\footnotetext{
${ }^{3}$ Expressão empregada por Roberto Pane, sobretudo na obra: PANE, R. Città antiche, edilizia nuova [19561957]. In: Attualità e dialettica del restauro [antologia a cura di Mauro Civita]. Chieti: M. Solfanelli, 1987.
} 
culturais) são aquisições conceituais devidamente contempladas em documentos internacionais sobre o tema; textos que sugerem diretrizes gerais para a preservação e restauro com base nas discussões travadas em décadas de amadurecimento teórico. A Carta de Veneza - principal referencial teórico do Icomos-Unesco, até hoje, e documento basilar para a nossa discussão - , aborda a questão da expansão do patrimônio cultural aos sítios urbanos e edifícios modestos que adquiriram significado cultural ao longo do tempo e reúne adequadamente os princípios amplamente debatidos e acordados em âmbito internacional com relação aos critérios gerais de intervenção em bens culturais. De maneira análoga, no que tange à atuação em sítios urbanos, a Declaração de Amsterdã e a Carta de Washington $^{4}$ aprofundam aspectos específicos da questão e nos oferecem bases conceituais seguras. Um aspecto de grande importância para o tratamento de áreas urbanas de interesse cultural, e do patrimônio industrial nesse contexto, é a discussão sobre a necessidade de integração entre os estudos da preservação e as iniciativas advindas do campo do planejamento urbano e territorial, a chamada conservação integrada, método de atuação que conclama a contribuição interdisciplinar como caminho para um correto tratamento do patrimônio urbano.

A conservação integrada, tema abordado notadamente no documento de Amsterdã, propõe a atuação interdisciplinar seja na fase de estudo das preexistências urbanas a serem preservadas, momento em que as análises multidisciplinares fazem-se necessárias dada a grande complexidade desses artefatos; seja nas fases propositiva e executiva, quando se deve buscar um esforço conjunto na elaboração de projetos que abarquem concomitantemente e adequadamente tanto as exigências da preservação do patrimônio, quanto aquelas do desenvolvimento urbano e territorial. Essas recomendações - considerando as particularidades do patrimônio urbano industrial e o contexto de oportunidades de transformação urbana que tanto o ameaça - , respondem perfeitamente à questão sobre os caminhos a serem trilhados para a sua preservação.

A observação do tratamento geralmente reservado aos edifícios e sítios industriais de interesse cultural, contudo, descortina um evidente distanciamento entre essas bases teóricas e as práticas efetivas de intervenção. Muitos dos projetos propostos para essas áreas, no Brasil e no exterior, têm sido elaborados sem recorrer à teoria do restauro ou referindo-se à mesma de modo equivocado. Essas propostas reservam pouca ou nenhuma

\footnotetext{
${ }^{4}$ Carta de Veneza (1964); Declaração de Amsterdã (1975); Carta de Washington (1986). In: Cartas patrimoniais. Rio de Janeiro: IPHAN, 2000.
} 
atenção aos critérios que deveriam reger a intervenção em um patrimônio; baseiam-se em prioridades alheias à esfera cultural e, em geral, esquivam-se dessa discussão. São intervenções, portanto, desprovidas das fundamentações teóricas que deveriam respaldá-las e distantes dos princípios ditados pela teoria do restauro, sintetizados, em linhas gerais, nos citados documentos internacionais ${ }^{5}$. A despeito da teoria do restauro, da conceituação do que seja um patrimônio urbano, dos estudos desenvolvidos pelos teóricos da chamada arqueologia industrial $^{6}$ e dos próprios objetivos de instituições criadas especificamente para defender esse patrimônio ${ }^{7}$, proliferam análises e projetos de intervenção pautados pela caracterização dos remanescentes industriais como meras reservas de terreno livre, pronto para a inserção de novas estruturas 'revitalizadoras'.

Tomando a Operação Urbana Diagonal Sul, ainda na fase de intenções, como mola propulsora para os nossos questionamentos, lançamo-nos à discussão sobre os possíveis motivos desse distanciamento entre a teoria e a prática. A área encampada pela Diagonal Sul possui diversos edifícios e sítios industriais de interesse cultural que sequer conhecemos com clareza, dada a inexistência de levantamentos aprofundados sobre a área, e que correm o risco iminente de serem destruídos sem que tenhamos tempo de identificálos e estudá-los adequadamente para propor métodos criteriosos de tutela e restauro. Diante da intenção do poder público municipal de implementar projetos de revitalização urbana nessa área, e diante das propostas geralmente apresentadas no cenário de discussões sobre a questão (projetos que giram em torno de denominações pouco precisas quanto ao tratamento de sítios históricos: revitalização, reciclagem, reabilitação...), evidenciou-se a necessidade de desenvolvermos discussões sobre os critérios que deveriam reger essas intervenções e sobre a orientação teórico-prática que deveria respaldar tais iniciativas. Colocamo-nos, assim, numa posição de buscar uma discussão que pudesse lançar luzes

\footnotetext{
${ }^{5}$ As discussões sobre os preceitos teóricos que deveriam reger as intervenções práticas em edifícios ligados à industrialização e sobre a aplicação da teoria do restauro no tratamento desses bens são evidenciadas e aprofundadas criticamente nos estudos desenvolvidos por Beatriz Mugayar Kühl, orientadora da presente pesquisa. Consultar principalmente: KÜHL, B. M. Preservação da arquitetura industrial em São Paulo: questões teóricas. Relatório Científico. São Paulo: FAUUSP, Fapesp, 2005.

${ }^{6}$ Campo disciplinar surgido no âmbito da valorização desses artefatos e que abrange a pesquisa, o levantamento, registro e, em alguns casos, a preservação de monumentos industriais. Dentre seus principais teóricos, destacamos K. Hudson, A. Raistrick, R. Angus Buchanan, N. Cossons, entre outros. Suas contribuições foram previamente analisadas em RUFINONI, M. Preservação do patrimônio industrial na cidade de São Paulo: o bairro da Mooca. Dissertação de Mestrado. São Paulo: FAUUSP, 2004.

${ }^{7}$ Como o TICCIH, The International Committee for the Conservation of Industrial Heritage, criado em 1978 e com representação brasileira oficial desde 1998, com a fundação do Comitê Brasileiro de Preservação do Patrimônio Industrial. Cabe destacar a elaboração por iniciativa do TICCIH da Carta de Nizhny Tagil para o Patrimônio Industrial, redigida em 2003, documento que reúne conceitos, definições, orientações sobre a realização de inventários e procedimentos gerais para a salvaguarda do patrimônio industrial.
} 
sobre a prática corrente de intervenções e identificar os nós conceituais, as lacunas do discurso na prática e os seus porquês.

Algumas indagações nos acompanharam ao longo da investigação: por que as prerrogativas acordadas nas cartas internacionais não são devidamente aplicadas na preservação e restauro dos bens culturais e, neste contexto, na atuação sobre o patrimônio urbano-industrial? Seria possível identificar os nós que inviabilizam a aplicabilidade dos conceitos adquiridos na atividade prática de preservação e intervenção? Uma das causas dessa dificuldade não residiria, diante da corrente avaliação dos sítios industriais como meras reservas de terreno livre, na própria incompreensão do caráter patrimonial dessas estruturas? Diante dessas indagações, enunciamos nossa hipótese fundamental: a verificação da aplicabilidade dos instrumentos teóricos do restauro urbano na prática de intervenções no patrimônio industrial.

Ao longo do percurso investigativo, sentimos a necessidade de olhar para trás, de retomar as origens do conceito de ambiente construído e de patrimônio urbano, de trazer à tona esse percurso de aquisição conceitual e vivificar os temas, discussões e argumentos que concorreram para o amadurecimento de conceitos que parecem estar esquecidos ou talvez pouco entendidos ainda hoje. Nesse caminho, intentamos evidenciar o percurso cognitivo que permitira compreender o organismo urbano como um sistema historicamente construído, dentro do qual certos agrupamentos reúnem estratificações construtivas com características compositivas únicas e irreproduzíveis. A aquisição do conceito de patrimônio urbano e o amadurecimento da discussão sobre as formas de intervir no mesmo, ou seja, o desenvolvimento da teoria do restauro, configurou-se ainda, em nosso caminho investigativo, como um percurso que permitiu a compreensão do fenômeno cidade como um processo contínuo de assimilação e reelaboração (de formas construídas, expressividades estéticas, vivências) e não de sucessiva anulação e reconstrução. Partimos do pressuposto, portanto, de que buscar as origens conceituais, perseguir o desenvolvimento das teorias do restauro e certos aspectos do próprio urbanismo poderia nos instrumentar nessa retomada dos liames entre a teoria e a prática; poderia nos ajudar a evidenciar que os sítios urbanos industriais, como estratificações significativas desse sistema, devem ser tratados como um patrimônio a ser preservado lado a lado à cidade contemporânea (num movimento de assimilação recíproca) e não descaracterizado pela 
inobservância de seus valores ou simplesmente demolido para ceder espaço ao desenvolvimento (na anulação completa de suas presenças).

De certa forma, esta pesquisa acabou por trilhar um caminho inverso: ao perceber a fragilidade na compreensão de pré-requisitos conceituais básicos para a preservação de um artefato cultural - o seu reconhecimento como tal e os pressupostos que pautam a teoria do restauro -, buscamos a origem desses princípios de modo a evidenciá-los como ponto de partida para desvendar as falhas de toda a seqüência do processo interpretativo que deveria conduzir as ações de preservação. O objetivo da pesquisa, portanto, não é a discussão específica sobre a Operação Urbana Diagonal Sul, a análise detalhada de projetos de intervenção ou mesmo a proposição de diretrizes ou orientações manualísticas sobre como tratá-los. O tema que nos impulsionou à discussão, a citada operação urbana, configura-se como um dos casos concretos que alicerçam o desenvolvimento do debate crítico sobre a aplicabilidade dos princípios teóricos da preservação na intervenção prática sobre o patrimônio urbano-industrial. Aplicabilidade discutida, portanto, a partir da retomada do percurso teórico, instrumento crítico que julgamos oportuno adotar para identificar as lacunas conceituais do discurso na prática.

Nossas argumentações pautaram-se, predominantemente, pela produção teórica e prática italiana devido à representatividade da tradição investigativa ali sediada. Além da contribuição inquestionável para a elaboração dos citados documentos internacionais, os debates travados em ambiente italiano continuaram a repercutir no prosseguimento das discussões e configuram ainda hoje um dos principais focos investigativos no tratamento contemporâneo sobre o tema ${ }^{8}$. Além da teoria, buscamos também exemplos de intervenções propostas para sítios urbano-industriais no próprio território italiano. Apesar da grande quantidade de experiências realizadas em diversos países - algumas em áreas talvez consideradas mais ilustrativas em termos de escala, de instrumentos propositivos ou mesmo em termos de representatividade internacional, a exemplo dos sítios ingleses listados como patrimônio mundial - , optamos por permanecer predominantemente no cenário italiano. A grandiosidade dos sítios ou a representatividade do passado industrial de uma dada região não foi o enfoque perseguido. Por intentarmos discutir a aplicabilidade prática das teorias amplamente discutidas notadamente no cenário italiano, julgamos mais

\footnotetext{
${ }^{8}$ Cabe ressaltar que o desenvolvimento do presente trabalho contou com um período de pesquisas sediado na Università degli Studi di Roma sob a orientação do professor Giovanni Carbonara. As pesquisas consistiram na análise de referências bibliográficas nos acervos da Universidade e do ICCROM, na realização de entrevistas com especialistas e em visitas a obras de intervenção já realizadas ou em andamento.
} 
oportuno observar diretamente como essa mesma teoria se aplica ou não dentro do próprio território que em grande parte a sediou.

Nesse sentido, o primeiro capítulo apresenta um percurso dos questionamentos e estudos que permearam a maturação do conceito de patrimônio urbano, desde as origens do entendimento da cidade como um organismo complexo e em constante mutação, até os questionamentos impulsionados pelas transformações urbanas advindas de um novo paradigma de desenvolvimento: a industrialização. As alterações provocadas pelas atividades produtivas e as discussões em torno da viabilização da vida moderna nas antigas cidades são situações identificadas como impulsionadoras da valorização dos tecidos históricos que então se dissolviam. Curioso observar que os espaços gerados pela indústria - elementos transformadores que ameaçavam os tecidos urbanos antigos e impulsionavam, nesse processo, o fortalecimento das discussões sobre os valores das preexistências - são hoje os espaços construídos que assumem representatividade cultural e que solicitam a valorização de suas próprias qualidades patrimoniais; valorização, por sua vez, em grande parte também impulsionada pela ameaça dos novos paradigmas de desenvolvimento. A discussão em torno da compatibilização entre preservação das preexistências e viabilização das necessidades de desenvolvimento, um dos temas que permeara o nascimento da disciplina do urbanismo no início do século XX, ainda permanece, sob novos contornos, bastante atual. Paralelamente, acompanhamos ainda o percurso de aquisição dos conceitos de 'monumento', 'ambiente' e 'valor' e suas relações com a teoria do restauro e com a apreensão das especificidades urbanas.

$\mathrm{Na}$ seqüência desse percurso, no segundo capítulo analisamos o gradativo aprofundamento investigativo sobre as qualidades do ambiente construído e sobre os modos de interferir nessa realidade. Observamos, nesse contexto, a passagem da compreensão do ambiente construído como entorno de obras monumentais, ou como conjunto de formas, para um entendimento mais complexo que abrange a apreensão desses espaços como conjunto de condições que delimitam uma realidade urbana que não é apenas física, mas também memorial e social. Esse processo foi acompanhado de contribuições diversas - sobretudo advindas dos estudos de estética urbana e dos aprofundamentos teóricos impulsionados pelo segundo pós-guerra - , e permitiu a evidenciação de uma série de questionamentos que ainda hoje geram novos debates no cenário atual sobre a preservação do patrimônio urbano: a questão das relações entre o 
antigo e o novo, a dimensão necessariamente urbana da preservação e do restauro, a busca pelas contribuições profissionais interdisciplinares. Essas indagações, alimentadas por um entendimento cada vez mais maduro sobre os valores que definem um patrimônio, abriram caminho para a expansão desse próprio conceito, momento em que observamos o reconhecimento e a valorização dos conjuntos arquitetônicos e urbanos provenientes da industrialização. Procuramos ainda observar o contexto de elaboração dos documentos internacionais e, nos limites de nossos enfoques, a repercussão dessas aquisições teóricas na realidade brasileira.

O terceiro capítulo volta-se à prática de intervenção em sítios urbanos, ao restauro urbano, com enfoque para atuação em sítios industriais de interesse cultural. Inicialmente, buscamos discutir as especificidades do patrimônio urbano industrial que acabam por gerar grandes dificuldades interpretativas e operacionais para a sua preservação, como a questão da escala, da apreensão de suas qualidades compositivas ou a pressão da especulação imobiliária. De posse desse panorama sobre os desafios a serem enfrentados na preservação desses artefatos, intentamos destacar os principais entraves operacionais do restauro urbano e, nesse contexto, do restauro urbano de áreas industriais. Observamos nesse percurso flagrantes lacunas entre as teorias e aquisições conceituais debatidas nos primeiros capítulos e a efetiva prática de preservação urbana. A discussão sobre esses 'nós' teórico-práticos desenvolve-se de modo a buscar a resposta de nossas prévias indagações: a questão da aplicabilidade dos conceitos teóricos - das prerrogativas acordadas em documentos internacionais -, na prática de preservação e restauro do patrimônio urbano industrial. São então analisados alguns casos de intervenção em sítios industriais considerados mais ilustrativos para a discussão dos principais entraves teóricos e problemas práticos que intentamos evidenciar. Analisamos por fim, nesse contexto, a situação da Operação Urbana Diagonal Sul, lançando a discussão para o panorama brasileiro e paulistano. Nessa realidade, buscamos confrontar a teoria e a prática frente aos projetos propostos para a área, à abordagem do plano diretor e aos recursos de tutela disponíveis.

Resgatar criticamente o percurso de aquisição teórica como instrumento para analisar o discurso prático, por fim, permitiu-nos levantar uma série de novas indagações. Nesse caminho, entendemos que o aprofundamento das questões envolvidas na preservação do patrimônio urbano, aqui preliminarmente enunciadas, pode ainda 
configurar-se como um relevante instrumento para instigar outros complexos debates; como a própria discussão sobre nossos modos de ver, de entender e de projetar a arquitetura e a cidade contemporânea. 


\section{PARTE I}

\section{A PRESERVAÇÃO URBANA}

e o contraponto da cidade industrial 


\section{CApítulo 1}

\section{A MATURAÇÃo do CONCEITO DE PATRIMÔNIO URBANO}

\section{OS ESPAÇOS DA INDÚSTRIA IMPULSIONAM O DEBATE}

Discutir a preservação urbana e, nesse contexto, o tratamento de sítios urbanos industriais de interesse cultural, é tarefa que nos impulsiona a evidenciar certos conceitos. Para defendermos a preservação de parcelas urbanas culturalmente significativas é necessário, inicialmente, que compreendamos com clareza por que tais artefatos nos são caros e quais os atributos ou valores responsáveis pela sua caracterização cultural. Nesse sentido, o estudo do percurso perceptivo e cognitivo que permitira a paulatina apreensão das especificidades de certos espaços urbanos e conjuntos arquitetônicos, ou seja, o próprio processo de amadurecimento da noção de patrimônio urbano, configura-se como um importante ponto de partida para nossas análises. Ao expor esse percurso investigativo, intentamos evidenciar que a preservação do patrimônio urbano, e qualquer intervenção sobre o mesmo, pressupõem esse conhecimento prévio e requerem cuidados específicos, requerem um claro entendimento das especificidades que o compõem e que devem ser preservadas sob pena de perdermos os próprios atributos que impulsionaram o seu reconhecimento e valorização.

O interesse pelos tecidos urbanos e a atribuição de valor histórico, estético e memorial aos conjuntos arquitetônicos são temas que ganharam força sobretudo ao longo do século XIX, quando uma série de transformações - impulsionadas seja pela atividade industrial, seja pela própria alteração nas relações políticas, econômicas e sociais no contexto europeu - provocaram alterações profundas na configuração de diversas cidades e, conseqüentemente, irreparáveis perdas no cenário arquitetônico e urbano. Diante desse quadro, questões como a dissolução da cidade antiga frente à cidade industrial e a distinção entre o preexistente e as novas intervenções da cidade moderna, paulatinamente ganhariam corpo frente ao novo paradigma de transformações. 
A transformação da cidade, no entanto, era apenas uma dentre tantas mudanças que então se evidenciavam ao longo do século XIX. Esse cenário em mutação era acompanhado de um complexo conjunto de discussões em diversos campos do saber, como o surgimento de novas teorias sociais que procuravam responder ao dilema da classe trabalhadora; a consolidação das identidades nacionais européias, notadamente a partir de referenciais nas artes e na arquitetura; os novos questionamentos sobre a historiografia das artes e sobre a própria estética como disciplina, e, lado a lado a tantos conceitos em ebulição, o próprio desenvolvimento dos campos disciplinares sobre os quais nos deteremos com maior atenção neste estudo: a preservação, a restauração, o urbanismo.

O rápido crescimento de algumas das principais cidades européias principalmente Londres e Paris - provocara uma série de disfunções urbanas nunca antes imaginadas, geradas pela impossibilidade da cidade medieval em responder às demandas funcionais da industrialização. Dentre tantos fatores, o grande fluxo populacional proveniente das migrações campo-cidade, a necessidade de novas construções para abrigar funções produtivas e a insuficiência das estruturas existentes face às novas necessidades foram alguns dos principais conflitos que exacerbaram a noção de ruptura entre o passado e o presente. E as transformações do ambiente urbano evidenciariam essa cisão. Nesse percurso, os espaços construídos que ora intentamos defender, os 'espaços' da indústria, representaram um papel fundamental. Como elementos transformadores que ameaçavam a integridade dos tecidos urbanos antigos, os espaços gerados pela industrialização (assim como as novas demandas sociais e urbanas) em grande parte impulsionaram o debate sobre os possíveis valores das preexistências urbanas que então se perdiam.

De um lado, voltam-se as atenções para a importância da cidade antiga diante das demolições e descaracterizações provocadas por essas transformações - cidade esta formada em grande parte por edificações medievais, góticas, estilo então eleito como representativo das culturas inglesa e francesa. A partir dessa vertente de estudos, desenvolver-se-ão grande parte das discussões sobre a preservação dos monumentos no século XIX com destaque para os escritos de John Ruskin e William Morris. De outro lado, será posta em questão a necessidade de interferir na cidade antiga para adequá-la às novas necessidades e rendê-la mais higiênica e eficiente. Esta é a abordagem desenvolvida pelos precursores do urbanismo que, a partir da tentativa de solucionar os problemas da cidade industrial, desenvolverão teorias e práticas de intervenção no tecido preexistente. As 
teorias de Ildefonso Cerdà e as reformas de Haussmann são grandes exemplos nesse sentido.

No que tange às discussões sobre a preservação, ainda que uma preocupação mais sistemática com os bens do passado possua raízes já no Renascimento, somente a partir do século XVIII a conservação e a restauração começam a despontar como ações atreladas à consciência do valor histórico e artístico do bem, adquirindo o caráter de projeto cultural. Após um lento processo de amadurecimento desde o século XV até o século XVIII, as discussões sobre a importância dos bens do passado são então interpeladas pela velocidade das transformações do século XIX que, ao acelerar a citada noção de ruptura entre o passado e o presente, despertaria a atenção para os possíveis valores daquilo que se perdia. E dentre tantos fatores, o papel das alterações da cidade antiga será crucial neste processo, seja pelo desejo de compreender e preservar as cidades que se dissolviam, seja pela busca de soluções estruturais e sociais para atender às suas novas funcionalidades.

A partir de diferentes pontos de vista que mantêm a cidade como o centro da discussão, o desenvolvimento de estudos em ambos os campos disciplinares - o restauro e o urbanismo - nos oferecerá, ao longo dos séculos XIX e XX, os instrumentos conceituais e operativos que delinearão a idéia de patrimônio urbano. Ambas as linhas investigativas originadas de um mesmo contexto de indagações - apesar de aparentemente seguirem caminhos diversos, forneceriam elementos de análise que contribuiriam, cada qual à sua maneira, para o amadurecimento do entendimento da cidade como um organismo dotado de atributos e mecanismos próprios.

Nesse sentido, ao lado dos desdobramentos teóricos no campo da história da arte, a observação da harmônica continuidade entre os diferentes momentos construtivos presentes na cidade antiga caminharia, ao longo do século XIX, em direção à compreensão de um 'todo' composto pela diversidade e, conseqüentemente, para a equiparação de valores entre os aportes construtivos de momentos históricos distintos. Isto é, a cidade antiga teria sido um dos instrumentos de estudo para evidenciar a inadequação de quaisquer predileções de estilo pois cada parcela, cada estrato urbano vinculado a uma especificidade de tempo e lugar, trazia consigo uma singular contribuição na composição desse todo que então se identificava. De certa forma, o olhar analítico sobre o organismo urbano contribuiria, portanto, para o posterior alargamento do conjunto de elementos detentores de atributos patrimoniais. Essa, porém, obviamente não foi uma constatação 
imediata, foram necessárias décadas de teorizações e análises, não isentas de oposições e contradições. Contudo, as numerosas contribuições teóricas e práticas em torno da apreensão dos organismos urbanos, geradas pelas indagações do século XIX e em permanente releitura ao longo do século XX: a relevância histórica e estética dos tecidos urbanos, a interferência sobre os mesmos, a relação entre monumento e ambiente circundante - , alimentaram, e alimentam ainda hoje, um contínuo debate.

\section{INTERPOLAÇÕES EM UM TEXTO}

Em diferentes épocas e contextos históricos, a relação entre o tempo passado e os seus testemunhos assumiu diversas conotações e significados que podem ser observados no modo como cada sociedade se manifesta em relação aos artefatos por ela produzidos. De maneira análoga, o restauro, ou qualquer intervenção sobre o preexistente, acompanhou essa complexa trama de condições culturais responsáveis pela diversidade na produção do espaço construído em vários momentos e destinos. Uma repercussão dessa pluralidade reside no próprio debate acerca da origem do restauro: se seria uma atividade que sempre existiu ou se seria um ato tipicamente moderno ${ }^{9}$. Se por restauro entendermos um conjunto de ações voltadas a recolocar em eficiência, resultará evidente que se trata de uma ação que sempre existiu, ou seja, uma ação de reparo, manutenção e adaptação constante a novas necessidades de uso. No entanto, se o considerarmos como uma intervenção que objetiva preservar um testemunho do passado com intuito eminentemente cultural, o restauro deverá ser considerado produto moderno, manifestação que ganha corpo entre os séculos XVIII e XIX ${ }^{10}$ quando o preexistente adquire valor cultural de interesse para transmissão ao futuro. Esses desdobramentos conceituais em torno da preservação e do restauro geralmente têm sido abordados na escala da arquitetura, com breves acenos no que se refere ao contexto urbano. No presente estudo, retomaremos alguns aspectos desse

\footnotetext{
9 SETTE, Maria Piera. Profilo storico. In: CARBONARA, Giovanni (Org.). Trattato di restauro architettonico. Torino: Utet, 1996, v.1, p. 111.

${ }^{10}$ Cabe ressaltar que desde a Antigüidade já se observavam ações voltadas à transmissão de bens e de seus significados para o futuro. Tais manifestações, no entanto, eram ações pontuais e sem o caráter de 'projeto cultural' que a questão assumiria a partir dos séculos XVIII e XIX. Para breves comentários sobre essas primeiras manifestações, consultar: JOKILEHTO, Jukka. A History of Architectural Conservation [1999]. Oxford: Butterworth-Heinemann, 2006, pp.1-13.
} 
percurso teórico ao longo do tempo e buscaremos percorrer as principais formulações conceituais sobre a preservação e o restauro a partir da escala urbana.

Com relação às ações sobre o preexistente urbano, diversos autores defendem que é impróprio denominarmos de 'restauro' as operações realizadas até o início do século XIX. Tais ações deveriam ser entendidas como uma atualização das obras do passado buscando adequá-las às exigências espirituais, materiais e estéticas do momento presente. Até o século XVIII, ainda que possamos identificar diversas manifestações de interesse pelos bens do passado, as ações sobre os mesmos eram geralmente guiadas por razões pragmáticas, configuravam-se como construções ou adaptações realizadas segundo o 'gosto' do presente e quase sem distinção com a produção do passado. As novas obras assemelhavam-se às construções preexistentes pois eram produzidas de acordo com os mesmos instrumentos conceituais e práticos de outrora. As intervenções realizadas nesse contexto objetivavam, portanto, modificar e adequar o preexistente em primeiro lugar; e, eventualmente, quando dispostas a conservar, voltam-se à manutenção de significados e não de testemunhos materiais. Nesse caso, o desejo de conservação relacionava-se prioritariamente a motivos devocionais, permitindo a preservação de um monumento característico de uma fé, por um lado, e destruindo as manifestações contrárias, por outro ${ }^{11}$.

Essa natureza de produção contínua do espaço segundo tais prerrogativas denota uma importante característica dos conjuntos edificados durante a Idade Média. As obras do passado não eram então consideradas como evento histórico, mas assumiam o caráter de tema aberto, de uma obra em 'eterno presente', cujos estratos construtivos realizados ao longo do tempo se inseriam sucessivamente no preexistente como "interpolações em um texto". ${ }^{12}$ Logo, a relação espontânea entre as novas formas e aquelas do passado criava uma unidade própria. Nesse sentido Sette destaca que é justamente a composição de uma unidade na multiplicidade e a presença da multiplicidade nesse todo, um dos elementos

\footnotetext{
${ }^{11}$ SETTE, M. P., Profilo storico..., op. cit., pp. 111-112. Diversos são os exemplos nesse sentido como vários edifícios eclesiásticos continuamente adaptados ao longo dos séculos às novas prerrogativas litúrgicas, ou mesmo as antigas estruturas das basílicas romanas que por adaptação e reinterpretação ditaram a espacialidade das igrejas cristãs em épocas posteriores.

${ }^{12}$ Expressão empregada por Viollet-le-Duc no século XIX ao se referir às construções medievais. "Se fosse necessário, em um edifício do século XII, substituir um capitel quebrado, era um capitel do século XIII, XIV ou XV que se colocava em seu lugar. Se em um longo friso de 'folhas montantes' do século XIII, um pedaço, somente um, viesse a faltar, era um ornamento conforme o gosto do momento que era incrustado. Por isso, aconteceu várias vezes, [...], de se considerar essas modificações como extravagâncias, de se atribuir data falsa a fragmentos que deveriam ter sido considerados como interpolações em um texto." (Grifo nosso). VIOLLET-LE-DUC, Eugène Emmanuel. Restauração. Trad. Beatriz Mugayar Kühl. São Paulo: Ateliê, 2000, p. 32.
} 
fundamentais de constituição da cultura artística medieval e das especificidades dos espaços construídos nesse período. ${ }^{13}$

Posteriormente, uma visão diferenciada dos remanescentes materiais do passado teria sido impulsionada pela cultura do Renascimento e pelos olhares atentos sobre os ensinamentos a serem obtidos a partir do estudo da Antigüidade clássica. Ao longo dos séculos XV e XVI, notamos a convivência paralela entre as primeiras idéias contrárias à destruição dos monumentos da Antigüidade e o uso indiscriminado dos mesmos como fonte de matéria prima para novas construções. Ao lado das constantes destruições, a indagação sobre os espólios da Antigüidade começava a criar corpo e o confronto com os vestígios arqueológicos passava a ser questionado em diversos escritos de cronistas da época. Exemplos nesse sentido são as manifestações de Petrarca por volta de 1336: “jogam-se por terra as casas, arruínam-se os muros, os templos caem, os lugares sacros se dissolvem"; os escritos de Pier Paolo Vergerio a respeito do estado precário das igrejas em 1398 e da destruição de muitos monumentos de pedra para convertê-los em cal, e os dizeres de Poggio Bracciolini, em 1450, lamentando o fato de as ruínas do Fórum Romano terem se transformado em pastagem para porcos e bois. ${ }^{14}$

A contribuição literária e prática de maior relevância nesse período, contudo, deve-se à figura de Leon Battista Alberti (1404-1472). Seguindo o interesse renascentista pelas obras da Antiguidade clássica, Alberti desenvolveu uma série de estudos sobre as ruínas da cidade imperial como parte dos trabalhos voltados à restauração de Roma por Nicolau V, papa humanista que pretendia edificar uma cidade cristã sobre as ruínas da antiga. Nessa mesma época trabalhou em diversos projetos arquitetônicos, sobretudo intervenções sobre o existente, e elaborou o tratado De re aedificatoria, discurso teórico baseado em tais estudos e experiências práticas. No famoso tratado, o autor levantou questões primordiais que repercutiriam nas reflexões de diversos teóricos séculos mais tarde. Dentre as diversas leituras possíveis de sua obra, dois aspectos merecem destaque em nossa abordagem: a valorização dos remanescentes materiais do passado como

\footnotetext{
${ }^{13}$ SETTE, M. P., op. cit., p.122. Segundo Sette o fazer arquitetônico medieval provinha de uma estreita relação entre figuração pictórica e plástica. Dessa forma, da ininterrupta linha de continuidade entre românico e medieval emergia uma nova compreensão do presente que considerava o passado como uma entidade unitária possuidora de um significado próprio a ser respeitado ou transformado; a preexistência era trabalhada, desmembrada, fracionada e depois englobada em um novo organismo, sempre em perfeita euritmia.

${ }^{14}$ Cronistas citados por LASCO, Antonio. Roma tra Rinascimento e antichità. In: MARTA, Roberto. Il Rinascimento a Roma fra Leon Battista Alberti e Donato Bramante. Roma: Elio de Rosa, 2004, pp. 224-228.
} 
instrumentos de conhecimento e a compreensão da cidade como o organismo único e autônomo que abriga a vida civil e a própria história, aspectos que conferem ao ambiente urbano o papel de contentor de uma historicidade que sutilmente começava a ser identificada e valorizada ${ }^{15}$.

Segundo Paolo Portoghesi, Alberti manifesta interesse e respeito pelas obras do passado, não apenas em relação à Antigüidade Clássica, mas também em relação a períodos mais recentes, como algumas edificações medievais, abrindo caminho para a noção de hereditariedade histórica que deverá firmar-se somente séculos mais tarde ${ }^{16}$. As intervenções realizadas no templo Malatestiano e o projeto para a Igreja de Santa Maria Novella são apontados como exemplos práticos nesse sentido. Apesar de não podermos utilizar o termo 'restauração' com a mesma conotação com que o utilizamos hoje, as obras citadas sinalizam certa sensibilidade para com o preexistente e sugerem recursos de projeto que somente muito mais tarde serão postos em teoria, como a questão da distingüibilidade e do respeito pela matéria original. ${ }^{17}$ Em algumas passagens do Tratado, Alberti demonstra interesse em compreender os processos construtivos dos antepassados e atribui, portanto, valor às obras antigas e aos vestígios arqueológicos como fonte de pesquisa e conhecimento.

Acontece que têm sido danificados e arruinados edifícios que outros iniciaram bem. Eu acredito que é necessário nos mantermos fiéis às intenções dos autores, as quais certamente eram fruto de madura reflexão. De fato, aqueles que em origem deram início à obra podem ter sido guiados por determinados objetivos que também nós, com exame mais atento e prolongado e um julgamento mais exato, poderemos descobrir. ${ }^{18}$

\footnotetext{
15 Sobre a concepção albertiana de cidade e para indicações bibliográficas complementares, consultar: LOEWEN, Andrea Buchidid. A concepção de cidade em Leon Battista Alberti. Dissertação de Mestrado. São Paulo: FAU Puccamp, 1999. Para um panorama geral dos projetos arquitetônicos de Alberti, consultar: BENEVOLO, Leonardo. Storia dell'architettura del Rinascimento. Roma: Laterza, 2002, pp. 94-100.

${ }^{16}$ Considerações de Paolo Portoghesi na introdução à edição italiana do De Re Aedificatoria. Na sequiência deste texto, todas as citações de Alberti foram traduzidas a partir da versão italiana: ALBERTI, Leon Battista. L'Architettura [De Re Aedificatoria]. Trad. Giovanni Orlandi. Milano: Il polifilo, 1966.

${ }^{17}$ BENEVOLO, L., Storia dell'architettura..., op. cit., pp. 92-114.

18 ALBERTI, L. B., op. cit., pp. 864-866. Trad. nossa. "Avviene che vengano guastati e mandati in rovina edifici che altri avevano iniziato bene. Io credo che occorra manteneri fedeli alle intenzione degli autori, le quali erano stato certo frutto di matura riflessione. Di fatti coloro che in origine diedero avvio all'opera possono essere stati guidati da determinati intenti che anche noi, con più attento e prolungato esame e un più esatto giudizio, potremo scoprire."
} 
Nesse sentido, condena as demolições indiscriminadas e sugere o respeito ao preexistente. As demolições seriam um erro a ser corrigido, pois não nos é conveniente desprezar as obras dos antepassados nem tampouco a comodidade que os cidadãos encontram nas casas de seus antepassados, "é, portanto, preferível manter intactas as antigas construções até que as novas possam ser construídas sem as demolir". ${ }^{19}$

Outra questão sinalizada por Alberti e de primordial importância para a discussão sobre a valorização de parcelas urbanas é a concepção da cidade como organismo único e harmônico, analogamente às estruturas da natureza. No Tratado, Alberti discorre sobre a cidade não apenas como um sistema geométrico regido por regras determinadas, a sua sensibilidade leva-o a considerar os infinitos parâmetros ambientais que influenciam a configuração urbana e, deste modo, direciona a atenção não apenas à cidade nova, mas à transformação da cidade presente. Nesse sentido, o Tratado não objetiva unicamente codificar as leis do construir mas sim descobrir as suas origens, descrever o processo genealógico do construir, processo este originado na idéia de cidade. ${ }^{20}$ Segundo Argan, a idéia de cidade como organismo autônomo e dotado de um significado que lhe é próprio, remonta ao cristianismo. A cidade da qual Alberti procura descrever a gênese é a representação visível dos valores da comunidade unida por uma mesma fé e pelos mesmos interesses vitais; valores, porém, não apenas econômicos e religiosos mas também históricos e políticos. A cidade não é mais um espaço fechado e protegido e sim um nó de relações e um centro de poder, em oposição à concepção da 'cidade' vitruviana, por antonomásia a urbs Romae.

Ao desenvolver estudos arqueológicos sobre as ruínas da cidade imperial, Alberti acreditava que a mesma havia sido edificada a partir de um processo perfeitamente atrelado às condições previamente impostas pela natureza; defendia portanto, que para fazer ressurgir a cidade, era necessário refazer a ciência natural dos antigos e superá-la. ${ }^{21}$

\footnotetext{
${ }^{19}$ ALBERTI, L. B., op. cit., p. 868. Trad. nossa. "È questo un errore da correggere [le demolizione]. Difatti l'avversità della sorte e dei tempi o la necessità di certi situazioni possono spesso indurci ad abbandonare l'impresa iniziata; e non è bene al tempo stesso non avere il minimo riguardo verso l'opera degli antichi, né si possono trascurare le comodità che i cittadini traggono dalla case tradizionali dei loro antenati. A demolire, a spianare, a distruggere qualsiasi struttura in qualsiasi posto c'è sempre tempo a disposizione. Quindi è preferibile lasciar intatte le antiche costruzione fin tanto che le nuove possano esser innalzate senza demolire."

${ }^{20}$ PORTOGHESI, Paolo. Introduzione. In: ALBERTI, L. B., op. cit., p. XX; ARGAN, Giulio Carlo. La città nel pensiero de Leon Battista Alberti. Rassegna di Architettura e Urbanistica, n.73,74,75, 1991, pp. 173-174.

${ }^{21}$ Cabe destacar, segundo bem observa Arnaldo Brushi, que um dos princípios fundamentais da cultura humanística do quattrocento considera que a 'pátria' do homem não é mais 'o mundo de fora', como na
} 
Porém, para Argan, a visão albertiana da cidade como sistema autônomo vai além: mais do que os monumentos sobreviventes e seus belos ornamentos, lhe interessavam as infraestruturas urbanas, a disciplina do curso do rio Tibre, os condutores, as cloacas, as vias militares, as pontes. Em outras palavras, a articulação entre a cidade antiga e a natureza. Segundo Argan, tal estudo das ruínas lhe sugeriu a metodologia a seguir que compõem o cerne do Tratado: a redução a categorias essenciais ${ }^{22}$, a análise lógica das construções, a pesquisa das motivações primordiais do edificar. Defende ainda que Alberti não haveria determinado e aplicado assim rigorosamente tal critério metodológico se não tivesse o intento de fundar uma nova ciência, a ciência da cidade. Segundo Françoise Choay,

[...] num momento de ruptura que implica todos os campos institucionais, Alberti decifra a espacialização como poder inerente à espécie humana de abolir as descontinuidades pela memória, de afirmar a fidelidade da nossa espécie a si mesma em um imprevisível processo de criação, que pode apenas ser continuação. Donde, sem precedente até a reflexão efetuada por John Ruskin nos anos 1840, a atitude de Alberti face ao patrimônio edificado do passado: a sua distinção entre um patrimônio arqueológico que concerne ao saber e um patrimônio vivo mais ou menos antigo ou recente, que constitui o quadro fundador de nossa cotidianidade e nos permite estabelecer uma permanente relação com as gerações passadas. ${ }^{23}$

\footnotetext{
Idade Média, e sim o mundo real no qual vivemos, a natureza. Daí o interesse pelo mundo no qual viveram e agiram os homens do passado. Dessa forma, Alberti considera a natureza e a história como fontes de todo o conhecimento -“Tutti i gradi dell'imparare dobbiamo noi cavare da essa natura”. Logo, o objetivo não é reconstruir o antigo, mas construir o moderno a partir das lições do antigo. BRUSCHI, Arnaldo. Osservazioni sulla teoria architettonica rinascimentale nella formulazione albertiana. Quaderni dell'Istituto di Storia dell'Architettura, n.31-38, 1961, pp. 115-117.

${ }^{22}$ Alberti defende que o edificar divide-se em seis partes ou categorias, fato considerado uma análise sem precedentes na literatura tratadística: regio, area, partitio, paries, tectum, apertio. Regio, que o mais recente tradutor interpreta como 'ambiente' é uma extensão territorial definida a partir das relações nas quais se explica a vida da comunidade. Não há delimitações precisas: nos termos da urbanística moderna, Regio seria o 'território', ou a zona que compreende uma comunidade urbana; Area seria uma porção da Regio delimitada pela estrutura muraria, ou seja, a zona compreendida por um perímetro urbano. Logo, a Regio é o Habitat, a Area, o Habitado. ARGAN, G. C., op. cit., pp. 178-179.

${ }^{23}$ CHOAY, Francoise. Le 'De re aedificatoria' e l'institutionnalisation de la société. In: CHOAY, F. Pour une antropologie de l'espace. Paris: Seuil, 2006, pp. 400-401. Trad. nossa. "En outre, dans un moment de rupture qui implique tous le champs institutionnels, Alberti déchiffre la spatialisation comme pouvoir inhérent à l'espèce humaine d'abolir les discontinuités par la mémoire, d'affirmer la fidélité de notre espèce à elle-même dans un imprévisible procès de création, qui ne peut être que continuation. D'où, sans précédent jusqu'à la réflexion menée par John Ruskin dans les années 1840, l'attitude d'Alberti face à l'heritage édifié du passé: sa distinction entre un patrimoine archéologique qui concerne le savoir et un patrimoine vivant plus ou moins ancien ou récent, qui constitue le cadre fondateur de notre quotidienneté et nous permet de nouer une permanente relation avec les générations passées."
} 
Não obstante as considerações de ordem teórica que despontavam nesse período, as intervenções realizadas antes do século XIX, na variedade de suas articulações e manifestações, significavam sobretudo 'atualização', modo de adaptação de forma e função arquitetônica. Na verdade, para delimitar as manifestações deste período seria mais adequado, segundo Sette, falarmos de 'arquitetura sobre o preexistente' e não necessariamente de 'restauro'. ${ }^{24}$

Apesar das análises históricas de diversos autores indicarem as origens do interesse pelos monumentos antigos, do ponto de vista da cultura ocidental, como provenientes do Renascimento, é necessário destacar que as intervenções realizadas nesta época, ainda que intentassem valorizar e estudar os monumentos, não pretendiam tutelálos, resultando freqüentemente na destruição dos mesmos. Dessa forma, sob diferentes abordagens, diversos teóricos defendem que o entendimento do restauro como um ato atrelado à consciência do valor artístico e histórico do monumento aconteceria somente a partir do século XVIII. É inegável, contudo, a transformação do panorama intelectual do mundo ocidental impulsionada a partir dos conceitos enunciados no Renascimento; conceitos que abriram caminho para uma série de eventos que possibilitariam a afirmação dos pressupostos do restauro moderno, ou seja, do restauro concebido como instrumento de conservação de uma preexistência entendida como produto histórico e como testemunho de um determinado passado. ${ }^{25}$

Ao longo do século XVIII, paralelamente ao desenvolvimento da estética e do aprofundamento dos estudos arqueológicos, a Antigüidade deixa de ser encarada como uma idade do ouro à margem do tempo para finalmente assumir uma objetividade histórica, temporal e geográfica, delineando a gradativa separação entre passado e presente. Conseqüentemente, as obras do passado passam a ser entendidas como representativas de uma cultura de um determinado tempo e lugar, ou seja, como material histórico cujo valor está diretamente relacionado à sua capacidade de fornecer informações sobre o mundo que o produziu. Diante dessa nova forma de encarar o passado, a intervenção de restauro assume caráter distinto daquele atribuído ao processo de formação da obra, pois incorpora a aproximação crítica ao objeto e a necessidade de reportar o antigo a sua real dimensão no tempo presente. ${ }^{26} \mathrm{O}$ amadurecimento do moderno senso histórico a partir, dentre outros

\footnotetext{
${ }^{24}$ SETTE, M.P., Profilo storico..., op. cit., p. 128.

${ }^{25}$ Idem, p. 139.

${ }^{26}$ BONELLI, Renato. Architettura e Restauro. Venezia: Neri Pozza, 1959, p. 13.
} 
fatores, do desenvolvimento da arqueologia e da história da arte, abrirá caminho para a gradativa passagem do olhar renascentista sobre o antigo - não seguido de uma efetiva ação de tutela - , ao olhar historicista entre o final do século XVIII e início do século XIX. O moderno conceito de restauro, portanto, inicia seu amadurecimento nessa paulatina aquisição de novos instrumentos interpretativos. ${ }^{27}$

O final do século XVIII, portanto, é considerado o momento em que as intervenções sobre bens do passado começam a firmar-se como ações de caráter cultural. Até então, diversas ações sobre o preexistente eram realizadas, porém geralmente ditadas por motivos funcionais e apenas pontualmente atreladas a discussões sobre a importância do preexistente. A partir de noções que começaram a despontar no Renascimento, as discussões sobre a importância dos bens do passado e sobre como intervir nos mesmos passaram por um lento processo de amadurecimento desde o século XV até o século XVIII, fornecendo paulatinamente o arsenal teórico e um vasto repertório de experiências práticas que possibilitariam o despontar das modernas conceituações do restauro. ${ }^{28}$ Percurso de aquisições conceituais que contou com contribuições teóricas de diversos estudiosos como Johann Joachim Winckelmann (1717-1768), sobretudo com relação à sistematização de metodologias precisas para o estudo das obras de arte; ou Giovanni Battista Piranesi (1720-1778), a partir de seus exercícios de levantamento e análise de obras arquitetônicas. $^{29}$

Essa lenta transformação conceitual está também relacionada a diversos fatos históricos que contribuíram para acentuar a noção de ruptura entre passado e presente. As idéias iluministas, a Revolução Industrial, notadamente na Inglaterra, e a Revolução Francesa, por exemplo, foram momentos em que se questionou a importância dos testemunhos do passado histórico. Seja por motivos políticos, quando os bens do passado representavam símbolos que se desejava aniquilar (como no caso da Revolução Francesa), seja pela própria transformação dos meios de produção e da composição dos tecidos urbanos (como no desenvolvimento industrial acelerado), as transformações abruptas dos

\footnotetext{
${ }^{27}$ CARBONARA, Giovanni. Avvicinamento al Restauro. Napoli: Liguori, 1997, p. 51.

${ }^{28}$ O recorte da presente abordagem sobre a preservação e a restauração não abarcará todas as contribuições nesse sentido. Para um amplo panorama, consultar: CARBONARA, G., op. cit.; JOKILEHTO, J., op. cit.

${ }^{29}$ Winckelmann, historiador da arte e arqueólogo alemão, desenvolveu análises pioneiras sobre a arqueologia científica e sobre a sistematização dos estudos sobre história da arte. Para uma aproximação ao tema, consultar: BORNHEIM, G. Introdução à leitura de Winckelmann. In: WINCKELMANN, J. J. Reflexões sobre a arte antiga. Tradução de Herbert Caro e Leonardo Tochtrop. Porto Alegre: Editora Movimento, UFRS, 1975.
} 
testemunhos do passado, ainda que não completamente entendidos como tais, bem como a destruição de paisagens e ambientes inteiros, contribuiu sobremaneira para o entendimento da escala de perdas e da importância dos bens que estavam sendo destruídos. Da mesma maneira que a destruição completa, a intervenção sobre esses bens também despertou a atenção, evidenciando-se cada vez mais a necessidade de distinção entre o momento da criação da obra e o momento histórico de sua transformação. Dessa forma, a partir do século XVIII, as ações sobre obras do passado afastam-se paulatinamente do pragmatismo, como razões de uso, econômicas ou políticas, para aproximar-se da questão cultural, voltada aos interesses estéticos, históricos, memoriais e simbólicos. ${ }^{30}$

Entre o final do século XVIII e início do século XIX, as enunciações do historiador da arte e arqueólogo francês Antoine Chrysostome, ou Quatremère de Quincy (1755-1849) representaram um grande salto em direção aos modernos conceitos de preservação e restauro ${ }^{31}$. Ao questionar os completamentos realizados em antigas esculturas arruinadas, afasta-se paulatinamente das asserções atreladas à 'repristinação' como vinha ocorrendo com outros teóricos ${ }^{32}$ - e levanta uma série de indagações que serão desenvolvidas posteriormente ao longo do século XIX. Além da pertinência dessas integrações, expõe a necessidade de manutenção constante das obras, a importância da pátina, a possibilidade de consolidar ruínas e o papel do contexto ao qual a obra de arte está associada desde a sua criação. Este último ponto, a preocupação com a contextualização do bem cultural, merece especial atenção na presente abordagem pois nos remete à paulatina consolidação histórica do entendimento do bem cultural a partir de uma perspectiva de maior amplitude.

Quatremère de Quincy é contrário à espoliação e deslocamento para os museus franceses das obras de arte pertencentes aos países ocupados pela expansão das tropas francesas lideradas pelo General Bonaparte, com especial atenção ao caso italiano. Nesse sentido, o autor desenvolve uma argumentação peculiar com relação à unidade formada pela cidade e seus artefatos. Considera a cidade de Roma e o conjunto de suas ruínas como

${ }^{30}$ KÜHL, Beatriz Mugayar. Preservação da arquitetura industrial em São Paulo: questões teóricas. Relatório Científico. São Paulo: FAUUSP, Fapesp, 2005., p.36.

${ }^{31}$ Sobre Quatremère de Quincy, o contexto histórico e cultural de sua produção literária e para referências bibliográficas complementares, consultar: KÜHL, Beatriz Mugayar. Quatremère de Quincy e os verbetes Restauração, Restaurar, Restituição e Ruína. Rotunda, n.2, 2003, pp. 100-117.

${ }^{32}$ Diversas definições do vocábulo 'restauro', nessa época, o associavam ao refazimento das obras segundo o estilo original. Sobre as definições correntes no período, consultar: DEZZI BARDESCHI, Marco. 'Conservare, non restaurare'. Hugo, Ruskin, Boito, Dehio e dintorni: Breve storia e suggerimenti per la conservazione in questo nuovo millenio. Restauro, n.164, pp. 69-108, 2003, pp. 71-74. 
um museu a céu aberto e afirma que a retirada de quaisquer artefatos provocaria a irremediável descontextualização dos mesmos pois estes deveriam ser estudados no ambiente em que foram criados. Seu conceito de ambiente vai além, abrange não apenas a cidade e suas obras mas também o sítio natural circundante, os aspectos geográficos da região e as características das cidades vizinhas ou de suas ruínas; elementos que conferem atributos territoriais ao chamado 'contexto' considerado. Cabe também ressaltar que tais considerações não se limitavam ao espaço físico, mas abrangiam também aspectos de ordem cultural como as tradições e as lembranças dos moradores locais, elementos que nos ajudariam a compreender os valores envolvidos na constituição de cada obra:

[...] a decomposição do museu de Roma seria a morte de todos os conhecimentos, que têm a unidade por princípio. [...]

O verdadeiro museu de Roma, aquele de que falo, se compõe, é verdade, de estátuas, de colossos, de templos, de obeliscos, de colunas triunfais, de termas, de circos, de anfiteatros, de arcos do triunfo, de tumbas, de estuques, de afrescos, de baixos-relevos, de inscrições, de fragmentos de ornamentos, de materiais de construção, de móveis, de utensílios etc., mas ele se compõe não menos dos locais, dos sítios, das montanhas, das pedreiras, das estradas antigas, das posições respectivas das cidades arruinadas, das relações geográficas, das relações de todos os objetos entre si, das lembranças, das tradições locais, dos usos ainda existentes, dos paralelos e aproximações que somente podem ser feitos no próprio local. ${ }^{33}$

Defende, portanto, não apenas a manutenção da obra em seu contexto de origem mas também a preservação deste próprio contexto como um importante elemento para a sua compreensão. Neste momento, observamos que o sentido de 'ambiente' conferido ao dito contexto está ainda associado à idéia de pano de fundo para as obras 'excepcionais'. Com o tempo veremos que a valorização da ambientação da obra aos poucos amadurecerá para a compreensão da unicidade monumento-ambiente (e, posteriormente, para a própria caracterização do ambiente como 'monumento'), paulatinas aquisições conceituais que se desdobrariam notadamente a partir final do século XIX.

No que tange às concepções do restauro e à posição do autor quanto à intervenção nos monumentos, os escritos de Quatremère de Quincy tecem considerações que contribuíram para o aprofundamento teórico da discussão. Em uma época em que predominava a idéia de restauro como recondução da obra à sua forma primitiva,

\footnotetext{
${ }^{33}$ QUATREMÈRE DE QUINCY. Lettres à Miranda sur le déplacement des monuments de l'art de l'Italie [1796]. Paris: Macula, 1989, pp. 100-102, apud KÜHL, B. M., Quatremère..., op. cit. p. 102.
} 
Quatremère de Quincy, por uma lado acena para a necessidade de critérios nesse sentido para que as recomposições, ou reproduções de certas partes de um edifício, não representassem falsos e induzissem o espectador ao erro e, por outro lado, atenta para as qualidades das superfícies envelhecidas, da pátina, e para a pertinência de, em alguns casos, manter os edifícios antigos no estado de ruína em que se encontravam. Tais enunciações abririam caminho para duas importantes vertentes que se desenvolveriam ao longo do século XIX. Uma visão mais conservativa, representada principalmente por John Ruskin, e outra vertente voltada aos refazimentos em estilo, encabeçada por Violet-LeDuc, sobre as quais nos debruçaremos a seguir.

Um importante passo para a oficialização da tutela dos bens culturais deve-se à pressão exercida por artistas e intelectuais franceses diante da destruição de monumentos ocasionada pelas demolições pós-revolução, bem como aos relatórios elaborados pelo abade Grégoire denunciando tais ações de vandalismo. A ação dos intelectuais contribuiu para o questionamento sobre a necessidade da intervenção do Estado na definição de modalidades de tutela do patrimônio histórico e artístico nacional. Assim, em 1830 foi criada a figura do 'inspetor geral de monumentos históricos', um profissional da esfera pública responsável pela observação e pelas providências de salvaguarda dos monumentos de importância histórica ameaçados em todo território francês. $\mathrm{O}$ cargo foi confiado a Ludovic Vitet (1802-1873), jovem crítico de arte que desenvolveu uma profícua pesquisa abarcando não apenas a descrição dos edifícios visitados, como também uma sistemática investigação sobre os problemas de conservação e as possíveis ações preventivas. As observações de Vitet corroboraram os principais pressupostos do chamado 'restauro estilístico', ao defender a recomposição em estilo, baseada em profundo conhecimento técnico e artístico da obra a ser restaurada. Posição semelhante será também seguida pelo seu sucessor no cargo, Prosper Mérimée (1803-1870). Mérimée prossegue os trabalhos denunciando a ação descaracterizadora de muitos restauradores que "são talvez tão perigosos quanto os demolidores", já que em muitos casos "alteraram completamente o aspecto dos edifícios que pretendiam restaurar". ${ }^{34}$ É interessante destacar, contudo, que Mérimée não se preocupava somente com as questões projetuais do restauro, mas também com o estudo minucioso dos elementos que compõem a obra arquitetônica. Nesse sentido, procurou desenvolver estudos precisos baseados em diversos escritos sobre arquitetura que abordavam desde a estrutura arquitetônica propriamente dita até os elementos

\footnotetext{
${ }^{34}$ Carta de Mérimée a Ludovic Vitet e a Thiers, 1834, apud SETTE, M. P., Profilo storico..., op. cit., p. 156.
} 
compositivos como vitrais, afrescos, estátuas, e também, antecedendo em muitas décadas os desdobramentos sobre a valorização dos bens culturais, estuda os edifícios considerados ‘menores' e a relação do monumento com o ambiente paisagístico e urbano circundante. ${ }^{35}$

O papel emblemático do chamado 'restauro estilístico', no entanto, coube a Eugène Emmanuel Viollet-le-Duc (1814-1879). Presente nas rodas de intelectuais franceses do período, Viollet-le-Duc travou contato com diversos personagens importantes do período, dentre eles Mérimée e Vitet, os quais o influenciaram sobremaneira. Atuando em um momento histórico em que o restauro procurava estabelecer-se como ciência, foi responsável pela decodificação de determinados conceitos teóricos e aplicações práticas (nem sempre coerentes entre si) que repercutiriam em toda a história da atuação sobre os edifícios do passado. A contribuição de Viollet-le-Duc para a consolidação de uma práxis de restauro é incontestável. Escritor produtivo e pesquisador erudito das obras antigas, contribui sobremaneira para a compreensão da técnica construtiva e compositiva da arquitetura medieval. Apesar das polêmicas suscitadas pelas suas teorias e dos inúmeros desdobramentos posteriores, muitos de seus conceitos permanecem válidos até hoje. Nas obras Entretiens sur l'Architecture e Dictionnaire Raisonné de l'Architecture Française du $X I^{e}$ au XVI Siècle, publicadas entre as décadas de 1850 e $1870^{36}$, o autor expõe parte dos resultados de suas extensas pesquisas sobre a arquitetura medieval, com destaque para análises sobre o seu caráter racional expresso na adequação entre formas, funções, estrutura portante e materiais empregados, análises que contribuíram e impulsionaram a reflexão sobre a arquitetura como um sistema coeso, racional e eficiente, idéias que, segundo alguns historiadores, antecedem as discussões posteriormente encampadas pela arquitetura moderna ${ }^{37}$.

A defesa da arquitetura como um sistema fechado, idealizado segundo uma práxis definida e coesa será, pois, observada na maneira como o autor desenvolve sua argumentação sobre o restauro arquitetônico. A unidade da obra arquitetônica deve ser alcançada a partir da compreensão do seu sistema gerador, da lógica de concepção do projeto original, da 'gramática' que deverá guiar a ação do arquiteto na intervenção sobre o

\footnotetext{
${ }^{35}$ SETTE, M. P., Profilo storico..., op. cit., p.156.

${ }^{36}$ Entretiens sur l'Architecture. Bruxelles, Liège: P. Mardaga, 1986 [publicado originalmente entre 18631872]; Dictionnaire Raisonné de l'Architecture Française du XI au XVI Siècle. Paris: LibrairiesImprimeries Réunies, s.d. [publicado originalmente entre 1854-1868].

37 Sobre essa leitura específica da obra de Viollet-le-Duc, bem como para uma análise da moderna historiografia sobre sua obra consultar: CARBONARA, G., Avvicinamento..., op. cit., pp.141-160; especialmente p. 146.
} 
existente, podendo significar refazimento e completamento - caso seja necessário restabelecer a suposta unidade estilística perdida ou o valor expressivo da obra - ou ainda 'melhoramentos', ou seja, supressão de partes da obra consideradas dissonantes, bem como substituições e reconstituições idealizadas, fantasiosas, daquilo que deveria ter sido construído caso o arquiteto autor do projeto possuísse a técnica e a compreensão ampla dos sistemas construtivos no momento da concepção da obra. A célebre passagem do verbete restauração do Dictionnaire, "restaurar um edifício não é mantê-lo, repará-lo ou refazê-lo, é restabelecê-lo em um estado completo que pode não ter existido nunca em um dado momento" ${ }^{38}$, denota, pois, o desejo de alcançar uma suposta unidade ideal inerente a toda obra arquitetônica, meta esta fruto, talvez, de uma fidelidade aos estudos analíticos como fonte para a revelação - ou "exumação", nas palavras do autor ${ }^{39}$ - de um saber projetual acumulado na história e parcialmente perdido, ou ainda não compilado satisfatoriamente.

Apesar do caráter polêmico de algumas de suas proposições teóricas e, principalmente, do resultado obtido em diversos casos práticos, muitas questões enunciadas por Viollet-le-Duc contribuíram sobremaneira para o desenvolvimento posterior das discussões sobre o conceito de restauro. Nesse sentido, destacam-se a sistematização dos estudos técnicos sobre a arquitetura do passado, a atenção dada ao restauro das estruturas portantes, ao levantamento preciso da situação preexistente e ao uso constante do edifício como importante fator para a sua conservação. Segundo o autor, “[...] o melhor meio para conservar um edifício é encontrar para ele uma destinação, é satisfazer tão bem todas as necessidades que exige essa destinação, que não haja modo de fazer modificações". ${ }^{40}$ Este tema em particular estará presente de modo incisivo no delineamento do moderno conceito de restauro, a partir do final do século XIX.

O modo como aborda a questão do 'estilo' e da suposta 'unidade estilística', contudo, um dos pontos de maior controvérsia na obra de Viollet, é ressaltada por Bonelli como fruto de um certo descompasso entre a sua produção teórica e o contexto cultural europeu do período - filosófico, literário e artístico - fato talvez originado pelo autodidatismo do autor. A concepção leduciana de estilo como um complexo unitário e prefixado de formas arquitetônicas, imóveis no tempo como uma formação supra-histórica, espécie de cultura figurativa fixada num passado remoto porém pronta a ressuscitar para

38 VIOLLET-LE-DUC, Eugène Emmanuel. Restauração. Trad. Beatriz Mugayar Kühl. São Paulo: Ateliê, 2000, p. 29. Verbete originalmente publicado no Dictionnaire Raisonné..., op. cit., vol.8, pp. 14-34.

${ }^{39}$ VIOLLET-LE-DUC, E. E. Restauração..., op. cit, p.34.

${ }^{40}$ Idem, p.65. 
incidir no monumento presente, pressupõe a aceitação de um modelo, do estilo como modelo, conceito acadêmico que o pensamento estético do período já havia abandonado, "substituindo-o por um lado pela idéia romântica da obra autônoma originada a partir da livre individualidade do artista, e por outro, pela conexão diacrônica dos eventos testemunhada a partir de uma leitura filológica dos fatos". ${ }^{41}$

Além do descompasso destacado por Bonelli no que tange ao conceito estético considerado nessas intervenções fantasiosas - fato talvez não satisfatoriamente depurado no século XIX - diversos intelectuais contemporâneos manifestaram descontentamento frente às intervenções realizadas de acordo com tais prerrogativas. Em geral, procurava-se defender o respeito à obra arquitetônica enquanto documento histórico, os traços da passagem do tempo e os aportes construtivos de diferentes épocas, e condenava-se os refazimentos, pregando uma atitude mais conservativa com relação aos edifícios do passado. Nesse sentido destaca-se o famoso axioma do arqueólogo francês Adolphe Didron (1806-1867), segundo o qual "é melhor consolidar do que reparar, reparar do que restaurar, restaurar do que refazer, refazer do que embelezar; em nenhum caso de deve acrescentar e, sobretudo, nada suprimir"; ou os dizeres do historiador francês Anatole Leroy-Beaulieu (1842-1912): "a questão não é fazer melhor, mas respeitar o que existe"; ${ }^{42}$ seguido ainda do arquiteto inglês Augustus Welby Pugin (1834-1875) que apelidou de “destruidor" o também arquiteto James Wyatt, seguidor das reconstituições em estilo na Inglaterra ${ }^{43}$.

Paralelamente ao desenvolvimento dos eixos teóricos aqui destacados, diversas experiências práticas contribuíram para a continuidade e delineamento das discussões ao longo do século XIX. Neste sentido destacam-se as restaurações realizadas em monumentos da Antigüidade, como as obras realizadas entre 1817 e 1824 no Arco de Tito, em Roma, por Raffaele Stern e Giuseppe Valadier. Neste exemplo, destaca-se a preocupação com questões que se tornarão primordiais nas discussões do século XX como a intenção de distinguir a intervenção realizada da matéria original da obra. Outro caso de

\footnotetext{
${ }^{41}$ BONELLI, Renato. Viollet-Le-Duc: fra teoria dell'architettura e restauro dei monumenti. Restauro, n.5657-58, 1981, pp. 176,184. Bonelli ressalta ainda que, nas definições de Viollet para estilo e gosto, residem a confusão conceitual entre arte e moralidade: "O gosto é o hábito da beleza e do bem; para ser homem de bom gosto, é por conseguinte essencial distinguir o bem do mal, o belo do feio", contrastando com o desenvolvimento histórico e filosófico da estética a ele contemporânea, a qual, a partir de Immanuel Kant (1724-1804), interpreta o gosto como modo de julgar e momento da subjetividade reflexiva. Para informações complementares, ver DELEUZE, Gilles. Relação das faculdades na crítica do juízo. In: $A$ Filosofia Crítica de Kant. Trad. Germiniano Franco. Lisboa: Edições 70, 1994.

${ }^{42}$ Apud KÜHL, B. M. Preservação..., op. cit., pp. 38-39.

${ }^{43}$ SETTE, M. P., Profilo Storico..., op. cit., p. 172
} 
destaque foram as intervenções de consolidação do Coliseu cujas obras foram realizadas em duas etapas, primeiramente por Stern com a participação de G. Camporesi e G. Palazzi (entre 1800 e 1823, durante o papado de Pio VII) e em seguida por Valadier (entre 1823 e 1829, no papado de Leão XII). Também neste segundo exemplo houve as preocupação em distinguir o material utilizado na consolidação do material original. Tais preocupações destacam a permanência de algumas idéias de Winckelmannn e Piranesi, preceitos que serão retomados por Boito décadas mais tarde. ${ }^{44}$

Observamos, portanto, que paralelamente às variadas manifestações vinculadas ao chamado restauro estilístico, desenvolveu-se uma corrente teórica de cunho conservativo (em geral associada ao restauro arqueológico, de tradição winckelmanniana), que buscou defender o respeito pelas obras antigas conforme se encontravam num dado momento, ou seja, com todas as marcas do tempo que lhe conferem a característica historicidade. Ao lado de teóricos e estudiosos da arquitetura e das artes, manifestavam-se ainda literatos e intelectuais que enxergavam o caráter documental e memorial dos monumentos do passado e condenavam tanto as demolições quanto as intervenções descaracterizadoras, notadamente as reconstruções em estilo. Nesse sentido, destacam-se os dizeres de Victor Hugo, segundo o qual "a arquitetura é o grande livro da humanidade, a expressão principal do homem em seus diversos estados de desenvolvimento, quer como força, quer como inteligência". Em diversas passagens, ao comparar o monumento e a arquitetura à palavra escrita ou às páginas de um livro, o autor elabora a famosa metáfora tantas vezes evocada para ressaltar o caráter documental das obras do passado.

Cada face, cada pedra do venerável monumento é uma página não somente da história do país, mas ainda da história da ciência e da arte. [...] Cada onda do tempo sobrepõe seu aluvião, cada raça deposita a sua camada sobre o monumento, cada indivíduo traz a sua pedra. [...] Certamente, há aí matéria para bem grossos livros e freqüentemente a própria história universal da humanidade, nestas soldaduras sucessivas de várias artes à várias alturas sobre o mesmo monumento. O homem, o artista, o indivíduo desaparecem sob essas grandes massas sem nome de autor; a inteligência humana alí resume-se e totalizase. O tempo é o arquiteto, o povo é o construtor. ${ }^{45}$

\footnotetext{
${ }^{44}$ KÜHL, B. M. Preservação..., op. cit., pp.37-38.

${ }^{45}$ HUGO, Victor. Notre-Dame de Paris. Paris: Gallimard, 2002 [1 $1^{\mathrm{a}}$ ed. 1831], p. 238 e em seguida pp. 161163. Trad. nossa. "L'architecture est le grand livre de l'humanité, l'expression principale de l'homme à ses divers états de devéloppement soit comme force, soit comme intelligence. [...] Chaque face, chaque pierre du vénérable monument et une page non seulement de l'histoire du pays, mais encore de l'histoire de science et de l'art. [...] Chaque flot du temps superpose son alluvion, chaque race dépose sa couche sur le monument, chaque individu apporte sa pierre. [...] Certes, il y a matière à bien gros livres et souvent histoire universelle del'humanité, dans ces soudures successives de plusieurs arts à plusieurs hauteurs sur le même monument.
} 
A partir de variadas manifestações, desenvolveram-se argumentações a favor da conservação, muitas vezes até mesmo condenando o restauro, considerando-o um ato destruidor por princípio. Dentre as variadas vozes nesse sentido, destacam-se as figuras de John Ruskin ${ }^{46}$ e William Morris. Além da defesa dos monumentos entendidos como de valor histórico considerável, a atuação desses teóricos foi responsável pelo amadurecimento de um importante fator vinculado à valorização dos bens culturais que começava a tomar fôlego na segunda metade do século XIX: a valorização histórica e estética do ambiente circundante, da arquitetura considerada 'menor' e dos conjuntos edificados. Não obstante os questionamentos advindos dessa corrente conservativa e desdobramentos posteriores, certos aspectos da visão leduciana do restauro (da idéia de restauro como recondução a um estado original) continuaram a repercutir na prática de intervenção e permanecem, ainda hoje, significativamente presentes em determinados contextos.

\section{Ambiente, MONUMENTO, VALOR: CONCEITOS EM FORMAÇÃo}

Um rápido percurso pelos principais escritos de John Ruskin (1819-1900) é suficiente para ilustrar a amplitude de temas que compunham o seu arcabouço teórico. A partir da observação da natureza, passando pela poesia, pela reflexão sobre as artes figurativas e particularmente pelo estudo sobre a arquitetura, seus estudos dirigiram-se para a análise do ambiente determinado pela arquitetura e a relação essencial entre o homem e o meio composto pela natureza, pela arte e pela história que o circunda. ${ }^{47}$

Inicialmente debruçado sobre o estudo da pintura de paisagem, na obra Modern Painters Ruskin inicia o desenvolvimento de suas teorias sobre a relação entre arte e paisagem, sendo talvez a partir dessa experiência teórica que o autor sentirá a necessidade

L'homme, l'artiste, l'individu s'effacent sur ces grandes masses sans nom d'auteur; l'intelligence humaine s'y résume et s'y totalise. Le temps est l'architecte, le peuple est le maçon." A seqüência na qual Victor Hugo desenvolve a comparação entre arquitetura e escrita, bem como sugere a analogia entre cidades e livros, está no capítulo Ceci tuera Cela, pp. 237-254.

${ }^{46}$ Para uma breve análise comparativa entre as idéias de Viollet-le-Duc e John Ruskin, ver: DI STEFANO, Roberto. John Ruskin, interprete dell'architettura e del restauro. Napoli: Edizione Scientifiche Italiane, 1983, pp. 75-99.

${ }^{47}$ Prefácio de Roberto di Stefano à edição italiana da obra The seven lamps of architecture. DI STEFANO, Roberto. Presentazione. In: RUSKIN, J. Le sette lampade dell'architettura [1849]. Milano: Jaca Book, 1993, 3.ed., pp. 11-29. 
de voltar-se ao estudo da arquitetura. Sendo "parte essencial da paisagem", considera que o estudo da arquitetura é indispensável ao pintor da mesma maneira que "um arquiteto não poderá nunca dirigir uma obra até que os seus projetos não sejam guiados por um profundo conhecimento da beleza selvagem da natureza". 48 Além de considerar arquitetura e paisagem como elementos complementares e indissociáveis, confere-lhes uma dimensão histórica e documental que residirá na base conceitual para a defesa de sua conservação, tema tratado com especial atenção no sexto capítulo da obra As sete lâmpadas da arquitetura, publicada em 1849. E o interesse nesse sentido não se volta apenas às grandes obras mas também à arquitetura dita 'menor', como as casas dos homens humildes, espaços construídos carregados da memória cotidiana daqueles que o edificaram e o vivenciaram em harmoniosa simbiose ao longo de toda uma vida, verdadeiros 'templos' que guardam as memórias e lembranças do cotidiano do homem comum:

Há uma certa santidade na casa de um homem bom, que não pode ser renovada em qualquer habitação que se levante sobre suas ruínas; e eu acredito que os homens bons, em geral, compartilhariam esta sensação; e que, após terem passado uma vida feliz e honrada, seria para eles um grande tormento, chegados ao fim, pensarem que o lugar de sua permanência terrena, que vira e parecera quase compartilhar com eles todas as suas honras, suas alegrias, ou seu sofrimento, - este lugar, guardião de todas as suas recordações e de todos os bens materiais que haviam amado e usado à sua maneira e aos quais haviam registrado a sua marca pessoal - devesse acabar varrido fora assim que lhes fosse dado um lugar na sepultura. ${ }^{49}$

A preocupação com a conservação desses registros da vida comum possui ainda um caráter social e moral, de certa maneira associado à temeridade diante do suposto declínio da sociedade, provocado pelas transformações impetradas pela industrialização. Tais transformações aniquilariam a individualidade do homem e alimentariam a perda de sua dignidade a partir do desprezo pelo seu próprio passado, pela vida de seus antepassados e, conseqüentemente, pelos testemunhos deixados por estes, negligenciando

\footnotetext{
${ }^{48}$ RUSKIN, John. Modern Painters, IV,1856, cap. VIII, apud SETTE, M. P., op. cit., p.180.

49 RUSKIN, John. The seven lamps of architecture [1849]. New York: Wiley, 1865, pp. 148-149. Trad. nossa. "There is a sanctity in a good man's house which cannot be renewed in every tenement that rises on its ruins; and I believe that good men would generally feel this; and that having spent their lives happily and honorably, they would be grieved at the close of them to think that the place of their earthly abode, which had seen and seemed almost to sympathise in all their honor, their gladness, or their suffering, - that this, with all the record it bare of them, and all of material things that they had loved and ruled over, and set the stamps of themselves upon - was to be swept away, as soon as there was room made for them in the grave."
} 
os valores religiosos associados à morada do homem como morada de Deus. ${ }^{50}$ Por outro lado, atenta ainda para a composição do conjunto urbano formado por essas pequenas casas e seu particular valor estético, afirmando que "aquilo que rende interessantes as mais belas cidades... [da Itália e da França] não depende tanto da riqueza isolada de seus grandes palácios, mas do culto refinado da decoração que se vê nas casas menores e que remonta ao período de seu maior esplendor". 51

Essa sensível apreensão do valor estético da paisagem urbana é um dos pontos da obra de John Ruskin que mais nos interessa nessa abordagem. Tal compreensão dos ambientes construídos enquanto lugares da história e da memória prenuncia o desenvolvimento do tema ao longo do século XX, lançando suas bases conceituais fundamentais. Em diversos escritos o autor defende que a conservação do patrimônio cultural não deve limitar-se à tutela dos monumentos de arquitetura e sim se estender a todos os documentos da civilização humana, inclusive à paisagem e ao território transformados pelo homem. Essa defesa da tutela do ambiente urbano, por sua vez, encontra respaldo na crescente preocupação com a rápida destruição ocasionada pelo desenvolvimento industrial do período. Ruskin acreditava que a industrialização apresentava perigo não somente devido à destruição física das cidades e da natureza mas também, como vimos, por insuflar a degradação social do homem. A esse respeito, Ruskin dedica diversas passagens nas quais ataca a cidade industrial: "Não é possível ter nenhuma justa moralidade, felicidade e arte, em um país onde as cidades são construídas desse modo [...] adensadas e coaguladas, manchadas de espantoso mofo que se propaga por todo o território" ${ }^{52}$. Ou ainda:

Toda a bela arquitetura foi desenhada para cidades sob um céu sem nuvens, cidades com praças e jardins abertos, pouco habitadas e em paz luminosa, cidades construídas de modo que os homens pudessem nelas viver felizmente, e alegrar-se a cada dia, na presença e força um do outro. Mas as nossas cidades, construídas sob um céu escuro, que, devido ao

\footnotetext{
${ }^{50}$ Sobre a analogia entre experiência estética e moral, bem como sobre a relação entre arte, sociedade e religiosidade em John Ruskin, ver Economia politica dell'arte / John Ruskin. Trad. Lucio Angelini. Torino: Bollati Boringhieri, 1991 (publicação que reúne as conferências proferidas por John Ruskin em Manchester no ano de 1857); Sobre a atualidade do pensamento político e sociológico de Ruskin e para referências bibliográficas complementares, ver: DI STEFANO, Roberto. John Ruskin, interprete dell'architettura e del restauro. Napoli: Edizione Scientifiche Italiane, 1983; SETTE, M. P., Profilo Storico...,op. cit., pp. 180-184.

${ }^{51}$ RUSKIN, J. The seven lamps..., op. cit.

${ }^{52}$ RUSKIN, J. Lectures on Art [1870]. London: G. Allen, 1890, § 123, pp. 142-143. Trad. da autora. "It is not possible to have nay right morality, happiness, or art, in any country where the cities are thus built, or thus, let me rather say, clotted and coagulated; spots of a dreadful mildew, spreading by patches and blotches over the country they consume."
} 
acúmulo de poluição, primeiro torna todo ornamento invisível à distância e em seguida sufoca os seus interstícios com a fuligem; [...] cidades nas quais o objetivo dos homens não é vida, mas trabalho [...]; cidades nas quais as ruas não são vias para o passeio e a procissão de gente feliz, mas canais para a descarga de uma multidão atormentada, [...] nas quais a existência transforma-se em mera transição e cada criatura é somente um átomo em um curso de poeira humana, [...] circulando aqui pelos túneis subterrâneos e ali pelos tubos de ar; para uma cidade, ou para cidades como esta, nenhuma arquitetura é possível, ou ainda, nenhum desejo disso é possível para os seus habitantes. ${ }^{53}$

Com relação à restauração dos edifícios antigos, Ruskin adota uma postura radical, defende o respeito total ao preexistente e renega qualquer tipo de intervenção, diferentemente de muitos de seus contemporâneos que vêem com naturalidade, ainda que na variedade de suas convicções, a atuação sobre as obras do passado com intuito de conservar, atualizar ou até mesmo completar partes faltantes. Para Ruskin, o restauro é a pior das destruições que um edifício poderia sofrer, "uma destruição após a qual nenhum remanescente pode ser reunido; uma destruição acompanhada da falsa descrição do objeto destruído"; considera, portanto, ser impossível, "tão impossível quanto ressuscitar os mortos, restaurar qualquer coisa que tenha sido grande ou bela em arquitetura". ${ }^{54}$ Segundo o autor, não temos o direito de tocar nessas obras pois estas não nos pertencem; pertencem em parte àqueles que as construíram e em parte a todas as gerações futuras. Em uma primeira leitura, tais dizeres sugerem uma atitude passiva frente ao edifício, quase que de contemplação, deixando-o livre à ação do tempo e à degradação progressiva que determinará a sua perda completa. No entanto, ainda que sutilmente, Ruskin propõe a manutenção e consolidação constantes, desde que realizadas de modo imperceptível: "cuidai bem de vossos monumentos e não vos será preciso restaurá-los depois". 55

\footnotetext{
53 RUSKIN, J. The study of architecture. Boston: D. Estes, [1890?], p.345. Trad. nossa. "All lovely architecture was designed for cities in cloudless air; in cities in which piazzas and gardens opened in bright populousness and peace; cities built that men might live happily in them, and take delight daily in each other's presence and powers. But our cities, built in black air, which, by its accumulated foulness, first renders all ornament invisible on distance, and them chokes its interstices with soot; cities which are mere crowded masses of store, and warehouse, and counter, and are therefore to the rest of the world what the larder and cellar are to a private house; cities in which the object of men is not life, but labour; [...] cities in which the streets are not the avenues for the passing and procession of a happy people, but the drains for the discharge of a torment mob, [...] in which existence becomes mere transition, and every creature is only one atom in a drift of human dust, [...]circulating here by tunnels under ground, and there by tubes in the air; for a city, or cities, such as this, no architecture is possible - nay, no desire of it is possible to their inhabitants."

${ }^{54}$ RUSKIN, J. The seven lamps.., op. cit. E prossegue ainda: "A primeira operação do restauro [...] consiste em fazer em pedaços a obra original; a segunda, geralmente, consiste em adicionar-lhe as menos preciosas e mais vulgares imitações."

${ }^{55}$ RUSKIN, J. The seven lamps.., op. cit., §. xix.
} 
Em suma, a contribuição teórica de Ruskin abriu um importante caminho para a interpretação do bem cultural em sua inteireza, ou seja, para a compreensão das especificidades que o fazem único e irreproduzível, fato que, aplicado particularmente à arquitetura e à cidade, pressupõe o entendimento das contingências históricas, sociais e materiais que a determinaram. Como bem destaca Di Stefano, ao afirmar que a mesma atenção seja dada tanto à arquitetura nova - à qual devemos conferir a devida dimensão histórica -, quanto à tutela da arquitetura antiga - a mais preciosa das heranças - , Ruskin compreende que ambas devem constituir harmonicamente um mesmo ambiente, um dos princípios fundamentais da conservação integrada, posteriormente assim definida em 1975, na Declaração de Amsterdã. ${ }^{56}$

As teorias defendidas por John Ruskin se inserem no contexto dos debates, e das variadas e polêmicas iniciativas práticas, que delinearam o vasto programa de restauros que se desenvolveu na França a partir de 1840. Como vimos, as observações e críticas lançadas por diversos intelectuais como Quatremère de Quincy e Alexandre Lenoir, bem como Victor Hugo, Didron e, sobretudo, Vitet, Mérimée e Viollet-le-Duc, contribuíram para a gradativa moldagem de uma práxis de restauro, um conjunto de métodos e critérios, que em pouco tempo estendeu-se para vários países da Europa. Tais métodos, representados principalmente pela atuação de Viollet-le-Duc, não foram, contudo, difundidos sem gerar polêmicas e reações contrárias. Além dos escritos de John Ruskin, surge na Inglaterra o Anti-Restoration Movement e a Society for the Protection of Ancient Building, fundada por William Morris em 1877.

Diferentemente do que ocorreu na França, onde a iniciativa de tutela dos monumentos partiu do próprio Estado, no Reino Unido a preocupação com os bens culturais foi inicialmente encampada por particulares que se agrupavam em associações voltadas seja para a realização de estudos arqueológicos e históricos, seja para a tutela propriamente dita. Foi neste contexto que surgiu a Sociedade para a Proteção dos Edifícios Antigos, a partir da iniciativa de William Morris (1834-96) ${ }^{57}$. O grupo, formado por literatos, artistas, arquitetos e intelectuais em geral, buscava reunir esforços a favor da conservação dos monumentos e contra a destruição dos mesmos sob a égide do chamado restauro. Observamos, portanto, que o grupo era contrário às intervenções, seguindo de

\footnotetext{
${ }^{56}$ DI STEFANO, R. Presentazione..., op. cit., p.17.

57 Além da SPAB, cabe ressaltar o surgimento de outras instituições como o Royal Institute of British Architects (Riba), fundado em 1834; a Oxford Architectural and Historical Society e a Cambridge Camden Society, as duas últimas voltadas ao estudo de edifícios eclesiásticos. SETTE, M. P., op. cit., p.184.
} 
perto as convicções de John Ruskin e Pugin. Dessa forma, enquanto na maioria dos países europeus difundiam-se as intervenções de restauro adeptas aos refazimentos e completamentos, na Inglaterra observa-se uma reação contrária, antiintervencionista (ao menos do ponto de vista teórico), cuja influência ainda hoje podemos sentir na abordagem predominante sobre o tema, na qual a palavra 'restauração' (restoration) é geralmente preterida pelo termo 'conservação' (conservation).

A partir dos princípios conservativos enunciados por Ruskin, as contribuições teóricas de Morris e da SPAB consolidavam a idéia de manutenção da matéria original e de suas modificações e adições, bem como da pátina, como importantes testemunhos da passagem do tempo sobre o monumento. $\mathrm{O}$ texto que melhor exemplifica as idéias que originaram a SPAB é o Manifesto ${ }^{58}$ de W. Morris. Escrito em contraposição à notícia de que a Abadia de Tewkesbury seria restaurada pelo arquiteto George Gilbert Scott, um dos protagonistas dos restauros em estilo na Inglaterra, o texto denuncia a destruição ao qual os monumentos estariam expostos nos projetos de restauração, fazendo ecoar o cerne das idéias conservacionistas: "É por todos esses edifícios, portanto, de todos os tempos e estilos, que nós imploramos e exortamos aqueles a quem eles estão confiados que coloquem a PROTEÇÃO no lugar da RESTAURAÇÃO, que adiem a deterioração pelo cuidado diário [...]". ${ }^{59}$ Morris insiste ainda no caráter insubstituível de cada monumento, noção adquirida a partir da tomada de consciência característica do século XIX que permitiria, paulatinamente, a compreensão do lugar do homem na dinâmica histórica e a atribuição do valor de herança cultural ao nosso passado:

Essa tomada de consciência, [...] ligou-nos de tal modo ao passado que ele é parte integrante de nossa vida e mesmo de nosso desenvolvimento. Esse fato, ouso dizer, nunca

\footnotetext{
58 MORRIS, William. The Society for the Protection of Ancient Buildings [1877]. In: Repair, not Restoration. London: The S.P.A.B., 1977. Neste texto utilizamos a tradução de Maria Lucia Bressan Pinheiro publicada anexo ao artigo: PINHEIRO, M. L. B. William Morris e a SPAB. Rotunda, n.3, out. 2004, pp. 2235. Remetemos ao mesmo texto para informações mais detalhadas sobre a SPAB e o contexto histórico de sua fundação.

${ }^{59}$ MORRIS, W., op. cit. No trecho destacado, observamos outro aspecto de interesse, a preocupação com edifícios "de todos os tempos e estilos". Ao lado da contribuição teórica de William Morris, os escritos de John James Stevenson, arquiteto escocês associado à SPAB, contribuíram sobremaneira neste sentido. J. J. Stevenson lançou luzes sobre a importância do monumento como documento histórico e, sendo assim, para a valorização dos edifícios ou aportes construtivos oriundos de outras épocas, e não apenas aqueles vinculados à arquitetura medieval. Maria Piera Sette atenta para a pouca valorização da contribuição de Stevenson na maior parte da historiografia sobre o restauro. Segundo a autora, os postulados de Stevenson abriram caminho para a conceituação do chamado restauro filológico, sobre o qual trataremos a seguir. SETTE, M. P., op. cit., p.185. Sobre a contribuição de Stevenson e para bibliografia complementar, consultar ainda: CARBONARA, G. Avvicinamento..., op. cit., pp. 172-173.
} 
tinha acontecido antes. É algo completamente novo. [...] Nós, que pertencemos a este século, fizemos uma descoberta impossível às épocas precedentes: sabemos agora que nenhum novo esplendor, nem obra moderna alguma pode substituir para nós a perda de um trabalho antigo que seja uma autêntica obra de arte. ${ }^{60}$

O papel preponderante de William Morris na historiografia da arquitetura, no entanto, está associado às suas reflexões sobre a relação entre arte e sociedade que estão no cerne de sua postura crítica frente à civilização moderna, idéias que também o conduziriam à atuação no campo político. Morris, assim como Ruskin, condena a sociedade industrial como a responsável pela decadência da arte e da arquitetura, já que a massificação da produção conduziria à ruptura identitária entre o homem e o produto de seu trabalho. É este debate que o levaria, juntamente com outros profissionais, à fundação da firma Morris, Marshall, Faulkner \& Co., um verdadeiro laboratório de arte decorativa e artesanal cuja contribuição para as artes do século XX será posteriormente estudada por diversos historiadores. ${ }^{61}$

De maneira análoga, a discussão sobre a dissociação entre artesanato e indústria está na base da valorização conferida por Morris aos conjuntos urbanos construídos pelo homem comum. A arquitetura da cidade industrial - massificada, mecânica e desprovida de beleza -, contrapõe-se à arquitetura construída na Idade Média - edificada com as próprias mãos, de modo artesanal, quando tanto as casas de campo quanto as catedrais "eram construídas com o mesmo estilo e com os mesmos ornamentos". Em diversas passagens, Morris enfatiza o seu desprezo para com a cidade industrial e a conseqüente valorização da cidade antiga, contentora do talento e conhecimento dos antepassados.

[...] um homem que deixa a Inglaterra por alguns anos encontra, ao voltar, uma Londres que cresceu meio condado de tijolos e cimento. Os otimistas podem pretender que o estilo arquitetônico dessas construções dá testemunho de um progresso? Pelo contrário, [...] a

\footnotetext{
${ }^{60}$ MORRIS, W. The Restauration of Ancient Buildings. The Builder, 1878, apud CHOAY, Françoise. A Alegoria do Patrimônio. Trad. Luciano Vieira Machado. São Paulo: Estação Liberdade, Unesp, 2001, p. 155.

${ }^{61}$ Principalmente PEVSNER, Nikolaus. Os Pioneiros do Desenho Moderno. São Paulo: Martins Fontes, 1980, pp. 42-43; e BENEVOLO, Leonardo. História da Arquitetura Moderna. São Paulo: Perspectiva, 2001, p. 13. Benevolo considera a fundação da Morris, Marshall, Faulkner \& Co. como um marco simbólico para o início da arquitetura moderna.
} 
última casa construída é sempre a mais vulgar e mais feia. A verdade é que praticamente toda casa nova é de uma fealdade vergonhosa e degradante. ${ }^{62}$

Ao longo de todo o século XIX são, portanto, as preocupações com a rapidez das transformações e suas conseqüências - no campo econômico, social, urbano - que ecoam em grande parte da produção cultural do período. Trata-se, como vimos, de um momento de profunda ruptura entre o sistema de vida agrícola, no qual geração após geração encontrava uma situação econômica e cotidiana de certa forma estável, uniforme e apreensível, para o sistema de produção industrial que, de modo abrupto, impetrou aos habitantes um mundo praticamente novo, irreconhecível, no qual a experiência acumulada e precedente parecia transformar-se em bagagem obsoleta, restando-lhe o estigma de mera lembrança nostálgica. As indagações sobre esse sistema de coisas, a partir de variadas abordagens e em diferenciados contextos geográficos e culturais, assumiriam contornos teóricos distintos porém estreitamente conectados, contornos esses por vezes manifestos na forma de figuras literárias, de veemente denúncia, de propostas socioeconômicas alternativas ou, no que tange ao nosso enfoque, nas diferenciadas maneiras de entender e tratar o passado arquitetônico e artístico frente à tais transformações.

Os espaços transformados ou produzidos nesse complexo contexto de mutações sociais e urbanas, no entanto, são contemporaneamente os artefatos que intentamos preservar; são esses espaços em grande parte moldados pela presença da atividade industrial e seus novos códigos sociais que agora adquirem representatividade como testemunhos de um particular desenvolvimento histórico e como componentes, eles próprios, de uma nova paisagem portadora de numerosos significados. A discussão sobre o destino de bairros e cidades industriais, um dos enfoques do presente estudo, deve considerar, portanto, não somente os inegáveis liames entre as estruturas industriais e a história urbana, mas também a representatividade desses mesmos artefatos no próprio processo de formulação conceitual do patrimônio urbano.

Prosseguindo nosso percurso, no contexto italiano cabe destacar a contribuição de Carlo Cattaneo (1801-1869), autor geralmente citado como um dos precursores da síntese

\footnotetext{
${ }^{62}$ MORRIS, W. Art, Wealth and Riches. In: The Collect Works of William Morris. Londres, 1915, tomo 23, pp. 147-150, apud CHOAY, Françoise. $O$ Urbanismo: utopias e realidades, uma antologia. Trad. Dafne N. Rodrigues. São Paulo: Perspectiva, 2003, p. 131.
} 
teórica de Camillo Boito ${ }^{63}$. Na mesma época em que John Ruskin e franceses como Baudelaire e Michelet elaboravam suas considerações sobre os complexos urbanos, Cattaneo interessa-se pelos tecidos urbanos medievais e desenvolve interessantes previsões de cunho urbanístico, bem como análises de projetos de intervenção na cidade antiga, que não somente pontuam a preocupação nascente com a funcionalidade urbana em transformação, como também se voltam à valorização estética e compositiva do ambiente urbano, temas que receberiam tratamento aprofundado somente décadas mais tarde, com os estudos do arquiteto austríaco Camillo Sitte ${ }^{64}$. Ainda na primeira metade do século XIX, Cattaneo discute critérios para a inserção de novos equipamentos na cidade antiga e elabora importantes recomendações sobre a necessidade de alocar determinadas funções possivelmente perturbadoras - como matadouros, depósitos de mercadorias ou estações ferroviárias - em regiões distantes do centro antigo. ${ }^{65}$

Sobre a sensibilidade de Cattaneo com relação aos aspectos compositivos dos espaços urbanos, devemos especial atenção às suas equilibradas considerações sobre a praça, tema que surge no seio dos debates sobre as obras de reestruturação dos arredores da Catedral de Milão. Ao manifestar-se contra os projetos de ampliação da praça da catedral, Cattaneo atenta para a importância do espaço urbano, da praça pública, não apenas como área circundante de um monumento mas como ambiente em um sentido mais complexo; ou seja, como um espaço que por um lado é composto fisicamente pelas relações entre área construída e vazios que determinam a escala secularmente construída entre as edificações; e por outro, como espaço também composto pelas relações sociais que abriga enquanto lugar de encontro da coletividade.

As obras de reestruturação da praça, previstas desde 1830 e em parte realizadas no início do século XX, previam a demolição das edificações mais próximas da Catedral de modo a ampliar a praça como recurso para valorizar o monumento. ${ }^{66}$ Tal atitude chama a

\footnotetext{
${ }^{63}$ Sobre Carlo Cattaneo e o contexto do período, consultar: ROCCHI, G. Camillo Boito e le prime proposte normative del restauro. Restauro, n.15, 1974; JOKILEHTO, J., op. cit., p. 198.

${ }^{64}$ Giuseppe Rocchi destaca o estudo La città considerata come principio ideale delle istorie italiane (CATTANEO, C. Scritti storici e geografici. Firenze: F. Le Monnier, 1957), como um dos principais escritos de Cattaneo onde podemos observar certos aspectos de suas preocupações sobre a dinâmica urbana do período. ROCCHI, G., op. cit, p.14.

${ }^{65}$ Datam da década de 1830 os estudos publicados por Cattaneo a respeito das obras em andamento na cidade de Milão e sobre a construção de matadouros em Nápoles. ROCCHI, op. cit., p. 19.

${ }^{66}$ As questões levantadas por Carlo Cattaneo com relação a este projeto serão retomadas e aprofundadas, décadas mais tarde, pelos arquitetos Luca Beltrami e Camillo Boito. Sobre as obras da praça da Catedral de Milão, Cf.: Piazza del Duomo di Milano. Storia, problemi, progetti, Milano: Mazzotta 1982; CATTANEO, Carlo. Sulla piazza del Duomo di Milano. In: Scritti su Milano e la Lombardia. Milano: Rizzoli, 1990;
} 
atenção de Cattaneo que se preocupa não apenas com a perda do sentido da praça urbana como local de sociabilidade mas também com a interferência no ambiente antigo e a conseqüente perda da escala monumental original da Catedral. Notamos, portanto, a atenção do autor para com os elementos que constituem e qualificam o ambiente construído, as relações de escala, a composição de volumes, a arquitetura menor circundante. Ao afirmar que "fazer uma praça não é refazer uma cidade", o autor sinaliza o que seria um dos pontos nodais das discussões posteriores sobre intervenções no tecido urbano antigo: a compreensão dos elementos e condições que o compõem como um sistema unitário, instrumento imprescindível para a atuação sobre o mesmo, sob pena de ferir ou mesmo destruir uma continuidade única e irreproduzível.

\begin{abstract}
A praça não é absolutamente um espaço vazio para quem quer contemplar a Cúpula, mas é um lugar útil e agradável à cidadania; é uma parte da cidade, ou melhor, é quase o seu coração. E se não pretendermos que permaneça deserta e desolada, a frequiência dos cidadãos deve animar-lhe continuamente por toda parte. Um espaço exagerado, que afastasse em excesso... [a área da praça das áreas habitadas] interporia um contínuo e inevitável impedimento a todas as relações sociais.

[...] Uma praça destinada a acrescentar magnificência a um edifício, deve primeiramente coordenar-se a ele. Ao mesmo tempo, consistindo esta em certa disposição das edificações circundantes, não pode desvincular-se totalmente das suas necessárias condições. Quando então se trata de abri-la no meio de uma antiga cidade, é necessário também considerar a construção geral; já que fazer uma praça não é refazer uma cidade. ${ }^{67}$
\end{abstract}

Cattaneo, portanto, caminha em direção ao reconhecimento das estratificações urbanas herdadas do passado e à conseqüente necessidade de buscar a conservação dessa unidade construída. Nesse sentido, retoma a metáfora do monumento - ou do tecido urbano - considerado como um livro, conforme Victor Hugo defendera décadas atrás. Ainda com relação ao projeto da praça de Milão, Cattaneo ataca o projeto de novos

BOITO, Camillo. La nuova piazza del Duomo a Milano. In: Il nuovo e l'antico in architettura. Milano: Jaca Book, 1988. A polêmica em torno do projeto seria ainda retomada ao longo do século XX como exemplo de intervenção radical e destruidora: ONESTI, Carlo Calzecchi. Urbanistica e Monumenti. Costruzioni Casabella, anno XVI, n.165, 1941, p.2.

${ }^{67}$ Trechos de artigos de Cattaneo publicados no periódico Politecnico entre 1839 e 1862, apud ROCCHI, G., op. cit., p. 21. Trad. nossa. "La piazza non è assolutamente un spazio vacuo per chi vuol contemplare il Duomo, ma è un luogo utile e aggradevole alla cittadinanza; è una parte della città, anzi ne forma quasi il cuore. E se non intendiamo che rimanga deserta e squallida, la frequenza dei cittadini deve animarne continuamente tutte le parte. Uno smoderato spazio, che allontanasse di soverchio le parti dell'abitato frapporrebbe un continuo ed inevitabile impedimento a tutte le relazione sociale. [...] Una piazza destinata ad aggiungere magnificenza ad un edificio, deve primamente coordinarsi ad esso. Nel medesimo tempo, consistendo essa in una certa disposizione delle fabbriche circostanti, non può svincolarsi del tutto dalle loro necessarie condizioni. Quando poi si tratta d'aprirla nel mezzo di una antica città, bisogna pur tenerne in qualche conto la costruzione generale; poiché fare una piazza non è rifare una città." 
edifícios monótonos opondo como exemplo o caso de Veneza, cidade onde a sobreposição e fusão de diversos aportes cronológicos e estilísticos conduziu a um resultado de insubstituível harmonia, um verdadeiro "[...] resumo das suas vicissitudes, um belo quadro preliminar ao livro das histórias venezianas [...] qualquer parte que se suprimisse dessa combinação arquitetônica, fortuitamente produzida pelos séculos, não seria como arrancar uma sílaba de uma palavra, uma corda de um cravo?" 68

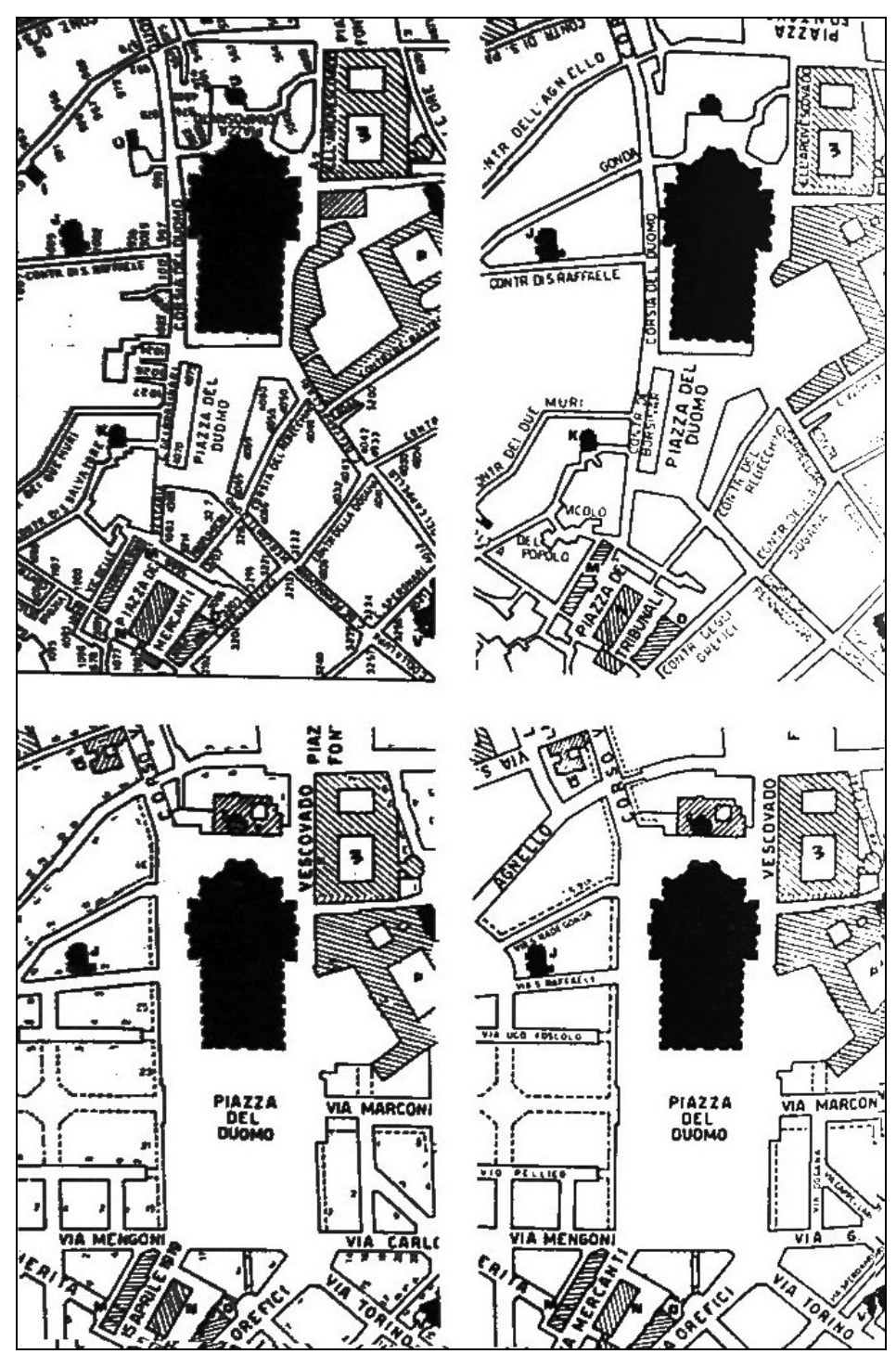

01. Modificações sucessivas na Praça da Catedral de Milão, Itália. Situação em 1730, 1818, 1940 e 1960. (ROCCHI, G., op. cit., p.26)

\footnotetext{
${ }^{68}$ CATTANEO, C. Scritti sulla Lombardia [a cura di G. Anceschi e G. Armani]. Milano: Ceschina, 1971, p.637, apud ROCCHI, G., op. cit., p.28. Trad. nossa. "[...] riassunto delle sue vicende, una bella tavola preliminare al libro delle istorie venete [...] qualunque parte che si sopprimesse di quella combinazione architettonica, fortuitamente prodotta dai secoli, non sarebbe come svellere una sillaba da una parola, una corda da un cembalo?"
} 
Nesta breve análise sobre o contexto teórico a partir da segunda metade do século XIX observamos que, nas variadas e por vezes antagônicas expressões sobre a importância dos monumentos, por um lado despontava a compreensão do monumento como matéria detentora de saberes e fazeres únicos e irreproduzíveis; e, por outro, a necessidade de reportá-lo ao momento presente por meio de intervenções e das chamadas 'atualizações'. Essas posições teóricas e práticas, inicialmente manifestas por meio de defesas radicais e até mesmo apaixonadas, confluiriam paulatinamente para a elaboração de teorias intermediárias, mais ponderadas, baseadas principalmente na admissão do valor documental da obra. Tal amadurecimento deveu-se não somente às contribuições dos teóricos aqui destacados, mas também a uma série de experiências práticas e debates paralelos que permitiram uma constante revisão desses conceitos em direção a uma atitude menos radical e cada vez mais voltada ao reconhecimento do valor histórico e documental da obra. Valor este não apenas manifesto na observação romântica da passagem do tempo sobre a matéria construída em iminente ruína ou na valorização do monumento como 'tipo' a ser imitado, mas sim, na compreensão da sua identidade documental e na necessidade de permitir a sua leitura no presente e no futuro.

Dessa forma, começam a despontar teorias mais ponderadas, baseadas em ações que permitam essa leitura e que não desnaturem ou se confundam com a matéria original, ou seja, ações pautadas pela distinção entre a intervenção de restauro e as partes preexistentes do monumento de modo a não induzir o observador ao engano e evitar falsificações e mistificações. Pretende-se conceber a restauração não mais como o retorno ao estado original ou como busca de uma suposta unidade estilística perdida, mas sim como um ato que respeite todo o passado da obra e suas estratificações, considerando-a como um verdadeiro documento da história. Assumem primordial importância, portanto, as pesquisas históricas e documentais sobre a obra a ser restaurada, princípio que delinearia o chamado 'restauro filológico', e a variante denominada 'restauro histórico'.

A chamada 'posição intermediária' 69 encontraria na figura do arquiteto italiano Camillo Boito (1836-1914) a sua síntese fundamental. As elaborações teóricas de Boito sobre a restauração basearam-se em uma rica formação cultural que lhe permitiu uma lúcida análise das teorias e práticas de seus antecessores. Em seu tempo, na segunda metade do século XIX, conviviam diferenciadas práticas na intervenção sobre os edifícios

\footnotetext{
${ }^{69}$ Boito e Giovannoni, eles próprios, se autodenominam defensores dessa suposta posição intermediária entre Viollet-Le-Duc e Ruskin.
} 
do passado, sejam voltadas ao refazimentos em estilo, conforme o legado de Viollet-leDuc, sejam atitudes mais conservativas, sob a égide de John Ruskin e seus sucessores ${ }^{70}$. A partir da observação das práticas em andamento, Boito procurou confrontar ambas as doutrinas e extrair o melhor de cada uma buscando agrupar de modo crítico, senão em uma síntese certamente em diretrizes claras e didaticamente eficazes, aquilo que vinha sendo elaborado em décadas de intervenções e de confrontos de idéias. Dessa forma, sua teoria encontra-se numa 'posição intermediária' entre o suposto fatalismo de Ruskin e as 'fantasias' de Viollet-le-Duc. ${ }^{71}$ Segundo Rocchi, esse visionarismo de Boito deve-se ao contexto histórico e ideológico do final do século XIX, marcado pelos progressos da ciência e da historiografia. Enquanto Viollet-le-Duc e Ruskin representavam pensamentos arraigados no século XIX, Boito convive com os avanços da ciência e da técnica e vislumbra o alvorecer do século XX, ou seja, vive em um ambiente que se projeta para o próximo século. $^{72}$

De Ruskin e Morris, Boito herdou a preocupação com a autenticidade do documento manifesta principalmente na defesa pela preservação das várias estratificações de uma obra, elementos geralmente condenados nas intervenções realizadas segundo o critério estilístico. Por outro lado, não compartilhava da visão antiintervencionista desses autores alegando que seria inaceitável deixar o monumento ruir assim como não se deve aceitar a morte de um homem doente antes de tentar curá-lo. Baseando-se, por sua vez, em Viollet-le-Duc, Boito buscou legitimar a restauração como um ato de conservação por vezes necessário, quando a manutenção ou outros recursos preventivos não puderem garantir a integridade da obra; desde que, no entanto, tais intervenções não criem falsificações que nos induzam ao erro. Tais pensamentos contribuiriam ainda para o aprofundamento de outras questões que já se evidenciavam, como a bipolaridade do valor do monumento enquanto obra de arte e enquanto documento de história - "a beleza pode vencer a velhice" 73 - , e a conseqüente dificuldade na definição dos critérios, históricos ou estéticos, que guiarão a escolha dos estratos a serem priorizados em uma restauração.

\footnotetext{
${ }^{70}$ Diversos autores dissertam sobre as principais obras de restauração empreendidas nesse período e suas respectivas filiações conceituais. Reportamos à bibliografia sobre história da restauração como guia geral nesse sentido, com destaque para as já mencionadas obras de G. Carbonara, M. P. Sette, e J. Jokilheto.

${ }^{71}$ Sobre Camillo Boito, consultar: CHOAY, F. A Alegoria ..., op, cit., pp.164-167; CESCHI, Carlo. Teoria e Storia del Restauro. Roma: Bulzoni, 1970, pp. 107-110; SETTE, M. P., op. cit., p. 202 et seq.

${ }^{72}$ ROCCHI, G., op. cit., p. 64 et seq.

${ }^{73}$ BOITO, C. Questioni pratiche di belle arti. Milano: Ulrico Hoepli, 1893, p. 22, apud KÜHL, Beatriz Mugayar. Os restauradores e o pensamento de Camillo Boito sobre a restauração. In: BOITO, Camillo. Os restauradores. Cotia: Ateliê, 2002, p. 19.
} 
Durante o IV Congresso de Engenheiros e Arquitetos, realizado em Roma em 1883, Camillo Boito, contando com contribuições de diversos profissionais, levantou questões-chave que contribuiriam para a formulação de um conjunto de diretrizes sobre a matéria. Segundo o documento resultante do Congresso

[...] os monumentos arquitetônicos do passado, não valem somente ao estudo da arquitetura, mas prestam-se, como documentos essenciais, a esclarecer e ilustrar a história dos diversos povos e tempos, e por conseguinte devem ser respeitados e mantidos com escrúpulo religioso, exatamente como documentos, nos quais uma ligeira modificação que possa parecer obra originária, causa o engano e conduz à deduções erradas. ${ }^{74}$

Tal documento é considerado como a primeira carta de restauração italiana e influenciará sobremaneira o ambiente cultural posterior. $O$ texto reúne uma série de orientações que vinham sendo teorizadas há anos como a preferência pela consolidação em detrimento do reparo, e do reparo ao invés da restauração, tema já destacado por Adolphe Didron, ou a realização de acréscimos e renovações, quando indispensáveis, com materiais diferentes dos originais, princípio de certa forma observado por Valadier na restauração do Arco de Tito. Outra questão destacada, a simplificação das formas e ornamentos que tenham sido reconstruídos com o intuito de não causar enganos, também comparecera, preliminarmente, no ambiente francês a partir das considerações de Quatremère de Quincy, assim como a documentação de todo o processo de restauração, por meio de levantamentos fotográficos e desenhos das várias fases de trabalho, prática em parte já adotada pela Comissão de Monumentos Históricos da França ${ }^{75}$. Nesse sentido destaca-se ainda a sugestão de construir-se uma lápide sobre o monumento com a data das intervenções realizadas. Deve-se ainda a Camillo Boito e aos debates do referido Congresso, a

\footnotetext{
${ }^{74}$ BOITO, C. Questioni pratiche..., pp. 28-30, apud CARBONARA, G., op. cit., p.209. Trad. nossa. "[...] i monumenti architettonici del passato, non solo valgono allo studio dell'architettura, ma servono, quali documenti essenzialissimi, a chiarire e ad illustrare in tutte le sue parti la storia dei vari popoli e dei vari tempi, e perciò vanno rispettati e serbati con iscrupolo religioso, appunto come documenti, in cui una modificazione anche lieve, la quale possa sembrare opera originaria, trae in inganno e conduce via a via a deduzione sbagliate."

${ }^{75}$ Ainda com relação ao contexto francês e para ressaltar a circulação de idéias no período, cabe destacar a moção votada no Congresso Internacional realizado anos mais tarde em Paris, a qual propunha que: “...todas as vezes em que se intervier em uma obra de arte, [...] o autor da restauração, assistido de uma comissão composta de arqueólogos, pintores, escultores e arquitetos, elabore um duplo memorial relatando, pormenorizadamente, o estado dessa obra antes e depois da restauração [...]”. Le Congrès International pour la Protection des Oeuvres d'Art et des Monuments tenu à Paris en 1889. L'Emulation, n.10, col.149. Bruxelles, 1889, apud KÜHL, B. M. Arquitetura do ferro e arquitetura ferroviária em São Paulo. São Paulo: Ateliê, Fapesp, Secretaria da Cultura,1998, p. 194.
} 
atribuição do caráter de norma a princípios-chave no desenvolvimento posterior da matéria como a mínima intervenção, principalmente com relação às obras de consolidação, e a manutenção das diversas estratificações da obra. ${ }^{76}$ Dessa forma, o conjunto de diretrizes enunciadas por Boito permitiram o estabelecimento dos fundamentos críticos da restauração como disciplina. De fato, mesmo após as contribuições e releituras posteriores, suas bases conceituais permanecem válidas até hoje.

No campo prático, no entanto, nem sempre esses critérios foram objetivamente perseguidos e a busca pelo embasamento dos projetos em fontes documentais por vezes conduziu a interpretações subjetivas. Nesse sentido, Miarelli Mariani considera inadequado o termo 'restauro histórico’ para designar uma categoria autônoma da restauração já que a existência e a recorrência a dados documentais sobre a obra não bastaram para garantir a objetividade dos resultados das intervenções. Segundo o autor, a recorrência dos chamados 'restauradores históricos' a integrações analógicas, ou até mesmo fantasiosas, dos dados documentais, melhor os classificaria como adeptos de uma variante do restauro estilístico. ${ }^{77}$ Algumas obras dos arquitetos Luca Beltrami e Gaetano Moretti podem ser destacadas como exemplos nesse sentido. $^{78}$

Outro aspecto de suma importância na obra de Camillo Boito foi a sua receptividade no campo da política italiana voltada à tutela dos monumentos, orientando a formulação da Lei n. 185, a Lei para a conservação dos monumentos e dos objetos de antigüidade e de arte, aprovada em 1902. Segundo Ceschi, a Lei n. 185 pode ser considerada uma das mais completas do mundo em seu tempo e uma das primeiras a contemplar, ainda que sutilmente, aspectos relacionados à tutela ambiental, temas que somente em 1931, com a Carta de Restauro de Atenas, seriam mais bem elaborados e difundidos internacionalmente, mérito devido a Gustavo Giovannoni.

O artigo 13 da Lei n.185 dizia:

\footnotetext{
${ }^{76}$ Para um panorama geral do IV Congresso de Engenheiros e Arquitetos e referências a outros autores que contribuíram neste debate, consultar SETTE, M. P., op. cit., pp.188-192.

77 MIARELLI MARIANI, Gaetano. Monumenti nel tempo. Per una storia del restauro in Abruzzo e nel Molise. Roma: Carucci, 1979, p. 112, apud SETTE, M. P., op. cit., p. 193.

${ }^{78}$ Dentre os projetos de Luca Beltrami, destaca-se a reconstrução da torre do Castelo Sforzesco em Milão, realizada no final do século XIX com base na interpretação subjetiva de desenhos antigos pouco precisos. De Gaetano Moretti, destaca-se a finalização do projeto de reconstrução em estilo do campanário de São Marco, em Veneza, concluída em 1912. SETTE, M. P., op. cit., pp. 212-216.
} 
Nos Municípios nos quais existam monumentos sujeitos às disposições da presente lei, poderão ser prescritos, para os casos de novas construções, reconstruções e ampliações de edifícios, as distâncias e medidas necessárias de modo que as novas obras não danifiquem a perspectiva ou a luz solicitada pela natureza própria dos monumentos. ${ }^{79}$

$\mathrm{Na}$ virada do século, os debates que se seguiram procuraram manter a objetividade alcançada nas análises de Camillo Boito, deixando pouco a pouco para trás a antiga postura de ardorosa denúncia que muitos intelectuais do século XIX adotavam em seus argumentos em defesa dos monumentos. Por outro lado, como vimos, a teórica objetividade da chamada 'restauração filológica' abriu caminho para uma perspectiva diferenciada em relação às obras do passado na qual a valorização do caráter histórico e artístico das obras adquire prioridade. Nova perspectiva, no entanto, não isenta de novos desafios. A atribuição do status documental como primordial em relação aos monumentos colocou os restauradores de fronte a uma série de novos questionamentos como a identificação e o reconhecimento dos valores envolvidos - e de suas especificidades - em bens agora considerados de modo mais complexo. Nesse sentido, a insuficiência de referências conceituais, como a própria dificuldade na determinação precisa da idéia de valor, ou a carência de estudos críticos e historiográficos que pudessem alicerçar as condutas e escolhas a serem tomadas, são destacados como os principais obstáculos para a fruição dessa desejada objetividade, por vezes substituída por atitudes de certa forma intuitivas, como afirma M. P. Sette:

$\mathrm{Na}$ realidade, as operações de reconhecimento são realizadas geralmente de modo intuitivo e parcial não somente devido à falta de quadros conceituais de referência mas também devido às incertezas relativas à própria idéia de valor, especialmente quando esse valor refere-se a aspectos históricos, estéticos e simbólicos. A primeira dificuldade está ligada a uma condição largamente inadequada da historiografia e da crítica, especialmente arquitetônica; a segunda refere-se à definição dos valores a serem determinados em uma obra. ${ }^{80}$

\footnotetext{
${ }^{79}$ Legge italiana n. 185, 12 giugno 1902, art. 13, apud CESCHI, Carlo. Teoria e storia del restauro. Roma: Bulzoni, 1970, p. 110. Trad. nossa. "Nei Comune nei quali esistono monumenti soggetti alla disposizioni della presente legge, possano essere prescritte, per i casi di nuove costruzioni, ricostruzioni ed alzamenti di edifici, le distanze e misure necessarie allo scopo che le nuove opere non danneggino la prospettiva o la luce richiesta dalla natura dei monumenti stessi”. Anos mais tarde esta lei será substituída pela Lei n.364, de 20 junho de 1909, que retoma as mesmas considerações com poucas alterações. Sobre a legislação concernente à tutela ambiental e paisagística na Itália, ver: GURRIERI, Francesco et al. Il restauro del paesaggio: dalla tutela delle bellezze naturali e panoramiche alla governance territoriale - paesaggistica. Firenze: Alinea, 2005.

${ }^{80}$ SETTE, M. P., Profilo Storico..., op. cit, p. 221. Trad. nossa. "In realtà, le operazioni di riconoscimento vengono compiute perlopiù in modo intuitivo e parziale non soltanto per la mancanza di quadri concettuali di
} 
Outra questão que ganha corpo nesse contexto - e que está no cerne do moderno conceito de restauração que então despontava - é a capacidade do monumento de satisfazer as exigências práticas da contemporaneidade, ou seja, a relação entre a conservação de um edifício antigo (ou a restauração, quando necessária) e a sua funcionalidade no presente. Às indagações anteriormente citadas, somam-se, portanto, os questionamentos associados à compatibilidade de usos e à definição de limites nesse sentido nas intervenções de restauração. Além das considerações desenvolvidas décadas atrás, como as orientações de Viollet-le-Duc que defendera o constante uso de um edifício como instrumento eficaz para sua conservação, merecem destaque, no contexto dos debates em andamento no final do século XIX, as formulações do belga Louis Cloquet (1849-1920).

O autor sugeriu a distinção das obras arquitetônicas em duas categorias cujas particularidades associam-se em grande parte à questão do uso na contemporaneidade. Nesse sentido, dividiu-as entre monumentos 'mortos' e monumentos 'vivos' e propôs critérios específicos de intervenção para cada caso. Os monumentos 'vivos' seriam aqueles ainda em uso e os monumentos 'mortos', aqueles que chegaram até nós como recordações de épocas passadas ou como documentos de arte, mas que não comportariam mais a restituição aos seus usos originais, como as ruínas antigas ou determinadas estruturas medievais. Não se trata, no entanto, de uma questão de antigüidade, já que alguns monumentos antigos - como o Panteon romano ou catedrais medievais - puderam conservar o seu uso original na atualidade sendo, portanto, considerados como monumentos 'vivos'. Nesses casos, o autor defende que além do interesse histórico, arqueológico ou estético das obras, deve ser priorizada a manutenção dessa utilidade original. Segundo o autor, são obras que "mesmo devendo durar, devem também servir", logo, "o ponto de vista arqueológico e pitoresco passa para segundo plano", sendo ainda lícito agir sobre esses monumentos de modo a "desenvolvê-los ou acrescentá-los em razão de suas modernas funções". ${ }^{81}$

Sendo assim, Cloquet, ao seu modo, legitima a restauração como um instrumento por vezes necessário para reportar o monumento ao presente, adaptando-o conforme as necessidades de uso atuais, porém, sempre respeitando o que chamou de "alma do

riferimento ma anche per le incertezze concernenti l'idea stessa di valore, specialmente quando queste valore riguardano aspetti storici, estetici, simbolici. La prima difficoltà é legata ad una condizione largamente inadeguata della storiografia e della critica, specialmente architettoniche; la seconda riguarda la definizione dei valori da individuare nell'opera".

${ }^{81}$ CLOQUET, Louis. La restauration des monuments anciens. Revue de l'Art Chrétien, 1901, pp. 498-503, apud CARBONARA, G., Avvicinamento..., op. cit., p. 191 et seq. 
monumento", assim como as suas características enquanto documento de arte e de história. Considera, dessa forma, os monumentos 'vivos' antes de tudo como obras funcionais, às quais deve-se prever não apenas a conservação de suas características primitivas, mas também as adaptações requisitadas pela atualidade.

Deve-se fazer, para esses edifícios, não apenas os trabalhos apropriados para lhes restituir a fisionomia primitiva e depois assegurar a sua conservação, mas também as obras necessárias para que sejam apropriados ao emprego atual [...]. Deve-se, portanto, repudiar por completo nesse caso a fórmula: conservar, não restaurar. Deve-se conservar, restaurar $\mathrm{e}$, mesmo, às vezes, aumentar [...]. ${ }^{82}$

Mas adverte, "isso deve ser feito somente quando necessário", e sempre respeitando "os vestígios da antiga arte e da história local que nele permanecem impressas", bem como "a alma do monumento, o caráter que lhe é próprio, seu estilo, e aquele que coloca a mão sobre ele deve se considerar como um continuador do artista que o concebeu". ${ }^{83}$ Nos trechos destacados, observamos que o autor compartilha da abertura teórica que se observa no final do século - que atenta para o caráter documental da obra mas carrega ainda certa orientação vinculada ao restauro estilístico, conceito ainda bastante arraigado na prática intervencionista francesa do período.

$\mathrm{Na}$ realidade, de modo algum o esboço cronológico que aqui apresentamos pressupõe a superposição de teorias ou práticas novas em detrimento das anteriores. Ao longo de todo o período enfocado, e mesmo ao longo do século $\mathrm{XX}$, como veremos, a continuidade das discussões permitiu o aprofundamento de determinados temas mas sempre em paralelo convívio com a permanência de antigas leituras. Estas, dependendo da situação, se por vezes solidificaram abordagens ultrapassadas, por vezes também puderam permitir a retomada de certos aspectos eventualmente negligenciados em determinados contextos.

Cabe ainda ressaltar que justamente com relação às considerações sobre o conceito de 'estilo' artístico, o momento histórico ora abordado assistia a importantes

\footnotetext{
${ }^{82}$ CLOQUET, L. op. cit., apud KÜHL, B. M., Preservação... op. cit., pp.124-125. Quanto a este aspecto em particular, é interessante destacar a complementação proposta por Cloquet à famosa máxima de Adolphe Didron: "Quando se trata de monumentos mortos, deve-se, dizemos nós, antes consolidar do que reparar, antes reparar do que restaurar, quando se trata de monumentos vivos, antes restaurar do que refazer, antes refazer do que embelezar."

${ }^{83}$ CLOQUET, L. apud KÜHL, B. M. Preservação... op. cit., p. 125.
} 
questionamentos. Ao longo da segunda metade do século XIX, era prática corrente a busca pela classificação de escolas específicas no campo das artes originando a conseqüente vinculação desses estudos, e da própria restauração neste contexto, à predileções de estilo. Segundo interpretações da historiografia da arte, tal atitude deveu-se ao particular ambiente cultural do período, quando o progresso da ciência e os seus desdobramentos alimentaram uma visão determinista da sociedade e de seus produtos culturais. Na virada do século diversos teóricos opõem-se a tais métodos, bem como às preferências por conteúdos de épocas precedentes, e abrem caminho para a interpretação das manifestações artísticas como linguagens expressivas e não unicamente como produtos imediatos de um meio histórico e cultural determinado. Os estudiosos da chamada escola de Viena, autores da teoria da pura-visualidade, como Konrad Fiedler, Adolf von Hildebrand, Alois Riegl, Heinrich Wölfflin, Max Dvořák, Franz Wickhoff, entre outros, integram esse grupo. ${ }^{84}$

Nesse contexto, no campo da historiografia da arquitetura e nos desdobramentos paralelos sobre a preservação e a restauração arquitetônica, ganham força as interpretações que valorizam e reinterpretam as contribuições artísticas de diferentes períodos, os então chamados estilos, a partir de suas identidades visuais. E esse passo qualitativo não se volta apenas aos evidentes atributos documentais associados às consecutivas estratificações de uma obra. A questão estética, tema já enunciado por Camillo Boito, adquire cada vez mais espaço nessa discussão. De certa forma, esse estado de coisas também abrirá caminho para a compreensão das qualidades figurativas do ambiente urbano, uma vez que o conjunto formado pelas arquiteturas urbanas, pela sua própria natureza aglutinativa, é a manifestação, agora artística, que melhor permite a visualização desses variados períodos e a harmonização entre suas respectivas identidades expressivas. ${ }^{85}$ Essa questão será enunciada, sob diferentes aspectos, pelos estudiosos da chamada estética urbana - entre outros Camillo Sitte e Charles Buls - personagens que abriram caminho para a apreensão das qualidades compositivas dos conjuntos construídos e, conseqüentemente, para o delineamento do conceito de patrimônio urbano.

Charles Buls (1837-1914), estudioso interessado na preservação do patrimônio e figura política em Bruxelas, ofereceu interessantes análises sobre o panorama da discussão no período e contribuiu para o amadurecimento da questão não apenas no que tange à

\footnotetext{
${ }^{84}$ ARGAN, Giulio Carlo e FAGIOLO, Maurizio. Guia de História da Arte. Trad. M. L. Gonçalves de Azevedo. Lisboa: Estampa, 1994, pp. 90-93.

${ }^{85}$ Esta questão foi sutilmente enunciada em BULS, Charles. Le nationalisme dans l'art. S.1.: s.n, s.d, p.6.
} 
formulação de regras sobre a intervenção em edifícios antigos - com base no aprofundamento de alguns temas enunciados por Cloquet -, mas sobretudo com relação ao estudo da cidade como organismo histórico dotado de atributos estéticos, tema que desenvolveu com grande maestria a partir dos estudos de Camillo Sitte.

Quanto à conservação e restauração dos monumentos, Buls retoma a distinção sugerida por Cloquet entre monumentos 'vivos' e 'mortos' e propõe diretrizes para a atuação sobre os mesmos em diferentes situações ${ }^{86}$. De certa forma, a necessidade de formular regras e delimitar conceitos - atitude que já observávamos desde os escritos de Camillo Boito -, apresenta-se de modo incisivo nas preocupações de diversos autores no início do século XX, sendo Alois Riegl, anos mais tarde, um dos grandes articuladores da questão nos campos prático e conceitual.

Quanto à contribuição classificatória de Buls, no entanto, destaca-se a distinção dos monumentos em cinco categorias de acordo com o estado de conservação, caracterização após restaurações anteriores e inserção no tecido urbano ${ }^{87}$. Para cada categoria são apresentadas considerações especiais e sugeridos os meios de intervenção adequados com a clara predominância dos aspectos conservativos, quesito no qual fica evidente a repercussão do pensamento de John Ruskin. Sendo assim, as imposições associadas às questões de uso, de certa forma priorizadas por Cloquet, passam para segundo plano. As diretrizes propostas evidenciam, portanto, a importância histórica e estética das obras. E toda a argumentação inicial do autor aponta neste sentido. Ao discorrer sobre a importância das obras do passado, destaca o valor documental e toma de empréstimo a mesma analogia empregada por Victor Hugo e Carlo Cattaneo na qual o monumento é como um livro: “[...] estes velhos monumentos falam mais alto que os livros, pois estão abertos diante de todos os olhos", e são, portanto, instrumentos de conhecimento, já que "o estudo das coisas de ontem constitui o ensino das coisas de

\footnotetext{
${ }^{86}$ BULS, Charles. La restauration des monuments anciens. Bruxelles: Weissenbruch, 1903. Para uma ampla análise das contribuições teóricas e práticas de Charles Buls nos campos da estética, da preservação e da urbanística, consultar: SMETS, Marcel. Charles Buls: i principi dell'arte urbana. Roma: Officina, 1999; GIAMBRUNO, Mariacristina. L'opera di Charles Buls: dall'estetica delle città al restauro dei monumenti. Ananke, nuova serie, N. 31, 2001, pp. 46-52.

${ }^{87}$ Resumidamente, o autor classifica os edifícios em: 1. Intactos; 2. Negligenciados (subdivididos em três casos: edifícios semi-arruinados mas que possuem documentação precisa, edifícios dos quais restam apenas fragmentos e edifícios dos quais não restam nem fragmentos, nem documentos); 3. Monumentos restaurados ou completados posteriormente em outro estilo; 4. Monumentos inacabados e 5. Monumentos não restauráveis. BULS, C. op. cit, pp. 11-33. Para esclarecimentos sobre as diretrizes conservativas propostas para cada categoria, consultar KUHL, B. M., Preservação... op. cit., pp. 126-127.
} 
amanhã". ${ }^{88}$ Nesse sentido, dentre os princípios sugeridos destacam-se aqueles voltados à conservação da obra como documento: a mínima intervenção, a atenção aos aportes construtivos de todas as épocas e estilos e muita cautela na realização de quaisquer recomposições. Logo, não condena a restauração e até mesmo sugere que sejam seguidas as regras de Viollet-le-Duc, desde que guiadas por documentação precisa e, ainda assim, sem exageros. Tece também importantes considerações sobre a necessidade de ampliações ou obras anexas e preconiza, nestes casos, que se busque uma transição entre a parte antiga e a parte nova que deverá ser marcadamente moderna. ${ }^{89}$

De grande interesse para a presente abordagem, no entanto, são as considerações de Buls com relação ao monumento e o entorno. Com grande sensibilidade, o autor retoma mais uma vez a apreciação dos tecidos urbanos medievais como fonte da argumentação a favor da manutenção dos conjuntos construídos em sua inteireza compositiva e contra a prática que então começava a despontar, de isolar os monumentos para promover a sua ampla visualização. Segundo o autor, a proximidade entre as edificações e as ruas e praças estreitas da cidade medieval criavam um cenário característico no qual o monumento, uma catedral gótica no caso, inseria-se perfeitamente pois fora projetado para compor este quadro. As dimensões monumentais de uma catedral e o seu domínio sobre a paisagem circundante dependiam, portanto, desta composição peculiar.

As igrejas góticas, construídas em uma época em que as ruas apertadas entre as muralhas de uma cidade fechada formavam uma rede de vias tortuosas e estreitas, estavam naturalmente adaptadas a este quadro restrito que ascendia em direção ao céu; tinham assim adquirido a agudeza vertical que é a sua característica e sua própria poesia. ${ }^{90}$

Considerando este contexto único, um projeto de restauração de uma catedral gótica que propusesse a retirada das edificações que a circundam causaria um prejuízo irreversível pois alteraria a relação de escala e a harmonia do conjunto que lhe conferia a característica grandiosidade. Ademais, tal intervenção seria ainda um contra-senso, um

\footnotetext{
${ }^{88}$ BULS, C. La restauration..., op. cit, pp. 6-7. Trad. nossa. "Ces vieux monuments parlent plus haut que les livres, car ils sont ouverts devant tout le yeaux. [...] L'étude des choses d'hier constitue l'enseignement des choses de demain".

${ }^{89}$ KÜHL, B. M., Preservação..., op. cit, p. 127; CARBONARA, G., op. cit., p.199.

${ }^{90}$ BULS, C. La restauration ..., op. cit., p. 50. Trad. nossa. "Les églises gothiques, construites à une époque oú les rues ressérrées entre les remparts d'une ville fermée formaient un lacis de voies tortueuses et étroites, s'étaient naturellement adaptées à ce cadre restreint en montant vers le ciel; elles avaient ainsi acquis l'élancement vertical qui est leur caractéristique et leur poésie propre."
} 
equívoco conceitual, já que, sendo a restauração, segundo grande parte das definições da época, um ato que pretende restabelecer algo destruído, não faria sentido promover um isolamento que na verdade nunca existiu.

A igreja envolvia com seus braços as humildes residências e unia-se assim às outras habitações da cidade.

Por isso, as igrejas das cidades medievais quase nunca estavam isoladas; soldavam-se aos edifícios de uma sala capitular, de um claustro, de uma diocese, de um asilo, e é um prejuízo moderno querer libertá-las.

Isolar as igrejas não constitui por conseguinte uma restauração, pois a palavra supõe o restabelecimento de uma coisa destruída; ora, o isolamento dessas igrejas em geral nunca existiu. ${ }^{91}$

A questão fica ainda mais clara em suas considerações sobre as obras de reconstrução do campanário da Praça São Marco, em Veneza, tema que propagou grande polêmica na primeira década do século XX. Buls criticou um dos projetos que propunha a reconstrução fora da praça, em local diferente de sua implantação original, com o intuito de liberar a visualização da catedral $^{92}$. Tal proposta significaria a alteração de uma composição única e harmônica, obra de artistas do passado em diferentes momentos históricos, cada qual agindo segundo as orientações estéticas próprias de seu tempo. É evidente, nesse aspecto, a influência direta dos ensinamentos de Camillo Sitte, um dos primeiros arquitetos a discutir a composição urbana a partir de seus atributos estéticos. No trecho em destaque, Buls remete textualmente a Sitte - que anos antes exaltara a perfeição e beleza compositiva da praça e do próprio campanário - e frisa a afiliação aos seus pressupostos em defesa da manutenção dessa paisagem.

Alguns arquitetos estrangeiros propuseram reconstruir o campanário fora da Praça São Marco, atrás ou ao lado da igreja, afim de que a sua fachada fosse visível de todos os pontos da praça. Sempre a obsessão irracional da liberação! eles pretenderam corrigir a obra do tempo e do sentido estético daqueles que lá plantaram o campanário. "Que

\footnotetext{
${ }^{91}$ BULS, C., op. cit., p.17. Trad. nossa. "L'église enveloppait de ses bras les humbles demeures et se rattachait ainsi aux autres habitations de la cité. Aussi, les églises des villes du moyen âge n'etaient-elles presque jamais isolées; elles se soudaient aux bâtiments d'un chapitre, d'un cloître, d'un évêché, d'un hospice et c'est un préjugé moderne de vouloir les dégager. Isoler les églises ne constitue donc pas une restauration, car le mot suppose le rétablissement d'une chose détruite; or, leur isolement n'a généralement pas existé."

${ }^{92}$ O campanário ruiu completamente em 1902. A partir de então, surgiram diversos projetos propondo a sua reconstrução de diferentes maneiras, inclusive em um novo local, fora da praça. Após grandes polêmicas sobre como e onde construí-lo, finalmente decidiu-se por manter o local de origem. As obras foram concluídas por volta de 1912. Sobre esse tema, ver CARBONARA, G., op. cit., pp. 183-186.
} 
pesadelo para um artista!" gritaremos nós junto ao Sr. Sitte, o sábio autor de A Arte de construir, associando-nos à sua admiração pelo quadro que este conjunto único oferecia ${ }^{93}$.

$\mathrm{Na}$ virada do século, como vimos, os desdobramentos teóricos nos campos da história da arte e da filosofia ofereciam novos instrumentos conceituais para a abordagem das questões relacionadas à atuação sobre os monumentos. Além das proposições filosóficas em resposta às idéias positivistas difundidas ao longo da segunda metade do século XIX - a exemplo dos estudos da fenomenologia ${ }^{94}$ - no campo das artes visuais, a linguagem artística começou a ser analisada como expressão de idéias. Tal abertura permitiria grandes transformações conceituais, como a gradativa valorização de todos os estilos e a superação da tradicional distinção entre artes 'menores' e 'maiores'. É neste contexto de novas abordagens que o advogado e historiador da arte Alois Riegl (18581905 ) desenvolveu seus estudos sobre a preservação e a restauração dos monumentos.

Em seus escritos sobre história da arte, Riegl evidencia a impossibilidade do valor artístico absoluto e abre caminho para a valorização de todas as artes consideradas de modo universal. Tal convicção é alicerçada pela definição de dois princípios estéticos fundamentais, Kunstwollen, traduzido como 'volição de arte' ou 'querer da arte' ${ }^{95} \mathrm{e}$ Volksgeist, ou 'espírito de um povo', entendido como a capacidade de um artista ou de um período de exprimir idéias através da arte. Segundo tais princípios, se cada povo (ou período) possui sua própria cultura - sua cosmologia, filosofia, psicologia, etc - e emprega a linguagem artística para expressar suas idéias segundo tais orientações, torna-se

\footnotetext{
${ }^{93}$ BULS, Charles. La restauration..., op. cit., pp. 27-28. Trad. nossa. "Quelques architectes étrangers ont proposé de rébatir le campanile en dehors de la place saint-Marc, derriére ou à côté de l'église, afim que sa façade fut visible de tous le points de la place. Toujours l'obsession irraisonnées du dégagement! ils ont prétendu corriger l'oeuvre du temps e du sens esthétique de ceux qui avaient planté là le campanile. 'Quel cauchemar pour un artiste!' nous écrierons-nous avec M. Sitte, le savant auteur de l'Art de Bâtir, en nous associant á son admiration pour le tableau qu'offrait cet ensemble unique.” A obra de Camillo Sitte à qual Buls se refere foi publicada em português com o título A construção das cidades segundo seus princípios artísticos. Trad. Ricardo Ferreira Henrique. São Paulo: Ática, 1992. Sitte disserta sobre as praças de Veneza nas páginas 71 a 74.

${ }^{94}$ Neste sentido, Jukka Jokilehto destaca as contribuições de Friedrich Niezstche, que postula a precariedade de verdades e valores absolutos; e Martin Heidegger, discípulo de Edmund Husserl, que desenvolve considerações sobre as especificidades da arte enquanto linguagem expressiva. Cf. JOKILEHTO, J., op. cit., pp.213-214.

${ }_{95}$ Segundo Marco Petrelli, é difícil estabelecer uma definição precisa para o termo Kunstwollen pois o seu significado parece variar de acordo com o contexto no qual é empregado. $\mathrm{O}$ autor remete a referências bibliográficas específicas sobre a interpretação do termo segundo diversos autores (especialmente na nota 10). PETRELLI, M. Alois Riegl. In: CASIELlO, Stella (Org.). La cultura del Restauro, teorie e fondatori. Venezia: Marsilio, 1996, pp.241-243.
} 
impossível defender que exista uma arte mais ou menos 'bela' do que outra ${ }^{96}$. Esses argumentos preconizariam, ainda, o despontar de um entendimento histórico-crítico dos produtos culturais que estará presente nas posteriores formulações teóricas sobre a restauração, notadamente a partir dos estudos do chamado 'restauro-crítico' e nas 'instâncias' delineadas pelo pensamento de Cesare Brandi. No que coube a Riegl, no entanto, a nova abordagem permitiu-lhe valiosa contribuição na definição moderna de certos termos - como o conceito de monumento histórico - e na análise crítica sobre a recepção desses monumentos pela sociedade e os valores que esta lhes atribui.

Tendo sido encarregado pela autoridade austríaca para reorganizar o serviço de tutela dos monumentos no território do império, Riegl desenvolveu um estudo introdutório onde procurou delimitar os valores associados ao patrimônio e definir conceitos até então empregados de modo vago ou pouco criterioso. Suas análises, reunidas na obra $O$ culto moderno dos monumentos $^{97}$, publicada em 1903, além da enunciação de certos aspectos normativos e conceituais, contemplam ainda importantes reflexões sobre a definição de patrimônio histórico e o seu papel na sociedade, reunindo elementos para a consolidação da preservação como um campo disciplinar autônomo. Dessa forma, seu trabalho teórico contribuiu para o deslocamento da discussão em uma nova direção, não mais centrada no conflito, até então predominante nesse debate, entre as posições conservacionistas e as intervencionistas, ou seja, entre a defesa da conservação ou a legitimação da restauração. ${ }^{98}$ Não obstante o caráter moderno e inovador de sua obra no contexto cultural do início do século XX, cabe ressaltar que sua interpretação e discussão são fatos recentes. Segundo observa Scarrocchia, somente a partir da década de 1980 o estudo da obra de Riegl ganhou repercussão na Itália e nos principais países europeus, notadamente após as primeiras traduções d' $O$ Culto Moderno, quando a obra adquiriu atualidade, dentre outros aspectos, a partir do diálogo com a teoria brandiana. ${ }^{99}$

Dentre os aspectos inovadores de seus estudos destaca-se a busca por uma categorização dos diferentes 'valores' atribuídos aos monumentos, considerando não

\footnotetext{
${ }^{96}$ ARGAN, G. C.; FAGIOLO, M., op. cit., pp. 91-92.

${ }^{97}$ Neste estudo utilizaremos a versão francesa: RIEGL, Aloïs. Le culte moderne des monuments, son essence et sa genèse. Trad. Daniel Wieczorek. Paris: Seuil, 1984 [1 $1^{\mathrm{a}}$ ed. 1903]. Para maiores aprofundamentos sobre a obra de Riegl, consultar: SCARROCCHIA, Sandro. Alois Riegl: teoria e prassi della conservazione dei monumenti. Bologna: Accademia Clementina di Bologna, 1995.

${ }^{98}$ KÜHL, B. M., Preservação..., op. cit., p. 43; SCARROCCHIA, S. Alois Riegl..., op. cit., pp.91-110.

${ }^{99}$ SCARROCCHIA, S. La ricezione della teoria della conservazione di Riegl fino all'apparizione della teoria di Brandi. In: ANDALORO, Maria (Org.). La teoria del restauro nel novecento da Riegl a Brandi. Firenze: Nardini, 2006, pp. 35-36. A este respeito, consultar ainda PETRELLI, M., op. cit., pp. 250-251.
} 
apenas a informação histórico-artística sobre os mesmos, mas também a maneira como a sociedade os percebe e recebe de acordo com os preceitos contemporâneos. Para tanto, inicia o tema procurando distinguir dois tipos específicos de monumentos: o chamado 'monumento intencional', construído com um intento específico de rememorar um acontecimento, um personagem; e o 'monumento não-intencional' ou 'involuntário' que, além dos objetivos específicos daqueles que originalmente o construíram, adquiriu posteriormente o caráter de monumento devido à atribuição de novos 'valores' por uma dada sociedade. São esses valores que Riegl procurou definir. Propôs, para tanto, uma divisão em dois grupos principais, os valores de 'rememoração' e os valores de 'contemporaneidade'. Dentre os chamados valores de rememoração, distinguiu ainda o valor de antigüidade (ou valor 'de antigo'), o valor histórico e o valor de rememoração intencional. Dentre os valores de contemporaneidade, subdividiu-os em valor de uso, valor artístico, valor de novidade e valor artístico relativo. Para cada categoria, que muitas vezes sobrepõe-se ou contrapõe-se, o autor desenvolveu uma série considerações e proposições.

Segundo a classificação de Riegl, o valor histórico é aquele com maior amplitude pois engloba "tudo aquilo que foi e hoje não é mais", considerando-se ainda o caráter irreproduzível do passado, bem como o papel insubstituível de cada um de seus testemunhos como um elo numa cadeia de desenvolvimento. ${ }^{100}$ Considera ainda que, segundo a moderna concepção de história, qualquer atividade humana que represente um testemunho deste desenvolvimento pode reivindicar um valor histórico. A partir desta asserção, conclui que todo monumento de arte é necessariamente um monumento histórico já que representa um percurso específico daquela arte neste contexto de desenvolvimento considerado. Da mesma forma, todo monumento histórico é também um monumento artístico pois, além de seu caráter documental - amadurecido sobretudo a partir das proposições do século XIX, apresenta também um certo número de elementos artísticos. Neste ponto, o autor desenvolve uma interessante reflexão sobre os traços, ou sinais artísticos então considerados 'menores'. Argumenta que, mesmo quando aparentemente os traços remanescentes de qualquer informação artística pareçam ser insignificantes, eventualmente tais traços podem ser os únicos exemplares daquela informação, daquela atividade artística naquele tempo, o que o torna especial e indispensável.

\footnotetext{
${ }^{100}$ RIEGL, A. Le culte moderne..., op. cit., p.37. Para uma interpretação mais aprofundada dessas passagens, ver CARBONARA, G. Avvicinamento..., op. cit., p. 219.
} 
No universo teórico de Riegl, portanto, observamos a inadequação do emprego dos termos monumento histórico e monumento artístico separadamente. Na citada sobreposição de categorias, toda obra artística está classificada como monumento histórico e todos os elementos artísticos presentes em qualquer obra interessam-nos sobretudo do ponto de vista histórico pois, como dito, fazem parte de uma cadeia de transformação na história da arte. São, pois, 'monumentos histórico-artísticos' ou somente ‘monumentos'.

Não obstante o valor histórico-artístico atribuível à todas as obras do passado, como exposto, as obras podem possuir ainda um valor artístico próprio, independentemente do local que ocupem nesta seqüência de transformações, ou seja, um valor artístico além de sua antigüidade ou raridade. O que definirá esse valor será a recepção contemporânea da obra, ou seja, o juízo daquele que a vê, em seu tempo e de acordo com suas próprias prerrogativas: pessoais e subjetivas, logo, mutáveis. Esse valor artístico próprio, conferido pelo moderno observador, se explica pelo fato de que certas obras antigas correspondem ao moderno Kunstwollen (volição de arte), ou seja, aproximam-se dos ideais figurativos do presente. Possuem, portanto, um valor relativo e contemporâneo destinado a mudar continuamente de sujeito a sujeito ou de momento a momento. Assim, não existe um valor artístico absoluto, somente relativo, concebido na contemporaneidade e bem diverso, portanto, do valor enquanto memória, concebido como um valor objetivo e inerente ao monumento. ${ }^{101}$

Um dos pontos mais inovadores de sua teoria é a consideração desta recepção. $\mathrm{O}$ monumento e a sua interpretação são reportados ao presente, analisados de acordo com a sua recepção pelo sujeito contemporâneo, ou seja, os monumentos não adquirem valores por si próprios, não existe 'monumento' sem o receptor, sem a cooperação interpretativa de um interlocutor, de um sujeito moderno. Ainda considerando o papel da contemporaneidade sobre o monumento, Riegl discorre sobre o 'valor de uso' atribuído aos monumentos que mantém a capacidade de satisfazer as necessidades práticas ou espirituais, quer seja por meio da conservação de suas funções antigas, quer seja pela coerente adaptação a novos usos. Logo, a satisfação das necessidades de uso faz parte do processo natural de desenvolvimento do monumento no tempo. Ao lado do valor de uso, destaca ainda o 'valor artístico'. Este poderá ser, como vimos, um 'valor artístico relativo', caso a obra antiga corresponda com o moderno Kunstwollen; ou ainda um 'valor de

${ }^{101}$ CARBONARA, G. Avvicinamento..., op. cit, pp. 219-220. 
novidade' que equivale à apreciação pela aparência fresca e intacta, como a de uma obra nova.

Dentre os valores de rememoração, Riegl destaca o 'valor de antigüidade', o valor atribuído às obras que, pela ação do tempo e do homem, chegaram até nós de modo diverso de sua forma original. É o caso das ruínas e dos sinais impressos sobre a obra, as estratificações, que nos dão a idéia do curso natural do tempo. Diferentemente do valor histórico que pressupõe um saber, o 'valor de antigo' baseia-se num sentimento que não depende de qualquer mediação cultural, de nenhum conhecimento prévio. Dessa forma, prevalece sobre o valor histórico pois, além de ser percebido de imediato por todos, ainda repousa sobre as obras de qualquer fase da produção humana.

$\mathrm{O}$ valor de antigüidade prevalece portanto à evidência sobre o valor histórico, que repousa sobre um fundamento científico e é, por conseguinte, acessível por intermédio de um esforço de reflexão. $\mathrm{O}$ valor de antigüidade, manifesta-se imediatamente à percepção ótica mais superficial, e direciona-se portanto diretamente à sensibilidade. Certamente, o conhecimento científico foi outrora a raiz comum do valor de antigüidade e do valor histórico; mas o valor de antigüidade quer precisamente pôr as conquistas da ciência ao serviço de todos, e tornar acessível ao sentimento aquilo que o intelecto elaborou. ${ }^{102}$

Dentre as variadas abordagens possíveis da complexa obra de Riegl, evidencia-se a maturação de pressupostos críticos até então nunca tão claros. A consideração concomitante de cada um dos valores descritos pode provocar ambigüidades $\mathrm{e}$ contrariedades na ação prática de conservação: o valor de antigüidade poderá anular o valor de novidade, o valor de uso poderá contrariar o valor histórico ou o valor artístico relativo... Mas esses impasses não são insolúveis. A necessidade de atentar para esses valores simultâneos e por vezes antagônicos, implicará na realização de escolhas, na busca por soluções críticas baseadas na observação das especificidades de cada monumento e na sua inserção em um determinado contexto social e cultural. A partir de tais contestações, a preservação e a restauração não deverão mais prescindir das considerações acerca do conjunto de valores reconhecíveis em uma obra. Segundo Choay:

\footnotetext{
${ }^{102}$ RIEGL, A. Le culte moderne..., op. cit., pp. 71-72. Trad. nossa. "La valeur d'ancienneté l'emporte donc à l'evidence sur la valeur historique, qui repose sur un fondement scientifique, et c'est donc acessible que par l'intermédiaire d'un effort de réflexion. La valeur d'ancienneté, elle, se manifeste immédiatement á la perception optique la plus superficielle, et s'adresse donc directament à la sensibilité. Certes, la connaissance scientifique a été jadis la racine commune de la valeur d'ancienneté et de la valeur historique; mais la valeur d'ancienneté veut précisément mettre les conquêtes de la science au service de tous, et rendre accessible au sentiment ce que l'intelelct a élaboré."
} 
A análise axiológica do historiador vienense funda uma concepção não dogmática do monumento histórico, em harmonia com o relativismo que ele introduziu nos estudos de história da arte. [...] Avaliando o peso semântico do monumento histórico, faz dele um problema da sociedade, ponto central sobre de um questionamento sobre o devir das sociedades modernas. ${ }^{103}$

Ainda fruto desta concepção não dogmática, segue-se a extensão considerável do conceito de monumento gerada de um lado pela possibilidade de atribuir valores a quaisquer obras do passado e, por outro, pela valorização de artefatos 'menores', abarcando diversas evidências que até então não possuíam reconhecimento pela tradicional historiografia da arte. E não seria a própria cidade uma dessas 'evidências' encampadas pela extensão patrimonial? Nesta abertura conceitual, ao instrumentar a valorização de quaisquer indícios do desenvolvimento humano, Riegl permite, apesar de não o afirmar especificamente, o entendimento da estrutura urbana como artefato passível de comportar tais valores. Nesse sentido, é clara a referência riegliana na atividade de tutela encampada pelo historiador da arte Hans Trietze em defesa do centro histórico de Viena após a Segunda Guerra Mundial, conforme afirma Frodl-Kraft:

[...] Baseando-se [Trietze] na teoria dos valores de Riegl (e especialmente no valor de antigüidade) e sobre o conceito de evolução histórica, conduz não à defesa de paradigmas estilísticos, mas sim à defesa do caráter e da forma da cidade e alcança também, conseqüentemente, uma compreensão dos percursos urbanísticos do Historicismo. ${ }^{104}$

A atenção aos valores envolvidos não se limitava ao monumento, procurava ainda abarcar as contrariedades existentes na relação deste com as transformações da sociedade e a conseqüente necessidade de inovação, tema que despontava com grande força diante do recente amadurecimento da disciplina do urbanismo e de suas respectivas experimentações. Nesse sentido, o reconhecimento do valor de antigüidade realizado a partir do contraste com os artefatos modernos - que por sua vez possuíam um valor de novidade - nos reporta à complexa dinâmica que despontava no alvorecer do século XX.

\footnotetext{
${ }^{103}$ CHOAY, F., A alegoria..., op. cit., p.170.

${ }^{104}$ FRODL-KRAFT, Eva. Hans Tietze 1880-1954. ÖZKD, XXXIV, 1980, p. 56, apud SCARROCCHIA, S., La ricezione..., op. cit, p. 43. Trad. nossa a partir da citação em italiano. "Basandosi sulla teoria dei valori di Riegl (e in special modo sul valore dell'antico) e sul concetto di evoluzione storica, lo conduce non alla difesa di paradigmi stilistici, bensì alla difesa del carattere e della forma della città e giunge perciò anche a una comprensione delle vicende urbanistiche dello storicismo."
} 
Tal concepção de valores, ao definir dois conceitos antitéticos porém complementares entre si, decodificava, de certa maneira, as transformações então em curso na cidade moderna, quando a preservação dos monumentos históricos acontecia lado a lado à destruição e reconstrução de algumas cidades européias. ${ }^{105}$ Este conflito estaria na base do que Riegl denominou a "lei estética fundamental da nossa época", quando a relação de oposição e atração entre o valor de antigo e o valor de novidade condicionaria o ciclo natural de transformações do espaço construído:

Em relação ao valor de antigüidade, a lei estética fundamental da nossa época pode ser formulada da seguinte maneira: exigimos da mão do homem que produza obras completas e terminadas, símbolos da lei da criação. Esperamos, pelo contrário, da ação da natureza ao longo do tempo, a dissolução destas obras, símbolo da lei igualmente necessária da degradação. Nas obras recentemente realizadas, os vestígios de degradação (desagregação precoce) obstruem-nos tanto quanto os sinais de uma criação muito fresca (restaurações vistosas) sobre a obra antiga. Está antes bem clara a percepção, em toda sua pureza, do ciclo necessário da criação e da destruição que agrada ao homem do século XX.

E para encontrar o equilíbrio necessário entre os conflitos aí envolvidos, atitude que compete ao culto dos monumentos, seriam então necessárias análises e escolhas baseadas em uma lúcida apreciação dos diversos valores envolvidos.

[...] O conflito parece sem saída: de um lado, a valorização do antigo em si, que condena por princípio qualquer renovação; e, de outro, a valorização do novo em si, que julga incômodo e desagradável qualquer vestígio de antigüidade, que se esforça em suprimir. ${ }^{106}$

Para concluir, Carbonara destaca ainda como uma das grandes contribuições de Riegl a condução dos estudos sobre conservação e restauração, como campo disciplinar,

\footnotetext{
${ }^{105}$ COLQUHOUN, Alan. Thoughts on Riegl. Oppositions, 1982, n. 25, p. 79.

106 RIEGL, A. Le culte moderne..., op. cit op. cit., pp. 66,98. Trad. nossa. "Au regard de la valeur d'ancienneté, la loi esthétique fondamentale de notre époque peut être formulée de la façon suivante: nous exigeons de main de l'homme qu'elle produise des oeuvres achevées et closes, symboles de la loi de la création. Nous attendons au contraire de l'action de la nature au cours du temps la dissolution de ces oeuvres, symbole de la loi également nécessaire de la dégradation. Dans l'oeuvre fraîchement réalisée, les traces de dégradation (désagrégation précoce) nous gênent autant que les signes d'une création tout fraîche (restaurations voyantes) dans l'oeuvre ancienne. C'est bien plutôt la claire perception, dans toute sa pureté, du cycle nécessaire de la création et de la destruction qui plaît à l'homme du XX siècle. [...] Le conflit semble sans issue: d'un côté, la valorisation de l'ancien en soi, qui condamne par principe toute rénovation; et, de l'autre, la valorisation du neuf en soi, qui juge gênante et déplaisante toute trace d'ancienneté, qu'elle s'efforce de supprimer."
} 
ao mesmo patamar das contemporâneas reflexões filosóficas e estéticas. Assim como Boito fora considerado aquele que elevaria os princípios do restauro ao nível da consciência filológica no final do século, Riegl seria aquele que superaria a visão positivista atrelada ao campo da conservação reportando-o às modernas conceituações estéticas, atitude que abriria caminho para os questionamentos do chamado 'restauro crítico', nas figuras de Roberto Pane e Renato Bonelli, bem como para o desenvolvimento da teoria de Cesare Brandi, conforme acenamos. Dessa forma, ao reportar a discussão sobre a conservação ao âmbito dos debates da moderna teoria estética, Riegl elaborou uma rica fundamentação conceitual e buscou indagar sobre as razões do conservar, considerando a temática dentro de um universo disciplinar preciso e com maior autonomia. Suas argumentações, por fim, conduzem a uma atitude crítica e investigativa diante dos desafios impostos pela intervenção, fruto de uma astuta e necessária compreensão do monumento e das particularidades que assim o definem. ${ }^{107}$

Ainda no contexto austríaco, destacamos a contribuição do historiador da arte Max Dvořák (1874-1921), notadamente em seu estudo Catecismo para a tutela dos monumentos, escrito em $1916^{108}$. À luz da teoria de valores de Riegl, e aproximando-se claramente da linha conservacionista, Dvořák discorre sobre as causas da destruição dos monumentos e ressalta a importância de sua tutela com base em argumentos de caráter social e moral, nos lembrando, sob certo aspectos, os recursos literários e interpretativos empregados por John Ruskin. Nesse sentido, levanta o tema do caráter social dos monumentos como principal motivo da tutela, e clama, neste contexto, pela participação do Estado para a efetivação da mesma.

No que tange ao nosso enfoque, chama-nos a atenção a recorrência imediata ao contexto urbano como primeiro argumento e exemplo para explicar o que seria a tutela dos monumentos. No parágrafos iniciais do Catecismo, remete-nos à imaginação de uma cidade hipotética e ressalta as belezas então observadas por aqueles que a visitaram trinta anos antes. Após discorrer sobre as diversas características urbanas que conferiam qualidades estéticas e memoriais à citada cidade, reporta-nos à imaginação do mesmo ambiente urbano no momento da narração, após trinta anos de descaracterizações

${ }^{107}$ CARBONARA, G. Avvicinamento..., op. cit., pp. 226-227.

108 DVǑ̌ÁK, Max. Katechismus der Denkmalpflege, 1916. Neste estudo utilizaremos a versão italiana: Catechismo per la tutela dei monumenti. Trad. Maria Bacci [Estratto della Rivista Paragone n.257, Inserto Redazionale]. Italia Nostra, pp. 1-38, Maggio, 1972 [1 ${ }^{\text {a. }}$ ed. 1916]. Para outras abordagens desta obra de Dvořák, consultar CARBONARA, G. Avvicinamento..., op. cit, pp.261-263. 
provocadas por intervenções de restauro e demolições voltadas às exigências da vida moderna. É evidente em sua argumentação a apreciação dos conjuntos urbanos antigos como verdadeiros monumentos, como conjuntos detentores de atributos patrimoniais associados ao próprio caráter de composição. Nesse sentido, considera com grande sensibilidade as relações de escala existentes entre as edificações e entre os espaços como vias e praças, bem como a importância das diversas estratificações construtivas e a conseqüente sensação de aconchego proporcionada pelos ambientes marcados pelos traços de sua formação, como uma "velha casa de família".

O que é a tutela dos monumentos? Poderia ser explicado com um exemplo.

Quem visitou trinta anos atrás a cidade de $\mathrm{N}$. terá admirado muito o agradável aspecto da antiga e bela localidade. Estava ao centro a antiga igreja gótica já cinza devido aos anos, com a sua torre barroca e uma bela decoração barroca no interior; construção solene e atraente, ligada a mil e mil lembranças. [...] Da igreja, através de um emaranhado de casinhas antigas que faziam parecer ainda mais imponente a antiga paróquia, se alcançava a alegre 'praça da cidade' [...] Amplas e sólidas casas burguesas, sem ornamentos falsos e supérfluos e todavia graciosas, com plantas trepadeiras, e limitadas em altura, se adensavam em seu entorno, submetendo-se com discrição ao aspecto unitário da praça que, homogênea apesar das diversas épocas às quais remontavam os singulares edifícios, suscitava em cada observador de gosto uma impressão de harmonia e em cada pessoa sensível um sentimento semelhante àquele que se prova entrando nos cômodos de uma velha residência de família.

[...] Mas quem a visitou trinta anos atrás, a muito custo saberia hoje reconhecê-la. A antiga igreja paroquial foi 'restaurada'. Foi abatida a torre gótica e substituída por uma nova em falso gótico [...] Mas ainda mais grave foi a devastação ao redor da igreja. As casinhas antigas foram arrasadas ao solo e substituídas por um assim chamado parque no qual murcham alguns arbustos entristecidos.

Assim circundada, também a antiga igreja, a um tempo tão imponente, parece esquálida e triste. $[\ldots]$

As tranquiilas casas burguesas tiveram que ceder lugar à lojas e à casas de aluguel horrendas [...] Mas assim fazendo, fora perdida quase toda a sua antiga beleza, sem que nada igualmente válido fosse-lhe substituído.

Impedir tais perdas e tais devastações é tarefa da tutela dos monumentos. ${ }^{109}$

109 DVOŘÁK, M., op cit., pp. 5-6. Trad. nossa a partir da versão italiana. "Che cos'é la tutela dei monumenti? Lo si potrebbe spiegare con un esempio. / Chi visitò trenta anni fa la cittadina di N. avrà molto ammirato il gradevole aspetto dell'antica e bella località. Ne era il centro l'antica parrocchiale gotica ormai grigia per gli anni, con la sua torre barroca e un bell'arredo barroco all'interno; costruzione solenne a attraente, legata a mille e mille ricordi. / [...] Dalla chiesa, attraverso un groviglio di antiche casette che facevano apparire ancor più imponente l'antica parrocchiale, si giungeva alla ridente 'piazza di città' [...]. Ampie e solide case borghesi, senza ornamenti falsi e superflui e tuttavia graziose, con piante rampicanti, e limitate in altezza, gli si addensavano intorno, sottometendosi con discrezione all'aspetto unitario della piazza che, omogenea com'era nonostante le epoche diverse a cui risalivano i singoli edifici, suscitava in ogni osservatore di gusto un'impressione di armonia e in ogni persona sensibile un sentimento simile a quello che si prova entrando nelle stanze di una vecchia dimora di famiglia. /[...] Ma chi la visitò trent'anni fa a stento saprebbe oggi riconoscerla. L'antica chiesa parocchiale è stata 'restaurata'. È stata abbattuta la torre barroca, sostituita da una nuova in falso gotico $[. .$.$] / Ma ancor più grave è stata la devastazione intorno alla$ chiesa. Le casette antiche sono state rase al suolo e sostituite da un cosidetto parco in cui appassiscono alcuni cespugli intristiti. Così circondata, anche l'antica chiesa, un tempo tanto imponente, appare squallida e triste. / [...] Le tranquille case borghesi avevano dovuto cedere il posto a magazzini e a case di affitto orrende [...] 
No trecho em destaque observamos a reunião de diversos argumentos em favor da conservação dos ambientes antigos, temas que já observávamos de maneira dispersa em vários autores desde meados do século XIX. Tanto nos parágrafos iniciais quanto no decorrer do texto, Dvořák retoma a apreciação dos tecidos urbanos medievais e destaca o aspecto pitoresco das vistas e perspectivas geradas pelo agrupamento dessas construções, assim como a qualidade estética dos conjuntos construídos e da arquitetura 'menor', capaz de proporcionar sensações semelhantes àquelas suscitadas por uma catedral ou por uma obra arquitetônica exemplar. Atenta ainda para a importância de todos os estilos e momentos construtivos, indicando a necessidade de serem preservados todos os estratos das obras, dos ambientes antigos e a própria paisagem.

Ao discorrer sobre a transformação e descaracterização desses ambientes, classifica logo de início o 'restauro' como um ato destruidor. No exemplo da cidade hipotética, a referência ao restauro então realizado denota a clara objeção aos refazimentos em estilo. O restauro é citado como uma intervenção que destruiu a igreja original para substituí-la por uma cópia, um gótico atemporal. Prossegue ainda condenando a devastação do entorno dos monumentos e a destruição das pequenas casas que conferiam, por um efeito único de conjunto e contraste, a devida monumentalidade à antiga igreja. Como já fizera Cattaneo décadas atrás, alerta para a perda da escala monumental gerada pelas interferências no entorno, fato que tornara a igreja "esquálida e triste", isolada de um contexto que originalmente fizera parte de sua composição. Remete ainda à construção de arquiteturas desprovidas de beleza, em substituição às antigas casas medievais que compunham o conjunto arquitetônico.

Tantas considerações assim reunidas, logo na abertura de seu estudo, evidenciam a importância que a observação das particularidades estéticas dos conjuntos urbanos começava a tomar nos primeiros anos do século XX. Em diversas passagens do Catecismo, Dvořák retoma argumentos relacionados à interferência destruidora no entorno dos monumentos e à relação imediata de pertencimento entre as pessoas e o lugar onde vivem, relação esta que será profundamente alterada após quaisquer intervenções descuidadas e descaracterizadoras. ${ }^{110}$

Ma così facendo, era andata perduta quasi tutta la sua antica belleza, senza che nulla di altrettanto valido le si fosse sostituito. / Impedire tali perdite e tali devastazione è compito della tutela dei monumenti."

${ }^{110}$ DVOŘÁK, M., op. cit., p.19. As suas vidas se empobreceriam se se empobrecesse artisticamente o ambiente que as circunda e se afrouxassem as mais estreitas relações que as mantinham unidas à sua pátria. 
Com relação aos perigos que ameaçam os monumentos, o autor destaca quatro causas principais que mantém estreita relação com a atualidade, fato que nos alerta para a recorrência secular dos mesmos problemas na valorização e tutela dos monumentos históricos. Segundo o autor, tais perigos provém: “1) da ignorância e da negligência; 2) da cobiça e da fraude; 3) das idéias equivocadas de progresso e das supostas exigências da época moderna; 4) da obsessão descabida de embelezamento e de renovação, da falta de educação estética e do mau gosto". ${ }^{111}$

Ao discorrer sobre a terceira causa destacada, as equivocadas idéias de modernidade, destaca que o desprezo pelos monumentos antigos foi visto, e infelizmente ainda o é, como um sinal de progresso. Nesse sentido, lamenta que em nome desse progresso cidades inteiras tenham sido sacrificadas sem ser absolutamente necessário já que, com ligeiras modificações, seria possível adaptar as antigas casas às novas exigências de higiene e comodidade. Edifícios belos, espaçosos e solidamente construídos poderiam ser aproveitados em vez de se despender grandes recursos para construir novas obras de qualidade inferior, um verdadeiro "aborto arquitetônico". E conclui: "não há dúvida que essas casas não têm nenhuma necessidade de serem reconstruídas mas podem sobreviver com adequadas adaptações. E aquilo que vale para as casas individuais, vale também para cidades inteiras". 112

Suas considerações sobre as transformações da cidade moderna, seu crescimento, as novas exigências urbanas e a conciliação das mesmas com a tutela dos monumentos e do tecido antigo são bastante sensíveis. $\mathrm{O}$ autor discorre sobre a impossibilidade de privar tais localidades das necessárias adaptações, mas ressalta que tal objetivo deve ser alcançado sem provocar a destruição de cidades inteiras. Tais adaptações não são justificativas válidas para as destruições realizadas já que, de posse das recentes contribuições do urbanismo moderno, apenas uma administração pública incapaz ou inerte deixaria de recorrer aos necessários estudos para conciliar ambas as exigências: as

Trad. nossa. "Si impoverisce la loro vita se si impoverische artisticamente l'ambiente che li circonda e si allentano i più stretti legami che li tenevano uniti alla loro patria."

${ }^{111}$ DVOŘÁK, M., op. cit., p.7. Trad. Nossa. "Questi pericoli provengono: 1) dall'ignoranza e dall'indolenza; 2) dall'avidità e dall'inganno; 3) da malintese idee di progresso e da presunte esigenze dell'età moderna; 4) dalla smania di abbellimento e di rinnovamento fuori luogo, dalla mancanza di educazione estetica e dal cattibo gusto."

112 DVOŘ́́K, M., op. cit., pp.12,13. Trad. nossa. "Non v’è dubbio che queste case non hanno alcun bisogno di essere ricostruite ma possono sopravvivere con adeguati adattamenti. E quel che vale per le singole case, vale anche per le intere cittá." 
adaptações necessárias para as grandes cidades e a conservação de suas representativas parcelas antigas. E prossegue:

Portanto não se poderá mais responder, como foi feito face aos problemas que vinham se apresentando, falando de progressos e novos tempos, mas estes problemas deverão ser resolvidos por homens especializados e sensíveis aos fatos artísticos analisando caso a caso, à luz de todas as experiências da urbanística moderna que tende a conservar, todas as vezes que é possível, os monumentos do passado. É dever dos administradores da cidade preocupar-se com tudo isso e não temer sacrifícios e cansaços quando estiver em jogo o destino de antigos edifícios ou de partes da cidade, porque eles são também os responsáveis por tudo isso e não somente pelas inovações técnicas. Cada monumento sacrificado sem absoluta necessidade deve-lhes ser debitado como marco de incapacidade ou de superficialidade na administração da coisa pública. ${ }^{113}$

No final do texto, o autor sugere uma série de princípios de tutela para os monumentos e para os ambientes urbanos. Tanto no campo como nos pequenos centros, sugere que nada de antigo seja destruído apenas para ser substituído pelo novo, que não seja mutilada sem razão a estrutura histórica de cidades ou a forma de praças e vias; que não sejam sacrificados edifícios antigos devido ao tráfego e que sejam observadas as relações de cada edifício novo com o entorno e a perspectiva geral dos arredores. Com relação às grandes cidades, propõe uma interessante observação. A necessária transformação das cidades não deve ser confiada somente às decisões dos escritórios de construção dos organismos voltados à conservação. Deve-se recorrer a pessoas, profissionais, com plena consciência de todas as exigências não apenas práticas mas também estéticas da arquitetura urbana, bem como de todos os direitos e exigências da tutela dos monumentos. ${ }^{114}$

A sensibilidade com que se volta ao organismo urbano e às experiências da urbanística moderna sugere que Dvořák tenha travado contato com os estudos contemporâneos sobre estética urbana, notadamente as contribuições de Camillo Sitte e

\footnotetext{
${ }^{113}$ DVOŘÁK, M., op. cit., p. 14. Trad. nossa. "Perciò non si potrà più rispondere, come è stato fatto di fronte ai problemi che via a via presentavano, parlando di progresso e di nuovi tempi, ma questi problemi dovranno essere risolti da uomini esperti e sensibili ai fatti artistici analizzando caso per caso, alla luce di tutte le esperienze dell'urbanistica moderna che tende a conservare, tutte le volte che è possibile, i monumenti del passato. È dovere degli amministratore della città preocuparsi di tutto questo e non paventare sacrifici e fatiche quando sia in gioco il destino di antichi edifici o di parti della città, perchè essi sono responsabili anche di tutto questo e non solo delle innovazione tecniche. Ogni monumento sacrificato senza assoluta necessità deve essere loro addebitato come segno di incapacità o di faciloneria nell'amministrazione della cosa pubblica."

${ }^{114}$ DVOŘÁK, M., op. cit., p. 37.
} 
Charles Buls. No contexto de nosso percurso historiográfico, Dvořák é um dos primeiros estudiosos sobre a conservação dos monumentos a propor de forma tão contundente a necessária aproximação entre conservação e urbanismo, princípio chave da chamada conservação integrada. Apesar de não aprofundar aspectos normativos ou operativos nesse sentido, suas considerações apontam para uma discussão que prosseguirá, com períodos de maior ou menor atenção, durante todo o século XX. E que, ousamos desafiar, mesmo após a década de 1970, com a Declaração de Amsterdã e seus desdobramentos teóricos e práticos, ainda permanece em aberto.

\section{AS CONTRIBUIÇÕES DA NASCENTE DISCIPLINA DO URBANISMO}

Como vimos, o complexo panorama intelectual do século XIX, nutrido por fervorosos debates sociais e políticos, bem como por uma constante busca pela reavaliação dos valores da sociedade urbana, impulsionaria a produção teórica e prática que delinearia um novo campo disciplinar, o urbanismo, termo que seria adotado no início do século XX a partir de derivações dos estudos de Ildefonso Cerdá, reunidos na obra Teoria geral da urbanização ${ }^{115}$. Entre meados do século XIX e início do século XX, ao lado das primeiras iniciativas práticas de intervenção sobre a cidade preexistente, diversos autores desenvolveram reflexões e análises sobre o ambiente urbano em seus múltiplos aspectos e abriram caminho para o delineamento da nova disciplina. Nesse contexto, ao se voltarem ao estudo da cidade, tais estudiosos buscaram instrumentos teóricos e práticos para compreender a sua estrutura, composição e trajetória, bem como para tentar orientar a sua transformação.

Não obstante a identificação de relações de causa e efeito entre as indagações que delinearam o nascimento da disciplina do urbanismo e aquelas que concorreriam para a invenção do patrimônio urbano, cabe ressaltar que ambos os caminhos não convergem numa mesma direção. E tratar de tais temas - ora solidários, ora antagônicos - é tarefa que se reveste de certos cuidados. Sabemos que a ampliação dos estudos urbanos e a

\footnotetext{
${ }^{115}$ Ildefonso Cerdá empregou o termo urbe para designar os diferentes tipos de assentamentos humanos e o termo urbanização para referir-se à ação sobre a urbe. Com base em tais termos cunhados por Cerdá surgirá posteriormente, no início do século XX, a palavra urbanismo para então denominar a nova disciplina. CERDÁ, Ildefonso. La théorie générale de l'urbanisation [1867]. Paris: Editions du Seuil, 1979.
} 
conseqüente transformação da cidade antiga em objeto de estudo e investigação, notadamente no final do século XIX, ocorreu mais pelo efeito de oposição, ou contraste, entre o tecido antigo e a cidade moderna que se formava, do que propriamente por um interesse objetivo pelo seu valor histórico e pela sua preservação. Françoise Choay adverte que a contraposição entre as cidades do passado e a cidade do presente não significou o desejo de conservar as primeiras, o processo foi outro: "quer o urbanismo se empenhasse em destruir os conjuntos urbanos antigos, quer procurasse preservá-los, foi justamente tornando-se um obstáculo ao livre desdobramento de novas modalidades de organização do espaço urbano que as formações antigas adquiriram sua identidade conceitual". ${ }^{116}$ Dessa forma, a construção de um esboço historiográfico sobre a maturação do conceito de patrimônio urbano, buscando relacionar tanto as contribuições da história da arquitetura e da restauração quanto aquelas do urbanismo, pressupõe a tessitura cuidadosa entre caminhos investigativos que até então pouco se tocaram, apesar dos evidentes antecedentes comuns que o complexo contexto histórico e cultural do século XIX lhes proporcionou.

No cenário das transformações em curso ao longo do século XIX, uma série de elementos condicionariam as variadas formas de refletir sobre a cidade e a sociedade que a produzia. De um lado, o nascente urbanismo nutria-se dos debates e reflexões sobre o ambiente urbano do ponto de vista filosófico e social, na variedade de suas manifestações ${ }^{117}$; e de outro, moldava-se a partir do embate com um série de questões de ordem técnica que emergiam desse cenário em mutação. Ao lado dos desafios gerados pelas novas invenções técnicas, com destaque para a radical transformação do território impulsionada pela implantação das ferrovias, ganhavam corpo os questionamentos dos higienistas sobre a salubridade urbana e a busca de soluções para remediar os problemas sanitários das cidades industriais. Nesse contexto, questões como a proliferação de epidemias, o congestionamento das cidades, a inexistência de regras para o uso dos terrenos e até mesmo o tratamento de detritos e contaminação dos rios, ocupavam o centro

\footnotetext{
${ }^{116}$ CHOAY, Françoise. A alegoria..., op. cit., pp. 179-180.

117 A este respeito cabe destacar os estudos dos chamados 'socialistas utópicos' - como Robert Owen, Charles Fourier, Etiene Cabet, entre outros - pensadores que denunciaram os problemas urbanos e buscaram propor modelos de cidades (e sociedades) ideais, ao longo da primeira metade do século XIX. Analogamente, destacam-se os estudos nos campos da sociologia e da filosofia que compunham o cenário crítico e investigativo do período. Para um breve panorama das discussões em torno da cidade industrial ao longo do século XIX do ponto de vista filosófico e político, bem como sobre a influência das teorias do Liberalismo econômico, do Positivismo e do Marxismo no desenrolar dos fatos urbanos neste período, Cf: DE FUSCO, Renato. Storia dell'architettura contemporanea. Roma: Laterza, 2000, pp. 6-18; CHOAY, F. O urbanismo..., op. cit., pp. 01-56; BENEVOLO, L. História..., op. cit., pp. 74-82; LAMAS, José M. R. G. Morfologia urbana e desenho da cidade. Porto: FCG / FCT, 2004.
} 
dos debates e impulsionavam a elaboração dos primeiros relatórios sanitários, propostas legislativas ${ }^{118}$ e intervenções práticas sobre o tecido urbano preexistente.

Nesse sentido, as obras de Haussmann em Paris representam o exemplo por excelência. O conjunto de reformas urbanas realizadas a partir da década de 1850, ao propor a reestruturação viária da cidade por meio da sobreposição de uma nova malha de vias largas e retilíneas sobre a antiga Paris, provocou a destruição de grande parte dos bairros medievais e colocou em pauta, pela primeira vez nesta escala, os problemas da relação antigo-novo na intervenção sobre a cidade antiga ${ }^{119}$. Independentemente das características positivas ou negativas atribuídas ao projeto de Haussmann pela historiografia crítica, a experiência de Paris abriu caminho para uma série de projetos urbanos supostamente inspirados em Haussmann, mas que nem sempre, porém, alcançaram resultados urbanísticos que justificassem as grandes demolições realizadas. Por outro lado, a experiência haussmanniana teria ainda contribuído para a difusão de uma prática que se tornava corrente, o isolamento de determinados monumentos arquitetônicos a partir da 'desobstrução' de seus arredores, ou seja, da demolição das edificações adjacentes consideradas sem valor. Notamos, portanto, que os principais elementos que delineavam os alcances da nova disciplina do urbanismo, nesse momento pouco se relacionavam com a discussão sobre a interferência de tais práticas sobre a cidade antiga considerando os seus possíveis valores históricos, estéticos e memoriais. Os teóricos

\footnotetext{
118 No contexto inglês, destacam-se as leis sobre saúde pública, como o Public Health Act, de 1848; o Artisan's and Labourer's Dwelling Act, de 1866; e o Housing of Worker Class Act, de 1890. Na França, apesar dos caminhos operativos terem sido outros, as motivações foram semelhantes. Um decreto promulgado em 1853 permitiu alterações na regulamentação da expropriação de terrenos urbanos, antes considerada apenas em caráter excepcional, e a transformou em um instrumento urbanístico que outorgou poderes às autoridades públicas para intervir na transformação da cidade. Tal instrumento teria sido a base legal que permitira a Haussmann a realização das reformas de Paris. Na Itália, destaca-se a Lei de 1865 sobre expropriação urbana para utilidade pública que provocou uma série de demolições em centros históricos considerados insalubres. BENEVOLO, L. História..., op. cit., pp. 345-346; GIULIANI, Aldo. Monumenti, Centri Storici, Ambiente. Milano: Tamburi, 1966, p. 10; CALABI, Donatella. O papel de Paris na urbanística italiana do século XIX: o mito da modernização. In: SALGUEIRO, Heliana Angotti (Org.). Cidades capitais do século XIX. São Paulo: Edusp, 2001, p.104.

119 As obras de Haussmann em Paris suscitam estudos e aprofundamento sob diferenciados aspectos. Um aspecto de grande relevância é o fato de Haussmann ter sido um dos primeiros a considerar o fator 'tempo' no projeto, ou seja, a considerar as projeções de transformação no futuro. Por outro lado, Benevolo também ressalta influências de caráter político na execução dessas obras que possuiriam o duplo papel de promover a popularidade de Napoleão III, e de tornar as ruas da cidade mais propícias à repressão de levantes populares, a partir da demolição das estreitas ruas medievais e da construção de vias mais espaçosas para o movimento das tropas. BENEVOLO, L., op. cit., p.96. Para aprofundamentos sobre as reformas de Hauusmann em Paris, além da contribuição referencial de Leonardo Benevolo, consultar as diferenciadas abordagens de: PINON, Pierre. Atlas de Paris Haussmannien. Paris: Parigramme, 2002; RONCAYOLLO, Marcel; PAQUOT, Thierry. Villes \& Civilisation Urbaine, XVIIIe-XXe siècle. Paris: Larousse, 1992; RÉAU, Louis (Org). L'oeuvre du Baron Haussmann, Préfet de la Seine (1853-1870). Paris: PUF, 1954; HAUSSMANN, Baron. Mémoires. Paris: Éditions du Seuil, 2000; SALGUEIRO, H. A. (Org.). Cidades capitais..., op. cit.
} 
contemporâneos que enalteciam os valores da cidade preexistente e condenavam a sua destruição, como Ruskin e Morris, entraram nos anais da história do urbanismo mais devido às suas críticas de caráter social vinculadas à industrialização do que propriamente pela defesa das cidades antigas.

Na última década do século XIX, no entanto, os estudos do arquiteto austríaco Camillo Sitte (1843-1903) abrem caminho para a aproximação entre a valorização da cidade preexistente e a abordagem dos problemas urbanísticos do período. A partir da análise da composição urbana das cidades medievais, Sitte atenta para a dimensão estética dos conjuntos edificados e busca enfatizar o caráter artístico da cidade e a repercussão de suas qualidades compositivas na percepção daqueles que a vivenciam. Suas considerações, reunidas na obra Der Städtebau ${ }^{120}$, o colocam em franca oposição aos projetos urbanísticos do período em grande parte influenciados pelas reformas de Haussmann, como o próprio projeto para a Ringstrasse de Viena, um dos temas de seu estudo. A obra de Sitte interessanos como uma importante referência dentre os estudos urbanísticos: por um lado, devido ao caráter inovador de sua abordagem e conseqüente ressonância sobre outros teóricos tanto no campo do urbanismo como na preservação dos monumentos, como Charles Buls e Max Dvořák -, por outro lado, devido às severas críticas que recebeu de teóricos do movimento moderno ao longo de várias décadas, fato que evidenciaria a abertura de percursos distintos com relação à intervenção sobre o tecido preexistente.

Tomando o tema da praça pública como ponto de partida, Sitte analisou a composição estética e as relações de escala entre os elementos que compõe o espaço urbano das cidades pré-industriais. Por meio do emprego de numerosos desenhos e exemplos práticos buscou evidenciar as qualidades projetuais desses conjuntos urbanos, as relações espaciais entre as praças e os edifícios públicos adjacentes, a escala do observador e os efeitos de perspectiva e percurso. Questões que, segundo o autor, o monótono urbanismo moderno não pretendia considerar. A partir de tais análises, condena uma série de recursos projetuais adotados pelo desenho moderno como a recorrência arbitrária ao centro livre na concepção das praças ou o isolamento de edifícios sem atentar para as imprescindíveis relações de escala com o entorno, questão de composição que os sensíveis

\footnotetext{
${ }^{120}$ SITTE, Camillo. A construção das cidades segundo seus princípios artísticos [1 ${ }^{\mathrm{a}}$. edição austríaca 1889]. Trad. Ricardo Ferreira Henrique. São Paulo: Ática, 1992. Para aprofundamentos sobre a obra de C. Sitte, consultar: COLLINS, George R. Camillo Sitte and the birth of modern city planning. New York: Random House, [1965]. Para um amplo panorama das teorias e práticas urbanísticas que o antecederam, ver: WIECZOREK, D. Camillo Sitte et les débuts de l'urbanisme moderne. Bruxelles: Pierre Mardaga, [1981].
} 
construtores antigos produziam espontaneamente e que nós, "armados de réguas e compassos" e "com uma geometria canhestra" $" 121$ tentamos inutilmente alcançar.

A localização dos edifícios no centro das praças, sejam eles projetos novos ou edifícios antigos cujas construções adjacentes foram demolidas, é um recurso amplamente condenado por Sitte, um "pedantismo moderno que decorre, naturalmente, do movimento do compasso e da régua sobre a prancheta, sem manter relação alguma com o quadro formado na realidade". ${ }^{122}$ Segundo tal disposição, a harmonia viva e orgânica entre os edifícios e seus arredores, bem como os efeitos de perspectiva, seriam totalmente anulados, conferindo à construção isolada o triste aspecto de "uma torta exposta numa bandeja". ${ }^{123} \mathrm{E}$ tal isolamento seria ainda mais grave quando envolve monumentos antigos. Nesse caso, a demolição do entorno anula o efeito de toda a composição da obra, certamente pensada a partir da integração com o ambiente circundante, subtraindo, portanto, um dos fundamentos essenciais de sua concepção. Segundo Sitte, essa "obsessão pelo isolamento de edifícios é um modismo nefasto" e atribui tal prática aos teóricos contemporâneos, como Reinhard Baumeister ${ }^{124}$, que defendera o isolamento praticamente como uma norma, como um recurso para "desimpedir" as construções antigas. Tal prática teria provocado intervenções inusitadas como o isolamento de antigos portões de burgos desconsiderando completamente a natureza de sua existência: "De fato, uma coisa muito bonita, isso de um portão que não se atravessa, mas em torno do qual se passeia!",125

A questão do isolamento dos monumentos foi um dos pontos essenciais da obra sittiana a ser referenciado por Charles Buls em seus estudos sobre a preservação dos monumentos, como vimos anteriormente, fato que ressalta a repercussão desses princípios para além do âmbito propriamente urbanístico.

Cabe ressaltar que os elementos analisados por Sitte - a composição dos traçados urbanos antigos, a incidência dos fatores ambientais sobre o projeto urbano, as relações de escala entre os espaços edificados, vias e praças, os efeitos de perspectiva gerados pela sinuosidade das ruas - não objetivaram a imitação indiscriminada de tais composições na

\footnotetext{
${ }^{121}$ SITTE, C., A construção..., op. cit., p. 35.

${ }^{122}$ Idem, p. 79.

${ }^{123}$ Idem, p. 42.

124 BAUMEISTER, Reinhard. Stadt-erweiterungen in technischer baupolizeilicher und wirthschaftlicher beziehung. Berlin: Korn, 1876. Trechos publicados em italiano como apêndice de: PICCINATO, Giorgio. La costruzione dell'urbanistica: Germania 1871-1914. Roma: Officina, 1974.

${ }^{125}$ SITTE, C., A Construção..., op. cit., p. 46.
} 
atuação contemporânea sobre a cidade, como acreditaram alguns teóricos, mas sim a apreensão do que chamou de 'essência' das obras urbanas antigas. O autor buscava, diante da insatisfação para com as intervenções urbanas modernas, desvendar os princípios projetuais geradores dos tecidos urbanos antigos, por ele considerados harmoniosos e acolhedores, para que pudessem ser aplicados com sensatez às necessidades da atualidade ou, na impossibilidade de tal aplicação, para que fossem ao menos preservados como patrimônio. Não obstante a crítica severa à falência artística dos recursos projetuais dos chamados "sistemas modernos", ${ }^{126}$ o autor não deixa de atentar para a importância do atendimento aos requisitos de higiene, salubridade e circulação, focos da discussão sobre a cidade nesse momento. Não pretende, no entanto, perseguir tal abordagem. E o autor esclarece os alcances de seu estudo logo no início da obra. Afirma que deseja evidenciar e compreender os motivos da composição artística das cidades a partir da análise técnica e científica das mesmas, sejam elas antigas ou modernas. ${ }^{127} \mathrm{E}$ em outras passagens esclarece ainda que não pretende promover a imitação de antigos desenhos, e sim o estabelecimento de um paralelo entre os mesmos e as condições e solicitações da atualidade.

Esse estudo não tem como objetivo promover a aplicação da chamada beleza pinturesca dos conjuntos urbanos antigos no contexto das propostas modernas, pois, sobretudo neste âmbito, faz jus o ditado: "A necessidade é mestra". Tudo o que já se evidenciou como necessário segundo aspectos higiênicos ou por outros motivos prioritários deve ser realizado ainda que em detrimento dos motivos pinturescos, sejam estes quais forem. Porém, esta convicção não nos deve impedir de investigar minuciosamente todos os motivos pinturescos das cidades antigas, estabelecendo um paralelo entre eles e as condições modernas, para que assim possamos esclarecer os aspectos artísticos desta questão, bem como identificar com precisão o que ainda pode ser resgatado, em nosso benefício, das belezas dos conjuntos urbanos antigos, conservando-as ao menos como patrimônio.

[...] Mas é possível inventar e construir em uma planta todas as casualidades geradas no decorrer dos séculos? [...] Certamente que não. [...] A vida moderna e a moderna técnica de construção não mais comportam uma imitação fiel dos complexos urbanos antigos - e não aceitar essa conclusão significa entregar-se a um devaneio infrutífero. As magníficas obras antigas [...] devem permanecer vivas entre nós de outro modo que não através da imitação insensata; e apenas quando apreendermos sua essência e conseguirmos aplicá-la com sensatez às circunstâncias modernas é que será possível obter ainda uma colheita florida de uma terra que se tornou estéril. ${ }^{128}$

\footnotetext{
${ }^{126}$ SITTE, C., A Construção..., op. cit., p.100.

${ }^{127}$ Idem, p. 15.

${ }^{128}$ SITTE, C., A Construção..., op. cit, pp.29-30,117.
} 
No entanto, diversas interpretações posteriores, embebidas pelos pressupostos do urbanismo moderno que se afirmariam notadamente após a década de 1930, conferiram-lhe por muito tempo os rótulos de passadista e retrógrado. Siegfried Giedion o acusa de querer "voltar à cidade medieval”, Le Corbusier, por sua vez, ironiza os seus princípios rotulandoos de "a religião dos estúpidos" e, analogamente, condena os traçados irregulares supostamente propostos por Sitte afirmando tratar-se de "caminhos para asnos". ${ }^{129}$ Ainda na década de 1960 há referência sobre sua obra como sendo obsessiva em relação aos aspectos estéticos e ignara quanto à evolução das condições de trabalho e dos problemas de circulação $^{130}$. Certamente Sitte não aprofundou tais problemas, que aliás não compunham o escopo sobre o qual se debruçara, mas não por desconhecimento da problemática. $\mathrm{O}$ conjunto de solicitações da vida moderna estão presentes ao longo da obra sob a forma de contraponto a toda sua argumentação, já que a compreensão da artisticidade urbana é buscada justamente diante da interferência modernizadora sobre a cidade antiga. Grande parte das interpretações de sua obra, portanto, repousam na incompreensão do objeto central de sua análise. Em Sitte, a cidade medieval é tomada como um artefato, um organismo que comporta saberes, tradições, e ao qual nos voltamos em busca do conhecimento, daí a valorização de sua historicidade. Não se trata de um modelo a ser copiado, mas sim da evidenciação de um conjunto de felizes soluções regidas por qualquer princípio artístico, o qual devemos compreender e eventualmente empregar em consonância com as atuais necessidades, de modo que a satisfação das mesmas não seja alcançada somente em detrimento de toda artisticidade urbana.

[...] seria uma espécie de cegueira não reparar nas eminentes conquistas da construção urbana moderna em relação aos antigos no âmbito da higiene. [...] Resta-nos [...] saber se, de fato, tais êxitos só podem ser obtidos pelo preço terrível da renúncia a toda beleza artística dos conjuntos urbanos. ${ }^{131}$

\footnotetext{
${ }^{129}$ LE CORBUSIER. Urbanisme. Paris: Crès, 1923, p.9. Na verdade, Sitte não propõe em seu texto o emprego de nenhum traçado viário em particular. Quem o fez foi Camille Martin, arquiteto suíço autor da primeira tradução francesa publicada em 1902. Essa tradução, além de apresentar fidelidade questionável ao original, trazia um capítulo inteiro de autoria de Martin no qual o tradutor abordava justamente o traçado de ruas. ANDRADE, Carlos R. M. Apresentação. In: SITTE, C., op. cit., p.5.

${ }^{130}$ Observações de Françoise Choay em sua Antologia cuja primeira edição é de 1965. Em textos mais recentes, no entanto, a abordagem de Choay assume outros contornos, sobretudo a partir do final dos anos 1960, quando a desmistificação do movimento dos CIAM abrirá espaço crítico para uma releitura da obra sittiana. CHOAY, F. O urbanismo..., op. cit., p.28 [1ª . ed. 1965]; CHOAY, F. A Alegoria..., op. cit., pp. 182190 [1ª . ed. 1992]; CHOAY, F. Pour une antropologie de l'espace. Paris: Éditions du Seuil, 2006, pp.86-105. ${ }^{131}$ SITTE, C., A Construção..., op. cit., p.116.
} 
A observação da crítica dos urbanistas modernos aos princípios sittianos nos interessa para pontuar um momento crucial na delimitação dos caminhos operativos com relação ao patrimônio urbano. De um lado, Camillo Sitte impulsiona a valorização dos tecidos antigos enquanto composição e estrutura, evidencia as especificidades estéticas do conjunto urbano e não apenas do monumento e seu entorno imediato e busca alinhavar, no limite do alcance histórico de suas análises, as conquistas do urbanismo e a importância da cidade antiga. De outro lado, despontam e paulatinamente se fortalecem os princípios do urbanismo moderno. Na esteira das teses e propostas de Otto Wagner, seguem-lhe outros teóricos e suas respectivas análises: Tony Garnier, Walter Gropius, Le Corbusier, entre outros $^{132}$. No quadro da presente abordagem, tais teóricos abririam caminho para a priorização das respostas da técnica e do redesenho urbano em detrimento da cidade preexistente. As estruturas antigas até poderão ser respeitadas, desde que não interfiram na reordenação dos espaços, como se afirmará anos mais tarde na Carta de Atenas do CIAM, de $1933^{133}$. No campo da preservação urbana, notadamente no contexto europeu, o embate entre as propostas urbanísticas, legislativas ou projetuais, consideradas mais conservadoras e atentas ao patrimônio preexistente e aquelas de influência marcadamente moderna, que defendiam a construção de novas estruturas como prioridade, será constante ao longo de todo o século XX. Apesar das premissas da preservação acordadas em âmbito internacional com a redação da Carta de Veneza, certos aspectos desse embate não encontrarão termo em 1964; antes, assumirão novos contornos e abordagens, permanecendo ainda hoje bastante evidentes sobretudo no contexto brasileiro.

No que tange à contribuição dos estudos de estética da cidade na concepção do patrimônio urbano, merecem ainda destaque as análises desenvolvidas pelo belga Charles Buls. Impulsionado pela obra de Camillo Sitte e nove anos antes de suas preciosas contribuições no campo da preservação dos monumentos, Buls dedicou-se ao estudo estético dos ambientes urbanos e procurou elaborar princípios gerais de atuação sobre tais espaços, apresentados no estudo intitulado Estética das Cidades, publicado em $1894^{134}$.

\footnotetext{
${ }^{132}$ Segundo Meyer, é possível identificar traços de ambas as tendências na observação atenta das influências manifestadas em diversos estudiosos ao longo de toda a história do urbanismo, na variedade e especificidade de suas respectivas proposições: de um lado os teóricos mais afeitos à Camillo Sitte (Patrick Geddes, Lewis Munford e Jane Jacobs, por exemplo), e de outro, aqueles que dividem pontos em comum com Otto Wagner (Tony Garnier, Walter Gropius e Le Corbusier). MEYER, Regina M. Prosperi. Urbanismo à procura do espaço perdido. Revista USP, n. 5, Dossiê Cidades, 1990.

${ }^{133}$ Notadamente no item n.69 da Carta. Retomaremos o tema oportunamente. Carta de Atenas CIAM, 1933. In: Cartas Patrimoniais. Rio de Janeiro: IPHAN, 2000, p. 54.

${ }_{134}$ BULS, Charles. Esthétique des Villes. Brussels: Bruyland-Christople, 1893. Devido à dificuldade de acesso ao texto original em francês, neste estudo utilizaremos a versão italiana, tradução de Maria Pasolini,
} 
Anos mais tarde, seus estudos urbanos alimentariam outra frente teórica, a preservação e restauração dos monumentos, contribuição anteriormente analisada e em consonância com o contexto investigativo do período no campo da preservação. De posse de certa estruturação teórica na esfera urbanística e também de significativa experiência prática no campo da administração urbana, Buls seria o responsável por um importante passo em direção à integração entre os temas do urbanismo e aqueles da tutela, ainda que o peso teórico dessa aproximação somente anos mais tarde viesse a apresentar resultados significativos, a partir da contribuição cumulativa de outros teóricos. No entanto, nesse momento são raros os estudiosos que transitam em ambos os campos disciplinares. Até mesmo em Camillo Sitte encontramos poucas referências, e em geral de passagem, à questão específica da preservação.

A obra Estética das Cidades foi escrita sob a clara repercussão das propostas de Sitte, num momento no qual Buls, prefeito de Bruxelas, defrontava-se com um projeto urbano que ameaçava destruir um importante bairro histórico da capital. Igualmente desapontado com os pressupostos urbanísticos em difusão nas principais cidades européias, sente-se impulsionado a formular diretrizes para as novas expansões urbanas buscando, de certo modo, propor soluções de mediação entre as reformas necessárias e a preservação da cidade preexistente. Dessa forma, defende a análise atenta dos projetos urbanos efetivamente necessários para as adaptações modernas, de modo a minimizar tanto quanto possível as intervenções sobre os bairros antigos, evitando demolições excessivas e permitindo o acesso dos habitantes às melhorias almejadas.

Seguindo de perto as considerações de Sitte, Buls retoma uma série de argumentos sobre a natureza estética das cidades pré-industriais - cuja beleza estaria relacionada ao caráter espontâneo de seu surgimento e crescimento; a relação entre a construção e a paisagem - atentando para a influência da disposição natural do terreno nas composições urbanas e a valorização do caráter agreste de certas localidades; a inconveniência de isolar monumentos originalmente concebidos entre massas construídas tema também abordado em seus estudos sobre restauração ${ }^{135}$; e a forte crítica aos recursos

republicada como apêndice na obra: SMETS, Marcel. Charles Buls: i principi dell'arte urbana. Roma: Officina, 1999, pp. 317-327. Remetemos ainda à obra de Smets para maiores aprofundamentos sobre C. Buls. ${ }^{135}$ Conforme analisamos anteriormente a partir do texto: BULS, C. La restauration des monuments anciens, op. cit. A este respeito, cabe ainda ressaltar a obra L'isolament des Veilles Eglises, onde o autor admite a necessidade de certas demolições e apresenta alguns critérios a respeito: "1. É necessário liberar as velhas igrejas das construções banais a ela adossadas, quando essas não apresentem nenhum interesse artístico ou arqueológico; 2. Não é necessário isolar as antigas igrejas, mas conservar-lhes, o mais possível, a velha 
projetuais modernos. Nesse sentido, sua posição está bem clara logo no início do estudo. O autor abre o tema ressaltando as características estéticas das composições urbanas antigas e prossegue, logo mais, atentando para a evidente diferença qualitativa entre esses conjuntos e a parte moderna da cidade construída segundo a nova ordem.

As antigas cidades e as antigas estradas têm um encanto particular para os espíritos delicados e sensíveis às impressões da arte. Não se poderá dizer que sejam belas, contudo agradam por aquela desordem que não provém da arte, mas do acaso se todavia ao acaso pode-se atribuir o efeito devido ao crescer das habitações ao longo de um caminho sinuoso, que pouco a pouco se tornou uma via. [...] Quando se lança o olhar sobre o plano de uma das nossas grandes cidades, pode-se distinguir à primeira vista a parte antiga da parte moderna: a primeira é formada por uma rede de estradas, que se ramificam e se amarram como as artérias e as veias de um organismo vivo; a segunda com as suas vias paralelas e perpendiculares tem o caráter de uma cristalização artificial árida e matemática. ${ }^{136}$

Não condena completamente, no entanto, a ordem simétrica dos novos traçados, por vezes destinada a conferir um caráter grandioso e monumental a certas partes da cidade, mas alerta para a recorrência insensata aos planos urbanos vistos a vôo de pássaro, ou seja, para a busca de simetrias e desenhos sobre o papel que jamais poderiam ser notados em um passeio real pelo ambiente construído. Tal tema também foi abordado por Sitte e ressalta a preocupação de ambos os autores com a perspectiva do ponto de vista do pedestre e com as relações sensíveis experimentadas no contato direto com a cidade, evidenciação de uma urbanidade que os sistemas modernos vindos da prancheta não poderiam fornecer.

Com relação à busca de soluções alternativas e mediadoras para a intervenção sobre os bairros antigos, grande interesse nos reserva o recurso proposto para a abertura de

'moldura' [...] 3. Antes de modificar a velha 'moldura' das igrejas, será necessário estudar com cura as repercussões sobre o entorno imediato [...], [considerando inclusive] a contribuição que a igreja traz ao conjunto da praça pública." BULS, Charles. L'isolament des Veilles Eglises. Bruxelles: Librairie Nationale D'Art et D'Histoire, 1910, p.28 apud GIAMBRUNO, Mariacristina. L'opera di Charles Buls: dall'estetica delle città al restauro dei monumenti. Ananke, n. 31, 2001, pp. 48-49. Trad. nossa.

${ }^{136}$ BULS, C. Estetica delle città. In: SMETS, Marcel., op. cit., p. 317. Trad. nossa. "Le antiche città e le antiche strade hanno un incanto particolare per gli spiriti delicati e sensibili alle impressioni dell'arte. Non si potrà dire che siano belle, ciò nondimeno piacciono per quel disordine che non proviene dall'arte, ma dal caso se pure al caso si può attribuire l'effetto dovuto al crescere delle abitazioni lungo un sentiero sinuoso, che poco a poco è divenuto una via. [...] Quando si getta lo sguardo sul piano d'una delle nostre grandi città, si può distinguere a prima vista la parte antica dalla parte moderna: la prima è formata da una rete di strade, che si ramificano e s'annodano come le arterie e le vene d'un organismo vivente; la seconda con le sue vie parallele e perpendicolari ha il carattere d'una cristallizzazione artificiale arida e matematica." 
vias. Buls propõe que sejam aproveitadas, sempre que possível, as vias e percursos já existentes, ampliando-os e adaptando-os, ao invés de criar novas aberturas que destruiriam grandes parcelas dos bairros antigos. Segundo tal critério, "conserva-se à cidade o seu caráter local e nacional, não se destroem as lembranças do passado senão na estrita necessidade das exigências modernas, obtém-se efeitos pitorescos, tem-se prudência para com as finanças municipais, e incomoda-se menos os costumes e os interesses da população". ${ }^{137}$ Não obstante as evidentes dificuldades de aplicação prática, o método proposto, além de minimizar as demolições, permitiria ainda seguir uma conformação espacial própria do contexto urbano de origem. Essa solução baseou-se nos estudos de Charles Van Mierlo, engenheiro muito admirado por Buls e textualmente referenciado na Estética. Em projeto datado de 1885, Van Mierlo atentou para a concepção de uma malha viária estreitamente relacionada com o funcionamento global da cidade e com suas características topográficas. Nesse sentido, o engenheiro procurou considerar os fluxos de circulação gerados por diferentes atividades, os diversos aspectos de ordem técnica envolvidos, a valorização imobiliária dos terrenos e as melhores alternativas para evitar a demolição de monumentos importantes ou para explorar a oportunidade de colocá-los em evidência. ${ }^{138}$ A defesa de tal recurso na tentativa de buscar uma mediação entre a conservação do existente e as transformações impetradas pelo desenvolvimento urbano coloca Charles Buls, de certo modo, dentre os teóricos que abririam caminho para a concepção do chamado 'desadensamento construtivo', ou diradamento edilizio, método mais tarde desenvolvido por Gustavo Giovannoni. ${ }^{139}$

\footnotetext{
137 BULS, C. Estetica..., op. cit., p. 319. Trad. nossa. "Si conserva alla cittá il suo carattere locale e nazionale, non si distruggono i ricordi del passato che nella stretta necessità delle esigenze moderne, si ottengono effetti pittoreschi, si ha riguardo alle finanze comunali, e si disturbano meno le consuetudini e gl'interessi della popolazione."

${ }^{138}$ SMETS, Marcel. Charles Buls et l'amorce d'une nouvelle politique urbaine a la fin du $19^{\text {eme }}$ siècle . In: SPAGNESI, Gianfranco (Org.). L'Architettura delle Trasformazioni Urbane 1890-1940. Roma: Centro di Studi per la Storia dell' Architettura, 1992, p.73.

${ }^{139}$ GIAMBRUNO, M. L'opera di Charles Buls..., op. cit., p. 46. Uma contribuição prática que conferiu à Buls certo prestígio foi a atuação sobre a Grand'Place de Bruxelas, evitando a sua destruição. Como burgomestre da cidade, Buls procurou conservar a praça e reconstruiu alguns de seus edifícios arruinados em 1850 com intuito de criar um encerramento visual e liberar o térreo ao tráfego de pedestres. SMETS, M. Charles Buls et l'amorce..., op. cit., pp. 83-84.
} 
02. Exemplo de saneamento realizado a partir de intervenções consideradas limitadas. Proposta baseada na eliminação das vias estreitas e criação de novos lotes.

Plano de expropriação e esquema de loteamento projetado por Charles Van Mierlo, 1889. (SMETS, M., Charles Buls: i principi..., op. cit., p.89.)

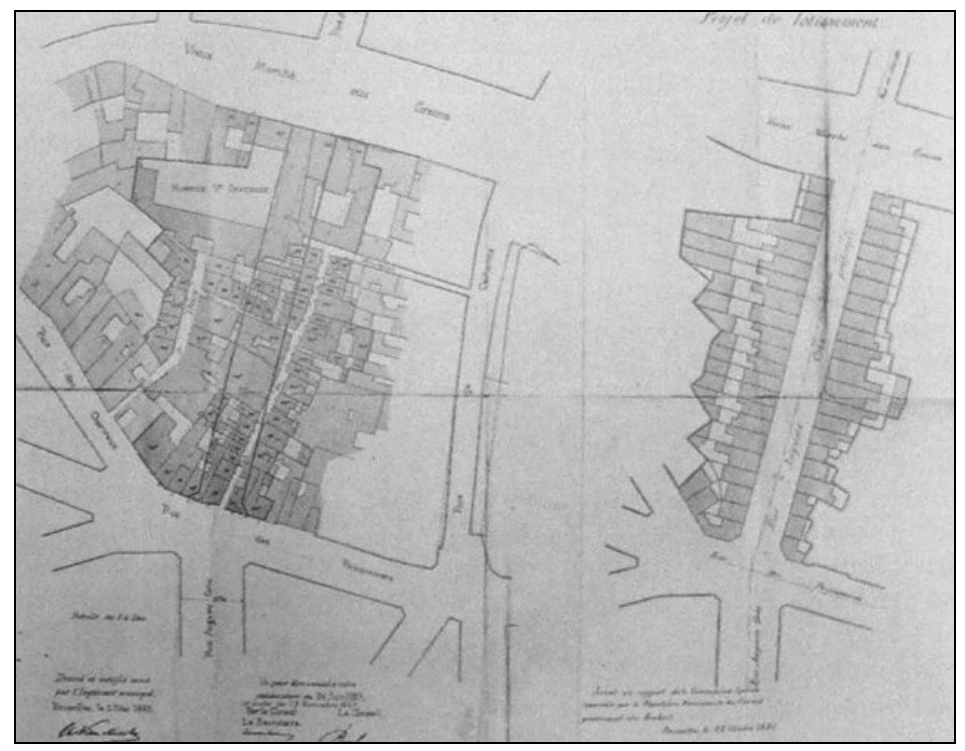

Tanto em Sitte quanto em Buls, notamos a construção de um esquema teórico baseado na crítica artística e arquitetônica, na observação atenta de exemplos práticos e na recorrência a um amplo repertório iconográfico para desvendar as possíveis origens projetuais dos tecidos antigos. Ambos, portanto, voltaram-se à cidade construída como objeto histórico e cognitivo, diferentemente da maioria dos técnicos urbanistas do mesmo período que procuravam solucionar os problemas urbanos aplicando teorias gerais a casos específicos, sem necessariamente analisar as particularidades dos espaços construídos. Nesse contexto, o arquiteto alemão Hermann Joseph Stübben (1845-1936), considerado um dos defensores da chamada estética urbana, buscou uma fundamentação teórica de certa forma intermediária entre ambas as posições preponderantes no período. O próprio Stübben declarou-se inflenciado tanto pela vertente que prioriza os aspectos técnicos da intervenção sobre a cidade, representada principalmente por Reinhard Baumeister, quanto pelos estudos que evidenciam os princípios artísticos, propostos por Camillo Sitte. Em sua obra Der Städtebau (Handbuch Der Architektur) ${ }^{140}$, publicada um ano depois do estudo de Sitte, Stübben procurou conceber os projetos urbanos considerando a cidade como um todo orgânico. Para tanto recorre a uma série manualística de elementos e exigências a serem observadas - notadamente de ordem técnica como o dimensionamento de equipamentos urbanos e sistemas de engenharia -, conferindo à sua obra um caráter verdadeiramente

\footnotetext{
${ }^{140}$ STÜBBEN, Joseph. Der Städtebau (Handbuch Der Architektur). Darmstadt: Bergsträsser, 1890. Alguns trechos da obra, selecionados por Donatella Calabi, foram publicados em italiano como apêndice de: PICCINATO, Giorgio. La costruzione dell'urbanistica: Germania 1871-1914. Roma: Officina, 1974.
} 
enciclopédico. ${ }^{141}$ Em sua visão da cidade como um todo orgânico, considera como prioridade a funcionalidade do sistema, o qual, sendo funcional, será certamente belo. A sua busca pela compatibilidade entre a técnica e a estética urbana, portanto, repousaria na crença da solução integrada de todas as questões envolvidas. ${ }^{142}$ Apesar de considerar os aspectos artísticos a partir da influência sittiana, como o próprio autor declara, a aplicação de tais prerrogativas sobre a cidade antiga, objeto de Sitte, dificilmente poderia garantir a conservação da artisticidade por este evidenciada. ${ }^{143}$

03. Imagem reproduzida em estudos sobre estética urbana para ressaltar as questões envolvidas na transformação desordenada das cidades. (CALABI, D., op. cit.)

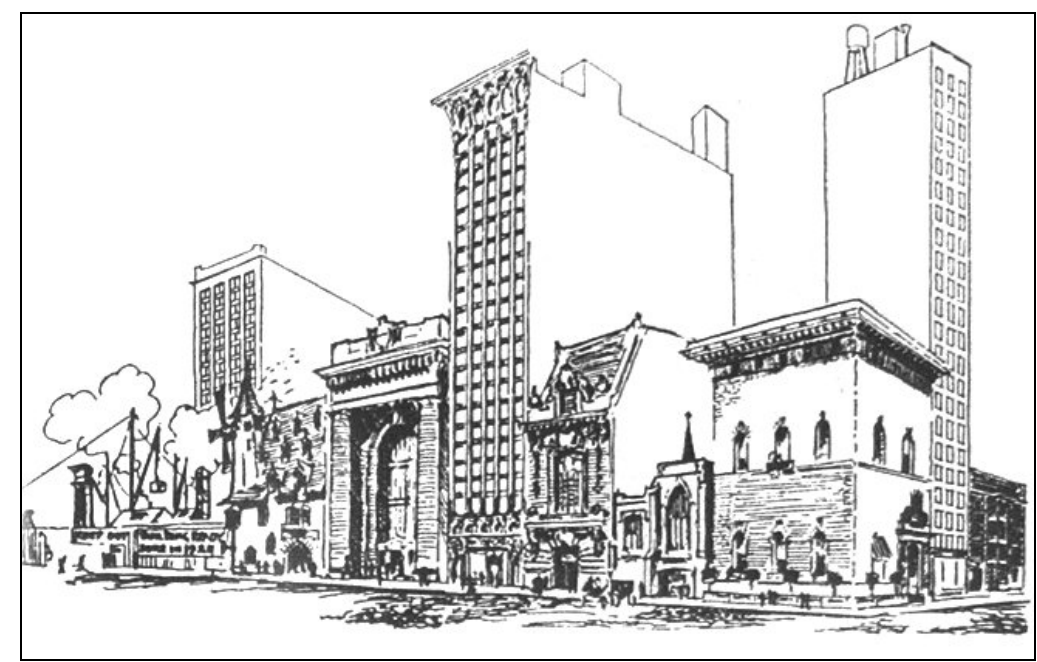

Os princípios sittianos repercutiram na produção de vários teóricos notadamente no início do século XX e abriram caminho para diferentes projetos urbanos, quer seja de intervenção sobre a cidade existente, quer seja de novos bairros cujos desenhos tomavam por base os elementos projetuais enunciados por Sitte e seus sucessores. Na variedade de suas teorias, encontramos nos escritos e projetos de diversos autores a recorrência aos pressupostos da chamada estética urbana o que, de certo modo, evidencia a adoção de um ponto de partida inovador no que tange ao estudo e orientação das transformações urbanas;

${ }^{141}$ A esse respeito cabe destacar a publicação de manuais de construção urbana que baseados no método proposto por Stübben. Na Itália, a editora Hoepli, dedicada desde o início do século XX a títulos de caráter manualístico voltados a engenheiros e arquitetos, publicou em 1915 a obra organizada por Aristide Caccia, Costruzione, trasformazione ed ampliamento delle città, compilato sulla traccia dello Städtebau di J. Stübben: ad uso degli ingegneri, architetti, uffici tecnici ed amministrazioni municipali. Milano: Hoepli, 1915. Fato que demonstra a considerável difusão de seus estudos no início do século XX.

142 Tomamos do texto de Oliver Karnau apenas as considerações sobre a obra de Joseph Stübben, estudioso pouco abordado em nosso ambiente acadêmico. KARNAU, Oliver. Sitte e Stübben: arte versus tecnica? In: ZUCCONI, G. (Org.). Camillo Sitte e $i$ suoi interpreti. Milano: FrancoAngeli, 1992, pp. 91-97.

143 A esse respeito, Jokilehto ressalta que as teorias de Stübben - de certa forma baseadas no desenvolvimento da cidade moderna sobre a cidade histórica, aproveitando-se das circunstâncias existentes teriam influenciado o Plano Diretor de Roma de 1908 que previa demolições e aberturas de novas vias sobre a cidade antiga, proposta posteriormente criticada por Giovannoni. JOKILHETO, J., op. cit., p.220. 
qual seja, o percurso investigativo que toma por base a cidade existente e as lições de desenho que tais agrupamentos construídos poderiam nos fornecer. Camillo Sitte foi o principal responsável por tal inovação.

A historiografia do urbanismo atribui a Sitte e seus discípulos a influência sobre várias linhas projetuais que se desenvolveriam no alvorecer do século, de orientação contrária às operações de cunho haussmanniano, em um momento no qual o conhecimento especializado no campo do urbanismo começava a atingir certa repercussão, inicialmente a partir da discussão de teorias e projetos em congressos e encontros internacionais e, em seguida, a partir da publicação dos primeiros estudos teóricos e suas respectivas traduções. ${ }^{144}$ Nesse sentido, o historiador alemão Cornelius Gurlitt (1850-1938), por exemplo, a partir da matriz sittiana, defendeu a elaboração de planos urbanísticos que atentassem para a quebra da monotonia dos percursos e explorassem os "ritmos da melodia urbana”. Já o urbanista inglês Raymond Unwin (1863-1940), dentre outros aspetos, ressalta a valorização do traçado viário como componente de desenho dotado de especificidades próprias e não somente como o negativo com relação à parte edificada. Em Werner Hegemann (1881-1936), arquiteto e urbanista alemão, a mensagem de Sitte pode ser observada na ênfase com a qual analisa os conjuntos arquitetônicos antigos. Hegemann considera os conjuntos edificados como composições formadas por cheios e vazios e dotadas de uma estética particular que seria responsável pela fruição de certa continuidade histórica e simbólica em cidades ameaçadas pela constante transformação. Dessa forma, considera os espaços entre os edifícios, a praça, suas formas e escalas, a continuidade e a regularidade dos edifícios que a enquadram, tão importantes quanto o monumento arquitetônico isolado. ${ }^{145}$

Também no contexto brasileiro tais estudos urbanos lograram considerável repercussão. Não obstante as diferenças entre o contexto europeu que delineava a problemática urbanística e aquele das transformações urbanas brasileiras no início do século, tanto o modelo haussmanniano quanto algumas das idéias vinculadas à estética urbana estiveram presentes na elaboração de projetos modernizadores para várias cidades

\footnotetext{
${ }^{144}$ SIMÕES Jr., José Geraldo. A urbanística germânica (1870-1914): Internacionalização de uma prática e referência para o urbanismo brasileiro. Arquitextos Vitruvius, n. 097.03, 2008.

${ }^{145}$ A análise da repercussão do pensamento de Camillo Sitte sobre os teóricos aqui destacados foi realizada com base em CALABI, Donatella. L'arte urbana in Europa: alcuni categorie concettuali nelle parole dei suoi teorici. In: SPAGNESI, Gianfranco (Org.). L'Architettura..., op. cit., pp. 50-57. Para um panorama geral dos teóricos desse período, suas filiações conceituais e contribuições, consultar: FREESTONE, Robert (Org.). Urban Planning in a Changing World: The Twentieth Century Experience. London: Taylor \& Francis, 2000.
} 
brasileiras. ${ }^{146}$. Nesse momento, no entanto, o contexto histórico e cultural brasileiro ainda não criara as condições de partida para a discussão sobre a interferência de reformas dessa envergadura do ponto de vista da conservação do patrimônio urbano existente.

No cenário europeu que moldara as manifestações teóricas abordadas, a variedade de caminhos interpretativos em torno do tema urbano evidencia um momento de conflito entre diversas preocupações em jogo: a compreensão do novo, a apropriação do progresso, a valorização do passado e a salvaguarda de seus testemunhos. No cerne da chamada estética urbana estão, pois, evidentes, as tensões de fim de século representadas pelo conflito entre o desejo de conservar a cidade antiga e a constatação de sua necessária tranformação, ou seja, a manifestação no campo urbanístico das tensões em torno da modernidade. O cenário das teorias analisadas é permeado, portanto, por "uma inquieta tensão com relação à modernidade, o esforço de acolhê-la, mas ao mesmo tempo de tomarlhe distância. Uma resposta, freqüentemente culta aos processos de transformação urbana induzidos pela modernização, que não se recusa a fazer as contas com o progresso, em relação ao qual continua a alimentar desconfianças". ${ }^{147}$

Com a disseminação dos pressupostos modernistas no campo do urbanismo, notadamente a partir da Carta de Atenas do CIAM, a contribuição das investigações sobre a cidade preexistente na intervenção prática sobre a cidade contemporânea não prosseguirá com a mesma força argumentativa desses primeiros teóricos, afastando-se pouco a pouco das práticas predominantes na atuação sobre a cidade. A partir de então, a discussão sobre o patrimônio urbano desenvolver-se-á mais no âmbito da preservação dos monumentos do que propriamente no campo do urbanismo, esfera disciplinar que efetivamente intervinha sobre a cidade. Releituras das investigações urbanísticas ora apresentadas, nas quais a cidade preexistente assumia o foco central, somente ganhariam espaço a partir dos anos

\footnotetext{
${ }^{146}$ Diversos autores indicam o modelo haussmanniano como principal norteador das obras de Pereira Passos na cidade do Rio de Janeiro. E sobre a repercussão dos estudos de estética urbana, alguns autores defendem a presença de certos aspectos desse pensamento nas propostas elaboradas por urbanistas paulistas como Victor da Silva Freire, Francisco Saturnino de Brito e Francisco Prestes Maia. Deve-se, contudo, considerar a abrangência dessa repercussão com cuidado. Apesar de alguns desses urbanistas abordarem o tema da estética urbana, na prática as prioridades de seus projetos eram sobretudo técnicas, vinculadas ao sistema viário. Para aprofundamentos e bibliografia complementar, consultar: CAMPOS Neto, Cândido Malta. Os rumos da cidade: urbanismo e modernização em São Paulo. São Paulo: Senac, 2002; SIMÕES Jr., J. G., op. cit., TOLEDO, Benedito Lima de. Prestes Maia e as origens do urbanismo moderno em São Paulo. São Paulo: Empresa das Artes, 1996.

147 BIANCHETTI, Cristina. Arte urbana e memoria disciplinare. In: SMETS, C. Charles Bul: $i$ principi dell'arte urbana ..., op. cit., p.11. Trad. nossa. "Ciò che conota quel mondo è una inquieta tensione verso la modernità, lo sforzo di accoglierla, ma nel contempo di prendervi distanza. Una risposta, spesso colta ai processi di trasformazione urbana indotti dalla modernizzazione che non rifiuta di fare i conti con il progresso, verso il quale continua a nutrire diffidenze."
} 
1960, no contexto de revisão do urbanismo moderno, com destaque para os estudiosos italianos da chamada Escola de Veneza, Giorgio Piccinato, Carlo Aymonino e Donatella Calabi; bem como os pesquisadores franceses vinculados ao Centro de Sociologia Urbana. 


\section{CAPítulo 2}

\section{O PATRIMÔNIO URBANO EM CENA: PRESERVAÇÃO E INTERVENÇÃO}

\section{REFLEXÕES SOBRE A RELAÇÃO 'ANTIGO-NOVO'}

No início do século $\mathrm{XX}$, a conjugação das diversas contribuições teóricas em torno da apreensão dos valores relacionados aos objetos patrimoniais, bem como das primeiras delimitações de critérios de atuação sobre os mesmos, permitiria a gradativa valorização das especificidades do ambiente urbano antigo. Inicialmente essa noção de 'ambiente histórico' abarcava a área construída imediatamente ao redor dos monumentos mais importantes, era o entorno, a 'moldura', um espaço que deveria ser valorizado como elemento que conferia às obras grandiosas as suas características de escala, contraste e composição. Essa abordagem estivera presente nas manifestações de Cattaneo contra o isolamento dos monumentos, ou mesmo de Charles Buls, anos mais tarde, e ainda permaneceria sob variadas formas ao longo do século XX. Os diversos modos de olhar o espaço urbano e de interpretar o conceito de monumento, no entanto, preparariam o terreno para um entendimento mais amplo dos valores relacionados aos conjuntos antigos, libertando-os gradativamente da dependência a um monumento principal que lhes conferisse importância.

Dentre as contribuições, já observávamos em Ruskin e Morris a evidenciação da dinâmica social do espaço urbano da cidade antiga e a defesa de suas qualidades e especificidades. Tais abordagens, no entanto, relacionavam-se à defesa de um habitar tradicional, condenando a iminente transformação do espaço urbano e diluindo, portanto, a sua historicidade. A partir das contribuições de Boito, e principalmente de Riegl, observamos uma abertura em direção à extensão dos bens considerados como patrimônio a partir da gradativa evidenciação do caráter cultural dos valores atribuíveis aos artefatos; ou seja, do caráter subjetivo e mutável de nossos juízos de valor dependendo de cada tempo e lugar, o que permitiria a atribuição de historicidade e artisticidade a diversos artefatos até então considerados 'menores', mas que agora adquiriam expressividade. Por essas abordagens, então, o tecido urbano antigo começaria a ser visto como um artefato 
patrimonial representativo, considerado em sua inteireza compositiva, como um conjunto dotado de especificidades estéticas e históricas próprias. Elaboração conceitual auxiliada também pelos estudos de estética urbana, notadamente de Camillo Sitte, e pelas diversas contribuições advindas dos questionamentos do urbanismo na busca pelas adaptações sanitárias e modernizadoras das cidades antigas. Cabe ressaltar, no entanto, que essa ampliação conceitual foi gradativa e nem sempre evidente em todos os contextos. Seriam necessárias várias décadas para a assimilação do conceito de patrimônio urbano além da idéia de entorno imediato de monumentos individuais. Na verdade, apesar de contribuições pontuais que já indicavam esse caminho, apenas após a Segunda Guerra Mundial haveria uma abertura maior para a compreensão das especificidades compositivas dos tecidos antigos. As contribuições de que temos tratado não se seguiram de forma linear e não representaram, necessariamente, uma seqüência de temas continuamente reelaborados a partir das proposições precedentes. As contradições e oposições sempre estiveram presentes, e continuarão ao longo de todo o século XX.

O conjunto das contribuições teóricas abordadas, na variedade de suas manifestações, articulações e contradições, ao permitir a expansão do conceito de monumento a uma série de artefatos 'menores', ao oferecer os instrumentos investigativos para a compreensão da dimensão patrimonial dos artefatos e impulsionar o questionamento sobre a coexistência do antigo e do novo forneceria, gradativamente, as bases conceituais para a valorização dos conjuntos edificados mais modestos, da chamada 'arquitetura menor'. Valorização baseada na paulatina compreensão das especificidades que concorrem para a formação da unidade compositiva desses conjuntos edificados. Gustavo Giovannoni (1873-1947) surgiria nesse cenário como o principal teórico a integrar as contribuições destacadas e permitir um passo adiante na formulação de métodos que conjugariam a conservação do patrimônio - agora considerado em sua dimensão urbana -, e as experiências urbanísticas de modernização. Logo, a atribuição de valor aos tecidos urbanos e à arquitetura menor será tema recorrente ao longo de toda sua produção teórica e prática.

Uma nova consciência veio nessa ordem de idéias amadurecendo nas últimas décadas. Agora em contrapartida apercebemo-nos de duas verdades: Uma é que um grande monumento tem valor em seu ambiente de visuais, de espaços, de massas e de cor no qual é erguido, [...]; a outra é que o aspecto típico das cidades ou povoados e o seu essencial valor de Arte e de história freqüentemente residem sobretudo na manifestação coletiva 
dada do esquema topográfico, dos agrupamentos construtivos, na vida arquitetônica expressa nas obras menores. ${ }^{148}$

Sendo assim, a atuação do arquiteto, engenheiro e urbanista Gustavo Giovannoni foi primordial para a aproximação entre as teorias do restauro e as contribuições advindas do urbanismo no que tange à valorização dos conjuntos urbanos antigos. Com uma vasta produção teórica e também prática, aliando conhecimentos no campo da história da arquitetura, das artes e das técnicas construtivas, assim como ampla experiência na área projetual, didática e na política urbana ${ }^{149}$, as teorias de Giovannoni representaram um importante passo para a compreensão dos tecidos urbanos como patrimônio, abrindo caminho para a delimitação de certos critérios de intervenção sobre a cidade histórica com vistas à preservação de suas especificidades. Considerado o primeiro autor a empregar a expressão 'patrimônio urbano ${ }^{, 150}$, Giovannoni elaborou estudos que permitiram a inserção, de modo até então pioneiro, da preservação dos tecidos urbanos tradicionais na pauta do discurso urbanístico. Na verdade, Giovannoni teria, mesmo, considerado a conservação das cidades antigas como parte integrante de sua prospectiva de urbanização.

Apesar do caráter inovador de suas idéias e da inegável influência sobre a legislação italiana e sobre a produção teórica de diversos autores, seus trabalhos ficaram durante muito tempo relegados ao ostracismo devido, principalmente, à sua postura crítica frente à arquitetura moderna e às suas escolhas no campo político, já que esteve vinculado ao fascismo. Assim, foram necessárias algumas décadas para que sua obra recebesse uma releitura imparcial, que considerasse suas atentas observações sobre as particularidades das cidades antigas e as condições de seu crescimento, independentemente de suas filiações

\footnotetext{
148 GIOVANNONI, Gustavo. Vecchie città ed edilizia nuova. Milano, Torino: Città Studi, 1995 [1 ${ }^{\text {a. }}$ ed. 1931], p.176. Trad. nossa. "Una nuova coscienza è venuta in questo ordine di idee maturando negli ultimi decenni. Ormai invece ci siamo accorti di due verità: L'una è quella che un grande monumento ha valore nel suo ambiente di visuali, di spazi, di masse e di colore in cui è sorto, [...]; l'altra è che l'aspetto tipico delle città o delle borgate ed il loro essenziale valore d'Arte e di storia spesso risiedono soprattutto nella manifestazione collettiva data dallo schema topografico, negli aggruppamenti edilizi, nella vita architettonica espressa nelle opere minori."

${ }_{149}$ Além da prática profissional voltada ao desenvolvimento de projetos de arquitetura, Giovannoni atuou ativamente na área didática, na pesquisa e na promoção de atividades culturais, bem como na elaboração de planos diretores e projetos urbanos de novos bairros. Sobre a produção teórica e projetos elaborados, bem como para estudos recentes sobre sua obra, consultar: CARBONARA, Giovanni. Avvicinamento al Restauro. Napoli: Liguori, 1997, pp.234-240; SETTE, Maria Piera (Org.). Gustavo Giovannoni: riflessioni agli albori del XXI secolo. Roma: Bonsignori, 2005; Atti del Seminario Internazionale "L'Associazione artistica tra i cultori di architettura e Gustavo Giovannoni”. In: Bolletino del Centro di Studi per la Storia dell'Architettura, n.36, 1990; ZUCCONI, Guido (Org.). Dal capitello alla città. Milano: Jaca Book, 1997.

${ }^{150}$ CHOAY, Françoise. A Alegoria do Patrimônio. Trad. Luciano Vieira Machado. São Paulo: Estação Liberdade, Unesp, 2001, p. 195.
} 
políticas. Dentre a sua vasta produção teórica, destaca-se a obra Vecchie città ed edilizia nuova ${ }^{151}$, publicação datada de 1931 e que reúne os diversos temas debatidos em artigos avulsos publicados desde 1911. Além de ser considerado o primeiro texto italiano de urbanismo, a obra possui importância crucial na presente abordagem, já que procurou integrar, de forma até então inovadora, as questões pertinentes ao tratamento do patrimônio histórico e aquelas voltadas à solução dos problemas urbanísticos. ${ }^{152}$

Dentre outras indagações, os estudos de Giovannoni buscaram responder à mesma questão que já intrigara outros teóricos como Sitte, Buls ou Stübben: o desafio de compreender e organizar as relações entre a cidade moderna e a cidade antiga. De posse de amplo conhecimento sobre as teorias urbanísticas até então elaboradas, Giovannoni defendeu a busca por uma solução projetual que considerasse os mecanismos de expansão da cidade - atentando para as evidentes diferenças entre o núcleo antigo e os novos bairros e para as questões econômicas e administrativas envolvidas na atuação sobre cada uma dessas diferenciadas parcelas urbanas. Nesse sentido, o autor defende que os núcleos urbanos antigos possuem especificidades morfológicas, escalas compositivas e qualidades históricas e estéticas que requerem uma atuação e uma destinação de usos apropriada. A maioria dos projetos de intervenção sobre a cidade antiga até então propostos, baseados nas radicais operações de 'desventramento' - aberturas drásticas de novas vias por motivos de higiene pública - não consideravam tais particularidades e propunham, como ponto de partida, a adaptação forçada a novos usos não condizentes com a estrutura urbana preexistente. Por fim, tais projetos não só destruíam importantes parcelas dos núcleos antigos como ainda não obtinham resultados satisfatórios com relação à desejada salubridade.

De maneira geral, os projetos desenvolvidos segundo esse modelo, ao buscar a assimilação de funções e condições modernas pelo organismo urbano antigo, partiam de uma premissa equivocada já que as particularidades dos tecidos tradicionais não eram devidamente consideradas. Dessa forma, Giovannoni não persegue soluções urbanas

\footnotetext{
${ }^{151}$ GIOVANNONI, Gustavo. Vecchie città..., op. cit. O livro conserva o título de artigo publicado pelo autor em 1913 na revista Nuova Antologia.

${ }^{152}$ CHOAY, Françoise. Introduction. In: GIOVANNONI, Gustavo. L'urbanisme face aux villes anciennes. Paris: Éditions du Seuil, 1998, p.8 [versão francesa da obra Vecchie città ed edilizia nuova]. Na introdução à versão francesa de Vecchie città, Choay afirma que as releituras da obra giovannoniana ganharam espaço sobretudo a partir dos anos 1980 - no contexto de revisão teórica de certos pressupostos do urbanismo moderno - sendo ainda impulsionadas ao longo dos anos 1990 após a reedição de Vecchie Città e respectiva tradução francesa.
} 
baseadas na dupla assimilação entre o modelo urbano antigo e o moderno. Ao contrário, busca a separação entre ambas as formações urbanas, reservando a cada uma delas as funções que lhes seriam compatíveis e projetando soluções de tráfego que permitissem a comunicação entre ambas as estruturas. Por uma lado, propõe reservar ao tecido antigo apenas a circulação local, isolando-o do grande tráfego urbano moderno; por outro lado, destina aos tecidos preexistentes as funções consideradas 'de proximidade' (moradia, pequeno comércio, serviços), sejam elas tradicionais ou novas, desde que compatíveis com sua escala e morfologia. As funções consideradas incompatíveis seriam locadas em novos centros, localizados em novos bairros construídos além do núcleo urbano antigo de modo a orientar a expansão da cidade e a evitar a recorrência a um centro único. ${ }^{153}$ Propõe, portanto, a adoção de duas escalas diferenciadas de gestão e intervenção e orienta, a partir de tais atribuições, o desenvolvimento de um organismo urbano 'pluripolar'. Dessa forma, assim como o projeto de novos bairros e vias, também a preservação das parcelas urbanas antigas deveria necessariamente integrar o escopo dos planos para as cidades, tanto na escala local, como regional e territorial, e não mais como no "velho método dos planos diretores, nos quais se desenhavam sobre a planta os edifícios mais notáveis, deixando o trabalho sobre os menores para as picaretas". ${ }^{154}$

Para os centros antigos propõe a realização de adaptações construtivas limitadas, de certa forma 'microcirúrgicas', com o intuito de sanar problemas sanitários ocasionados pelo adensamento descontrolado e paralelamente permitir a fruição contemporânea das funções consideradas compatíveis sem prejudicar as qualidades históricas e estéticas do conjunto urbano. Dessa forma, o tecido urbano antigo - agora denominado patrimônio urbano - é considerado como um "organismo vivo", 155 como uma parcela urbana integrante de um organismo maior e integrada à vida contemporânea, que possui, portanto,

\footnotetext{
${ }^{153}$ Esse modelo teria sido posto em prática na construção dos bairros de Monte Sacro e La Garbatella, localizados na então periferia de Roma, ambos projetados por Giovannoni (o segundo com a participação de M. Piacentini). GIULIANI, Aldo. Monumenti, Centri Storici, Ambiente. Milano: Tamburi, 1966, pp.12-14. Giovannoni discorre sobre a descentralização urbana em diversos escritos, ver p. ex.: GIOVANNONI, G. $L a$ urbanistica e la deurbanizzazione. Roma: Società Italiana per il Progresso delle Scienze, 1936.

${ }^{154}$ GIOVANNONI, G. Restauro dei monumenti e urbanistica. Le Arti, 1942, pp. 33-39, p.34.

155 Giovannoni emprega a expressão 'organismo vivo' como referência à Charles Buls. "A cidade, o povoado, o bairro, a praça, o jardim, a via, são portanto considerados como obras de Arte, como 'organismos vivos', para empregar a expressão de Buls”. GIOVANNONI, G. Vecchie città..., op. cit., p.116.
} 
um 'valor de uso', além da função considerada 'museal' que de certa forma emergia como prioritária em algumas interpretações e intervenções conservativas do período ${ }^{156}$.

As adaptações limitadas propostas por Giovannoni configurariam o método conhecido como diradamento edilizio, ou seja, o 'desadensamento construtivo' ${ }^{157}$ dos conjuntos urbanos antigos. A análise do autor considerava que a insalubridade dos velhos núcleos urbanos não era devida à composição original do tecido antigo e sim ao adensamento posterior e descontrolado que ocupara os interstícios dos edifícios e provocara aumentos construtivos não condizentes com a escala e a capacidade original das antigas estruturas. Dessa forma, a intervenção 'microcirúrgica' do 'desadensamento' consistia na adaptação e no saneamento, sem prejuízo para o patrimônio urbano, por meio da abertura de espaços, da supressão de obstáculos visuais e da realização de demolições controladas dos aportes construtivos considerados superficiais, tanto na parte interna quanto na área externa das edificações, com intuito de abrir novas visuais e facilitar a iluminação e a ventilação. ${ }^{158}$ Tal solução conciliaria três fatores essenciais: a desobstrução da circulação local, a conservação do aspecto artístico e o atendimento das necessidades higiênicas. $^{159}$

Apesar de o método do desadensamento sugerir demolições apenas quando estritamente necessárias - quando os edifícios estivessem em estado muito precário ou quando as vias fossem muito estreitas, por exemplo - a aplicação de tais prerrogativas

\footnotetext{
156 Dentre outros, Choay ressalta a posição de Marcello Piacentini que de certa forma propunha a 'museificação' dos tecidos antigos, isolando-os da vida contemporânea. Quanto às intervenções, merece destaque o projeto de Charles Buls para a Grand'Place de Bruxelas, considerado por Choay como o paradigma da 'conservação urbana museal', CHOAY, F., Introduction, op. cit., p. 13; CHOAY, F. A Alegoria..., op. cit., p.192; Analogamente, sobre o mesmo projeto de Buls, Marcel Smets afirma que os edifícios da praça, 'objetos históricos', teriam sido tratados como "modelos em tamanho natural, dispostos num museu ao ar livre constituído pela cidade em si". SMETS, M. Charles Buls et l'amorce d'une nouvelle politique urbaine a la fin du $19^{\text {eme }}$ siècle . In: SPAGNESI, G. (Org.). L'Architettura delle Trasformazioni Urbane 1890-1940. Roma: Centro di Studi per la Storia dell'Architettura, 1992, p.79.

${ }^{157}$ A expressão diradamento edilizio pode ser traduzida por desadensamento, espaçamento, diluição. Em inglês, Jukka Jokilehto emprega o termo thinning-out. JOKILEHTO, Jukka. A History of Architectural Conservation. Oxford: Butterworth-Heinemann, 2006, p.220. Françoise Choay afirma que o termo consiste numa metáfora botânica que busca associar a atuação sobre os tecidos urbanos ao trabalho de um jardineiro na supressão de vegetações excedentes ou parasitárias com o intuito de facilitar o crescimento das demais plantas. CHOAY, F. Introduction, op. cit., p.14.

${ }_{158} \mathrm{Um}$ exemplo considerado bem sucedido é o projeto para Bergamo Alta, no qual o arquiteto Luigi Angelini, inspirado em Giovannoni, realizou uma intervenção sensível de diradamento, recorrendo à poucas demolições e permitindo a conservação do aspecto original do centro antigo. SANTORO, Lucio. Restauro dei monumenti e tutela ambientale dei centri antichi. Cava dei Tirreni: Di Mauro, 1970, p. 23. Sobre outros projetos baseados nas proposições giovannonianas, consultar: CARBONARA, G., op. cit., p.240; PANE, Andrea. Dal monumento all'ambiente urbano: la teoria del diradamento edilizio. In: CASIELLO, Stella (Org.). La cultura del restauro: teorie e fondatori. Venezia: Marsilio, 1996, pp. 293-314.

${ }^{159}$ GIOVANNONI, G. Vecchie città..., op. cit., p.248.
} 
encerrou certas dificuldades. Por um lado, o próprio traçado estreito configurava um importante documento histórico e fator essencial na definição dos valores ambientais de determinados agrupamentos; por outro lado, os limites do que poderia ser considerado aporte construtivo superficial não estavam claros, assim como os critérios a serem empregados na construção de novas obras ou completamentos. Como conseqüência, seguiram-se uma série de intervenções supostamente baseadas nesse método mas que não garantiam a conservação do patrimônio urbano conforme preconizara Giovannoni, provocando a demolição de grandes parcelas urbanas e a substituição de edificações consideradas inexpressivas por reconstruções em estilo. ${ }^{160}$

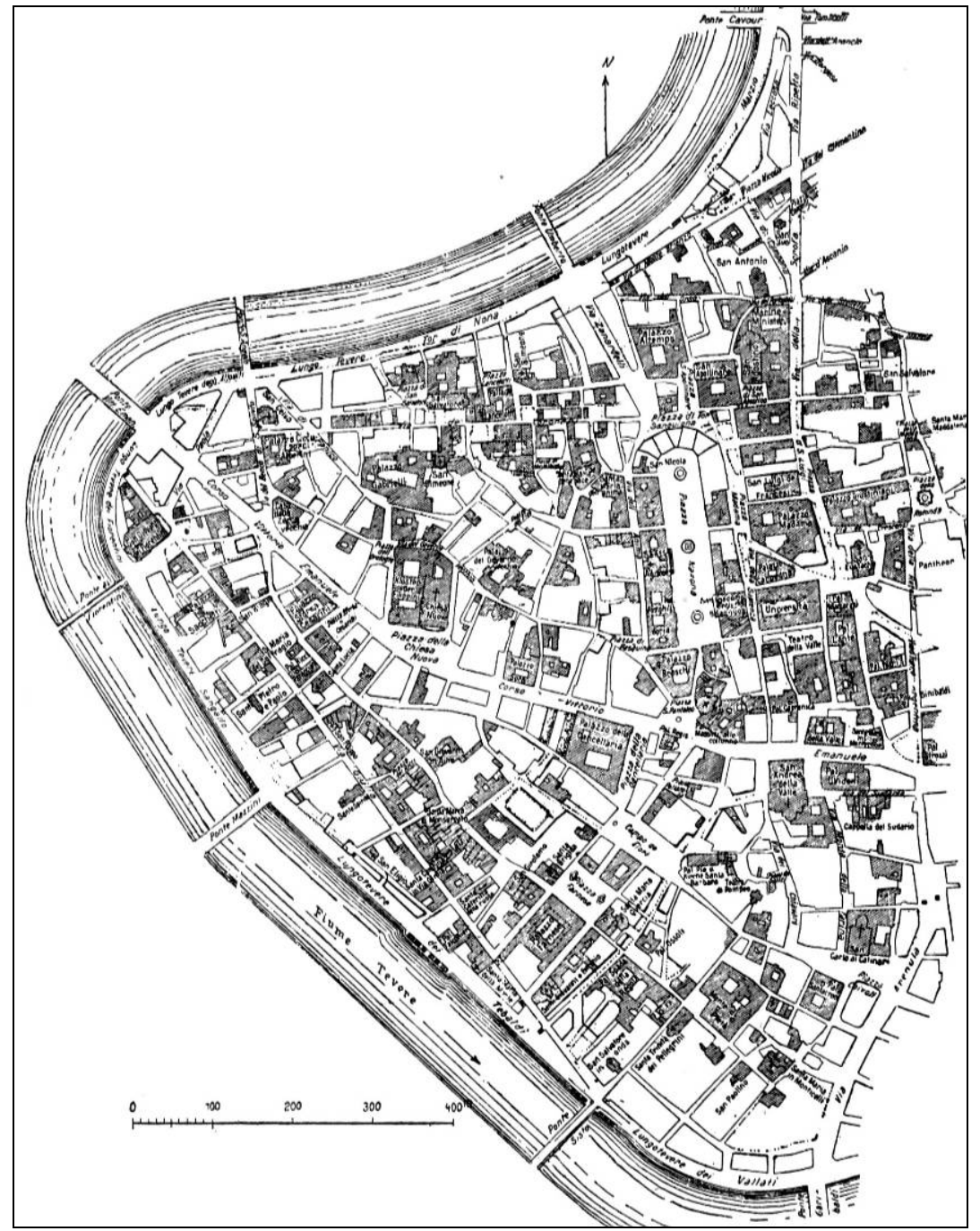

04. O bairro do Renascimento, em Roma. Intervenção proposta segundo o método do 'desadensamento construtivo’. Em destaque, as edificações de excepcional interesse. As áreas a serem parcialmente demolidas estão demarcados em linha pontilhada. (GIOVANNONI, G. Vecchie città..., op. cit., p.277)

\footnotetext{
${ }^{160}$ Nesse sentido podemos citar os trabalhos de demolição do bairro de S. Croce, em Florença, realizados contemporaneamente ao projeto de Bergamo Alta, porém sem a mesma sensibilidade. O projeto resultou na demolição de vários edifícios, posteriormente reconstruídos ex novo. SANTORO, L. op. cit., p.23.
} 
A abordagem de Giovannoni encerrava uma constante alternância entre escalas de intervenção - do detalhe ao edifício monumento, do edifício ao ambiente monumento - , sempre buscando uma comunicação harmoniosa entre os seus diferentes níveis. As considerações quanto ao desadensamento construtivo, portanto, não se limitaram aos escritos sobre urbanismo. Em seus estudos voltados à restauração dos monumentos o autor reserva grande espaço para a dinâmica urbana associada às intervenções de restauro, uma vez que considera, como vimos, todo o tecido urbano antigo como um único monumento. Dessa forma, os procedimentos de preservação e restauro indicados para as parcelas urbanas seriam análogos àqueles indicados para os monumentos individuais. Quanto ao procedimento do desadensamento, classificado como 'restauro de liberação', Giovannoni alerta para o perigo de avançar nas demolições para além do que considera estritamente necessário, deixando-se levar pela 'obsessão do isolamento', que tanto preocupara Sitte e Buls. Tal prática, considerando a dinâmica urbana, alteraria as relações compositivas entre as massas construídas e prejudicaria o efeito estético do conjunto urbano.

Outros temores relativos ao restauro de liberação são aqueles urbanísticos. A liberação pode compreender edifícios secundários insignificantes que escondem o monumento: mas freqüentemente desvia-se no desejo de isolá-lo e colocá-lo em honra sobre um grande espaço, e com isto alteram-se as condições da externa arquitetura, feita por visuais limitadas, por efeitos de contraste, por associação da obra maior com outras menores. ${ }^{161}$
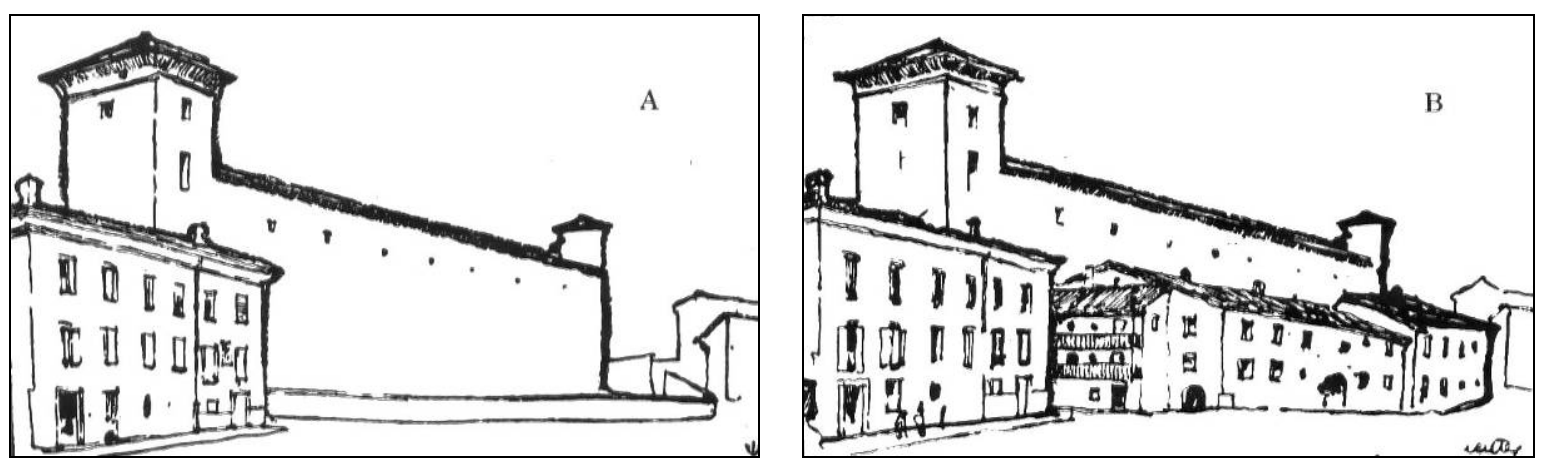

04. Ilustração empregada por Giovannoni em Vecchie Città. Trata-se da Torre Aquila, em Trento, Itália, em duas situações distintas: em A, a proposta de isolamento do edifício; em B, a situação Original, na qual as relações entre edifícios de diferentes escalas configuram uma paisagem particular. (GIOVANNONI, G. Vecchie città..., op. cit., p.179)

\footnotetext{
${ }^{161}$ GIOVANNONI, G. Il restauro dei monumenti. Roma: Cremonese, [1939?], p.72. Trad. nossa. "Altri temi attinenti al restauro di liberazione sono quelli urbanistici. La liberazione può comprendere edifici secondari insignificanti che occultano il monumento: ma spesso traligna nel desiderio d'isolarlo e metterlo in onore su di un grande spazio, e con questo altera le condizioni dell'esterna architettura, fatta per visuali limitate, per effetto di contrasto, per associazione dell'opera maggiore con altre minori."
} 
Quanto às ações específicas de restauro, Giovannoni elabora uma releitura da teoria de Boito e mantém grande fidelidade aos seus pressupostos reiterando, de certa forma, a idéia de 'teoria intermediária' entre as proposições de Viollet-le-Duc e Ruskin. Consolidava-se, portanto, a apreensão do monumento enquanto documento histórico e a compreensão do caráter temporal do restauro, a partir da valorização de todas as estratificações históricas do monumento e da necessidade de evidenciar a atuação contemporânea sobre o mesmo. Nesse sentido, Giovannoni considerava o restauro estilístico anticientífico devido às falsificações geradas e à negligência com relação aos aportes construtivos de diferentes épocas ${ }^{162}$. Tais intervenções, apesar de superadas pelas teorias modernas, seriam ainda prejudiciais pois estariam muito vivas "na semiconsciência e na semicultura do povo, que é ainda atraído pela perigosa fórmula do retorno ao tipo antigo". ${ }^{163}$ Mesmo descontando certa carga de elitismo contida na idéia de uma 'semicultura popular', a crítica de Giovannoni é perspicaz, pois aponta para o perigo do uso indiscriminado dos refazimentos em estilo. Por outro lado, também não apoiava a construção de edificações modernas junto às antigas. Apesar de defender que os novos edifícios e intervenções devessem apresentar as características projetuais contemporâneas, Giovannoni duvidava que a arquitetura de então, ou seja, a arquitetura do movimento moderno, fosse realmente a expressão de sua época, posição que lhe rendeu numerosas críticas. ${ }^{164}$ Admitia o emprego da arquitetura e da técnica moderna em alguns casos e sob certas condições, como nas intervenções de consolidação, por exemplo, onde estariam presentes "nas formas meramente construtivas sem intenção de arte, como pilares e esporões, e nos esquemas estruturais do organismo, manifestos ou escondidos, que dão nova estabilidade aos monumentos." ${ }^{165}$ No entanto, quando fosse necessário construir

\footnotetext{
162 Algumas correntes da historiografia do restauro classificam as posturas de Giovannoni como 'restauro científico' ou 'restauro filológico'. Ao reelaborar as teorias de Boito, Giovannoni propõe uma classificação de tipos de restauro: de consolidação, de recomposição (anastilose), de liberação, de completamento e de renovação. Defendia a fundamentação rigorosa dos projetos de restauro e dava maior atenção ao valor documental e histórico em detrimento da configuração estética da obra. CARBONARA, G. Avvicinamento..., op. cit., pp. 234-240.

${ }^{163}$ GIOVANNONI, G. Il restauro..., op. cit., p.28. Trad. nossa. "[...] è ora superato nei moderni restauri; ma non nella semicoscienza e nella semicoltura del popolo, che è ancora attratto dalla pericolosa formula del ritorno al tipo antico."

${ }^{164}$ Carbonara aponta, porém, que o próprio conceito de 'arquitetura moderna' nesse momento, comportava grandes contradições. E, em defesa de Giovannoni, afirma ainda que a incompatibilidade por ele evocada entre o novo e o antigo hoje pode ser revista com maior equilíbrio e distanciamento histórico. Dessa forma, a recusa apontada poderia ser encarada mais como uma incompatibilidade entre as naturezas muito díspares da arquitetura tradicional e dos elementos construtivos e linguagens 'modernas', e não necessariamente como uma questão de recusa em relação ao moderno enquanto estilo. CARBONARA, G., op. cit., p.238.

165 GIOVANNONI, G. Il restauro..., op. cit., p.30-31. Trad. nossa. "Può invece la nostra architettura moderna esser presente nelle forme puramente costruttive senza intenzione d'arte, come pilastri e speroni, e negli schemi strutturali dell'organismo, palesi o nascosti, che diano nuova stabilità ai monumenti."
} 
adições, estas deveriam adotar linhas simplificadas, e no caso de completamentos, a alternativa para fugir das hipóteses duvidosas e restabelecer o efeito de conjunto seria o emprego das chamadas 'zonas neutras'. Suas considerações quanto às adições construtivas, portanto, geraram e ainda geram grandes polêmicas. Essa suposta neutralidade é um dos pontos da teoria giovannoniana em que notamos com clareza a priorização da conservação documental dos monumentos e conjuntos urbanos e a renúncia por qualquer expressão contemporânea. Não obstante sua relevante afeição pelos estudos de estética urbana, a recorrência à neutralidade certamente não contribuía para a fruição estética dos tecidos preservados. Esse ponto em particular seria questionado por Agnoldomenico Pica e vários outros teóricos anos mais tarde.

Além da considerável influência na elaboração de planos diretores e no caminho traçado pela própria legislação italiana concernente às matérias do urbanismo e da tutela ${ }^{166}$, no início do século as teorias de Giovannoni contribuiriam significativamente em âmbito internacional, como podemos observar nos temas debatidos durantes o XII Congresso Internacional de Habitação e dos Planos Diretores e na Conferência Internacional sobre Conservação e Restauração dos Monumentos Históricos, da qual resultara a Carta de Restauro de Atenas, de reconhecida inspiração giovannoniana, assim como a Carta de Restauro Italiana, também formulada a partir dos princípios acordados nessa Conferência.

Durante o XII Congresso Internacional de Habitação e dos Planos Diretores, em 1929, estudiosos e urbanistas de diversos países - dentre os quais Raymond Unwin, Joseph Stübben, Luigi Piccinato e o próprio Giovannoni - estiveram reunidos em Roma para discutir, dentre outros temas, a questão da atuação sobre as cidades históricas para adaptálas às exigências da vida moderna. Na ocasião, as observações de urbanistas oriundos de diversos países evidenciaram que os temas em debate no contexto italiano encontravam considerável ressonância em outros países, sobretudo europeus, sendo até mesmo difícil identificar o quanto esse contexto geral de indagações gerava a circulação de idéias, ou o

\footnotetext{
${ }^{166}$ Giovannoni participou de comissões de estudo para subsidiar a formulação de leis, sendo considerado, ao lado de Virgilio Testa e Alberto Calza Bini, um dos protagonistas das discussões em torno dos instrumentos legislativos urbanos no início do século XX. Segundo Giuliani, a atividade de Giovannoni estaria presente nos conteúdos das leis n. 1089, de $1^{\circ}$. de junho, sobre a tutela das coisas de interesse histórico e artístico, e n.1497, de 29 de junho, sobre a proteção das belezas naturais, dos parques, dos jardins e da paisagem, ambas de 1939, bem como na Lei de Urbanismo n. 1552, de 1942, que orientou as escalas de planejamento e estabeleceu uma hierarquia de planos diretores. GIULIANI, A. op. cit., p.23; GURRIERI, F.; VAN RIEL, S. e SEMPRINI, M. P. Il restauro del paesaggio: dalla tutela delle bellezze naturali e panoramiche alla governance territoriale / paesaggistica. Firenze: Alinea, Associazione ARSPAT, 2005, pp.12-23.
} 
quanto as mesmas foram impulsionadas pelas teorias de Giovannoni. ${ }^{167}$ Mas um ponto é claro: o tema da intervenção sobre a cidade histórica ganhava espaço como problema urbanístico. Nesse sentido, nos chama a atenção considerações de grande pertinência e atualidade como os dizeres de Luigi Piccinato sobre a necessidade de integrar as várias escalas de intervenção em um único plano diretor que considerasse a cidade como um organismo único:

Os planos diretores de organização dos antigos bairros devem ser estudados não como uma organização isolada, separada do quadro geral da cidade, mas como organização que é compreendida e resolvida em harmônica relação com todo o plano geral, porque a solução de detalhe está em estreita correlação com o próprio plano geral. [...] Sou de opinião que um programa urbanístico geral deve sempre também conduzir as transformações dos bairros individuais.

[Tão perigosa quanto o isolamento e o 'desventramento', é] a falta de uma visão global e unitária de um plano geral de transformação que conduza a totalidade do desenvolvimento urbano antecedendo com as suas soluções de conjunto o estudo das soluções de detalhe. Já que de qualquer modo o problema apresenta duas fases: uma geral e outra de detalhe; e não é possível enfrentar a segunda sem ter resolvido aquela mais completa e global do plano diretor geral. ${ }^{168}$

O embate entre o antigo e o novo, entre a preservação e a modernização, permanece um dos grandes nós da questão. São citados os problemas enfrentados em alguns países e a insuficiência normativa das legislações então empregadas para a atuação sobre a cidade histórica. Em geral, a legislação dessas localidades baseava-se ainda em instrumentos de expropriação que propunham o reloteamento dos bairros considerados insalubres, porém nem sempre garantiam a preservação do patrimônio urbano, principalmente da chamada arquitetura 'menor'. Pelo contrário, além de provocar grandes

\footnotetext{
167 Sobre intervenções nas cidades antigas, além da contribuição italiana representada principalmente por Giovannoni, Piccinato e Piacentini, destacaram-se ainda as contribuições dos ingleses H. P. Lafontaine, membro do RIBA e Patrick Abercrombie, professor da Universidade de Liverpool, bem como do francês Marcel Poëte e do alemão Joseph Stübben. Atti del XII Congresso Internazionale dell'Abitazione e dei Piani Regolatore. Roma: s.n., 1929, v.I, pp.5-488.

${ }^{168}$ PICCINATO, Luigi. Atti del XII Congresso Internazionale dell'Abitazione e dei Piani Regolatore. Roma: s.n., 1929, v.III, pp. 104-105; v.I, p.343. Trad. nossa. "I piani regolatori di sistemazione degli antichi quartiere debbono essere studiati no come una sistemazione a sé, avulsa dal quadro generale della città, ma come una sistemazione che va compresa e risolto in armonico rapporto con tutto il piano generale, perché la soluzione di dettaglio è in stretta correlazione col piano generale stesso [...]. Sono d'opinione che un programma urbanistico generale deve presiedere sempre anche alle trasformazioni dei singoli quartieri." - "E ancora più pericolosa e più grave è la mancanza di una visione globale e unitaria di un piano generale di trasformazione che presieda dall'intero sviluppo cittadino precedendo con le sue soluzione di insieme lo studio delle soluzione di dettaglio. Poiché in ogni modo il problema presenta due fasi: l'una generale e l'altra di dettaglio; e non è possibile affrontare la seconda senza aver risolto quella più completa e globale del piano regolatore generale."
} 
demolições, impulsionavam práticas agressivas de valorização imobiliária. ${ }^{169}$ Cabe ressaltar, no entanto, que a defesa da preservação do patrimônio urbano não era uma unanimidade. Questionavam-se também a pertinência de se preservar certas parcelas urbanas ou monumentos diante de necessidades modernas consideradas mais importantes. E defendia-se, nesse sentido, a necessária participação de equipes multidisciplinares para a avaliação dessas escolhas.

\begin{abstract}
É justo que se deva salvar o centro histórico, mas não se deve esquecer que às vezes uma artéria posta na balança pode ter mais peso que uma igreja, um monumento. É por isso que à mesa de discussão do projeto de um plano diretor de uma cidade não podem sentarse apenas arquitetos, arqueólogos ou artistas, mas também higienistas, e técnicos pertencentes a todos os ramos da técnica moderna. ${ }^{170}$
\end{abstract}

$\mathrm{Na}$ Conferência de Atenas de 1931, reunião organizada pelo Escritório Internacional de Museus da Sociedade das Nações (Office International des Musées, Société des Nations) e primeira conferência internacional sobre o tema da conservação e restauração de monumentos, a questão dos conjuntos urbanos foi abordada principalmente a partir das considerações apresentadas por Giovannoni, recebidas no conjunto das demais proposições como elementos de grande novidade. ${ }^{171}$ A partir de um discurso centrado em questões conceituais e de método, Giovannoni apresentou o progressivo caminho em direção ao entendimento do valor patrimonial de inteiras zonas urbanas, para as quais seriam aplicadas medidas de conservação e restauro equivalentes àquelas voltadas aos monumentos individuais, reafirmando, nesse sentido, os princípios de Camillo Boito, com

\footnotetext{
${ }^{169}$ Dentre os exemplos citados, temos a lei Adickes, na Alemanha, voltada para a expropriação de áreas cujos edifícios eram considerados sem valor. Essa determinação de 'valor', no entanto, gerava controvérsias. $\mathrm{Na}$ localidade de Colonia, um instrumento de expropriação semelhante também teria causado grandes demolições. Atti del XII Congresso..., op. cit., v.III, pp.107-111. Sobre a inadequação das leis de expropriação na condução dos projetos urbanos no cenário italiano, ver p. ex. GIOVANNONI, G. $L a$ urbanistica e la deurbanizzazione. Roma: Società Italiana per il Progresso delle Scienze, 1936.

${ }^{170}$ PANTALEO, Vittorio. Atti del XII Congresso..., op. cit., v.III, p.95. Trad. nossa. "È giusto che se debba salvare il centro storico, ma non se deve dimenticare che alle volte un'arteria messa nella bilancia può avere più peso di una chiesa, un monumento. Ecco perché al tavolo di discussione del progetto di un piano regolatore di una città non possano sedere soltanto architetti, archeologi o artisti, ma bensì anche igienisti, e tecnici appartenenti a tutti i rami della tecnica moderna."

${ }^{171}$ Sobre a Conferência de Atenas, ver: CARBONARA, G., op. cit., pp. 241-244. A consulta direta às Atas da Conferência é recurso imprescindível para uma correta apreensão da amplitude de certas temáticas abordadas no evento; amplitude que a concisão e pragmatismo da Carta de Atenas não nos permite notar: La Conservation des Monuments d'Art e d'Histoire. Paris: Office International des Musées, 1933. Devido ao difícil acesso às Atas, remetemos também à publicação organizada por Françoise Choay, apesar das lacunas: La Conférence d'Athènes sur la Conservation Artistique et Historique des Monuments (1931) [Édition établie par Françoise Choay]. Besançon: Éditions de l'imprimeur, 2002.
} 
destaque para a necessidade de contemporizar com bom senso as teorias adeptas da pura conservação e aquelas voltadas às reconstruções em estilo. ${ }^{172}$

Dentre os temas relacionados aos conjuntos urbanos antigos, emergem como grandes contribuições da representação italiana no evento, com destaque para Giovannoni, a abordagem de questões como a complementaridade entre monumentos maiores e menores, a indissociabilidade entre o monumento e o entorno, a noção de patrimônio urbano e a integração entre conservação do patrimônio construído e urbanismo. De grande interesse nesse sentido foram ainda as considerações do italiano Giorgio Nicodemi que enfatizou o caráter urbanístico da preservação dos monumentos, bem como a pertinência de buscar a preservação de áreas urbanas inteiras que representassem interesse patrimonial. Tais observações antecedem em décadas os debates que originariam certos instrumentos legislativos especiais voltados à preservação urbana como os 'setores protegidos' ${ }^{173}$, na França, bem como os debates que seriam encampados pela chamada conservação integrada, temática que constituiria o cerne da Declaração de Amsterda $\tilde{a}^{174}$.

Em cada cidade, em cada lugar habitado onde ainda é possível fazê-lo, seria necessário delimitar a extensão de certa parte que deveria ser conservada, tanto quanto possível, sem modificação. Do mesmo modo seria necessário sempre fixar tudo o que serve para estabelecer as perspectivas, as cenografias do interior de uma cidade. Os planos de regularização não deveriam tocar essas partes, que se poderá sempre adaptar à vida daqueles que lá devem residir [...].

Os problemas relacionados à integração dos monumentos em seu contexto são necessariamente do domínio do urbanismo como aqueles que se referem às relações entre os edifícios e a natureza. Não se trata de afastar os monumentos da vida [urbana], isso seria dedicá-los à uma morte próxima; é necessário saber compreendê-los e dar-lhes sempre um lugar vivo na cidade viva. ${ }^{175}$

\footnotetext{
172 GIOVANNONI, G. La restauration des monuments en Italie. In: La Conférence d'Athènes..., op. cit., pp.57-60.

${ }^{73}$ Os secteurs sauvagardés foram instituídos pela Lei Malraux (n.62-903/1962). Integrada ao Código de Urbanismo Francês, a Lei orientou a criação desses setores em torno das áreas consideradas de interesse patrimonial, sobre as quais incidiria o Plano Permanente de Preservação e Valorização. Cabe ressaltar que a Lei sobre os Monumentos Históricos, de 1913, já previa a vinculação das ações sobre os bens protegidos e seus respectivos entornos aos planos locais de urbanismo. MEC/SPHAN. Restauração e revitalização de núcleos históricos: análise frente a experiência francesa. Brasília: FPM, 1980.

${ }^{174}$ Declaração de Amsterdã. Congresso do Patrimônio Arquitetônico Europeu. Amsterdã, 1975. In: Cartas Patrimoniais. Rio de Janeiro: IPHAN, 2000, pp. 199-210. Retornaremos ao tema oportunamente.

175 NICODEMI, Giorgio. L'environnement des monuments. In: La Conférence d'Athènes sur la Conservation Artistique et Historique des Monuments (1931) [Ėdition établie par Françoise Choay]. Besançon: Éditions de l'imprimeur, 2002, pp.70-72. Trad. nossa. "Dans chaque ville, dans chaque lieu habité où il est encore possible de le faire, il faudrait délimiter l'étendue d'une certaine partie qui devrait être conservée, autant qu'il est possible, sans modification. De même il faudrait toujours fixer tout ce qui sert à établir des perspectives, de scénographies dans l'interieur d'une ville. Les plans de régularisation ne devraient pas toucher à ces parties, qu'on pourra toujours adapter à la vie de ceux qui doivent y demeurer. [...] Les problèmes liés à l'integration des monuments dans leur contexte sont nécessairement du domaine de
} 
A Conferência de Atenas de 1931 representou um momento-chave na história das teorias e práticas voltadas à conservação e restauração dos monumentos, quer seja pela oportunidade de discussão entre estudiosos de várias origens, quer seja pela formulação de princípios gerais de atuação em nível internacional e pela conseqüente abertura de novas problemáticas para debate. Era, portanto, um momento de troca de idéias, assimilação de conceitos e busca por consensos e proposições gerais. No que se refere ao tratamento de áreas urbanas, as considerações de Nicodemi, bem como de Giovannoni, mostravam-se sensíveis à importância de se preservar certos conjuntos antigos não somente para garantir as relações entre o monumento e o seu entorno, mas também devido à importância conferida aos próprios conjuntos. Essa concepção, no entanto, ainda não alcançara amplo entendimento. Não obstante os avanços conceituais de Giovannoni quanto à valorização de zonas urbanas inteiras consideradas como um único monumento - conceito expresso não somente na Conferência mas ao longo de sua ampla produção teórica -, nas conclusões finais do evento, reunidas na Carta de Restauro de Atenas, prevaleceria ainda a idéia de ambiente representativo enquanto entorno de um monumento principal, enquanto 'moldura' e contexto para as obras consideradas 'maiores'. A Carta, apesar do pioneirismo na formulação de princípios e diretrizes, ao menos no que tange à problemática dos conjuntos urbanos, não logrou assimilar a amplitude dos temas abordados no evento.

A conferência recomenda respeitar, na construção de edifícios, o caráter e a fisionomia das cidades, sobretudo na vizinhança dos monumentos antigos, cuja proximidade deve ser objeto de cuidados especiais. Em certos conjuntos, algumas perspectivas particularmente pitorescas devem ser preservadas. ${ }^{176}$

As diretrizes emanadas pela Carta de Atenas foram adotadas com pequenas adaptações na redação da Carta Italiana de Restauro, bem como na elaboração das Instruções para o Restauro dos Monumentos, documento complementar redigido por uma comissão formada, dentre outros, por Giovannoni, Longhi, De Angelis D’Ossat e Calzecchi Onesti. Esses instrumentos normativos indicariam certa oficialização de uma posição cultural que vinha se estabelecendo ao longo de décadas de discussões,

l'urbanisme comme ceux qui se réfèrent aux rapports entre les édifices et la nature. Il ne s'agit pas de mettre les monuments hors de la vie, ce serait les vouer à une mort prochaine; il faut savoir les comprendre et leur donner toujours une place vivante dans la ville vivante."

176 Carta de Restauro de Atenas. Escritório Internacional de Museus. Atenas, 1931. In: Cartas Patrimoniais..., op. cit., p.14. 
contribuindo ainda para a elaboração das novas lei de tutela na Itália. ${ }^{177}$ No que concerne ao valor patrimonial dos tecidos urbanos, a Carta de Restauro Italiana retomou a enunciação de Atenas e reservou aos mesmos, portanto, o papel de "condição ambiental" de um monumento principal, alertando, ainda, para a inserção de novos edifícios invasivos.

Que junto com o respeito pelo monumento e por suas várias fases prossiga aquele por suas condições ambientais, as quais não devem ser alteradas por isolamentos inoportunos; por construções de novos edifícios próximos invasivos por massa, por cor, por estilo. ${ }^{178}$

Nas Instruções para o Restauro dos Monumentos, redigidas em 1938, o texto sugere uma expansão maior do conceito de 'ambiente', aproximando-se da concepção giovannoniana de patrimônio urbano, na qual observamos a autonomia figurativa do tecido urbano enquanto composição global formada por obras 'maiores' e 'menores'. Além da atenção aos tecidos antigos como entorno, a preservação proposta pelas Instruções estendeu-se aos "complexos construtivos que, mesmo sem possuir particulares elementos artísticos, elevam-se como solução urbanística a um valor histórico e artístico", sugerindo, portanto, a valorização do tecido construído além do mero caráter de 'pano de fundo' para obras excepcionais, ainda que em termos normativos e práticos essa concepção não tenha prevalecido nesse momento. Também a partir de uma clara influência giovannoniana, o documento propõe o princípio da 'neutralidade espacial' na atuação sobre os entornos não mais originais, aspecto normativo que evidencia uma vez mais a predileção pela conservação documental, não atentando para as possibilidades de diálogo estético entre o preexistente e as novas construções.

Posto que cada monumento coordena à própria unidade figurativa o espaço circundante, tal espaço é naturalmente objeto das mesmas cautelas e do mesmo rigoroso respeito que o próprio monumento. E portanto categoricamente a excluir-se, como arbitrário, a transferência de edifícios monumentais, a alteração de ambientes monumentais conservados nas formas originárias e daqueles complexos construtivos que, mesmo sem possuir particulares elementos artísticos, elevam-se como solução urbanística a um valor

\footnotetext{
177 Conforme acenamos em nota anterior a respeito da contribuição de Giovannoni na elaboração da legislação italiana de tutela. VAN RIEL, S. e SEMPRINI, M. P. Il restauro del paesaggio..., op. cit., pp.1223. Para maiores considerações sobre as Cartas e Instruções citadas, ver: CARBONARA, G., op. cit., pp.241-247

${ }^{178}$ Carta Italiana del Restauro 1932. Consiglio Superiore per le antichità e belle arti. Norme per il restauro dei monumenti, art. 6. Trad. nossa. "Che insieme col rispetto pel monumento e per le sue varie fasi proceda quello delle sue condizioni ambientali, le quali non debbono essere alterate da inopportuni isolamenti; da costruzioni di nuove fabbriche prossime invadenti per massa, per colore, per stile."
} 
histórico e artístico. O isolamento de edifícios monumentais, não mais inseridos em seus ambientes originários, deve ser inspirado ao princípio de uma absoluta neutralidade espacial e perspéctica, evitando assim todas as organizações a caráter genericamente monumental e cenográfico. ${ }^{179}$

A expansão do conceito de patrimônio histórico em direção aos tecidos urbanos antigos, considerados como artefatos dotados de especificidades próprias, receberia um impulso maior sobretudo no período do segundo pós-guerra, quando novas situações e questionamentos colocariam em suspensão certos critérios e conceitos até então empregados. A noção preponderante de ambiente como entorno, no entanto, ainda provocaria uma série de interpretações equivocadas e variadas propostas de intervenções baseadas na velha 'obsessão pelo isolamento'. À concepção predominante de ambiente como 'moldura', somava-se ainda a consolidação dos princípios do urbanismo moderno, difundidos sobretudo a partir da atuação dos Congressos Internacionais de Arquitetura Moderna, os CIAM $^{180}$. A partir do $4^{\circ}$ Congresso, após reuniões, debates e pesquisas, seria elaborada a também denominada Carta de Atenas, datada de 1933, um documento de caráter doutrinário que buscou sintetizar os preceitos do urbanismo moderno, em grande parte influenciados pelas idéias de Le Corbusier. ${ }^{181}$

No que concerne ao patrimônio histórico das cidades, a Carta mostra-se favorável à preservação dos conjuntos históricos, porém, a partir de critérios bastante controversos e contraditórios. Segundo a Carta, esses "testemunhos preciosos do passado [devem ser] respeitados, a princípio por seu valor histórico ou sentimental, depois porque alguns trazem uma virtude plástica na qual se incorporou o mais alto grau de intensidade do gênio

\footnotetext{
${ }^{179}$ Istruzioni per il Restauro dei Monumenti, Ministero della Pubblica Istruzione,1938. Trad. nossa. "Posto che ogni monumento coordina alla propria unità figurativa lo spazio circostante, tale spazio è naturalmente oggetto delle stesse cautele e dello stesso rigoroso rispetto che il monumento stesso. E quindi categoricamente da escludersi, come arbitraria, la traslazione di edifici monumentali, 1'alterazione di ambienti monumentali conservati nelle forme originarie e di quei complessi edilizi che, anche senza tener conto di particolari elementi artistici, assurgono come soluzione urbanistica ad un valore storico ed artistico. L'isolamento di edifici monumentali, non più inseriti nel loro ambiente originario, deve essere ispirato al principio di una assoluta neutralità spaziale e prospettica, evitando cosi tutte le sistemazioni a carattere genericamente monumentale e scenografico."

${ }_{180}$ Os CIAM iniciaram-se em 1928, à princípio voltados ao tema da habitação e após 1930 debruçados principalmente sobre os problemas do urbanismo. Objetivavam discutir como os princípios teóricos da arquitetura moderna poderiam responder aos problemas causados pelo rápido crescimento urbano. CHOAY, F. O Urbanismo: utopias e realidades. Trad. Dafne N. Rodrigues. São Paulo: Perspectiva, 2003, p.19.

${ }^{181}$ Carta de Atenas, CIAM - Congresso Internacional de Arquitetura Moderna, 1933. In: Cartas patrimoniais..., op. cit., pp.21-68. Cumpre salientar que, apesar de reunir os temas abordados no Congresso de 1933, a Carta não foi publicada logo após o evento. Depois do Congresso surgiram duas edições com conteúdos diversos, a primeira datada de 1942, publicada pela Universidade de Harvard e de autoria de José Luis Sert; a outra foi publicada em 1943, na França, sem indicação de autor. Na segunda edição desse texto, de 1957, a autoria é atribuída a Le Corbusier. Essa é a versão mais difundida atualmente.
} 
humano". Considerados como parte do patrimônio humano, deve-se "fazer tudo que é lícito para transmitir intacta para os séculos futuros essa nobre herança”. No entanto, como "nem tudo que é passado tem, por definição, direito à perenidade", a Carta recomenda a realização de escolhas sábias para determinar o que deve ser respeitado. E para subsidiar tais escolhas, sugere uma série de critérios bastante contraditórios com relação ao entendimento dos conjuntos urbanos enquanto obras autônomas; critérios que evidenciam o esvaziamento conceitual de expressões como "valor histórico e sentimental" ou "virtude plástica", então empregadas no mesmo documento para exaltar as qualidades dos conjuntos urbanos. Apesar de algumas sugestões pertinentes (porém lacônicas) como a busca por soluções alternativas de circulação ou o deslocamento de atividades muito intensas para evitar destruições, chamam a atenção sugestões como a demolição de "construções repetidas" ou o isolamento da "única parte" que constitui um "valor real", além da afirmação de que a demolição do entorno histórico e a sua substituição por áreas verdes poderia criar uma ambiência nova, diretriz que sublinharia a prática dos isolamentos. De certa forma, a preservação proposta pela Carta subordinava-se à nova orientação urbanística, ou seja, poderia ser efetivada desde que não interferisse nas soluções modernas para a salubridade, a circulação e as áreas verdes.

Nos casos em que se esteja diante de construções repetidas em numerosos exemplares, algumas serão conservadas a título de documentário, as outras demolidas; em outros casos poderá ser isolada a única parte que constitua uma lembrança ou um valor real; o resto será modificado de maneira útil [...].

É possível que, em certos casos, a demolição de casas insalubres e de cortiços ao redor de algum monumento de valor histórico destrua uma ambiência secular. É uma coisa lamentável, mas inevitável. Aproveitar-se-á a situação para introduzir superfícies verdes. Os vestígios do passado mergulharão em uma ambiência nova, inesperada talvez, mas certamente tolerável, e da qual, em todo caso, os bairros vizinhos se beneficiarão amplamente. $^{182}$

Outra questão em foco tanto na Carta Italiana quanto nas Instruções é a preocupação com a inserção de novos elementos em contextos antigos, um dos principais pontos de conflito na elaboração de propostas de intervenção e fulcro da polêmica sobre a

\footnotetext{
${ }^{182}$ Carta de Atenas CIAM..., op. cit., pp.52-54. A atenção quanto à preservação dos conjuntos antigos está presente, mas ocupa uma posição desconfortável no contexto global do documento. Uma série de princípios defendidos pela mesma Carta ratificavam propostas como o Plan Voisin, de Le Corbusier, por exemplo, projeto que propunha a destruição de todo o centro histórico de Paris para ceder espaço a novas torres de edifícios. Dessa forma, a amplitude conceitual do patrimônio e de seus valores, observável desde os avanços teóricos de Alois Riegl, não comparece na enunciação dessa suposta preservação, como pudemos observar no emprego ambíguo das expressões destacadas.
} 
pertinência e os limites da relação antigo-novo. Grande parte da discussão sobre a preservação das áreas antigas girava em torno da pertinência de se inserir construções atuais junto às antigas e de que modo fazê-lo. O velho dilema da relação antigo-novo, no entanto, assumia agora novos contornos. À direta oposição oitocentista entre conservação e modernização, quando a intervenção do 'novo' era diretamente associada às práticas de desventramento, somava-se agora a gradual consolidação de um conceito de 'novo' um pouco mais amplo, ou seja, a afirmação de uma expressão arquitetônica contemporânea, a arquitetura moderna, que começava a reivindicar a legitimação de seus valores enquanto manifestação cultural e, logo, o seu espaço na composição da cidade. A oposição entre os arquitetos mais tradicionais e aqueles que se identificavam com as propostas modernas sublinhava o embate entre uma série de valores da sociedade, abarcando orientações de cunho político em certos contextos e evidenciando a atualidade das dúvidas em torno da assimilação das transformações da cidade e da própria sociedade contemporânea.

No seio dessa polêmica, Giulio Carlo Argan apresentou em artigo de 1939 argumentos sólidos para legitimar a arquitetura moderna como expressão artística contemporânea e defender a sua inserção em ambientes antigos por meio de um pensamento urbanístico que não fosse meramente teórico e sim ancorado na representatividade cultural do presente. Os próprios problemas urbanos que impulsionaram o nascimento da disciplina do urbanismo - e alimentaram a discussão em torno da conservação das arquiteturas tradicionais e da relação entre as mesmas e as expressões modernas -, são apresentados pelo autor como condições históricas da cidade de então e, também por esse motivo, como questões a serem enfrentadas com os recursos técnicos e as expressões arquitetônicas contemporâneas. Nesse sentido, afirma a necessidade de buscar uma relação de diálogo entre o antigo e o novo, porém não a partir de uma exigência estética abstrata, e sim tomando por base o entendimento das particularidades de cada momento construtivo que, na variedade de suas premissas culturais, representam expressões históricas e manifestações estéticas igualmente válidas. E a individuação crítica desses valores deverá ser considerada como tarefa conjunta do urbanismo e do restauro dos monumentos:

A tarefa do urbanismo não consiste em conciliar por compromissos o antigo e o moderno em nome de um indefinível e de qualquer modo extrínseco ideal de decoro urbano, mas em individuar o valor dos diversos fatos históricos, reconhecendo a idêntica legitimidade [...]. A prática consequiência de uma distinção crítica dos valores é o restauro: nem ocorre 
repetir que o restauro, pela própria necessidade de uma preliminar reflexão crítica, não se limita à consolidação das estruturas e à conservação material do edifício, mas logicamente se estende às condições ambientais que, concorrendo diretamente à exata leitura histórica do texto, constituem uma parte integrante deste. E dado que cada edifício, como se diz, realiza determinadas condições urbanísticas, é tarefa do restauro qualificálas, para que possam constituir um dado de cultura histórica para a identificação dos problemas sucessivos. ${ }^{183}$

Segundo o autor, a desconfiança de diversos arquitetos da época para com a arquitetura moderna, aqui entendida como a arquitetura do movimento moderno, teria sido impulsionada por uma série de projetos apressados e que certamente provocaram grandes destruições, mas que na verdade não representavam o verdadeiro caráter da nova arquitetura. Enquanto os estudiosos alimentavam a discussão inútil sobre o caráter científico ou artístico do urbanismo, o verdadeiro problema permanecia inatingível e proliferavam essas supostas soluções - irracionais, desordenadas e incoerentes - gerando demolições arbitrárias em vários centros urbanos. Após tamanhos estragos, qualquer proposta séria e rigorosa que tomasse por base princípios modernos acabava sendo recebida com desconfiança e sendo alijada da cultura geral do urbanismo. Tais juízos partiam da incompreensão da arquitetura recente enquanto proposta e associavam, equivocadamente, quaisquer manifestações especulativas do mercado imobiliário como projetos oriundos de uma mesma mentalidade moderna. Argan prossegue sua defesa afirmando que os enunciados de racionalismo e funcionalismo representavam apenas uma parte de um processo de raciocínio. Segundo o autor, a arquitetura recente, ao assumir como uma de suas premissas a organização dos fatos práticos e técnicos, bem como as exigências sociais higiênicas, extra-artísticas, não objetivava, de modo algum, renunciar à qualquer expressividade artística.

Se então se objetar, como de fato freqüentemente acontece, que a nova arquitetura, com o citado princípio de standard e aqueles análogos de funcionalidade e racionalidade, outro não faz que substituir à antiga uma nova tipologia, é fácil responder que essa possui,

\footnotetext{
183 ARGAN, Giulio Carlo. Urbanistica e architettura. Le Arti, Year 1939, p.368. Trad. nossa. "Il compito dell'urbanistica non consiste nel conciliare per compromessi l'antico e il moderno in nome di un indefinibile e comunque estrinseco ideale di decoro cittadino, ma nell'individuare il valore dei diversi fatti storici, riconoscendo l'identica legittimità. [...] La pratica conseguenza di un'individuazione critica dei valori è il restauro: né occorre ripetere che il restauro, per la necessità stessa di una preliminare riflessione critica, non se limita al consolidamento delle strutture e alla conservazione materiale dell'edificio, ma logicamente si estende alle condizioni ambientali che, direttamente concorrendo all'esatta lettura storica del testo, ne costituiscono parte integrante. E poiché ogni edificio, come s'è detto, realizza determinate condizioni urbanistiche, è compito del restauro qualificarle, affinché possano costituire un dato di cultura storica per l'impostazione dei problemi successivi."
} 
como a antiga, a sua justificação histórica em relação aos interesses artísticos aos quais se refere. $^{184}$

Argan tece ainda considerações a respeito das teorias urbanísticas da época e faz críticas, mesmo que não diretamente identificadas, ao verdadeiro alcance de métodos como o desadensamento construtivo, defendido principalmente por Giovannoni. Discorre que o dualismo arbitrário entre teoria e prática alimentava a aceitação teórica do método sem a necessária contrapartida da prática. Dessa forma, a teoria podia mostrar-se aplicável a alguns casos, mas cessava "de ser válida quando os documentos de uma antiga tradição construtiva [criavam] condições preliminares intransgredíveis ao posterior desenvolvimento". Critica ainda a busca por resoluções caso a caso, recurso que não permitia a elaboração de programas prévios, impedindo desse modo a possibilidade do encontro prático, ainda que polêmico, entre a tradição e o pensamento moderno. Para Argan, a prática deve ser considerada como uma condição particular do operar artístico, como a própria experiência histórica demonstra uma vez que os antigos núcleos urbanos formaram-se a partir de soluções aos seus respectivos problemas, encontradas sem meditação teórica, e sim "por espontânea e necessária aderência a um princípio de ordem". Assim, a própria coerência do processo artístico estaria intimamente relacionada à conciliação prática dos problemas urbanísticos, bem como o atendimento dos problemas técnicos de uma construção reside nos resultados puramente formais da arquitetura. E no contexto da cidade, deve-se ainda considerar que não somente a obra arquitetônica responde às condições urbanísticas mas também lhe proporciona uma nova realidade, e é dessa relação dialética que emerge a expressão formal de um dado momento histórico.

Pode portanto afirmar-se que cada obra arquitetônica não somente responde à determinadas condições urbanísticas, mas lhes impõe novas, quase projetando no espaço o princípio orgânico da clareza formal: o que explica como, em uma primeira articulação da idéia urbanística, a cidade perfeita fosse considerada (Alberti, Filarete) obra de arte unitária e completa, resultado integral de uma só uma vontade expressiva. ${ }^{185}$

\footnotetext{
${ }^{184}$ ARGAN, G. C., op. cit., p.368. Trad. nossa. "Se poi si obbietti, come di fatto frequentemente accade, che la nuova architettura, con il citato principio di standard e quelli analoghi di funzionalità e razionalità, altro non fa che sostituire all'antica una nuova tipologia, è facile rispondere ch'essa ha, come l'antica, la sua giustificazione storica rispetto agli interessi artistici cui si riferisce." (Grifos do autor).

${ }_{185}$ ARGAN, G. C., op. cit., p.367. Trad. nossa. "Può dunque affermarsi che ogni opera architettonica non soltanto risponde a determinate condizioni urbanistiche, ma ne pone di nuove, quasi proiettando nello spazio il principio organico della chiarezza formale: ciò che spiega come, in un primo articolarsi dell'idea
} 
Logo, qualquer solução urbanística contemporânea seria contraditória se não buscasse atuar de acordo com as mais atuais expressões arquitetônicas. O urbanismo, portanto, não deveria encerrar uma teoria fechada e sim se mostrar como "um problema de cultura e de método", ou seja, buscar soluções de acordo com as condições culturais do presente. A oposição entre antigo e moderno, portanto, se resolveria nessa reflexão crítica na qual nem o antigo, nem o moderno seriam mais "considerados em relação à autoridade das respectivas premissas, necessariamente diversas, de cultura e de gosto, mas em relação à qualidade das obras e ao seu direto significado histórico". E essas soluções urbanísticas, ao legitimar os valores da produção arquitetônica atual, ratificariam também a sua própria historicidade, pois "um problema urbanístico bem determinado é igualmente relativo aos valores artísticos do passado, aos do presente e aos de um futuro que, com lúcida consciência, viverá sobre o plano de sua própria atualidade, a experiência histórica da arte de hoje". 186

$\mathrm{O}$ arquiteto Carlo Calzecchi Onesti, um dos redatores das citadas Instruções de 1938, respondeu ao artigo de Argan dando prosseguimento à acirrada polêmica ${ }^{187}$. Calzecchi ataca intempestivamente os arquitetos modernos classificando-os como os "adeptos do estilo caixa", que cortam a qualquer custo as velhas cidades somente para assegurar a rapidez do tráfego. Sobre as questões aventadas por Argan - a eqüipolência de valores entre as construções antigas e novas e a possibilidade de coexistência num mesmo tecido urbano -, Calzecchi as classifica como uma velada visão otimista, como a "República de Platão: já que tudo deve andar bem, tudo vai bem!". E ressalta a impossibilidade artística da nova arquitetura: "o mal é que os nossos olhos não nos permitem por ora descobrir, pelas estradas onde hoje se misturam o velho e o novo, o 'artista'," 188

urbanistica, la città perfetta venisse considerata (Alberti, Filarete) opera d'arte unitaria e compiuta, risultato integrale di una sola volontà espressiva."

186 ARGAN, G. C., op. cit., p.373. Trad. nossa. "Un problema urbanistico bene impostato è ugualmente relativo ai valori artistici del passato, a quelli del presente ed a quelli di un avvenire che, con lucida coscienza, vivrà sul piano della propria attualità, l'esperienza storica dell'arte di oggi'"

${ }^{187}$ CALZECCHI ONESTI, Carlo. Urbanistica e Monumenti. Costruzioni Casabella, anno XVI, n.165, 1941, pp. 2-7. Somam-se ainda a esse debate o artigo de Ragghianti, que buscou afastar a questão do contexto cultural e lançá-la aos domínios da política: RAGGHIANTI, Carlo Ludovico. Nota sull'urbanistica. Costruzioni Casabella, anno XVI, n.166, 1941, pp. 2-5; bem como o artigo de Melis, que buscou um consenso pouco esclarecedor entre ambas as posições: MELIS, Armando. Ancora di urbanistica e vecchi centri. Urbanistica, anno X, n.4-5, luglio-ottobre 1941, pp.23-24.

${ }^{188}$ CALZECCHI ONESTI, C., op. cit., p.4. trad. nossa. "Il male é che i nostri occhi non ci permettono per ora di scoprire, per le strade dove si mescola oggi il vecchio e il nuovo, l'artista." (grifo do autor). 
Observamos, portanto, que por um lado o autor, assim como Giovannoni, não acreditava na arquitetura moderna como expressividade artística da atualidade e, por outro, alimentava aquela "confusão mental", como diria Argan, que provocava a esquiva de parte da crítica na distinção entre as manifestações da chamada arquitetura moderna - imbuídas de fundamentos projetuais válidos, ainda que questionáveis ou polêmicos - e as intervenções de caráter especulativo, atividades construtivas que, assim como hoje, não necessariamente representavam a vontade e o objetivo de toda a nova produção arquitetônica do período. Em posição semelhante manifestava-se o arquiteto Arata, que admitia a possibilidade de inserção de novos edifícios entre os antigos, desde que fundamentada em criteriosas análises. No entanto, recorre ainda à associação direta entre a totalidade dos chamados arquitetos modernos e aqueles cuja prática baseava-se nas operações de desventramento, ou seja, na criação apressada de 'vazios' posteriormente preenchidos com "soluções urbanísticas incoerentes e desconcertantes, das quais ninguém depois tem coragem de assumir a paternidade". E conclui com ironia: "É realmente necessário favorecer essa inconsciente mania destrutiva, a qual, no final das contas, é apenas o efeito de um deplorável diletantismo? Escreveu-se várias vezes que demasiada cultura faz o artista cético; os urbanistas modernos certamente não pecam de ceticismo". ${ }^{189}$

Em defesa da legitimidade da expressão arquitetônica contemporânea na intervenção sobre a cidade antiga, citamos por fim as manifestações de Agnoldomenico Pica. Em artigo datado de 1943, o autor tece considerações de grande atualidade e busca defender que o encontro entre o antigo e o novo é, na verdade, uma questão de projeto, uma questão de postura crítica, sensibilidade artística e de precisão projetual. Nesse sentido, apresenta argumentos contrários às teorias de Giovannoni e problematiza certos limites teóricos que constituiriam o centro dos debates sobre a conservação urbana logo após a Segunda Guerra Mundial. Os limites destacados residem principalmente na predileção pelos aspectos científicos da intervenção - tanto no monumento individual quanto no tecido urbano -, e nas soluções urbanísticas baseadas na separação entre a nova e a velha cidade.

Quanto ao 'restauro científico', o autor questiona a preocupação excessiva com o caráter documental da obra arquitetônica em detrimento de uma leitura estética, inclusive

${ }^{189}$ ARATA, G. U. Ricostruzioni e restauri, l'urbanistica e la conservazione dei monumenti. Milano: Ulrico Hoepli, 1942, p. XXVI. Trad. nossa. "È proprio necessario favorire quest'incosciente mania distruttiva la quale, in fin dei conti, non è che l'effetto di un deplorevole dilettantismo? Si è scritto più volte che la troppa cultura fa l'artista scettico; gli urbanisti moderni non peccano certamente di scetticismo." 
com a participação da expressão artística contemporânea, e atenta para a conseqüente formação de uma atmosfera artificial que não representa coerentemente nem o passado, nem o presente. Dessa forma, enquanto teoria destinada a fazer danos menores, Giovannoni e seus sucessores mantiveram o anonimato da restauração e limitaram-se às ambições estritamente científicas:

À força de querer respeitar e deixar à vista cada elemento de interesse histórico, à força de querer não excluir, mas subordinar, quaisquer expressões da intervenção moderna, acabam, sim, por não contaminar o monumento com refazimentos e contatos heterogêneos, mas também por transpô-lo em uma espécie de atmosfera artificial, demasiado limpa e exata, em uma espécie de limbo que não é verdadeiramente seu e não é verdadeiramente nosso. ${ }^{190}$

Analogamente, considera o recurso às zonas neutras, reproposto nas Instruções como "princípio de uma absoluta neutralidade espacial e perspéctica", basicamente como uma solução de renúncia pois não permite colocar em debate, como já evidenciara Argan, outras possibilidades projetuais que arriscassem novas composições estéticas a partir do diálogo entre o antigo e o novo. Por motivos semelhantes, não concorda que a construção de novas arquiteturas devesse acontecer somente em zonas distantes dos centros antigos. Pelo contrário, a nova arquitetura deveria enfrentar os desafios frente à atuação sobre os tecidos históricos e permitir "uma nova invenção urbanística", 191 ou ainda, uma releitura do antigo a partir dos recursos estéticos a ele contemporâneos.

No cerne dessa polêmica observamos que a preocupação com a conservação dos conjuntos urbanos tradicionais permanece uma constante, independentemente da postura defendida quanto aos meios e critérios para se efetivar essa conservação. As divergências que então despontavam evidenciavam as diversas faces de um complexo debate que se acentuaria sobretudo a partir da década de 1950. Debate este que, sob alguns aspectos, apresenta ainda grande atualidade, não obstante os aprofundamentos e novas abordagens

\footnotetext{
${ }^{190}$ PICA, Agnoldomenico. Attualitá del restauro. I monumenti antichi sul tavolo dell'urbanista. Costruzioni, anno XVI, n. 182, 1943, p.4. Trad. nossa. "Ma qui anche è il suo limite. A forza di voler rispettare e lasciare in vista ogni elemento di interesse storico, a forza di voler non escludere ma pretermettere qualsiasi espressione dell'intervento moderno, si finisce, sì, per non contaminare il monumento con rifacimenti e con eterogenei contatti, ma anche per trasporlo in una sorte di atmosfera artefatta, troppo pulita ed esatta, in una sorta di limbo che non è veramente suo e non è veramente nostro."

${ }^{191}$ PICA, A., op. cit., p.10. Trad. nossa. "Il monumento antico può essere, deve essere, nel quadro urbano il fulcro prezioso di una nuova invenzione urbanistica, e come tale esso può essere - in certo modo - scoperto, anzi proprio 'inventato' di nuovo.”
} 
do porvir, notadamente a partir das contribuições teóricas advindas da estética e da história da arte.

\section{A DimenSÃo URBANA DA PRESERVAÇ̃̃o E dO RESTAURo}

As questões em debate ao longo das quatro primeiras décadas do século $\mathrm{XX}$ seriam finalmente interpeladas por um fato novo: as conseqüências e destruições em larga escala provocadas pela Segunda Guerra Mundial (1939-1945). Após o confronto, o amargo desafio imposto aos arquitetos diante das cidades devastadas comportaria, inevitavelmente, a busca por novas respostas teóricas e operativas. Os critérios até então empregados, mesmo considerando as variantes teóricas, mostraram-se insuficientes diante da magnitude das destruições e uma série de temas que já suscitavam amplos debates, como a relação antigo-novo e os critérios para recomposições e preenchimento de lacunas, receberiam novo impulso investigativo, agora buscando considerar aspectos relativos à composição estética e à imagem figurativa dos complexos urbanos, questões até então abordadas com menor atenção em favor de uma leitura filológica do monumento.

Paralelamente às discussões sobre os critérios a serem empregados, a escala das destruições impulsionaria ainda outras frentes de debates abarcando o questionamento da própria abrangência do termo patrimônio. Diante da perda ou comprometimento de vastas áreas atentou-se para a importância de determinadas relações urbanas que não emergiam com tanta evidência em sua permanência secular. Assim, a coexistência de diferentes estratificações e identidades visuais, conjunto que compunha "o grande livro da humanidade", como diria Victor Hugo, e a própria identificação cotidiana da população com essas paisagens, foram interpretadas como particularidades dos ambientes históricos que respondiam às indagações frente ao desejo de 'recompor' aqueles 'lugares' perdidos. Logo, a desmaterialização de um cenário até então conhecido e consolidado permitiria a compreensão e a valorização da paisagem existente enquanto evidência histórica e cultural, e traria à tona o conjunto de relações e de elementos que interagem entre si para a conformação de um patrimônio. 
Dois aspectos cruciais emergiam desse cenário. Por um lado, esse olhar diferenciado sobre os valores relacionados ao ambiente construído permitiria o gradativo amadurecimento daquela compreensão do patrimônio urbano como monumento coletivo, autônomo, e não mais subordinado às obras excepcionais. Por outro lado, a busca por soluções de restauro que atentassem para a composição estética das obras fortaleceria o debate sobre a necessária relação antigo-novo e impulsionaria a integração do trinômio 'restauro - arquitetura - urbanismo', campos disciplinares que, apesar dos avanços teóricos dos períodos precedentes, ainda insistiam em atuar como matérias isoladas.

Dessa forma, o segundo pós-guerra representaria um período rico em reformulações teóricas e análises consistentes e maduras, notadamente sobre a nova abrangência do conceito de patrimônio a conservar e sobre a apreensão dos atributos culturais do restauro, ou seja, sobre sua gradativa compreensão enquanto ação cultural determinada, independente do momento da criação original da obra e necessariamente atrelada a diversos campos do saber como a história da arte, a sociologia, o urbanismo. Tais discussões lançariam as bases teóricas e práticas da nossa concepção contemporânea do restauro em suas múltiplas e por vezes antagônicas manifestações.

Quanto à atuação sobre os monumentos e ambientes históricos, consolidava-se o entendimento do restauro como ato histórico-crítico, ou seja, como intervenção que comporta, inevitavelmente, um certo grau de interferência na configuração figurativa da obra e que, portanto, deve assumir como premissa a investigação, a apreensão e o conhecimento dessa realidade compositiva. Dessa forma, o restauro assume a tarefa de compreender as especificidades de cada monumento (ou ambiente-monumento), de indagálo atentamente, com sensibilidade e competência técnica, de modo a buscar os meios mais corretos de atuação a partir das repostas fornecidas pelo próprio artefato. Dentre os principais estudiosos que abarcavam tais questionamentos, destacam-se Roberto Pane, Renato Bonelli e Paul Philippot, principais representantes do chamado 'restauro-crítico' e responsáveis por sólidas releituras dos percursos teóricos do restauro, buscando articulálos, inclusive, a novas e importantes contribuições como a teoria brandiana. ${ }^{192}$ Uma

192 KÜHL, Beatriz Mugayar. Preservação da arquitetura industrial em São Paulo: questões teóricas Relatório Científico. São Paulo: FAUUSP, Fapesp, 2005, pp.49-50. Para uma análise meticulosa do 'restauro-crítico', seus principais protagonistas e suas respectivas teorias, consultar: CARBONARA, G., op. cit., pp.271-390. Para aprofundamentos sobre a produção teórica específica, consultar: PANE, R. Attualità $e$ dialettica del restauro [antologia a cura di Mauro Civita]. Chieti: Marino Solfanelli, 1987; BONELLI, Renato. Scritti dul Restauro e sulla Critica Architettonica. Roma, Bonsignori, 1995; PHILIPPOT, Paul. Saggi sul restauro e dintorni: antologia. Roma: Bonsignori, 1998. 
posição de certo consenso entre as várias discussões em pauta a partir da década de 1940 seria finalmente alcançada em 1964, com a formulação da Carta de Veneza ${ }^{193}$, documento que mantém a sua atualidade como nosso principal referencial teórico.

Na esfera urbana, intensificava-se a polêmica sobre a relação antigo-novo, tema em torno do qual se desenvolvia grande parte da discussão sobre a preservação do ambiente urbano e sobre a afirmação de sua historicidade ${ }^{194}$. Para efetivar a recomposição de monumentos arruinados alguns arquitetos recorreram a posturas solidárias ao restauro estilístico, retrocedendo em décadas o percurso investigativo e teórico adquirido e evidenciando certa tendência a conceber o restauro de modo autônomo em relação à produção arquitetônica. Do lado oposto emergiam estudiosos contrários à qualquer recomposição em estilo e que reivindicavam, alternativamente, a busca por soluções criativas além do campo da filologia e baseadas na verdadeira "formatividade arquitetônica", solução que se desenvolvia sobretudo a partir da compreensão da dimensão estética dos monumentos ${ }^{195}$. Um dos principais teóricos dessa corrente foi o arquiteto Roberto Pane que ilustrou com grande lucidez o novo panorama investigativo e deu passos decisivos para a compreensão da autonomia do patrimônio urbano e para a defesa de sua preservação como organismo mutável, ou seja, a partir da aproximação criteriosa e fundamentada entre restauro e produção arquitetônica do novo.

\begin{abstract}
Antes os restauros eram freqüentemente sugeridos por uma exigência de gosto ou por uma predileção cultural; hoje esses nos são impostos por uma imperiosa necessidade [...] de salvar os restos de formas preciosas cujo abandono seria inconciliável com uma sociedade culta e civilizada [...] A extrema variedade e necessidade dos casos a resolver está a demonstrar como não é possível conter o restauro dentro dos limites rigidamente pré-estabelecidos, pois se trata de passar da pura e simples consolidação à reconstrução $e x$
\end{abstract}

\footnotetext{
193 Carta de Veneza. Carta Internacional sobre Conservação e Restauração de Monumentos e Sítios. II Congresso Internacional de Arquitetos e Técnicos dos Monumentos Históricos. Veneza, 1964. In: Cartas patrimoniais..., op. cit., pp. 91-95. Retornaremos ao tema oportunamente.

${ }^{194}$ Para um panorama das primeiras reconstruções do segundo pós-guerra e das principais questões em pauta, remetemos aos textos de Roberto Pane, Renato Bonelli, Guglielmo De Angelis D'Ossat e Alfredo Barbacci reunidos em: PEROGALLI, Carlo (Org.). Architettura e restauro: esempi di restauro eseguiti nel dopoguerra. Milano: Görlich, 1955. Para um panorama internacional da questão, Cf.: Monuments et sites d'art et d'histoire et fouilles archeologiques: problemes actuels. Paris: UNESCO, 1950.

195 Sette ressalta que o próprio Giovannoni em alguns escritos chegou a questionar os limites dos instrumentos filológicos e propor, em certos casos, a recorrência ao restauro estilístico, à formas clássicas suscetíveis de imitação e continuação, uma certa “conservação aproximativa do caráter ambiental". SETTE, M. P. Profilo storico. In: CARBONARA, G. (Org.). Trattato di restauro architettonico. Torino: Utet, 1996, v.1, p.273.
} 
novo de imponentes massas edificadas, ou seja, de percorrer toda a distância que se coloca entre o restauro propriamente dito e a moderna construção arquitetônica. ${ }^{196}$

Ao longo de sua extensa produção teórica, Pane defenderia a busca por alternativas de diálogo entre as estruturas preexistentes e a arquitetura atual, porém sempre a partir de criteriosos estudos e projetos cuidadosos, conforme ditavam os pressupostos do restauro-crítico.

Chegará sempre o momento no qual será necessário lançar uma ponte, operar uma conjunção, e isso poderá ser feito apenas graças ao ato criador no qual quem opera não encontrará outra ajuda se não em si mesmo, nem poderá, como acontecia anteriormente, enganar-se que esteja ao seu lado, a guiá-lo, o fantasma do primitivo criador. ${ }^{197}$

Sobre a recorrência aos critérios estilísticos ou sobre a inserção do novo, a experiência adquirida até então não permitia um consenso entre os arquitetos restauradores, quer seja pela significativa consolidação dos princípios filológicos frente aos estilísticos, quer seja pela clara oposição à inserção de elementos contemporâneos. O caminho da reconstrução, no entanto, apresentava a vantagem de não propor formas arquitetônicas polêmicas e de, em alguns casos, responder aos anseios da comunidade de ver restituídos os monumentos perdidos na guerra, mesmo que não fossem autênticos. A questão, portanto, comportava aspectos de grande complexidade.

Essa polêmica tornou-se clara nos artigos consecutivos de Bernard Berenson e Ranuccio Bianchi Bandinelli a respeito das intervenções de reconstrução em Florença, ambos datados de 1945. Segundo Berenson, diante da destruição do caráter tradicional de grandes parcelas da cidade, se "amamos Florença como um organismo histórico que se

\footnotetext{
${ }^{196}$ PANE, Roberto. Restauro dei Monumenti. In: La ricostruzione del patrimonio artistico italiano. Roma: Libreria dello Stato, 1950, p.10 apud SETTE, M., op. cit., p.273. Trad. nossa. "Prima i restauri erano spesso sugeriti da un'esigenza di gusto o da una predilezione culturale; oggi essi ci sono imposti a una imperiosa necessità [...] di salvare i resti di forme preziose il cui abbandono sarebbe inconciliabile con una società colta e civile $[\ldots . .$.$] L'estrema varietà e necessità dei casi da risolvere sta a dimostrare come non sia possibile$ contenere il restauro entro i limiti rigidamente prestabiliti poiché si trata di passare dal puro e semplice consolidamento alla ricostruzione ex novo di imponenti masse di una fabbrica, e cioè a percorrere tutta la distanza che si pone tra il restauro vero e proprio e la moderna costruzione architettonica"

${ }^{197}$ PANE, R. Città antiche, edilizia nuova. Napoli: Edizioni Scientifiche Italiane, 1959 apud GIULIANI, A., op. cit., p.28. Trad. nossa. "Verrà sempre il momento in cui sarà necessario gettare un ponte, operare una congiunzione, e ciò potrà essere fatto soltanto grazie ad un atto creativo nel quale chi opera non troverà altro aiuto se non in se stesso, né potrà, come avveniva una volta, illudersi che gli stia accanto a guidarlo il fantasma del primitivo creatore".
} 
transmitiu através dos séculos, como uma configuração de formas e de perfis que permaneceu originalmente intacta apesar das transformações", devemos reconstruí-la “onde estava e como era”. E acrescenta: "Há uma quantidade de desenhos, estampas, incisões, fotografias, aquarelas e outros documentos visuais que podem servir ao escopo. Tudo aquilo que se pede é a boa vontade, a firme decisão de fazê-lo". ${ }^{198}$ No número seguinte da mesma revista, Bandinelli manifesta-se contrariamente, considera qualquer reconstrução em estilo, absolutamente condenável, não somente por motivos estéticos mas também morais. Segundo o autor as reconstruções comportam dois perigos: "o primeiro, que se reconstruam as nossas cidades indiscriminadamente em vidro e concreto; o segundo, que queiram reintegrá-las como eram, reconstruindo-as a partir de fotografias e modelos". O segundo perigo seria ainda mais grave, "porque terá em seu favor a opinião de uma maioria de pessoas que se dizem cultas, das classes burguesas, sempre favoráveis à retórica do falso antigo". ${ }^{199}$ E prossegue afirmando ser ainda mais falso pretender recompor um organismo urbano cujas particularidades que tanto nos agradam residem justamente no caráter espontâneo de seu lento desenvolvimento, sem intenções arquitetônicas predeterminadas.

No prosseguimento dessa polêmica, sobretudo a partir da década de $1950^{200}$, Pane desenvolveria extensa produção teórica em defesa da conservação do ambiente das cidades históricas, cada vez mais entendidas como um monumento único, coletivo, e não somente como a soma de grandes monumentos e seus respectivos entornos. Nesse sentido, destacava-se como uma de suas principais preocupações a atuação da especulação imobiliária na transformação dos ambientes históricos, atividade desordenada e

\footnotetext{
${ }^{198}$ BERENSON, Bernard. Come ricostruire la Firenze demolita. Il Ponte, vol.1, n.I, 1945, p.35. Trad. nossa. "Se invece noi amiamo Firenze come un organismo storico che si è tramandato a traverso i secoli, come una configurazione di forme e di profili che è rimasta singolarmente intatta nonostante le trasformazioni a cui sono soggette le dimore degli uomini, allora essi vanno ricostruiti al modo che fu detto al Campanile di San Marco, 'dove erano e come erano'. [...] C’è una quantità di disegni, stampe, incisioni, fotografie, acquerelli ed altri documenti visivi dhe possono servire allo scopo. Tutto ciò che si richiede è la buona volontà, la ferma decisione di esegurilo."

${ }^{199}$ BANDINELLI, Ranuccio Bianchi. Come non ricostruire Firenze demolita. Il Ponte, vol.1, n. II, 1945, p. 114. Trad. nossa. "I pericoli sono due: il primo, che si ricostruiscano le nostre città indiscriminatamente in vetro-cemento; il secondo, che si vogliono ripristinare 'come erano' ricostruendole sulle fotografie e sui calchi. Dei due pericoli denuziamo subito come il piu grave il secondo, anche perché avrà in proprio favore l'opinione di una maggioranza di persone cosiddette cólte dei ceti borghesi, sempre favorevoli alla retorica del falso antico."

${ }^{200}$ Para um amplo panorama dos debates em torno da relação antigo-novo ao longo das décadas de 1950 e 1960, bem como para referências específicas sobre as posições defendidas por diversos autores como Bruno Zevi, Ernesto Rogers, Gillo Dorfles, Antonio Cederna, Leonardo Benevolo, Giuseppe Samonà, Luigi Piccinato, entre outros, consultar: SANTORO, L. op. cit., pp.49-97; GIULIANI, A. op. cit., pp.39-55; DE FUSCO, Renato. Dov'era ma non com'era. Firenze: Alinea, 1999.
} 
descompromissada com quaisquer atributos do ambiente preexistente que não somente destruía em larga escala o patrimônio urbano, como também se eximia de qualquer compromisso com relação aos interesses da população. Situação que reserva, portanto, intrigantes paralelos com a nossa realidade atual.

A cidade que se aproxima e se sobrepõe à antiga mostra-se como a expressão de um impulso econômico demasiado forte para que seja possível alterar-lhe e ordenar-lhe os movimentos. A caótica expansão obedece às solicitações de um imediato e cego interesse privado, e o chamado à uma ordenada predisposição urbanística que considere os interesses da comunidade, quase nunca é ouvido. ${ }^{201}$

Para o autor, o modo de empreender a conservação - considerando os instrumentos de tutela empregados e as estratégias de intervenção sobre a cidade preexistente -, deveria atentar para as brechas conceituais e práticas que acabavam por impulsionar a ação dessa especulação imobiliária. Dessa forma, enquanto os arquitetos discutiam se seria lícito ou não a construção de novas construções junto às antigas, a impossibilidade prática do Estado em empreender a tutela dessas extensas áreas consideradas intocáveis impulsionava uma contrapartida perigosa do mercado imobiliário. Enquanto alguns arquitetos defendiam essa 'intangibilidade' e eximiam-se de uma discussão cautelosa e fundamentada sobre como viabilizar projetualmente a relação antigonovo, alimentava-se, paradoxalmente, a tese absolutamente oposta: se o Estado não pode assegurar a conservação do ambiente antigo, que se preocupe somente com as grandes obras, enquanto aquelas que representem apenas um valor ambiental poderão ser demolidas e ceder espaço ao mercado imobiliário. Essa seria a resposta mais cômoda e pronta a ser empregada por toda a especulação imobiliária e por grande parte da classe profissional dos arquitetos e engenheiros. E prossegue afirmando que o maior prejuízo proveniente dessa situação é a perda desse patrimônio urbano enquanto monumento coletivo, ou ainda, a perda do "valor coral da estratificação histórica [...], justamente o patrimônio que a mais moderna experiência de história e de arte contribuiu para colocar em justa evidência, ou seja, o ritmo determinado pelos espaços externos por meio daquelas

\footnotetext{
${ }^{201}$ PANE, R. Città antiche, edilizia nuova [1956-1957]. In: PANE, R. Attualità e dialettica ..., op. cit., p. 113. Trad. nossa. "La cittá che si accosta e si sovrappone all'antica ci appare come l'espressione di un impulso economico troppo forte perché sia possibile mutarne ed ordinarne i movimenti. La caotica espansione obbedisce alle sollecitazioni di un imediato e cieco interesse privato, e quasi mai trova ascolto il richiamo ad una ordinata predisposizione urbanistica che faccia salvi gli interesse della comunità.”
} 
formas que portam coerentemente o nome de uma particular tradição de cultura e não o nome desse ou daquele arquiteto de exceção". ${ }^{202}$

A inserção harmônica de novas arquiteturas e a convivência entre antigo-novo se resolveria no contraste entre a imagem rica e estratificada do passado e a imagem nova que se sobreporia com critério e respeito ao preexistente. Promovendo essa convivência, o ambiente urbano antigo deixaria de ser visto como uma imagem acabada, completa, concepção que o furta da historicidade que o faz vivo e mutável. ${ }^{203} \mathrm{E}$ a salvaguarda desse ambiente não seria uma conservação integral de uma soma de obras e sim a manutenção de relações de massas e de espaços, situação que consente a inserção de um novo edifício, desde que este se subordine às escalas e relações preexistentes. A questão do 'novo', portanto, é substancialmente uma questão de qualidade projetual, seja com relação à proposta de integração com o existente, seja quanto aos próprios atributos formais e compositivos da nova obra. Logo, o problema não é a técnica moderna, sem dúvida uma grande conquista, o problema é que os arquitetos devem apropriar-se desses meios técnicos, empregá-los com juízo crítico, e não deixá-los nas mãos imediatistas dos atores do mercado. Não basta a disponibilidade de novos instrumentos para que a disposição criativa se renove, "os arquitetos devem conquistar a possibilidade de determinar, sem obediência forçada e constrangimentos desumanos, a relação entre o novo e o antigo e a criação, orgânica e não adicional, de um novo ambiente". E conclui: "aquilo que nos falta não é a possibilidade de indicar alguns exemplos felizes, mas uma produção média que seja aceitável e digna, já que uma civilização alcançada não poderá ser demonstrada por algumas obras de poesia, mas por uma difusa literatura arquitetônica que encontre lugar ao lado daquela do passado". 204

\footnotetext{
${ }^{202}$ PANE, R. op. cit., p.114. Trad. nossa. "Poiché quello che si va distruggendo è proprio il patrimonio che la più moderna esperienza di storia e d'arte ha contribuito a porre in giusta evidenza, e cioè il ritmo determinato dagli spazi esterni, mediante quelle forme che portano coerentemente il nome di una particolare tradizione di cultura e non quello del tale o tal'altro architetto di eccezione."

${ }^{203}$ PANE, R. op. cit., p.115. "A tese da inconciabilidade entre construção nova e antiga se funda, em suma, sobre uma fatalística aceitação do fato realizado, generalizando-o como um dado inevitável e definitivo para as experiências que se deverão realizar-se amanhã".

${ }^{204}$ PANE, R. op. cit., pp.123,128-129. Trad. nossa. "L'architetto deve conquistare la possibilità di determinare, senza forzate obbedienze e disumane costrizione, il rapporto tra il nuovo e l'antico e la creazione, organica e non addizionale di un nuovo ambiente. [...] Ciò che manca da noi non è la possibilità di indicare alcuni esempi felice ma una media produzione che sia accetabile e degna; poiché, una raggiunta civiltà non potrà essere dimostrata da alcune opere di poesia ma da una difusa letteratura architettonica che trovi posto accanto a quella del passato" (grifo do autor). Segundo Renato De Fusco, a distinção de Pane entre arquitetura e arte é paralela à distinção elaborada pelo filósofo Benedetto Croce (1866-1952) entre literatura e poesia, daí a analogia direta empregada por Pane na citação acima. A 'literatura arquitetônica' é a atividade cotidiana, cuja arte reside na resposta espontânea às demandas práticas do ambiente urbano; a
} 
A polêmica travada entre Bruno Zevi e Cesare Brandi fez emergir ainda outros contornos. Ao lado de Pane, Zevi enfatiza que o ponto mais grave da questão relacionavase ao projeto e à execução do restauro, etapas muitas vezes confiadas a arquitetos incompetentes. Logo, bons projetos de arquitetura moderna poderiam inserir-se em tecidos antigos. Brandi, por sua vez, nega essa possibilidade, e seus motivos são de natureza estética. Afirma não ser possível projetar essa convivência pois a arquitetura moderna baseia-se em princípios projetuais que contradizem o caráter fundamental da arquitetura tradicional, ou seja, contradizem um critério de espacialidade que a partir da visão perspéctica de Brunelleschi tratou de orientar e remodelar todo o mundo construtivo medieval. ${ }^{205}$ Para Brandi, a arquitetura moderna "não pode ser inserida em um antigo complexo urbano sem o destruir e sem se autodestruir, porque uma obra de arte se destrói onde venha a aceitar condições espaciais que a negam, e ainda destrói em razão daquilo que negando afirma". ${ }^{206}$ Zevi, no entanto, prossegue defendendo a legitimidade da inserção da arquitetura moderna em contextos históricos e enfatiza uma vez mais a diferença entre a boa arquitetura e as experiências desastrosas impulsionadas pela especulação imobiliária que de modo algum poderiam representar a verdadeira linguagem arquitetônica contemporânea. $^{207}$

'poesia arquitetônica' são as obras excepcionais. "Aqui [n'A Poesia, de Croce] estão distintas faculdade poética e faculdade literária ou prática. A primeira, no seu abandono ao universal, a segunda na intenção que é realmente de não perder nunca de vista aquela 'razão' que é guia e apoio ao prático operar. [...] As conseqüências que de tais considerações pode-se tirar no campo da arquitetura me parecem evidentes. [...] A arquitetura é arte quando o é, e acrescentaria ainda: quando quer sê-lo, ou seja muito raramente. Ao imenso trabalho que se realiza no mundo, edificando e escrevendo, somente em algumas ocasiões é reconhecido um valor diverso do que é normalmente solicitado e ditado por razões práticas." PANE, R. Architettura e arti figurative. Venezia: Neri Pozza, 1948, p.63 apud DE FUSCO, R. Roberto Pane teorico del restauro. In: CASIELLO, S. (Org.), op. cit., p.357; Para aprofundamentos, consultar: CROCE, B. A poesia: introdução à crítica e história da poesia e da literatura. Trad. Flávio Loureiro Chaves. Porto Alegre: Faculdade de Filosofia, 1967 [1ª ed. 1946].

${ }^{205}$ CRISTALLINI, Elisabetta. Ragghianti, Zevi e il dibattito sulla tutela del patrimonio artistico negli anni della ricostruzione. In: ANDALORO, M. (Org.) La teoria del restauro..., op. cit., p.123; Brandi desenvolve o tema sobretudo no artigo: Processo all'architettura moderna. L'archietttura cronache e storia, n.11, 1956. Para aprofundamentos sobre a questão da "espacialidade perspéctica" e para um amplo panorama da polêmica entre Brandi e Zevi, consultar: KÜHL, B. M. Preservação da arquitetura industrial..., op. cit., pp.128-131.

${ }^{206}$ BRANDI, Cesare. Il vecchio e il nuovo nelle antiche città italiane [1956]. In: BRANDI, C. Terre d'Italia. Milano: Bompiani, 2006, p.49. Brandi retoma essa questão no terceiro apêndice da Teoria da Restauração, retomaremos o tema oportunamente. Trad. nossa. "l'architettura moderna [...] non può essere inserita in un antico complesso urbano senza distruggerlo e senza autodistruggersi, perché un'opera d'arte si distrugge ove venga ad accettare delle condizioni spaziali che la negano, e altrettanto distrugge in ragione di quello che negando afferma."

${ }^{207}$ Em ampla produção bibliográfica, Bruno Zevi desenvolveu uma série de temas em torno da relação antigo-novo como o debate contra o chamado "moderno ambientado", propostas de intervenção baseadas em construções modernas "ambientadas" ao antigo, ao invés de se buscar uma verdadeira nova forma de expressão. Cf.: ZEVI, B. Visione prospettica e spazio-temporalità nell'architettura moderna. L'Architettura Cronache e Storia, n.11, settembre 1956, pp. 322-323; ZEVI, B. Contro ogni teoria dell'ambientamento. 
Também o arquiteto Renato Bonelli, um dos principais protagonistas do 'restaurocrítico', mostrava-se pouco otimista quanto às possibilidades de inserção da arquitetura moderna em contextos históricos, mas concordava com Pane e Zevi em diversos argumentos, sobretudo quanto à qualidade projetual da nova arquitetura ${ }^{208}$. Ao comentar as afirmações de Pane sobre a renúncia de parte dos arquitetos em apropriar-se conscientemente dos recursos projetuais por eles próprios criados, Bonelli acrescenta um questionamento de grande interesse: a necessidade de rever o próprio ensino da arquitetura. Segundo o autor, em vez de os jovens receberem uma formação pautada na ética e na responsabilidade pelas escolhas tomadas, aspetos que poderiam mudar o curso da produção arquitetônica frente aos valores da cidade histórica, encontravam, ao contrário, uma grande confusão de conceitos e de métodos e um ensinamento viciado pela predileção aos projetos de exceção. E Bonelli prossegue afirmando ainda que tais danos eram provocados

pela ação profundamente deseducadora que desenfreia sem controle o individualismo absoluto do discente, incentiva as piores tendências, estimula descomposto ativismo. A escola perdeu a consciência dos fins educativos, a clareza dos princípios e dos métodos, a responsabilidade do próprio operar; recruta os professores nos quadros do grande arrivismo profissional e corrompe os próprios alunos pondo o valor da personalidade do arquiteto no grau de excentricidade de seus inventos e no número de sucessos práticos e econômicos atingidos. ${ }^{209}$

Situação que reserva intrigante atualidade. Logo, no panorama geral dessa polêmica emergia o confronto que até hoje observamos entre as prioridades lucrativas do mercado imobiliário, apoiadas por grande parte da classe dos arquitetos, e a batalha pela tutela e intervenção criteriosa sobre os bens culturais. A partir da observação desse

L'Architettura Cronache e Storia, n.4, agosto 1965, pp. 212-213. Sobre o tema do 'ambientamento', cumpre salientar as considerações de Miarelli Mariani sobre as posturas defendidas por Ugo Procacci, Roberto Papini, Gillo Dorfles, Ragghianti,Giovanni Michelucci e Piero Bigongiari. Cf.: MIARELLI MARIANI, G. Riflessioni su un vecchio tema: il nuovo nella città storica. Restauro, n.164, 2003, pp.25-27.

${ }^{208}$ Renato Bonelli também contribuiu no debate sobre a relação antigo-novo e suas colocações apresentam certos pontos de contato com aquelas de Roberto Pane. Mas, ao contrário deste, Bonelli mostra-se pouco otimista quanto à possibilidade de inserção coerente de novas construções em ambientes históricos. Sobre as posturas de Bonelli, consultar: CHIRICI, Cesare. Il problema del restauro. Milano: Ceschina, 1971.

${ }^{209}$ BONELLI, Renato. Il rapporto antico-nuovo nei suoi aspetti storici generali. In: Attualità urbanistica del monumento e dell'ambiente antico. Milano: Görlich, Centro Studi della Triennale di Milano, 1957, p.57. trad. nossa. "Ma questo non basta, poiché il danno più grave è recato in questi istituti dall'azione profondamente diseducatrice che disfrena senza controllo l'individualismo assoluto del discente, ne incoraggia le peggiori tendenze, ne stimola lo scomposto attivismo. La scuola ha perduto la coscienza dei fini educativi, la chiarezza dei principi e dei metodi, la responsabilità del proprio operare; essa recluta i docenti nei quadri del grosso affarismo professionale e corrompe i propri allievi ponendo il valore della personalità dell'architetto nel grado di eccentricità delle sue trovate e nel numero dei successi pratici ed economici conseguiti. 
perigoso embate, Pane desenvolveu uma breve proposta articulada em três pontos básicos para garantir a tutela dos monumentos. A partir de tais pontos, desenvolveriam-se grande parte das discussões sobre a normativa de tutela dos centros históricos sobretudo em congressos nacionais e internacionais que começavam a ser organizados para o enfrentamento do tema, fato que evidenciava a consolidação dessa necessária dimensão urbanística $^{210}$. Os pontos elencados, mesmo sem considerar os aprofundamentos teóricos posteriores, guardam estreitos paralelos com os mesmos problemas que enfrentamos na atualidade, sobretudo quando se trata da defesa de parcelas urbanas cuja representatividade patrimonial é pouco valorizada. Os mesmos fenômenos que hoje nos afligem já estavam claramente identificados e analisados há cinqüenta anos atrás, antes mesmo das prerrogativas acordadas na Carta de Veneza ou das premissas de integração defendidas pela Declaração de Amsterdã. Pane propõe:

I - definir os limites do centro histórico-artístico;

II - estabelecer, sem admitir nenhuma exceção, que dentro dos limites supracitados, não seja consentido, nem a entidades públicas nem privadas, a construção de edifícios cuja altura supere aquela média dos edifícios circunstantes. É claro que a caótica especulação não teria tido razão de considerar o centro antigo uma mina de ouro se, no lugar de um velho edifício, não pudesse construir um outro de altura ao menos duas vezes maior;

II - expropriar, a título de utilidade pública, as zonas verdes privadas compreendidas no centro supracitado, de modo a impedir que essas sejam exploradas como solos edificáveis. ${ }^{211}$

\footnotetext{
${ }^{210}$ Santoro e Giuliani nos oferecem um significativo panorama dos principais encontros realizados ao longo da década de 1950. São analisados os encontros ou congressos ocorridos nas cidades de Palermo (1950), Veneza (1952), Milão e Luca (1956), Bolonha (1958), entre outros. Cf.: SANTORO, L. op. cit., pp.29-97; GIULIANI, A. op. cit., pp.26-55.

${ }^{211}$ PANE, R. Città antiche..., op. cit., p.120. Trad. nossa. "I - Definire il confine del centro storico-artistico. II - Stabilire, senza ammettere alcuna eccezione, che dentro i confini sudetti non sia consentito, né a publici enti né a privati, di costruire edifici la cui altezza superi quella media degli edifici circostanti. È chiaro che la caotica speculazione non avrebbe avuto ragione di considerare il centro storico una miniera d'oro se, al posto di un vecchio edificio, non avesse potuto costruirne un altro di altezza per lo meno doppia. III - Espropriare a titolo di pubblica utilità le private zone verdi comprese nel centro sudetto onde impedire che esse vengano sfruttate come suoli edificatori." Interessante ainda destacar a diferenciação que Pane estabelece entre os termos centro histórico e centro antigo. Segundo o autor: "se o centro antigo corresponde ao âmbito da estratificação arqueológica, aquele histórico é a própria cidade em seu conjunto, então inclusos os seus aglomerados modernos. Em outras palavras, aquilo que é antigo é histórico, mas nem tudo que é histórico é antigo. $\mathrm{O}$ conceito de antigo exclui o novo e o moderno (grifo do autor). "se il centro antico corrisponde all'ambito della stratificazione archeologica, quello storico è la città stessa nel suo insieme, ivi compresi $\mathrm{i}$ suoi agglomerati moderni. In altre parole, ciò che è antico è storico, ma non tutto ciò che è storico è antico. Il concetto di antico esclude il nuovo e il moderno." PANE, R. Centro storico e centro antico [1968]. In: Attualitá e dialética..., op. cit., p.281. Sobre o tema, ver também: MIARELLI MARIANI, Gaetano. Centri Storici: alcune definizioni [1980]. In: Centri Storici: note sul tema. Roma: Bonsignori, 1992, pp.40-43.
} 
No congresso intitulado Atualidade Urbanística do Monumento e do Ambiente Antigo, um dos primeiros encontros de grande porte para discutir especificamente a intervenção e tutela dos ambientes históricos, as discussões em torno da valorização patrimonial e dos métodos de intervenção nos mesmos, reservadas as oposições e confrontos de idéias, culminaram na evidenciação da dimensão urbanística da tutela e do restauro, sendo necessária a sua inserção nos planos diretores e uma relação de maior proximidade entre órgãos públicos e profissionais da arquitetura e do urbanismo. Logo, consolidava-se a idéia de que "nenhuma tutela é concebível senão em estreita coerência com uma geral e orgânica previsão urbanística inspirada em uma vasta experiência de cultura" e buscava-se, portanto, meios para viabilizar o cumprimento de quaisquer normativas, destacando-se nesse sentido a proposta de Pane para a criação de um quadro de arquitetos, profissionais liberais seriamente qualificados, que colaborariam com os departamentos públicos de tutela, não somente no fornecimento de pareceres sobre temas polêmicos, mas também na assistência técnica para a resolução projetual de determinados problemas urbanísticos e de restauro. ${ }^{212}$ Discutiu-se também a oportunidade de buscar o aperfeiçoamento dos instrumentos de tutela através de estudos comparativos entre as legislações atuantes em âmbito internacional, bem como a possibilidade da participação da Unesco nesse processo.

Importante destacar que a análise comparativa das legislações atuantes em diversos países evidenciou uma série de pontos de contato com as discussões travadas no contexto italiano. No campo jurídico, os instrumentos existentes tornavam clara certa convergência nos critérios adotados para a tutela dos bens patrimoniais, como a proibição de demolição e as restrições de modificações. De modo geral, as diversas normas procuravam atentar para a conciliação entre a tutela do público interesse na conservação do patrimônio e o respeito pelo direito de propriedade. A definição do objeto da tutela continha geralmente um conteúdo comum, ou seja, residia sobre artefatos representativos do ponto de vista histórico-artístico. Esses artefatos a serem preservados seriam 'vinculados' ou 'listados', um instrumento semelhante ao tombamento. Nesses casos, incidia sobre o imóvel a proibição de demolição e certas restrições quanto às modificações que poderiam ser realizadas apenas mediante autorização das autoridades competentes. Variava, no entanto, a incidência de responsabilidade quanto à conservação do imóvel. Em

\footnotetext{
${ }^{212}$ PANE, R. Restauro dei monumenti e conservazione dell'ambiente antico. In: Attualità urbanistica del
} monumento e dell'ambiente antico. Milano: Görlich, Centro Studi della Triennale di Milano, 1957, pp. 7-18. 
alguns países, a responsabilidade incidia sobre o próprio proprietário e, em outros, sobre o poder público. Na Inglaterra, por exemplo, o proprietário podia confiar a custódia de seu imóvel protegido ao Estado sem prejuízos quanto ao direito de propriedade. Em algumas legislações, o poder público poderia conceder auxílios financeiros ao proprietário para custear a conservação. A expropriação imobiliária para utilidade pública continuava sendo bastante utilizada em vários países, podendo incidir tanto sobre imóveis ou áreas que representassem interesse de tutela ou intervenção direta do Estado, como também sobre imóveis protegidos porém ameaçados pela negligência dos proprietários na efetivação de sua manutenção. Alguns países previam ainda o direito de visitação pública aos imóveis protegidos, dentro de horários pré-estabelecidos. Quanto à proteção paisagística, termo que abarcava a defesa de conjuntos urbanos, na maioria dos países a legislação era recente e pouco precisa. Em geral, a definição do objeto de tutela era bastante genérica, podia "compreender, sejam as verdadeiras criações da própria natureza, sejam os complexos paisagísticos aos quais concorreram para sua criação também as obras do homem". ${ }^{213}$

Nesse breve resumo apresentado por ocasião do citado congresso, não obstante as variações quanto ao alcance e às delimitações de cada legislação, ressaltou-se a recorrência a certas diretrizes comuns, evidenciando uma relativa concordância quanto ao emprego de instrumentos jurídicos na ação de tutela. Observou-se, no entanto, que alguns países possuíam normas ainda muito incipientes e levantou-se, dessa forma, a necessidade de buscar um esforço coletivo de estudo e de colaboração internacional para auxiliar a tutela jurídica desses patrimônios. Consolidava-se a idéia de patrimônio cultural enquanto um bem comum da humanidade e que, portanto, "o interesse público internacional na conservação de uma beleza artística ou natural [deveria prevalecer] sobre o mesmo interesse público nacional do Estado no qual tal beleza se situa". ${ }^{214}$ A colaboração dos Estados nacionais na elaboração de uma uniformização de certas normas de proteção mostrava-se interessante não somente pela dimensão mundial que a idéia de patrimônio começava a alcançar, mas também devido à possibilidade de difusão de conhecimentos e experiências em nível internacional. O congresso entendia aquele momento como particularmente propício para realizar tal tarefa pois muitos países estavam revendo suas

\footnotetext{
${ }^{213}$ MATTEUCCI, Mario. Il problema della tutela dei monumenti e dell'ambiente artistico considerato sul piano internazionale. In: Attualità urbanistica..., op. cit., p.44.

${ }^{214}$ MATTEUCCI, M., op. cit., p.44. Em defesa da pertinência e eficácia da colaboração internacional para a proteção do patrimônio cultural, o autor cita como exemplo a Convenção da UNESCO para a Proteção dos Bens Culturais em caso de Conflito Armado, realizada em 1954: Convention for the Protection of Cultural Property in the Event of Armed Conflict with Regulations for the Execution of the Convention. The Hague, Unesco, 1954.
} 
próprias normas e diversos conceitos passavam por reelaborações, notadamente quanto à abrangência do patrimônio a preservar e quanto aos critérios a serem empregados na intervenção sobre os monumentos individuais e coletivos.

Em encontros e artigos sucessivos, o aprofundamento de determinados pontos da problemática relativa à atuação sobre os ambientes antigos abriria caminho para uma série de novos questionamentos e formaria, paulatinamente, o cenário de indagações teóricas e desafios operacionais que até hoje acompanham a questão. Começavam a ser abordados com maior atenção aspectos econômicos e sociais relacionados à interferência sobre os bairros antigos, como a situação dos moradores locais e a relação e integração dessas áreas com o desenvolvimento das demais regiões da cidade. Nesse sentido, aprofundam-se as discussões quanto aos métodos de atuação. De um lado, propunha-se a abordagem da questão a partir de planos urbanísticos gerais que regulassem a atuação em áreas de interesse histórico - postura defendida por Ludovico Quaroni, Luigi Piccinato, Liliana Grassi, entre outros. Tais autores defendiam os Planos Diretores como eficazes instrumentos de tutela dos valores ambientais urbanos e argumentavam que os mesmos deveriam assumir a tarefa de planejar a transformação urbana numa direção justa, eficiente e lógica, bem como orientar métodos diferenciados de atuação e definir as funções a serem abrigadas por cada uma dessas áreas. ${ }^{215}$ De outro lado, afirmava-se a necessidade de trabalhar sobre cada parcela urbana a partir de uma abordagem 'caso a caso', atentando para as particularidades de cada localidade - postura em certos aspectos defendida por Roberto Pane, assim como por Ernesto Rogers, arquiteto que rejeitava "o abstrato raciocínio por categorias" em favor de um enfrentamento analítico de cada fenômeno, buscando as soluções a partir de cada condição particular. Apesar de não excluir a necessidade de planos, estes, no entanto, deveriam ordenar um determinado espaço por um determinado tempo - uma espécie de 'plano aberto' - e não se apoiarem unicamente em formulações genéricas, de modo a evitar a indução a tipologias projetuais preestabelecidas. ${ }^{216}$ Reproduzia-se, portanto, outra faceta da polêmica em torno da relação antigo-novo. Apenas para ilustrar a complexidade e continuidade desse debate, Ludovico Quaroni manifestou-se contra a perigosa atuação 'caso a caso' e, em resposta a Rogers, afirmou preferir uma "lei estúpida", porém eficiente, ou seja, uma lei que imobilizasse as

\footnotetext{
${ }^{215}$ SANTORO, L., op. cit., p.48.

${ }^{216}$ ROGERS, Ernesto N. Verifica culturale dell'azione urbanistica. Urbanistica, n.23, marzo 1958, p.118, apud GIULIANI, A., op. cit., p.43; ROGERS, E. N. Il problema del costruire nelle preesistenze ambientali non riguarda soltanto i valori emergenti monumentali ma implica la responsabilità di tutti gli interventi architettonici. L'Architettura Cronache e Storia, n.22, agosto 1957, pp.255-256.
} 
áreas históricas até que se soubesse como agir, em vez de confiar no bom senso dos arquitetos frente às brechas de um plano aberto. E mostrava-se bastante descrente tanto na possibilidade de atuação criteriosa dos arquitetos, como na participação da população e na capacidade dos órgãos públicos na efetivação das ações de tutela: "para defender hoje na Itália, o patrimônio artístico antigo, não podemos esperar que a cultura dos urbanistas tenha aperfeiçoado a idéia de 'plano aberto', ou que uma população de ignorantes torne-se por virtude divina iluminada mais do que sejam hoje os superintendentes". ${ }^{217}$

$\mathrm{Na}$ variedade das argumentações, o aprofundamento do debate impulsionava o inequívoco amadurecimento da dimensão urbanística da tutela e do próprio restauro. Independentemente da abrangência conferida aos planos urbanísticos enquanto instrumentos reguladores, era clara a necessidade de uma visão de conjunto que permitisse entender e coordenar a atuação sobre a cidade. E a compreensão desse organismo buscava cada vez mais abarcar não apenas os aspectos formais relativos à unidade e à diversidade dos conjuntos construídos, mas também as atividades existentes, as relações cotidianas ali abrigadas, os espaços de sociabilidade. Além das questões de ordem técnica e das controvérsias em torno da legitimidade da intervenção como produção formal do espaço, voltavam-se as atenções para os elementos responsáveis pela configuração do espaço urbano extrafísico: as relações sociais, o cotidiano das comunidades residentes, as funções econômicas e atividades culturais tradicionais, os aspectos psicológicos vinculados à paisagem urbana, ou seja, elementos que conferiam vitalidade aos espaços urbanos. Essa percepção mais aguçada frente à complexa gama de elementos que concorrem para a conformação do patrimônio urbano consolidou-se a partir da década de 1960, impulsionada sobretudo pela maturação do caráter cultural da preservação e do restauro. Nesse cenário, considerado como ação que interfere sobre um artefato preexistente de interesse patrimonial, o restauro somava-se ao urbanismo, "confundia-se com ele", ${ }^{218}$ na tarefa de investigação e apreensão desse complexo objeto urbano dotado de especificidades formais, figurativas, comportamentais e culturais; aproximação crítica que necessariamente deveria

217 QUARONI, Ludovico. Per difendere il patrimono artistico antico non possiamo aspettare... L'Architettura Cronache e Storia, n.22, agosto 1957, p.259. O autor refere-se a 'superintendentes' para designar os profissionais atuantes nos órgãos públicos responsáveis pela tutela dos bens culturais na Itália, as Superintendências para os Bens Culturais (Soprintendenze per i Beni Culturali), departamentos vinculados ao Ministério para os Bens e Atividades Culturais (Ministero per i Beni e le Attività Culturali). Trad. nossa. "Per difendere oggi in italia, il patrimonio artistico antico non possiamo aspettare che la cultura degli urbanisti abbia perfezionato l'idea di 'piano aperto', o che una popolazione di ignoranti diventi per virtù divina illuminata più di quanto lo siano oggi i sovrintendenti."

${ }^{218}$ BONELLI, R. Il restauro come forma di cultura. In: Architettura e restauro. Venezia: Neri Pozza, 1959, p.21. "il restauro d'ambiente confluisce nell'urbanistica, si prolunga e si confonde in essa." 
anteceder qualquer intervenção sobre um artefato cultural, segundo as premissas do restauro crítico. Nesse contexto teórico, a atuação sobre o ambiente urbano assim qualificado foi denominada por Bonelli de 'restauro urbano'.

Como conseqüência o restauro, enquanto operação crítica direta ao entendimento e à conservação, investe e compreende em seu próprio campo o inteiro ambiente urbano e toda a cidade antiga, transformando-se em 'restauro urbano'. E essa transformação é marcada por uma correspondente ampliação de conceitos: se no restauro arquitetônico (que trata obras de arte ou expressões individuais de linguagem) pela absoluta exigência expressiva que requer o destacamento da realidade pura daquela existencial, o uso prático e a função do edifício não podem influenciar sobre o juízo crítico e portanto determinar o modo do restauro, no restauro urbano (que trata o ambiente urbano) intervém a relação entre figuração e motivo prático, na qual ambos os termos formam objeto de avaliação. Nos chamados centros históricos, que se configuram segundo a espontânea atitude da força vital guiada pela coerência interna, este impulso de vitalidade, compenetrato na forma e fundido nela, não constitui mais realidade prática, mas vida traduzida em forma e forma impregnada de vida; e é em tal complexa realidade histórica e sub-histórica que o restauro deve incidir. ${ }^{219}$

Nessa asserção, aquilo que qualifica um ambiente urbano antigo é tanto a sua 'presença formal' viva e ativa que comporta e atualiza a história, quanto a própria vida cotidiana que ocupa e molda o espaço, imprimindo-lhe significados de acordo com cada momento histórico. Para Bonelli, o valor incomparável e insubstituível dos conjuntos urbanos reside na fusão essencial entre forma e ação, aspectos indissociáveis de uma imagem histórica e cultural mutável que é a própria cidade. Dessa forma, para intervir sobre as arquiteturas individuais, valem os pressupostos do restauro crítico e criativo; quando se tratar de ambientes antigos, no entanto, o processo crítico deve ampliar-se e compreender todo um quadro histórico concretizado na forma, no qual coexistem valores artísticos e extra-artísticos; valores práticos, éticos, psicológicos, culturais, etc., que

\footnotetext{
${ }^{219}$ BONELLI, R. voce: Il Restauro Architettonico. In: Enciclopedia Universale dell'Arte, v. IX. VeneziaRoma: Istituto per la collaborazione culturale, 1963, republicado na antologia: BONELLI, R. Scritti dul Restauro e sulla Critica Architettonica. Roma, Bonsignori, 1995, p.31. Trad. nossa. "Di conseguenza il restauro, in quanto operazione critica diretta all'intendimento ed alla conservazione, investe e comprende nel proprio campo l'intero ambiente urbano e tutta la città antica, trasformandosi in "restauro urbanistico". E questa trasformazione è contrassegnata da un corrispondente ampliamento di concetti: se nel restauro architettonico (che tratta opere d'arte o singole espressioni di linguaggio) per l'assoluta esigenza espressiva che richiede il distacco della realtà pura da quella esistenziale, l'uso pratico e la funzione dell'edificio non possono influire sul giudizio critico e quindi determinare il modo del restauro, nel restauro urbanistico (che tratta l'ambiente urbano) intervienne il rapporto tra figurazione e motivo realistico, per cui entrambi i termini formano oggetto di valutazione. Nei cosiddetti centri storici, che si configurano secondo lo spontaneo atteggiarsi della forza vitale guidata da interiore coerenza, quest'impulso della vitalità, compenetrato nella forma e fuso in essa, non costituisce più realtà pratica, ma vita tradotta in forma e forma pregnante di vita; ed è in tale complessa realtà storica e substorica che il restauro deve incidere."
} 
interagem entre si. Logo, o restauro urbano comporta a complexidade de buscar interpretar uma série de elementos em jogo que ultrapassam a configuração formal. A apreensão dessa totalidade abarcaria, segundo Bonelli, algumas fases principais: inicialmente, seria necessária uma preparação filológica, uma espécie de estudo cronológico das fases que compõem o espaço urbano, seus períodos construtivos e transformações sucessivas; outra fase comportaria a avaliação artística e literária do conjunto construído a partir da análise dessas etapas construtivas enquanto processos possuidores de uma vitalidade própria, atentando, portanto, para as atividades formantes desse espaço ainda permanentes e atuais. Desse modo, o restauro assumiria a tarefa de manter o caráter da cidade enquanto forma significante e viva, evidenciando as relações entre essa forma e o processo históricocultural que a determinou. ${ }^{220}$

O intervalo entre 1953-1962 é destacado pelo autor como um importante período de análises e estudos para definição dos aspectos técnico-construtivos, jurídicos e econômicos do restauro em sua dimensão urbana. Algumas diretrizes essenciais são apontadas pelo autor como a necessidade de considerar a atuação sobre as parcelas históricas no contexto dos planos diretores urbanos que assumiriam a tarefa de definir o papel dessas áreas no contexto funcional da cidade, considerando a apreensão de todas as citadas particularidades formadoras desses ambientes.

Desta ampliação do plano cultural, resulta a necessidade de que o restauro urbano, enquanto restauro da antiga cidade histórica, cuide de coordenar estreitamente os seus critérios e programas aos correspondentes métodos de estudo e de operação do urbanismo, já que uma intervenção de tal porte não pode prescindir do planejamento urbano e territorial. [...] Nesse sentido, o restauro não pode ignorar os aspectos sociais e econômicos, e deve portanto considerar a vida que se desenvolve nos antigos bairros, com todos os seus problemas: a estrutura e a composição das coletividades que os habitam, as suas necessidades psicológicas e materiais. ${ }^{221}$

O autor prossegue elencando outras diretrizes como a conveniência de atribuir às parcelas urbanas históricas, em planos urbanos, funções adequadas às suas dimensões e

\footnotetext{
${ }^{220}$ BONELLI, R. voce: Il Restauro Architettonico..., op. cit., p.32.

${ }^{221}$ Idem, pp.32-33. Trad. nossa. "A questo ampliamento del piano culturale, consegue la necessità che il restauro urbanistico, in quanto restauro dell'antica città storica, provveda a coordinare strettamente i propri criteri e programmi ai corrispondenti metodi di studio e di operazione dell'urbanistica, poiché un intervento di tale portata non può prescindere dalla pianificazione urbana e territoriale. [...] Su questo piano il restauro non può ignorare gli aspetti sociali ed economici, e deve perciò considerare la vita che si svolge negli antichi quartieri, con tutti i suoi problemi: la struttura e la composizione delle collettività che vi abitano, i loro bisogni psicologici e materiali."
} 
estrutura construtiva. Os serviços que gerassem tráfego acentuado deveriam ser transferidos para outras áreas, buscando atentar, no entanto, para a permanência daquelas atividades tradicionais que determinassem a fisionomia desses conjuntos e que possuíssem importante papel na manutenção da vitalidade urbana, evitando a decadência funcional. Atenta ainda para a ineficácia da política dos 'vínculos', instrumento semelhante ao tombamento, que repousava, segundo Bonelli, numa ação de repressão e defesa passiva. Esse instrumento deveria ser suplantado por uma política ativa e programada de intervenções mediante uma grande operação de restauro estendida a todo o núcleo histórico, como um verdadeiro programa de planejamento urbano-territorial integrado a planos gerais de desenvolvimento em níveis municipal e regional. O próprio autor reconhece, no entanto, a dificuldade de aplicação prática dessas idéias, principalmente devido ao custo elevado dessas operações, à falta de instrumentos jurídicos adequadamente coordenados com a legislação econômica e urbana, e à precariedade técnica, operacional e cultural dos órgãos públicos na viabilização das várias etapas do projeto.

O caráter eminentemente cultural do restauro receberia grande e decisivo impulso a partir das contribuições de Cesare Brandi, um dos mais importantes teóricos italianos no campo do restauro e da história da arte, cujas discussões e teorias repercutiriam nas elaborações conceituais vinculadas ao restauro crítico e adensariam o debate sobre a conservação e restauro a partir de sólidas reflexões pautadas na valorização dos atributos artísticos dos artefatos patrimoniais ${ }^{222}$. Autor de extensa produção bibliográfica, Brandi investigou uma vasta gama de temas no campo das artes e também do urbanismo, desde a teorização de critérios de restauro até considerações sobre a intervenção em ambientes antigos (a exemplo da polêmica travada com Bruno Zevi, como vimos), e análises sobre a política urbana italiana e os planos diretores para áreas históricas. ${ }^{223}$

Brandi analisou o restauro como um ato crítico dirigido ao reconhecimento da obra e de sua individualidade a partir de criteriosos estudos sobre história da arte e estética.

\footnotetext{
${ }^{222}$ Carbonara destaca que a teoria brandiana não contrasta com as formulações do chamado 'restauro-crítico', mas aborda certas questões a partir de um quadro mais amplo. Em concordância com o restauro-crítico, a teoria brandiana preconiza a prevalência da instância estética, assim como faz objeções à certos pressupostos do restauro científico ou filológico. CARBONARA, G. Brandi e il restauro architettonico oggi. In: ANDALORO, M. (Org.) La teoria del restauro..., op. cit., p.226.

${ }^{223}$ Para aprofundamentos sobre a obra de Cesare Brandi e para desdobramentos bibliográficos, consultar: CARBONARA, G. Avvicinamento..., op. cit., pp.303-323; CARBONI, Massimo. Cesare Brandi. Teoria e esperienza dell'arte. Roma: Riuniti, 1992; KÜHL, B. M. Cesare Brandi e a teoria da restauração. Pós Revista do Programa de Pós Graduação em Arquitetura e Urbanismo da FAUUSP, v.21, 2007, pp. 198-211. Além da extensa produção do próprio autor, sobre a qual faremos algumas referências no decorrer deste texto, nos limites de nossos recortes temáticos.
} 
Evidenciava-se, portanto, a priorização do caráter artístico do monumento, demanda interpretativa que vinha se delineando desde os desafios interpostos pelas destruições da Segunda Guerra e do conseqüente limite operativo atribuído ao 'restauro científico'. A obra Teoria do Restauração ${ }^{224}$, publicada em 1963, reúne uma série de textos que vinham sendo publicados desde 1940 com base em investigações teóricas e também desafios práticos enfrentados pelo autor ao longo de sua experiência frente ao Instituto Central de Restauro entre 1939 e 1961, fato que confere importante vínculo entre formulação teórica e aplicação prática às suas proposições. ${ }^{225}$

Na Teoria, Brandi defende que qualquer intervenção em uma obra de valor artístico deverá ser precedida pelo reconhecimento desta obra de arte enquanto tal. Existe, portanto, um elo indissolúvel entre o restauro e a própria obra, "pelo fato de a obra de arte condicionar a restauração e não o contrário". ${ }^{226}$ Esclarece ainda que a apreensão da obra, por se tratar de um produto da atividade humana, pressupõe a observância de sua dúplice instância: a instância estética, que corresponde à qualidade do artístico pelo qual a obra é obra de arte; e a instância histórica, que lhe confere, como um produto humano realizado, a especificidade de um dado tempo e lugar. Com relação à instância da utilidade, o autor a considerada subordinada às demais, pois qualquer decisão a respeito estará ancorada nas instâncias estética e histórica, responsáveis pela configuração da obra em nossa percepção $^{227}$. Como nos lembra Carbonara, Brandi reduz a duas as três instâncias histórica, estética e prática - já enunciadas por Alois Riegl no início do século XX, e lança luzes, inclusive, para uma retomada da teoria riegliana a partir de novas perspectivas de abordagem. $^{228}$

O restauro para Brandi é ato histórico-crítico, "momento metodológico do reconhecimento da obra de arte, na sua consistência física e na sua dúplice polaridade estética e histórica, com vistas à sua transmissão para o futuro". ${ }^{229}$ De maneira geral, em casos controversos, Brandi sugere a predileção pela instância estética pois a singularidade

\footnotetext{
${ }^{224}$ BRANDI, Cesare. Teoria da restauração. Trad. Beatriz Mugayar Kühl. Cotia, São Paulo: Ateliê, 2004.

${ }^{225}$ KÜHL, B. M. Cesare Brandi..., op. cit., p.202.

226 BRANDI, C. Teoria..., op. cit., p.29.

227 A questão da funcionalidade, tema sempre presente quando se trata da intervenção em obras arquitetônicas, pode ser um dos quesitos a serem considerados, porém estará sempre subordinado à fruição dos aspectos históricos e estéticos da obra. "Mas, quando se tratar, ao contrário, de obra de arte, [...] claro estará que o restabelecimento da funcionalidade, se entrar na intervenção de restauro, representará, definitivamente, só um lado secundário ou concomitante, e jamais o primário e fundamental que se refere à obra de arte como obra de arte." BRANDI, C. Teoria..., op. cit., p.26.

${ }^{228}$ CARBONARA, G. La reintegrazione dell'immagine. Roma: Bulzoni, 1975, p.198.

${ }^{229}$ BRANDI, C. Teoria..., op. cit., p.30.
} 
de uma obra de arte em relação aos outros produtos humanos não depende de sua materialidade ou historicidade e sim de sua condição artística; uma vez perdida esta condição, teremos apenas um resíduo. Dá-se um grande passo, portanto, na apreensão das qualidades estéticas da obra e reconhece-se que o restauro deve fundamentar-se na observação das complexas particularidades que a definem, ou seja, no reconhecimento da obra enquanto dado cultural. Esse reconhecimento inclui a observação das estratificações históricas, de sua transformação ao longo do tempo, de seus aspectos formais e materiais, baseando-se em instrumentos de reflexão oferecidos pela historiografia da arte e pela filosofia. ${ }^{230}$ Brandi vem consolidar, portanto, o afastamento do restauro da ação personalizada ou empírica. Apesar das especificidades de cada caso e da conseqüente impossibilidade de estabelecer regras peremptórias de conduta, as formulações de Brandi evidenciam que o restauro jamais poderá incorrer em uma escolha arbitrária; e atentam para a necessária recorrência a diversos campos disciplinares e a criteriosos estudos para orientar o caminho de qualquer intervenção a ser realizada. ${ }^{231}$

A primazia da instância estética, por outro lado, não significa que a instância histórica poderá ser subestimada. Neste aspecto em particular, Brandi ressalta a dupla historicidade inerente às obras artísticas: a primeira coincide com o ato da criação e se refere ao artista, a um tempo e lugar; a segunda historicidade se refere ao fato da obra incidir no presente de modo contínuo, carregando traços de uma série de momentos que se tornaram passado. Trata-se da valorização de todas as etapas pelas quais a obra foi submetida durante o percurso de sua existência; etapas que transcrevem uma trajetória histórica e a composição gradativa de sua configuração formal.

A teoria brandiana, ao abordar sobretudo aspectos relacionados à qualidade do artístico nas obras patrimoniais, ofereceria ricos subsídios para o aprofundamento do debate em torno da preservação e do restauro de bens culturais, seja com relação a um único monumento, móvel ou imóvel, seja também com relação à atuação sobre ambientes

\footnotetext{
${ }^{230}$ Do reconhecimento da obra de arte em sua dúplice instância advêm os dois princípios brandianos do restauro: $1^{\circ}$ : "restaura-se somente a obra de arte"; e $2^{\circ}$ : "a restauração deve visar ao restabelecimento da unidade potencial da obra de arte, desde que isso seja possível sem cometer um falso artístico ou um falso histórico, e sem cancelar nenhum traço da passagem da obra de arte no tempo.” BRANDI, C. Teoria..., op. cit., pp.31-33.

${ }^{231}$ Para aprofundamentos sobre as questões aqui enunciadas, consultar: KÜHL, B. M. Cesare Brandi..., op. cit., pp.198-211; bem como os capítulos ou trechos referentes à teoria da restauração nas obras da mesma autora: Preservação da arquitetura industrial..., op. cit., pp.54-55; e Questões teóricas relativas à preservação da arquitetura industrial. Desígnio Revista de História da Arquitetura e do Urbanismo, n. 1, março 2004, pp. 103-104.
} 
inteiros, abordados pelo autor como monumentos coletivos. Diante do debate que se desenvolvia nesse momento sobre os modos de intervenção em ambientes históricos, as análises de Brandi ofereciam novos argumentos para a compreensão dos atributos patrimoniais da composição urbana considerando seus aspectos materiais e figurativos.

Brandi defende que os mesmos princípios sugeridos para a restauração das obras de arte móveis (pinturas, esculturas) devem igualmente incidir sobre a restauração dos monumentos arquitetônicos. Considerada como obra artística, também a arquitetura goza "da dúplice e indivisível natureza de monumento histórico e de obra de arte", logo, "o restauro arquitetônico recai também sob a instância histórica e estética". ${ }^{232}$ Adverte, no entanto, que a apreensão da estrutura formal da arquitetura difere substancialmente daquela das demais obras de arte nas quais, em geral, "a espacialidade que se realiza em uma dada figuratividade não vem à obra a partir do exterior, mas é função da sua própria estrutura". ${ }^{233}$ Nos monumentos arquitetônicos, por sua vez, deve-se considerar os dados ambientais externos que concorrem para a conformação figurativa da obra. Nesse contexto, em uma obra de "arquitetura como exterior" deve-se considerar os vínculos compositivos entre o 'espaço físico' e a 'espacialidade' própria de cada obra e solicitada por cada obra; aspectos que remetem à observação tanto das relações entre a construção e o sítio onde foi erigida, como também às relações perceptivas entre os espaços arquitetônicos internos e $\operatorname{externos}^{234}$. E é essa estreita relação compositiva, indissolúvel, entre monumento e entorno, um dos fatores a impulsionar a própria apreensão do caráter monumental de certos ambientes que, ao compor a espacialidade das obras arquitetônicas, pode ainda representar um monumento coletivo do qual as obras individuais fazem parte. Dessa forma, não apenas as teorias são diretamente aplicáveis à arquitetura, como também ao próprio ambiente que a contém e que a compõe; ou seja, ao espaço externo como contentor e interlocutor da obra construída.

[...] na arquitetura a espacialidade própria do monumento é coexistente ao espaço ambiente em que o monumento foi construído. Se então, em uma obra de arquitetura como interior, a salvaguarda da dimensão exterior-interior é assegurada só pela conservação do interior, em uma obra de arquitetura como exterior, a dimensão interior-

\footnotetext{
${ }^{232}$ BRANDI, C. Teoria..., op. cit., p.131.

${ }^{233}$ Idem, p. 132.

${ }^{234}$ Sobre as relações interior-exterior no pensamento brandiano, Carboni atenta que não se trata de uma relação puramente física, material, entre espaços fechados e abertos. Deve-se considerar os aspectos compositivos / perceptivos inerentes ao interno ou ao externo que por vezes podem conferir características de exterioridade ao interno ou de interioridade ao externo. CARBONI, M. Cesare Brandi..., op. cit., p.116.
} 
exterior exige a conservação do espaço ambiente em que o monumento foi construído. [Logo, o problema da intervenção em uma obra arquitetônica] apresenta duas faces diferentes: pode ser contemplado do ponto de vista do monumento ou do ambiente em que se encontra que, além de estar ligado de modo indissolúvel ao próprio monumento do ponto de vista espacial, pode constituir, por sua vez, um monumento, de que o monumento em questão constitui um elemento. ${ }^{235}$

Definida a interação monumento-ambiente, Brandi levanta algumas questões a serem observadas. Primeiramente, considera a inalienabilidade do monumento como exterior do sítio histórico no qual fora erguido, não sendo possível, por exemplo, exceto quando a sua salvaguarda não puder ser assegurada de outro modo, retirar um monumento do lugar e reconstruí-lo em outra parte. Tal atitude representaria a alteração dos dados espaciais que fazem parte da própria configuração do monumento e invalidaria, portanto, a artisticidade que o qualifica. Em segundo lugar, atenta para a problemática gerada após uma alteração significativa de um sítio histórico. Nesse caso, sugere que seja avaliado se os elementos desaparecidos ou alterados eram em si monumentos ou não.

Se não constituem monumentos em si, poderá ser admitida uma reconstituição, pois, mesmo que sejam falsos, não sendo obras de arte, reconstituem, no entanto, os dados espaciais; mas exatamente porque não são obras de arte, não degradam a qualidade artística do ambiente em que se inserem só como limites espaciais genericamente qualificados [...] mas esse não é um problema de restauração mas, antes, de criação, que não se resolve com base em princípios, mas, sim, com a elaboração, de maneira geral, de uma imagem nova. ${ }^{236}$

Por outro lado, se os elementos alterados são obras de arte, não se admite qualquer reconstituição. Nesse caso, o ambiente alterado deverá ser reconstituído com base nos dados espaciais e nunca a partir dos aspectos formais da obra desaparecida ou comprometida.

Essa duplicidade inerente às obras arquitetônicas conforme apresentada por Brandi - a obra considerada em si mesma ou em relação a um sítio mais amplo que se configura também como um monumento - nos remete, segundo Carbonara, à escala mais vasta que o próprio conceito de monumento começava a abarcar nesse momento: “desde o menor objeto artístico, reconhecível como monumento já em si mas também como

\footnotetext{
${ }^{235}$ BRANDI, C. Teoria..., op. cit., p.133.

${ }^{236}$ idem, p. 136
} 
elemento de um contexto monumental maior, até o inteiro tecido de uma cidade, à configuração de uma paisagem ou à conformação histórica de uma amplíssimo território". ${ }^{237}$ Essa nova dimensão conceitual, cada vez mais ampla, traz consigo uma série de problemas críticos, interpretativos e técnicos, desde a busca por novos métodos de intervenção, inclusive recorrendo ao diálogo com o urbanismo e o planejamento urbano, até os problemas impulsionados pela própria escala da arquitetura que, devendo ser considerada sempre inserida em um ambiente preexistente, também monumental, sugere, portanto, a adoção dos mesmos instrumentos críticos de restauro empregados em quaisquer obras individuais. Carbonara atenta ainda para a necessidade de estender a compreensão crítica também ao 'sentido de lugar', abarcando as conexões perceptivas com o entorno de modo a assimilar dados figurativos e espaciais nas propostas de intervenção. Dessa forma, o entendimento extensivo dessa duplicidade brandiana permitiria um precioso vínculo com o urbanismo que não resultaria somente em projetos naquela escala de vista aérea, que Sitte já condenara, mas sim em projetos urbanos dotado de formas e percepções espaciais, sem se descuidar dos conteúdos técnicos, sociais e políticos ${ }^{238}$.

De fato, Carbonara ressalta que um dos maiores problemas de estudo e interpretação da teoria brandiana hoje é estender a sua experimentação, de início voltada ao campo da pintura e da escultura, a outros âmbitos, como a arquitetura e o restauro urbano e paisagístico; atitude que permitiria não somente a renovação dos métodos de aplicação, mas também uma provável melhoria da qualidade média dos restauros efetuados na atualidade. Essa tarefa tem sido afrontada com certa timidez frente aos métodos operativos consolidados (e viciados) aos quais se voltam a maioria dos arquitetos na elaboração de projetos de restauro. Um arquiteto que procurou empregar a concepção crítica brandiana no campo do restauro urbano, foi Francesco Blandino, ${ }^{239}$ autor do Plano de Saneamento e de Restauração da Cidade Antiga de Taranto.

\footnotetext{
${ }^{237}$ CARBONARA, G. La reintegrazione..., op. cit., p.161. Trad. nossa. "Dal più piccolo oggetto artistico, riconoscibile come monumento già in sé ma anche specificabile come 'elemento' di un più grande contesto monumentale, fino allo intero tessuto di un'antica città, alla configurazione di un paesaggio o alla conformazione storica di un ampissimo territorio".

${ }^{238}$ CARBONARA, G. La reintegrazione ..., op. cit., pp.161-162.

${ }^{239}$ CARBONARA, G. Brandi e il restauro architettonico oggi..., op. cit., p.228. Nesse sentido, cabe ainda ressaltar variados autores que atualmente se têm voltado à extensão da unidade conceitual e metodológica de Brandi a outros temas não abordados diretamente em seus escritos. Kühl cita como exemplo os esforços em relação à diversas formas de manifestação cultural como o cinema, a arte contemporânea ou arquitetura moderna, temas em estudo por autores como Heinz Althöfer, Giovanni Urbani, Michele Cordaro, Giuseppe Basile e o próprio Carbonara. KÜHL, B. M. Cesare Brandi..., op. cit., p.202.
} 
O Plano Blandino, elaborado e aprovado na década de 1970, considerou toda ilha que contém a cidade antiga como "um documento de história civil, a preservar e a recolocar em evidência no conjunto de seus valores histórico-artísticos e socioculturais". ${ }^{240}$ O restauro urbano foi proposto pelo Plano como meio de permitir a conservação de toda a ilha, ou seja, buscou-se uma operação global que abarcasse o estudo de todo o conjunto construído considerando seus aspectos materiais, figurativos e sociológicos. Com base principalmente em parâmetros tipológicos (aos quais Carbonara faz uma sutil objeção metodológica) $)^{241}$, o Plano propôs a divisão da área em vinte e seis setores considerados homogêneos que receberiam as intervenções sucessivamente, de modo a garantir a unidade do projeto e a seqüência de sua execução. De modo geral, a hipótese de restauração da cidade antiga defendida pelo Plano Blandino comportava a eliminação de todas os aportes contrutivos, internos ou externos, que contrastassem com o ambiente e "desfigurassem a face da velha cidade", com especial atenção para os elementos que influenciavam negativamente na ventilação e na insolação.

Além da duplicidade da "arquitetura como exterior" - conceito que remete à qualidade do artístico da obra construída e do espaço que a contém e compõe - a produção teórica de Brandi compreende ainda a abordagem de sítios urbanos ou rurais além do caráter artístico, ou seja, trata tais artefatos a partir de uma visão alargada do conceito de patrimônio cultural que identifica como monumento tanto os afamados artefatos artísticos, como também aqueles dotados de importância memorial e culturalmente representativos, como os conjuntos urbanos formados pela chamada 'arquitetura menor'.

\footnotetext{
${ }^{240}$ O Plano foi confiado ao arquiteto F. Blandino em 1968, proposto em 1971 e aprovado pela região da Puglia em 1973. Uma atenção particular foi voltada à recuperação funcional e à restauração de edifícios e de elementos que constituíam a memória histórica da cidade. O plano propôs a manutenção das funções residenciais, reservando aos grandes volumes e aos antigos palácios aristocráticos a função de abrigar alguns serviços públicos que impulsionariam a revitalização do centro histórico. A execução das intervenções programadas ocorreu com a colaboração das organizações de tutela do patrimônio arqueológico e históricoartístico-monumental. Algumas realizações do Plano Blandino foram apresentadas na Exposição Internacional de Amsterdã de 1979, por ocasião das comemorações do Ano Europeu do Patrimônio Arquitetônico. STAZIO, Attilio. Taranto: faire revivre un patrimoine negligé. In: Patrimoine architectural: un atout pour réussir la ville. Conférence internationale, Halifax (Royaume-Uni), 24-27 octobre 1988. Strasbourg: Conseil d'Europe, 1989, pp.29-35.

${ }^{241}$ No que tange à análise urbana tipológica empregada por Blandino, Carbonara ressalta a dívida metodológica no confronto com o pensamento de Saverio Muratori. CARBONARA, G. Brandi e il restauro architettonico oggi..., op. cit., p.228. Para aprofundamentos sobre o método de análise tipológica dos tecidos urbanos desenvolvido por Muratori, consultar: MURATORI, S. Studi per una operante storia urbana di Venezia. Venezia: Istituto Poligrafico dello Stato, s.d.; PIGAFETTA, Giorgio. Saverio Muratori architetto: teoria e progetti. Venezia: Marsilio, 1990; bem como os textos de G. Caniggia, G. Cataldi e A. Giannini publicados no número especial da revista Storia Architettura dedicado a S. Muratori: Storia Architettura, VII, n.1-2, 1984. Para outros métodos, consultar ainda: AYMONINO, Carlo. Il significato delle città. Venezia: Marsilio, 2000 [1 ${ }^{\mathrm{a}}$ ed. 1975].
} 
Nesse ponto se deve especificar que por monumento entendemos qualquer expressão figurativa, seja arquitetônica, pictórica, escultórica e também qualquer complexo ambiental que seja particularmente caracterizado por monumentos singulares ou simplesmente pela qualidade do tecido construtivo de que é formado, mesmo se não relacionado a uma só época. ${ }^{242}$

A partir dessa concepção alargada de monumento, Brandi desenvolveu extensa produção bibliográfica voltada à observação e análise de cidades e conjuntos urbanos, textos de caráter literário que evidenciam a sensibilidade do autor na apreensão das qualidades compositivas que qualificam os conjuntos construídos, cada qual imbuído de características locais, culturais e materiais próprias. De fato, no prefácio de uma dessas obras, Argan afirma que Brandi "sabia perfeitamente que nenhum texto é lido corretamente se não for lido como contexto, e este contexto é determinado pelas obras menores que se agrupam ao redor de uma obra-prima, que derivam dessa obra-prima e formam o tecido de uma cidade, de um território, de um país, de um continente". ${ }^{243}$

Essa sensibilidade para com os conjuntos construídos impulsionaria também a sua atuação crítica frente às políticas públicas destinadas à tutela desses artefatos. Em sucessivos artigos publicados notadamente a partir da década de 1950, Brandi buscou comentar e analisar diversos planos diretores, propostas legislativas e projetos urbanos destinados à áreas culturalmente significativas. De modo geral, a posição de Brandi é pontuada pelo engajamento e pelo ceticismo. Por um lado defendia propostas normativas mais rígidas para a efetivação das ações de tutela do patrimônio urbano:

Se então se chegasse a resolver a questão com uma formulação puramente jurídica, pareceria poder ser fácil alcançar o resultado da salvaguarda. Se, por assim dizer, houvesse uma lei que realmente 'detivesse' nos limites historicamente determinados o complexo edificado de uma cidade, mas de modo que realmente não fossem admitidas mais do que intervenções de simples manutenção, os proprietários infelizes do edifício monumental, do jardim com potencial área edificável, do infeliz casebre que, pelo fato de

\footnotetext{
242 BRANDI, C. Il nuovo sul vecchio [1964]. In: BRANDI, C. Il restauro: teoria e prática [antologia organizada por Michele Cordaro]. Roma: Riuniti, 2005, p.35. Trata-se do mesmo texto publicado em1967 com o título 'L'inserzione del nuovo sul vecchio', em: BRANDI, C. Struttura e Architettura. Torino: Giulio Einaudi, 1967. Trad. nossa. "A questo punto occorrerà specificare che per monumento intendiamo qualsiasi espressione figurativa, sia architettonica, pittorica, scultorea, ed anche qualsiasi complesso ambientale che sia particolarmente caratterizzato da monumenti singoli o semplicemente dalla qualità del tessuto edilizio di cui consta, anche se non in relazione ad una sola epoca."

${ }^{243}$ ARGAN, G. C. Viaggiando con Brandi. In: BRANDI, C. Terre d'Italia ... op. cit, p.XIV. Trad. nossa. "Sapeva perfettamente che nessun testo è correttamente letto se non letto come contesto, e questo contesto è determinato dalle opere minori che si raggruppano intorno ad un capolavoro, che si diramano da capolavoro e formano il tessuto di una città, di un territorio, di un paese, di un continente."
} 
encontrar-se preso em um complexo arquitetônico não pode aspirar a tornar-se a base de um arranha-céu, colocariam o espírito em paz, como os cônjuges que em vão depositam esperanças na instituição do divórcio. ${ }^{244}$

Por outro lado, porém, não acreditava que essas normas pudessem surtir real efeito em um ambiente cultural contaminado pela inércia das autoridades e influenciado por idéias equivocadas de desenvolvimento urbano. $\mathrm{O}$ autor demonstra a inexistência de uma consciência de 'urbanismo' na raiz da opinião pública, em geral convencida de bom grado que a cidade pode perfeitamente continuar a crescer como o fez espontaneamente através dos séculos até hoje. Segundo o autor, o argumento de que cada época traz novas maravilhas e compensam as possíveis perdas com novas obras igualmente belas é uma afirmação muito perigosa, "uma postura [...] largamente difundida [que] se baseia numa absoluta ignorância da história". ${ }^{245} \mathrm{Na}$ verdade, o conjunto da cidade não poderia comportar um crescimento sucessivo, nos moldes do desenvolvimento urbano atual, pois este inevitavelmente destruiria os ambientes antigos pela necessidade cada vez maior de criar cruzamentos e vias de comunicação entre as regiões antigas e aquelas recémconstruídas.

O belo é que a hipócrita premissa de todos os planos é aproximadamente a mesma: salvar o centro histórico. Mas é possível salvar o centro histórico, se a cidade continua a se expandir a 'mancha de óleo', em sucessivos anéis concêntricos? É claramente impossível, porque a partir de hoje e de amanhã, os cruzamentos se tornarão sempre mais difíceis e invocarão alargamentos, correções, numa palavra, demolições e reconstruções, que em pouco tempo terão alterado o tecido conectivo da cidade até torná-lo irreconhecível, e tornar-lhe inoperante a conservação. ${ }^{246}$

244 BRANDI, C. Ancora e sempre del vecchio e del nuovo nelle antiche cittá italiane [1956]. In: BRANDI, C. Il patrimonio insidiato: scritti dulla tutela del paessagio e dell'arte [antologia organizada por Massimiliano Capati]. Roma: Riuniti, 2001, p.27. Trad. nossa. "Se allora si giungesse a risolvere la questione con una formulazione puramente giuridica, sembrerebbe potesse essere facile raggiungere il risultato della salvaguardia. Se, per così dire, ci fosse una legge che veramente 'fermasse' entro i limiti storicamente determinati il complesso edilizio di una città, ma in modo che davvero non fossero ammessi che interventi di ordinaria manutenzione, i proprietari infelici del palazzo monumentale, del giardino come potenziale area fabbricabile, della disgraziata casuccia che, per il fato di trovarsi presa in un complesso architettonico non può aspirare a divenire la base di un grattacielo, si metterebbero l'animo in pace, come i coniugi che invano sperano nell'introduzione dell'istituto del divorzio."

${ }^{245}$ BRANDI, C. I piani regolatori della città [1959]. In: BRANDI, C. Il patrimonio insidiato..., op. cit., p.97. Trad. nossa. "Un attegiamento del genere, largamente invalso, si fonda su un'assoluta ignoranza della storia". ${ }^{246}$ BRANDI, C. I piani regolatori della città [1959]. In: BRANDI, C. Il patrimonio insidiato..., op. cit., p.96. Trad. nossa. "Il bello é che l'ipocrita premessa di tutti questi piani è pressappoco la medesima: salvare il centro storico. Ma è possibile salvare il centro storico, se la città continua a espandersi a macchia d'olio o a raggiera? È chiaramente impossibile, perché dàgli oggi, dàgli domani, gli attraversamenti diverrano sempre più difficili e invocheranno allargamenti, correzioni, in una parola demolizioni e ricostruzioni, che in breve 
Logo, a salvaguarda não poderia ser alcançada apenas com ações jurídicas de proteção das áreas históricas. Seria necessário buscar compreender os mecanismos de expansão da cidade e propor novos moldes de crescimento compatíveis com as estruturas urbanas já consolidadas. Uma alternativa seria a elaboração de uma legislação rígida que afastasse o crescimento para além dos núcleos tradicionais, já que "a necessidade de expandir as cidades", defende o autor, "não como círculos concêntricos e sufocadores, mas em núcleos autônomos e satélites, não é mais nem mesmo um conceito a ser debatido, mas uma verdade adquirida". ${ }^{247}$ A aplicação de tais leis, no entanto, é o grande nó da questão. O autor manifesta pessimismo e desconfiança na ação do poder público na Itália, onde uma 'lei drástica' nunca resultará drástica, pois "são as próprias autoridades que deveriam tutelá-la, a fazer-se promotoras para que venha a ser violada". ${ }^{248}$ Resta-lhe finalmente a confiança no poder da opinião pública para alterar essa mentalidade e exigir o respeito às normas jurídicas de preservação do patrimônio. A atenção deveria recair, portanto, na difusão da informação e na conscientização da população.

\section{OS DOCUMENTOS INTERNACIONAIS E A EXPANSÃO DO PATRIMÔNIO CULTURAL}

No início dos anos sessenta, o debate em torno da preservação dos bens culturais centrava-se na continuidade da revisão crítica impulsionada pelo segundo pós-guerra, bem como no aprofundamento das investigações teóricas que solicitavam, cada vez mais, a participação de diferentes campos disciplinares. Aproximação necessária frente à gradativa expansão e diversidade dos artefatos cuja representatividade cultural começava a ser identificada e valorizada à luz das recentes conquistas teóricas. É, portanto, um momento histórico crucial para o amadurecimento dos principais pressupostos da preservação e do restauro na formulação que conhecemos hoje. Em 1964, a realização do II Congresso Internacional de Arquitetos e Técnicos de Monumentos Históricos, evento que culminaria

tempo avranno alterato il tessuto connettivo della città fino a renderlo irriconoscibile, e a renderne ormai inoperante la conservazione".

${ }^{247}$ BRANDI, Cesare. Il vecchio e il nuovo nelle antiche città italiane [1956]. In: Terre d'Italia..., op. cit., p.53. Trad. nossa. "La necessità di espandere le città non a cerchi concentrici e soffocatori, ma in nuclei autonomi e satelliti, non è più nemmeno un concetto da dibattere, ma una verità acquista".

${ }^{248}$ BRANDI, C. Ancora e sempre..., op. cit., p.27. Trad. nossa."Ma in un paese come 1'Italia questa legge drastica, non risulterà mai drastica, perché anche quando c'è, sono magari le autorità che dovrebbero tutelarla, a farsi promotrici che venga violata." 
com a redação da Carta de Veneza, teve papel fundamental para a síntese dos debates travados desde a década de 1940. Com base na concepção histórico-crítica, a Carta enuncia a necessidade de se formularem princípios de conservação e restauração válidos internacionalmente, com a devida adaptação ao contexto cultural de cada país. Não obstante a continuidade dos debates e a realização de outros encontros que orientariam a elaboração de novos documentos, principalmente para aprofundar tópicos específicos, a Carta de Veneza continua sendo o principal referencial teórico até os dias de hoje, mesmo sem pretender qualquer efeito legislativo.

A diversidade de temas abordados no Congresso nos permite uma ampla visualização do cenário teórico e investigativo do período - sobretudo no ambiente europeu -, e evidencia ainda a repercussão e a troca de idéias sobre diversos temas em diferentes contextos geográficos e culturais. Logo, muitos dos problemas amplamente abordados no ambiente italiano, sobre o qual temos nos debruçado com maior atenção, vinham sendo enfrentados em diferentes países, e, freqüentemente, a partir de recursos investigativos semelhantes. Dentre as preocupações em pauta no Congresso, buscou-se discutir a problemática relativa à tutela dos centros históricos, a questão do encontro antigo-novo, o papel do projeto de intervenção com relação ao preexistente e a preservação de ambientes e paisagens em acelerada transformação. Ao lado de tais temas, reafirma-se ainda a necessidade de enfatizar a diferenciação entre conservação e restauração. Por um lado, consolida-se o caráter preventivo da conservação, associado principalmente à adoção de medidas que garantam a integridade da obra; por outro lado, a restauração é concebida como uma intervenção excepcional que, quando necessária, deve visar a evidenciação dos valores patrimoniais intrínsecos ao monumento. Consolida-se ainda a idéia de definir o projeto de restauro segundo uma metodologia precisa, apoiada sobre um rigoroso reconhecimento da obra, ou seja, o projeto de restauro é visto como o resultado de um ato crítico e cultural - conforme determinavam as contribuições teóricas do restauro crítico e da teoria brandiana. Essa questão é evidenciada numa das conferências introdutórias, nas palavras de Roberto Pane:

como se sabe, a orientação da restauração moderna é determinada pela instância estética e pela instância histórica, de modo que todo o processo que se desenrola na programação da 
intervenção e na sua execução prática consistirá na moderação e na conciliação das considerações que cada uma das duas instâncias impõem ao restaurador. ${ }^{249}$

Outro tema abordado por muitos estudiosos ao longo do evento foi a defesa do caráter eminentemente cultural da ação de preservação e restauro, seja na abordagem das polêmicas em torno da relação antigo-novo, seja no enfrentamento dos desafios impostos pela interferência das instâncias econômicas na ação de tutela, como a ameaça constante da especulação imobiliária ou o avanço de uma idéia de turismo prejudicial ao patrimônio, que classifica os monumentos como elementos de consumo e não de cultura. Nesse sentido, Pane ressalta que a tutela deve considerar os monumentos como um patrimônio vivo, como parte integrante de nosso presente, ou ainda, como elementos que permitem a fruição e a continuidade de uma herança cultural e não somente como uma imagem nostálgica, 'museificada', de um passado isolado do presente.

Não queremos conservar os monumentos do passado como um raro mundo de imagens que serve de refúgio à nossa nostalgia, mas como um patrimônio vivo e atual do nosso presente. Como em toda concepção moderna humanística, os princípios da conservação dos monumentos baseiam-se na suposição que uma relação de continuidade cultural e histórica entre o passado e o presente pode e deve subsistir. E, por outro lado, se neste domínio e em outros nós cessássemos de aspirar à 'qualificação' em oposição à divulgação da 'quantificação', não poderíamos mais falar da sobrevivência de uma cultura. $^{250}$

As discussões do congresso evidenciavam o amadurecimento de uma apreensão mais ampla daquilo que definimos como patrimônio cultural, abarcando sob a denominação do termo não apenas os monumentos excepcionais, mas também obras modestas e conjuntos urbanos. Com o objetivo de formular um documento internacional mais preciso que incluísse essas recentes contribuições teóricas e que permitisse a

${ }^{249}$ PANE, R. Conférence Introductive. In: Il Monumento per l'uomo. Atti del II Congresso Internazionale del Restauro. Venezia 25-31 maggio 1964. Padova: ICOMOS, Marsilio, 1971. Trad. nossa. "Comme on le sait, l'orientation de la restauration moderne est déterminée par l'instance esthétique et par l'instance historique, si bien que tout le processus qui se déroule dans la programmation de l'intervention et dans son exécution pratique consistera à tempérer et à concilier les considérations que chacune des deux instances impose au restaurateur".

${ }^{250}$ PANE, R. Conférence..., op. cit. Trad. nossa. "Nous ne voulons pas conserver les monuments du passé comme un rare monde d'images servant de refuge à notre nostalgie, mais comme un patrimoine vivant et actuel de notre présent. Comme pour toute conception moderne humanistique, le principes de la conservation des monuments se fondent sur la supposition qu'un lien de continuité culturelle et historique entre le passé et le présent peut et doit subsister. Et, d'autre part, si en ce domaine et dans d'autre nous cessions d'aspirer à la 'qualification' en opposition à la diffusion de la 'quantification', nous ne purrions même plus parler de la survivance d'une culture." 
continuidade do debate, foram revistos certos pressupostos contidos na Carta de Atenas de 1931 com o intuito de aproximá-los aos debates teóricos travados nos últimos trinta anos. Roberto Pane ressaltou que os critérios expressos na Carta Italiana de Restauro de 1931, assim como nas Instruções, respondiam bem a uma concepção crítica relativa a um momento histórico determinado. Após a Segunda Guerra, no entanto, ainda que certos preceitos permanecessem válidos de acordo com as exigências que lhes inspiraram, "tais critérios deviam ser alterados na medida das mais recentes experiências culturais, e em particular das novas relações entre o urbanismo e a tutela dos monumentos e dos valores ambientais". ${ }^{251}$ No texto intitulado 'Propostas para uma carta internacional de restauro', Pane e Gazzola comentam vários itens da Carta Italiana (que possui muitas semelhanças com a Carta de Atenas pois ambas contaram com a participação ativa de Giovannoni em sua redação) e propõem atualizações. No que concerne à tutela do ambiente histórico, a análise dos autores considera o breve Artigo $6^{\circ}$ da Carta Italiana ${ }^{252}$ pouco abrangente e superficial frente às recentes conquistas teóricas e ao atual entendimento do tema que passava a considerar as relações entre monumento e ambiente de modo mais amplo. Os autores sugeriram, portanto, que a redação do artigo fosse modificada de maneira à adaptar-se à nova visão das relações entre os monumentos e o urbanismo. ${ }^{253}$

Outra questão abordada ao longo do Congresso foram os aspectos sociológicos a serem considerados nas ações de tutela ou intervenção em antigas parcelas urbanas, tema que ganhava força sobretudo a partir da década de 1960. Hubert Fernand Joway expõe a questão com clareza. ${ }^{254} \mathrm{O}$ autor sugere que os bairros antigos sejam preservados não apenas devido aos valores histórico-artísticos mas sobretudo em razão de seu papel essencial na dinâmica social de toda a cidade. Logo, propostas de preservação baseadas na produção de 'bairros-museu', voltados aos turistas, são vistas pelo autor como tão destrutivas como a própria demolição, pois furta aos bairros antigos o desenvolvimento de suas funções originais na conformação social do organismo urbano. Os profissionais envolvidos na intervenção desses conjuntos deveriam, portanto, buscar uma formação

\footnotetext{
${ }^{251}$ PANE, R. Conférence..., op. cit. Trad. nossa. "Tali criteri dovessero essere emendati alla stregua delle più recenti esperienze culturali, ed in particolare dei nuovi rapporti tra l'urbanistica e la tutela dei monumenti e dei valori ambientali."

${ }^{252}$ Carta Italiana del Restauro 1932. Consiglio Superiore per le antichità e belle arti. Norme per il restauro dei monumenti, art. $6^{\circ}$ : "Que junto com o respeito pelo monumento e por suas várias fases prossiga aquele por suas condições ambientais, as quais não devem ser alteradas por isolamentos inoportunos; por construções de novos edifícios próximos invasivos por massa, por cor, por estilo."

${ }^{253}$ GAZZOLA, Piero e PANE, Roberto. Proposte per una carta internazionale del restauro; LEMAIRE, Raymond M. Rapport Géneral. In: Il Monumento per l'uomo..., op. cit.

${ }^{254}$ JOWAY, Hubert F. L'environnement urbain des ensembles anciens: leur valeur sociale. In: Il Monumento per l'uomo..., op. cit.
} 
sociológica que os orientasse na compreensão das necessidades desses habitantes. ${ }^{255} \mathrm{O}$ autor cita ainda a Lei francesa de 1962 como um importante impulso jurídico para a valorização dessa escala sociológica da preservação, já que buscava assegurar a proteção dos conjuntos urbanos considerando necessariamente a sua inserção na dinâmica urbana contemporânea. $^{256}$

Quanto aos instrumentos jurídicos em âmbito internacional, Mario Matteucci faz uma síntese da organização administrativa em matéria de proteção dos monumentos, dos centros históricos e da paisagem, com destaque para os problemas recorrentes em vários países e as principais iniciativas adotadas. Como já o fizera no Congresso Atualidade Urbanística do Monumento e do Ambiente Antigo, de 1957, Matteucci ${ }^{257}$ ressalta que um dos principais problemas associados a todas as formas de proteção é a conciliação entre o interesse público na conservação do patrimônio nacional e o direito da propriedade privada. Dentre as principais novidades legislativas com relação ao evento de 1957, o autor discorre sobre a regulamentação do direito de alienação para determinados bens de interesse cultural, instrumento que começava a ser adotado em alguns países. Além da já citada constatação do interesse público na preservação de um bem e sua sucessiva 'notificação' (ou listagem, o equivalente a um tombamento) que consistia na imediata limitação de certas ações sobre o mesmo, a inalienabilidade representava um segundo

\footnotetext{
${ }^{255} \mathrm{O}$ autor prossegue citando bairros antigos que desempenham importantes funções na dinâmica social parisiense e disserta sobre a valorização do critério social, além das instâncias estética e histórica. "Certos bairros, como o Bairro Latino e os grandes bairros da margem direita de Paris, têm um papel essencial: aquele de misturar harmoniosamente camadas extremamente diversas de população, o que permite trocas enriquecedoras. [...] Este papel de mesclar a população é insubstituível e é um motivo capital de conservação, de apropriação destes bairros à vida presente. Nestes bairros em especial, o habitante passa à frente do turista, o critério social passará por conseguinte se necessário à frente do critério estético e do critério histórico?" Trad. nossa. "Certains quartiers, comme le Quartier Latin et les grands quartiers de la rive droite à Paris, ont un rôle essentiel: celui de mêler harmonieusement des couches estrêmement diverses de population, ce qui permet des échanges fructieux et enrichissants. [...] Ce rôle de brassage de population est irremplaçable et c'est un motif capital de conservation, d'appropriation de ces quartiers à la vie présente. Dans ces quartiers en particulier, l'habitant passe avant le touriste, le critère social passera donc au besoin avant le critère esthétique et avant le critère historique?" JOWAY, H. F., op. cit.

${ }^{256} \mathrm{O}$ tema da preservação dos centros históricos foi abordado por diversos autores que discorreram sobre propostas e/ou iniciativas de tutela em seus países de origem, como Husref Redzic, sobre as iniciativas de tutela em Sarajevo, ex-Iugoslávia (Le monument historique, son ambience et son utilisation actuelle); Antoine de Saussure, sobre a criação das zonas de proteção em Genebra (Une expérience de conservation active des 'ensembles'. Méthodes législatives et d'urbanisme); e Robert Hotke, sobre a tutela da chamada 'arquitetura menor' nos Países Baixos (La sauvagarde de l'allure historique des villes).

${ }^{257}$ MATTEUCCI, Mario. Conférence Introductive. In: Il Monumento per l'uomo..., op. cit. Nos deteremos nos aspectos legislativos que melhor ilustram o processo de assimilação das teorias em discussão na prática legislativa de alguns países europeus, não considerados, portanto, individualmente e detalhadamente. Para um panorama mais detalhado da legislação sobre a proteção do patrimônio histórico na França, Inglaterra e Itália, remetemos à obra: SANT'ANNA, Marcia. Da cidade-monumento à cidade-documento: a trajetória da norma de preservação de áreas urbanas no Brasil (1927-1990). Dissertação de Mestrado. Salvador: UFBA, 1995, pp.37-48.
} 
efeito limitativo sobre a propriedade privada e objetivava garantir a possibilidade de aquisição por parte do poder público de certos imóveis ou grupos de imóveis culturalmente significativos; com esse instrumento, o Estado possuiria, portanto, uma espécie de direito de preempção na aquisição de imóveis considerados de interesse público.

Alguns países já aplicavam normas que estendiam a proteção do monumento aos arredores e estabeleciam algumas regras para a manutenção das relações ambientais como, por exemplo, a limitação do direito de construir em certo perímetro com intuito de preservar as visuais do monumento e as características ambientais do conjunto. A Lei francesa de 1962, comentada também por Joway, possuía esse caráter. Segundo François Sorlin, a chamada Lei Malraux fora criada para complementar a ação protetora de normas mais antigas que não abordavam suficientemente a proteção de conjuntos urbanos, bairros e sítios históricos ${ }^{258}$. A Lei Malraux não visava unicamente a proteção do monumento e de seu entorno imediato, mas reconhecia os conjuntos de imóveis que "apresenta[vam] um caráter histórico, estético ou de natureza, a justificar a conservação, a restauração ou a valorização". Essas zonas seriam definidas como secteurs sauvegardés, ou setores protegidos, áreas sobre as quais deveria incidir a aplicação de procedimentos específicos de proteção e valorização. ${ }^{259}$ Antes da promulgação da Lei, parcelas urbanas antigas eram protegidas apenas de modo indireto, como áreas envoltórias de monumentos históricos preservados individualmente. A Lei Malraux reconhecia, portanto, o valor patrimonial de bairros e até mesmo de inteiros territórios urbanos, concepção que atribuía novo papel às estratégias de reabilitação urbana. ${ }^{260}$ Dentre as características a serem observadas para

\footnotetext{
${ }^{258}$ SORLIN, François. Le systéme français pour la sauvegarde et la mise en valeur des sites historiques urbains. In: Il Monumento per l'uomo..., op. cit. Sorlin cita a lei de 1913, que introduziu a noção de "entorno" e implicava a consideração de um raio de proteção ao redor do monumento principal e a lei de 1930 que introduziu a noção de "sítio", com base na legislação francesa sobre sítios e monumentos naturais. Cabe ainda ressaltar a Lei de 1943 que criou a noção de ambiente urbano e propôs a manutenção de um campo de visibilidade para proteger os arredores do monumento protegido. GOZE, Maurice. La ville patrimoine et l'habitat ancien: le synchrétisme des politiques publiques. In: LAMY, Y. (Org.). L'alchimie du patrimoine. Bordeaux: MSHA, 1996.

${ }^{259}$ No que concerne aos setores protegidos, o Código de Urbanismo Francês conserva praticamente a mesma redação até hoje. Cf.: Code de l'Urbanisme: Version consolidée au 6 août 2008. Livre III, Titre I, Chapitre III, Section I: Secteurs sauvegardés. Article L. 313-1; § I.: "Des secteurs dits 'secteurs sauvegardés' peuvent être créés lorsqu'ils présentent un caractère historique, esthétique ou de nature à justifier la conservation, la restauration et la mise en valeur de tout ou partie d'un ensemble d'immeubles bâtis ou non." Disponível em: http://www.legifrance.gouv.fr

${ }^{260}$ Sobre a Lei Malraux, consultar: MEC/SPHAN. Restauração e revitalização de núcleos históricos..., op. cit.; GOZE, Maurice. La ville patrimoine et l'habitat ancien: le synchrétisme des politiques publiques. In: LAMY, Y. (Org.). L'alchimie du patrimoine. Bordeaux: MSHA, 1996; SOUCY, Claude. La tutela delle città storiche in Francia: un bilancio della legge Malraux. Restauro, n.102, 1989. Para breves análises críticas, ver ainda: CAPASSO, Tiziana. Il dibattito sulla salvaguardia dei centri storici dagli anni sessanta ad oggi. Restauro, n.144, 1988, pp.80-83.
} 
definir os setores protegidos, atentava-se para os conjuntos urbanos que apresentassem unidade e homogeneidade arquitetônica; buscava-se, com isso, tutelar uma 'atmosfera', ou uma ambiência peculiar, de certos bairros ou conjuntos construídos. Tais setores tutelados, no entanto, como também observara Joway, deveriam manter-se intimamente conectados com a vida de toda a cidade e integrar-se aos planos de expansão econômica e social. Com o intuito de evitar a criação de 'bairros-museus', deveriam ser buscadas formas de desenvolvimento adequadas ao contexto urbano no qual cada setor protegido se inseria, sendo possíveis usos diversos como o residencial, comercial, cultural, etc. Essas medidas fariam com que a tutela e a valorização dos sítios históricos urbanos participassem ativamente da organização do território. A Lei previa ainda a realização do Plano de Salvaguarda e Valorização para cada setor determinado. O Plano compreenderia diretrizes desde a escala arquitetônica até a escala urbana e orientaria as futuras transformações no perímetro considerado, ou seja, quaisquer alterações poderiam acontecer somente se em conformidade com as prescrições do plano. Tais planos, por sua vez, estariam ainda associados aos Plano Diretor da cidade. Quanto aos meios financeiros, incentivava-se a participação tanto de recursos públicos quanto privados. ${ }^{261} \mathrm{Um}$ instrumento semelhante aos 'setores protegidos' fora também instituído pela legislação inglesa. As Conservation Areas foram criadas pelo Civic Amenities Act, de 1967, que estipulava a designação, a ser realizada pelas autoridades locais responsáveis pelo planejamento urbano, de áreas urbanas de interesse histórico ou arquitetônico que seriam denominadas 'áreas de conservação'. Em tais áreas seriam preservadas tanto as edificações quanto as suas características arquitetônicas e paisagísticas. ${ }^{262}$

Na seqüência das análises acerca do panorama normativo internacional, Matteucci comenta ainda as diretrizes propostas pela Convenção Geral da Unesco de $1962^{263}$. A chamada Recomendação relativa à salvaguarda da beleza e do caráter das paisagens $e$ sítios propunha medidas de salvaguarda tanto para as paisagens naturais quanto para as paisagens e sítios formados pela ação do homem, principalmente os sítios urbanos, geralmente os mais ameaçados pela urbanização acelerada e pela especulação

\footnotetext{
${ }^{261}$ Naquele momento, tais diretrizes estavam em experiência em quatorze cidades francesas: Paris (bairro Marais), Aix-en-provence (bairros centrais), Chartres (bairro da catedral), Lion (bairro Saint-jean), entre outras. SORLIN, F. Le systéme français..., op. cit.

${ }^{262}$ SANT'ANNA, Marcia., op. cit., p.42. Sant'anna cita ainda os chamados Town Schemes, planos diretores voltados à preservação de centros históricos em locais onde se verifique a necessidade de programas de recuperação que integrem várias instâncias governamentais. Para um breve panorama sobre a questão da preservação urbana na Grã-bretanha, ver ainda: CAPASSO, T. Il dibattito..., op. cit., pp.84-89.

${ }^{263}$ MATTEUCCI, Mario. Conférence Introductive. In: Il Monumento per l'uomo..., op. cit.
} 
imobiliária ${ }^{264}$. Entre outras medidas, a Recomendação sugeriu o controle dos projetos mais suscetíveis a danificar essas paisagens como as grandes obras de engenharia e métodos gerais para assegurar as medidas de salvaguarda como a inserção de restrições nos planos urbanos, a proteção legal por zonas, a criação e manutenção de reservas e parques nacionais, bem como a aquisição de sítios representativos pelas próprias comunidades. Recomenda finalmente que as normas e princípios fundamentais de salvaguarda tenham força de lei e que os Estados instituam órgãos especializados de caráter administrativo ou consultivo, assim como programas de ação educativa voltada ao público.

Quanto ao planos urbanos, Mario Berucci levanta a questão da ação do poder público após a definição do 'vínculo', ou seja, após a incidência da tutela legal. Com relação aos conjuntos urbanos formados por arquiteturas 'menores', o autor sugere a definição detalhada - e com força de lei - das novas condições admissíveis para cada unidade em quaisquer obras de intervenção, porque "freqüentemente a ação de tutela se cristaliza no vínculo do 'não fazer' ao invés de aprofundar o seu julgamento e suas disposições na sugestão de 'fazer' obras restauro e de liberação". ${ }^{265}$ Dessa forma, o proprietário e o arquiteto restaurador saberiam com clareza quais as limitações impostas ao imóvel, cabendo aos órgãos de tutela a função de dirimir dúvidas ou imprevistos, ou seja, uma ação de assistência e colaboração. E conclui:

Aquilo que importa é que nenhum imóvel que tenha interesse no campo monumental seja subtraído à tutela [e] que as Superintendências tenham a possibilidade de explicar a sua ação de tutela mesmo no último momento e com autoridade de lei, mesmo em todos aqueles casos de arquitetura menor ou de valor ambiental para os quais em sua singular individualidade não recorrem aos extremos de uma 'notificação,' mas que no seu conjunto constituem um complexo de considerável interesse. ${ }^{266}$

\footnotetext{
${ }^{264}$ Recomendação relativa à salvaguarda da beleza e do caráter das paisagens e sítios. Conferência Geral da UNESCO, 12a . sessão, Paris, 1962. In: Cartas Patrimoniais..., op. cit., p.83. "A salvaguarda não deveria limitar-se às paisagens e aos sítios naturais, mas estender-se também às paisagens e sítios cuja formação se deve, no todo ou em parte, à obra do homem. Assim, disposições especiais deveriam ser tomadas para assegurar a salvaguarda de algumas paisagens e de determinados sítios, tais como as paisagens e sítios urbanos, que são, geralmente, os mais ameaçados, especialmente por obras de construção e pela especulação imobiliária. Uma proteção especial deveria ser assegurada às proximidades dos monumentos."

${ }^{265}$ MATTEUCCI, M., op. cit. Trad. nossa. "Troppo spesso l'azione tutelatrice si cristallizza nel vincolo di 'non fare' anziché approfondire il suo giudizio e le sue disposizioni nel suggerimento di 'fare' opere di restauro e di liberazione."

${ }^{266}$ MATTEUCCI, M., op. cit. Trad. nossa. "Ciò che importa è che nessun immobile che abbia interesse nel campo monumentale sia sottrato alla tutela; che le Sovrintendenze abbiano la possibilità di esplicare la loro azione di tutela anche all'ultimo momento e con autorità di legge, ed anche in tutti quei casi di architettura minore o di valore ambientale per i quali nella loro singola individualità non ricorrano gli estremi per una 'notifica' ma che nel loro insieme costituiscano un complesso di notevole interesse."
} 
Também Luciano Pontuale centra sua atenção na valorização e tutela dos conjuntos urbanos, ou seja, estende a atribuição de valor monumental a toda a cidade e não apenas aos episódios arquitetônicos de especial valor artístico. Defende, portanto, "aquela nova visão histórica do ambiente que abraça em sua múltipla estrutura qualquer organismo arquitetônico-construtivo, independentemente dos seus intrínsecos valores formais". ${ }^{267}$ Apesar de aqui destacarmos exaustivamente diversos autores que reivindicavam a valorização e a proteção do ambiente histórico, essa concepção mais alargada dos valores patrimoniais, ainda que teoricamente aceita, estava longe de ser suficientemente traduzida na prática cotidiana de intervenção urbana. Diante da transformação urbana acelerada e da dificuldade de defender os valores patrimoniais da cidade, despontava nas afirmações de Pontuale a preocupação com os artefatos urbanos mais recentes, geralmente pouco lembrados nessa polêmica, mas que podem representar importantes referências culturais na configuração da paisagem urbana contemporânea.

A cidade [...] deve ser protegida substancialmente independentemente das suas diversas propriedades formais. Esta realidade, racionalmente entendida através do conhecimento das suas estruturas construtivas, é carregada de conteúdos ético-civis, cuja síntese expressiva se resolve formalmente na unidade de todo um tecido construtivo historicizado até quase os nossos dias. Isso se evidencia através da homogeneidade do sistema de loteamento, da constância do tipo construtivo e da unidade do organismo edificado [...]. Esta unidade, de fato, é testemunho histórico do valor moral e civil da cultura de um povo inteiro [e também por este motivo] a conservação destes monumentos de história civil deve ser total e deve compreender também [aquelas construções] mais recentes, características de um valor civil e ético próprio da civilização contemporânea. ${ }^{268}$

A constatação de que independentemente dos profícuos debates teóricos grande parte da produção prática ainda se pautava pelo empirismo, impulsionava a necessidade de

\footnotetext{
${ }^{267}$ PONTUALE, Luciano. Nuove considerazioni sul concetto di monumento e di ambiente monumentale. In: Il Monumento per l'uomo..., op. cit. Trad. nossa."[...] quella nuova visione storica dell'ambiente, che abbraccia nella sua molteplice struttura qualsiasi organismo architettonico-edile, indipendentemente dai suoi intrinseci contenuti di valore formale."

${ }^{268}$ PONTUALE, L., op. cit. Trad. nossa. "La città, invece, nata da quelle componenti edilizie, che sono opera esclusiva del lento precedere dell'uomo, costituisce una sola realtà che deve essere sostanzialmente tutelata indipendentemente dalle sue varie proprietà formali. Questa realtà, razionalmente intesa, attraverso la conoscenza delle sue strutture edili, è carica di contenuti etico-civili, la cui sintesi espressiva si risolve formalmente nell'unità di tutto un tessuto edile storicizzato fin quasi ai nostri giorni. Esso si evidenzia attraverso l'omogeneità del sistema di lottizzazione, la costanza del tipo edilizio e la unità dell'organismo edile, che sono singoli forme parametriche, tutte concorrenti nell'unità della sintesi corale, tra loro armonicamente legate ed indissolubilmente risolte nell'unità di un discorso urbanistico chiaramente determinato e sintaticamente concluso." [...] questa unità infatti è testimonianza storica del valore morale e civile della cultura di un intero popolo [e anche per questo motivo] la conservazione di questi monumenti di storia civile deve essere totale e deve comprendere anche quegli aspetti edili più recenti, che ormai sono caratteristici di un valore civile ed etico proprio della civiltà contemporanea."
} 
elaborar uma síntese das discussões teóricas travadas entre os estudiosos na esperança de orientar as futuras ações de preservação e intervenção. E a Carta de Veneza, elaborada a partir dos temas abordados no Congresso, buscou atingir tal objetivo. No documento observamos a assimilação da citada ampliação do conceito de patrimônio cultural a partir da extensão da noção de monumento histórico aos sítios urbanos e rurais que tenham adquirido significado histórico ou cultural ao longo do tempo. Outra questão relacionada à expansão dos bens culturais é a orientação quanto à colaboração multidisciplinar nas atividades de conservação e restauração, observação que alude aos diversos elementos envolvidos na configuração de determinados monumentos, conforme a nova abrangência do termo.

Art $1^{\circ}$. A noção de monumento histórico compreende a criação arquitetônica isolada, bem como o sítio urbano ou rural que dá testemunho de uma civilização particular, de uma evolução significativa ou de um acontecimento histórico. Estende-se não só às grandes, mas também às obras modestas, que tenham adquirido, com o tempo, uma significação cultural.

Art $2^{\circ}$. A conservação e a restauração dos monumentos constituem uma disciplina que reclama a colaboração de todas as ciências e técnicas que possam contribuir para o estudo e a salvaguarda do patrimônio monumental. ${ }^{269}$

Com relação à defesa do caráter cultural da preservação e do restauro, a Carta esclarece: "a conservação e a restauração dos monumentos visam à salvaguardar tanto a obra de arte quanto o testemunho histórico". ${ }^{270}$ Assim, quaisquer propostas de novos usos para monumentos históricos deverão ser criteriosamente estudadas de modo a garantir o respeito às especificidades de cada monumento, ou seja, a nova função não poderá interferir na apreensão das qualidades históricas e artísticas da obra. O novo uso é considerado um recurso favorável para a conservação do monumento, já que permite a sua integração na dinâmica contemporânea da cidade, porém, busca-se atentar para o perigo de subverter a ordem de prioridades, para evitar o equívoco de priorizar o uso em detrimento dos atributos culturais do bem. Outro aspecto abordado com maior clareza é a preservação da ambiência dos monumentos; a observação dos aspectos compositivos relacionados às relações recíprocas entre o edifício e o ambiente onde se insere.

\footnotetext{
${ }^{269}$ Carta de Veneza. Carta Internacional sobre Conservação e Restauração de Monumentos e Sítios. II Congresso Internacional de Arquitetos e Técnicos dos Monumentos Históricos. Veneza, 1964. In: Cartas patrimoniais..., op. cit., p.92.

${ }^{270}$ Carta de Veneza..., op. cit., p.92.
} 
Art $6^{\circ}$ A conservação de um monumento implica a preservação de uma ambiência em sua escala. Enquanto sua ambiência subsistir, será conservada, e toda construção nova, toda destruição e toda modificação que possam alterar as relações de volumes e de cores serão proibidas. ${ }^{271}$

Segundo observa Carbonara, no entanto, a diretriz do Artigo $6^{\circ}$, ainda que justa em suas afirmações, mostra-se genérica e talvez insuficiente para abarcar os atributos patrimoniais da cidade como um todo ${ }^{272}$. Logo, as observações de Pane e Gazzola sobre a necessidade de incorporar os avanços teóricos nesse campo não chegaram a comparecer satisfatoriamente na redação final da Carta. Tais temas seriam abordados com maior profundidade em documentos posteriores.

Quanto à intervenção nos monumentos, além da citada preocupação com o caráter excepcional do restauro, a Carta enuncia uma série de diretrizes baseadas na extensa experiência teórica adquirida em décadas de debates. Os princípios propostos, apesar dos desdobramentos teóricos posteriores, mostram-se bastante atuais, o que confirma sua representatividade como documento base, corroborado como tal pelo Código de Ética do ICOMOS de 2002.

Dentre as principais diretrizes, a Carta recomenda que as intervenções de restauro estejam fundamentadas no respeito pelo material original e pelos documentos autênticos, detendo-se onde começar a hipótese. Quando julgadas indispensáveis, por motivos estéticos ou técnicos, as ações de reconstituição ou consolidação deverão destacar-se da composição arquitetônica original de modo a evidenciar a sua contemporaneidade e evitar quaisquer falsificações ${ }^{273}$. Além de ressaltar a distinção entre o original e a intervenção, todas essas ações, assim como a construção de acréscimos, deverão integrar-se harmonicamente à composição existente, respeitando suas relações com o entorno. Com respeito às intervenções de consolidação, o uso de técnicas modernas de conservação e restauração cuja eficácia tenha sido comprovada é considerado aconselhável e necessário quando as técnicas tradicionais se revelarem inadequadas. $\mathrm{O}$ documento recomenda ainda

\footnotetext{
${ }^{271}$ Carta de Veneza..., op. cit., p.93.

272 CARBONARA, G. I Trent'anni di una buona Carta del Restauro. Restauro, anno XXIV, n. 131-132, 1995, pp. 61-62.

${ }^{273} \mathrm{O}$ Artigo $9^{\circ}$ é citado por Carbonara como possivelmente aquele que mais gerou discussões entre os estudiosos. Apresenta claramente a concepção conservativa e reveladora do restauro, de acordo com as indicações do pensamento crítico elaborado sobre as bases filológicas precedentes. CARBONARA, G. I Trent'anni..., op. cit., p.63.
} 
o respeito às estratificações de todas as épocas. Em um monumento em que se superpõem etapas construtivas de diferentes períodos, a predileção por um estrato histórico subjacente deverá ser sustentada por rigorosos estudos e só será aceita quando a contribuição eliminada possuir pouco valor em relação ao material revelado.

A Carta apresenta ainda um artigo específico para o tema dos 'sítios monumentais' e ressalta que a preservação e a intervenção sobre os mesmos deverá inspirar-se nos pressupostos acima enunciados.

Art $14^{\circ}$. Os sítios monumentais devem ser objeto de cuidados especiais que visem a salvaguardar sua integridade e assegurar seu saneamento, sua manutenção e valorização. Os trabalhos de conservação e restauração que neles se efetuarem devem inspirar-se nos princípios enunciados nos artigos precedentes. ${ }^{274}$

A orientação de recorrer, na atuação nos sítios urbanos ou rurais, às mesmas diretrizes propostas para a preservação e o restauro de quaisquer categorias de bens culturais, configura-se como um importante passo em direção ao entendimento das qualidades patrimoniais dos conjuntos construídos, ou seja, fortalece a convicção de que, se consideramos tais conjuntos como patrimônio cultural, as intervenções sobre os mesmos devem configurar-se como ações de restauro. A diretriz da Carta consolida, portanto, a unidade conceitual do restauro e evita o equívoco afastamento para o campo técnico de questões que são, primordialmente, de natureza histórico-crítica ${ }^{275}$.

Dentre os significativos avanços conceituais alcançados na década de 1960 e sintetizados na Carta de Veneza, no entanto, um dos aspectos cruciais para o presente estudo é a apreensão cada vez mais ampla dos artefatos possuidores de representatividade cultural, ou seja, a citada expansão do conceito de patrimônio, contexto no qual se inserem os conjuntos construídos mais modestos, as arquiteturas ditas 'não-excepcionais', e a conseqüente compreensão da dimensão urbana da tutela. Ainda que o valor dos conjuntos construídos tenha sido alvo de significativo interesse em diferentes momentos históricos e a partir de variadas interpretações - de Ruskin a Cattaneo, de Sitte a Giovannoni, estudiosos que forneceram as bases das concepções atuais nesse campo - a apreensão das especificidades culturais da chamada arquitetura 'menor', dos conjuntos urbanos como

\footnotetext{
${ }^{274}$ Carta de Veneza..., op. cit., p.94.

${ }^{275}$ CARBONARA, G. I Trent'anni..., op. cit., p.65.
} 
artefatos autônomos e não necessariamente vinculados a um monumento principal, receberia maior aprofundamento sobretudo a partir das discussões impulsionadas pelo segundo pós-guerra, como vimos, bem como a partir da constatação das grandes perdas geradas pelo desenvolvimento urbano acelerado que transformava as paisagens cotidianas e desfigurava os lugares de memória na cidade. As rápidas transformações da sociedade que ameaçavam elementos significativos de nossa cultura sem que tivéssemos tempo de analisá-los e compreendê-los como tais, foram o ponto de partida para buscar motivações que justificassem a preservação de um conjunto cada vez maior de artefatos. É justamente no âmbito desta problemática que se evidencia a valorização de um importante grupo de artefatos até então deixados à sombra de qualquer representatividade cultural: os edifícios e sítios industriais.

A preocupação com a sobrevivência das estruturas industriais, notadamente as originárias dos períodos de intensa industrialização dos últimos séculos, começou a surgiu, portanto, paralelamente aos debates em torno da extensão da idéia de patrimônio. Notadamente a partir da década de 1960, alguns estudiosos começaram a voltar as atenções para os artefatos provenientes da industrialização, assim como para a valorização da história industrial como parte integrante de uma herança cultural. A Inglaterra foi pioneira nesse debate - talvez devido ao análogo pioneirismo na industrialização em larga escala e à presença de uma grande concentração de sítios industriais em seu território, complexos cuja implantação impulsionara fervorosos debates em torno da valorização de especificidades urbanas ameaçadas pelo novo modelo econômico e que, hoje, paradoxalmente, adquiriam representatividade cultural como elementos formadores de uma nova paisagem. Apesar de uma nascente preocupação com o tema já nos anos 1950, quando surgem os primeiros escritos em torno da chamada arqueologia industrial ${ }^{276}$, o tema ganharia maior impulso sobretudo a partir da década de 1960, quando foram destruídos importantes exemplares da arquitetura da industrialização ${ }^{277}$. A partir de então,

\footnotetext{
${ }^{276}$ Kenneth Hudson afirma que o termo 'arqueologia industrial' teria surgido na década de 1950 por iniciativa do inglês Donald Dudley. Acredita-se que a expressão tenha sido publicada pela primeira vez em 1955, no artigo escrito por Michael Rix para a revista The Amateur Historian, no qual o autor expõe sua preocupação com a documentação e a preservação de testemunhos da industrialização ameaçados de destruição. HUDSON, K. Industrial Archaeology: an introduction [1963]. London: Baker, 1966, p.11; RAISTRICK, A. Industrial Archaeology: an Historic Survey. Frogmore: St. Albans, Paladin, 1973, p.02; COSSONS, N. Cossons. The BP Book of Industrial Archaeology [1975]. London: David \& Charles, 1978, p.19.

${ }^{277}$ Como a Estação Euston, em Londres, um dos exemplos mais significativos da fase pioneira da arquitetura ferroviária, demolida em 1962 apesar do empenho de diversas organizações a favor de sua preservação; e também o Coal Exchange, importante exemplo de aplicação estrutural e formal do ferro fundido, demolido
} 
seguiram-se diversos estudos e iniciativas em torno da valorização e preservação desses artefatos como o aprofundamento dos debates em torno de definições conceituais mais precisas para a abordagem do tema ${ }^{278}$, a publicação de revistas especializadas ${ }^{279}$, o desenvolvimento de pesquisas e a realização de inventários voltados ao estudo de artefatos industriais móveis (equipamentos, maquinários), ou imóveis (edifícios ou conjuntos edificados relacionados à atividade industrial). Tais iniciativas logo se expandiram para outros países como a Alemanha e a Suécia, bem como para a França, Bélgica e Itália, notadamente a partir da década de $1970 .^{280}$

Dentre as especificidades dos conjuntos industriais que começavam a ser identificadas e valorizadas, além do caráter histórico-documental, destacava-se o papel decisivo na caracterização da paisagem, considerando tanto os aspectos formais e espaciais determinados pela peculiar arquitetura industrial, quanto também as relações sociais originadas e consolidadas em torno da atividade produtiva, aspectos de um cotidiano que moldava o espaço 'extrafísico' responsável pela caracterização de certas localidades. Partindo da observação de tais atributos, a tutela de remanescentes industriais era vista por alguns pesquisadores como um importante recurso educacional, tanto para o estudo da história da técnica, dos processos produtivos ou equipamentos, como para a abertura de novas perspectivas de análises e releituras históricas sobre o próprio processo de industrialização e as transformações sociais, espaciais, políticas e econômicas dele

na mesma época. A partir de então, cresce o interesse pelo estudo e conservação de edifícios industriais. Em 1965, o Ancient Monuments Board reconhece a tipologia industrial como digna de proteção, da mesma forma que outros sítios monumentais e arqueológicos tradicionais. KÜHL, B. M. Arquitetura do ferro e arquitetura ferroviária em São Paulo. São Paulo: Ateliê, 1998, p.221; KÜHL, B. M. Preservação da arquitetura industrial..., op. cit., p.16; GAZANEO, J. Verso il Recupero del Patrimonio Archeologico Industriale. In: GENOVESE, R. A. Archeologia Industriale in Campania alla fine del XIX secolo. [S.1]: [s.n], 1983, p. 06.

${ }^{278}$ Significativos foram os debates em busca de uma definição precisa para o termo 'arqueologia industrial', bem como sobre os limites cronológicos e métodos de pesquisa a serem empregados, temas enfrentados por Kenneth Hudson, Arthur Raistrich, Angus Buchanan, Neil Cossons e Maurice Daumas. Para um panorama dessas discussões, consultar: RUFINONI, M. Preservação do patrimônio industrial na cidade de São Paulo. Dissertação de Mestrado. São Paulo: FAUUSP, 2004, pp.117-127.

${ }^{279}$ Um importante espaço de divulgação nesse sentido foi a revista criada em 1963 por Kenneth Hudson, The Journal of Industrial Archaeology. A publicação foi interrompida em 1974 e ressurgiu em 1976 com o nome The Industrial Archaeology Review, veículo de expressão da National Association for Industrial Archaeology. HUDSON, K. World Industrial Archaeology. London: Cambridge University Press, 1979, pp.2-3; GAZANEO, J., op. cit., p. 06.

${ }^{280}$ Além dos estudos teóricos, cabe destacar algumas iniciativas práticas de tutela do patrimônio industrial que alcançaram grande repercussão como a preservação, ainda na década de 1970, das salinas de Chaux, e a criação do Museu do Homem e da Indústria, no complexo do Le Creusot, ambas iniciativas francesas. KÜHL, B. M. Preservação da arquitetura industrial..., op. cit., p.19. Sobre o papel dos ecomuseus na preservação do patrimônio industrial, consultar: BERGERON, Louis. TICCIH et L'Ecomusée du CreusotMontceau les Mines: les cheminements d'une convergence. Patrimoine de l'Industrie, 1999, n.1, pp.7-13. Para aprofundamentos e referências bibliográficas complementares: BARBUY, Heloísa. A conformação dos ecomuseus: elementos para compreensão e análise. Anais do Museu Paulista, 1995, v.3, pp. 209-236. 
derivadas. ${ }^{281}$ A noção de paisagem, por sua vez, fazia emergir a apreciação de certas qualidades estéticas que não residiam nas arquiteturas individualmente significativas, mas justamente nessa composição de conjunto na qual grandiosos edifícios industriais estabeleciam regras próprias de diálogo com o entorno, com as residências operárias, as vias ou os aglomerados preexistentes que se reordenavam funcionalmente em torno da atividade produtiva. Qualidades que, segundo Cossons, despertavam a atenção não apenas de pesquisadores e estudiosos, mas de toda a comunidade. ${ }^{282}$ Paralelamente, portanto, às enunciações da Carta de Veneza e dos documentos posteriores, as paisagens industriais adquiriam representatividade como patrimônio cultural; e o olhar mais atento para as relações que as compõem permitia desvendar atributos estéticos e formais inesperados, promover novas perspectivas de abordagem sobre a história social e urbana, assim como compreender a atribuição de valor referencial pela população que as vivencia.

Nos anos seguintes, uma série de documentos seriam elaborados com o intuito de aprofundar tópicos específicos da Carta de Veneza. A questão da valorização dos conjuntos e paisagens urbanas é um dos temas a serem abordados com maior atenção em diversos eventos posteriores que permitiriam a elaboração de definições conceituais mais precisas e a delimitação de diretrizes teóricas e práticas de tutela e intervenção sobre o patrimônio urbano. Em 1972, a Conferência Geral da Unesco realizada em Paris aprofundou os temas enunciados na reunião de 1962 e abarcou em sua definição de patrimônio cultural, além dos monumentos artísticos, os conjuntos edificados possuidores de particulares valores de história, arte ou ciência, assim como os sítios, naturais ou manipulados pelo homem, que tenham adquirido representatividade cultural.

Art $1^{\circ}$ Para os fins da presente convenção, serão considerados como "patrimônio cultural':

- os monumentos: obras arquitetônicas, de escultura ou de pintura monumentais, elementos ou estruturas de natureza arqueológica, inscrições, cavernas e grupos de elementos que tenham um valor universal excepcional do ponto de vista da história, da arte ou da ciência;

- os conjuntos: grupos de construções isoladas ou reunidas que, em virtude de sua arquitetura, unidade ou integração na paisagem, tenham um valor universal excepcional do ponto de vista da história, da arte ou da ciência;

\footnotetext{
${ }^{281}$ BUCHANAN, R. A. Industrial Archaeology in Britain. Harmondsworth: Penguin, 1972, pp. 24-49.
}

${ }^{282}$ COSSONS, Neil. The BP Book ..., op. cit., pp.22, 424-425. 
- os sítios: obras do homem ou obras conjugadas do homem e da natureza, bem como as áreas que incluam sítios arqueológicos, de valor universal excepcional do ponto de vista histórico, estético, etnológico ou antropológico. ${ }^{283}$

A chamada Convenção de Paris ressaltou o aumento constante da ameaça aos bens culturais principalmente devido às transformações aceleradas das últimas décadas e propôs o estabelecimento de um sistema internacional de cooperação e assistência à identificação e preservação de bens culturais mundialmente representativos que passariam a integrar a 'Lista do Patrimônio Mundial' ${ }^{284}$. A Convenção propôs ainda a criação de um fundo para a proteção do patrimônio mundial, cultural e natural de valor universal excepcional, o 'Fundo do Patrimônio Mundial', sustentado pelas contribuições obrigatórias e voluntárias dos Estados-membros da Convenção e também por doações de quaisquer entidades ou pessoas interessadas. A definição de patrimônio cultural adotada pela Convenção abriria caminho para a inclusão de diversos representantes do patrimônio industrial na então criada Lista de bens culturais, principalmente a partir da década de 1990. São considerados patrimônio mundial diversos sítios industriais no Reino Unido (Blaenavon, Saltaire e New Lanark, bem como os Moinhos do Vale de Derwent e a paisagem mineira da Cornuália e do oeste de Devon, entre Reino Unido e Irlanda do Norte); na Alemanha (usina siderúrgica de Völklingen, e o complexo industrial da Mina Carvoeira de Zollverein); na Suécia (as forjas de Engelsberg e a área mineira da Grande Montanha de Cobre em Falun); na Itália (sítio industrial Crespi d'Adda); no Chile (usinas de salitre de Humberstone e Santa Laura e a cidade mineira de Sewell); assim como áreas de exploração e produção em vários países e certas estruturas industriais significativas, como o conjunto de elevadores do Canal du Centre, na Bélgica. ${ }^{285}$

\footnotetext{
283 Convenção sobre a Salvaguarda do Patrimônio Mundial, Cultural e Natural. Conferência Geral da UNESCO, $17^{\mathrm{a}}$. sessão, Paris, 1972. In: Cartas patrimoniais ..., op. cit., pp.178-179.

${ }^{284}$ Convenção sobre a Salvaguarda..., op. cit., pp.182-183. "Artigo $11^{\circ}, \S 2^{\circ}$ Com base no inventário apresentado pelos Estados, em conformidade com o parágrafo 1, o Comitê organizará, publicará e divulgará, sob o título de 'Lista do Patrimônio Mundial', uma lista dos bens do patrimônio cultural e natural, tais como definidos nos artigos $1^{\circ}$. e $2^{\circ}$. desta convenção, que considere de valor universal excepcional, segundo os critérios que haja estabelecido. Uma lista atualizada será distribuída pelo menos uma vez a cada dois anos."

${ }^{285}$ Datas de inclusão na Lista: sítios industriais no Reino Unido: Blaenavon (2000), moinhos do Vale de Derwent, New Lanark e Saltaire (2001), paisagem mineira da Cornuália e Devon (2006), Alemanha: usina siderúrgica de Völklingen (1994), complexo industrial da Mina Carvoeira de Zollverein (2001); Suécia: Forjas de Engelsberg (1993), área mineira da Grande Montanha de Cobre em Falun (2001); Itália: Crespi d'Adda (1995); Chile: usinas de salitre de Humberstone e Santa Laura (2005); cidade mineira de Sewell (2006). Áreas de exploração e produção na China: Monte Qincheng e o sistema de irrigação de Dujiangyan (2000); Japão: mina de prata de Iwami Ginzan e sua paisagem cultural (2007); Polônia: Jazidas de Sal de Wieliczka (1978), entre outros países aqui não elencados. Estrutura industrial significativa na Bélgica: os quatro elevadores do Canal du Centre e seu sítio (1998). Disponível em: http://whc.unesco.org/en/list
} 
A visão mais ampla de patrimônio cultural e a inclusão de conjuntos edificados de variadas origens dentre os artefatos a serem tutelados, compareceria ainda em diversos documentos posteriores que gradativamente, ao ampliar a discussão sobre a matéria, buscavam contemplar aspectos mais detalhados do problema: critérios e métodos de atuação, interfaces operacionais com o planejamento urbano, bem como análises mais depuradas dos variados elementos, materiais e imateriais, presentes na configuração dos tecidos urbanos. No ambiente italiano, a Carta de Restauro 1972, além dos monumentos arquitetônicos e artísticos em geral, estende ainda a salvaguarda e a restauração aos complexos edificados de interesse monumental, histórico ou ambiental, para os quais apresenta uma série de diretrizes específicas de atuação, conteúdo do anexo "D" da Carta, denominado Instruções para a tutela dos 'Centros Históricos' ${ }^{286}$ Nas Instruções, segue-se uma definição mais precisa do que se entende por 'complexos edificados de interesse histórico', ou seja, esclarece-se que não apenas os antigos 'centros' urbanos se enquadram nessa definição, mas também "todos os assentamentos humanos cujas estruturas, unitárias ou fragmentárias, ainda que parcialmente transformadas ao longo do tempo, tenham sido feitas no passado; ou, entre aquelas sucessivas, as que porventura tenham adquirido particular valor de testemunho histórico ou proeminentes qualidades urbanísticas ou arquitetônicas". ${ }^{287}$ Compreende-se, portanto, que as discussões sobre a preservação de parcelas urbanas significativas denominadas de 'centro histórico' ou 'centro antigo', podem igualmente ser aplicadas, de acordo com as particularidades da região abordada, ao estudo de diferentes categorias de grupos edificados que não necessariamente representam o 'centro' de uma dada localidade. Independentemente de seu papel no organismo urbano, ou de especiais qualidades artísticas ou ambientais, afirma-se que o caráter histórico de tais assentamentos relaciona-se à sua representatividade como documento de cultura urbana $\mathrm{e}$ como testemunho de comunidades do passado, destacando, mais uma vez, os valores

\footnotetext{
${ }^{286}$ Carta de Restauração 1972. Publicada no apêndice da obra: BRANDI, Cesare. Teoria da Restauração..., op. cit., pp.225-261. A Carta possui quatro anexos destinados a orientações específicas para cada grupo de artefatos: Anexo A: Instruções para a salvaguarda e a restauração das antigüidades; Anexo B: Instruções para a condução das restaurações arquitetônicas; Anexo C: Instruções para a execução de restaurações pictóricas e escultóricas e Anexo D: Instruções para a tutela dos centros históricos.

${ }^{287}$ Carta de Restauração $1972 \ldots$.. op. cit., p.256. A definição dos artefatos contemplados pelas diretrizes da Carta segue nos artigos $1^{\circ}$. e $2^{\circ}$. do documento, p.228: “Art. $1^{\circ}$ Todas as obras de arte de qualquer época, na acepção mais vasta, que vai dos monumentos arquitetônicos aos de pintura e escultura [...] para os fins de sua salvaguarda e restauração, são objetos das presentes instruções, que adotam o nome de Carta de Restauração 1972; Art. $2^{\circ}$ Além das obras indicadas no artigo precedente, são assimiladas a elas, para assegurar sua salvaguarda e restauração, os conjuntos de edifícios de interesse monumental, histórico ou ambiental, em particular os centros históricos; as coleções artísticas e as decorações conservadas em sua disposição tradicional; os jardins e parques que forem considerados de particular importância".
} 
associados às estruturas urbanas além daqueles diretamente associados às arquiteturas isoladas.

Com relação às intervenções em 'centro históricos' ou em 'assentamentos significativos', conforme as definições acima enunciadas, o documento afirma que o objetivo primordial deverá ser a garantia de permanência no tempo dos valores responsáveis pelas características do complexo. Logo, os projetos de restauro não deverão buscar a conservação apenas das características formais de arquiteturas ou ambientes considerados individualmente, mas se estende também à "conservação substancial das características de conjunto do inteiro organismo urbano e de todos os elementos que concorrem para definir tais características". ${ }^{288}$ Para atingir tal objetivo, a conservação dos sítios históricos deverá compreender a reordenação dessas áreas em harmonia com o amplo contexto urbano e territorial do qual fazem parte, ou seja, programas e intervenções em nível territorial poderão coordenar as ações urbanas específicas de modo a promover a tutela das parcelas históricas a partir de uma visão global da cidade e de seu entorno. De maneira análoga, a coordenação em nível territorial abarcaria ainda as exigências de conservação ambiental de extensas áreas que estabeleceram vínculos compositivos com as estruturas históricas que abrigam. Com relação aos elementos construtivos tutelados em conjunto, deverão ser considerados não apenas os aspectos formais que qualificam sua expressão arquitetônica ou ambiental, mas também o caráter tipológico do todo ou de partes do complexo. A análise de todas essas especificidades deverá ser guiada por uma leitura histórico-crítica, não apenas para buscar procedimentos operativos - já que sobre todo o complexo deve-se atuar de modo homogêneo -, mas principalmente para determinar os diferentes graus de intervenção, em nível urbano ou arquitetônico, e as medidas de 'saneamento conservativo' a serem aplicadas em cada caso. E define:

[...] por 'saneamento conservativo' se deve entender, sobretudo, a manutenção das estruturas viárias e construtivas em geral (manutenção do traçado, conservação da rede viária, do perímetro dos quarteirões, etc); e, ademais, a manutenção das características gerais do ambiente que comportem a conservação integral dos elementos monumentais e ambientais mais marcantes e significativos e a adaptação dos outros elementos ou organismos construídos singulares às exigências da vida moderna, considerando apenas excepcionalmente as substituições, mesmo parciais, dos próprios elementos e apenas na

${ }^{288}$ Carta de Restauração $1972 \ldots$.. op. cit., p 257. 
medida em que isso seja compatível com a conservação do caráter geral das estruturas do centro histórico. ${ }^{289}$

As Instruções procuraram também elencar os principais tipos de intervenção urbana em sítios históricos: a 'reestruturação urbanística', intervenção voltada a verificar e a corrigir, quando necessário, as relações territoriais ou urbanas com as quais o sítio considerado forma unidade, atentando, inclusive, para o papel funcional que as parcelas históricas desempenham hoje e para a integração dessas funções com o desenvolvimento contemporâneo; a 'reordenação viária', voltado à análise e revisão das conexões viárias e dos fluxos de tráfego que interfiram sobre as áreas históricas; e ainda a 'revisão mobiliário urbano', voltada à reordenar a relação entre os edifícios e os espaços adjacentes. Na escala do edifício, são citadas as intervenções de 'saneamento estático e higiênico dos edifícios', que verificariam a manutenção física das edificações e as compatibilidades de uso de acordo com as diretrizes para o restauro arquitetônico propostas pela mesma Carta; e a 'renovação funcional dos organismos internos'.

A Carta e as sucessivas Instruções, no que concerne à atuação em sítios históricos, procuraram atentar para as diferentes escalas de intervenção envolvidas na conservação de um ambiente construído - do objeto arquitetônico à cidade; da cidade ao território circundante - , complexidade operativa que reclamava o emprego de diferentes métodos de projeto e instrumentos legais específicos como os 'planos diretores gerais', responsáveis pela reestruturação das relações gerais entre essas variadas escalas; os 'planos detalhados', relativos à organização dos centros em seus elementos mais significativos; e os 'planos executivos setoriais', voltados à atuação sobre blocos edificados (quarteirões compactos, por exemplo) ou sobre conjuntos homogêneos de construções.

A inserção da tutela e da conservação de conjuntos urbanos dentre os quesitos a serem abordados pelos instrumentos de planejamento urbano, tema que vinha sendo explorado com freqüência cada vez maior, seria finalmente exposto com maior clareza no Congresso do Patrimônio Arquitetônico Europeu de 1975, evento em que foi redigida a Declaração de Amsterda $\tilde{a}^{290}$. O documento expôs com detalhes a necessidade e oportunidade de inserir as exigências da preservação do patrimônio arquitetônico dentre os objetivos do planejamento urbano e territorial. Levando-se em consideração a noção

\footnotetext{
${ }^{289}$ Carta de Restauração $1972 . . .$, op. cit., p.259.

${ }^{290}$ Declaração de Amsterdã. In: Cartas patrimoniais..., op. cit., pp.199-210.
} 
ampliada de patrimônio, as questões envolvidas na tutela, na conservação e no restauro deveriam ser abordadas não mais como um tema marginal, e sim como um dos objetivos principais dos programas de planejamento que abarcassem áreas ou conjuntos construídos de interesse cultural. Para tanto, conforme a abrangência do conceito de patrimônio cultural solicita, o documento indica uma série de diretrizes para a abordagem do tema como a participação de diferentes esferas do poder público, a colaboração de equipes necessariamente multidisciplinares, a conscientização das comunidades envolvidas e a busca por critérios e procedimentos específicos a serem empregados na elaboração e aplicação de tais programas. Assim, a questão que vinha delineando-se ao longo de décadas de debates - das sutis observações de Ruskin e Dvořák; de Piccinato e Nicodemi no congresso de Atenas, até os debates do segundo pós-guerra nas figuras de Pane, Bonelli, entre outros - , figurava agora em um documento propositivo que, ao cunhar a expressão conservação integrada, abria caminho para um vasto campo investigativo. De fato, a partir da década de 1970, diversas particularidades da conservação integrada vêm sendo amplamente estudadas. A busca por métodos e procedimentos de planejamento e gestão urbana e territorial, a questão da colaboração multidisciplinar, dos instrumentos de financiamento e da participação das comunidades são alguns dos temas abordados com maior frequiência. ${ }^{291}$

Na Declaração de Amsterdã, considera-se a ampliação do conceito de patrimônio um fato consolidado: entende-se como patrimônio arquitetônico "não somente as construções isoladas de um valor excepcional e seu entorno, mas também os conjuntos, bairros de cidades e aldeias que apresentem um interesse histórico ou cultural". ${ }^{292}$ Os procedimentos para a salvaguarda desse extenso patrimônio, portanto, devem ser abordados a partir dessa nova dimensão de análise. Nesse sentido, busca-se incentivar procedimentos pautados no diálogo entre urbanistas e arquitetos restauradores de modo a alcançar o atendimento às exigências de preservação no contexto dos procedimentos operacionais do planejamento urbano e das políticas públicas. Os programas que atendem concomitantemente tanto as exigências de preservação do patrimônio, quanto as necessidades de desenvolvimento urbano ordenado, poderiam abarcar uma série de

\footnotetext{
${ }^{291}$ No contexto italiano destacam-se as contribuições de Carlo Cesari, Pier Luigi Cervellati, Antonino Terranova e Roberto Di Stefano, bem como as análises de Francesco Forte e Luigi Fusco Girard voltadas às questões econômicas envolvidas na conservação integrada. No contexto internacional, destacam-se ainda as contribuições de Nathaniel Lichfield e David Warren. Cabe ainda destacar a participação brasileira neste debate com a atuação do Centro de Estudos Avançados da Conservação Integrada, instituição que promove cursos, eventos e publicações sobre o tema. Referências completas na bibliografia.

${ }^{292}$ Declaração de Amsterdã.., op. cit., p.200.
} 
proposições como o incentivo de novas atividades em zonas degradadas, a proposta de novos usos em construções antigas como mecanismo de revitalização e a redução da expansão urbana por meio da reabilitação de bairros antigos. Tais iniciativas, além de incentivar a preservação do patrimônio urbano, representariam ainda economia de recursos pois impulsionariam a valorização de áreas já servidas de considerável infra-estrutura urbana. Nas propostas de reabilitação, no entanto, alguns requisitos devem ser observados. Deve-se atentar para a manutenção das comunidades tradicionais e propor medidas que evitem a sua expulsão indireta após a valorização imobiliária advinda da reabilitação. Além disso, deve-se ainda prever programas de educação patrimonial com o intuito de envolver essas comunidades em todas as etapas do projeto. Também a preocupação com a polêmica em torno do encontro antigo-novo é sutilmente enunciada pelo documento que atenta para a necessidade de se projetar uma arquitetura de qualidade em quaisquer ambientes de interesse histórico-cultural.

A integração proposta entre planejamento urbano e preservação do patrimônio evidencia o amadurecimento de uma visão global da tutela, ou seja, o entendimento de que as particularidades espaciais e as relações compositivas que compõem certos conjuntos urbanos somente podem ser preservadas a partir de uma ação coordenada que abarque as diferentes escalas de intervenção - do edifício à cidade e da cidade ao edifício - , seja com relação à proposta projetual, seja com relação à administração, implementação e gestão de tais programas.

O que hoje necessita de proteção são as cidades históricas, os bairros urbanos antigos e aldeias tradicionais, aí incluídos os parques e jardins históricos. A proteção desses conjuntos arquitetônicos só pode ser concebida dentro de uma perspectiva global, tendo em conta todos os edifícios com valor cultural, dos mais importantes aos mais modestos, sem esquecer os da época moderna, assim como o ambiente em que se integram. Essa proteção global completará a proteção pontual dos monumentos e sítios isolados. ${ }^{293}$

Para o desenvolvimento de projetos nesse nível de complexidade, os profissionais envolvidos na elaboração de planos urbanos devem dispor de instrumentos, bem como de qualificação profissional apropriada, que os oriente na identificação das especificidades de cada área e na definição de métodos diferenciados de atuação sobre cada uma delas. Logo,

${ }^{293}$ Declaração de Amsterdã.., op. cit., p.201. 
o reconhecimento dos valores estéticos e culturais deve ser considerado como dado de projeto. A realização de inventários das edificações e dos conjuntos urbanos, assim como a definição de zonas ou perímetros de particular interesse são alguns dos métodos propostos para auxiliar nessa etapa de identificação e delimitação das áreas a serem preservadas. A elaboração de projetos urbanos integrados reclama também a revisão dos instrumentos legislativos e administrativos voltados à tutela. Diante da nova dimensão projetual, deve-se prever em lei: a delimitação precisa dos complexos arquitetônicos e das zonas de proteção a serem consideradas; a condução de programas de conservação como uma obrigatoriedade na elaboração dos planos urbanos; uma redistribuição orçamentária que contemple os recursos necessários à conservação integrada, ao lado da criação de dispositivos específicos para viabilizar financiamentos e a aplicação de recursos, inclusive provenientes da iniciativa privada.

Em 1986, a Carta internacional para a salvaguarda das cidades históricas, conhecida como Carta de Washington, complementa as questões enunciadas na Carta de Veneza (1964) e na Declaração de Amsterdã (1975), e procura enfocar precisamente as cidades ou bairros que além de sua condição de documento histórico, representem valores específicos das civilizações urbanas; valores particularmente ameaçados pela urbanização acelerada dos últimos tempos. Segundo o documento, todas as cidades do mundo, sejam resultantes de um desenvolvimento espontâneo ou de um projeto deliberado, são expressões materiais da diversidade das sociedades ao longo da história e, por esse motivo, todas devem ser consideradas como cidades históricas.

A Carta de Washington define a salvaguarda das cidades históricas como o conjunto de medidas necessárias à sua proteção, conservação e restauração, assim como ao seu desenvolvimento e adaptação harmoniosa às necessidades da vida contemporânea. Neste tópico em particular, a Carta retoma questões já enunciadas na Declaração de Amsterdã ao inserir a preservação urbana dentre os objetivos das políticas de desenvolvimento econômico, social e urbano. Consolida-se, portanto, a constatação de que a preservação de áreas urbanas deverá necessariamente estar integrada a planos de maior abrangência, com a participação de equipes profissionais multidisciplinares e da própria população local no estudo e na conciliação dos diversos fatores envolvidos. A preservação dessas áreas urbanas especiais deverá atentar para a manutenção das relações físicas e imateriais que as compõem e qualificam, ou seja, as relações entre volumes e espaços 
vazios, o traçado urbano e o parcelamento, as características arquitetônicas, as relações com o entorno natural ou construído, as atividades tradicionais.

Os valores a preservar são o caráter histórico da cidade e o conjunto de elementos materiais e espirituais que expressam sua imagem, em particular:

a) a forma urbana definida pelo traçado e pelo parcelamento;

b) as relações entre os diversos espaços urbanos, espaços construídos, espaços abertos e espaços verdes;

c) a forma e o aspecto das edificações (interior e exterior), tais como são definidos por sua estrutura, volume, estilo, escala, materiais, cor e decoração;

d) as relações da cidade com seu entorno natural ou criado pelo homem;

e) as diversas vocações da cidade, adquiridas ao longo de sua história. ${ }^{294}$

Com relação aos métodos e instrumentos adequados, a Carta recomenda que as ações de tutela sejam precedidas de estudos multidisciplinares. O plano de salvaguarda, nesta perspectiva, deverá contemplar não apenas análises arqueológicas, históricas, arquitetônicas, sociológicas, econômicas; mas também o estudo de alternativas relativas às questões administrativas, jurídicas e financeiras. Toda ação de preservação deverá atentar para a integração harmoniosa entre o conjunto histórico e a cidade contemporânea considerando seus novos usos, equipamentos, infra-estrutura e serviços urbanos, existentes no presente ou previstos em seu desenvolvimento futuro. Após os devidos estudos e de acordo com as especificidades de cada caso, deverão ser definidos graus diferenciados de proteção para cada edificação ou grupos de edificações. Serão elencadas aquelas que serão particularmente protegidas, as que poderão ser conservadas em certas condições e aquelas que, excepcionalmente, poderão ser demolidas. Todas as ações de conservação e restauração, ou mesmo as transformações que se julgarem necessárias, deverão visar a manutenção da organização espacial, do parcelamento, da volumetria e escala existente, sempre de acordo com os princípios e métodos recomendados pela Carta de Veneza. A inserção de novas edificações, de acordo com a linguagem arquitetônica contemporânea, será necessária e desejável, desde que procure integrar-se harmonicamente ao conjunto com o objetivo de enriquecer o diálogo entre as manifestações artísticas de diferentes épocas. O mesmo cuidado deverá ser observado com relação aos novos usos. As novas funções deverão respeitar o caráter, vocação e estrutura física da área preservada. A Carta

${ }^{294}$ Carta de Washington. Carta Internacional para a salvaguarda das cidades históricas (Adotada pela Assembléia Geral do Icomos - Conselho Internacional de Monumentos e Sítios, em Washington, 1987). In: Cartas patrimoniais..., op. cit., pp. 282. 
de Washington, em seus parágrafos finais, enuncia a preocupação com o incentivo às pesquisas arqueológicas urbanas e viabilização de programas de educação patrimonial voltados à população local. Apesar de não aprofundar esta questão, notamos que a participação e interesse dos habitantes na conservação do patrimônio é considerado um elemento fundamental para o sucesso dessas iniciativas. ${ }^{295}$

Com relação ao contexto cultural em que foram elaboradas as cartas internacionais comentadas, notadamente a Declaração de Amsterdã e a Carta de Washington, cumpre salientar a contribuição advinda das reelaborações teóricas no campo do urbanismo; discussões que buscavam, dentre outros aspectos, uma compreensão mais atenta dos valores do patrimônio urbano. Segundo Barthélemy, os principais fatores que fortalecem a função diretiva de tais documentos associam-se à gradativa desconstrução da prioridade da técnica na transformação da cidade e à valorização da idéia de 'lugar', ou seja, o desejo da população de retomar e reinterpretar seus laços de pertencimento a um determinado espaço, a uma história e uma cultura. Logo, o urbanismo passa a enxergar o patrimônio urbano de modo diferenciado: seja a partir de novas análises das estruturas urbanas seculares, agora interpretadas como exemplos significativos de organizações espaciais que transcendem a evolução das técnicas e mantêm inesperada atualidade; seja a partir da interpretação dos valores simbólicos para os quais o homem se volta em busca de refúgio, diante de uma suposta mundialização da cultura que ameaça as individualidades. ${ }^{296}$ Preocupação presente de modo inequívoco na Declaração de Amsterdã:

\footnotetext{
295 Outras cartas, manifestos e recomendações, aprofundam tópicos específicos das questões destacadas. Jokilehto cita, dentre outras, diversas cartas regionais como as Normas de Quito de 1967 e a Carta de Machu Picchu de 1977, no Peru; a Carta de Burra de 1981, na Austrália; a Carta de Deschambault de 1982 e Appleton de 1983, no Canadá; bem como a Recomendação de Nairóbi, elaborada na Conferência Geral da Unesco de 1976, a Carta de Petrópolis, documento nacional redigido durante o $1^{\circ}$ Seminário Brasileiro para a Preservação e Revitalização de Centros Históricos, em 1987, e uma série de outras recomendações elaboradas pelo Conselho da Europa ou provenientes de Conferências da Unesco, as quais, em geral, versam sobre problemas afins e propõem medidas bastante semelhantes. Várias dessas Cartas podem ser consultadas na coletânea publicada pelo IPHAN (Cartas patrimoniais..., op. cit.). Para um panorama geral dos temas abordados, consultar ainda: JOKILEHTO, Jukka. L'approccio al restauro ed il pluralismo culturale. Restauro, anno XXIV, n. 131-132, pp. 155-165, 1995.

296 O autor esclarece: "Diante de um mundo que ao amplificar suas interdependências, se banaliza, manifestamente o homem prova a necessidade de intensificar-se: procura reconhecer-se como um elo de uma longa rede de filiações da qual participa na perpetuação da originalidade". Trad. nossa "Dans un monde que en amplifiant ses interdépendences se banalise, manifestemente l'homme éprouve le besoin de s'intensifieril cherche à se reconnaître comme un maillon d'une longe chaîne de filiations dont il participe à perpétuer l'originalité." BARTHÉLEMY, Jean. De la Charte de Venise a celle des Villes Historiques. Restauro, anno XXIV, n. 131-132, 1995, pp. 109-116. A temática aqui exposta é retomada pelo autor em BARTHÉLEMY, J. Noveau rôle pour l'urbaniste? Restauro, n.144, 1998, pp.17-22.
} 
Sabe-se que preservação da continuidade histórica do ambiente é essencial para a manutenção ou a criação de um modo de vida que permita ao homem encontrar sua identidade e experimentar um sentimento de segurança face às mudanças brutais da sociedade: um novo urbanismo procura reencontrar os espaços fechados, a escala humana, a integração das funções e a diversidade sociocultural que caracterizam os tecidos urbanos antigos. ${ }^{297}$

Esse olhar sobre o ambiente urbano tradicional como instrumento cognitivo abriu a oportunidade para a compreensão de seus mecanismos geradores e para a apreensão de suas especificidades materiais e imateriais. Esse novo entendimento fortaleceu um sentimento de confiança nas referências fornecidas por certas experiências seculares e felizes, em detrimento dos esquemas meramente teóricos, de difícil verificação prática, propostos por urbanistas até meados da década de 1970. A aceitação de tais estudos como referências para a prática atual - não como uma cópia fortuita mas como fonte de um novo entendimento dos processos de formação urbana, de certa forma retomando o desejo de Sitte - , pode permitir, acredita o autor, encontrar grande parte das respostas projetuais na correta apreensão da própria preexistência. Nessa asserção, traça-se um novo rumo para a 'imaginação criadora'.

[A imaginação criadora], em vez de atordoar-se num imaginário fora de escala, deve conciliar-se com as proporções humanas. Em vez de extrair-se do real, deve, ao contrário, dele impregnar-se. Ela deve apreender toda a complexidade e ressaltar no âmbito dessa riqueza os menores indícios que permitam orientar a especificidade da resposta arquitetônica. Ela não mais procede de um distanciamento a priori com relação à realidade. ${ }^{298}$

Nos documentos mencionados, portanto, além da evidente base teórica advinda do campo disciplinar da preservação dos monumentos, repercutiam ainda reelaborações conceituais relativas ao urbanismo que começaram a despontar sobretudo a partir da década de 1960. Num contexto de revisão de certos pressupostos do urbanismo moderno emergiam variadas releituras de antigos teóricos da estética urbana e voltava-se a atenção

\footnotetext{
${ }^{297}$ Declaração de Amsterdã..., op. cit., p.202.

${ }^{298}$ BARTHÉLEMY, J. De la Charte de Venise..., op. cit., p.111. Trad. Nossa. "Au lieu de s'étourdir dans un imaginaire hors échelle, elle doit s'accorder aux proportions humaines. Au lieu de s'extraire du réel, elle doit au contraire s'en imprégner. Elle doit en saisir toute la complexité et relever au sein de cette richesse les moindre indices permettant d'orienter la spécificité de la réponse architecturale. Elle ne procède plus d'une distanciation a priori par rapport aux réalités."
} 
para reflexões teóricas pautadas na análise e valorização da cidade existente, assim como na realidade perceptiva por ela gerada. $\mathrm{Na}$ variedade de suas proposições, as contribuições de Kevin Lynch, Jane Jacobs, Christopher Alexander, entre outros, integram esse grupo de análises. ${ }^{299}$ A partir de variadas interpretações, busca-se contrapor àquelas prioridades do urbanismo baseadas sobretudo nas exigências de circulação e na definição de zonas de uso, um novo grupo de necessidades relacionadas a um novo entendimento do papel da cidade. Compreende-se, portanto, que a cidade de hoje não comporta a delimitação estanque de áreas supostamente mais favoráveis para cada grupo de funções. Nesse novo entendimento, o organismo urbano assume funções de outra ordem, não delimitáveis e mais complexas. Além da idéia de função associada ao uso ou aos serviços oferecidos por determinados espaços construídos, busca-se compreender outras funções dos conjuntos urbanos associadas ao seu poder de atração simbólica e ao seu papel como espaço de manifestação cultural e social. Não se trata de abandonar quaisquer elementos analíticos ou propositivos de caráter funcionalista, mas sim de revisá-los a partir dessa visão mais alargada das especificidades urbanas. Logo, ao urbanista caberá apreender e depurar toda essa complexidade e buscar propostas integradoras nas quais, inevitavelmente, o reconhecimento dos valores do patrimônio urbano assume um papel fundamental. Esse 'novo' método de pensar e fazer urbanismo pressupõe a compreensão das especificidades do organismo existente (sejam elas econômicas, sociais, culturais, espaciais) - e do patrimônio urbano nesse contexto -, para, a partir da apreensão desse complexo panorama, poder efetuar análises cuidadosas e pautar quaisquer propostas de atuação em consonância com o desenvolvimento da cidade de hoje e com a inequívoca preservação do patrimônio urbano que a configura e consolida, cotidianamente.

Impõe-se, portanto, uma nova metodologia urbanística. Esta supõe análises morfológicas e semânticas aprofundadas do patrimônio arquitetônico e um excelente conhecimento das necessidades e das aspirações sociais do bairro. [...] Uma das condições fundamentais de melhoria funcional das nossas cidades depende da sabedoria dos urbanistas: que eles sejam conscientes de seu papel de protetores ansiosos, atentos e incorruptíveis do tecido social complexo da cidade, que atuem como servidores fiéis da imagem urbana, da sua coerência, de sua força e de sua originalidade; que eles sejam, enfim, conscientes de que a vontade de reutilizar criteriosamente o patrimônio arquitetônico e a preocupação de

\footnotetext{
299 Além dos teóricos destacados, cumpre salientar o pioneirismo da Escola de Veneza neste debate, nas figuras de Giorgio Piccinato, Carlo Aymonino e Donatella Calabi; bem como dos pesquisadores do Centro de Sociologia Urbana, no contexto francês. Para aprofundamentos, consultar: JACOBS, Jane. Morte e vida de grandes cidades [1961]. São Paulo: Martins Fontes, 2000; LYNCH, Kevin. A imagem da cidade [1960]. São Paulo: Martins Fontes, 1997; ALEXANDER, Christopher. Ensayo sobre la Síntesis de la Forma [1966]. Buenos Aires: Infinito, 1969.
} 
reencontrar 'a escala justa' para qualquer nova operação, longe de ser obsoleta, [é uma preocupação que] corresponde perfeitamente à evolução desejável da nossa sociedade. ${ }^{300}$

No contexto da conservação integrada, Barthélemy sugere que as novas estratégias urbanas devam direcionar-se para uma atenção maior às realidades locais e à participação popular; para a análise das questões urbanas em um contexto mais amplo que considere as diversas variantes envolvidas e para o atendimento criterioso das questões econômicas (que não devem ser prioritárias, mas não podem ser negligenciadas). Deve-se ainda observar a compatibilidade entre novas funções e estruturas existentes, buscando, inclusive, alternativas para a reabilitação de áreas degradadas, para a valorização das potencialidades da paisagem urbana e para a integração harmoniosa entre as novas estruturas e o ambiente existente. Logo, o urbanista deve estar consciente de que a qualidade de vida urbana dependerá da coerência e da interdependência entre diversos fatores a serem criteriosamente estudados e sabiamente considerados em projeto. ${ }^{301}$

\footnotetext{
${ }^{300}$ BARTHÉLEMY, J., op. cit., pp. 113-114. Trad. Nossa. "Dès lors, s'impose une nouvelle méthodologie urbanistique. Celle-ci suppose des analyses morphologiques et sémantiques approfondites du patrimoine architectural et une excellente connaissance des besoins et des aspirations sociales du quartier. Une des conditions fondamentales d'amélioration fonctionelle de nos villes depend de la sagesse des urbanistes: qu'ils soient conscients de leur rôle de gardiens anxieux, attentifs et incorruptibles du tissu social complexe de la ville, qu'ils agissent en serviteurs fidèles de l'image urbaine, de sa coherence, de sa force et de son originalité; qu'ils soient conscients enfin que la volonté de réutiliser judicieusement le patrimoine architectural et le souci de retrouver 'l'échelle juste' pour toute operation nouvelle, loin d'être démodés, correspondent parfaitement à une evolution souhaitable de notre societé."

${ }^{301}$ BARTHÉLEMY, J., op. cit., pp. 115-116. O autor sugere dez proposições básicas a serem consideradas nesta nova dimensão do 'fazer urbanístico': "De minha parte, considerarei laconicamente dez propostas como base desse novo estado de espírito: 1. ouvir as pessoas sem renegar as suas próprias convicções alimentadas pela experiência; 2. analisar o problema colocando-o num contexto suficientemente amplo; 3. ser econômico no uso do espaço lutando contra a dispersão geográfica; 4. dar prioridade à requalificação das zonas mais degradadas; 5. estar atento à configuração e às proporções dos espaços coletivos; 6. otimizar a compatibilidade entre as funções novas e as estruturas existentes; 7 . valorizar as potencialidades da paisagem urbana; 8. procurar a escala justa integrando a construção nova em seu ambiente; 9. distribuir criteriosamente os novos sinais urbanos tendo em conta seus valores simbólicos e comunitários; 10. ser consciente que a qualidade das condições de vida depende da coerência de uma infinidade de detalhes." Trad. nossa. "Dans cette perspective, il s'agira de dégager de nouvelles stratégies urbaines plus singularisées, - sensibles aux réalités concrètes locales - , plus globales - , plus approfondies, - soucieuses autant des détails de mise en oeuvre d'une politique urbanistique que des schémas fonctionnels d'organisation - , et plus participatives, attachées à s'assurer consensus et collaboration active auprès des populations concernées. Pour ma part, je retiendrai laconiquement dix propositions comme base de ce nouvel état d'espirit: 1 . être à l'écoute des gens sans renier ses propres convictions nourries aux sources de l'experience; 2. analyser le problème posé en le plaçant dans un contexte suffisamment large; 3. être économe de l'espace en luttant contre l'éparpillement géographique; 4. donner la priorité à la requalification des zones plus dégradées; 5. être attentif à la configuration et aux proportions des espaces collectifs; 6. optimiser la compatibilité entre les fonctions nouvelles et les structures existantes; 7. valoriser les potentialités du paysage urbain; 8. chercher l'échelle et le ton justes en intégrant le bâti nouveau dans son environnement; 9. répartir judicieusement les nouveaux signes urbains en tenant compte de leurs valeurs symboliques et communautaires; 10. être conscient que la qualité du cadre de vie dépend de la cohérence d'une infinité de détails."
} 
As diretrizes dos documentos internacionais aqui comentadas representam, de modo geral, uma espécie de síntese dos debates em andamento nas últimas décadas, tanto nos domínios da preservação dos monumentos quanto naqueles do urbanismo, considerando ainda os pontos de contato entre ambos os campos disciplinares, pouco evidentes no contexto geral, mas suficientemente abordados por diversos teóricos, como temos tratado. Essa síntese nos permite a visualização do percurso histórico de certos princípios paulatinamente amadurecidos a partir de sucessivas contribuições teóricas e práticas e que, não obstante o contínuo desenrolar de um debate sempre vivo, compõem ainda hoje a base conceitual com a qual os novos questionamentos procuram dialogar. Os pressupostos apresentados, portanto, mesmo após décadas de debates, não perderam interesse e atualidade. Segundo Carbonara, os novos desafios interpretativos e operacionais surgidos nas últimas décadas relacionam-se em grande parte à expansão crescente do conceito de patrimônio cultural que constantemente nos coloca uma série de casos específicos a serem analisados, como a própria questão do patrimônio industrial; a base conceitual para proceder a tais análises, no entanto, permanece válida. Estudiosos como Carbonara e Cordaro defendem que os documentos existentes contemplam suficientemente a questão da preservação e da restauração dos bens culturais. As recomendações da Carta de Veneza (1964), ao lado das indicações da Declaração de Amsterdã (1975) e também da Carta das Cidades Históricas (1987) abordam adequadamente e com a devida cautela as diversas variantes envolvidas na atuação sobre uma ampla gama de bens e podem, portanto, oferecer diretrizes seguras para a conservação e o restauro. Ambos os autores, no entanto, sugerem a busca pela definição de técnicas e códigos de aplicação prática com o intuito de providenciar instruções e especificações de caráter didático que possam orientar a condução de certos trabalhos. ${ }^{302}$

\footnotetext{
${ }^{302}$ CARBONARA, G. I Trent'anni..., op. cit., p.57. Michele Cordaro concorda com as afirmações de Giovanni Carbonara e afirma a necessidade não de uma nova Carta, mas sim do aprofundamento dos debates acerca das especificações técnicas e dos métodos práticos na aplicação das diretrizes já propostas; debates que deveriam ser atualizados periodicamente. A questão da atualidade da Carta de Veneza e da Carta de Restauro 1972 surgiu diante de controvérsias acerca de métodos operativos que culminaram com a proposta de uma nova Carta. A iniciativa foi apoiada pelo Ministério dos Bens Culturais e levada adiante por um grupo de estudiosos coordenado por Paolo Marconi e composto por Umberto Baldini, Corrado Maltese, Paolo Mora, entre outros. O texto, no entanto, jamais foi adotado oficialmente pelo Ministério. Segundo Cordaro, a nova Carta proposta não acrescenta contribuições teóricas válidas e não difere substancialmente da Carta 1972, sendo, portanto, desnecessária qualquer reelaboração. Cf.: CORDARO, Michele. Sull'inutilità di una nuova carta del restauro. Restauro \& Città, n. 11-12, 1989, pp. 97-101; Carta 1987 della Conservazione e del Restauro degli oggetti d'Arte e di Cultura. Arte Documento Rivista di Storia e Tutela dei Beni Culturali, 1988, n. 1, pp.91-106.
} 
Com relação aos avanços teóricos após a elaboração dos principais documentos internacionais, Carbonara sustenta que não surgiram enunciações conceituais radicalmente diversas daquilo que já se discutia entre os anos 1940 e 1960 e distingue, dentre os principais debates em aberto, três tendências principais na atuação sobre os bens culturais. $^{303}$ A partir de uma base teórica comum - paulatinamente fundamentada em décadas de experiências e reflexões sobre o tema - por um lado se acentuaram posições contrárias às intervenções de restauro, representadas pela vertente conhecida como "pura conservação' ou 'conservação integral', linha interpretativa que privilegia a instância histórica e defende a preservação do artefato tal como chegou aos nossos dias ${ }^{304}$ e, por outro, em evidente contraste com a 'pura-conservação', surge a vertente denominada 'hipermanutenção' ou 'manutenção-repristinação' que defende a manutenção constante da obra e sua reintegração ou reconstituição por analogias com o emprego de formas e técnicas do passado sem distinção clara entre a matéria original e a intervenção. A oposição direta entre ambas as tendências repropõe um nova versão dos mesmos contrastes oitocentistas $^{305}$.

$\mathrm{Na}$ direção do restauro-crítico, a vertente denominada 'crítico-conservativa ou criativa' ou ainda 'posição-central', baseia-se na releitura do restauro-crítico e possui raízes na teoria brandiana. Fundamenta-se, pois, no juízo histórico-crítico, na análise da relação dialética entre as instâncias estética e histórica, com base em estudos criteriosos sobre as condicionantes envolvidas em cada caso particular. Dessa forma, reserva-se grande atenção tanto aos valores documentais, aos traços da passagem do tempo na obra, quanto aos valores formais, aos aspectos compositivos responsáveis pela sua imagem figurada. A intervenção de restauro não intenta privilegiar uma determinada fase histórica

\footnotetext{
${ }^{303}$ No âmbito do presente estudo, atentaremos para a repercussão das vertentes citadas - quando possível observar - na atuação sobre conjuntos urbanos. Sobre as tendências atuais da preservação e da restauração e para referências bibliográficas complementares, consultar: KÜHL, B. M. Preservação da arquitetura industrial..., op. cit., pp.61-72; CARBONARA, G. Avvicinamento..., op. cit., pp.393-439; CARBONARA, G. Restauro fra conservazione e ripristino: note sui più attuali orientamenti di metodo. Palladio, n.6, 1990, pp. 43-76.

${ }^{304}$ Dentre os principais autores partidários dessa linha interpretativa, podemos citar: Amedeo Bellini, Marco Dezzi-Bardeschi e Ana Lucia Maramotti. Também Paolo Torsello desenvolve reflexões que se aproximam dessa tendência. A leitura desses autores nos permite um amplo panorama das variadas interpretações existentes na atualidade. Para maiores aprofundamentos, consultar as referências bibliográficas no final deste estudo, bem como as já citadas obras de Carbonara e Kühl.

${ }^{305}$ Um dos principais representantes dessa linha teórica é Paolo Marconi, coordenador da citada Carta 1987. De modo geral, um dos pontos de conflito que gerou a redação de um novo documento, a questão da renovação das superfícies de certos monumentos, ilustra convenientemente a filiação teórica de Marconi. Marconi defendia o uso de técnicas tradicionais para refazer essas superfícies e acreditava que os preceitos da Carta 1972 não permitiam o emprego desse recurso. Para maiores detalhes, consultar: KÜHL, B. M., Preservação..., op. cit., pp.66-67; KÜHL, B. M. Arquitetura do ferro..., op. cit., pp.211-215.
} 
ou composição formal; valendo-se da interpretação histórico-crítica, o restauro buscará reinterpretar o monumento hoje, ou seja, observará atentamente a repercussão de ambas as instâncias na conformação de sua imagem atual e buscará os meios adequados para valorizá-la e transmiti-la ao futuro. Essa intervenção possui um caráter conservativo, porém, com a liberdade de propor recursos criativos quando necessário, desde que criteriosos. Na vertente 'crítico-conservativa' o método interpretativo baseia-se no respeito pelo monumento e busca o reconhecimento das especificidades que o qualificam como tal; vertente que julgamos a mais coerente, com base na exposição conceitual em curso, pois impulsiona a correta apreensão e estudo das especificidades dos monumentos como recurso prévio para a condução criteriosa e crítica das intervenções a serem realizadas, em qualquer escala. Método de especial relevância, notadamente frente à expansão dos artefatos de interesse cultural, cada qual possuidor de particularidades que suscitam análises meticulosas e soluções diferenciadas, como é o caso do patrimônio industrial.

Cabe ressaltar, no entanto, que a intervenção sobre um monumento, como ato histórico-crítico, jamais deve ser encarada como uma solução definitiva. Qualquer proposta consciente e criteriosa inevitavelmente carregará consigo os parâmetros culturais de sua época, certamente diversos daqueles a serem considerados no futuro. Tal fato não nos exime, contudo, da responsabilidade pela preservação dos bens culturais hoje. E justamente devido à pertinência relativa das soluções adotadas, toda discussão sobre a preservação e o restauro deve estar ancorada à realidade de cada época, assim como nutrir-se de amplos estudos que fundamentem com clareza as diretrizes seguidas em conformidade com a realidade cultural considerada. Nesse contexto de relativizações, as intervenções de restauro têm sido pautadas por três princípios hoje considerados fundamentais: a 'retrabalhabilidade', com o intuito de não impedir intervenções futuras; a distingüibilidade da ação contemporânea, ou seja, a evidenciação da intervenção para não se confundir com o preexistente e também para documentar-se a si própria; e a mínima intervenção, a inserção sobre o bem cultural de modo cuidadoso e respeitoso, tanto em relação ao documento histórico quanto em relação à imagem figurada da obra. ${ }^{306}$

Não obstante os distintos e por vezes antagônicos pontos de vista, cada uma das vertentes teóricas traz consigo a preocupação comum com a preservação dos valores patrimoniais dos monumentos considerados. Cabe ainda ressaltar que nos últimos anos tem

${ }^{306}$ KÜHL, B. M. Preservação..., op. cit., pp.70-72; KÜHL, B. M. Questões teóricas..., op. cit., p. 106. 
ocorrido uma retomada do diálogo entre as várias tendências. Essa aproximação busca discutir os temas pertinentes à preservação a partir dos diferentes pontos de vista, não com o intuito de trilhar um caminho único, mas sim de enriquecer o diálogo a partir da busca por pontos de contato entre as várias posturas e promover novos diálogos pautados na pluralidade de enunciações. Busca-se, ainda, com base nessas diferenciadas contribuições, o enfrentamento de uma série de problemas comuns a todos, como a questão do distanciamento entre teoria e prática, os problemas de formação acadêmica advindos de um excessivo tecnicismo ou a influência prejudicial dos fatores econômicos e políticos na preservação dos bens culturais. ${ }^{307}$ Cada uma das vertentes teóricas, na variedade de suas enunciações, permanece indubitavelmente nos domínios da cultura, ou seja, circunscrevem a preservação e a restauração como ações de caráter prioritariamente cultural. Longe de ser evidente, essa constatação deve sempre ser ressaltada no âmbito do presente estudo, pois as citadas influências econômicas - ou mesmo a formação precária de grande parte dos arquitetos - tem impulsionado, tanto no Brasil como no exterior, a realização de projetos de intervenção em bens culturais absolutamente desrespeitosos e desprovidos de qualquer fundamentação teórica válida. E o problema aumenta, como veremos, quando os bens considerados integram aqueles grupos de artefatos que passaram a ser valorizados recentemente, como é o caso dos edifícios e sítios históricos industriais. As formulações teóricas das vertentes citadas, portanto, como observa Kühl, "permitem que pelo menos se circunscreva e se defina o campo de ação de maneira adequada e fundamentada, separando-o daquilo que exorbita completamente dos objetivos da preservação; pois uma coisa é possuir uma pertinência relativa; outra, é ser de todo impertinente ao campo". 308

De posse de um representativo arsenal teórico - gradativamente amadurecido em décadas de profícuos debates e hoje suficientemente flexível para a interpretação de variadas realidades - , a preservação do patrimônio na contemporaneidade enfrenta desafios não muito dissonantes dos mesmos questionamentos que impulsionaram toda a formulação teórica do campo disciplinar: a priorização das demandas econômicas, técnicas e políticas; as lacunas pedagógicas ou mesmo a predileção por uma formação arquitetônica

\footnotetext{
${ }^{307}$ Um panorama das questões atuais e das aproximações recentes entre as variadas tendências é apresentado por: KÜHL, B. M. Preservação..., op. cit., pp.67-69. A autora cita duas importantes referências para o tema: o livro de Chiara Lumia que traz o resultado de colóquios realizados entre autores oriundos das diferentes vertentes: LUMIA, Chiara. A proposito del restauro e della conservazione. Colóquio com Amedeo Bellini, Salvatore Boscarino, Giovanni Carbonara e Paolo Torsello. Roma: Gangemi, 2003; e o artigo: MIARELLI MARIANI, Gaetano. I restauri di Pierre Prunet: un pretesto per parlare di architettura. Palladio, n.27, 2000, pp.65-67.

${ }^{308}$ KÜHL, B. M. Preservação..., op. cit., p.72.
} 
pautada em valores alheios aos bens culturais; e uma cômoda predisposição operativa acrítica que impulsiona o distanciamento entre o discurso e a prática.

\section{A APREENSÃO DO PATRIMÔNIO URBANO NO CONTEXTO BRASILEIRO}

No Brasil, as discussões sobre a preservação do patrimônio histórico e artístico começaram a ganhar fôlego a partir da década de 1920. Apesar de colher os frutos do discurso europeu, fato que observamos sobretudo na questão normativa, com a referência constante à legislação francesa e italiana, o contexto de desenvolvimento da temática em solo brasileiro foi bastante particular. Uma das peculiaridades do processo brasileiro foi a atuação decisiva de arquitetos e intelectuais vinculados ao movimento moderno na institucionalização da tutela de nossos bens culturais. Enquanto no contexto europeu, grande parte do debate da década de 1930 centrava-se nas controvérsias sobre o encontro antigo-novo, representada pela polêmica entre os arquitetos 'conservadores' - que defendiam a preservação documental da arquitetura e dos conjuntos urbanos - e os arquitetos adeptos da arquitetura do movimento moderno - a favor da inserção de novas estruturas em ambientes antigos -, no Brasil, foram os próprios arquitetos modernistas que impulsionaram a organização e a instituição do órgão federal voltado à preservação dos monumentos.

Os primeiros passos da preservação do patrimônio brasileiro foram motivados por um panorama cultural e político pautado pelo ideário nacionalista que objetivava buscar e moldar uma nova imagem para o país. ${ }^{309}$ No campo das artes, o desejo de desvelar as raízes do povo brasileiro esteve expresso nas manifestações das vanguardas artísticas; no campo político, a ordem vigente abraçava o nacionalismo como instrumento de fortalecimento do Estado e de impulso ao crescimento econômico.

Contando com significativa influência das vanguardas artísticas européias que então se inspiravam nas artes primitivas de outras civilizações e reagindo contra o que

\footnotetext{
${ }^{309}$ Sobre a trajetória da proteção aos bens culturais no Brasil, consultar: FONSECA, Maria Cecília Londres. O patrimônio em processo: trajetória da política federal de preservação no Brasil. Rio de Janeiro: UFRJ/Minc/IPHAN, 2005; ANDRADE, Antonio Luiz Dias de. Um estado completo que pode jamais ter existido. Tese de Doutorado. São Paulo: FAUUSP, 1993; ANDRADE, Rodrigo Melo Franco de. Brasil: monumentos históricos e arqueológicos. México: Instituto Pan-americano de Geografia e História, 1952.
} 
entendiam como academicismo, ou mesmo contra o excesso de referências ao passado no processo criativo, certos intelectuais e artistas brasileiros lançaram-se à identificação e valorização das expressões artísticas consideradas genuinamente brasileiras. Nesse processo, se por um lado a retomada de expressões consideradas 'autênticas' cultivou a resistência ao passado de influência européia e o menosprezo às obras oriundas dessa relação - como a arquitetura eclética e grande parte da produção artística do século XIX e início do século XX; por outro, a nova abordagem abriu caminho para a retomada de artefatos e expressões artísticas nacionais pouco estudadas e permitiu, ainda que dentro dos recortes então estabelecidos, o reconhecimento de especificidades formais e técnicas que nos eram próprias. Na busca por uma identidade nacional, "o voltar as costas a um passado europeu e academicista fez perceber uma manifestação artística autêntica que, mesmo se permeada de influências externas, nos era peculiar". ${ }^{310}$ Essas expressões redescobertas e reinterpretadas passam a ser valorizadas como elementos norteadores da identidade artística e cultural que se buscava. O nosso primeiro conceito de patrimônio histórico e artístico nacional, portanto, nasceu no bojo dessa busca identitária, precisamente recortada, e reuniu os artefatos então considerados apropriados para a formulação dessa imagem. Enquanto na Europa os artistas buscaram inspiração para o novo nas artes primitivas de outras nações, no Brasil, a redescoberta de nossas próprias raízes culturais é que impulsionou uma nova atividade artística; daí as expressões artísticas lançadas com a Semana de 22, daí a presença marcante dos modernistas no processo de institucionalização da tutela federal desse patrimônio. Como observa Fonseca, foram "os mesmos intelectuais que se voltaram, simultaneamente, para a criação de uma nova linguagem estética - no sentido de ruptura com o passado - e para a construção de uma tradição - no sentido de buscar a continuidade". ${ }^{311}$ Duas faces aparentemente paradoxais, porém complementares no processo de gestação e desenvolvimento da expressão modernista em solo brasileiro.

Apesar de iniciativas isoladas anteriores à 1920, somente a partir desta data as discussões em favor da preservação dos monumentos históricos e artísticos brasileiros começaram a despontar com maior determinação, representadas principalmente pela elaboração de propostas e projetos de lei voltados a este fim. Essas propostas pioneiras bem como a própria efetivação do serviço federal de proteção com a promulgação do Decreto-Lei 25, em 1937 -, pautavam-se pela emergência do citado ideário nacionalista

\footnotetext{
${ }^{310}$ KÜHL, B. M. Arquitetura do ferro..., op. cit., p.202.

${ }^{311}$ FONSECA, M. C. L., op. cit., p.92.
} 
que buscava desvendar ou 'moldar' uma identidade genuinamente brasileira. Dentre os projetos pioneiros não implementados, merecem destaque para o enfoques da presente pesquisa as propostas de Jair Lins e de José Wanderley de Araújo Pinho. Ambos os projetos representaram uma importante referência para o prosseguimento das propostas e algumas de suas enunciações compareceriam com poucas alterações na elaboração final do Decreto-Lei 25 , até hoje em vigor. ${ }^{312}$ Com base na legislação estrangeira, o anteprojeto de lei federal elaborado por Jair Lins, datado de 1925, além de preocupar-se em argumentar a favor da intervenção do Estado na propriedade privada, principal entrave das propostas anteriores, enunciou certos temas que compareceriam na legislação futura, como a catalogação dos artefatos em livros especiais, o impedimento de demolição sem autorização legal e até mesmo uma versão primitiva da defesa da visibilidade do bem protegido, ainda que a área de influência se limitasse a 1,5m. Já no projeto de Wanderley Pinho, datado de 1930, merece destaque a definição de patrimônio que abarcava, dentre "as coisas móveis e imóveis a que deva estender a proteção do Estado, em razão de seu valor artístico, de sua significação histórica ou de sua peculiar e notável beleza", além dos monumentos de excepcional relevância, obras de arte e elementos arquitetônicos, também "os imóveis isolados ou em conjunto, os sítios de reconhecida e peculiar beleza, cuja proteção e conservação sejam necessárias para manter-lhes o aspecto típico-artístico catalogado". Observa-se, portanto, a preocupação com a manutenção da ambiência do bem protegido; prevendo-se, inclusive, a possibilidade de intervir nessas áreas de entorno, tanto para conservar quanto para eliminar estruturas, conforme fosse conveniente "à conservação, luz, perspectiva e moldura do imóvel catalogado". ${ }^{313}$ Com a revolução e a dissolução do congresso, a tramitação de tais propostas foi interrompida. É inegável, no entanto, sua influência na consolidação de diretrizes e no documento final de 1937.

Ainda antes de alcançar-se no Brasil uma organização legislativa voltada à tutela, e no contexto da dimensão conceitual associada ao termo 'patrimônio', cabe ainda mencionar o decreto presidencial datado de 1933 que declarou a cidade de Ouro Preto como Monumento Nacional. Nessa data, poderíamos indagar se a delimitação de toda uma estrutura urbana como patrimônio monumental não seria um ato pioneiro em relação à preservação urbana, inclusive em termos internacionais. Mas não foi bem assim. Não há

\footnotetext{
${ }^{312}$ ANDRADE, Antonio L. D. de., op. cit., pp.107-108.

${ }^{313}$ PINHO, José Wanderley de Araújo. Projeto de lei n. 230 de 1930, apud ANDRADE, A. L. D. de., op. cit., p.108; SANT'ANNA, M., op. cit., p.87. Segundo Sant'Anna, a íntegra do projeto pode ser consultada no Arquivo Central do IPHAN, Pasta n.1, sob o título 'Legislação'.
} 
motivos para crer que, em 1933, a elevação da cidade tenha se baseado na compreensão dos valores patrimoniais do conjunto urbano como monumento coletivo, considerando o conjunto de seus atributos históricos, estéticos, memoriais, simbólicos, etc. Como vimos, apesar das valiosas contribuições de Giovannoni, o amadurecimento de tal conceito remonta aos debates do segundo pós-guerra e encontraria termo somente entre as décadas de 1940 e 1960. Até mesmo na Carta de Atenas de 1931, redigida pelo próprio Giovannoni e elaborada em congresso internacional no qual a questão dos conjuntos urbanos chegou a ser abordada com grande abrangência, a noção de patrimônio considerada não chegou a abarcar as especificidades do organismo urbano como artefato autônomo ${ }^{314}$. No cenário brasileiro, não seria diferente. O conteúdo do decreto, portanto, possuía razões de cunho ideológico e buscava firmar certos marcos históricos que auxiliavam na definição daquela nacionalidade que se procurava configurar. No contexto de moldagem de uma identidade nacional, Ouro Preto e posteriormente outras cidades históricas mineiras, assumem o papel de espaços simbólicos "por meio dos quais uma narrativa histórico-política e cultural ou artística ganha coerência e autenticidade"; 315 logo, os objetos, lugares e casas adquiriram representatividade mais como suportes para a significação de personagens e acontecimentos históricos do que pelas suas próprias especificidades como artefato urbano. O texto do decreto esclarece esse objetivo ao justificar que "fazem parte das tradições de um povo os lugares em que se realizaram os grandes feitos de sua história”, como a cidade de Ouro Preto, "teatro de acontecimentos de alto relevo histórico na formação de nossa nacionalidade". ${ }^{316}$ Ademais, como observa Sant'Anna, a elevação da cidade a monumento nacional não impulsionou iniciativas significativas para garantir a sua efetiva preservação. $^{317}$

Anos mais tarde, com as alterações no cenário político e a promulgação das Constituições de 1934 e 1937, caminha-se em direção à reorganização legislativa que

\footnotetext{
${ }^{314}$ Carta de Restauro de Atenas, 1931. In: Cartas Patrimoniais..., op. cit., p. 14. A menção à proteção de conjuntos urbanos surge no item III, ainda vinculada à idéia de ambiência de monumentos excepcionais. "A conferência recomenda respeitar, na construção dos edifícios, o caráter e a fisionomia das cidades, sobretudo na vizinhança dos monumentos antigos, cuja proximidade deve ser objeto de cuidados especiais. Em certos conjuntos, algumas perspectivas particularmente pitorescas devem ser preservadas."

${ }^{315}$ GONÇALVES, José Reginaldo Santos. A retórica da perda. Rio de Janeiro: UFRJ/MinC/IPHAN, 2002, p. 118

316 BRASIL. Decreto n. 22.928, de 12 de julho de 1933. Erige a cidade de Ouro Preto em Monumento Nacional, apud GONÇALVES, J. R. S. op. cit., pp.118-119.

${ }^{317}$ SANT'ANNA, M., op. cit., pp.122-123.
} 
respaldaria a oficialização da proteção dos monumentos. ${ }^{318}$ Nesse sentido, em 1937 foi promulgado o Decreto-lei 25 e criado o SPHAN, Serviço do Patrimônio Histórico e Artístico Nacional. Elaborado por Rodrigo Melo Franco de Andrade, o Decreto-lei 25 baseou-se em propostas anteriores, como aquelas de Lins e Pinho, bem como no anteprojeto elaborado em 1936 por Mário de Andrade ${ }^{319}$. No texto definitivo do decreto-lei atentou-se para os meios legais que garantiriam a atuação do órgão federal de preservação, principalmente no sentido de depurar as questões envolvidas com o direito de propriedade, assim como desonerar o Estado na tutela do patrimônio histórico, seja desvinculando o tombamento da desapropriação do bem, seja atribuindo ao proprietário a responsabilidade pela sua conservação, como já se observava na legislação européia.

O texto do Decreto-lei 25, ao traduzir as idéias pioneiras da preservação baseadas na formulação de uma identidade nacional, privilegia as obras consideradas notáveis, vinculadas a "fatos memoráveis da história do Brasil"; fatos esses prioritariamente cenografados, como demonstrariam os critérios de seleção do então criado SPHAN, pela produção artística e arquitetônica dos séculos XVI a XVIII. O documento também contempla a preocupação com a manutenção de sítios e paisagens, naturais ou criadas pelo homem (contexto no qual se inserem os conjuntos urbanos), porém vinculando sua valorização à notabilidade ou excepcionalidade.

Art. 1. Constitui o patrimônio histórico e artístico nacional o conjunto de bens móveis e imóveis existentes no país e cuja conservação seja de interesse público, quer por sua vinculação a fatos memoráveis da história do Brasil, quer por seu excepcional valor arqueológico ou etnográfico, bibliográfico ou artístico [...].

\footnotetext{
${ }^{318}$ No governo Vargas e no Estado Novo, a idéia de construção da nacionalidade a partir do reconhecimento de uma produção cultural autêntica seria definitivamente encampada pelo discurso político oficial. Na Constituição de 1934 atribui-se ao Estado a função de "proteger os objetos de interesse histórico e o patrimônio artístico do país", e o direito de propriedade é reinterpretado em consonância com o interesse social e coletivo. Já na Constituição de 1937, instaurada após o golpe que instituiu o Estado Novo destacamos a inserção da proteção das belezas naturais e dos monumentos dentre as incumbências do Estado, e a imposição de sanções aos contraventores, disposição corroborada pelo Código Penal de 1940.

${ }^{319}$ Sobre o anteprojeto de Mário de Andrade, do qual pouco permaneceu na redação final do Decreto-lei, costuma-se discutir a amplitude do conceito de patrimônio, que abarcaria - a partir de uma ampla noção de 'arte' - , uma série de artefatos e manifestações culturais, populares e eruditas, dentre os elementos merecedores de proteção (porém, de acordo com os recortes temporais e ideológicos vigentes). Poucas enunciações do anteprojeto de 1936, no entanto, foram incorporadas ao texto definitivo do Decreto-lei, dentre elas podemos citar o uso do termo 'tombamento' e a nomenclatura sugerida para os Livros do Tombo. Cf.: ANDRADE, Mário de. Anteprojeto para criação do Serviço do Patrimônio Artístico Nacional [1936]. In: CAVALCANTI, Lauro (Org.). Modernistas na repartição. Rio de Janeiro: UFRJ/Minc/IPHAN, 2000, pp. 37-52.
} 
$\S 2^{\circ}$ Equiparam-se aos bens a que se refere o presente artigo e são também sujeitos a tombamento os monumentos naturais, bem como os sítios e paisagens que importe conservar e proteger pela feição notável com que tenham sido dotados pela natureza ou agenciados pela indústria humana. ${ }^{320}$

A questão do entorno dos bens tombados é tratada pelo Artigo 18 do Decreto-lei cuja redação permitiu estender certas disposições restritivas para além do bem oficialmente protegido. Esse artigo é particularmente importante pois abriu caminho para a gradativa apreensão do valor patrimonial associado às relações entre monumento e ambiente e contribuiu, no decorrer da atuação do órgão, para consolidar a idéia de tutelar-se certos contextos urbanos não necessariamente 'exemplares' (portando não classificáveis, num primeiro momento, como sítios ou paisagens de interesse patrimonial conforme as disposições do parágrafo $2^{\circ}$ do Artigo $1^{\circ}$ ), porém possuidores de características próprias que lhes conferiam a particular autonomia compositiva.

Sem prévia autorização do Serviço do Patrimônio Histórico e Artístico Nacional, não se poderá, na vizinhança da coisa tombada, fazer construção que lhe impeça ou reduza a visibilidade, nem nela colocar anúncios ou cartazes, sob pena de ser mandada destruir a obra ou retirar o objeto, impondo-se nesse caso multa de cinqüenta por cento do valor do mesmo objeto. ${ }^{321}$

As disposições do Artigo 18, no entanto, geraram grandes controvérsias, principalmente devido ao emprego de termos pouco precisos como 'visibilidade' e 'vizinhança', às lacunas legais quanto aos critérios de avaliação a serem empregados e à conseqüente falta de clareza das análises caso a caso empreendidas pelo órgão. A questão gerou muita discórdia e diversas contestações, inclusive judiciais, principalmente devido às limitações do direito de construir em determinadas áreas ${ }^{322}$. Essas e outras questões em torno da preservação de áreas urbanas impulsionaram a discussão sobre a pertinência de se elaborar regulamentações específicas para esclarecer pontos conflitantes do Decreto-lei.

\footnotetext{
${ }^{320}$ BRASIL. Decreto-lei n. 25, de 30 de novembro e 1937. Organiza a proteção do patrimônio histórico e artístico nacional.

${ }^{321}$ BRASIL. Decreto-lei n.25, op. cit.

${ }^{322}$ Por força da jurisprudência firmada em vários casos judiciais, prevalece, de modo geral, a seguinte conceituação para a 'visibilidade': "O conceito de visibilidade para fins da Lei de Tombamento, é amplo, alcançando não só a retirada da vista da coisa tombada, como a modificação do ambiente ou da paisagem adjacente, a diferença de estilos arquitetônicos, e tudo o mais que contraste ou afronte a harmonia do conjunto, tirando o valor histórico ou a beleza original da obra protegida." MEIRELLES, Hely Lopes. Direito administrativo brasileiro. São Paulo: Ed. Revista dos Tribunais, 1977, p.534 apud SANT'ANNA, op. cit., p.99.
} 
Diversas propostas foram elaboradas e discutidas entre 1940 e o início dos anos 1980 sem contudo efetivar-se qualquer alteração ou complementação da legislação vigente.

A observação de certas diretrizes propostas, no entanto, permite-nos constatar a atualidade dos temas abordados e a competência argumentativa com que foram expostos, mostrando que muitos estudiosos brasileiros acompanhavam a discussão internacional e buscavam atualizar o debate e implementá-lo na prática legal. No que concerne à preservação urbana, as propostas de regulamentação ou complementação tocaram em pontos cruciais que vinham sendo amplamente discutidos em âmbito internacional. Nesse sentido, cabe destacar a proposta de Prudente de Moraes Neto, que em 1940 já indicava a necessidade de prever, paralelamente ao tombamento de áreas urbanas, a execução de planos complementares de desenvolvimento urbanístico; ${ }^{323}$ a proposta de Rômulo Almeida, de 1959, que buscava alternativas econômicas para viabilizar a preservação de conjuntos urbanos e promover atividades auto-sustentáveis com a participação de parcerias entre o setor público e o privado; ${ }^{324}$ e ainda a contribuição de Paulo Armindo de Azevedo que propôs, em 1973, a criação dos 'Setores Monumentais e Paisagísticos', com base nas diretrizes propostas pela Lei Malraux e na abordagem das questões de caráter social e econômico associadas à preservação urbana, além daquelas formais, em concomitância com a caracterização multidisciplinar que o tema assumiria a partir da década de 1970, em âmbito internacional. ${ }^{325}$

Quanto às intervenções de preservação e restauração empreendidas pelo SPHAN até aproximadamente meados da década de 1970 - sejam em monumentos isolados, sejam em áreas urbanas - , observamos uma postura de certo distanciamento com relação ao atendimento de preceitos há muito arraigados no contexto internacional, a exemplo dos princípios acordados na Carta de Restauro de Atenas de 1931. Em muitas intervenções de restauro conduzidas pelo órgão, desconsiderou-se as diversas estratificações históricas dos monumentos e dos conjuntos urbanos, propondo, por vezes, a recondução da obra ao seu estado original; estado geralmente hipotético pois o próprio conhecimento historiográfico

\footnotetext{
${ }^{323}$ Proposta de decreto de regulamentação do decreto-lei n. 25/37, elaborada pelo advogado Prudente de Moraes Neto em 1940. SANT'ANNA, M. op. cit., pp.100-102.

324 Proposta de lei federal estabelecendo condições especiais de financiamento para conservação e restauração de monumentos e conjuntos urbanos, elaborada pelo economista Rômulo Almeida em 1959. SANT'ANNA, M., op. cit., 106.

${ }^{325}$ Proposta para complementação legislativa apresentada por Paulo Armindo de Azevedo. AZEVEDO, P. A. Contribuição à criação de uma legislação específica para Setores Monumentais e Paisagísticos. In: Anais do II Encontro de Governadores. Rio de Janeiro: MEC, 1973, apud SANT'ANNA, M., op. cit., p.112.
} 
da arquitetura e do urbanismo brasileiro era bastante incipiente. ${ }^{326}$ Outros fatores agravavam esse quadro: a inexistência de um debate mais amplo com relação às soluções adotadas - a cargo de um grupo restrito de profissionais -, a completa ausência de participação popular e a escassa oferta de profissionais habilitados em restaurações, o que se traduziu, em grande medida, na realização de obras praticamente empíricas. ${ }^{327}$

No que concerne aos conjuntos urbanos históricos, as intervenções realizadas pelo órgão nessa primeira fase evidenciam uma resposta operacional aos parâmetros estabelecidos para a delimitação do patrimônio nacional: a preservação de uma tradição eleita e a promoção da criação moderna, ambas produções consideradas genuinamente brasileiras. Nesse sentido, por vezes prevalecia a influência da Carta de Atenas dos CIAM com a inserção de criações contemporâneas e grandiosas em ambientes preexistentes sem gerar maiores discussões sobre os efeitos provocados, ou mesmo, com a demolição indiscriminada de áreas urbanas consolidadas que não correspondiam à visão urbanística da época, inclusive cercanias de importantes monumentos. ${ }^{328} \mathrm{Em}$ outras ocasiões, quando necessário construir novos edifícios nos espaços ainda livres, sugeria-se que os mesmos seguissem o 'espírito' dos antigos; e nas restaurações, a busca pela restituição de um suposto estado primitivo era traduzida pela neutralização ou eliminação de quaisquer elementos considerados estranhos ao recorte de tradição arquitetônica cultuado; isto é, eram "eliminadas platibandas, frontões, esquadrias ou elementos decorativos de gosto eclético e reconstruídos beirais, cimalhas e outros elementos típicos do período colonial". ${ }^{329}$ Em vários processos de tombamento, indicava-se áreas de expansão urbana fora do núcleo protegido. Esse território externo era considerado 'livre', não recebia nenhuma restrição construtiva; solução que, a curto prazo, provocava o afastamento de qualquer discussão sobre o encontro antigo-novo, tema de fervorosas e profícuas polêmicas

\footnotetext{
326 Sobre as questões envolvidas nas obras de restauro conduzidas pelo SPHAN em sua fase pioneira, consultar: ANDRADE, Antonio Luiz Dias de., op. cit., pp.119-153.

${ }^{327}$ KÜHL, B. M. Preservação..., op. cit., p.75.

${ }^{328}$ De modo geral, as edificações novas de maior porte inseridas em núcleos históricos deveriam expressar a linguagem da "boa arquitetura". SANT'ANNA, M., op. cit., p.135; Sobre as demolições, Antonio Luiz Dias de Andrade destaca o caso da Igreja de Nossa Senhora da Glória do Outeiro, no Rio e Janeiro, da Igreja de São Francisco de Assis, em Ouro Preto, bem como dos monumentos do centro histórico de Recife, "casos nos quais o SPHAN procurou liberar os monumentos das construções que amesquinhavam a sua dignidade." ANDRADE, A. L. D. de., op, cit., p.118.

${ }^{329}$ SANT'ANNA, M., op. cit., pp.132-133,136. A autora cita o caso das diretrizes propostas para novas construções em Diamantina, que “deveriam seguir o mesmo 'espírito' das antigas, ou seja, tirar partido da utilização dos materiais característicos da região e do sistema construtivo tradicional, sem, entretanto, "copiar estilo"”; e ainda o caso de Parati, onde um decreto de 1947 estabelecia que nenhuma nova construção seria autorizada na cidade "sem que as respectivas características se [ajustassem] às das antigas edificações próximas ao terreno a que se destina".
} 
no contexto internacional; e, a longo prazo, alimentava a criação de verdadeiras barreiras entre a cidade histórica e a cidade nova - privando o fragmento antigo do contato dinâmico com a cidade contemporânea; e privando a parcela nova do diálogo cotidiano com sua própria história.

Esses procedimentos, aparentemente pouco criteriosos, provavelmente deviam-se à ausência de uma linha diretiva clara na atuação de um órgão novo, que inaugurava uma prática nova e com base em prerrogativas conceituais imbuídas de grandes antagonismos. E que enfrentava, nesses primeiros passos, grandes lacunas técnicas, profissionais, metodológicas e, principalmente, teóricas. O distanciamento para com o discurso teórico internacional devia-se mais à uma opção ideológica (haja vista as contradições conceituais advindas do pensamento modernista na 'invenção' do patrimônio, como vimos) do que propriamente por desconhecimento. Os princípios da Carta de Atenas de 1931 eram conhecidos, conforme os escritos de Lúcio Costa e de Rodrigo M. F. de Andrade nos esclarecem $^{330}$, mas o embate com os desafios práticos acabou por consolidar uma postura diferenciada, baseada na busca por um passado idealizado e na implementação dessas heranças na restauração e na criação. Diante dessa postura diferenciada e da ausência de critérios claros a seguir, Lúcio Costa assumiu a responsabilidade de conduzir as decisões técnicas e de cunhar métodos que progressivamente instituíram uma espécie de corpo doutrinário suficientemente flexível para abarcar os citados antagonismos teóricos. Apesar de Lúcio Costa não possuir escritos sobre a atuação específica em áreas urbanas, acreditase que grande parte das decisões tomadas passavam pelo seu crivo, tanto relativas à definição de critérios para o tombamento, quanto às soluções de intervenção levadas a cabo pelo SPHAN. Em texto de Rodrigo M. F. de Andrade sobre a conservação de conjuntos urbanos $^{331}$, baseado na experiência prática adquirida e sem dúvida na influência diretiva de Lúcio Costa, fica claro o reconhecimento das especificidades patrimoniais das áreas urbanas históricas, assim como a percepção da necessidade de serem desenvolvidos meios legais específicos para a sua proteção - diferenciados daqueles empregados em edifícios isolados -, e integrados aos mecanismos de planejamento urbano. Não obstante as práticas de certa forma 'repristinatórias' empreendidas em ambientes urbanos, no seio da atuação do órgão frutificavam importantes elaborações conceituais que paulatinamente vinham

\footnotetext{
${ }^{330}$ Segundo trechos de autoria de ambos os autores citados em: ANDRADE, A. L. D. de, op. cit., p.121.

331 ANDRADE, R. M. F. de. Conservação de Conjuntos Urbanos. In: ANDRADE, R. M. F. de. Rodrigo e o SPHAN: coletânea de textos sobre o patrimônio cultural. Rio de Janeiro: MinC/FNPM, 1987, apud SANT'ANNA, M., op. cit., p.137.
} 
sendo formuladas frente aos desafios operacionais enfrentados, no contato direto com os artefatos históricos. Nesse sentido, cabe ainda ressaltar outro texto de Rodrigo M. F. de Andrade, de 1941, no qual o autor esclarece os critérios adotados para o tombamento da cidade de Diamantina. Observamos com nitidez a percepção do organismo urbano como artefato autônomo (e não como somatória de edifícios excepcionais), aludindo, inclusive, às imaterialidades que concorrem para a configuração do tecido histórico.

O que se constitui monumento, pelo seu excepcional valor histórico e artístico, nos aludidos casos, não é nenhum dos edifícios considerados em si mesmo, isoladamente, mas a sua coexistência, a sua conservação em conjunto, formando um todo que, por isso mesmo, assume feição urbanística e arquitetônica de valor inestimável, tanto do ponto de vista puramente histórico, como do histórico-artístico. É esse conjunto que importa preservar, no seu todo, pois empresta às cidades, que ainda apresentam essa documentação viva da sua formação e desenvolvimento originários, a sua fisionomia particular. É, portanto, esse conjunto (bem imaterial, que é de toda a cidade sem pertencer particularmente a quem quer que seja) o objeto de tombamento, o monumento incorporado ao patrimônio histórico e artístico nacional. Não é isso o mesmo que uma série de tombamentos especiais, de bens individualizados, cada um isoladamente considerados. ${ }^{332}$

Com relação ao recorte histórico cultuado pelo SPHAN, é inegável a sua repercussão e consolidação, na sociedade, de uma idéia de patrimônio e memória associada a certos panoramas e imagens históricas eleitas, em detrimento de outras, obscurecidas. Esse recorte temporal relegou ao esquecimento (e à destruição) grande parte das manifestações arquitetônicas e urbanas datadas ou transformadas a partir da segunda metade do século XIX (com exceção do Neoclassicismo e das obras do movimento moderno), e só muito recentemente o conceito de patrimônio cultural adotado pelo órgão tem se expandido para artefatos não contemplados pelo conceito firmado na década de 1930. Essa visão recortada do que se entendia como patrimônio nacional, desde cedo reservou ao Estado de São Paulo uma posição bastante desconfortável no cenário das 'representatividades' nacionais. O próprio Mário de Andrade, então Diretor do Departamento de Cultura do Município de São Paulo e defensor de um entendimento mais amplo dos conceitos de 'arte' e 'patrimônio', afirmara que os critérios de tombamento em terras paulistas só poderiam pautar-se pelo viés histórico.

\footnotetext{
${ }^{332}$ Esclarecimento redigido por Rodrigo M. F. de Andrade em 17/09/1941 sobre os critérios adotados pelo SPHAN no tombamento de Diamantina (grifo do autor), apud SANT 'ANNA, M., op. cit., p.138. Esse documento está anexado ao processo de tombamento da cidade de Diamantina (processo n. 64-T-38).
} 
Vagar assim, pelos mil caminhos de São Paulo, em busca de grandezas passadas é trabalho de fome e de muita, muita amargura. Procura-se demais e encontra-se quase nada. Vai subindo no ser uma ambição de achar, uma esperança de descobrimentos admiráveis [...] E encontramos ruínas, tosquidões. [...]

O critério para um trabalho proveitoso de defesa e tombamento do que o passado nos legou tem de se pautar, no estado de São Paulo, quase exclusivamente pelo ângulo histórico. No período que deixou no Brasil as nossas mais belas grandezas coloniais, os séculos XVIII e XIX até fins do Império, São Paulo estava abatido, ou ainda desensarado dos reveses que sofrera. Não pôde criar monumentos de arte. [...]

$\mathrm{O}$ critério tem que ser outro. Tem de ser histórico e, em vez de se preocupar muito com a beleza, há de reverenciar e defender especialmente as capelinhas toscas, as velhices dum tempo de luta e os restos de um luxo esburacado que o acaso se esqueceu de destruir. ${ }^{333}$

E não poderia ser diferente. Nessa data, a idéia de monumento ainda associava-se, em grande parte, aos fatos considerados notáveis; e o conceito de patrimônio urbano também não alcançara a maturidade necessária para abarcar conjuntos arquitetônicos com especificidades e cotidianidades distintas daquelas conhecidas pelos cânones estabelecidos, estranhas ao recorte histórico que então vigorava. Hoje, no entanto, considerando o panorama contemporâneo de expansão do conceito de patrimônio cultural e a consequiente complexidade envolvida na preservação de artefatos recentemente valorizados - como são as arquiteturas e os sítios industriais paulistas e paulistanos -, a avaliação dos artefatos a partir de uma ampla perspectiva, multidisciplinar e integradora, deveria ser evidente e imprescindível. Diante da inegável representatividade da industrialização paulista para a história cultural do país, seria esperado que os diferentes níveis administrativos voltados à tutela (federal, estadual e municipal), buscassem esforços conjuntos para a valorização e preservação desse patrimônio. Na esfera federal, contudo, exemplares do patrimônio industrial, novas 'tosquidões' paulistas, ainda não têm recebido muita atenção, remetendonos à indagação sobre a permanência de certos vícios interpretativos na atuação contemporânea do órgão. ${ }^{334}$

\footnotetext{
333 ANDRADE, Mário de. A capela de Santo Antonio [1937]. In: CAVAlCANTI, Lauro (Org.). Modernistas..., op. cit., pp.25-26.

${ }^{334}$ No Estado de São Paulo, usufruem proteção federal os remanescentes da Real Fábrica de Ferro São João de Ipanema (Iperó - SP), sítio industrial que remonta à 1818, tombado em 1964 (Livro Histórico, processo $\mathrm{n}$. 0727-T-64) e as ruínas do Engenho dos Erasmos (Santos - SP), datado da primeira metade do século XVI e considerada a primeira tentativa oficial de exploração açucareira no Brasil, tombado em 1963 (Livro Histórico, processo n. 0678-T-62), ambos exemplares industriais que remontam ao período histórico enfocado pelo SPHAN. Em outros Estados (Paraíba, Bahia, Maranhão, Minas Gerais), há edifícios e sítios tombados (fábricas e engenhos), em geral datados do período histórico citado (século XVI a, no máximo, final do século XIX). A produção industrial paulista, portanto, não está representada. Dados extraídos do site do IPHAN (Base de dados do Arquivo Noronha Santos).
} 
A partir da década de 1970, as experiências iniciais do SPHAN começaram a ser reavaliadas. Questionou-se, então, tanto os critérios de seleção adotados que desprezavam grande parte da produção artística dos séculos XIX e início do século XX, quanto as posturas de intervenção que priorizavam uma dada leitura da obra e desconsideravam aspectos de sua passagem pela história. A abertura dessa abordagem crítica demarca a busca pelo amadurecimento teórico do tema, a consolidação de um conceito de patrimônio cultural mais abrangente e a conseqüente convergência em direção aos princípios debatidos internacionalmente e incorporados à Carta de Veneza. ${ }^{335}$

Esse período de reavaliação foi ainda impulsionado por um complexo panorama de transformações econômicas e sociais advindas de um modelo de desenvolvimento nacional baseado na modernização e urbanização aceleradas. O cenário das décadas de 1960 e 1970, portanto, na complexidade dos processos desencadeados (abruptas rupturas com a continuidade histórica, migração intensa para as capitais, crescimento urbano acelerado e conseqüente valorização do solo das cidades) ${ }^{336}$, acabou por promover a busca de novas estratégias, a revisão de conceitos e a formulação de novas formas de enfrentamento para a questão da preservação urbana com o intuito de garantir a salvaguarda dos agrupamentos ameaçados pela nova dinâmica de desenvolvimento. Apenas o apelo ao interesse público na preservação de valores culturais não era mais suficiente. Somam-se ao discurso preservacionista, portanto, novas estratégias que buscam alinhavar valor cultural e valor econômico, como a promoção do potencial turístico e a tentativa de atribuir à valorização cultural um papel orientador para um desenvolvimento adequado; abordagens, inclusive, recomendadas pelos documentos elaborados em eventos que buscaram discutir a problemática do crescimento urbano acelerado, principalmente em cidades históricas de países em desenvolvimento: as Normas de Quito (1967), o Compromisso de Brasília (1970) e o Compromisso de Salvador (1971). ${ }^{337}$ Essas discussões levariam à criação do Programa Integrado de Reconstrução das Cidades Históricas (PCH), em 1973, e do Centro Nacional de Referência Cultural (CNRC), em 1975. O primeiro, voltado a facilitar a reunião de recursos financeiros provenientes de diversos agentes

\footnotetext{
${ }^{335}$ KÜHL, B. M., Preservação..., op. cit., p.83.

${ }^{336}$ FONSECA, M. C. L., O patrimônio..., op. cit., p.141.

${ }^{337}$ Normas de Quito: Reunião sobre conservação e utilização de monumentos e sítios de interesse histórico e artístico. OEA, 1967; Compromisso de Brasília: I Encontro dos governadores de Estado, secretários estaduais da área cultural, prefeitos de municípios interessados, presidentes e representantes de instituições culturais, 1970; Compromisso de Salvador: II Encontro de governadores para a preservação do patrimônio histórico, artístico, arqueológico e natural do Brasil, Ministério da Educação e Cultura, IPHAN, 1971. Cartas Patrimoniais..., op. cit., pp.105-122,137-146.
} 
públicos para subsidiar as ações de implementação e desenvolvimento de atividades turísticas; o segundo, voltado à pesquisa e atualização do debate sobre a concepção de cultura brasileira na contemporaneidade, articulando-a aos novos parâmetros de desenvolvimento. ${ }^{338}$ Os novos debates advindos dessas iniciativas demarcam a apreensão, em solo brasileiro, da expansão da idéia de patrimônio cultural. Ao longo da década de 1970, portanto, o antigo conceito de patrimônio histórico-artístico exemplar, de monumento como símbolo da nação, gradativamente cede espaço para a consolidação de um conceito mais amplo de patrimônio que ultrapassa classificações estanques: abre-se caminho para a apreensão da dimensão cultural de variados artefatos, assim como para a compreensão de seus complexos vínculos com a realidade social, econômica e política. A nova abordagem que se consolidava, permitia agora a visualização de novos cenários patrimoniais e a valorização de diversificadas manifestações culturais, materiais e imateriais, que em tese poderiam usufruir a atenção preservacionista. Aspectos finalmente encampados pela Constituição de 1988:

Art. 216. Constituem patrimônio cultural brasileiro os bens de natureza material e imaterial, tomados individualmente ou em conjunto, portadores de referência à identidade, à ação, à memória dos diferentes grupos formadores da sociedade brasileira, nos quais se incluem: I - as formas de expressão; II - os modos de criar, fazer e viver; III - as criações científicas, artísticas e tecnológicas; IV - as obras, objetos, documentos, edificações e demais espaços destinados às manifestações artístico-culturais; V - os conjuntos urbanos e sítios de valor histórico, paisagístico, artístico, arqueológico, paleontológico, ecológico e científico. ${ }^{339}$

O alargamento do conceito de bem cultural e a abertura de novos caminhos interpretativos para a seleção de tombamentos e a ação prática de tutela promoveria também a descentralização da preservação e a criação, em diversos estados e municípios, de órgãos e normativas regionais e municipais para a proteção do patrimônio cultural. A esses órgãos cabe a tutela de bens considerados representativos em âmbito local; e ao IPHAN (antigo SPHAN) cabe a tutela de bens representativos para toda a nação. No Estado de São Paulo foi criado, em 1968, o Conselho de Defesa do Patrimônio Histórico, Arqueológico, Artístico e Turístico (CONDEPHAAT); e no município de São Paulo foram

\footnotetext{
338 FONSECA, M. C. L., op. cit., p.144,154. Em 1979 ocorre a fusão IPHAN/PCH/CNRC. Conforme observa Fonseca, reuniram-se "numa só instituição, os recursos e o know-how gerencial do PCH, o prestígio e a competência técnica do IPHAN e a visão moderna e renovadora do CNRC."

${ }^{339}$ BRASIL. Constituição da República Federativa do Brasil de 1988.
} 
criados, em 1975, o Departamento do Patrimônio Histórico da Prefeitura Municipal de São Paulo (DPH-PMSP) e, entre 1985 e 1986, o Conselho de Preservação de São Paulo (CONPRESP).

Ambos os órgãos, estadual e municipal, têm se voltado à questão da preservação urbana e à valorização das especificidades e urbanidades responsáveis pela configuração de certos conjuntos construídos, contexto no qual poderíamos inferir a promoção da tutela e da reabilitação de sítios industriais significativos. Em âmbito estadual, além da preocupação com o entorno de bens tombados a partir da aplicação de restrições de uso e ocupação do solo nas áreas envoltórias ${ }^{340}$, busca-se ainda preservar áreas urbanas inteiras por meio de tombamento de bairros e partes de cidades. Algumas iniciativas nesse sentido têm sido implementadas, a exemplo de alguns bairros paulistanos ${ }^{341}$ e de centros históricos de diversas cidades, como Iguape e Cananéia, exemplos em que se tem buscado, inclusive, promover a integração entre a preservação e os instrumentos de planejamento urbano local. $^{342}$

Na esfera municipal, a preservação das áreas envoltórias de bens tombados pautase em grande parte pelas diretrizes da Resolução $n^{0} 10 / 95^{343}$. Para a tutela do patrimônio urbano como 'monumento coletivo', contudo, um instrumento que tem sido utilizado são as chamadas Zonas de Preservação Cultural (ZEPEC), áreas demarcadas pelo Plano Diretor e que passam a ser estudadas para possível tombamento. ${ }^{344}$ A ZEPEC, no entanto,

\footnotetext{
${ }^{340}$ A preservação das áreas envoltórias é regida pelo artigo 137 do Decreto Estadual 13.426 de 16.03.79, cuja redação foi alterada pelo Decreto 48.137 de 07.10.03 (Cabe ressaltar que o diploma legal 13.426/79 foi revogado pelo de $\mathrm{n}^{\circ} 20.955$, em 01.06.1983, exceto quanto aos artigos 134 a 149 que permanecem em vigor). Na nova redação do Artigo 137, temos: "A Resolução de Tombamento preverá, no entorno do bem imóvel tombado, edificação ou sítio, uma área sujeita a restrições de ocupação e de uso, quando estes se revelarem aptos a prejudicar a qualidade ambiental do bem sob preservação, definindo, caso a caso, as dimensões dessa área envoltória. Parágrafo único - Nenhuma obra poderá ser executada dentro da área envoltória definida nos termos deste artigo sem que o respectivo projeto seja previamente aprovado pelo CONDEPHAAT."

${ }^{341}$ Em 1986, foram tombados os bairros jardim América, Europa, Paulista e Paulistano (processo 23.372/85, Resolução 2 de 23/01/86) e em 1991, foi tombado o bairro do Pacaembú (processo n. 23.972/85, Resolução 8 de 14/03/91). Outros bairros estão sendo estudados para futuro tombamento (bairros de Santa Ifigênia, Campos Elíseos, Sumaré e City Lapa). LANÇA, Antonio. Preservação do patrimônio urbano paulista. Tese de Doutorado. São Paulo: FAUUSP, 2005.

${ }^{342}$ Além de Iguape e Cananéia, são também tombados os centros urbanos de Amparo, Bananal, Iporanga, Carapicuíba, Itu, Paranapiacaba, Santana de Parnaíba, São Luís do Paraitinga e São Sebastião. Sobre as ações de preservação e a integração com planos urbanos locais em Iguape e Cananéia, consultar LANÇA, A., op. cit., p. 134 et seq.

${ }^{343}$ A Resolução 10/95 indica procedimentos para a determinação das área envoltórias de bens tombados. Em síntese, propõe a delimitação do espaço envoltório a partir de critérios de visibilidade, observação das perspectivas a serem geradas e valorização dos valores estéticos e históricos do bem protegido. SÃO PAULO (Cidade). CONPRESP. Resolução 10/95.

${ }^{344}$ Segundo o Plano Diretor em vigor (Lei $\mathrm{n}^{\circ}$ 13.430, 13.09.2002), "as Zonas de Preservação Cultural ZEPEC são porções do território destinadas à preservação, recuperação e manutenção do patrimônio
} 
é um instrumento jurídico geralmente empregado para a preservação de lotes considerados individualmente, sendo difícil justificar a preservação de vários lotes contíguos na intenção de abranger um perímetro significativo. Ademais, apenas o tombamento, como já observava Bonelli, é insuficiente para promover a preservação de quaisquer áreas urbanas. E a implementação de programas complementares, além de esbarrar em infindáveis entraves políticos e econômicos, geralmente é tarefa que extrapola a capacidade operacional dos órgãos citados. Outro instrumento que poderia ser empregado para a proteção de áreas urbanas é o direito de preempção, recurso previsto em lei federal e que garante, a partir da demarcação em plano diretor, a preferência de compra do imóvel para o poder público $^{345}$. A aplicação deste instrumento na cidade de São Paulo com o intuito específico de preservação urbana, no entanto, esbarra em complexas questões políticas e econômicas.

Com relação à intervenção em sítios urbanos, alguns programas têm sido pensados em conjunto com a esfera federal de preservação, a exemplo do Programa Monumenta $^{346}$ que vem sendo implementado no centro histórico de São Paulo, na área da Luz. O programa objetiva revitalizar a região a partir da criação de um pólo cultural. Entretanto, volta-se prioritariamente à intervenção em edifícios isolados, ou seja, atua no sentido de promover obras 'âncora' com o intuito de induzir o processo de revitalização do entorno. Inexiste, contudo, um planejamento de maior amplitude que relacione as obras pontuais de restauro com as áreas circundantes e que conduza o desejado efeito revitalizador frente às edificações 'menores' que compõem o conjunto, evitando demolições arbitrárias. Como o programa se encontra em andamento, ainda não possuímos dados suficientes para avaliar seus efetivos resultados em termos de preservação e valorização do patrimônio urbano. No entanto, a atuação pontual e o modo como algumas obras de restauração em edifícios isolados têm sido conduzidas (a exemplo da polêmica em torno das intervenções na Estação da Luz, ou no antigo edifício do DOPS), ${ }^{347}$ não nos traz muito otimismo.

histórico, artístico e arqueológico, podendo se configurar como sítios, edifícios ou conjuntos urbanos." As ZEPEC substituem as antigas Z8-200, criadas em 1975. SÃO PAULO (Cidade). Lei 8.328 de 03.12.1975.

${ }^{345}$ BRASIL. Lei n. 10257, de 10 de julho de 2001. Estatuto da Cidade. "Art. 25. O direito de preempção confere ao Poder Público municipal preferência para aquisição de imóvel urbano objeto de alienação onerosa entre particulares. $\S 1^{\circ}$ Lei municipal, baseada no plano diretor, delimitará as áreas em que incidirá o direito de preempção [...]."

346 Programa voltado à recuperação do patrimônio cultural urbano brasileiro, promovido pelo Ministério da Cultura e que conta com recursos financeiros do BID - Banco Interamericano de Desenvolvimento.

${ }^{347}$ O tema é aprofundado em KÜHL, B. M., Preservação..., op. cit., pp.111-115;149-170. 
Essa é uma questão fundamental com a qual concluiremos este breve percurso sobre as concepções da preservação do patrimônio urbano no Brasil. Em todos os níveis administrativos, apesar da aparente filiação aos princípios teóricos da Carta de Veneza, observamos certas incongruências na atuação prática, assim como a falta de debate sobre a adaptação desses preceitos para a realidade cultural brasileira, com o intuito de elaborar, inclusive, instrumentos legislativos mais específicos e eficazes, tanto no sentido de permitir a proteção de artefatos diferenciados (como são os sítios urbanos e os sítios industriais), quanto no sentido de orientar a intervenção prática sobre os bens já protegidos. Essas lacunas conceituais, além de incentivar medidas equivocadas e arbitrárias, assumem proporções perigosas na abordagem de artefatos recentemente considerados de interesse cultural, geralmente pouco estudados ou compreendidos em sua inteireza compositiva. A preservação e a restauração de áreas estratégias como centros urbanos, bairros ou sítios industriais reclamam a elaboração de estudos aprofundados sobre suas especificidades materiais e imateriais, sua dinâmica evolutiva e integração com o tecido urbano envoltório; fundamentos que deveriam respaldar ações conscientes de tutela e de intervenção. E é a própria ausência desses estudos e de argumentações sólidas na abordagem de artefatos dessa natureza que acaba por legitimar a interferência arbitrária de interesses diversos daqueles envolvidos na esfera cultural. 


\section{PARTE II}

\section{O RESTAURO URBANO}

e o espaço industrial como artefato cultural 


\section{CApítulo 3}

\section{PRESERVAÇÃO E RESTAURO DO PATRIMÔNIO URBANO-INDUSTRIAL}

\section{AS ESPECIFICIDADES DO PATRIMÔNIO INDUSTRIAL E A ESCALA URBANA}

A expansão do conceito de patrimônio cultural para um grupo cada vez maior de artefatos, contexto em que destacamos o crescente interesse pela salvaguarda de paisagens urbanas, abriu caminho para a identificação e reconhecimento de diversos exemplares arquitetônicos e conjuntos urbanos relacionados à industrialização. Inseridos no conjunto de artefatos contemplados pela ampliação do conceito de patrimônio, muitos edifícios e sítios industriais começaram a ser considerados tanto pela sua importância documental, como também por suas especificidades estéticas e figurativas, bem como pelo próprio caráter de conjunto responsável pela conformação de paisagens que começavam a adquirir representatividade; interesse também impulsionado pela consolidação da noção de patrimônio urbano como 'monumento coletivo'. Como vimos, a atenção para artefatos até então considerados 'menores' e a apreensão das especificidades de certos conjuntos urbanos permitiu o reconhecimento do valor cultural de tecidos e agrupamentos arquitetônicos cuja homogeneidade de volumes, escalas e elementos figurativos compunham o testemunho histórico e estético que os qualificava, contexto em que inserimos muitos exemplares do patrimônio industrial.

Ao lado desse percurso de aquisições conceituais e da elaboração das citadas cartas internacionais sobre a preservação e o restauro de bens culturais - documentos que, como vimos, abordam a expansão do conceito de patrimônio cultural - , diversos pesquisadores, sobretudo historiadores e arqueólogos, voltaram-se para a identificação e estudo sobre o patrimônio da industrialização e procuraram discutir métodos e critérios para a sua salvaguarda (inicialmente na Inglaterra, expandindo-se, em seguida, para outros países). As discussões encampadas por esses estudiosos despontaram em época relativamente recente, com maior vigor sobretudo a partir da década de 1960, quando importantes testemunhos da industrialização começaram a ser demolidos principalmente devido à obsolescência ou desocupação de muitas dessas antigas instalações. Nesse 
contexto, a preocupação inicial desses teóricos, como Kenneth Hudson e Arthur Raistrick, ${ }^{1}$ diante da ameaça constante de demolição a que tais artefatos estavam submetidos, era evidenciar a necessidade de documentá-los e, em alguns casos, preservá-los. Esses estudos pioneiros, abarcados pela então recém-criada arqueologia industrial, voltavam-se tanto à discussão sobre os limites cronológicos que a nova disciplina deveria abarcar, quanto aos métodos de registro e identificação das edificações e sítios existentes, e aos critérios de seleção de quais artefatos deveriam ser efetivamente preservados ${ }^{2}$.

Com relação à sistematização e organização desses estudos, cabe ressaltar as contribuições de Angus Buchanan, autor que destaca, inclusive, o necessário caráter interdisciplinar dessas análises. Além da preocupação com a elaboração de métodos de registro e documentação, o autor demonstra o interesse progressivo na preservação desse patrimônio propondo critérios ou diretrizes para auxiliar no esclarecimento da dúvida 'o que preservar?' com relação ao patrimônio da industrialização. Nesse sentido, propõe algumas diretrizes gerais para orientar a seleção dos artefatos mais significativos: a observação do grau de unicidade ou singularidade do artefato, de sua representatividade como referencial de determinada técnica ou época, de suas dimensões e possibilidades de reuso, inclusive para o turismo; a verificação do suporte local com relação à incentivos financeiros que viabilizem a sua preservação e, finalmente, a identificação dos artefatos associados a pessoas ou fatos importantes. ${ }^{3}$

Outra contribuição de grande relevância para os enfoques da presente pesquisa encontramos nos escritos de Neil Cossons. O autor desenvolveu interessantes análises no

\footnotetext{
${ }^{1}$ HUDSON, K. Industrial Archaeology: an Introduction. London: Baker, 1966; RAISTRICK, A. Industrial Archaeology, an Historic Survey. Frogmore, St. Albans: Paladin, 1973. Outros autores também desenvolveram o tema, a exemplo de K. Major e J. P. M. Pannell, referências bibliográficas completas no final deste volume.

${ }^{2}$ Muito se discutiu em torno da definição e dos recortes cronológicos da chamada 'arqueologia industrial', expressão cunhada por volta de 1950 na Inglaterra. Buscou-se definir se os artefatos a serem estudados seriam aqueles provenientes da Revolução Industrial, ou se atividades de produção anteriores também deveriam ser estudadas, e os próprios limites da expressão 'Revolução Industrial' foram questionados devido às diferentes épocas e fases de industrialização nos diversos países. A definição empregada por Angus Buchanan, parece ter atingido certo consenso: "arqueologia industrial é um campo de estudo relacionado com a pesquisa, levantamento, registro e, em alguns casos, com a preservação de monumentos industriais. Almeja, além do mais, alcançar a significância desses monumentos no contexto da história social e da técnica. Para os fins dessa definição, um 'monumento industrial' é qualquer relíquia de uma fase obsoleta de uma indústria ou sistema de transporte, abarcando desde uma pedreira de sílex neolítica até uma aeronave ou computador [...]." BUCHANAN, R. A. Industrial archaeology in Britain. Harmondsworth: Penguin, 1974, pp. 20-21. Para análises mais aprofundadas sobre essas discussões, consultar: KÜHL, B. M. Preservação da arquitetura industrial em São Paulo: questões teóricas. Relatório Científico. São Paulo: FAUUSP, Fapesp, 2005, pp.1523; RUFINONI, M. Preservação do patrimônio industrial na cidade de São Paulo. Dissertação de Mestrado. São Paulo: FAUUSP, 2004, pp.116-127.

${ }^{3}$ BUCHANAN, R. A., Industrial Archaeology..., op. cit., pp.52-54.
} 
que tange à interpretação dos artefatos industriais como patrimônio cultural e procurou enfatizar a importância do estudo da paisagem para a compreensão das transformações espaciais geradas pela industrialização. Segundo o autor, o crescimento do interesse pela arqueologia industrial configura-se não apenas como uma reação contra a destruição desses artefatos, mas também como uma tentativa de se opor ao ciclo de destruição e reconstrução impetrado pela alternância de diferentes paradigmas econômicos que sucessivamente alteram as paisagens e cotidianidades urbanas tradicionais. Nessa interpretação, os remanescentes físicos da industrialização transcendem a pura evidência histórica e adquirem representatividade como evidências culturais.

Com relação às qualidades paisagísticas do patrimônio industrial, Cossons busca enfatizar que as paisagens industriais, além da importância como testemunhos históricos ou técnicos, contribuem ainda para a configuração do que chamou de 'personalidade' de uma região. ${ }^{4}$ Para apreender essa personalidade, o autor ressalta a necessidade de desenvolvermos uma sutil apreciação estética que nos permita vislumbrar as características formais e construtivas dos edifícios, os detalhes arquitetônicos e também as "características intangíveis de uma área." E ressalta ainda que os elementos que compõe essa paisagem fato também evidenciado pelos estudos que delinearam a 'invenção' do patrimônio urbano - , não representam interesse isoladamente. São justamente a escala monumental, a perfeita assimilação dos edifícios ao entorno e o efeito de conjunto, os atributos que lhe conferem a destacada representatividade; atributos que "excitam a imaginação e estimulam os sentidos". Tais considerações, portanto, evidenciam a inequívoca caracterização de certos conjuntos arquitetônicos industriais como patrimônio urbano e cultural.

Paulatinamente, principalmente a partir da década de 1970, as discussões sobre a preservação do patrimônio industrial vêm se ampliando e diversos países têm se voltado ao desenvolvimento de seus próprios inventários e estudos. $\mathrm{O}$ fortalecimento do tema também se observa na realização de diversas reuniões científicas, cuja freqüência possibilita certa difusão de experiências, a exemplo dos encontros promovidos pelo TICCIH, The International Committee for the Conservation of Industrial Heritage, organização criada em 1978 e voltada especificamente à preservação desse patrimônio. ${ }^{6}$ Também no contexto

\footnotetext{
${ }^{4}$ COSSONS, Neil. The BP Book of Industrial Archaeology. London: David \& Charles, 1978, pp. 424-425.

${ }^{5}$ Idem, p. 22.

${ }^{6}$ O TICCIH possui representação brasileira oficial desde 1998, com a fundação do Comitê Brasileiro de Preservação do Patrimônio Industrial. A criação do comitê representou um significativo impulso para a expansão dos estudos no contexto brasileiro.
} 
brasileiro o tema vem ganhando maior fôlego com a produção de significativas pesquisas acadêmicas e a realização de vários encontros científicos ${ }^{7}$. Cabe ressaltar, contudo, que a ampliação do debate não tem representado, tanto no contexto nacional como internacional, a consolidação de uma efetiva prática de reconhecimento dos valores do patrimônio industrial ou a garantia de seu devido estudo, seleção e preservação. De modo geral, defender a preservação de edifícios ou sítios industriais de interesse cultural é ainda tarefa muito difícil; o próprio reconhecimento do valor cultural de edifícios ou sítios industriais esbarra em grandes entraves, seja devido às características arquitetônicas da maioria dos edifícios industriais, em geral pouco apreciadas, ou mesmo devido ao caráter de conjunto que não se compreende bem, predominam ainda as atitudes pautadas pela caracterização desses artefatos segundo critérios de funcionalidade e lucro. Dessa forma, prosseguem as demolições e várias intervenções são realizadas como se fossem reformas comuns.

As especificidades compositivas dos edifícios e sítios industriais e as dificuldades para o seu reconhecimento como patrimônio cultural são os principais motivos que dificultam um tratamento adequado nos projetos de readaptação para novos usos. Ao atuar em áreas industriais desativadas, a prioridade geralmente é de ordem funcional: busca-se verificar qual o potencial que os edifícios possuem para abrigar novos usos ou quais as possibilidades para nova ocupação dessas áreas após a demolição; a verificação de suas possíveis qualidades históricas e estéticas, portanto, facilmente passa para segundo plano ou nem mesmo chega a ser aventada. Esse tipo de abordagem se fortalece ainda mais quando consideramos a escala urbana desse patrimônio. $\mathrm{O}$ fato de muitos sítios industriais ocuparem extensas áreas, por um lado dificulta a apreensão de suas especificidades de conjunto, e, por outro lado, aguça ainda mais o interesse na implementação de novas construções.

Nesses casos, a questão da preservação do patrimônio industrial adquire indubitavelmente dimensão urbana e deve, portanto, ser tratada nos moldes da conservação integrada, conforme as recomendações de Amsterdã. O tratamento de áreas extensas, geralmente desativadas e degradadas, necessariamente precisa ser pensado a partir de uma escala mais ampla, considerando a articulação de diversos fatores envolvidos na dinâmica urbana em jogo e buscando o diálogo entre as diretrizes de planejamento urbano e as exigências do restauro. É uma situação, portanto, que nos remete às discussões em torno da

\footnotetext{
${ }^{7}$ Para um panorama das principais pesquisas e encontros científicos realizados em solo brasileiro, consultar KÜHL, B. M., Preservação..., op. cit., pp.24-25.
} 
preservação de áreas urbanas: a necessidade de pensar a inserção de novos elementos em sintonia com o preexistente, de propor novos usos condizentes com a escala e a dinâmica urbana local, bem como a oportunidade de integrar projetos pontuais a projetos de maior abrangência reinserindo com cuidado as áreas restauradas em uma nova realidade.

Esse tema foi exposto por Genovese que buscou inserir a questão do patrimônio industrial no contexto das discussões sobre a preservação do patrimônio cultural em geral, ou seja, buscou evidenciar que a preservação desse patrimônio deve considerar com cuidado o equilíbrio entre valor cultural e valor econômico (ou desenvolvimento urbano), e que as diretrizes para a condução desse equilíbrio, como se trata de áreas caracterizadas como bens culturais, devem necessariamente ser guiadas pela teoria do restauro e pelos documentos internacionais. Do mesmo modo, ressalta ainda a necessidade de estudos aprofundados para desvendar as especificidades desse patrimônio como recurso imprescindível para uma fundamentação criteriosa das escolhas a serem tomadas, sobretudo relacionadas à seleção de quais artefatos industriais deverão ser preservados.

[...] a cultura do restauro consagrou (e desde 1964, com a Carta de Veneza), o caráter de documento histórico a ser atribuído a tudo aquilo que é testemunho da evolução da civilização e, portanto, também da civilização industrial. Isto comporta como conseqüência que também para a fábrica e outras obras de engenharia (pontes, canais, ferrovias, etc.) impõe-se a necessidade de um estudo histórico que leve a exprimir um juízo crítico sobre a exigência, a conveniência, a oportunidade de preservar, certamente não tudo, mas aqueles episódios que satisfaçam as características indicadas no Art. 1 citada Carta. $^{8}$

A dimensão urbana geralmente associada ao patrimônio industrial requer, portanto, o desenvolvimento de levantamentos e estudos aprofundados e cuidadosos para depurarmos essa complexa trama de elementos e condições que a compõe, estudos que deverão subsidiar não apenas a seleção destacada por Genovese, mas também e sobretudo a condução consciente de quaisquer projetos a serem executados nessas áreas.

\footnotetext{
${ }^{8}$ GENOVESE, Rosa Anna. Presentazione. Restauro, anno XIV, n.82,1985, p.6. Trad. nossa. “[...] la cultura del restauro ha ormai sancito (e già dal 1964, con la Carta di Venezia), il carattere di documento storico a assegnare a tutto ciò che è testimonianza della evoluzione della civiltà e, quindi, anche della civiltà industriale. Ciò comporta come conseguenza che anche per la fabbrica e le altre opere d'ingegneria (ponti, canali, ferrovie, ecc.) si impone l'esigenze di uno studio storico che conduca ad esprimere un giudizio critico sull'esigenza, la convenienza, l'opportunità di conservare non certo tutto, ma quelli episodi che rispondono alle caratteristiche indicate nell'art. 1 della citata Carta." Consultar também, da mesma autora: Architettura e città antiche: conoscenza e valorizzazione. Restauro, anno XIV, n.79, maggio-luglio 1985, pp. 95-99.
} 
Os antigos sítios industriais geralmente agrupam diversos edifícios construídos em diferentes épocas, com tipologias construtivas distintas, e cuja composição espacial provém de complexas relações pautadas pelo desenvolvimento das atividades produtivas ali sediadas. Dessa forma, os sítios industriais são compostos por grupos de edifícios e espaços envoltórios vinculados entre si em função do processo produtivo. Eventualmente, uma única edificação industrial isolada pode representar valores excepcionais, mas em muitos casos (como no perímetro da Diagonal Sul, em São Paulo), trata-se de uma rede de edifícios, fabris ou não, inter-relacionados em torno da produção (galpões, edifícios fabris, vilas operárias, pátios de manobras, equipamentos, estruturas voltadas ao fornecimento de água, etc.), cuja avaliação e preservação não fará sentido se todos os elementos que compõem esse cenário não forem analisados como um conjunto, como um patrimônio urbano ${ }^{9}$. Também o entorno desses sítios - áreas voltadas a outros usos, residenciais por exemplo -, deve ser observado e analisado com atenção pois geralmente é composto por parcelas urbanas formadas e consolidadas em grande parte devido à presença da indústria, são conjuntos construídos que mantêm a homogeneidade volumétrica e a horizontalidade responsáveis pela configuração da paisagem e da tradição urbana de muitos bairros industriais. A questão foi habilmente exposta por Parisella:

O problema da reinserção [dos edifícios e sítios industriais] na realidade urbana, então, não é somente aquele de dar-lhes qualquer um dos usos possíveis, mas de buscar um uso adequado tanto com relação à sua configuração espacial e realidade construtiva e arquitetônica, como também à sua realidade histórica. A necessidade de prestar atenção a esta última deriva de uma dupla exigência. A primeira diz respeito ao edifício individualmente e às relações diretas e específicas entre o seu uso (significado) original e o uso (significado) que deveria / poderia assumir. [...] A segunda exigência diz respeito à compreensão do duplo sistema de relações que o edifício assumia, horizontalmente, dentro do espaço urbano organizado onde se situava (bairro, zona) e, verticalmente, dentro do setor produtivo do qual fazia parte. ${ }^{10}$.

\footnotetext{
9 A atenção para a configuração espacial desses sítios como documentos históricos únicos também foi abordada por: MENESES, Ulpiano Bezerra. Patrimônio, Preservação e História da Energia. In: Anais do $1^{o}$ Seminário Nacional de História e Energia. São Paulo: DPH, 1988, pp. 68-73.

${ }^{10}$ PARISELLA, Antonio. Il futuro del passato industriale. Roma Moderna e Contemporanea, anno VIII, n.12, 2000, p.52. Trad. nossa. "Il problema della loro ricollocazione nella realtà urbana, allora, non è solo quello di dare ad essi uno qualsiasi degli usi possibile, ma di ricercare un uso adeguato sia alla loro collocazione spaziale e alla loro realtà edilizia o architettonica, ma anche alla loro realtà storica. La necessità di prestare attenzione a quest'ultima deriva da una duplice esigenza. La prima è quella relativa al singolo edificio e al rapporto singolare diretto e specifico fra il suo uso (significato) originario e l'uso (significato) che dovrebbe / potrebbe assumere. [...] La seconda esigenza è quella di comprendere il duplice sistema di relazioni e funzioni che l'edificio assumeva, orizzontalmente, all'interno dello spazio urbano organizzato dove era collocato (quartiere, zona) e, verticalmente, all'interno del settore produttivo di cui faceva parte."
} 
As características de parcelamento do solo em regiões ocupadas ou influenciadas pela atividade industrial apresentam um ordenamento espacial específico para o atendimento de funções produtivas que repercute em toda a composição do conjunto, seja na distribuição dos edifícios fabris, seja na localização de vilas operárias e outros equipamentos urbanos. A procura pela funcionalidade e otimização de fluxos produtivos e logísticos criou uma configuração própria e dinâmica que, ao se transformar de acordo com a evolução dos sistemas produtivos, permite a observação de diferentes períodos da história da técnica e da própria urbanização de cada localidade. Em alguns ramos industriais específicos, a necessidade de extensas áreas repercutiu diretamente no parcelamento do solo urbano com a delimitação de grandes lotes e a conseqüente ordenação do sistema viário que acaba por contornar extensas e compactas parcelas urbanas. ${ }^{11}$ A preservação de edifícios isolados, portanto, não surte muito efeito para a manutenção dessa paisagem. A importância e relevância cultural dos sítios industriais está diretamente relacionada à apreensão dessas especificidades, ao entendimento das qualidades materiais, espaciais, compositivas, sociais, memoriais, que concorrem para a configuração desse cenário. Em síntese, os elementos que definem a 'personalidade' de uma dada região, como diria Cossons.

O reconhecimento dessas especificidades e a garantia de sua salvaguarda, conforme recomendam os documentos internacionais analisados, no entanto, são ações que enfrentam grandes dificuldades práticas. $\mathrm{O}$ fato de geralmente ocuparem grandes parcelas de terreno urbano é um dos principais entraves para a sua efetiva preservação. Além das dificuldades relacionadas ao entendimento das particularidades compositivas desse patrimônio, essas extensas áreas desativadas são muito cobiçadas pelo mercado imobiliário, fato que dificulta sobremaneira qualquer ação de preservação. Em qualquer cidade que possua exemplares significativos desse passado, como no caso de São Paulo, sabemos que não será possível preservá-los em sua totalidade; precisaremos realizar uma seleção. Essas escolhas, contudo, deverão basear-se em aprofundados estudos e pautar-se por rigorosas análises histórico-críticas para que se possa definir quais parcelas devem ser preservadas, como manter parte significativa dessas complexas relações e quais as diretrizes de desenvolvimento futuro para as áreas envoltórias.

\footnotetext{
${ }^{11}$ RUFINONI, M. Preservação..., op. cit., p.137.
} 
Além da dificuldade de apreensão e reconhecimento desses artefatos como patrimônio cultural, a abordagem das questões envolvidas em sua preservação e restauro apresentam grandes lacunas teóricas e interpretativas. Apesar do esforço de diversos países na realização de inventários, pesquisas, estudos acadêmicos e eventos científicos sobre o patrimônio industrial, iniciativas que tem permitido o desenvolvimento de relevante material descritivo e analítico sobre certos aspectos da problemática, observamos que a realização de intervenções nesse patrimônio poucas vezes tem sido abordada à luz dos princípios fundamentais que regem a preservação. Em muitos casos, as intervenções executadas em edifícios ou sítios industriais culturalmente representativos descortinam a inobservância dos princípios mais básicos da teoria do restauro, em flagrante discordância com as diretrizes da Carta de Veneza e documentos complementares ${ }^{12}$. Muitas dessas intervenções, seja devido à incompreensão das especificidades que compõem esses artefatos, por não reconhecê-los como patrimônio cultural, seja devido ao desconhecimento desses princípios teóricos (independentemente da natureza do artefato a receber a intervenção), configuram-se como meras reformas que deturpam o documento histórico e alteram indiscriminadamente sua imagem figurativa. Configuram-se como exemplos dessa problemática, apenas para citar dois casos emblemáticos na cidade de São Paulo, as polêmicas obras recentemente realizadas na Estação da Luz - edifício tombado em nível federal, estadual e municipal - , para a instalação do Museu da Língua Portuguesa, intervenção que resultou em demolições e alterações incisivas, notadamente nos interiores de partes da Estação, e a reforma realizada no conjunto arquitetônico do Cotonifício Crespi - cujo edifício principal representa um dos exemplares mais importantes da arquitetura industrial em nossa cidade e é objeto de estudo para tombamento em nível municipal - , para a instalação de um hipermercado ${ }^{13}$.

No caso do Crespi, a reforma conservou apenas as fachadas do edifício principal e praticamente todo o seu interior foi demolido (uma ossatura metálica autônoma, exemplar raro dessa técnica em nossa cidade). Vários edifícios adjacentes que compunham o conjunto arquitetônico foram também demolidos para ceder espaço ao estacionamento. E

\footnotetext{
12 Beatriz Mugayar Kühl aprofunda essa discussão em detalhes. Ao longo de sua pesquisa são debatidas questões conceituais relacionadas à preservação da arquitetura industrial em São Paulo, procurando analisar sua relação com a contemporânea teoria da restauração. Nesse percurso, são analisadas criticamente algumas obras de intervenção realizadas em São Paulo. KÜHL, B. M. Preservação..., op. cit.

${ }^{13}$ Para aprofundamentos sobre ambos os projetos, consultar: KÜHL, B. M. Preservação..., op. cit., pp.155175; Especificamente sobre o Cotonifício, consultar: RUFINONI, M. Patrimônio industrial ameaçado: o Cotonifício Rodolfo Crespi. Arqueologia Industrial, v.1, n.1-2, 2005, pp.73-88.
} 
mesmo as fachadas que restaram foram 'preservadas' segundo critérios bastante polêmicos pois vários trechos foram refeitos com tijolos novos.

Em ambas as obras citadas observamos o emprego de soluções projetuais bastante distantes dos critérios amplamente discutidos com relação à intervenção em bens culturais. De modo geral, a inserção de um novo uso assumiu prioridade. As especificidades compositivas das obras e do conjunto construído do qual fazem parte não foram devidamente estudadas e respeitadas em projeto, ao contrário, foram propostas incisivas alterações nas volumetrias, na materialidade e na própria imagem das obras. Os aspectos conservativos limitaram-se às fachadas e, ainda assim, de modo pouco criterioso. É claro que qualquer proposta envolvendo alterações de usos implicará certas transformações e não intentamos sugerir o contrário, ou seja, defender o ‘congelamento' de um bem cultural. A própria Carta de Veneza, em seu Artigo $5^{\circ}$, recomenda a atribuição de novos usos como um importante recurso para favorecer a conservação da obra, inserindo-a na sociedade. O documento, porém, ressalta com clareza que a nova função deverá ser compatível com as características do monumento e permitir a permanência das qualidades que efetivamente o configuram como um patrimônio cultural: seus atributos históricos, estéticos, memoriais:

A conservação dos monumentos é sempre favorecida por sua destinação a uma função útil à sociedade; tal destinação é, portanto, desejável, mas não pode nem deve alterar a disposição ou a decoração dos edifícios. É somente dentro destes limites que se devem conceber e se podem autorizar as modificações exigidas pela evolução dos usos e costumes. ${ }^{14}$

Logo, projetos de intervenção em bens culturais inevitavelmente implicam alguma transformação. A questão é justamente a condução criteriosa dessas escolhas projetuais de acordo com os princípios da contemporânea teoria do restauro. O restauro entendido como ato crítico, como vimos, remete a uma atitude de cunho intelectual, sem fórmulas prontas, porém pautada por um claro entendimento dos moventes culturais da preservação, das características do bem a ser preservado e do caráter histórico-crítico das análises a serem efetuadas. Entretanto, notadamente quando se trata de patrimônio industrial, artefatos complexos e sujeitos a fortes interferências econômicas, a prática geralmente não segue a teoria. Diversas intervenções, que a princípio deveriam preservar esses bens, desenvolvem-

\footnotetext{
${ }^{14}$ Carta de Veneza, 1964. In: Cartas patrimoniais. Rio de Janeiro: IPHAN, 2000, pp. 92-93.
} 
se a despeito desse debate teórico, propõem soluções pautadas por outros interesses e, em muitos casos, deturpam sua dimensão cultural, que indubitavelmente deveria ser a prioridade. $^{15}$

Com base na análise de numerosas referências bibliográficas voltadas à preservação do patrimônio industrial, Kühl evidenciou a carência ou debilidade do debate teórico frente a atuação prática sobre esses bens. Não obstante a pertinência e interesse de muitos textos na abordagem de outros aspectos da questão, foram poucas as referências que buscaram efetivamente discutir os critérios empregados em projetos de intervenção no patrimônio industrial. A maioria dos textos examinados limita-se à descrição dos complexos industriais e dos novos usos propostos sem vislumbrar os critérios possivelmente empregados na realização dessas intervenções e qual a relação que possuem com a teoria do restauro. ${ }^{16}$ Ademais, quando a teoria é citada, observam-se interpretações bastante equivocadas, a exemplo dos dizeres de Aguilar que propõe a restauração 'ao estado original', postura que desvela total desinformação sobre a atual teoria do restauro e remete a procedimentos há muito ultrapassados, do ponto de vista teórico ${ }^{17}$. Também Emmanuel De Roux desenvolve comentários equivocadas ao afirmar que a manutenção dos estratos históricos de uma obra, recomendação da Carta de Veneza, é inoperante para o caso do patrimônio industrial, pois sua adaptação para novos usos requer necessariamente incisivas transformações. Interpretação bastante distorcida das diretrizes da Carta pois, como vimos, o respeito pela historicidade e pela configuração da obra não implica, de forma alguma, o seu 'congelamento'.18

O mesmo distanciamento entre teoria do restauro e prática de intervenção também pode ser observado na abordagem predominante dos eventos promovidos pelo TICCIH, organização voltada especificamente à preservação do patrimônio industrial. Tomando como exemplo dois congressos realizados recentemente, apesar das numerosas contribuições voltadas à história da técnica, métodos de inventário e outros temas de grande relevância, no que tange especificamente ao debate sobre intervenções realizadas, não foram feitas referências significativas aos critérios empregados de acordo com os

${ }^{15}$ B. M. Kühl. Questões teóricas relativas à preservação da arquitetura industrial. Desígnio Revista de História da Arquitetura e do Urbanismo, FAUUSP, n. 1, 2004, pp. 101-117.

${ }^{16}$ Uma breve descrição de cada uma das centenas de referências bibliográficas examinadas por Kühl, pode ser consultada no apêndice 1 da obra: KÜHL, B. M. Preservação..., op. cit., pp.269-340.

${ }^{17}$ AGUILAR, I. Restauración del património arquitectónico industrial. In: Preservación de la arquitectura industrial en Iberoamérica y España. S.1.: Instituto Andaluz del Patrimonio Historico, 2001, pp.160-203.

${ }^{18}$ DE ROUX, Emmanuel. Patrimoine industriel. Paris: Scala, 2000, p.26 apud KÜHL, B. M., Preservação..., op. cit., p.31. 
preceitos teóricos que deveriam guiar a preservação e a restauração ${ }^{19}$. Pelo contrário, uma relevante quantidade de artigos e apresentações orais voltou-se à descrição de projetos propostos ou executados absolutamente à revelia da teoria do restauro, sem referência ao estudo prévio das estruturas preexistentes e pouco atentos, quando voltados à áreas urbanas, à necessidade de integração com o planejamento urbano. Muitos projetos apresentados assumiam como prioridade a adaptação das estruturas industriais para novos usos e destacavam como prerrogativas projetuais a versatilidade desses edifícios e sítios para a inserção de diferenciadas funções, tratando-os, portanto, como meros receptáculos para o novo. No Congresso Internacional realizado em 2006, uma das sessões reservou espaço para a apresentação de propostas elaboradas por estudantes de um curso de especialização voltado à preservação e à elaboração de projetos de intervenção no patrimônio industrial, propostas que, curiosamente, não se referiam à teoria do restauro ${ }^{20}$. Em outro congresso realizado no mesmo ano, o projeto para inserção do Museu da Língua Portuguesa na Estação da Luz, obra reconhecidamente polêmica, foi apresentado como um exemplo de preservação do patrimônio industrial, sem levantar discussões ${ }^{21}$. O mais curioso é que, justamente em um encontro científico promovido por um órgão especificamente voltado à preservação do patrimônio industrial, a significativa anulação das particularidades compositivas de edifícios e sítios não chegou sequer a ser tema de debate diante das apresentações citadas.

Esses equívocos conceituais, a dificuldade de integrar teoria e prática no tratamento desses artefatos, assim como o próprio afastamento de muitos estudos voltados à preservação do patrimônio industrial do campo da preservação e do restauro, como

\footnotetext{
${ }^{19}$ Congreso Internacional Puesta en Valor del Patrimonio Industrial: Sitios, Museos y Casos. Santiago de Chile, 2006; XIII International TICCIH Congress, industrial heritage and urban transformation productive territories and industrial landscape. Terni-Roma, 2006. A autora desta tese esteve presente am ambos os encontros.

${ }^{20}$ Trata-se do curso: Master in Conservazione, Gestione e Valorizzazione del Patrimonio Industriale, promovido a partir de uma parceria entre várias instituições: Universidade de Padova (Departamento de História); Instituto Universitário de Arquitetura de Veneza (Departamento de Urbanismo); Primeira Faculdade de Arquitetura do Politécnico de Torino (Departamento de Projeto Arquitetônico), com a participação da Universidade de Ferrara, Perugia e Lecce e outros institutos e administrações comunais. O curso se estrutura em três blocos: Conhecimento, conservação e gestão do patrimônio industrial; Conhecimento, conservação e valorização de maquinários e ciclos históricos; Projeto e recuperação do patrimônio industrial. Desconhecemos o conteúdo ministrado para saber com certeza como a teoria do restauro é abordada (ou se é abordada, já que aparentemente não há a participação dos departamentos de História da Arquitetura ou de Preservação e Restauro). As apresentações realizadas pelos alunos do curso, no entanto, assistidas pela autora da presente tese, não fizeram menção à teoria do restauro e os projetos propostos sugerem o seu desconhecimento.

${ }^{21}$ Cf.: Actas del Congreso Internacional Puesta en Valor del Patrimonio Industrial: Sitios, Museos y Casos. Santiago de Chile, 2006, pp.557-563.
} 
sugerem os congressos citados, tem afastado a abordagem do tema da esfera cultural, abrindo caminho, perigosamente, para a influência de interesses econômicos, políticos ou setoriais. O tratamento dos sítios industriais de interesse cultural, como aqueles encampados pela Operação Urbana Diagonal Sul, em São Paulo, solicita um aprofundado conhecimento de suas especificidades formais, dinâmica evolutiva, relações com o entorno, urbanidades e cotidianidades locais, conhecimento imprescindível para garantir a preservação e respaldar intervenções criteriosas e, necessariamente, pautadas pelos pressupostos da teoria do restauro.

\section{PRESERVAÇÃO URBANA E PATRIMÔNIO INDUSTRIAL: DESAFIOS E PERSPECTIVAS}

A formulação de conceitos e princípios ao longo de décadas de discussões e experiências sobre a preservação dos bens culturais e o entendimento cada vez mais amadurecido, notadamente a partir da década de 1970, sobre a necessidade de pensar de modo integrado o restauro, o urbanismo e o projeto arquitetônico, são conquistas que nos oferecem instrumentos fundamentais para uma atuação criteriosa sobre áreas urbanas de interesse cultural, contexto no qual se inserem diversos exemplares do patrimônio urbanoindustrial. $\mathrm{O}$ arsenal teórico e prático que aqui temos buscado sintetizar, no entanto, não parece ter sido suficiente para lançar o desenvolvimento do debate em terreno seguro.

A preservação e a intervenção urbana são ainda um grande desafio teórico e prático que tem continuamente aguçado a atenção de especialistas de diferentes campos disciplinares e impulsionado a realização de numerosos estudos. Temas como a preservação de centros históricos, a intervenção em áreas urbanas de interesse cultural, o encontro antigo-novo, a conservação integrada e diversos outros assuntos correlatos, têm sido explorados em publicações e encontros científicos para discussão e troca de idéias. ${ }^{22}$ A este complexo panorama de desafios teóricos e operativos advindos da complexidade

\footnotetext{
${ }^{22}$ Citando apenas alguns dos mais recentes realizados na Itália: Atti della giornata di studi sul tema: Restauro Urbano. Che fare? [Quasar, n.23]. Firenze: Facoltà di Architettura dell'Università degli Studi di Firenze, 2000; Atti del Convegno Internazionale "La Città di Domani: strategie, programmi, progetti di riqualificazione urbana". Bologna, Ferrara: Facoltà di Architettura di Ferrara, Regione Emilia Romagna, 2000; Atti del Seminario Internazionale 'Città in Trasformazione: Le aree dismesse nella riqualificazione della città europea'. Roma: Dipartimento di Pianificazione Territoriale e Urbanistica, Università degli Studi di Roma La Sapienza, 1993.
} 
das estruturas urbanas culturalmente significativas, somam-se ainda as dificuldades inerentes ao patrimônio específico da industrialização que, como vimos, apresenta especificidades compositivas e congrega interesses econômicos difíceis de depurar em quaisquer atividades de intervenção.

As principais questões envolvidas na preservação e na elaboração de projetos de restauro em áreas urbanas são, na verdade, um complexo emaranhado de temas gerados e alimentados, em última análise, por um único problema central: mesmo diante de tão extensa e profícua produção teórica nesse campo, como vimos, prevalece ainda a fragilidade na interpretação de certos conceitos e princípios, e uma grande distância entre a teoria e a prática. Observamos em certas propostas e projetos o emprego de noções equivocadas de 'monumento', 'valor' e até mesmo de 'restauro'. No que tange ao patrimônio urbano, predomina a falta de clareza sobre sua real caracterização como um bem cultural e sobre sua natureza necessariamente articulada e coral. Muitas das intervenções realizadas, pautam-se geralmente por prioridades de caráter funcional e econômico (a valorização de áreas degradadas, a implementação do turismo, a busca por melhorias no tráfego, etc.); questões que devem ser trabalhadas mas que jamais poderiam assumir prioridade em projetos dessa natureza, ou seja, trata-se de um modo de abordar a questão que distancia o tema da esfera cultural e acaba por corromper os próprios objetivos de um projeto restauro.

A observação atenta dos desafios no campo da preservação urbana, de acordo com análises dos autores até aqui comentados, nos leva a apontar o escasso entendimento da noção de bem cultural e do próprio restauro, como causas fundamentais de cada um dos entraves apontados; fragilidade interpretativa que se manifesta em dois caminhos igualmente perigosos: de um lado as forças do mercado imobiliário, cômodo 'desconhecedor' das prioridades de uma intervenção criteriosa, e, de outro lado, a atuação pautada por interpretações falhas a respeito dos princípios da preservação por parte dos próprios profissionais que desenvolvem os projetos. A constatação dessas falhas interpretativas foi o motivo que nos impulsionou para a busca dessa extensa exposição dos percursos teóricos que definiram tais conceitos, ou seja, dos caminhos investigativos que definiram a aquisição do conceito de ambiente e de patrimônio urbano, conteúdo da primeira parte deste estudo, na esperança de retomar ou reatar algum elo perdido entre a teoria e a prática em longos anos de discussão. De fato, se analisarmos o conteúdo principal das discussões travadas a partir da década de 1940, apesar da dimensão que os 
problemas urbanos assumiriam nos anos seguintes, percebemos que grande parte das questões envolvidas na preservação urbana já estava em análise. Muitas questões já vinham sendo discutidas de acordo com os instrumentos teóricos disponíveis naquele momento, mas, sem dúvida, a partir de lúcida interpretação. Versões embrionárias do conceito de conservação integrada, como vimos, já despontavam desde a década de 1930 e ainda hoje o tema impulsiona grandes questionamentos que parecem rodar em torno dos mesmos temas e afastar-se dos reais entraves que dificultam a ação prática. Entraves, na verdade, de ordem conceitual e interpretativa, pois as aquisições relativas ao reconhecimento de valores e ao entendimento do que seja um 'bem cultural', assim como a própria compreensão da noção de 'restauro', parecem distanciar-se cada vez mais do debate.

Um dos principais motivos que agravam tais dificuldades interpretativas é a ampliação conceitual do que definimos como bem cultural e a necessidade de abordar artefatos complexos, em diferentes escalas e contextos. Essa noção mais alargada do objeto a preservar, principalmente quando se trata de áreas urbanas, impulsionou a necessidade de promover relações interdisciplinares, tanto na fase de estudo, como na fase propositiva. A participação e contribuição de diversos saberes (dos campos da preservação e do restauro, do urbanismo, do projeto arquitetônico, bem como da engenharia, história, estética, sociologia, etc.) tornou-se, portanto, indispensável para a apreensão das especificidades que compõem artefatos tão complexos e dinâmicos. Daí advém um segundo problema: a dificuldade de se trabalhar numa chave interdisciplinar. De modo geral, cada disciplina procura desenvolver a sua etapa, a 'parte que lhe cabe' no processo da preservação, sem buscar o entendimento e o contato com os demais campos do saber envolvidos na questão. Dessa forma, a desejada interdisciplinaridade recomendada pelos documentos internacionais não acontece, pois

os vários aportes de competências não propiciam esclarecimentos; de fato, as contribuições que deveriam concorrer para o desenvolvimento exaustivo de um determinado tema, longe de tender a uma nova síntese, insistem geralmente em acentuar interesses e particularidades próprias do campo disciplinar do qual provêm, ignorando qualquer conexão e subtraindo-se à busca de denominadores comuns. ${ }^{23}$

\footnotetext{
${ }^{23}$ MIARELLI MARIANI, G. Qualche pensiero effimero sul restauro dei monumenti architettonici. Storia Architettura, ano XI, n.1-2, 1988, p.16. Trad. nossa. "I vari apporti di competenze non propiziano i chiarimenti; infatti i contributi che dovrebbero concorrere a svolgere esaurientemente un tema determinato, lunghi dal tendere a nuova sintesi, insistono comunemente nell'accentuare gli interesse e le particolarità propri del campo disciplinare dal quale provengono, ignorando ogni connessione ed eludendo ogni ricerca di denominatori comuni." O autor retoma o tema em: MIARELLI MARIANI, G. Su alcune attuali difficoltà del
} 
Não obstante as relevantes contribuições de cada campo disciplinar, essa multiplicidade de pesquisas isoladas, que se pretendem entrelaçadas, mas que de fato reforçam suas singularidades, lança o tema a territórios delicados, e até mesmo controversos, desfocando a própria natureza do debate. Cada disciplina não relaciona a sua especificidade ao tema central; dessa forma, independentemente do valor individual de cada contribuição, essas não satisfazem a necessidade de interdisciplinaridade. Como destaca Miarelli Mariani, uma verdadeira relação dialética com as outras matérias deve considerar a completa aderência de cada contribuição às exigências múltiplas e mutáveis do real, porém sempre mantendo o vínculo indissociável com os fundamentos conceituais e com a própria finalidade do restauro. ${ }^{24}$ Esse diálogo poderia, inclusive, ser promovido pela universidade.

Diante desse quadro, observamos por um lado, análises especialíssimas sobre certos temas e a total ignorância sobre o real motivo de sua elaboração, e, por outro, a perigosa fragilização do argumento central, absorvido pelas especialidades isoladas, abrindo caminho para a atuação de interesses obtusos como as prioridades econômicas e quantitativas. Realidade habilmente apontada por Miarelli Mariani na elaboração dos planos urbanísticos italianos que, apesar da consolidada idéia de conservação integrada, referem-se ao restauro de modo pouco preciso ou até mesmo errôneo.

A tendência ao isolamento disciplinar também tem sido observada em estudos voltados especificamente à conservação integrada que, em alguns contextos, chega a ser abordada quase como um tema autônomo e distante da própria teoria da preservação: são discutidos os métodos para reabilitar áreas degradadas a partir da adoção de novos usos, as possibilidades para a promoção de atividades turísticas, os instrumentos jurídicos e administrativos para viabilizar tais empreendimentos, os métodos de financiamento das operações, as parcerias público-privadas, tabelas e gráficos sobre as questões econômicas e sociais envolvidas, etc., assuntos sem dúvida alguma também pertinentes à conservação integrada e que devem ser devidamente analisados. Mas o que nos espanta é o tratamento desses temas sem se referir ao próprio restauro e aos seus princípios basilares, ou seja, o desenvolvimento de discussões em torno da atuação no patrimônio urbano sem mencionar os critérios de intervenção adotados e sem relacionar os assuntos acima citados com os prioritários princípios histórico-críticos do restauro, dos quais derivam, inclusive, a própria

recupero urbano e territoriale. In: Atti del Convegno Nazionale: una normativa e un Centro regionale per il recupero dei centri storici calabresi. Catanzaro: Rubbetino, 1991, p.136.

${ }^{24}$ MIARELLI MARIANI, G. Su alcune attuali difficoltà..., op. cit., p. 136. 
formulação da conservação integrada. $O$ centro desses debates privilegia aspectos econômicos e operacionais em detrimento das teorias da restauração. ${ }^{25}$

Ainda mais nocivas são as análises e projetos de intervenção em áreas industriais consideradas abandonadas, onde praticamente inexiste a preocupação com um suposto valor cultural dessas antigas estruturas e, quando o tema comparece, é de modo marginal, como uma curiosidade que provavelmente agregará valor econômico ao empreendimento em pauta. O discurso sobre a prática de intervenções em áreas industriais independentemente do sucesso dessas obras com relação à almejada requalificação -, possui poucos pontos de contato com as teorias do restauro e se desenvolve, inclusive, em nichos acadêmicos e profissionais alheios à discussão sobre os bens culturais. Mais uma vez, abordagens que evidenciam a fragilidade no reconhecimento de valores, no entendimento do que configura um bem cultural, ou um projeto de restauro, e, talvez, até o próprio desconhecimento da existência desse campo disciplinar. Certos aspectos dessas questões têm sido abordados por diversos autores como Miarelli Mariani, Cervellati, Carbonara, Ranellucci, entre outros; estudiosos que objetivam identificar os problemas e propor soluções para os principais entraves práticos da preservação urbana, discussões que vêm se desenvolvendo sobretudo a partir da década de 1980.

Como vimos, a complexidade atribuída às operações de restauro, sobretudo em sua dimensão urbana, e a conseqüente necessidade de pensá-lo em consonância com as proposições urbanísticas e com a própria produção arquitetônica trouxe à tona uma série de questionamentos e dificuldades operacionais que descortinam perigosas cisões entre teoria e prática; evidentes distanciamentos entre as aquisições teóricas aqui apresentadas e as efetivas ações de tutela e de intervenção.

Em ampla produção bibliográfica, Miarelli Mariani buscou analisar as causas desse distanciamento e as principais dificuldades na atuação sobre conjuntos construídos e ambientes históricos. E a observação atenta de suas considerações nos remete ao que intentamos identificar como o fulcro de toda a questão: a citada fragilidade interpretativa, seja no próprio reconhecimento das especificidades do bem cultural, seja no entendimento dos reais objetivos de um projeto de restauro; verdadeiros 'nós' de onde derivam uma série

\footnotetext{
${ }^{25}$ A produção científica em torno da conservação integrada é extensa e diversificada. No cenário italiano destacamos as contribuições de Carlo Cesari, Pier Luigi Cervellati, Antonino Terranova e Roberto Di Stefano, bem como as análises de Francesco Forte e Luigi Fusco Girard voltadas principalmente às questões econômicas. No contexto internacional, destacam-se as contribuições de Nathaniel Lichfield e David Warren. Ressaltamos ainda a participação brasileira com a atuação do Centro de Estudos Avançados da Conservação Integrada, conforme citamos no segundo capítulo.
} 
de complicações e caminhos aparentemente sem saída. Ao discorrer sobre as possíveis causas que dificultariam a fruição do trinômio 'restauro-urbanismo-arquitetura' compromisso multidisciplinar defendido desde a década de 1940 e finalmente consolidado nas cartas internacionais -, o autor destaca, de um lado a equivocada tendência, principalmente no campo prático, de se tratar o restauro como uma disciplina autônoma e enfraquecer, ou negligenciar, seus necessários elos com outros campos do saber, ${ }^{26}$ e, de outro lado, a expansão dos bens considerados de interesse cultural e a conseqüente necessidade de articular conhecimentos interdisciplinares ao projeto de restauro tornando-o muito mais complexo e gerando situações de difícil controle, já que geralmente cada campo disciplinar tende a atuar de acordo com objetivos próprios, perdendo-se a real dimensão da operação como um todo ${ }^{27}$. Ora, ambas as causas parecem convergir para um mesmo ponto. A primeira, a concepção do restauro como um projeto autônomo (isolado), configura-se como postura absolutamente desvinculada do próprio caminho teórico que a disciplina da preservação e do restauro tem traçado ao longo de anos de debates; a segunda causa apontada é, na verdade, uma aquisição advinda do próprio desenvolvimento da noção de bem cultural, capítulo elementar no percurso histórico das teorias do restauro. Se a elaboração do projeto de restauro - ato histórico-crítico e momento metodológico que visa o reconhecimento e transmissão para o futuro das especificidades históricas, formais, materiais e memoriais do bem cultural ${ }^{28}$ - , não busca a colaboração e a organização interdisciplinar necessária para fundamentar os estudos voltados à compreensão de artefatos cada vez mais complexos, trata-se, na verdade, de uma elaboração projetual carente de bases conceituais, na qual se perde de vista o objetivo central do restauro, ao se esquivar da criteriosa compreensão do próprio artefato sobre o qual se pretende intervir. A carência dessas claras e sólidas bases conceituais que deveriam fundamentar os objetivos do restauro e orientar a articulação dos demais saberes envolvidos, acaba por alimentar projetos nos quais cada campo disciplinar atua isoladamente, sem conseguir visualizar a relação entre os demais atores e elementos envolvidos. Seguindo esse caminho de

\footnotetext{
${ }^{26}$ Cabe ressaltar as considerações de Sandro Ranellucci com relação à estrutura ainda predominante no ensino de arquitetura na qual se nota a distinção clara entre o arquiteto 'criador' e o 'restaurador', outra faceta que evidencia o entendimento equivocado do 'restauro' como disciplina autônoma. RANELLUCCI, S. Restauro Urbano: teoria e prassi. Torino: UTET, 2003, p. 267.

${ }^{27}$ MIARELLI MARIANI, Gaetano. Restauro e Territorio: appunti su un rapporto difficile e controverso [1978]. In: Centri Storici: note sul tema. Roma: Bonsignori, 1992, p.9.

${ }^{28}$ Retomando a definição de Cesare Brandi: "A restauração constitui o momento metodológico do reconhecimento da obra de arte, na sua consistência física e na sua dúplice polaridade estética e histórica, com vistas à sua transmissão para o futuro". BRANDI, C. Teoria da restauração. Trad. B. M. Kühl. Cotia, São Paulo: Ateliê, 2004, p.30.
} 
equívocos, não raro as propostas de intervenção mostram-se absolutamente alheias à convicções teóricas há muito tempo comumente aceitas; um verdadeiro retrocesso.

A fragilidade na interpretação de conceitos como origem da dificuldade de integração entre os campos disciplinares também fica clara no modo como certas expressões lexicais tem sido empregadas em diferentes estudos sobre o patrimônio urbano. Termos como 'restauro urbano', 'restauro do território', ou mesmo 'urbanismo dos centros antigos', são empregados indistintamente sem esclarecimentos sobre o tipo de operações de que se trata em cada caso. Utilizados por diferentes campos disciplinares, esses termos muitas vezes assumem significados diversos e geram caminhos interpretativos e operacionais que ignoram ou enfraquecem importantes aspectos a serem considerados, quando não o próprio cerne da questão: a preservação de um bem cultural. Nesse mesmo caminho é cada vez mais comum e problemático o emprego de termos como 'recuperação', 'renovação', 'reuso', 'reutilização', 'reabilitação', largamente utilizados para designar os mais variados tipos de projetos e até mesmo como sinônimo de 'restauro', independentemente dos atributos patrimoniais do preexistente ${ }^{29}$. Confusão lexical certamente alimentada por análoga confusão conceitual pois não se denomina precisamente aquilo que não se compreende bem, ou que comodamente julgou-se oportuno compreender mal. É o caso da difusão do termo 'recuperação' para designar projetos de intervenção sobre a chamada 'arquitetura menor'; recurso empregado por determinadas esferas políticas, grupos empresariais e profissionais da construção como subterfúgio para as solicitações criteriosas de um verdadeiro restauro, como se o patrimônio urbano não possuísse qualidades equiparáveis às de um 'monumento excepcional' e pudesse ser tratado a partir de instrumentos menos criteriosos. Nessa asserção, a operação de recuperação seria “a face razoável do restauro, aquela que não levanta muitas questões, em contraposição à outra, autoritária, de [pessoas atentas] à defesa das memórias históricas, [que continuam] a colocar problemas de conservação com rigor" ${ }^{30}$ Logo, a recuperação é concebida como um instrumento mais apropriado para intervir "sem tantas complicações históricas e teóricas" sobre o preexistente não excepcional, seja ele novo ou antigo, uma espécie de 'restauro breve', ou simplificado, voltado à satisfazer exigências imediatas de

\footnotetext{
${ }^{29}$ MIARELLI MARIANI, G. Sul recupero dei centri storici: uno schematico sguardo d'insieme. In: Centri storici..., op. cit., p.55.

${ }^{30}$ CARBONARA, G. Equivoci di lessico... Paesaggio Urbano, gennaio-febbraio 1990, p.24. Trad. nossa. "Esso è concepito come la faccia ragionevole del restauro, quella che non solleva troppe questioni, contro l'altra, autoritaria, di chi, soprintendente coscienzioso o semplice uomo di cultura attento alla difesa delle memorie storiche, continua a porre con rigore problemi di conservazione."
} 
adaptação dos antigos edifícios às necessidades modernas. A atribuição do status de preexistência simplória ao tecido histórico, na contracorrente de toda a teoria do restauro, acaba por corroborar práticas de intervenção alheias às aquisições teóricas há muito aceitas e consolidadas. Um termo cunhado, portanto, à revelia da concepção moderna de bem arquitetônico e ambiental que há decênios expandiu-se para inteiros agrupamentos arquitetônicos e urbanos. ${ }^{31}$

Analogamente, similares confusões conceituais são observadas no emprego de termos básicos na temática da preservação e do restauro como 'bem cultural' e até mesmo 'monumento'. Argan observa que em certos contextos o emprego do termo 'bem cultural' esconde motivações de origem econômica e a noção de 'bem' como movente afetivo, como herança cultural, freqüentemente passa para segundo plano sem muitos questionamentos. ${ }^{32}$ A própria idéia de 'monumento', por outro lado, curiosamente ainda pode assumir a conotação unívoca de obra excepcional para a história da arte, negligenciando séculos de discussões teóricas e toda a reflexão histórico-crítica do século XX. Os termos 'conservação' e 'restauro' também não fogem aos equívocos. No ambiente inglês a 'restauração' (restoration) é diretamente identificada com refazimentos de caráter estilístico, desconsiderando todas as reinterpretações do termo desde Boito até nossos dias. Para denominar intervenções sobre bens culturais prefere-se o uso do termo 'conservação' (conservation), entendido como “o 'lado melhor' do restauro (aquele eminentemente conservativo, que não suja as mãos com as questões de reintegração das lacunas e sobretudo de remoção das adições)"; ${ }^{33}$ em outras palavras, a conservação é vista como a versão mais palatável do restauro.

Nas intervenções em sítios industriais de interesse patrimonial o emprego de expressões inadequadas para os bens culturais é ainda mais evidente e revelador. Artefatos recentemente encampados pela ampliação do conceito de patrimônio e, como vimos, bastante suscetíveis a toda sorte de equívocos conceituais, os sítios industriais freqüentemente são alvo de projetos de intervenção pautados por pressuspostos alheios à esfera cultural, geralmente de origem econômica e utilitarista. Termos como

\footnotetext{
${ }^{31}$ Carbonara cita a Lei italiana n. 457 de 5 de agosto 1978 como um dos instrumentos legislativos que corroboraram essa idéia de 'recuperação' como intervenção 'simplificada', atribuindo-lhe uma identidade oficial a partir da definição de 'níveis de intervenção' (saneamento conservativo, reestruturação construtiva, etc). CARBONARA, G. Equivoci..., op. cit., p. 25 .

${ }^{32}$ ARGAN, G. C. Il governo dei beni culturali. Storia dell'Arte, n. 19, 1973, pp. 190-191.

${ }^{33}$ CARBONARA, G. Equivoci..., op. cit, p.26. trad. nossa. "Conservation [...] è stata intesa come il "lato migliore' del restauro (quello eminentemente conservativo, che non si sporca le mani con le questioni di reintegrazione delle lacune e soprattutto di rimozione delle aggiunte)."
} 
'revitalização', 'recuperação', 'renovação', 'reconversão', 'reciclagem' são atribuídos indistintamente às intervenções em sítios industriais de interesse cultural como se fossem meros projetos de reforma ${ }^{34}$. Não se trata apenas de uma questão de termos impróprios empregados ocasionalmente e por descuido. Tais denominações - certamente bastante distantes do restauro como ato histórico-crítico - , evidenciam, por um lado, o escasso ou inexistente reconhecimento dos atributos culturais desses conjuntos urbanos; e, por outro, o flagrante desconhecimento dos preceitos mais elementares das teorias da restauração. $\mathrm{O}$ emprego do termo 'reciclagem', por exemplo, geralmente empregado no sentido de adaptação para nova utilização, dirige-se diretamente ao novo uso como prioridade da intervenção. No campo semântico, contudo, o termo nos remete à idéia de aproveitamento de dejetos, de coisa inútil que precisa ser aprimorada ou reinventada. ${ }^{35}$

Conotações semelhantes associam-se à expressão 'áreas desativadas', comumente empregada em grande parte da bibliografia sobre projetos de intervenção em antigas áreas industriais. Como destaca Dezzi Bardeschi, o termo evidencia a atenção prioritária aos valores fundiários do terreno subutilizado em detrimento das estruturas remanescentes que eventualmente poderiam ser valorizadas e tuteladas ${ }^{36}$. Independentemente da pertinência das análises consideradas de modo isolado (a questão da valorização econômica, da recuperação de áreas contaminadas, da reabilitação de áreas e edifícios subutilizados, da revitalização de bairros degradados, etc. $)^{37}$, prevalece a ausência de discussão sobre a caracterização desses artefatos como bens culturais e sobre o seu tratamento conforme a teoria do restauro; ou seja, os possíveis aspectos culturais do artefato a ser transformado são suplantados por outras prioridades, quando não absolutamente esquecidos. Logo, é comum a abordagem das chamadas 'áreas desativadas' como grandes reservas de terreno que abrigam edifícios 'embaraçantes' que devem ser eliminados ou transformados a partir de projetos de 'reciclagem', nos quais a aparência de 'antigo' é explorada para agregar

\footnotetext{
${ }^{34}$ KÜHL, B. M. Questões teóricas relativas à preservação do arquitetura industrial. Desígnio Revista de História da Arquitetura e do Urbanismo, n. 1, março 2004, pp.109-110.

${ }^{35}$ Ver considerações apresentadas anteriormente em: RUFINONI, M. Preservação do patrimônio industrial na cidade de São Paulo: o bairro da Mooca. Dissertação de Mestrado. São Paulo: FAUUSP, 2004, p.155.

36 DEZZI BARDESCHI, Marco. Dall'archeologia al patrimonio industriale: un passaggio obbligato. ANAГKH, n.24, dicembre 1998, p.3.

37 O tema das 'áreas desativadas' ou 'desocupadas' (industriais, portuárias, etc.) tem sido amplamente discutido no ambiente europeu (aree dismesse na Itália; brownfields no Reino Unido; friches industrielles na França) porém dentro do campo disciplinar do projeto e do planejamento urbano, com raros e breves acenos sobre o eventual valor cultural das estruturas remanescentes e, conseqüentemente, pouco associado à idéia de intervenção defendida pela teoria do restauro. A bibliografia sobre o tema é extensa. Neste estudo buscamos referências gerais, sobretudo com relação ao contexto italiano, nos escritos de Stefano Garano, Michelangelo Russo, Raimondo Innocenti, Raffaele Paloscia, Francesco Karrer, Marina Dragotto, Egidio Dansero, Agata Spaziante, Angelica Ciocchetti, entre outros. Referências bibliográficas completas no final deste volume.
} 
curiosidade ao novo empreendimento, sem grandes preocupações conceituais com relação à importância documental, formal ou memorial desses conjuntos arquitetônicos.

Resta-nos indagar se a dificuldade de reconhecimento dos valores culturais referese a quaisquer conjuntos urbanos ou se a dúvida reside justamente na identificação e compreensão das especificidades inerentes ao patrimônio urbano-industrial. Se considerarmos a frágil recorrência aos fundamentos teóricos como origem dessas indeterminações, a diversificação dos artefatos contemplados pela atual dimensão dos interesses conservativos, uma das causas apontadas por Miarelli Mariani, é, sem dúvida, um sério elemento complicador. Diante da compreensão aparentemente consolidada de que o restauro não se volta apenas às chamadas 'obras de arte' mas também a diversos produtos da atividade humana possuidores de específicos valores culturais - valores esses que devem definir e guiar o restauro - , observamos que o primeiro passo da preservação urbana consiste no reconhecimento das qualidades peculiares do ambiente antrópico, na identificação de seus valores; atitude esta suficientemente presente no conceito moderno de restauro. $\mathrm{O}$ autor procura enfatizar, no entanto, que a fruição de um processo aparentemente simples assume proporções complexas no tratamento de artefatos de recente valorização patrimonial e, portanto, pouco estudados e interpretados, como são a grande maioria dos elementos e fenômenos que configuram o ambiente antropizado ${ }^{38}$ e, neste contexto, o patrimônio industrial.

Devido ao próprio percurso de reconhecimento dos valores ambientais - partindo da idéia de entorno imediato de monumentos excepcionais, passando pela valorização como 'moldura' insubstituível desse 'episódio emergente', até a sua apreensão como expressão autônoma e conjunto de lugares da experiência humana - a atuação sobre o patrimônio urbano esteve por muito tempo atrelada aos critérios e métodos empregados nas intervenções sobre as chamadas obras monumentais. Dessa forma, a tutela de valores ambientais, ou seja, valores de composição de um dado ambiente, acabou por privilegiar os aspectos externos, visíveis, formais; enquanto, na realidade, como observado por diversos autores, encontramo-nos diante de "resultados de atividades práticas que tendem a realizar uma arte de viver, uma arte de fabricar e que, justamente no cumprimento de tais fins, dão vida à formas, e por conseguinte também a valores estéticos". ${ }^{39}$ Logo, o patrimônio urbano

\footnotetext{
${ }^{38}$ MIARELLI MARIANI, Gaetano. Restauro e Territorio..., op. cit., p.13.

${ }^{39}$ Idem, p.13. Trad. nossa. "In realtà ci si trova, di regola, davanti ai risultati di attività pratiche che tendono a realizzare un'arte di vivere, un'arte di fabbricare e che, proprio nel perseguire il loro fine, danno vita a forme, quindi anche a valori estetici." (Grifo do autor).
} 
que se busca compreender é produto de uma série de fenômenos (práticas e funções cotidianas) não necessariamente voltados à materialização de formas ou de conjuntos arquitetônicos intencionalmente construídos como 'obras de arte', ainda que assumam tal conotação, em certos casos. Esse patrimônio deve, portanto, ser apreendido, valorizado e tutelado não somente, ou prioritariamente, com base em valores formais e sim com base em sua importância testemunhal e em seu papel na composição de uma estrutura, de um organismo figurativamente completo. Nesse sentido, uma valorização que priorize características materiais e visíveis mostra-se inadequada para o estudo do patrimônio urbano e a difusão dessa idéia talvez tenha contribuído para o precário desenvolvimento de instrumentos de análise mais apropriados, sobretudo se considerarmos a diversidade de ambientes antropizados e suas respectivas particularidades.

Partindo de pressupostos pouco claros, diversas questões deixam de ser abordadas com o rigor necessário e geram novas dificuldades interpretativas e operacionais. Uma das questões levantadas por Miarelli Mariani nesse sentido é a velha polêmica do encontro entre o antigo e o novo, tema ainda controverso pois o modo de abordar a inserção do novo evidencia, uma vez mais, a frágil compreensão desse valor estrutural, daquela 'literatura arquitetônica' defendida por Roberto Pane ${ }^{40}$. Defende-se, geralmente, a substituição de edifícios históricos por novas construções que mantenham os volumes originais e sejam realizadas com materiais, cores e outros elementos baseados no repertório tradicional. Tais procedimentos acabam por alterar o ambiente tornando-o "nem antigo e nem moderno", 41 além de por em risco a própria estrutura e organicidade responsáveis por seus especiais valores.

As falhas metodológicas na identificação e valorização dos valores ambientais ficam ainda mais claras na análise das diretrizes propostas por grande parte dos planos urbanísticos italianos ${ }^{42}$. Mesmo naqueles considerados mais eficazes é comum

\footnotetext{
${ }^{40}$ PANE, R. Città antiche, edilizia nuova [1956-1957]. In: Attualità e dialettica del restauro. Chieti: Marino Solfanelli, 1987, p.129.

${ }^{41}$ Nesse tema em particular, Miarelli Mariani coloca-se em sintonia com as idéias de Leonardo Benevolo e Ludovico Quaroni, contra o 'ambientamento' e a favor da integração harmoniosa entre restauro e projeto arquitetônico. "[Um centro antigo] na maioria feito de edifícios novos substituídos aos velhos nos mesmos lugares e com os mesmos alinhamentos seria um resultado intolerável; nem antigo nem moderno; conservaria, nos dizeres de Quaroni, apenas os defeitos do antigo e nenhum dos seus valores." Trad. nossa. "[Un centro antico] fatto in maggioranza di edifici nuovi sostituiti ai vecchi negli stessi luoghi e con gli stessi allineamenti sarebbe un risultato intollerabile; nè antico nè moderno; conserverebbe, come dice Quaroni, solo i difetti dell'antico, e nessuno dei pregi”. BENEVOLO, L. La conservazione dei centri antichi e del paesaggio come problema urbanistico. Ulisse, anno XI, fasc. XXVII, 1957, p.1446.

${ }^{42}$ MIARELLI MARIANI, Gaetano. Restauro e Territorio..., op. cit., p.15. O autor cita o plano intitulado 'Hipótese de organização territorial para o programa regional de desenvolvimento do Lazio', elaborado com
} 
encontrarmos previsões que ignoram as características estruturais mais essenciais dos sítios urbanos de interesse cultural. Em sua grande maioria, os planos urbanos e territoriais pautam-se por parâmetros prioritariamente quantitativos e funcionais e sua eficácia é verificada a partir de dados numéricos abstratos como a metragem quadrada de áreas destinadas a determinados usos e o número de habitantes supostamente beneficiados. Os planos de maior abrangência, quando abordam especificidades patrimoniais da área em estudo, geralmente o fazem em um segundo momento, como se o planejamento ou o 'reequilíbrio' territorial - no sentido de conjunto de ações voltadas ao alcance de metas de desenvolvimento econômico e social -, fosse uma primeira etapa de definição de objetivos gerais e o restauro - voltado à garantir a transmissão ao futuro das reconhecidas qualidades desse mesmo ambiente - , viesse depois, em uma segunda etapa (que talvez nunca aconteça). Nessa asserção, os objetivos do planejamento urbano assumem a posição de premissas da intervenção e a preservação e o restauro submetem-se às mesmas. Se a preservação fosse realmente um dos objetivos, jamais poderíamos aceitar essa seqüência de prioridades. Nessa lógica operativa, as premissas apontadas, alheias aos interesses culturais, podem justamente prever a destruição dos mesmos valores que se pretendia salvaguardar. Por outro lado, o próprio conceito de restauro urbano não admitiria esses intervalos operativos, pois, como temos tratado, um de seus principais objetivos é justamente projetar as condições necessárias para favorecer a preservação, em concomitância com as exigências contemporâneas de crescimento e desenvolvimento urbano. ${ }^{43}$ É imprescindível, portanto, buscar um caminho de projeto integrado, no qual as prioridades do restauro sejam consideradas simultaneamente com as demais questões envolvidas, considerando-as como ações intimamente integradas e correlacionadas.

Também na legislação italiana voltada ao urbanismo o autor destaca análoga falta de integração propositiva e operacional. As operações de restauração (ou recuperação) são tratadas pela lei urbanística como uma disciplina separada, ou como uma etapa menos importante e não necessariamente integrada e contínua ao processo de planejamento

a participação de Luigi Piccinato, Piero Moroni e Marcello Vittorini, em 1967, como exemplo de proposta alheia ao contexto cultural e às realidades territoriais da área considerada [MINISTERO dei lavori pubblici, Provveditorato regionale alle opere pubbliche nel Lazio. Ipotesi di assetto territoriale per il progetto di programma regionale di sviluppo del Lazio, Roma, 1967]. Por outro lado, considera a 'Proposta de organização do território do Lazio', de 1973, bastante apropriada na análise da estrutura do território e na defesa de alternativas de adequação que satisfaçam de uma lado as razões culturais e históricas e de outro, e no pleno respeito das primeiras, as exigências da vida contemporânea [REGIONE Lazio. Documento per la deliberazione programmatica sull'assetto del territorio regionale. Roma, 1973]. Sobre o tema, consultar ainda: MIARELLI MARIANI, G. Su alcune attuali difficoltà..., op. cit., pp.133-137.

${ }^{43}$ MIARELLI MARIANI, Gaetano. Restauro e Territorio..., op. cit., p.16 
urbano. A falta de visão unitária de ambos os processos impulsiona a realização de intervenções conservativas autônomas, pontuais e desvinculadas de quaisquer hipóteses e propostas urbanas; muitas vezes em absoluto contraste com os próprios pressupostos da preservação. ${ }^{44}$ De fato, segundo Mirelli Mariani "os ditames legislativos apresentam a característica comum de contradizer de modo flagrante a norma das Cartas de Restauro", 45 ou seja, da Carta 1972 e da Carta de Veneza, documentos cujas diretrizes oferecem caminhos seguros, fundamentados em amplos debates, para a condução de intervenções em áreas urbanas de interesse cultural.

Essa contradição pode ser observada seja na equivocada legitimação de operações há muito ultrapassadas pela cultura do restauro, seja pelos próprios termos empregados que alimentam perigosas práticas erroneamente confundidas com o restauro. Comodamente lacônica, a principal lei italiana sobre construção e intervenção baseia-se em interpretações subjetivas e abre caminho para a livre aplicação de procedimentos evidentemente inadequados para a atuação em edificações e sítios de interesse cultural. Face às lacunas da lei, operações de intervenção definidas como 'manutenção extraordinária', voltada à modificações e renovações de partes dos edifícios; ou 'reestruturação urbanística', voltada à substituição do tecido existente por outro diverso; ou mesmo 'restauro', definido como o conjunto de operações que “compreendem a consolidação, a 'repristinação’ e a renovação dos elementos construtivos do edifício"; ${ }^{46}$ foram indistintamente aplicadas tanto em

\footnotetext{
${ }^{44} \mathrm{O}$ autor comenta a desconexão entre restauro e urbanismo na legislação italiana com base no tratamento dado ao tema nas leis: Lei n. 457 de 5 de agosto 1978, Normas para a construção residencial; Lei n.10 de 28 janeiro de 1977, Normas para a ocupação do solo, Lei urbanística n. 1150 de 17 de agosto 1942, entre outras. MIARELLI MARIANI, G. Sul recupero..., op. cit., pp.56-66. Para aprofundamentos sobre a análise crítica da legislação italiana sobre tutela, restauro e instrumentos urbanísticos, consultar o número especial da revista Restauro. La legge 457/78 ed i centri storici. Napoli: Edizione Scientifiche Italiane, n.41, 1979; assim como os textos de Carbonara, Capasso e Dezzi Bardeschi publicados pela mesma revista em 1998: Restauro, n.144, pp.38-98; ou ainda: BENEDETTI, S. La cultura del restauro nel 'recupero' dei centri storici. Storia Architettura, n. 1, 1982, pp. 89-104.; GURRIERI, F.; VAN RIEL, S. e SEMPRINI, M. P. Il restauro del paesaggio. Firenze: Alinea, Associazione ARSPAT, 2005.

45 MIARELli MARIANI, G. Sul recupero..., op. cit., p.59. Trad. nossa. “[...] i dettami legislative presentano il carattere comune di contraddire in modo flagrante la norma delle Carte del Restauro; vale a dire le regole certamente più adeguate a guidare gli interventi di recupero conservativo, qual è postulato in larga misura dai centri storici."

46 Lei 457/78, art. 31. "Definição das intervenções. As intervenções de recuperação do patrimônio arquitetônico existente assim são definidas: a) intervenções de manutenção ordinária, aquelas que se referem às obras de reparação, de renovação e substituição de acabamentos dos edifícios e aquelas necessárias para integrar ou manter em eficiência as instalações tecnológicas existentes; b) intervenções de manutenção extraordinária, as obras e as modificações necessárias para renovar e substituir partes, mesmo estruturais, dos edifícios, assim como para realizar e completar os serviços higiênico-sanitários e tecnológicos, sempre que esses não alterem os volumes e as superfícies das unidades imobiliárias individuais e não comportem modificações nas destinações de uso; c) intervenções de restauro e de saneamento conservativo, aquelas voltadas a conservar o organismo construído e a assegurar a funcionalidade mediante um conjunto sistemático de obras que, no respeito dos elementos tipológicos, formais e estruturais do próprio organismo,
} 
edificações sem interesse cultural, como naquelas cujos critérios evidentemente deveriam ser outros, principalmente em um país com ampla e sólida tradição investigativa no campo da preservação e do restauro. Tanto na elaboração dos planos urbanísticos como em significativa parcela da legislação italiana, as lacunas na verdade configuram-se como oportunas brechas para a priorização de interesses diversos daqueles próprios à esfera cultural como as citadas metas desenvolvimentistas e econômicas desconectadas do tema em pauta.

Essa relação entre desenvolvimento e conservação ou entre urbanismo e restauro não pode ser uma relação qualquer: nem as operações sobre o patrimônio urbano podem ser confiadas exclusivamente e pontualmente ao restauro, nem tampouco ao planejamento urbano; deve-se, como defendem os pressupostos da conservação integrada, buscar soluções a partir de esforços e contribuições multidisciplinares. É necessário compreender contudo que a extensão do conceito de patrimônio não representou apenas uma conquista quantitativa de novas funções no campo do restauro. A ampliação conceitual e a atenção às especificidades de ambientes complexos como são os sítios industriais que ora analisamos, impõem a busca por procedimentos e adequações que, de posse dos pressupostos teóricos amplamente debatidos, nos permitam conduzir soluções apropriadas e originais em diferentes situações. ${ }^{47}$ Procedimentos que deveriam pautar-se, inevitavelmente, pela busca de qualidade projetual a partir da integração inequívoca entre composição arquitetônica e restauro. Essa busca, no entanto, não vem acontecendo; ao contrário, proliferam as obras intituladas como operações de restauro absolutamente alheias às definições, métodos e procedimentos tradicionalmente debatidos nesse campo disciplinar ${ }^{48}$. Mais uma vez, emerge como problemática central a carência conceitual, a dificuldade de se delimitar os objetos e os objetivos da intervenção de restauro.

permitam-lhe destinações de uso compatíveis. Tais intervenções compreendem a consolidação, o ripristino e a renovação dos elementos constitutivos do edifício, a inserção de elementos acessórios e de instalações solicitadas pelas exigências de uso, a eliminação dos elementos estranhos ao organismo construído; d) intervenções de reestruturação da construção, aquelas voltadas a transformar os organismos construídos mediante um conjunto sistemático de obras que podem conduzir a um organismo construído em todo ou em parte diverso do precedente. Tais intervenções compreendem o repristino ou a substituição de alguns elementos constitutivos do edifício, a eliminação, a modificação e a inserção de novos elementos e instalações; e) intervenções de reestruturação urbanística, aquelas voltadas à substituir o existente tecido urbanístico-construtivo com outro diverso mediante um conjunto sistemático de intervenções construtivas, até mesmo com a modificação do desenho dos lotes, dos blocos construídos e da rede viária." (Trad. e grifos nossos)

47 De acordo com a proposições de Giovanni Carbonara e Michele Cordaro, conforme acenamos anteriormente. CARBONARA, G. I Trent'anni di una buona Carta del Restauro. Restauro, n. 131-132, 1995, p. 57; CORDARO, M. Sull'inutilità di una nuova carta del restauro. Restauro \& Città, n. 11-12, 1989, pp. 97-101.

${ }^{48}$ MIARELLI MARIANI, G. Esiste il restauro? Storia Architettura, anno II, n.2, 1975, pp.5-6. 
Dessas lacunas conceituais nascem perigosas influências. A valorização dos sítios históricos a partir da contrapartida econômica é talvez a pior delas. A nefasta priorização dos lucros a serem gerados em quaisquer operações prefixadas pelo "re" (recuperação, revitalização, renovação...) conduz não somente à classificação dos bens culturais em ultrapassadas categorias, como também ao retrocesso de se desvalorizar grande parte da chamada 'arquitetura menor', do tecido conectivo e das urbanidades não imediatamente identificadas como patrimônio monumental. Frente aos interesses econômicos, os bens culturais passam a ser classificados entre aqueles inadequados para um novo uso, porém possuidores de valor formal ou simbólico; e aqueles que, por outro lado, podem ser reutilizados de modo lucrativo. Situação que repropõe a velha distinção de Cloquet entre monumentos 'vivos' e 'mortos', ultrapassada pela teoria e pela normativa do restauro desde as Instruções italianas de $1938 .{ }^{49}$ Tal classificação coloca os edifícios privados de valores singulares ou recentemente reconhecidos em uma difícil situação, já que receberiam alguma atenção somente no contexto de uma atribuição funcional lucrativa. Incômoda situação à qual freqüentemente são submetidos os sítios industriais; exatamente o inverso do tratamento desejado aos conjuntos dessa natureza, uma vez que precisam enfrentar, frente ao mercado imobiliário, o já difícil reconhecimento de suas qualidades compositivas como primeiro obstáculo para sua efetiva tutela. Conforme observa Miarelli Mariani, "a salvaguarda dos bens arquitetônicos - e tanto mais das construções históricas privadas de valores individuais - pode ser garantida somente subtraindo-lhes à desgastante dinâmica do uso - própria dos bens econômicos - através de sua ancoragem ao atributo fundamental de valor que lhe compete e que, nessa concepção [econonômica], é praticamente ignorado e fortemente limitado". 50

Outra questão que por vezes assume caráter desproporcional é a valorização dos sítios históricos a partir de sua função social. É evidente que o tema faz parte das preocupações da preservação e do restauro mas a questão deve ser encarada com critério e bom senso. Tem-se observado proposições exageradas nas quais as áreas históricas ou tombadas, entendidas como bens coletivos, devem necessariamente ser capazes de

${ }^{49}$ Cf.: CLOQUET, Louis. La restauration des monuments anciens. Revue de l'Art Chrétien, 1901, apud KÜHL, B. M. Preservação..., op. cit., pp.124-125; Istruzioni per il Restauro dei Monumenti, Ministero della Pubblica Istruzione, 1938.

${ }^{50}$ MIARELLI MARIANI, G. Centri Storici: alcune definizioni [1980]. In: Centri Storici..., op.cit., p.38. Trad. nossa. "Infatti, la salvaguardia dei beni architettonici - e tanto più dell'edilizia storica priva di valori singolari - può essere garantita solamente sottraendoli alla logorante dinamica d'uso - propria dei beni economici - attraverso il loro ancoraggio all'attributo fondamentale di valore che gli compete e che, in questa concezione, viene praticamente ignorato o fortemente limitato." (Grifo do autor). 
satisfazer todas as exigências sociais da cidade atual. Opera-se, portanto, uma nova modalidade de 'utilidade', dessa vez 'social', e comete-se, assim como na priorização econômica, o equívoco de contrariar os verdadeiros moventes da preservação propondo a atribuição de funções não compatíveis com determinadas estruturas. ${ }^{51}$

Frente aos entraves conceituais e conseqüentemente metodológicos e práticos, diversos autores buscaram indicar caminhos para viabilizar a preservação e o restauro urbano. Para Miarelli Mariani seria necessário, inicialmente, repensar algumas etapas básicas e amplamente discutidas com novo fôlego e disposição interpretativa. Nesse sentido, de posse dos conceitos teóricos e atento às orientações das Cartas, deve-se atentar para os reais objetivos do restauro e dosar adequadamente os fatores envolvidos. Além das indiscutíveis razões culturais, devem ser considerados os benefícios gerados para a coletividade e a melhoria da qualidade de vida nas áreas afetadas, ou seja, ter em mente que a preservação do patrimônio urbano "significa, em síntese, assegurar as relações sociais e o bem estar da comunidade, tendo como vínculo ineliminável o respeito aos seus valores históricos e estéticos, prevalentes e não repetíveis". 52 Essas áreas de interesse cultural não podem, por outro lado, ser consideradas como ilhas separadas do processo de desenvolvimento urbano e territorial, daí novamente o apelo à integração e à condução adequada de uma série de ações correlacionadas, urbanísticas e arquitetônicas, conforme as prerrogativas da Declaração de Amsterdã. Até aqui, nenhuma novidade. A questão primordial nesse processo, portanto, é como efetivamente codificar os pressupostos de Amsterdã diante da evidente cisão entre as disciplinas do urbanismo e do restauro. Um primeiro passo seria buscar, a partir de criteriosos debates interdisciplinares, uma orgânica integração entre as duas normativas de modo a correlacionar as prescrições dos planos voltados à preservação com os instrumentos urbanísticos. As normativas deveriam, ainda, subordinar-se a planos mais amplos com o intuito de permitir um processo contínuo em ambas as frentes, ou seja, um projeto que verdadeiramente vislumbre a tutela e o desenvolvimento como metas interdependentes. Os procedimentos para efetivamente alcançar tais objetivos, no entanto, ainda estão por ser definidos. ${ }^{53}$

\footnotetext{
${ }^{51}$ MIARELLI MARIANI, G. Centri Storici. Alcune definizioni..., op. cit., pp.39-40.

${ }^{52}$ MIARELLI MARIANI, G. Sul recupero..., op. cit., p.61.

${ }^{53}$ A previsão de diretrizes de preservação em planos urbanísticos mais abrangentes, de modo a evitar que essas áreas configurem-se como 'ilhas' na cidade é, em parte, contestada por Renato De Fusco que propõe alternativas de intervenção do particular ao global, retornaremos ao tema mais à frente. DE FUSCO, Renato. Dov'era ma non com'era: il patrimonio architettonico e l'occupazione. Firenze: Alinea, 1999, p.40, 60-62.
} 
Essa criteriosa revisão conceitual e operativa abriria caminhos para o desenvolvimento de políticas coerentes de intervenção urbana, com prioridades claras e livre das citadas confusões e ambigüidades conceituais. E também forneceria, podemos dizer, instrumentos cognitivos apropriados para o estudo amplo e pluridisciplinar sobre os processos de formação e transformação urbana, etapa prévia imprescindível na elaboração de quaisquer planos e projetos de intervenção. Nesse sentido, Miarelli Mariani destaca o papel crucial dos estudos voltados à compreensão da estrutura preexistente da área considerada. Projetos pautados pela coerente integração disciplinar que intentamos circunscrever devem considerar a realidade preexistente como ponto de partida na elaboração de qualquer proposta pois é essa estrutura, carregada de valores culturais, a origem de todo o processo. É, portanto, a partir do conhecimento dessa preexistência que podemos debater e elaborar propostas que atendam, de modo integrado e contínuo, tanto as exigências conservativas quanto as exigências próprias da vida moderna. Miarelli Mariani esclarece:

De fato, para satisfazer as nossas exigências são necessários, pelo contrário, modelos que encontrem o seu fundamento primordial e a sua legitimidade na concretude da antiga, articulada e complexa estrutura do território; uma realidade que não pode ser removida arbitrariamente mas, basicamente, deve ser colocada em condições de satisfazer, de uma parte as razões da história, de outra, e em seu pleno respeito, as exigências reais da contemporaneidade. ${ }^{54}$

Procedimento também defendido por Barthélemy ${ }^{55}$, como vimos, que expõe com clareza a necessidade de se buscar, na atuação sobre áreas de interesse cultural, métodos diferenciados de pensar e de fazer urbanismo; baseados no reconhecimento dos valores do patrimônio urbano como primeiro passo para quaisquer proposições práticas consonantes com a preservação desse legado e com o desenvolvimento desejável e necessário da cidade contemporânea. Logo, como defendem ambos os autores, a dialética conservaçãodesenvolvimento não é uma utopia e sim um instrumento de compreensão e modificação dos parâmetros de intervenção e produção da cidade.

\footnotetext{
${ }^{54}$ MIARELLI MARIANI, G. Sul recupero..., op. cit., p.62; MIARELLI MARIANI, G. Su alcune attuali difficoltà..., op. cit., p.135. Trad. nossa. "Infatti per soddisfare le nostre esigenze occorrono, al contrario, modelli che trovino il loro primo fondamento e la loro legittimità nella concretezza dell'antica, articolata $\mathrm{e}$ complessa struttura del territorio; una realtà che non può essere rimossa arbitrariamente ma, più semplicemente, deve essere messa in grado di soddisfare, da una parte le ragioni della storia, dall'altra, e nel loro pieno rispetto, le esigenze reali della contemporaneità."

${ }^{55}$ BARTHÉLEMY, J. De la Charte de Venise a celle des Villes Historiques. Restauro, n. 131-132, 1995, pp. 109-116; BARTHÉLEMY, J. Noveau rôle pour l'urbaniste? Restauro, n.144, 1998, pp.17-22.
} 
Na seqüência de suas propostas, Miarelli Mariani atenta para o caráter criterioso dessa primeira etapa de conhecimento do preexistente. Contrariamente ao que em geral se observa na maioria dos estudos preliminares à elaboração de planos urbanísticos, as análises prévias não podem ser encaradas como banais investigações de rotina voltadas à aspectos quantitativos e funcionais. Ao contrário, essas análises devem compreender uma completa e acurada leitura da realidade urbana, de seus dados funcionais, estruturais e formais, bem como abarcar a compreensão do tecido histórico, sua estrutura fundiária, processo formativo e os materiais, técnicas, padrões cromáticos e tipos construtivos que o compõem. ${ }^{56} \mathrm{Na}$ escala do território, deve-se ainda atentar para os modos de formação e fruição desses espaços ao longo do tempo, ou seja, para os mecanismos inicialmente espontâneos e progressivamente intencionais com os quais as comunidades tradicionais moldaram esses espaços de acordo com suas necessidades e interesses. ${ }^{57}$

Após essa primeira etapa cognitiva, o autor sugere que se discuta as intervenções em construções isoladas, sempre atentando para as relações existentes entre os chamados monumentos 'excepcionais' e a arquitetura menor que constitui o tecido. Sobre os primeiros podem recair normativas específicas e com relação à arquitetura menor, mesmo se confiada a uma normativa geral, será necessária uma visão de conjunto associada à problemática da preservação. Todas as ações propostas deverão pautar-se pelas diretrizes da Carta de Veneza e, no contexto italiano, também pela Carta de Restauro de 1972. Tais documentos esclarecem adequadamente as elaborações conceituais e toda a experiência acumulada pela cultura histórica sobre o restauro e constituem, nesse sentido, instrumentos fundamentais para afastar a arbitrariedade e conduzir projetos criteriosos. O caminho analítico-operativo proposto pelo autor, portanto, compreende três etapas fundamentais: "a aquisição dos conhecimentos, que impõe o controle dos relativos, múltiplos e diferenciados instrumentos e métodos; a exegese dos conhecimentos, que implica o domínio de um claro sistema conceitual" e, finalmente, "o emprego dos conhecimentos, que postula uma familiaridade com as atuais concepções do restauro". 58

Em texto mais recente, o autor acrescenta observações fundamentais. Como contrapartida às intervenções ditadas por critérios estilísticos e simulações figurativas, ou

\footnotetext{
${ }^{56}$ MIARELLI MARIANI, G. Sul recupero..., op. cit., p.64.

${ }^{57}$ MIARELLI MARIANI, G. Restauro e territorio..., op. cit., p.14.

58 MIARELLI MARIANI, G. Qualche pensiero..., op. cit., p.22. Trad. nossa. "L'acquisizione delle conoscenze, che impone la padronanza dei relativi, molteplici e differenziati strumenti e metodi; L'esegesi delle conoscenze, che implica il possesso di un chiaro sistema concettuale; L'impiego delle conoscenze, che postula una familiarità con le concezioni attuali del restauro."
} 
baseadas em "regurgitações lexicais" (as famosas operações prefixadas pelo 're'), defende a busca de um conhecimento criterioso não apenas da produção arquitetônica e urbana ditas antigas mas também das contribuições advindas da arquitetura moderna, procedimento que sublinha a necessária presença da história no processo de intervenção e produção do espaço urbano. "História que, contudo, não deve ser entendida como pedante erudição mas sim como imagem formativa e sintética da vida e da prática visiva; visão que, sozinha, pode gerar um verdadeiro procedimento operativo". ${ }^{59} \mathrm{O}$ caminho a ser percorrido poderia ser aquele trilhado pelo método muratoriano. No final dos anos 1940, Saverio Muratori desenvolveu estudos voltados ao reconhecimento dos conjuntos arquitetônicos como categoria histórica e como elementos dotados de específica consistência física e figurativa. Dessa forma, considerou adequadamente o problema arquitetônico em termos estruturais e buscou uma compreensão global do organismo construído de modo que cada elemento constitutivo é parte não intercambiável de um todo ${ }^{60}$. E justamente por ser parte de um todo caracterizado por determinadas especificidades formais e constitutivas, "cada um desses elementos é aquilo que é somente em virtude de sua relação e na sua relação com todos os outros componentes da estrutura". ${ }^{1}$ São esses valores estruturais assim correlacionados que geralmente respondem pelas qualidades da chamada 'construção de base' ou 'arquitetura menor'. Daí a necessidade de compreender o processo histórico de formação desses conjuntos, de onde derivaram e como se transformaram, para que se possa garantir a integridade de identidades formais únicas.

Seguindo semelhante caminho propositivo, Carbonara elenca uma série de questões a serem observadas e repensadas: uma reforma legislativa que incentive a colaboração de outras entidades nas operações de tutela, ainda que a responsabilidade principal permaneça confiada ao Estado; a elaboração de normas e regulamentações que traduzam na prática o conteúdo dessa legislação; a promoção de convincentes políticas de apoio fiscal para os imóveis tutelados; a coadunação entre tutela territorial e paisagística na elaboração de planos urbanísticos; o estímulo à qualidade projetual e de execução das

\footnotetext{
${ }^{59}$ MIARELLI MARIANI, G. Riflessioni su un vecchio tema: il nuovo nella città storica. Restauro, n.164, 2003 , p.33.

${ }^{60}$ Sobre o método de análise urbana e territorial proposto por Saverio Muratori, considerado por Miarelli Mariani como um importante passo na sistematização de estudos do ambiente construído, consultar: MURATORI, S. Studi per una operante storia urbana di Venezia. Venezia: Istituto Poligrafico dello Stato, s.d.; PIGAFETTA, Giorgio. Saverio Muratori architetto: teoria e progetti. Venezia: Marsilio, 1990; PIRAZZOLI, N. e CANDIDO, A. Restauro \& Città. In: Atti della giornata di studi sul tema: Restauro Urbano. Che fare?..., op. cit., bem como o número especial da revista Storia Architettura, VII, n.1-2, 1984.

${ }^{61}$ MIARELLI MARIANI, G. Riflessioni..., op. cit., p.33.
} 
obras de restauro e manutenção e, finalmente, a aplicação de uma contundente política de conservação integrada que garanta a salvaguarda dos bens culturais e incentive dinâmicas econômicas e sociais compatíveis, afastando, dessa forma, a velha idéia de que conservar (ou tombar) signifique 'mumificar' e 'congelar'. ${ }^{62} \mathrm{E}$ uma vez mais, defende que os fundamentos teóricos para promover tais medidas há tempos estão à nossa disposição, o que nos falta é buscar a correta aplicação prática, inicialmente por intermédio de uma nova legislação, depois por meio da concreta experimentação.

A temática da conservação integrada - argumento presente nas considerações de Miarelli Mariani e Carbonara -, tem levantado, contudo, certos questionamentos que não devem ser ignorados. A questão da integração das exigências da tutela aos planos urbanos de maior abrangência como um dos recursos para assegurar a continuidade e o diálogo entre áreas culturalmente representativas e o organismo urbano tem sido alvo de severas ressalvas na interpretação de Renato De Fusco. Segundo o autor, buscar a inserção de casos individuais de intervenção em planos diretores municipais ou regionais pode significar uma cômoda fuga diante da incapacidade ou falta de vontade para resolver a questão. O recurso tem sido utilizado por políticos e profissionais aéticos que lançam o tema a uma esfera superior e aproveitam o desenrolar do processo para cultivar outros interesses; e o real problema da tutela passa para segundo plano. ${ }^{63}$ Dentre outros motivos, a ineficácia de tal procedimento residiria na impossibilidade atual de se desenvolver, frente à dinâmica urbana contemporânea, um planejamento urbano em escala realmente global. Como alternativa o autor defende a necessidade de elaborarmos uma revisão de nossa cultura de projeto urbano. Essa revisão de procedimentos não visaria, em oposição direta, o desenvolvimento de projetos isolados e parciais que não se relacionam com o todo, mas sim a substituição de diretrizes gerais de cunho dedutivo por sistemas de projeto que alcançariam a generalização por via indutiva. Em oposição à lógica da 'caixa chinesa', em que sistemas mais abrangentes ditam as regras para os demais, deveríamos experimentar a lógica dos 'mosaicos', na qual diversos sistemas se apóiam mutuamente para formar um todo, procedimento interpretativo defendido pelo autor como o mais apropriado para as operações de restauro urbano. Dessa forma, a intervenção seria pensada do particular para o geral. Inicialmente seria necessário delimitar algumas áreas de intervenção que

\footnotetext{
${ }^{62}$ CARBONARA, G. Spunti di riflessione sulla salvaguardia dei centri storici. Restauro, n. 144, 1998, p.43.

${ }^{63}$ DE FUSCO, R., op. cit., p.40. O autor mostra-se bastante pessimista. Acredita que lança-se o tema a uma esfera superior sabendo-se que nessa escala mais ampla o problema nunca encontrará solução e, sendo assim, visa-se, na verdade, cultivar interesses e objetivos de promoção política.
} 
funcionariam como amostragens do processo indutivo; tal delimitação não tomaria por base limites administrativos abstratos e sim a concentração espacial de determinados problemas urbanos que seriam afrontados e solucionados na escala da amostragem determinada. Após a realização das intervenções, se os resultados fossem positivos, essas áreas transformariam-se em 'modelos', partes do sistema de 'mosaico' e elementos indutores de novos projetos. Caso contrário, se os resultados não fossem suficientemente úteis ou aplicáveis para outros contextos, as áreas abordadas não seriam consideradas soluções-modelo mas ao menos teriam recebido melhorias pontuais - em um bairro ou em parte dele, por exemplo - sem o envolvimento ou comprometimento de todo o organismo urbano. $^{64}$

Outra questão que impulsiona renovados debates e também traz à tona semelhantes incongruências conceituais é o debate sobre o encontro 'antigo-novo' que agora assume novos contornos e congrega novos adeptos. Quando convenientemente alicerçado em pressupostos teóricos de acordo com a teoria da restauração, o tema assume grande relevância e abre caminho para profícuos debates como a questão em torno da articulação entre projetos, a leitura do preexistente, o tratamento de lacunas, a reintegração da imagem. Na renovada polêmica sobre a relação ' antigo-novo', seja entre aqueles que defendem a inconciliabilidade, seja entre os que apóiam a inserção da produção contemporânea como expressão de nossa época, em consonância ou em dissonância com o preexistente; se a clareza conceitual sobre o quê e o porquê preservar permanecer como centro da questão, ainda podemos vislumbrar, na variedade das linhas adotadas, alguma coerência projetual $^{65}$. Contudo, as releituras do tema nem sempre têm sido alimentadas pelas diferenças entre correntes interpretativas e sim pela arbitrariedade com que grande parte dos projetos vem sendo conduzida, sobretudo quando se trata de artefatos recentemente valorizados, como os edifícios e sítios industriais, geralmente considerados como ‘terra de ninguém' e espaço livre para o novo, independentemente do interesse cultural das estruturas remanescentes.

Para Pier Luigi Cervellati, muitas das novas versões desse velho debate descortinam a atual dificuldade ou incapacidade de criar mecanismos operativos eficazes, mesmo de posse de toda a teoria e experimentação acumulada. Dessa forma, o autor

\footnotetext{
${ }^{64}$ DE FUSCO, R., op. cit., pp.61-62.

${ }^{65}$ Para um panorama das tendências de intervenção em áreas urbanas propostas pelas diferentes vertentes contemporâneas do restauro, e para indicações bibliográficas complementares, consultar: KÜHL, B. M. Preservação..., op. cit., pp.134-141.
} 
condena a inserção em ambientes históricos de certos projetos novos que reivindicam o status de 'obras de arte' e que parecem ignorar as diversas destruições que essa mesma visão provocara em um passado não muito distante. Tais projetos, propostos como alternativas 'vivificadoras' e testemunhos de nosso tempo contra a 'mumificação' da cidade, ignoram as especificidades do patrimônio urbano e configuram-se, em última análise, como diferenciadas manifestações da velha tendência especulativa onde o verdadeiro movente é o interesse econômico. ${ }^{66}$ Nesse processo, muitas intervenções intituladas de 'restauro urbano' atuam, na verdade, na contramão da conservação integrada não apenas por ignorar o patrimônio existente e propor modelos formais e espaciais cujos parcos resultados práticos já conhecemos, mas também por interferir radicalmente na composição funcional e social original, inserindo novos usos nem sempre compatíveis e expulsando os antigos moradores. Observa-se, portanto, uma crise no modo de projetar e de elaborar planos urbanos e uma recorrência constante a modelos e soluções comprovadamente ineficazes. A observação atenta das considerações de Cervellati demonstra que o autor não é exatamente contra os novos projetos; ou seja, não busca defender a incompatibilidade entre o antigo e o novo, mas sim denunciar a recorrência constante à polêmica como subterfúgio para a apresentação de projetos alheios à preservação do patrimônio urbano, projetos de má qualidade, os quais o autor não se intimida de nomear 'feios'. Para aqueles que ainda ficam perplexos com as obras de restauro que 'congelam' a cidade, sugere ironicamente que indiquem e desenhem novas alternativas, porém sem recorrer aos velhos e gastos argumentos e com a humildade necessária para evitar "as presunções de um projeto voltado ao "novo milênio", provavelmente outra reproposição de qualquer modelo já conhecido: outro "modernismo ou pós-modernismo destinado a ser 'revisitado' a cada três ou quatro anos". ${ }^{67}$

Interessante ressaltar a resposta de Antonino Terranova às considerações de Cervellati, debate que revela o desconhecimento, ou talvez um frágil entendimento, dos princípios da preservação e do restauro amadurecidos em décadas de discussões teóricas e experimentações práticas nesse campo. Em síntese, apesar de concordar com a tutela do patrimônio urbano, Terranova curiosamente defende o empirismo projetual como forma de

\footnotetext{
${ }^{66}$ CERVELLATI, Pier Luigi. Nessun'alternativa alla conservazione integrata. Italia Nostra, anno XXV, $\mathrm{n}$. 206, 1981, p.17.

${ }^{67}$ CERVELLATI, P. L., op. cit., p.22. Trad. nossa. "Con umiltà, ben inteso, laica; tale da evitare le presunzioni di un progetto rivolto al 'duemila' il quale altro non sia che la consunta riproposizione di un conosciuto novecento, di un ben noto modernismo o post-modernismo destinato a essere 'rivisitato' ogni tre o quattro anni."
} 
"resolver praticamente o problema", e responde que o processo de projeto é naturalmente contrário ao excesso de teorizações, “às atitudes téorico-doutrinárias, burocráticonormativas, globalístico-ideológicas”, responsáveis pela falência da experiência. E frente às críticas de Cervellati aos novos projetos desprovidos de critérios, acrescenta: "Não seria salutar um pouco menos de doutrina em troca de um pouco de empirismo? Ou, também aqui, a motivação [das críticas] é o medo?". ${ }^{68}$ Tal postura, ao atribuir à teoria do restauro o caráter de mera 'cultura defensiva' responsável pela imobilização e passividade no embate com os problemas urbanos contemporâneos, adota um argumento perigoso e evidencia o flagrante desconhecimento (ou seria descaso?) frente aos princípios fundamentais do restauro crítico. Nessa asserção declaradamente 'empírica' os resultados projetuais obtidos tenderão a repercutir outras influências; ou seja, no descarte de fundamentações teóricas consideradas 'paralisantes', outros interesses, bastante dinâmicos como aqueles econômicos, poderão desenvolver-se livremente. Por esse caminho, como já observava Bruno Zevi na década de $1950^{69}$, proliferam as arquiteturas de má qualidade que contribuem para alimentar a crença na incompatibilidade entre o novo e o antigo.

Assim, novamente busca-se enfatizar que a inserção da produção contemporânea ao lado da preexistência histórica é essencialmente um problema de projeto; uma resposta que deve ser buscada em verdadeiros projetos de arquitetura, devidamente fundamentados no juízo histórico-crítico. E ainda, uma arma poderosa contra os projetos arquitetônicos desastrosos gerados pela especulação imobiliária. Segundo De Fusco, pautar a conservação do patrimônio urbano pela proibição excessiva, recurso que de certa forma abstém-se de buscar soluções, é um caminho perigoso pois acaba por impulsionar, pelo contrário, o abusicionismo e a arbitrariedade. ${ }^{70} \mathrm{~A}$ via alternativa seria a busca por uma nova cultura de projeto arquitetônico e urbanístico que, retomando as observações de Miarelli Mariani, se comprometesse em buscar o diálogo com a história e com o restauro, não a partir de frágeis laços interdisciplinares, mas sim a partir do real entendimento da interdependência dos

\footnotetext{
${ }^{68}$ TERRANOVA, Antonino. L'alternativa c'è ed è progettuale. Italia Nostra, n.220, 1983, p.62. Trad. nossa. "Sul piano più generale, un atteggiamento 'progettuale' è il contrario delle attitudini teoretico-dottinarie, generalizzanti e tipizzanti, burocratico-normative (nella fattispecie, vincolistiche), globalistico-ideologiche, le quali hanno dominato largamente negli anni Settanta il dibattito sul recupero, e sono, a mio parere, alla radice del parziale fallimento delle esperienze. [...] Non sarebbe salutare un pó meno dottrina in cambio di un pó di empirismo? O anche qui, la motivazione è la paura?". Para comentários contrários às posturas de Terranova, consultar: RANELLUCCI, S. Restauro Urbano: teoria e prassi. Torino: UTET, 2003, pp.77-79.

${ }^{69}$ ZEVI, B. Visione prospettica e spazio-temporalità nell'architettura moderna. L'Architettura Cronache e Storia, n.11, settembre 1956, pp. 322-323.

${ }^{70}$ Como observara Roberto Pane na década de 1950: PANE, R. Città antiche, edilizia nuova [1956-1957]. In: Attualità e dialettica del restauro. Chieti: Marino Solfanelli, 1987.
} 
saberes na concepção projetual. Essa aproximação deveria ser buscada já no próprio processo de formação do arquiteto, seja na atenção aos preceitos éticos que deveriam pautar o aprendizado, como observara Bonelli ${ }^{71}$, seja no incentivo à um renovado debate sobre o papel do profissional na intervenção e na produção da cidade existente.

Uma vez que não se pode proibir de se construir além de um razoável limite de tempo, das duas, uma: ou retém-se que a arquitetura seja uma arma indispensável contra a especulação imobiliária ou a considera-se, no melhor dos casos, somente uma cobertura formalística do extra-poder especulativo. Como conseqüência, no primeiro caso, nas nossas escolas seria necessário incrementar o estudo científico do projeto, da história, do restauro, da tecnologia e de tudo aquilo que contribua para a qualidade da arquitetura. No segundo, diante do chamado ao pragmatismo, à relação entre a Universidade e a profissão, para as nossas escolas seria mais útil (talvez com a graduação curta [laurea breve], um enésimo expediente demagógico e desqualificante), ensinar como monopolizar um solo, como vencer um concurso de projetos, como tornar mais ágil uma prática de concessões e similares. ${ }^{72}$

Uma formação pautada pela correta compreensão da interdisciplinaridade aqui defendida deveria pressupor a imprescindível atenção aos instrumentos teóricos da preservação e do restauro na elaboração de quaisquer projetos de intervenção no patrimônio urbano, não importa a escala. Portanto, não se deveria admitir ensinar a intervir sobre a preexistência histórica "recorrendo à linguagem das 'estrelas' da arquitetura"; pelo contrário, a elaboração de um projeto de restauro urbano deveria ser estudada "longe das revistas ilustradas, lendo diretamente as estruturas no território e no ambiente histórico, revelando-as com cuidado, percebendo-as e tocando-as com os dedos", ${ }^{73}$ ou seja, buscando estudos criteriosos para fundamentar os caminhos interpretativos adotados. De certa forma, as questões envolvidas na preservação do patrimônio urbano nos induzem a discutir o próprio processo de produção da cidade. Mais do que construir em espaços livres, a

\footnotetext{
${ }^{71}$ BONELLI, Renato. Il rapporto antico-nuovo nei suoi aspetti storici generali. In: Attualità urbanistica del monumento e dell'ambiente antico. Milano: Görlich, Centro Studi della Triennale di Milano, 1957, p.57.

${ }^{72}$ DE FUSCO, R., op. cit., pp.46-47. Trad. nossa. "Poiché non si può vietare di costruire oltre un ragionevole limite di tempo, delle due l'una: o si ritiene che l'architettura sia un'arma indispensabile contro la speculazione edilizia oppure la si considera, nei migliore dei casi, solo una copertura formalistica dello strapotere speculativo. Di conseguenza nel primo caso nelle nostre scuole bisognerebbe incrementare lo studio scientifico della progettazione, della storia, del restauro, della tecnologia e di quant'altro contribuisca alla qualità dell'architettura. Nel secondo, visto peraltro il richiamo al pragmatismo, al collegamento fra l'Università e la professione, per le nostre scuole sarebbe più utile (magari con la laurea breve, un ennesimo espediente demagogico e dequalificante), insegnare come accaparrare un suolo, come vincere una gara d'appalto, come rendere più spedita una pratica di concessioni e simili".

${ }^{73}$ RANELLUCCI, S., op. cit., p. 267. Trad. nossa. "L'architettura per il restauro urbano certamente non può essere insegnata ricorrendo il linguaggio delle 'star' dell' architettura; essa si impara lontano dalle riviste patinate, leggendo direttamente le strutture nel territorio e nell'ambiente storico, rivelandole con cura, annusandole e sfiorandole con le dita."
} 
realidade da cidade contemporânea nos lança à discussão sobre o reconhecimento dos valores da preexistência e sobre a pertinência de se conduzir as contínuas transformações do espaço urbano a partir de uma fundamentada interpretação histórico-crítica.

Como ressalta Carbonara, a partir do momento em que são reconhecidos os valores patrimoniais que motivam o imperativo da conservação de determinado bem, devemos inevitavelmente operar de modo a garantir a sua tutela e preservação. Quando tratarmos de intervenções em áreas urbanas de interesse patrimonial, os critérios prevalentes devem sempre ser aqueles de caráter cultural. As questões de ordem prática (estratégias técnicas de intervenção, prescrições administrativas, procedimentos burocráticos e legislativos, arrecadação de fundos, etc.) e de ordem urbanística (ordenação do tráfego, circulação, etc.) deverão ser devidamente observadas, mas sem assumir a prioridade da intervenção, como equivocadamente muitos estudos da conservação integrada têm proposto. As modificações, adaptações e propostas de novos usos são necessárias para a preservação do bem, notadamente quando tratamos de áreas desocupadas e degradadas como muitos sítios industriais; no entanto, devemos ter clareza de que a questão do novo uso é um meio para buscar a preservação, e não a finalidade da intervenção ${ }^{74}$. Os conceitos, princípios e diretrizes metodológicas sobre como proceder estão lançados, figuram em ampla produção teórica e nos documentos internacionais anteriormente analisados, o que nos falta é buscar uma correta interpretação e um sólido entendimento desses preceitos. De posse de uma lúcida interpretação dos mesmos, não somente guiaremos adequadamente a atividade prática conforme as premissas históricocríticas, como também poderemos evidenciar, de modo fundamentado e com bons exemplos práticos, que a elaboração de projetos criteriosos pode atender tanto às prioritárias exigências da preservação, como também, em certa medida, aquelas de ordem econômica, sem precisar recorrer à destruição completa ou à inserção incisiva de novas estruturas.

\footnotetext{
${ }^{74}$ CARBONARA, Giovanni. Avvicinamento al Restauro. Napoli: Liguori, 1997, pp. 429-433.
} 


\section{INTERVENÇÕES URBANAS EM SÍTIOS INDUSTRIAIS DE INTERESSE CULTURAL}

O distanciamento entre teoria e prática no tratamento do patrimônio urbano assume proporções ainda maiores quando os sítios em pauta são de origem industrial. No tratamento de sítios industriais de interesse cultural, os entraves anteriormente mencionados e a debilidade interpretativa dos preceitos que regem a teoria do restauro ficam ainda mais evidentes, sobretudo devido às dificuldades relacionadas com a valorização desses artefatos, à incompreensão de suas especificidades, ou ainda devido às fortes pressões especulativas de diferentes naturezas.

Em geral, os projetos de intervenção para áreas industriais tratam-nas como reservas de terreno para novos projetos, a despeito dos valores eventualmente atribuíveis às estruturas preexistentes que, em muitos casos, não chegam sequer a ser devidamente estudadas e analisadas. Esse potencial fundiário se deve à grande extensão das áreas ocupadas, ao fato de geralmente localizarem-se em regiões estratégicas de grandes cidades e ao considerável baixo custo dos terrenos. Dessa forma, representam uma oportunidade para novos empreendimentos imobiliários e projetos de reabilitação urbana em grande escala, ocasiões em que poucas vezes o tema da representatividade cultural dos artefatos preexistentes é efetivamente abordado.

Em propostas de intervenção para áreas dessa natureza, quando a questão do patrimônio industrial é citada, raramente assume prioridade na elaboração dos projetos. Diferentemente das diretrizes propostas pela teoria da preservação dos bens culturais, o estudo das estruturas preexistentes e das especificidades que compõem o conjunto construído, conforme temos tratado, é um tema geralmente tratado em segundo plano. A prioridade é a transformação em si, o novo projeto, a alteração de um quadro de degradação para impulsionar a valorização, e o patrimônio industrial existente assume um papel coadjuvante. Nessa asserção, a composição espacial do conjunto industrial considerando as especificidades de implantação e projeto condicionadas pela atividade produtiva e as relações desses conjuntos com as áreas urbanas envoltórias, elementos que compõem uma paisagem particular - geralmente não é respeitada. Em muitos casos, a preservação do patrimônio industrial resume-se à manutenção de edifícios ou estruturas ('excepcionais'?) isoladas: um edifício de arquitetura interessante, uma chaminé ou um 
equipamento 'curioso'; estruturas preservadas para serem mergulhadas em uma ambiência nova, em uma imagem nova na qual o passado industrial é identificável somente pela presença de resíduos descontextualizados. Logo, o entendimento da noção de patrimônio urbano, a identificação de conjuntos construídos como monumentos coletivos portadores de valores e especificidades que compõem paisagens únicas, aquisição conceitual que buscamos enfatizar nesta pesquisa, geralmente não comparece na elaboração de projetos de intervenção em sítios industriais de interesse cultural.

Tomando como base predominantemente exemplos da experiência italiana - país com proeminente tradição investigativa sobre a preservação e o restauro, como temos visto - , a análise de alguns projetos de intervenção em sítios industriais evidencia a presença inequívoca dos entraves operacionais que aqui buscamos destacar. De modo geral, observamos a transformação de áreas degradadas como a prioridade da intervenção e a manutenção do patrimônio industrial e de suas paisagens, quando comparece, está em segundo plano. As intervenções objetivam transformar e valorizar essas áreas tanto a partir de projetos 'âncora' - grandes obras, geralmente confiadas a arquitetos de renome, que objetivam incrementar a valorização da região, induzir novos projetos ou promover o turismo - , como na proposição de novos usos, nem sempre compatíveis, ou o próprio reloteamento dessas áreas para novas construções. Cabe ressaltar, contudo, que os comentários sobre os projetos que se seguem não intentam traçar um panorama exaustivo das intervenções em andamento na Itália, nem propor exemplos-chave para ilustrar a questão da preservação do patrimônio industrial; tentativa que, com certeza, comportaria a abordagem de diversos outros aspectos de grande complexidade que escapam ao nosso escopo. Buscamos comentar algumas experiências recentes que pudessem nos fornecer elementos para debater certos aspectos envolvidos no tratamento do tema, bem como evidenciar os específicos entraves conceituais e metodológicos analisados pela presente pesquisa.

Um projeto que tem assumido grande repercussão no cenário italiano é o Projeto Urbano Ostiense-Marconi, em Roma. Trata-se de um amplo projeto voltado à requalificação de um perímetro que abarca dois bairros separados pelo rio Tibre. O projeto busca intervir em parcelas residenciais construídas na década de 1950, no bairro Marconi, e áreas industriais subutilizadas ou desocupadas, dispersas pelo bairro Ostiense. 
A cidade de Roma não passou por momentos intensos de industrialização e também não chegou a sediar setores produtivos de grande porte, como Milão ou Nápoles, por exemplo. O bairro romano Ostiense, no entanto, possui uma série de edificações industriais e significativas instalações destinadas à produção, coleta e distribuição de serviços urbanos; estruturas não necessariamente concentradas em um único sítio, mas suficientemente próximas para configurar uma paisagem urbana expressiva. Essa região reúne vários equipamentos e sedes produtivas, hoje desativadas, como o Gasômetro, os Mercados Gerais, o Matadouro, a Central Elétrica e outras importantes instalações fabris ${ }^{75}$.

O tratamento dos diversos sítios e edifícios industriais desocupados existentes nessa região integra as políticas de renovação urbana previstas pelo último plano diretor de Roma. No âmbito do projeto Ostiense-Marconi, o plano diretor vislumbra tanto a realização de melhorias na escala urbana (obras viárias, construção de novas pontes para integrar ambos os bairros, e até mesmo a tentativa de promover a navegabilidade do rio Tibre desde o Testaccio até a cidade de Ostia Antiga como um diferencial para revitalizar a área), bem como uma série de intervenções pontuais de recuperação de edifícios industriais ou demolição e reconstrução com o intuito de induzir a requalificação local. Alguns projetos já foram executados como a instalação da Faculdade de Direito da Universidade Roma Três na antiga Vidraria Bordoni, da Faculdade de Arquitetura em parte do antigo Matadouro $^{76}$ e a instalação de um museu na Central Elétrica Montemartini. Está também prevista a instalação do Museu da Ciência na área dos antigos Gasômetros. ${ }^{77}$

\footnotetext{
75 Para um panorama histórico sobre o desenvolvimento industrial da área Ostiense e dados sobre os principais edifícios da área, consultar: NERI, Maria Luisa. Sviluppo produttivo ed espansione urbana. Roma Moderna e Contemporânea, anno VIII, n.1/2, 2000, pp.83-141; CANCIANI, Marco (Org.). Piano di assetto per l'attuazione del progetto urbano Ostiense-Marconi. Roma: Kappa, 2004, pp.16-37.

${ }^{76}$ A publicação: Fabbriche della conoscenza: Roma Tre nel territorio e nella riqualificazione dell'area Ostiense. Roma: Università degli Studi Roma Tre, 2001, reúne informações gerais sobre a adaptação de alguns edifícios industriais da área Ostiense para novos usos voltados à Universidade Roma Três. A publicação possui caráter ilustrativo e não há menção aos critérios adotados nos projetos de intervenção citados.

${ }^{77}$ Marcelloni ressalta outras importantes iniciativas em andamento em Roma, além da área Ostiense. No caminho do chamado 'eixo cultural' que parte do auditório de Renzo Piano e alcança o Foro Itálico e o Palácio das Armas (de Luigi Moretti), os antigos alojamentos militares da via Guido Reni estão sendo adaptados para abrigar parte da Universidade La Sapienza e outros empreendimentos como o Museu Nacional das Artes do Século XXI (Museo Nazionale delle Arti del XXI Secolo), projeto de Zaha Hadid recentemente inaugurado, e a sede da Agência Espacial Italiana, projeto de Massimiliano Fuksas. Outras iniciativas relevantes são: projeto 'Nova Saxa Rubra' ao longo de Via Flaminea, que prevê a requalificação das Fornalhas Mariani (Fornace Mariani); e a 'Nova Fiorentini', antiga área industrial nas proximidades da via Tiburtina transformada em 'cidadela da pequena e média empresa', projeto do arquiteto Paolo Desideri. Há o intuito de transformar o eixo tradicionalmente industrial da Tiburtina, em área voltada à inovação tecnológica empresarial. MARCELLONI, Maurizio. Roma: Recenti esperienze di sostituzione. In:
} 


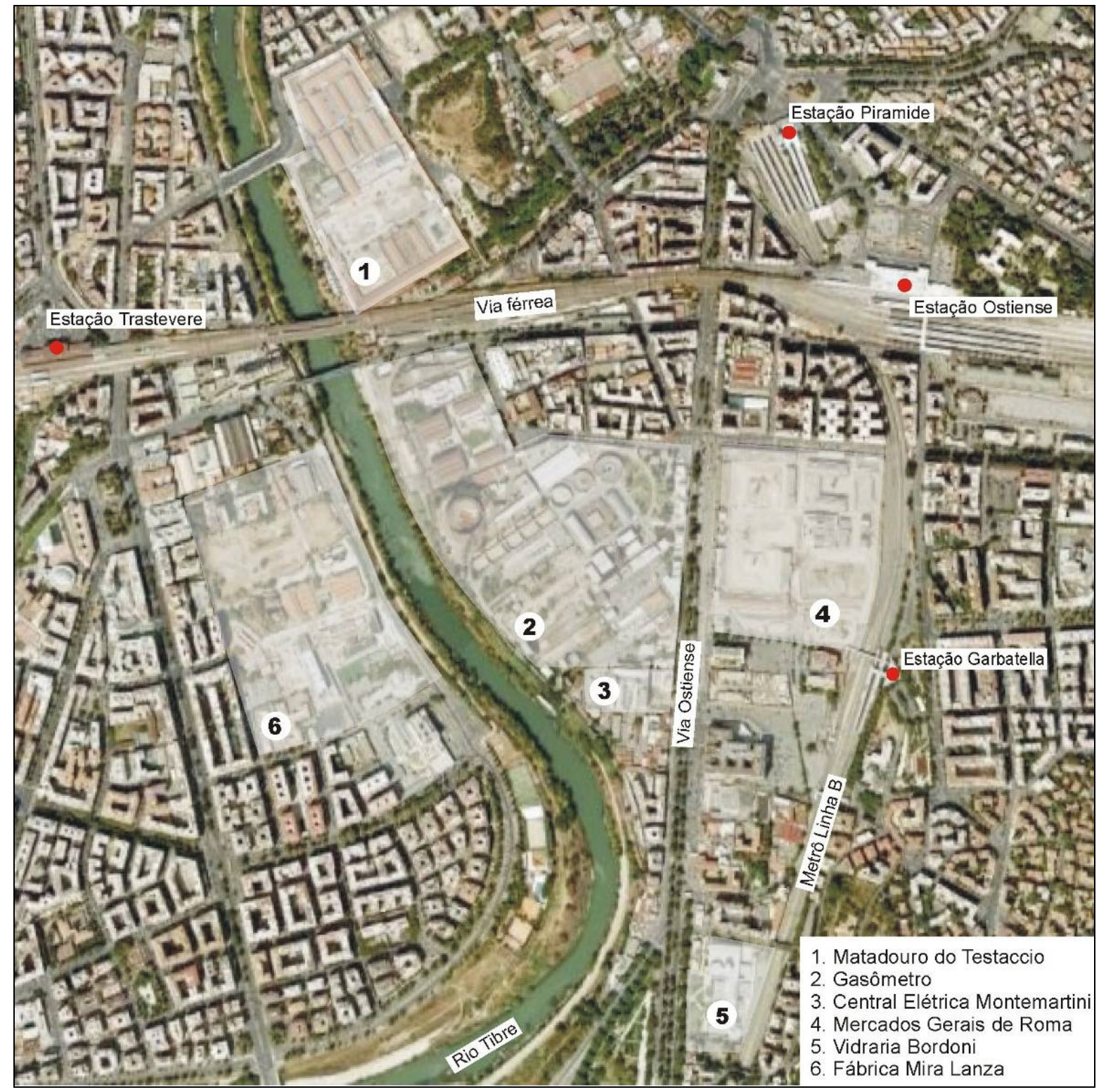

06. Sítios industriais no bairro Ostiense, Roma, Itália. Os sítios destacados (e áreas envoltórias) integram o Projeto Urbano Ostiense-Marconi (sem escala).

Esses projetos têm sido propostos e executados em etapas. Dada a grande extensão da área encampada pelo projeto urbano - uma das principais dificuldades de abordagem e tratamento desses sítios, como vimos - , a requalificação da região tem sido buscada a partir da promoção de intervenções pontuais, de projetos de readaptação de edifícios ou sítios industriais considerados isoladamente com o intuito de promover, gradualmente, a valorização da área. A transformação desses setores industriais desativados está prevista em plano diretor, mas não há diretrizes claras com relação à

DRAGOTTO, Marina e GARGIULO, Carmela (Org.). Aree dismesse e città: esperienze di metodo, effetti di qualità. Milano: FrancoAngeli, 2003, pp.215-222. 
preservação dessas estruturas e inexiste um plano inicial, pensado em escala urbana, que coordene a condução desses trabalhos pontuais visando a coadunação entre a preservação e as necessárias transformações urbanas, atentando, sobretudo, para as especificidades do conjunto construído entendido como um patrimônio urbano.

Tem sido adotado o procedimento de planejamento denominado planning by doing, metodologia predominante na redação do novo plano diretor de Roma e bastante criticada por alguns estudiosos do urbanismo. Tal metodologia pressupõe que o plano diretor é 'um plano que se faz operando', ou seja, que se resolve ao longo do processo de implantação das propostas pontuais, método considerado por Archibugi como um 'nãométodo', já que alimenta a prática empírica e enfraquece a estratégia propositiva e operacional, elementos básicos de um planejamento. ${ }^{78}$ Nesse modo de intervir, as obras isoladas podem até apresentar bons resultados, mas não necessariamente se articulam com o todo que é, como patrimônio urbano, um monumento único. Devemos ter em mente que não somente os sítios de atividades produtivas específicas possuem importantes valores compositivos mas também a articulação entre os vários sítios industriais da área, responsáveis pela configuração da paisagem do bairro industrial. Dessa forma, essas soluções pontuais, buscadas conforme a disponibilidade de recursos e desarticuladas entre si, podem representar um perigoso caminho no tratamento desse patrimônio e gerar, inclusive, o caráter de puzzle, já observado por estudiosos. ${ }^{79}$

No caso da área Ostiense, alguns projetos de adaptação de sítios industriais para novos usos apresentaram resultados interessantes, apesar do citado isolamento. A instalação do novo pólo expositivo dos Museus do Capitólio na Central Elétrica

\footnotetext{
${ }^{78}$ ARCHIBUGI, Franco. Il nuovo Piano regolatore di Roma (2001): un piano senza strategia. In: Rome: a new planning strategy. London, New York: Routledge, 2005, p. 11. "Planejar através do fazer é um slogan que diz tudo e nada ao mesmo tempo. Uma vez que planejar é já um fazer, e nada mais que um fazer [...]; mas se identificado somente no fazer, significa eliminar o sentido específico do planejar, que quer, me parece, significar justamente o não querer somente fazer, mas fazer mediante um plano (doing by planning). E então que sentido tem essa expressão?". Trad. nossa. "Pianificare attraverso il fare è uno slogan che dice tutto e niente nello stesso tempo. Giacché pianificare è già un fare, e niente altro che un fare [...]; ma se identificato solo nel fare, significa eliminare il senso specifico del pianificare, che vuole, mi sembra, significare proprio di non volere solo fare, ma fare mediante piano (doing by planning). E allora che senso ha l'espressione ?" (Grifos do autor).

${ }^{79}$ RACHELI, Alberto M. Il quartiere Ostiense-Marconi nel nuovo Piano Regolare. Roma Moderna e Contemporânea, anno XII, n.1/2, 2004, p.255. Para o autor, esse tipo de orientação do plano diretor funciona como 'um mosaico de casuais tesselas localizadas naquele 'tabuleiro de xadrez' da cidade [...] Um incerto, desproporcionado e descontínuo puzzle, gerado por exigências diversas, em momentos diferentes." Trad. nossa. "[...] un mosaico di casuali tasselli situati in quello scacchiere della città in modo a dir poco inopinato. un incerto ed oltremisura dicontinuo puzzle, sorto da esigenze diverse, in tempi diversi, ed in base a affari diversi".
} 
Montemartini e as obras realizadas no antigo Matadouro, são exemplos nesse sentido. O projeto do Museu buscou soluções projetuais interessantes a partir de uma leitura cuidadosa dos espaços internos da antiga Central Elétrica, de modo a inserir o novo uso com respeito ao preexistente. $\mathrm{Na}$ adaptação dos espaços internos, a galeria de esculturas clássicas ocupou a antiga sala de máquinas onde, curiosamente, as máquinas foram mantidas: um imponente grupo de motores a diesel e um turbo-alternador a vapor. A exposição das esculturas segue ao lado das máquinas preexistentes permitindo a leitura do espaços originais e a fruição do novo uso, em relevante contraste. Trata-se de um caso exemplar onde a adaptação funcional não significou a anulação dos espaços originais, não considerou o edifício industrial como um 'receptáculo' para o novo (como geralmente acontece); ao contrário, não somente respeitou suas características, como também evidenciou a memória das formas de produção ali sediadas, e sem comprometer as funções do novo museu que, na verdade, resultou em um espaço ainda mais interessante. ${ }^{80}$

As obras de adaptação do antigo Matadouro do Testaccio também apresentaram resultados significativos. O complexo, construído entre 1888 e 1891 e desativado em 1977, ocupa uma área de 10 hectares e vem recebendo adaptações para usos culturais, a exemplo do pavilhão ocupado pelo Museu de Arte Contemporânea e outros recintos adaptados para a Faculdade de Arquitetura. Pretende-se ainda inserir outros usos como salas para mostras de arte, ateliês de artistas e serviços voltados para o bairro. O projeto foi fundamentado em rigoroso estudo histórico e amplos levantamentos ${ }^{81}$. Até o momento, as intervenções realizadas dialogam convenientemente com o preexistente.

\footnotetext{
80 Sobre o projeto de adaptação da Central Elétrica em Museu, ver: ROMEO, Ippolita. La centrale termoelettrica Montemartini. Patrimoine de l'industrie, n. 6, 2001, pp. 89-98; STORELLI, Grazia. Museo in doppia esposizione, l'ex-centrale elettrica Montemartini. Recupero e Conservazione, n. 38, 2001, pp. 55-66. ${ }^{81}$ Para aprofundamentos, consultar: CUPELLONI, Luciano (Org.). Il Mattatoio di Testaccio a Roma. Roma: Gangemi, 2001.
} 

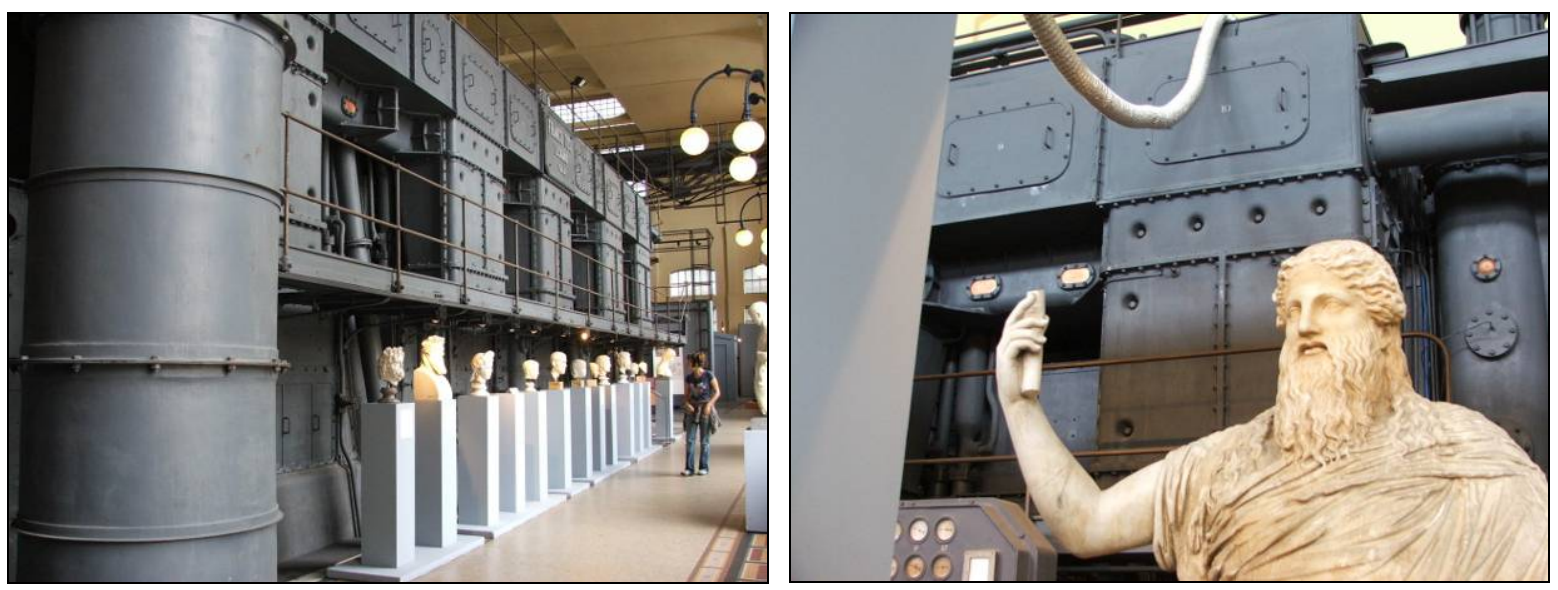

07. Novo pólo dos Museus do Capitólio na Central Elétrica Montemartini (Musei Capitolini Centrale Montemartini), vista da sala das máquinas. Projeto de adaptação realizado em 1997 (Foto da autora, 2006).
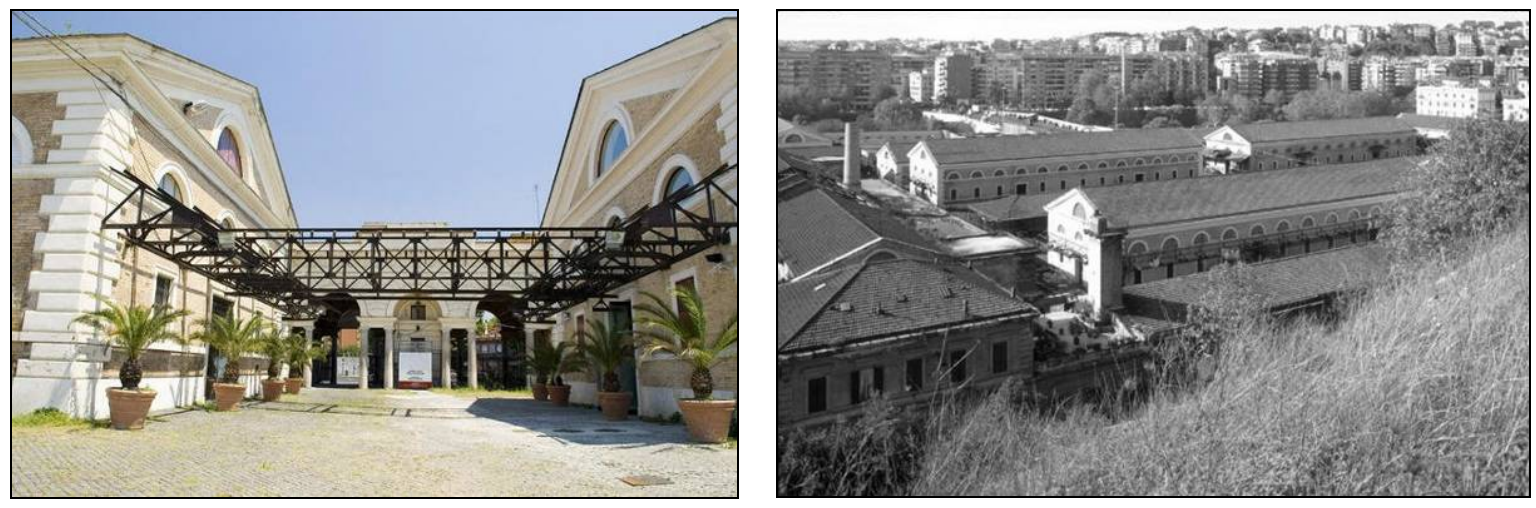

08. Antigo Matadouro do Testaccio, Roma. À esquerda, pavilhões ocupados pelo MACRO, Museu de Arte Contemporânea de Roma. À direita, vista geral do conjunto arquitetônico (site MACRO).

Do ponto de vista de alguns profissionais do planejamento urbano, contudo, tanto a questão do isolamento dos projetos, como também a própria qualidade projetual das intervenções, são considerados temas secundários, questionamentos que não cabem aos planejadores. A postura de Marcelloni é clara. O autor prioriza a funcionalidade dos novos projetos como elementos que trarão vitalidade a certos setores urbanos e busca destacar os meios políticos para viabilizar a realização das obras, mas não leva em consideração o valor cultural possivelmente atribuível às estruturas envolvidas ou mesmo a qualidade projetual das intervenções a serem realizadas. Pelo contrário, o autor entende como 'qualidade' somente o resultado final que repercutirá nos arredores a partir dessas intervenções, e não o projeto propriamente dito. Postura que evidencia um flagrante distanciamento entre o pensamento urbanístico e as questões da preservação. 
Por qualidade eu entendo o resultado final da intervenção e não a específica qualidade arquitetônica do projeto realizado. Creio que a qualidade deva ser medida, se posso usar esse termo, sobre o caráter estratégico que cada projeto grande ou pequeno deve apresentar e que se avalia com relação a dois parâmetros: a sua contribuição ao fortalecimento geral da cidade, à sua competitividade, à sua imagem geral [...]; e a sua contribuição para a melhoria da qualidade local, pontual, onde o projeto se insere. ${ }^{82}$

Dentre as obras previstas pelo projeto urbano Ostiense-Marconi, a análise do projeto de reutilização dos Mercados Gerais de Roma evidencia alguns dos principais problemas interpretativos e metodológicos associados à prática de intervenção em áreas industriais, conforme temos abordado. A idéia de propor a revitalização do complexo surgiu logo após a sua desativação, em 2002, e em pouco tempo iniciaram-se os procedimentos para viabilizar a obra. Uma primeira fase de trabalhos foi destinada ao estudo da área, aquisição de dados sobre a população local e pesquisas sobre o complexo industrial e sobre o tecido urbano circundante com intuito de verificar quais os possíveis novos usos para a área.

O complexo dos Mercados Gerais de Roma foi construído pela administração municipal entre 1910 e 1926, na via Ostiense, e ocupa uma área de aproximadamente $82.000 \mathrm{~m}^{2}$ em um quadrilátero de cerca de $280 \mathrm{~m}$ de lado. ${ }^{83} \mathrm{O}$ projeto original é composto por uma série de pavilhões em concreto armado. Em 2002, os Mercados Gerais foram desativados e transferidos para outro local mais afastado do centro urbano. O complexo compreende basicamente duas partes: o antigo mercado das ervas, próximo da via Ostiense - recinto com edifícios de no máximo dois pavimentos, alguns dos quais de notável interesse arquitetônico - , e a área dos grandes pavilhões: a ex-Ovipol, o novo e o velho mercado do peixe, edifícios de grandes dimensões e considerável relevância arquitetônica no âmbito das tipologias industriais.

\footnotetext{
${ }^{82} \mathrm{O}$ autor Maurizio Marcelloni é professor de projeto urbano na Universidade La Sapienza. MARCELLONI, M., Roma: Recenti esperienze..., op. cit., pp.221-222. "Per qualità io intendo il risultato finale dell'intervento e non la specifica qualità architettonica del progetto realizzato. Credo che la qualità vada misurata, se posso usare questo termine, sul carattere di strategicità che ogni progetto grande o piccolo deve presentare e che si valuta rispetto a due parametri: il suo contributo al rafforzamento generale della città, alla sua competitività, alla sua immagine generale [...]; e il suo contributo al miglioramento della qualità locale, puntuale dove il progetto si inserisce."

${ }^{83} \mathrm{O}$ projeto dos Mercados Gerais foi elaborado pelo escritório técnico da administração municipal e coordenado pelo engenheiro Emilio Saffi. O projeto previa duas zonas separadas: uma para o mercado das frutas e ervas e outra para o mercado de peixe, carne e ovos, bem como uma ampla área destinada aos binários de ligação com a ferrovia, edifícios para escritórios, depósitos, etc. CAMPITELLI, A. e TOLOMEO, M. G. Servizi generali e industrie private sulla via Ostiense. In: Architettura e urbanistica: uso e trasformazione della città storica. Venezia: Marsilio, 1984, p.458; MUSSO, Umberto. Roma. Il riuso del complesso degli ex Mercati Generali. In: DRAGOTTO, M. e GARGIULO, C. (Org.)., op. cit., pp.223-229.
} 
Segundo Musso, a escolha de um novo uso procurou respeitar os valores arquitetônicos do complexo e corresponder às expectativas sociais do bairro e da cidade. Após os primeiros estudos, principalmente baseados nas demandas locais, optou-se pela transformação dos antigos Mercados em um centro de atividades e serviços destinados aos jovens: esportes, formação, cultura e entretenimento em geral ${ }^{84}$. Para construir a chamada Cidade dos Jovens, intervenção que deveria abarcar a adaptação de alguns edifícios existentes e a construção de novos, foi realizado um concurso internacional de projetos em 2004, tendo sido escolhida a proposta do arquiteto holandês Rem Koolhaas.

A realização do concurso de projetos evidencia o interesse da administração pública local de 'internacionalizar' a cidade, colocando-a em confronto com outras metrópoles européias no plano das grandes obras arquitetônicas, bem como na oferta de atividades culturais e de entretenimento, como esclarece a própria prefeitura na exposição dos objetivos do projeto ${ }^{85}$. Ainda segundo essa exposição, o projeto escolhido "é um exemplo concreto de como Roma está intervindo na recuperação de estruturas e de complexos surgidos na primeira fase industrial e agora em desuso", e com relação às estruturas preexistentes, "é obviamente respeitoso com relação à história desses edifícios, e ainda tutela sua qualidade e seus valores arquitetônicos, combinando funcionalmente antigo e moderno". ${ }^{86}$ A observação do andamento das obras, no entanto, evidencia outra realidade. Grandes demolições já foram realizadas e o material divulgado sobre o projeto não faz nenhuma menção aos critérios empregados para inserção das novas estruturas no complexo antigo. As maquetes eletrônicas apresentadas ressaltam a nova arquitetura e os edifícios demolidos sequer são citados, sendo até mesmo difícil identificar 'onde está o antigo', em meio às novas estruturas grandiosas. Em linhas gerais, a proposta prevê a construção de novos volumes em linguagem arquitetônica marcadamente contemporânea

\footnotetext{
${ }^{84}$ Musso ressalta as dimensões gerais do complexo que lhe conferem destacada expressividade no contexto urbano no qual se insere: superfície total do complexo: $82 \mathrm{mil} \mathrm{m}^{2}$; área edificada: cerca de $42 \mathrm{mil} \mathrm{m}^{2}$; superfície da rede viária e áreas desocupadas: cerca de $40 \mathrm{mil} \mathrm{m} \mathrm{m}^{2}$. MUSSO, U. Il riuso..., op. cit., p.224.

${ }^{85}$ Essa tendência, a "internacionalização da cidade", tem sido observada da execução de várias obras projetadas por grandes nomes da arquitetura mundial: Renzo Piano (Auditório); Odile Decq (ampliação da sede do MACRO, Museu de Arte Contemporânea), Zaha Hadid (Museu de Arte do Século XXI), Richard Meier (Museu Ara Pacis), além da previsão de futuros projetos de Massimiliano Fuksas, Santiago Calatrava, Juan Navarro Baldeweg, Vittorio Gregotti, entre outros. ROSSI, Fabio. Il futuro di Roma nel segno dei grandi architetti. Il Messaggero. Roma, 03 ago. 2005.

${ }^{86}$ Dizeres extraídos do site oficial do Comune di Roma, departamento VI: Políticas da programação e planejamento do território (Politiche della programmazione e pianificazione del territorio). Trad. nossa. "Il progetto per i nuovi Mercati è un esempio molto concreto di come Roma stia intervenendo nel recupero di strutture e di complessi sorti nella prima fase industriale e poi caduti in disuso [...] Il progetto di riqualificazione è ovviamente rispettoso della storia di questi edifici, e anzi ne tutela la qualità e i pregi architettonici, combinando funzionalmente antico e moderno."
} 
ao lado de alguns dos antigos edifícios que serão adaptados para novas funções. Serão também criados grandes espaços comerciais que funcionarão como praças públicas, o que tem determinado a destruição de grande parte do antigo complexo industrial. Interessante ainda notar que a nova arquitetura e a adaptação dos antigos edifícios parecem ter sido pensados separadamente, já que, como aponta a descrição do processo de desenvolvimento da proposta, a recuperação da 'parte histórica' dos Mercados Gerais foi confiada a outros arquitetos, os romanos Bruno Moauro e Roberto Capocaccia. Metodologia de projeto que evidencia o frágil reconhecimento das particularidades responsáveis pela configuração do conjunto industrial e do próprio processo de restauro, como se as novas construções a serem inseridas em um patrimônio urbano pudessem ser projetadas a despeito do preexistente, da 'parte histórica', cujo tratamento caberia a outros profissionais. Outra questão controversa no processo de requalificação dos Mercados foi a condução e abrangência dos estudos históricos preliminares, considerados insuficientes por muitos estudiosos. Ainda antes da escolha do projeto de Rem Koolhass, em 2000, Racheli já demonstrava preocupação com a realização de estudos mais aprofundados sobre as edificações existentes e sobre o processo de transformação da área, recurso imprescindível para subsidiar a elaboração dos futuros projetos de intervenção. Essa carência de informações documentais, por si só já deveria inviabilizar a proposição de novos projetos. $^{87}$

Além dos edifícios industriais do Mercado que foram destruídos sem grandes aprofundamentos e estudos prévios, o movimento de terra realizado para a construção das novas obras trouxe à tona documentos arqueológicos inesperados: uma antiga via romana, um engenhoso sistema para isolamento da umidade composto por centenas de ânforas enfileiradas, e partes dos antigos túneis do sistema de drenagem do rio Almone; elementos que despertam a atenção sobre a necessidade de estudos ainda mais aprofundados sobre os sítios a serem restaurados, principalmente em uma cidade como Roma. ${ }^{88}$

87 RACHELI, Alberto M. Conservare innovando o progettare distruggendo? Roma Moderna $e$ Contemporânea, anno VIII, n.1/2, 2000, pp. 13-36. Na mesma publicação, os artigos de Antonio Parisella e Barbara Elia também abordam a questão.

${ }^{88}$ Além das estruturas de engenharia, foram também encontrados sarcófagos, estátuas, afrescos e cerâmicas. A descoberta dos restos arqueológicos não comprometeu o andamento do projeto de Koolhaas. Estuda-se apenas a possibilidade de manter algumas aberturas para permitir a visualização dos artefatos. BUCCI, Carlo Alberto. Ostiense, il tesoro dei mercati, scoperte centinaia di anfore. La Repubblica. Roma, 14 dic. 2007. 


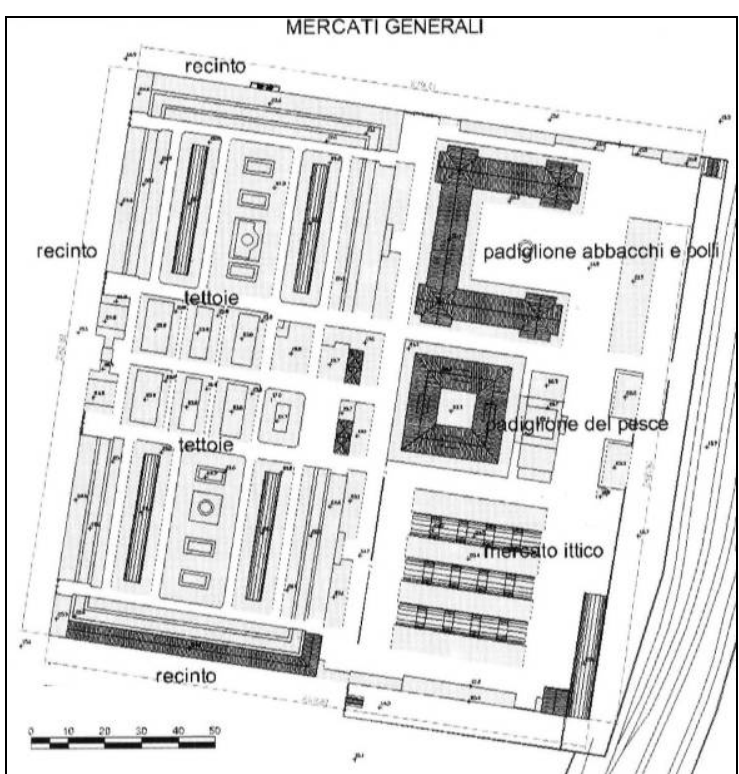

09a. Mercados Gerais de Roma. Configuração original: pavilhões e espaços externos para venda de produtos (CANCIANI, M., op. cit., p.173).

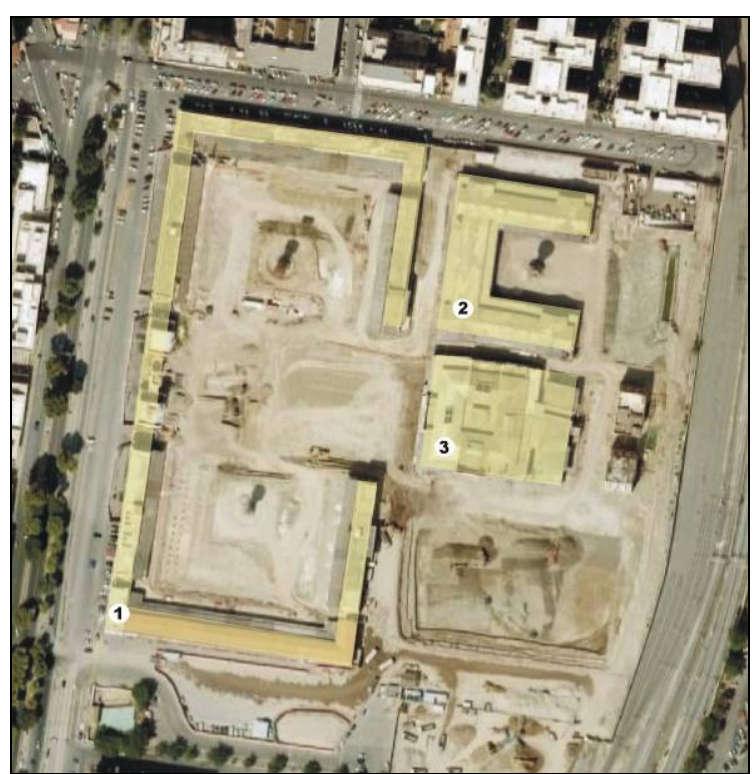

09b. Situação em 2007, após o início das demolições. Edifícios remanescentes: 1. pavilhão de acesso; 2. pavilhão das carnes e ovos; 3. pavilhão do peixe.

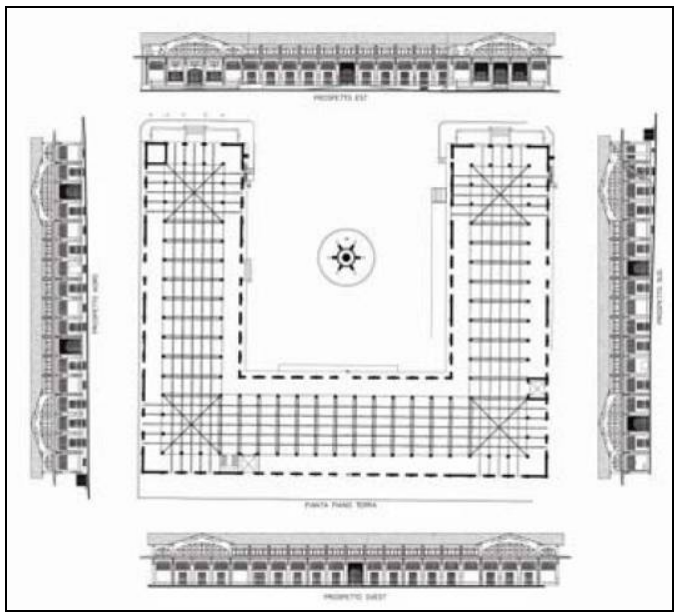

a.

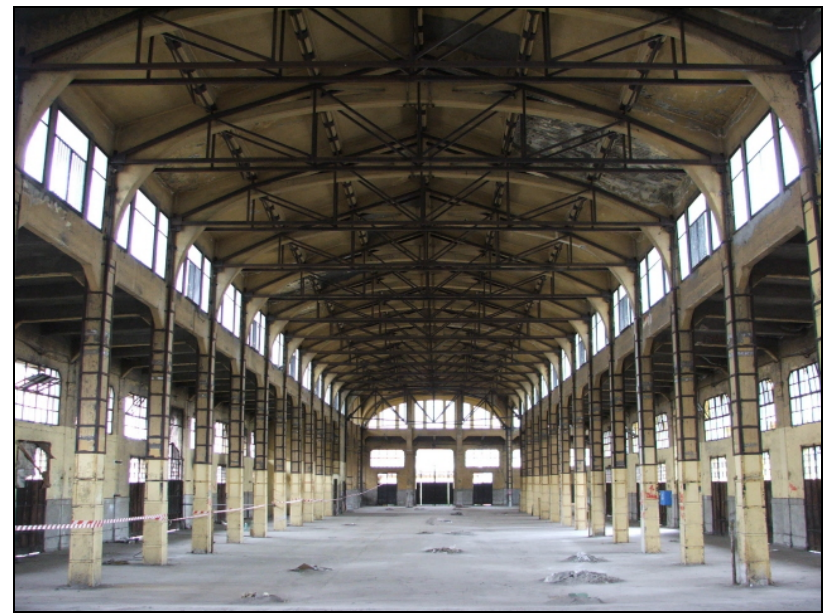

b.

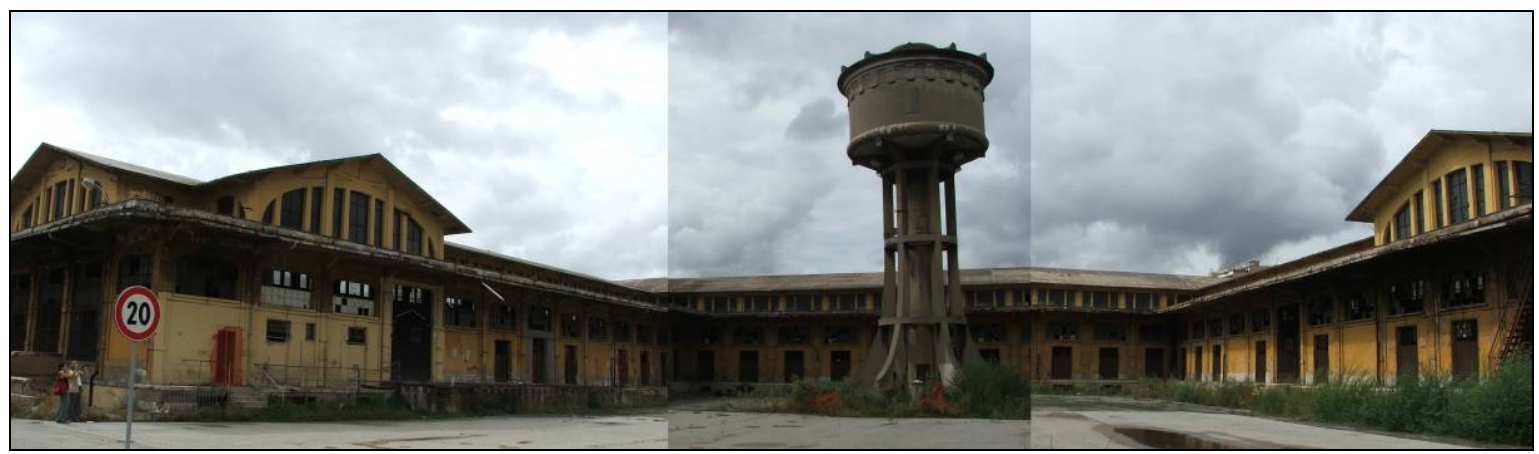

c.

10. Mercados Gerais. Antigo pavilhão para venda de carnes e ovos (n.2 na foto aérea da ilustração 9b). a. Projeto original; b. Vista interna do pavilhão; c. Vista externa, situação em 2006. (Fotos da autora) 


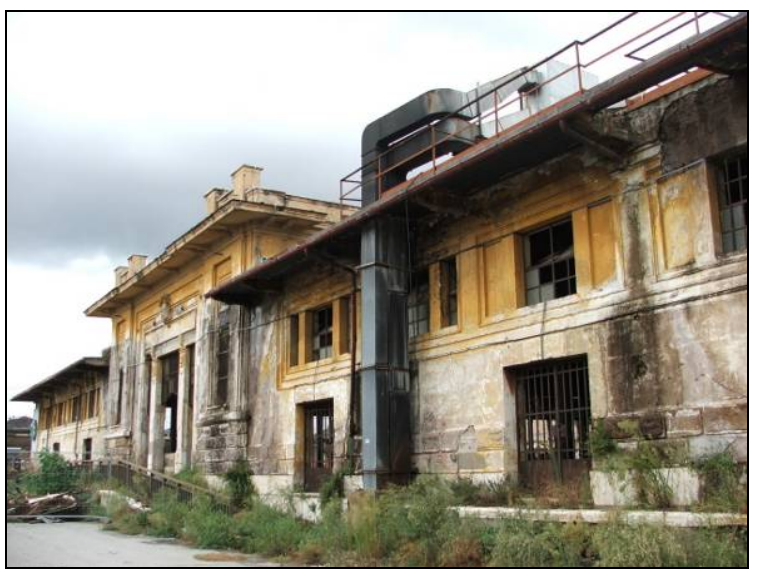

a.

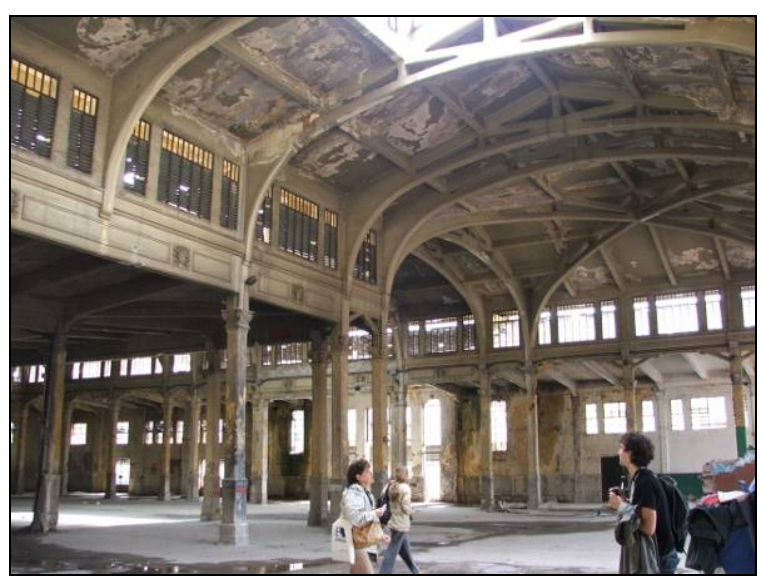

b.

11. Mercados Gerais. Antigo pavilhão para venda de peixe. Situação em 2006 (Fotos da autora).

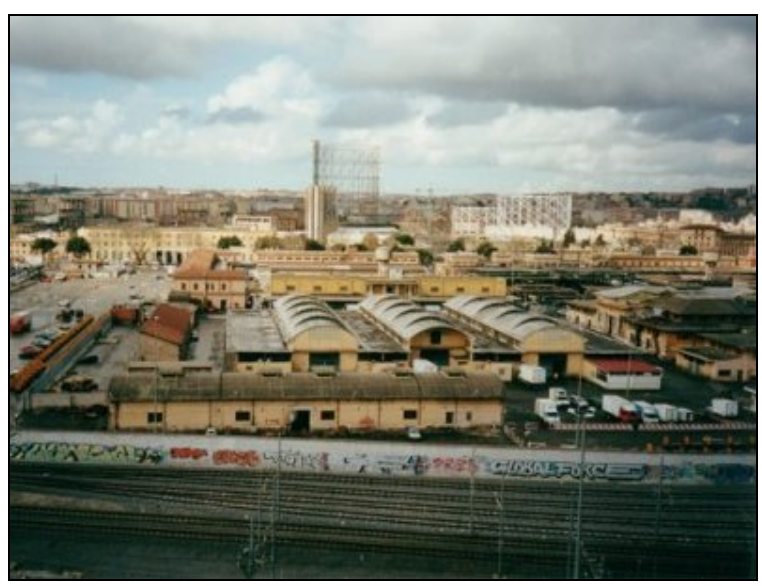

12. Vista geral dos Mercados a partir da linha do metrô. Em primeiro plano, pavilhões demolidos em 2007. Ao fundo, estruturas do Gasômetro (OMA).

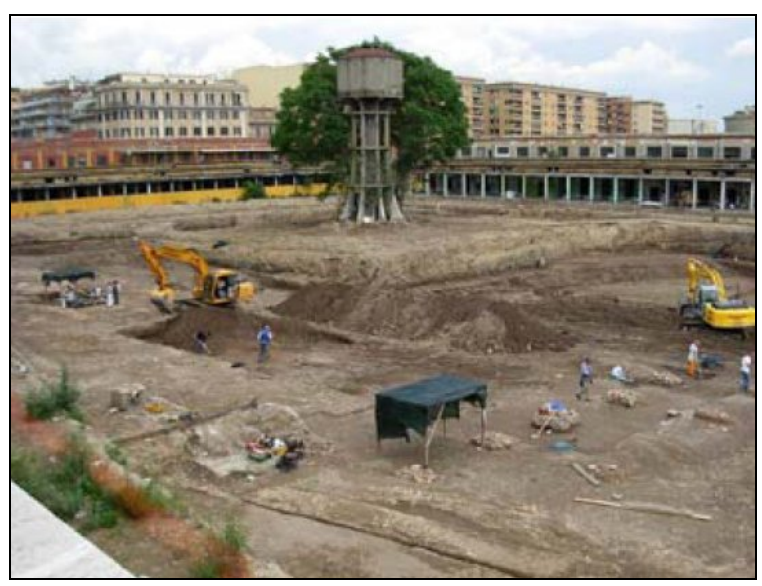

13. Mercados Gerais. Início das demolições em 2007 (OMA - Office for Metropolitan Architecture).

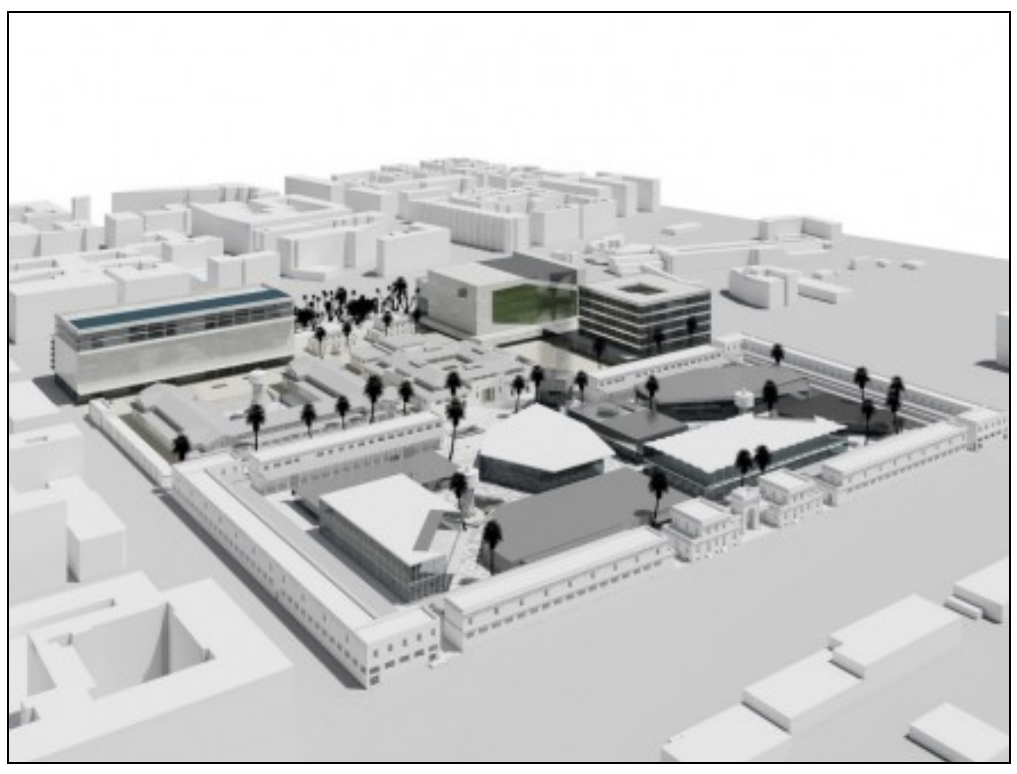

14. Revitalização dos Mercados Gerais. Perspectiva eletrônica do projeto de Rem Koolhaas. Em primeiro plano, o antigo pavilhão de acesso e a nova praça de serviços. Ao fundo, os pavilhões da carne e do peixe adaptados para novos usos e os novos edifícios propostos (OMA). 


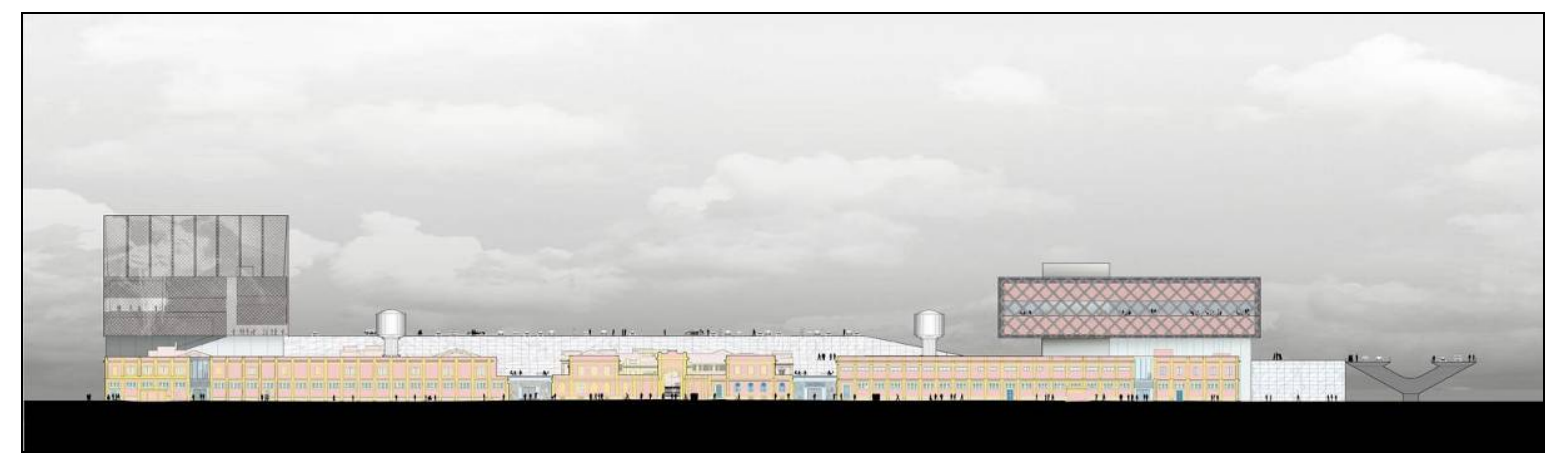

a.

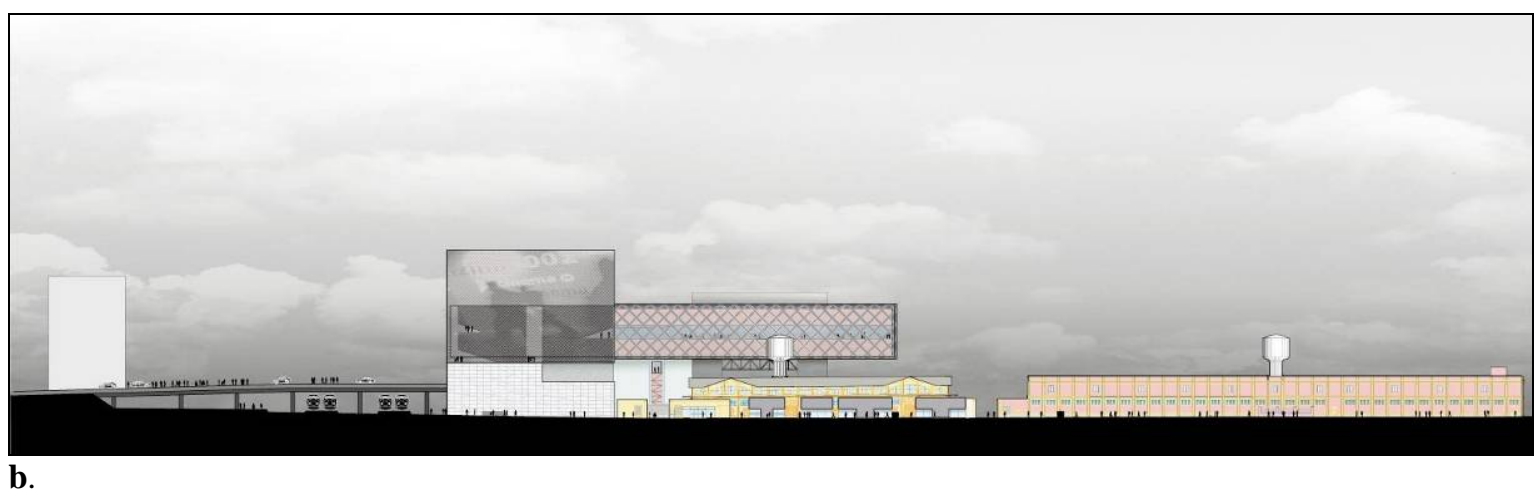

15. Revitalização dos Mercados Gerais, projeto de Rem Koolhaas.

a. Elevação via Ostiense; b. Elevação lateral esquerda. (OMA).

A definição do procedimento jurídico que conduziria a intervenção também foi outro ponto polêmico. Logo após os estudo preliminares, decidiu-se por confiar todo o projeto, execução e gestão à iniciativa privada. Foi adotado o procedimento denominado project financing: a execução do empreendimento é confiada à iniciativa privada que receberá a concessão de uso dos espaços e responderá pela sua gestão e exploração econômica por uma prazo de no máximo sessenta anos. O papel da administração pública restringe-se às intervenções nos espaços públicos e à determinação de certos parâmetros iniciais do projeto, como a previsão de alguns serviços para a população local e a exigência de conservação dos bens 'vinculados' (o equivalente ao nosso tombamento). O mecanismo tem sido considerado inadequado para intervenções no patrimônio urbano, pois a integração entre tutela e projeto de transformação inevitavelmente fica comprometida quando o próprio instrumento jurídico que viabiliza o empreendimento pressupõe a geração de lucro como prioridade. ${ }^{89}$

\footnotetext{
${ }^{89} \mathrm{O}$ grupo contratante e gestor do projeto é composto pela The Mills Corporation, sociedade internacional de investimentos e gestão imobiliária que atua nos Estados Unidos e Europa; pelo grupo Lamaro, que atua
} 
Dessa forma, tanto o projeto urbano Ostiense-Marconi, como a requalificação dos Mercados Gerais, têm recebido muitas críticas por parte dos profissionais envolvidos com a preservação. Para Alberto Racheli, o projeto para a área Ostiense está mais inclinado à produção de novas obras arquitetônicas do que à adaptação do patrimônio industrial desocupado para novos usos. Essa visão se origina, segundo o autor, em uma idéia equivocada de que a preservação e recuperação da cidade existente passa para segundo plano frente à possibilidade de redesenhar a cidade segundo a linguagem arquitetônica de nossa época. Não se trata apenas de um problema metodológico de projeto urbano, mas da noção cada vez mais difundida de que recuperar, ou restaurar sítios de grandes dimensões, significa substituir o existente com novas obras grandiosas; e a manutenção de algumas estruturas antigas, quando acontece, acaba por desempenhar um papel oposto ao que entendemos por preservar, ou seja, são situações onde

não se pode falar de recuperação, mas de projeto ex novo e o apelo à primeira categoria representa o frágil pretexto de fazer dialogar em contraponto os léxicos arquitetônicos de hoje com aqueles de ontem. Só que os últimos, em vez de serem revitalizados, geralmente são reduzidos à medida de fragmentos urbanos voltados à exaltar [...] a presença da arquitetura nova dentro de meras imagens alusivas de reminiscências do passado. ${ }^{90}$

Propostas segundo tais orientações não somente descontextualizam o artefato original, como também, no caso de composições urbanas, anulam o sentido das conexões e relações entre as estruturas. De certa forma, é um modo de intervir no qual o edifício antigo não faz e não pode fazer parte da vida moderna, ao contrário, está à sua margem, como uma ruína. ${ }^{91}$ São comuns, nesse sentido, as propostas que conservam uma chaminé ou uma parcela de um edifício industrial como recurso para agregar ao projeto a idéia de reutilização e valorização da arqueologia industrial, quando, na verdade, as prioridades da intervenção são de outra natureza. ${ }^{92}$ Racheli ressalta ainda, assim como De Fusco (e

principalmente nos setores financeiro e administrativo; a Sociedade Cinecittà Due, voltada à gestão comercial; e a Cogeim, empresa que desenvolve projetos de recuperação urbana e arquitetônica.

${ }^{90}$ RACHELI, Alberto M. Conservare innovando..., op. cit., p. 15. Trad. nossa. "In realtà, non di recupero si può parlare, ma di progettazione ex novo e l'apello alla prima categoria rappresenta il fragile pretesto di far colloquiare in contrapunto i lessici architettonici dell'oggi con quelli di ieri. Ė solo che questi ultimi anziché essere revitalizzati, vengono di norma ridotti alla stregua di lacerti urbani volti a esaltare in una tetra aura ossianica la presenza della'architettura nuova all'interno di mere immagini allusive di reminiscenza del passato."

${ }_{91}^{91}$ CONTI, A. Manuale di restauro. Torino: Einaudi, 1996, p. 62 apud RACHELI, A. M., op. cit., p.16.

${ }^{92}$ Como o projeto de Aldo Rossi para a antiga área industrial Perugina a Perugia, no qual uma chaminé repousa isolada entre dois edifícios modernos, como 'testemunho do passado'; ou ainda o projeto para a 
também Bonelli, décadas atrás), que a dificuldade de valorização do patrimônio urbano e, conseqüentemente, o emprego de recursos projetuais que desconsideram o preexistente, possui raízes na própria orientação didática preponderante no ensino universitário, a qual deveríamos, portanto, rever e reinterpretar.

É o que os fatos infelizmente demonstram, e isso é em grande parte atribuível aos resultados do ensino universitário, que deixa mão livre aos professores [de projeto] para orientar os alunos na realização de operações de sistemática destruição do ambiente construído, sem nem mesmo colocar-se preliminarmente o objetivo de efetuar uma pesquisa prévia digna de tal nome, apta a verificar, ao menos em suposição, se algum edifício por acaso seja merecedor de conservação ou não. [...] A preparação universitária deveria [ao contrário] induzir os estudantes, desde os primeiros anos, a compreender que para operar é necessário primeiro conhecer, e que fazer uma boa arquitetura, como dizia Adolf Loos, não significa a todo custo fazer-se por força notar. ${ }^{93}$

O tratamento do tema pelos instrumentos urbanísticos vigentes também foi considerado inadequado, conforme as análises de Barbara Elia. Os conjuntos industriais desativados, até 2000, integravam as chamadas zonas de uso $\mathrm{C}$ ou D. ${ }^{94} \mathrm{~A}$ zona $\mathrm{C}$ (redimensionamento viário e construtivo), abrangia áreas degradadas dentro do tecido consolidado para as quais era necessário a aprovação de planos específicos para a condução de qualquer intervenção; já para as áreas delimitadas como zona D (completamento), a aprovação desses planos não era obrigatória. Dessa forma, muitas intervenções em sítios industriais de interesse cultural ocorreram mediante concessão construtiva direta, sem a necessidade de aprovação prévia de projetos detalhados, logo, sem o desenvolvimento de qualquer pesquisa documental. Essas concessões, "livres de aprofundamentos historiográficos (que a lei também não torna obrigatórios) [reflete, portanto] o gosto subjetivo do projetista, sem considerar a objetividade da fundamental

Faculdade de Psicologia da Universidade La Sapienza, no qual foram destruídas as estruturas preexistentes da antiga Cervejaria Whürer, em Roma. RACHELI, A. M., Conservare..., op. cit., p.16.

93 RACHELI, A. M., Conservare..., op. cit., p.16,23. Trad. nossa. "È quanto i fatti purtroppo dimostrano, e ciò è in grande parte ascrivibile ai risultati dell'insegnamento universitario, che lascia mano libera ai compositori di addestrare gli allievi a compiere operazioni di sistematica distruzione dell'ambiente costruito, senza neppure porsi preliminarmente l'obiettivo di effetuare una previa ricerca degna di tale nome, atta a verificare, almeno in via suppositiva, se qualche manufato debba per caso risultare meritevole di conservazione o no.[...] La preparazione universitaria [...] dovrebbe costringere sin di primi anni gli studenti a comprendere che per operare bisogna prima conoscere, e che fare una buona architettura, come diceva Adolf Loos, non significa dover a tutti i costi farsi per forza notare." (grifo do autor).

${ }^{94}$ Esse zoneamento fora determinado pelo Plano Diretor de Roma de 1965 e mantido nas revisões de 1974, ainda vigentes em 2000. ELIA, Barbara. Strumenti urbanistici e conoscenza dell'edificio: preliminare per il progetto di recupero, un esempio nel quartiere Ostiense. Roma Moderna e Contemporanea, anno VIII, n.1-2, 2000, p.331 et seq. 
instância do reconhecimento dos valores históricos, sem a qual não há obra de restauro", ${ }^{95}$ Já no novo Plano Diretor de Roma, parcelas urbanas como a área industrial Ostiense foram enquadradas como 'centralidades metropolitanas e urbanas', assim definidas:

As Centralidades metropolitanas e urbanas são voltadas à nova organização multipolar do território metropolitano, a partir de uma forte caracterização funcional e morfotipológica, assim como uma estreita conexão com as redes de comunicação. Essas áreas compreendem partes de cidade caracterizadas por elevada acessibilidade pela rede de transporte público (particularmente o ferroviário), por uma forte integração funcional, por relevantes conotações de identidade social e histórica, e por um alto potencial para a transformação. ${ }^{96}$

Segundo Barbara Elia, o texto do plano sugere uma realidade preexistente 'desestruturada' e o citado "alto potencial para a transformação" acaba por condicionar o desenvolvimento de projetos urbanos pautados pela implementação de obras pontuais e excepcionais, entendidas como 'pontos de força' que induzem a continuidade da requalificação do entorno. Dessa forma, o processo de reutilização da área tem sido conduzido segundo pressupostos equivocados e a própria orientação jurídica, expressa pelo plano diretor e pelos textos oficiais do projeto urbano Ostiense-Marconi, tem alimentado esse caminho. A autora identifica três 'modalidades' de intervenção nos citados textos oficiais. Além do emprego equivocado de termos e conceitos, os textos evidenciam a

\footnotetext{
95 ELIA, B., Strumenti..., op. cit., p.333. Trad. nossa. "una concessione edilizia, qualora esente da approfondimenti di tipo storiografico (che la normativa peraltro non rende obbligatori) riflette, viceversa, il gusto soggettivo del progettista non tenendo presente in alcun modo l'oggettività della fondamentale istanza del riconoscimento dei valori storici senza il quale non si dà opera di restauro."

${ }^{96}$ As Centralidade metropolitanas e urbanas estão demarcadas por um perímetro apresentado na prancha 3 do novo Plano Diretor: 'sistemas e regras'. Tal perímetro contém todos os imóveis cuja transformação, reuso e requalificação concorrem para a definição do papel de centralidade. As Centralidades estão subdivididas em: centralidades a planejamento definido (centralità a pianificazione definita) e centralidades a serem planejadas (centralità da pianificare). A área encampada pelo projeto urbano Ostiense-Marconi está enquadrada na primeira categoria, ou seja, áreas para as quais já foram aprovados (ou encaminhados para aprovação) instrumentos urbanísticos e programas de intervenção. Essa documentação pode ser acessada no site do Comune di Roma. Norme tecniche di attuazione: delibera di adozione del Consiglio Comunale n.33 del 19/20 marzo 2003. Roma: Comune di Roma, 2003, Titolo II, capitolo 6ª art. 60, p.74. Trad. nossa. "Le Centralità metropolitane e urbane sono finalizzate alla nuova organizzazione multipolare del territorio metropolitano, attraverso una forte caratterizzazione funzionale e morfo-tipologica, nonché una stretta connessione con le reti di comunicazione. Esse riguardano parti di città caratterizzate da elevata accessibilità mediante la rete di trasporto pubblico (in particolare su ferro), da una forte integrazione funzionale, da rilevanti connotati di identità sociale e storica, e da una alta potenzialità alla trasformazione." Cf.: Compendio delle norme tecniche di attuazione del PRG vigente: aggiornate al 31.03.2005. Roma: Comune di Roma, 2005 .
} 
grande desconexão entre teoria do restauro e planejamento urbano, na contramão das diretrizes dos documentos internacionais anteriormente analisados. ${ }^{97}$

Uma das modalidades de intervenção citadas pela autora é denominada ‘demolição e reconstrução'. Como o próprio nome já diz, trata-se de predisposições legislativas que permitem a concessão de alvarás de demolição (total ou parcial) de edifícios localizados na chamadas 'centralidades' para a inserção de novos projetos 'de utilidade pública', como por exemplo a construção de áreas residenciais, com a contrapartida de ceder superfícies para o poder público. Sem adentrar na discussão sobre a eventual qualidade dos projetos realizados no lugar das demolições (que porventura podem até resultar bons), a autora ressalta o aparente 'esquecimento' de que essas áreas demolidas são, na verdade, partes da cidade histórica. Projetos dessa natureza partem de pressupostos antitéticos, pois ignoram comodamente as preexistências e eximem-se da discussão teórico-crítica que deveria respaldar o seu desenvolvimento. Um projeto na área Ostiense que se enquadra nessa modalidade é a proposta de intervenção nos armazéns da Federação Italiana Consórcios Agrários (ex magazzini della Federazione Italiana Consorzi Agrari), que prevê a demolição de grande parte do conjunto arquitetônico para a construção de novos edifícios residenciais. Segundo Elia, o sítio industrial da antiga fábrica de velas e sabão Mira Lanza também estaria ameaçado por projetos semelhantes. ${ }^{98}$

16. Proposta de intervenção no conjunto de armazéns da Federação Consórcios Agrários de Roma, também localizado no bairro Ostiense. O novo projeto propõe a construção de cinco edifícios residenciais (em cinza escuro, no desenho). (TRAVAGLINI, M., op. cit., p.617).

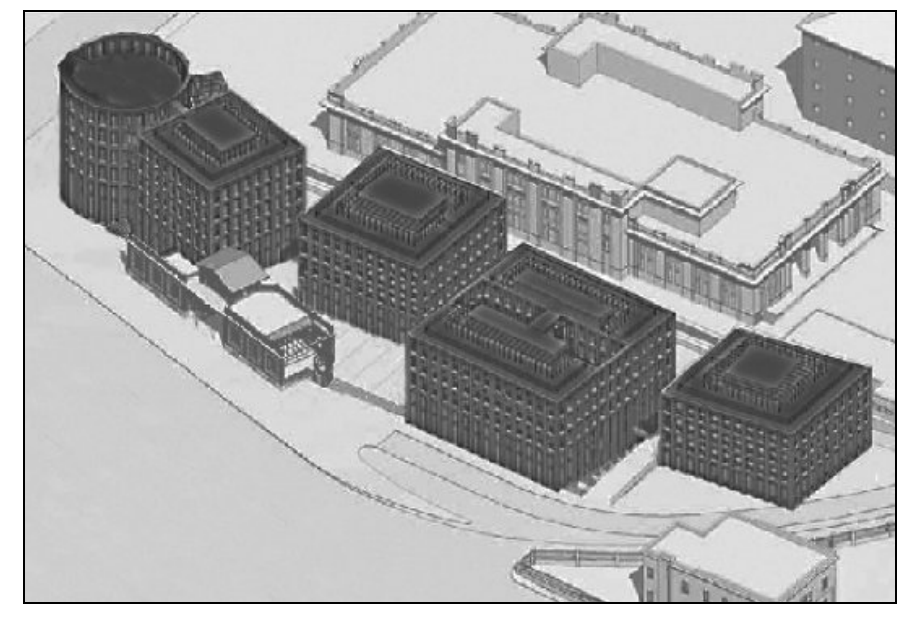

97 ELIA, B. Pianificazioni ed attuazioni passate e presenti per il quartiere Ostiense. Roma Moderna $e$ Contemporanea, anno XII, n.1-2, 2004, pp.247-252.

98 ELIA, B. Pianificazione..., op. cit., p. 249. Sobre esse projeto, ver ainda: TRAVAGLINI, Carlo M. Archeologia industriale e paesaggi urbani. Città e Storia, n. I-2, 2006, pp. 614-619. 
17. Sítio industrial Mira Lanza. O projeto de intervenção prevê demolições parciais e inserção de novos edifícios: salas de teatro, casa para estudantes, um parque público e um hotel. (Archeologia industriale a Roma).

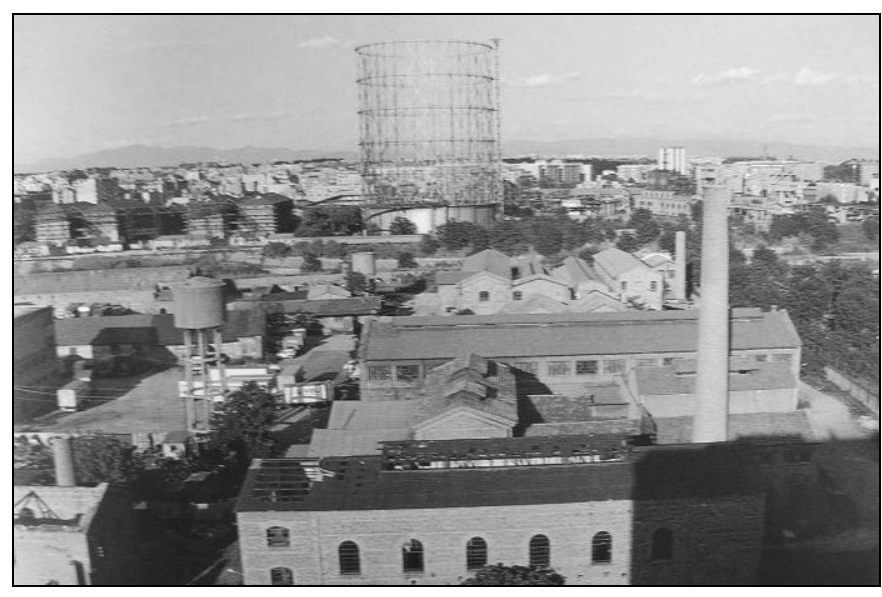

A segunda categoria é aquela classificada como 'restauro leve', um termo “criado pela fantasia dos administradores" para designar as adaptações que não destroem tudo indiscriminadamente, ou seja, o que denominamos comumente de 'restauro. ${ }^{99}$ Finalmente, a terceira categoria identificada pela autora é aquela ironicamente chamada de 'restauro pseudo-filológico'. De um lado, a preocupação com a conservação é incentivada a partir da contratação de um grupo de especialistas para elaborar levantamentos e estudos históricos e documentais sobre a área a ser objeto de intervenção; e, de outro lado, são adotados mecanismos operativos que frustram as investigações previamente efetuadas, como o citado project financing, adotado no projeto de requalificação dos Mercados Gerais de Roma; um instrumento, como vimos, alimentado pela lucratividade do empreendimento.

Essa distância entre as análises desenvolvidas em âmbito acadêmico e as proposições práticas finais, fica ainda mais evidente nos dizeres de Francesco Cellini ao introduzir a publicação sobre os estudos da área Ostiense-Marconi realizados pela Universidade Roma Três a pedido da administração municipal, e o fato não parece ser visto como um problema ${ }^{100}$. A publicação que reúne levantamentos diversos, análises históricas, mapeamento das preexistências arqueológicas, estudos do tecido urbano e dos principais edifícios, documentação arquivística (mapas, projetos antigos), e propostas de projetos para alguns sítios do perímetro, é apresentada como uma documentação paralela com relação aos projetos em andamento. Cellini afirma: “a presença de títulos quase

\footnotetext{
${ }^{99}$ A autora classifica como um verdadeiro projeto de restauro as intervenções realizadas no antigo Matadouro do Testaccio (ex Mattatoio di Testaccio) para abrigar as salas expositivas da nova sede do MACRO. ELIA, B. Pianificazione..., op. cit., p. 250.

${ }^{100}$ Estudos elaborados, a pedido do administração municipal, pelo Departamento de Projeto e Estudo da Arquitetura da Universidade Roma Três (Università degli Studi di Roma Tre). CANCIANI, Marco (Org.). Piano di assetto per l'attuazione del progetto urbano Ostiense-Marconi. Roma: Kappa, 2004.
} 
idênticos entre o projeto urbano precedente, o projeto apresentado neste volume, e o conjunto de projetos [...] hoje vigentes no setor como instrumentos aplicativos do novo Plano Diretor, e que outra vez recebem o nome de Projeto Urbano Ostiense-Marconi, pode gerar confusão". ${ }^{101}$ No entanto, o fato é considerado um dado positivo, um "sintoma de uma realidade propositiva e projetual verdadeiramente inovadora" e um método que permite a proposição de um vasto "repertório de possibilidades projetuais". Se os levantamentos e propostas do volume foram encarados como um exercício projetual propositivo, alternativo, o esforço certamente é valido. O curioso é não se questionar por que os projetos efetivamente em curso não buscaram dialogar com a preexistência e nem mesmo se valeram desses levantamentos documentais previamente realizados em âmbito acadêmico.

Uma das principais questões apontadas no projeto de requalificação dos Mercados Gerais é a recorrência a projetos arquitetônicos de grande visibilidade que priorizam a 'nova imagem' em detrimento das preexistências históricas. Conforme temos abordado, tem sido comum o tratamento de áreas industriais desativadas - parcelas urbanas extensas e estratégicas -, como uma oportunidade para grandes empreendimentos, ocasião em que o novo projeto assume a dianteira frente à valorização do patrimônio. A questão poderia ser encarada como mais uma das faces do velho debate sobre o encontro entre o antigo e o novo. No entanto, a dimensão das novas obras, as prioridades equivocadas e o frágil reconhecimento dos valores das preexistências industriais, não nos permitem, neste caso, legitimar um debate sobre este suposto diálogo. A inserção do novo, em exemplos como este, acaba por anular completamente aquelas especificidades compositivas do patrimônio urbano, conforme temos procurado evidenciar. E não faz sentido, portanto, iniciar qualquer discussão sobre a qualidade projetual, como ressalta Racheli:

Não tem sentido, de fato, falar de qualidade arquitetônica quando se encontra diante à infausta possibilidade de que um ambiente urbano de relevante interesse históricoarquitetônico possa ser drasticamente destruído. O discurso sobre a qualidade arquitetônica acontece em um segundo tempo, somente depois de se ter decidido o que conservar e o que destruir, e não certamente a priori: querendo ser mais explícito, nenhuma pessoa, se dotada de bom senso, decidiria abater o Coliseo para substituí-lo por

\footnotetext{
${ }^{101}$ CELLINI, M. Introduzione. In: CANCIANI, M. (Org.), op. cit., pp.11-12. Trad. nossa. "La conpresenza di titolazione quasi identiche fra il progetto urbanistico precedente, il progetto presentato in questo volume, e l'insieme di progetti, in parte variati, che oggi sono vigenti nel settore come stumenti applicativi del nuovo Piano Regolatore, e che di nuovo vanno sotto il nome di Progetto Urbano Ostiense-Marconi, può generare confusione".
} 
uma estela luminosa projetada por Massimiliano Fuksas, em nome da arquitetura moderna. Portanto, não conseguimos compreender o autêntico significado das palavras [empregadas para defender a] suposta qualidade arquitetônica que o bairro Ostiense deveria assumir a partir da execução das intervenções programadas. ${ }^{102}$

Instrumentos semelhantes de requalificação urbana (projetos baseados na inserção de grandes obras arquitetônicas como indutoras de revitalização), também têm sido empregados na área portuária de Genova. As obras de requalificação do Porto foram iniciadas em 1992, por ocasião das celebrações do quinto centenário da descoberta da América e, desde então, novos projetos tem sido propostos para dar prosseguimento ao processo de revitalização funcional do Porto. Esse processo teve início a partir da escolha da cidade de Genova para sediar a exposição sobre a história da navegação, a Expo 92, ocasião que impulsionou o direcionamento da política urbana para a requalificação da antiga área portuária, então escolhida como palco da exposição. A ocasião foi vista como um estímulo para a promoção internacional da cidade, objetivo que seria alcançado com a realização de grandes obras arquitetônicas: "Genova, considerada uma cidade industrial sem particulares qualidades, tinha portanto a ocasião de mostrar-se no cenário internacional e propor uma outro imagem de si mesma". ${ }^{103}$ Esse impulso inicial, contudo, foi motivo de grande polêmica. Alguns estudiosos classificaram as propostas como mera operação propagandística com objetivos estritamente comerciais, uma ocasião para a especulação urbanística e construtiva.

Por muito tempo o Porto de Genova assumiu a posição de principal porto italiano e as atividades industriais sediadas na cidade, principalmente no setor da produção naval e

\footnotetext{
${ }^{102}$ Comentário de Alberto Racheli em resposta às declarações realizadas pelos promotores do Projeto Urbano Ostiense-Marconi na mídia. RACHELI, Alberto. Il quartiere..., op. cit., p. 257. Trad. nossa. "Non ha senso, infatti, parlare di qualità architettonica quando ci si trova dinanzi all'infausta possibilità che un ambiente urbano di rilevante interesse storico-architettonico possa venire drasticamente distrutto. Il discorso sulla qualità architettonica avviene in un secondo tempo, soltanto dopo avere deciso cosa conservare e cosa distruggere, e non certo a priori: a voler essere più espliciti, nessuna persona, se dotata di buon senso, deciderebbe di abbattere il Colosseo per sostituirlo con una stele luminosa progettata da Massimiliano Fuksas, in nome dell'architettura moderna. Perciò non riusciamo a comprendere l'autentico significato delle parole che l'assessore Roberto Morassut è solito impiegare nel corso delle sue svariate interviste agli organi di stampa, circa la presunta qualità architettonica che il quartiere Ostiense dovrebbe assumere attraverso l'esecuzione degli interventi programmati."

${ }^{103}$ A descrição do processo de revitalização o Porto de Genova foi baseada nas informações fornecidas por Roberto Bobbio, professor da Universidade de Genova, em entrevista concedida à autora da presente tese em julho de 2007; bem como no artigo: BISIO, Lidia e BOBBIO, Roberto. Gestione dei grandi eventi e strategie di riqualificazione urbana a Genova. In: IMBESI, Paola Nicoletta (Org.). Governare i grandi eventi, l'effetto pulsar e la pianificazione urbanistica. Roma: Gangemi, 2004, p. 40. Trad. nossa. "Genova, considerata una città industriale senza particolari qualità, aveva comunque l'occasione di mostrarsi sul palcoscenico internazionale e proporre un'altra immagine di se stessa."
} 
na siderurgia, conferiam à Genova um lugar de destaque entre os maiores centros industriais do país. Tanto as atividades portuárias, quanto as industriais, no entanto, começaram a entrar em declínio entre os anos 1960 e 1970. O Porto não acompanhou as adaptações tecnológicas necessárias e tornou-se obsoleto. No final da década de 1980, com a reestruturação do Consórcio Portuário como sociedade público-privada e a reorganização de serviços e construção de novos terminais, o Porto começou a buscar sua reinserção funcional, mas muitas das antigas estruturas ainda precisavam ser readaptadas para corresponder às novas atividades. A exposição, portanto, foi uma oportunidade de alavancar projetos de requalificação que já vinham sendo pensados.

A área mais antiga do porto, mais próxima do centro histórico, não poderia mais ser readaptada para funções portuárias modernas, nem mesmo para passageiros, por isso acabou sendo escolhida como o primeiro sítio para a inserção das desejadas renovações urbanas. O desenvolvimento do programa contou com a constituição de um acordo entre poder municipal, regional e entidade responsável pelo Porto. Esse acordo teve importância fundamental para a viabilização das obras pois, no passado, as intervenções realizadas na antiga área portuária sempre esbarravam em questões envolvendo o direito de propriedade, já que a área era administrada pela autoridade portuária o que dificultava sobremaneira qualquer ação da prefeitura. $\mathrm{O}$ acordo permitiu a solução de dois problemas: a autoridade do Porto passava adiante áreas obsoletas e degradadas não mais adaptáveis para funções portuárias; e as administrações públicas, por sua vez, adquiriam terrenos fundamentais para dar prosseguimento aos projetos de revalorização urbana.

Essa primeira etapa do projeto de intervenção, a requalificação do porto antigo, foi confiada ao arquiteto genovês Renzo Piano, profissional de renome internacional. $\mathrm{O}$ projeto compreendeu uma área de 13 hectares e incluiu a maior parte do porto medieval e sucessivas alterações dos séculos XVI ao XIX. Inicialmente, foram construídos apenas dois edifícios novos: o Aquário e um bloco de serviços ao lado do antigo Armazém do Algodão (Magazzini del Cotone) que foi adaptado para novo uso: salas expositivas, centro de convenções e outros serviços. ${ }^{104}$ Além dos novos edifícios, as áreas envoltórias foram trabalhadas em projeto paisagístico com a criação de amplos espaços públicos e diversos equipamentos de serviços e lazer.

\footnotetext{
${ }^{104}$ Cabe ressaltar que o Plano Diretor de 1980, então em vigor, não previa a inserção desse tipo de serviços na área portuária, bem como não permitia uma intervenção desse porte, tendo sido necessário providenciar uma 'adaptação' do Plano. BISIO, Lidia e BOBBIO, Roberto. Gestione..., op. cit.
} 
18. Porto Histórico de Genova. Em destaque, área onde se concentram os principais projetos de revitalização já executados ou em andamento (sem escala).

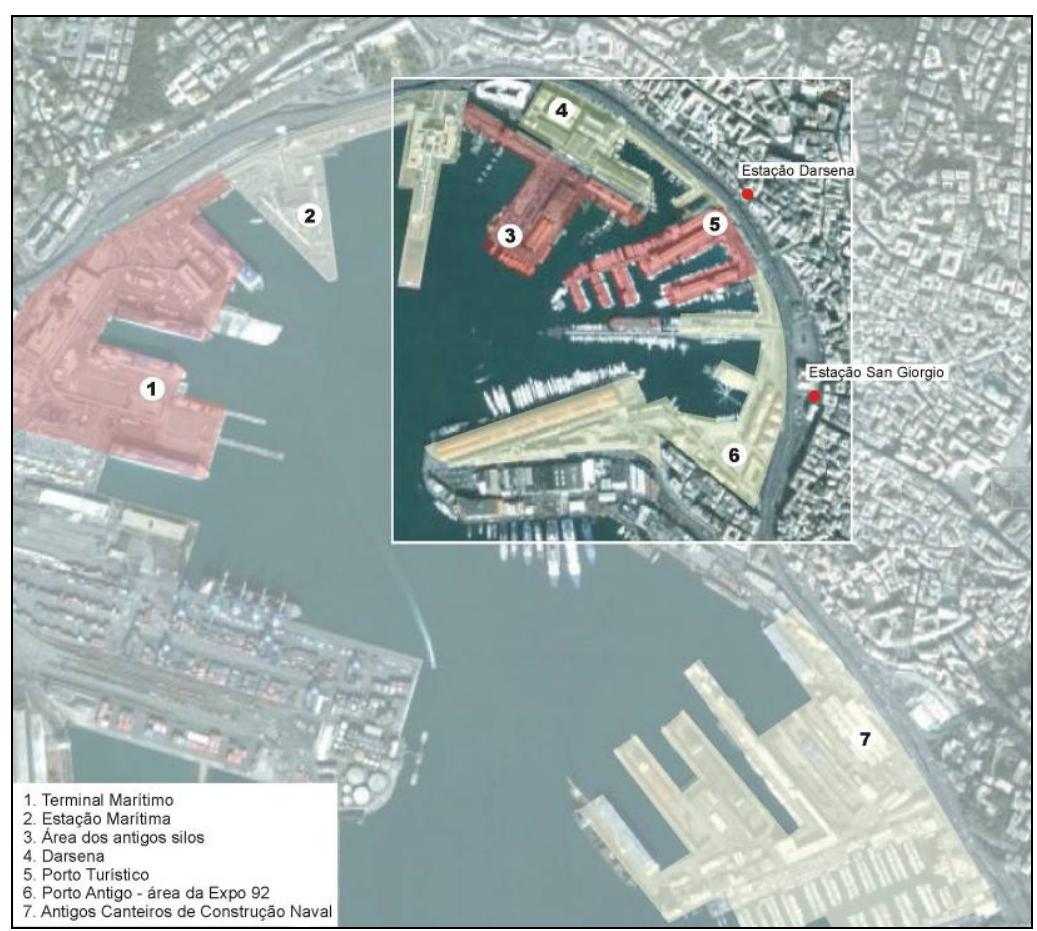

19. Porto de Genova. Indicação dos galpões industriais adaptados para novos usos e das áreas em processo de revitalização.

\footnotetext{
1. Silos atribuídos a François Hennebique 2. Faculdade de Economia e Comércio

Museu do Mar e da Navegação

Ponte Parodi

5. Galpões que abrigarão o Instituto Náutico

6. Aquário de Genova

Biosfera de Renzo Piano

8. Praça de Eventos

8. Armazéns portuários cortados pela via elevada

10. Área envoltória tratada em projeto paisagístico

11. Area envoltoria tratada
}

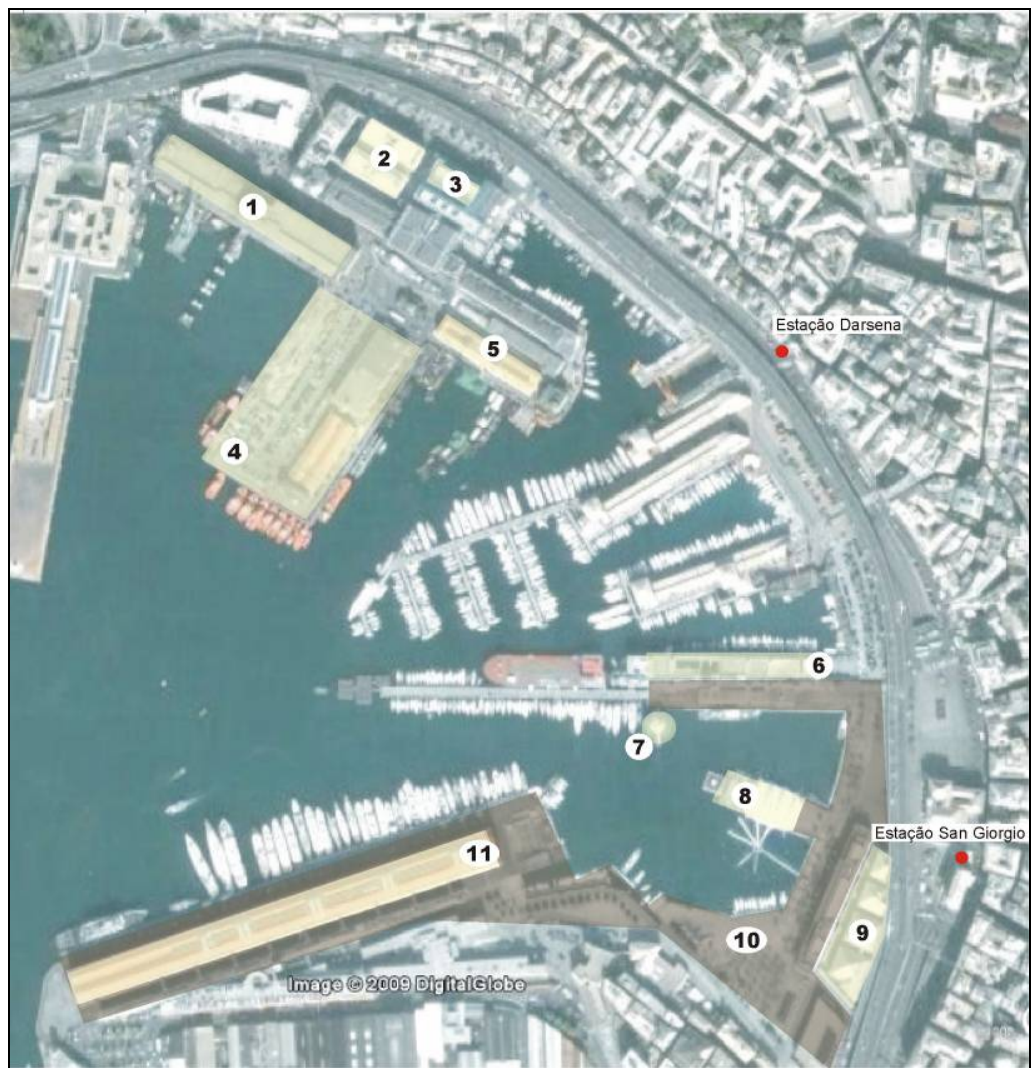


20. Vista geral do Porto Antigo. Em primeiro plano, o edifício

longitudinal dos antigos Armazéns do Algodão. Ao fundo, as intervenções de Renzo Piano. (INU Istituto Nazionale di Urbanistica)

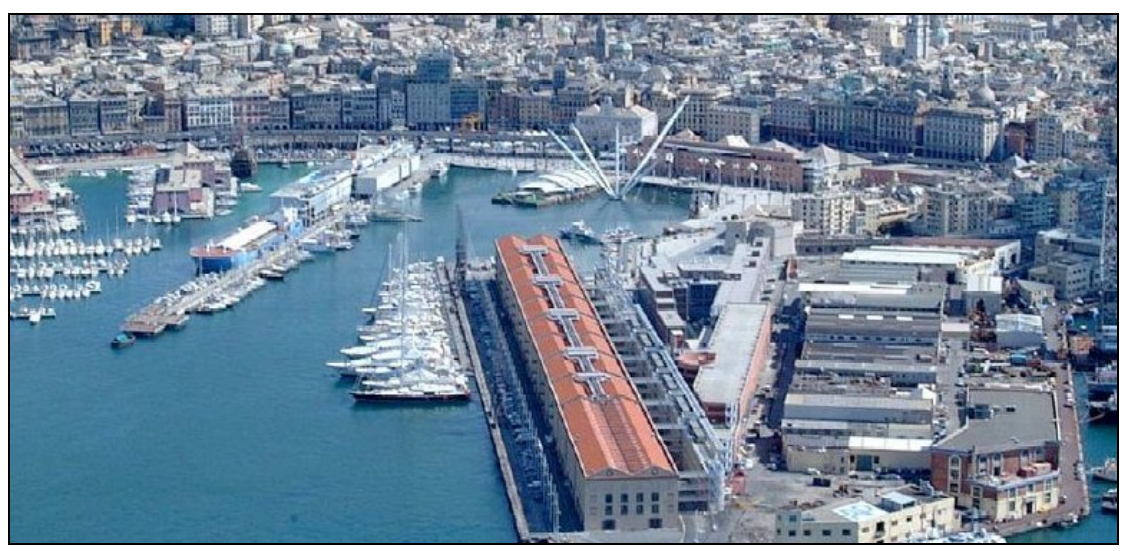

21. Vista geral do Porto. Em primeiro plano, a

Praça de Eventos e os mastros que sustentam o Bigo, elevador

panorâmico, elementos projetados por Renzo

Piano. Ao fundo, a cidade antiga. (INU)

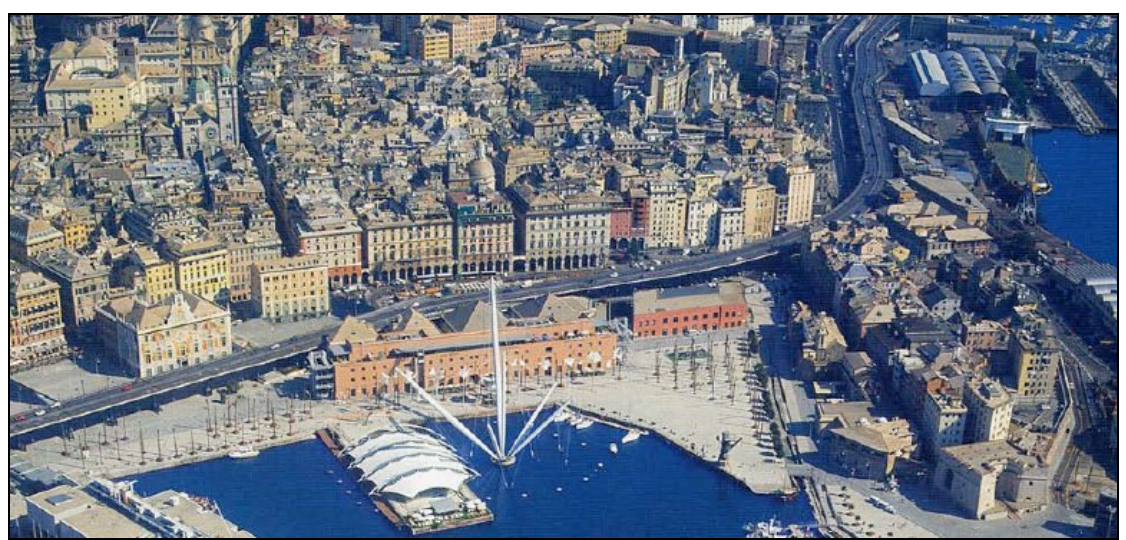

22a. Vista geral da Darsena. Situação em 2002, antes da demolição dos grandes silos na Ponte Parodi. (INU)
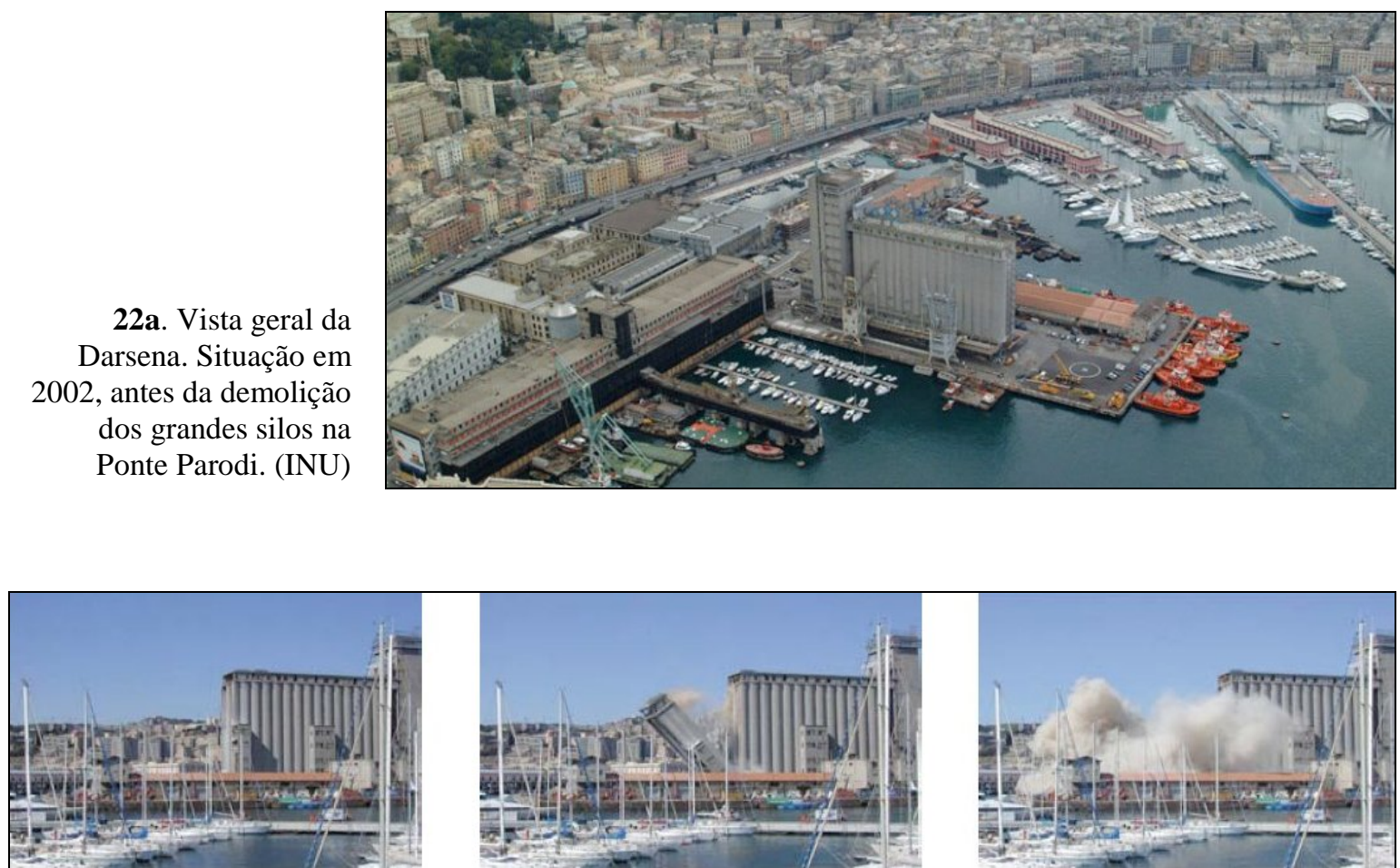

22b. Demolição dos silos na Ponte Parodi, 2002. (INU) 


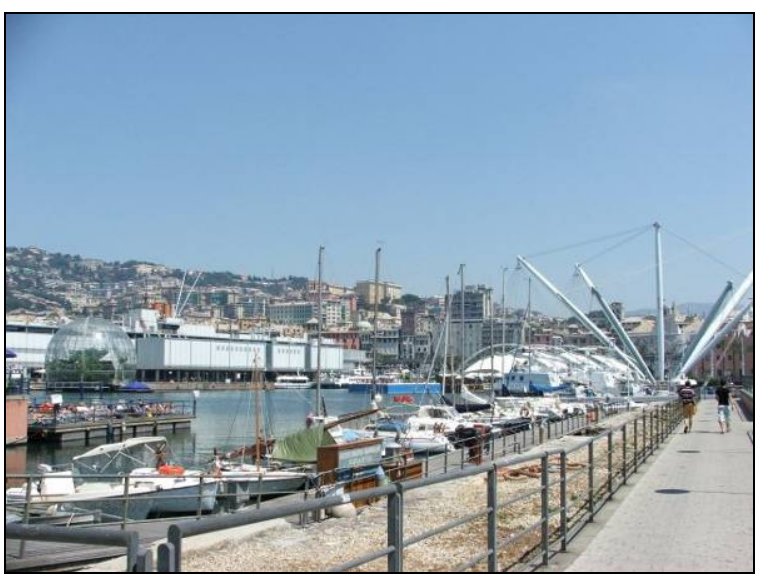

23a. Vista geral do Porto, 2007. (Fotos da autora)

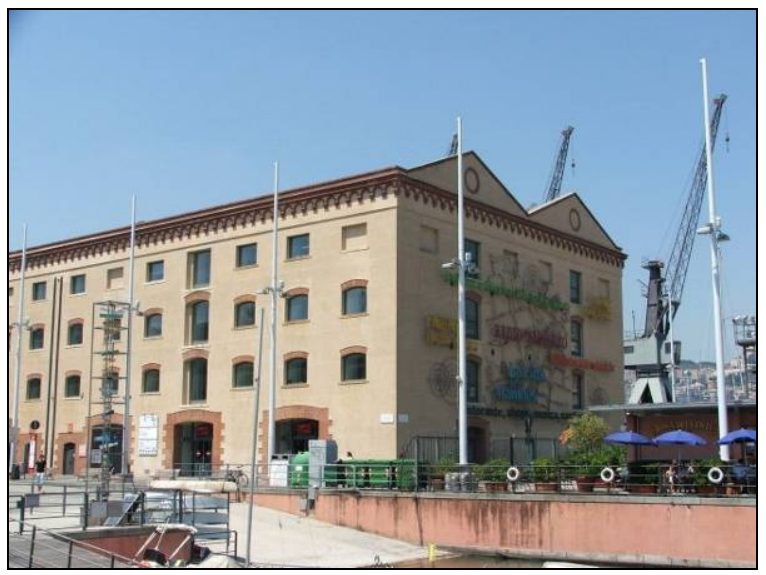

24a. Antigo Armazém do Algodão adaptado para novos usos: espaços culturais e comerciais, 2007.

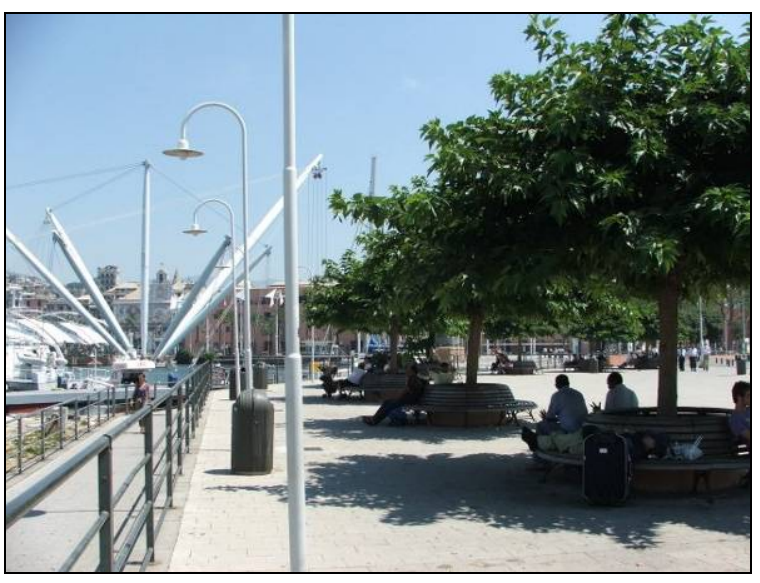

23b. Espaços públicos criados na Expo 92, 2007.

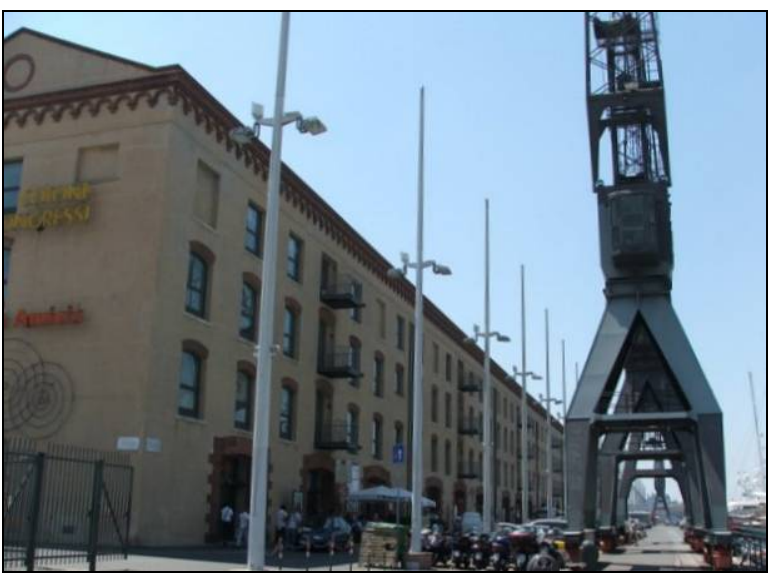

24b. Arredores do Armazém. Os antigos guindastes do porto foram conservados, 2007.

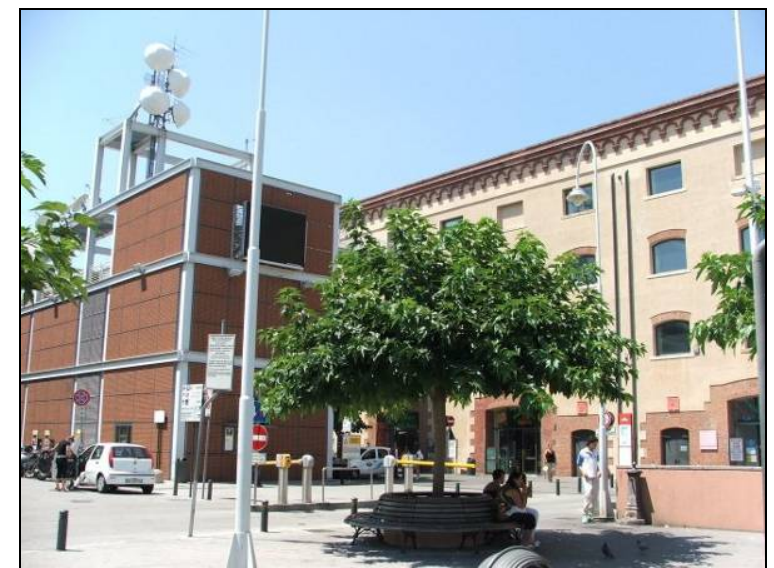

24c. Em primeiro plano, bloco de serviços construído na primeira etapa da revitalização, 2007.

24d. Adaptação dos espaços internos do armazém, 2007.

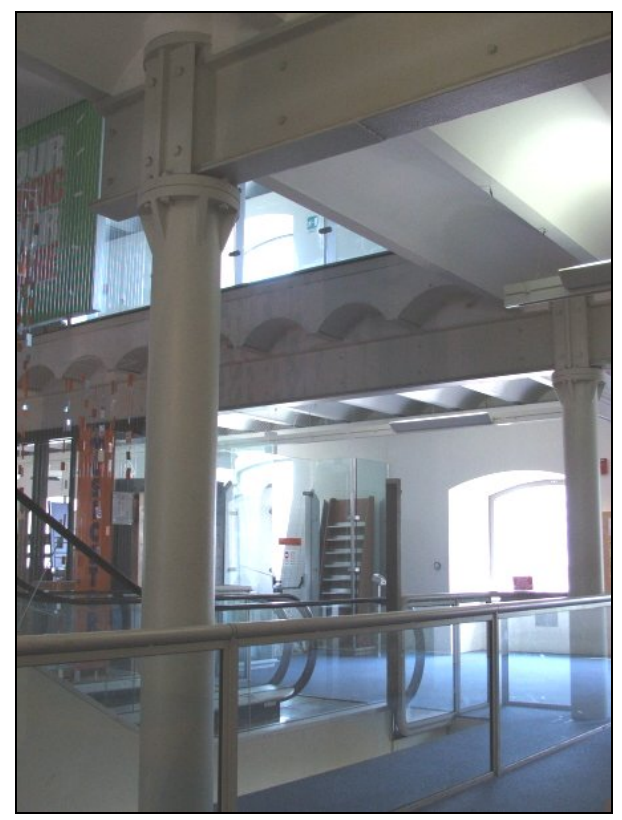




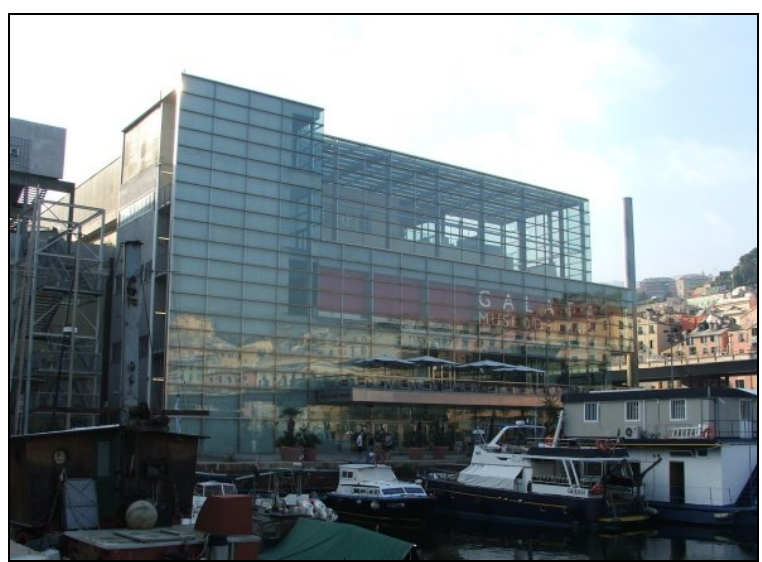

25a. Museu do Mar e da Navegação, na Darsena. Construído em um antigo estaleiro segundo projeto do arquiteto espanhol Guillermo Vázquez Consuegra, 2007. (Foto da autora)

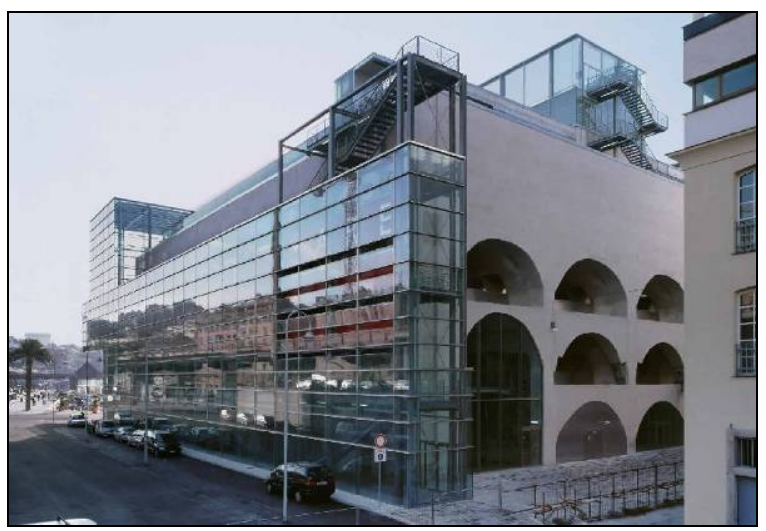

25c. Museu do Mar. Detalhe das antigas estruturas em arco. (site G. V. Consuegra)

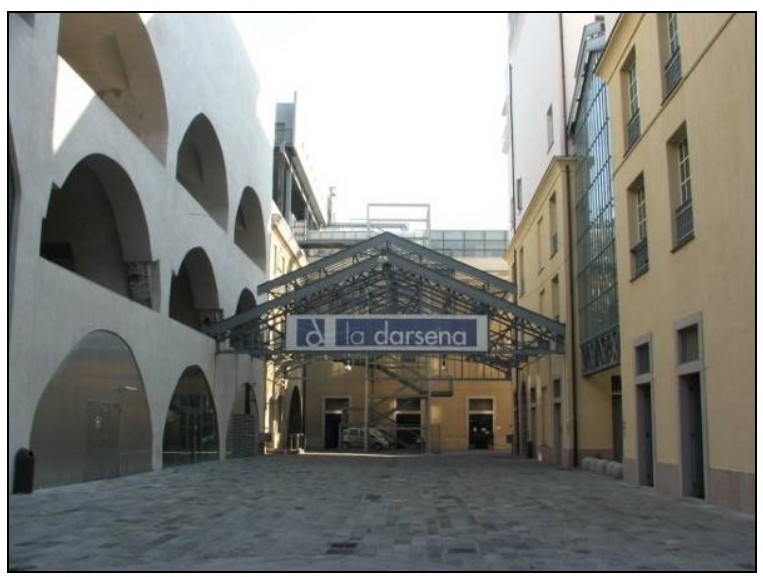

27. Faculdade de Economia e Comércio instalada em antigos galpões, ao lado do Museu do Mar. Projeto de adaptação do arquiteto italiano Aldo Rizzo, 2007.

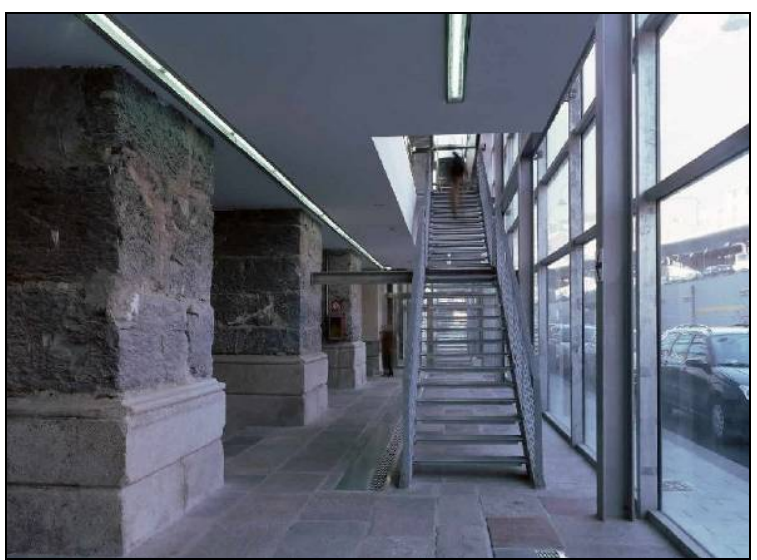

25b. O projeto de Consuegra, vencedor de concurso realizado em 2000, substituiu a antiga fachada por uma pele de alumínio e vidro e evidenciou as estruturas originais de pedra. (site G. V. Consuegra)

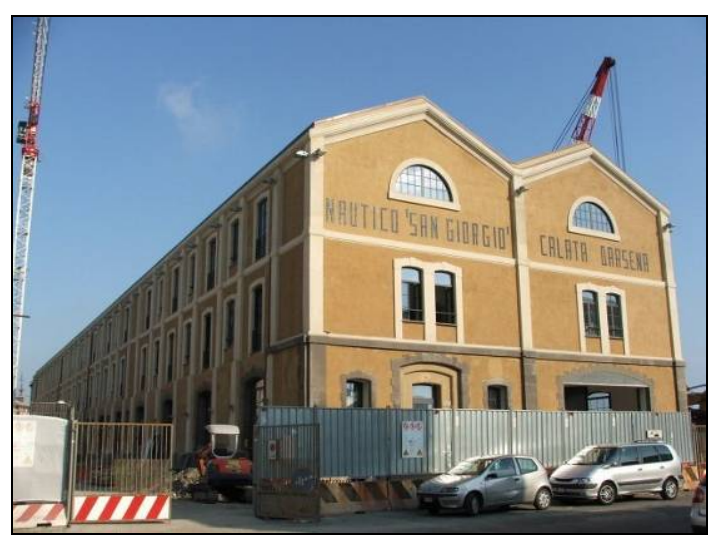

26. Armazéns do Instituto Náutico, na Darsena, 2007. (Fotos da autora)

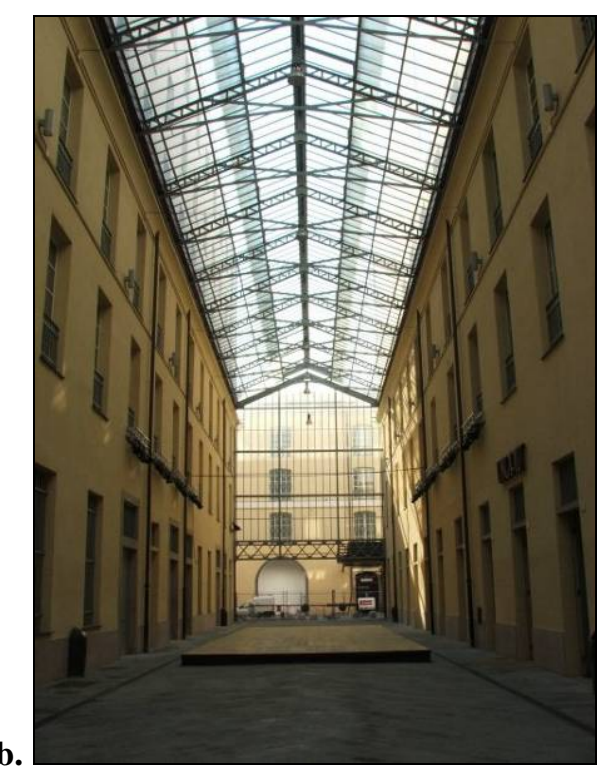


A área portuária degradada pelo desuso, no entanto, vai muito além do porto antigo; e o fato desta ter sido uma primeira etapa do projeto, não significava que as etapas seguintes seguiriam algum planejamento pensado em grande escala. Os próximos projetos foram sendo pensados isoladamente, conforme as possibilidades e oportunidades, notadamente políticas e econômicas, do momento. As grandes dimensões, tanto da área a ser trabalhada, como também dos armazéns e edifícios fabris desocupados, têm sido, desde o início, um dos grandes problemas projetuais. Essas extensas áreas representam um sério entrave tanto com relação às questões de ordem econômica e administrativa, como também pela dificuldade de apreender a área portuária como um conjunto urbano único e propor projetos articulados em grande escala e longa duração; questão ainda agravada pela própria dificuldade de encontrar usos compatíveis para tantas e tão grandes estruturas.

Devido a tais motivos, a área continua em processo de revitalização e outros projetos, pensados caso a caso, estão sendo propostos. Nos anos seguintes à Expo 92, além da construção da 'biosfera' de Renzo Piano, outras obras foram implementadas, como o projeto de Aldo Rizzo para a Faculdade de Economia e Comércio, instalada em antigos galpões; e o Museu do Mar, projeto de Guillermo Vázquez Consuegra, construído em um antigo estaleiro e inaugurado em 2004. Um antigo galpão deverá ainda abrigar o Instituto Náutico São Jorge e a antiga Ponte Parodi será recuperada segundo projeto de Ben Van Berkel. Há ainda a intenção de se construir uma nova zona residencial de luxo sobre os antigos canteiros de construção naval; ocasião que deverá determinar a demolição das antigas estruturas.

Dentre os edifícios abandonados cujas particularidades formais e estruturais dificultam a escolha de um novo uso compatível, destacam-se os silos construídos em concreto armado, segundo projeto atribuído ao engenheiro francês François Hennebique (1841-1921), talvez o primeiro edifício construído nesse sistema na Itália. Anos atrás cogitou-se de recuperar os enormes silos para abrigar um hotel ${ }^{105}$ e recentemente surgiu a proposta de instalar ali a Faculdade de Engenharia, projeto que estaria a cargo de Rem Koolhaas e Stefano Boeri ${ }^{106}$; qualquer adaptação, no entanto, inevitavelmente provocará o

\footnotetext{
105 POLEGGI, Ennio. Waterfront o riva? Progetti per il porto antico. In: ROCCA, Alessandro e SAMBONET, Guia (Org.). La città dipinta: Genova '92. Milano: Electa, 1991, p.14.

${ }^{106}$ GABRIELLI, Bruno. La 'Rinascita' di Genova: città europea della cultura 2004. Urbanistica Dossier INU, anno VIII, n.74, 2005, p.35.
} 
rompimento interno dos silos, descaracterizando o projeto. Atualmente o edifício está abandonado.
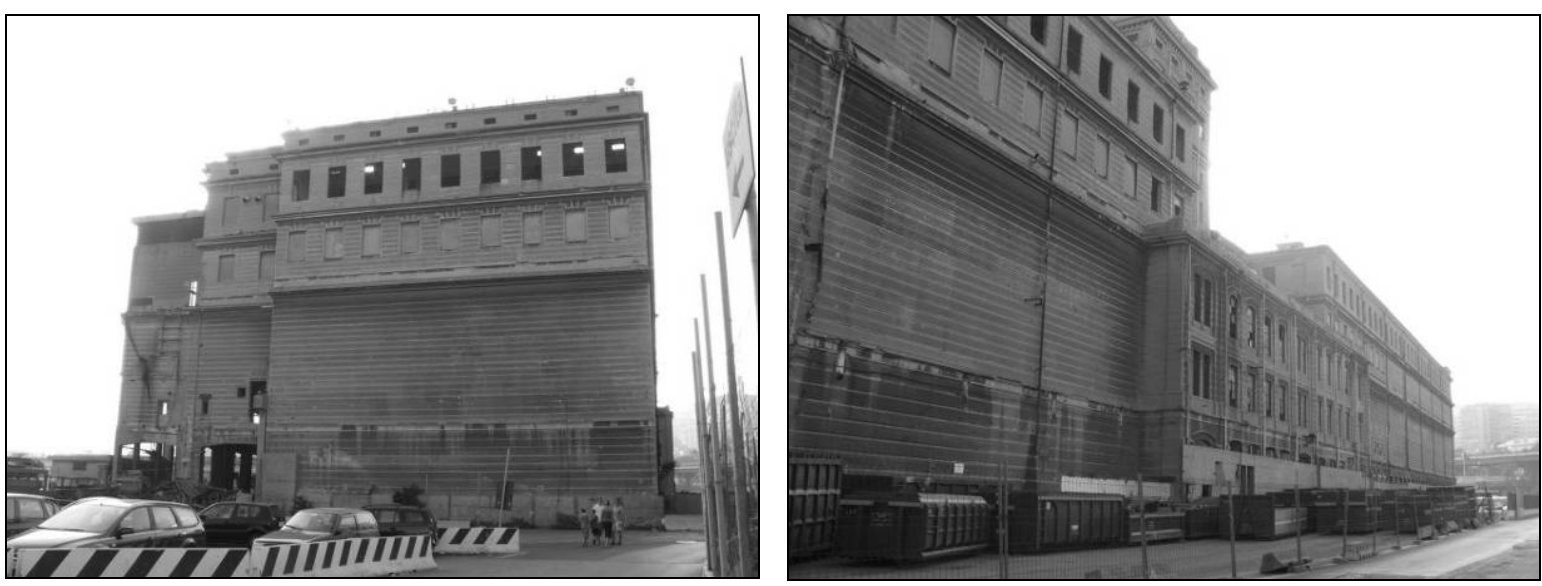

28. Silos de concreto armado, atribuídos a Hennebique. Atualmente abandonados, 2007. (Foto da autora)

Pelos exemplos construídos ou previstos, no entanto, notamos que a tônica das intervenções tem sido a recorrência a projetos 'âncora' para induzir a valorização da área e promover o turismo. Esse modelo de intervenção, inclusive, já era pensado antes das obras da Expo $92^{107}$. Na década de 1980 o arquiteto americano John Portman propôs a construção de um edifício multifuncional de 34 andares, com cerca de $250 \mathrm{~m}$ de altura, nas proximidades da área onde hoje está o Aquário. O grandioso edifício, conhecido como o 'cone de Portman', seria inserido na então degradada área portuária como uma estrutura absolutamente estranha ao contexto, ou seja, o sítio histórico seria encarado como um mero contentor para o novo projeto.

As propostas efetivamente implementadas no Porto não chegaram a ser tão audaciosas em termos de escala, mas como um todo foram pautadas, ainda assim, primeiramente pelos retornos econômicos advindos da revitalização; e a preservação e valorização das antigas estruturas portuárias subordinou-se a tais objetivos. Dessa forma, o sucesso atribuído aos projetos relaciona-se ao atendimento dessa prioridade econômica e não à uma preservação criteriosa de todo o conjunto, ainda que muitos dos projetos isolados possam representar bons projetos arquitetônicos.

\footnotetext{
107 Para um panorama das primeiras propostas apresentadas para a reutilização do Porto, as discussões contrárias à privatização de grandes áreas das antigas plataformas para empreendimentos privados e idéias alternativas desenvolvidas no âmbito da universidade, consultar: GENOVA: Come utilizzare il porto storico. Italia Nostra, anno XXX, n.241, agosto 1986, pp. 15-17.
} 


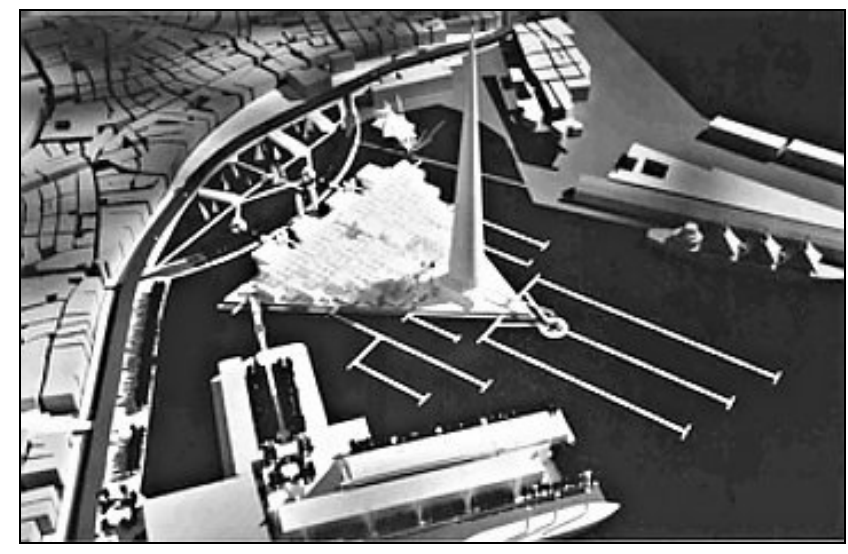

29. O 'cone' de Portman. Projeto da década de 1980 para a revitalização do Porto. Tratava-se de um edifício de $250 \mathrm{~m}$ de altura cuja forma teria sido inspirada em um mastro de navio. O edifício e anexos abrigariam diversos usos: marina, hotel, comércio, restaurantes e escritórios. (site John Portman Associates \& Inc.)

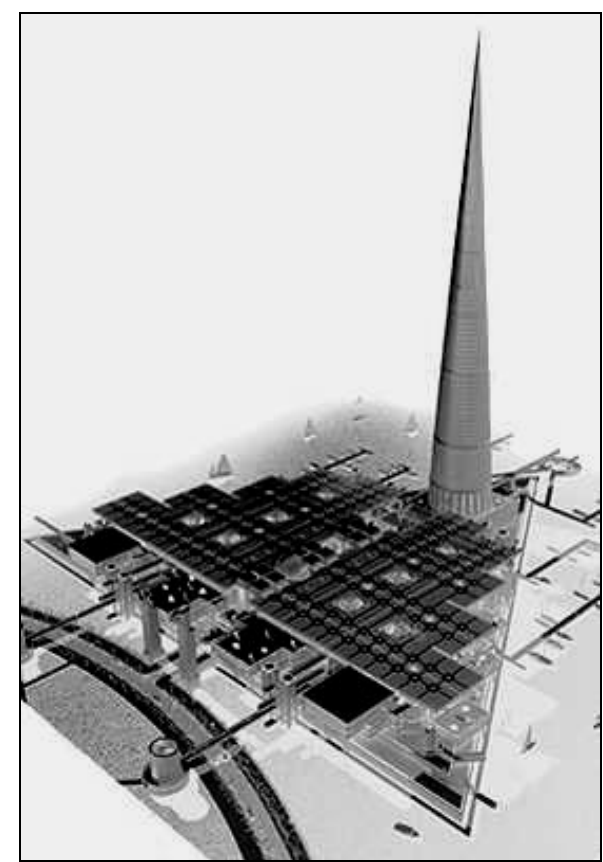

De fato, após a primeira etapa de requalificação, o turismo na cidade realmente recebeu um grande impulso, motivo pelo qual muitos arquitetos e urbanistas consideram a intervenção bem sucedida e defendem a metodologia adotada ${ }^{108}$. A questão da preservação do conjunto arquitetônico e urbano do Porto, bem como de suas relações com a cidade antiga, no entanto, é tema geralmente citado em segundo plano.

Desde a década e 1960, As antigas áreas portuárias já vinham sendo descaracterizadas por obras associadas ao desenvolvimento urbano da cidade. Durante a construção da via elevada, vários armazéns portuários foram 'cortados'. Segundo Bobbio, a construção desses armazéns remonta aos séculos XVII e XVIII. De maneira análoga, a construção do túnel e do metrô, na década de 1990, condenou as antigas estruturas portuárias que vieram à tona durante as escavações para realização das obras. Tratava-se das estruturas do sistema portuário medieval composto por plataformas de pedra e que ficara escondido sobre as sucessivas estratificações advindas das modernizações posteriores do Porto. As estruturas estavam intactas no subsolo e foram totalmente retiradas para a passagem do metrô, restando apenas uma parede que hoje está à mostra na entrada da estação. O sistema representava um testemunho único de arqueologia industrial e acabou sendo removido sem gerar muita discussão. Na época, foram poucos os que se

\footnotetext{
${ }^{108}$ Para se ter uma idéia, hoje o Aquário de Genova é o terceiro ponto turístico mais visitado da Itália, atrás somente dos Museus Vaticanos, em Roma, e do Museu Uffizi, em Florença.
} 
levantaram contra a destruição, como Edoardo Benvenuto, que buscou, sem sucesso, evidenciar a importância de se preservar tais testemunhos. ${ }^{109}$
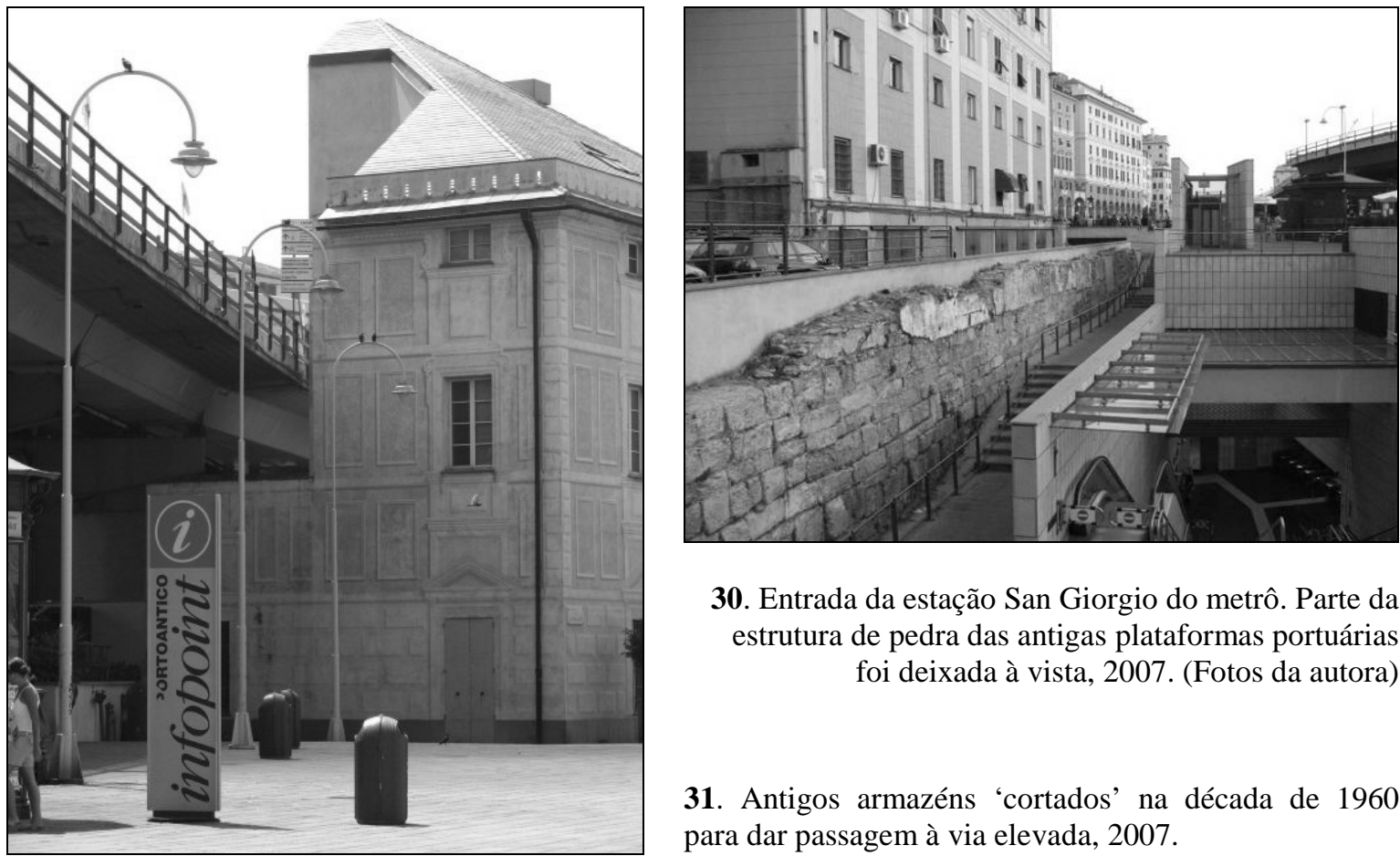

30. Entrada da estação San Giorgio do metrô. Parte da estrutura de pedra das antigas plataformas portuárias foi deixada à vista, 2007. (Fotos da autora)

31. Antigos armazéns 'cortados' na década de 1960 para dar passagem à via elevada, 2007.

Com relação à inserção do processo de revitalização em planos urbanos de maior abrangência, Bobbio ressalta as dificuldades envolvidas no tratamento de áreas tão extensas. A execução dessas intervenções tem sido prevista em plano diretor, mas sob a forma de diretrizes gerais. De acordo com a dinâmica projetual adotada, é difícil prever o próximo passo das operações, pois é necessário aguardar a resposta dos empreendimentos já realizados para poder prosseguir com novos projetos. Ainda segundo Bobbio, uma das questões principais é o que fazer com edifícios tão grandes. Já existe um grande centro comercial, um aquário, museus, faculdades... e agora começa a ficar difícil definir novos usos.

Essa dificuldade, porém, pode ter sido originada pelo próprio processo desarticulado de intervenção, um processo que se iniciou sem saber ao certo onde deveria chegar, concebido, portanto, sem a visualização de um cenário global que conduzisse as obras pontuais para alcançar um objetivo comum. A inexistência de um projeto amplo já era observada por estudiosos desde a década de 1980, quando Vittorio Borachia, refletindo

\footnotetext{
${ }^{109}$ Informações fornecidas pelo professor Roberto Bobbio, em entrevista. Sobre a destruição das estruturas portuárias da época de Colombo para a construção do túnel, também comenta: POLEGGI, E., Waterfront..., op. cit. op. cit., p.12.
} 
sobre o Plano Diretor de Genova, então em vigor, comentou sobre a necessidade de elaborar um projeto de longa duração para a reutilização das antigas áreas portuárias, um plano que soubesse utilizar as várias formas de planejamento do território para evidenciar os traços da história urbana como um recurso para conduzir as intervenções futuras, ou seja, um processo que buscaria "ler na história dos projetos de cidade que lhe deram forma e que a fizeram reconhecível, as indicações, as regras, as liberdades concedidas para construir sobre o passado um futuro conectado com as suas raízes". ${ }^{110}$

As intervenções executadas no Porto foram tema de debates desde o início da operação. Segundo Ceccaroni ${ }^{111}$, o modelo de intervenção adotado, baseado em grande parte em experiências norte-americanas de remodelação de áreas portuárias, a exemplo de Boston e Baltimore, pautou-se pela inserção de grandes estruturas comerciais visando o aproveitamento máximo da área. Logo, diferentemente do que se deveria esperar no tratamento de bens culturais, a operação não teve como objetivo inicial a valorização das estruturas históricas e a proposição de novos usos com o intuito de reintegrá-las à dinâmica urbana contemporânea. Não só as particularidades compositivas do Porto não foram devidamente consideradas (os edifícios, os percursos originais, a composição espacial e volumétrica, etc.), como também as relações existentes entre a área portuária e a estrutura da cidade antiga. Essas relações condicionaram, historicamente, a própria conformação do centro antigo, configurado e consolidado a partir da presença do Porto que se configura, portanto, como "a matriz fundamental do organismo urbano" circunstante, característica fundamental que não poderia ter sido negligenciada no processo de requalificação. No conjunto das intervenções propostas, “a transformação do antigo porto em 'portinho' turístico representa uma solução que perturba o caráter essencialmente público e utilitário que esse setor sempre manteve em confronto com cidade". ${ }^{112}$

Com a instalação das novas estruturas, o centro histórico passou a assumir a função de apoio à função turística do Porto, desnaturando seus originais significados e privando-o das relações que historicamente o configuraram. O autor destaca, no bojo de

\footnotetext{
${ }^{110}$ BORACHIA, Vittorio. Progettare Genova. Storia, architettura, piano e città. Genova: Costa \& Nolan, 1989, pp.13-15 apud POLEGGI, E., Waterfront..., op. cit., p.12. Trad. nossa. "leggere nella storia dei progetti di città che le hanno dato forma e che l'hanno resa riconoscibile, le indicazione, le regole, le libertà concesse per costruire sul passato un avvenire connesso alle sue radici."

${ }^{111}$ CECCARONI, Marco. Genova 1992: La scoperta del Porto Vecchio. Spazio \& Società, anno XV, n.58, 1992.

112 CECCARONI, Marco. Genova 1992..., op. cit. Trad. nossa. "La trasformazione del Porto Antico in porticciolo turistico rappresenta una soluzione che stravolge il carattere essenzialmente pubblico e utilitaristico che questo ambito ha sempre mantenuto nei confronti con la città."
} 
propostas dessa natureza, uma falta de visão e compreensão das particularidades que compõem o organismo urbano; uma interpretação falha do 'fenômeno cidade' que impossibilita a elaboração de projetos urbanos criteriosos, de maior completude, que abarquem adequadamente essas complexas transformações e renovações, vislumbrando, inclusive, questões sociais. No caso específico da área portuária de Genova, o necessário estabelecimento de um novo equilíbrio entre cidade e Porto vai muito além de uma simples reapropriação material dos edifícios e das plataformas. Seria necessário redesenhar um conjunto de relações entre os dois setores sob o risco de a 'descoberta' do porto antigo configurar-se, quinhentos anos depois, como mais um ato de "invasão e colonização".

Para Poleggi, as obras no Porto são uma ocasião especial em que "a cidade é chamada a uma escolha radical entre o bom senso e a 'modernidade', entre o retorno às origens e a destruição sem retorno". Na análise dos documentos oficiais sobre a operação de revitalização em pauta, o autor evidencia o distanciamento entre o discurso no papel, em que se observa o emprego de léxicos profissionais que sugerem a preocupação com a preservação, e a prática das intervenções. ${ }^{113}$ Nos documentos analisados, dentre os objetivos da operação estão a "integração entre cidade e arco portuário", ou a "tutela dos valores ambientais e arquitetônicos [...] com rigoroso critério de salvaguarda", expressões que, na verdade, não encontram repercussão na ação prática, pautada, como vimos, por projetos pontuais e desarticulados, regidos pela promoção de uma nova imagem, atitudes que sacrificam seculares permanências arquitetônicas e ambientais.

Do ponto de vista de grande parte dos urbanistas, contudo, as obras da Expo 92 e experiências posteriores têm sido consideradas como um verdadeiro "renascimento da cidade", um impulso bem sucedido para a "diversificação da economia urbana", conferindo à Genova, inclusive, a alcunha de cidade da cultura e do turismo. ${ }^{114} \mathrm{O}$ novo Plano Diretor, elaborado entre 1999 e 2000, dá continuidade aos processos em andamento. As intervenções urbanas são abordadas pelo Plano sob diferentes aspectos, sobretudo relacionados à continuidade do incentivo aos usos culturais, ao desenvolvimento portuário e ao crescimento econômico da cidade ${ }^{115}$. No que tange às áreas urbanas de interesse cultural, como são as áreas portuárias, a questão da preservação continua condicionada à

\footnotetext{
${ }^{113}$ POLEGGI, E., Waterfront..., op. cit., pp.16-17. Os documentos oficiais citados são: Delibera n.167 del 1.3.1990, intitulada 'Inquadramento urbanistico degli interventi nel Porto Storico' e o 'Studio organico di insieme, 1984'.

${ }^{114}$ DANSERO, Egidio; GIAIMO, Carolina; SPAZIANTE, Agata. Se i vuoti si riempiono. Aree industriali dismesse: temi e ricerche. Firenze: Alinea, 2001, p.107.

${ }^{115}$ Sobre o novo Plano Diretor de Genova, consultar: GABRIELLI, B., La 'Rinascita'..., op. cit., pp. 33-35.
} 
execução das intervenções de revitalização que prosseguem segundo os critérios anteriormente analisados. Podemos observar, portanto, não somente a submissão dos valores culturais da área portuária às perigosas prioridades econômicas e promocionais, como também um flagrante distanciamento entre os discursos da preservação e do planejamento urbano.

Um exemplo de intervenção em sítios industriais de interesse cultural que evidencia questões interessantes para debate, é o projeto de reutilização dos sítios industriais desativados de Bagnoli, em Nápoles, área que abrigou, entre outros estabelecimentos, uma grande indústria siderúrgica, hoje desativada. O projeto de intervenção no antigo sítio industrial, a exemplo do que temos observado em Roma e Genova, também tem sido encarado como uma oportunidade para alçar Nápoles ao cenário internacional, colocando-a "em competição com as grandes metrópoles do mundo no circuito do turismo e dos intercâmbios internacionais". ${ }^{116}$ A atenção para com os artefatos industriais existentes, contudo, de certa forma tem comparecido na condução dos projetos.

A área a ser objeto de intervenção é constituída pela planície de Coroglio, no bairro Bagnoli, quase toda ocupada pelas antigas estruturas industriais da siderúrgica IlvaItalsider e da Eternit, antiga fábrica de produtos de cimento amianto. A área compreende cerca de 4,7 km² entre o Golfo de Pozzuoli e a Colina de Posillipo, em uma bela região litorânea. As atividades industriais na região remontam à segunda metade do século XIX, tendo se intensificado no início do século XX, a partir de diretrizes legislativas que incentivaram a ocupação industrial na região. Um dos setores industriais de maior representatividade em Bagnoli, a siderurgia, instalou-se no bairro em 1910 com a implantação da Ilva, cujas instalações compreendiam todo o ciclo de produção do aço. Cabe ressaltar que a presença do porto foi fundamental para a instalação das indústrias na região, facilitando a chegada de matéria prima e o escoamento dos produtos finais. $\mathrm{O}$ período de maior ascensão da Ilva foi ao longo da década de 1960, quando passou a denominar-se Ilva-Italsider. Logo em seguida, contudo, na década de 1970, a empresa

\footnotetext{
${ }^{116}$ GIANNİ, Roberto. Il centro storico e le aree ex industriali. Spazio \& Società, anno XVIII, n.69, 1995. Sobre outros projetos de revitalização em áreas industriais napolitanas, ver: RUSSO, Michelangelo. Napoli: scenari futuri. La difficile condivisione. Il Giornale dell'Architettura, n.47, gennaio 2007, p.5.
} 
começou a entrar em declínio, principalmente frente à concorrência da produção japonesa. $^{117}$

Já nesta época, na década de 1970, o Plano Diretor de Nápoles vislumbrava a possibilidade de destinar parte da área de Coroglio (incluindo áreas ocupadas pela Italsider), para a implantação de áreas verdes e construção de empreendimentos turísticos buscando explorar as potencialidades da região litorânea. Essas novas funções ocupariam cerca de $30 \%$ da planície, e os $70 \%$ restantes receberiam atividades produtivas não poluentes e empresas voltadas à pesquisa na área industrial. Tais propostas antecipavam o atual cenário de reconversão da área. No entanto, ainda aconteceria uma última tentativa de reerguer a atividade siderúrgica na região, com a realização de modernizações nos equipamentos e processos produtivos de modo a adequá-la à competitividade internacional. Poucos anos depois, contudo, a produção enfrenta nova crise e o estabelecimento é definitivamente fechado entre 1989 e 1991 . Entre 1991 e 1994 inicia-se a desmontagem de algumas instalações da fábrica. As outras atividades industriais da região também entram em decadência na mesma época. ${ }^{118}$

Ainda antes do fechamento total dos estabelecimentos, no final dos anos 1980, a administração municipal já pensava em algumas opções para a reutilização das áreas industriais de Bagnoli. Duas possibilidades eram aventadas: um parque científico e tecnológico, mantendo parte das estruturas industriais existentes ou o aproveitamento da área para fins turísticos. Essas idéias não foram bem recebidas pela comunidade local pois havia o receio de que a valorização da área expulsasse os moradores tradicionais, em grande parte antigos trabalhadores das fábricas desativadas.

Em 1994, foi elaborado um plano para a recuperação ambiental das áreas desocupadas de Bagnoli, por iniciativa da CIPE (Comitato Interministeriale Programmazione Economica). O plano determinou a desmontagem das indústrias IlvaItalsider e Eternit e a despoluição dos terrenos. As operações foram também previstas no Plano Diretor de Nápoles, em revisão de 1994. Em síntese, o plano de recuperação objetiva "a formação de um vasto território de baixa densidade construtiva onde atividades

\footnotetext{
${ }^{117}$ Sobre a história da industrialização e desindustrialização de Nápoles e análise dos planos diretores em diferentes momentos, consultar: CARDILLO, Enrico. Napoli: l'occasione post-industriale. Da Nitti al piano strategico. Napoli: Guida, 2006.

${ }^{118}$ STANGHERLIN, Bernardino. L'ex area industriale di Bagnoli: la bonifica degli impianti dismessi e il piano di risanamento ambientale. Recuperare l'edilizia, anno 3, n.13, 2000, pp. 22-29.
} 
produtivas ligadas à pesquisa se integram com atividades para o turismo, o tempo livre, a cultura". ${ }^{119}$ Especificamente em Coroglio, o plano de recuperação abrange uma área de aproximadamente 470 hectares. Essa área deverá ser paulatinamente transformada com a construção de um grande parque entre a Colina e a praia, com a previsão da recuperação das áreas de areia para atividades de balneário, a criação de um porto turístico, bem como novas edificações para residência e atividades terciárias. As diretrizes para condução dessas transformações foram reunidas no Plano Urbanístico Executivo de CoroglioBagnoli, aprovado em $2005^{120}$.

A desocupação da área para dar espaço aos novos usos iniciou-se já em 1999, quando começaram a ser demolidos alguns equipamentos da siderúrgica e iniciaram-se os procedimentos técnicos para despoluição dos terrenos. Nem todos os testemunhos industriais foram demolidos. Foram selecionadas 16 estruturas, classificadas como de particular interesse arqueológico e/ou arquitetônico, que deverão ser preservadas e reintegradas às novas funções. Inicialmente, o plano de 1994 previa a manutenção de 43 artefatos. Cabe ressaltar, contudo, que por se tratar de uma atividade muito poluente, a escolha dos exemplares do patrimônio industrial a serem mantidos, sobretudo equipamentos, precisou pautar-se também por critérios de viabilidade com relação à possibilidade de manutenção ou reutilização dos mesmos de modo seguro. Além dessa exigência, contudo, desconhecemos quais os outros critérios adotados, ou mesmo a profundidade dos estudos prévios realizados, para subsidiar a escolha desses 16 artefatos.

O sítio industrial, como ressalta Stangherlin, possui numerosos espaços, edifícios e estruturas de grande interesse, como o Cais Norte, que avança sobre o mar por cerca de $750 \mathrm{~m}$, uma enorme chaminé e sobretudo o grande edifício da aciaria, localizado no centro do complexo. Tais estruturas possuem grande representatividade na configuração da paisagem do bairro, bem como na memória dos moradores locais, e têm sido consideradas com atenção desde os primeiros projetos para a área. Na seleção, procurou-se observar, "além dos peculiares valores de caráter arquitetônico e tecnológico dos edifícios e artefatos presentes na área, também, e sobretudo, o atendimento do principal objetivo, presente no Plano Diretor, de formação de um parque urbano sobre grande parte da antiga área

\footnotetext{
${ }^{119}$ STANGHERLIN, B., L'ex area industriale..., op. cit. Trad. nossa. "la formazione di un vasto territorio a bassa densità edilizia dove attività produttive legate alla ricerca si integrano con attività per il turismo, il tempo libero, la cultura."

${ }^{120}$ Piano Esecutivo Urbanistico di Coroglio-Bagnoli (PUE). Napoli: Comune di Napoli, 2000-2003.
} 
industrial". Parque que, "além de representar o sinal tangível da requalificação, deverá também conservar o testemunho histórico do passado industrial da região". ${ }^{121}$ Desse modo, procurou-se atentar para os artefatos que pudessem testemunhar o ciclo produtivo do aço com intuito de promover um percurso didático, e também 'espetacular', no sentido de evocar as diversas fases do processo, mesmo se de modo fragmentário.

32. Planície de Coroglio, bairro Bagnoli, Nápoles. Mapeamento das futuras intervenções segundo o PUE. A área demarcada como n.1 será destinada ao Parque Urbano. (PUE Coroglio-Bagnoli)

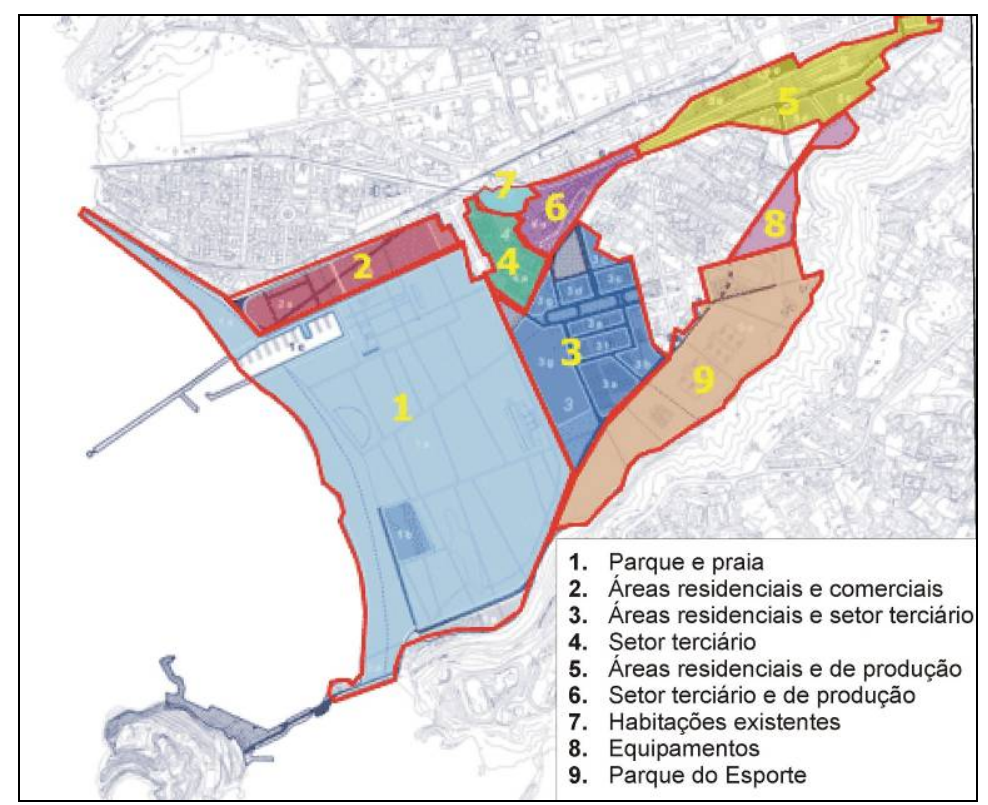

33. Vista aérea de Coroglio-Bagnoli. Em destaque, sítio industrial objeto das futuras intervenções. Em vermelho, primeira etapa das obras.

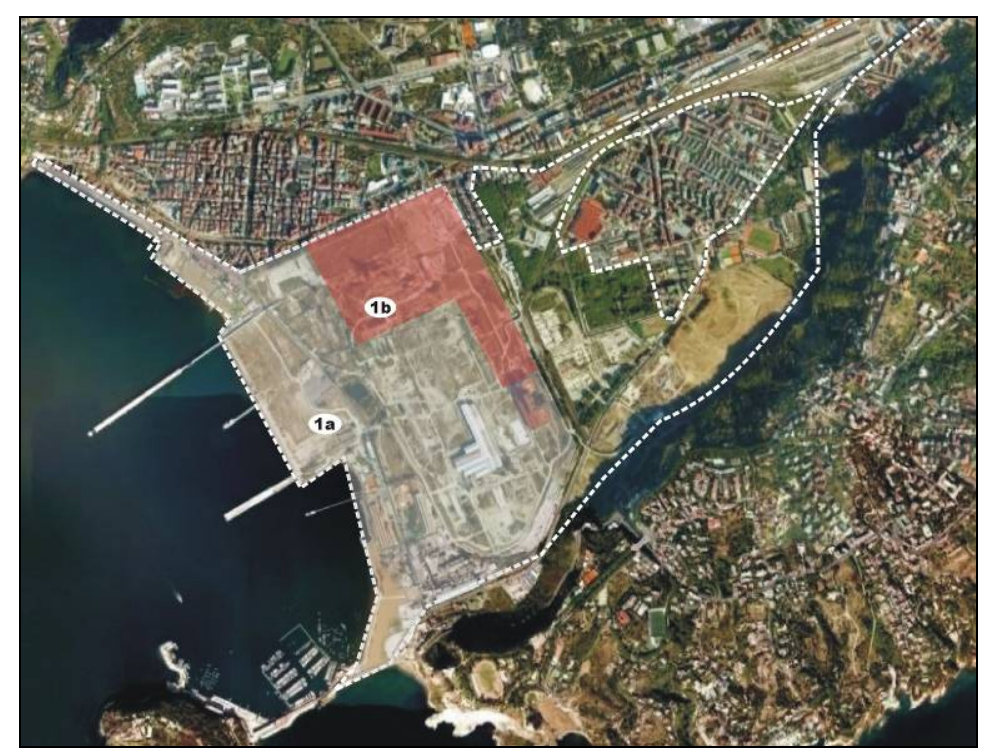

${ }^{121}$ STANGHERLIN, B., L'ex area industriale..., op. cit., pp. 26-27. Trad. nossa. "I criteri di selezioni sono stati orientati, oltre che dalle peculiari valenze di carattere architettonico e tecnologico degli edifici e manufatti presenti nell'area, anche e soprattutto dal perseguimento dell'obiettivo primario, presente nella Variante al Piano Regolatore, di formazione di un parco urbano su gran parte dell'ex area industriale, parco che oltre a rappresentare il segno tangibile della riqualificazione, dovrà conservare anche la testimonianza storica del passato industriale della zona" 


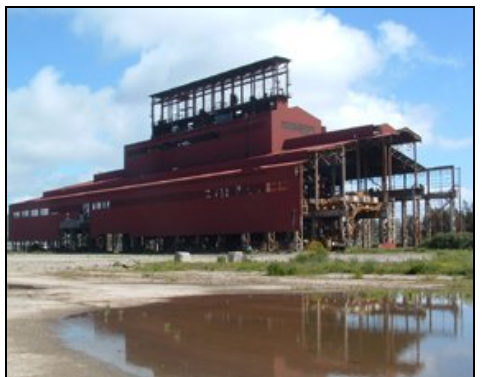

a.

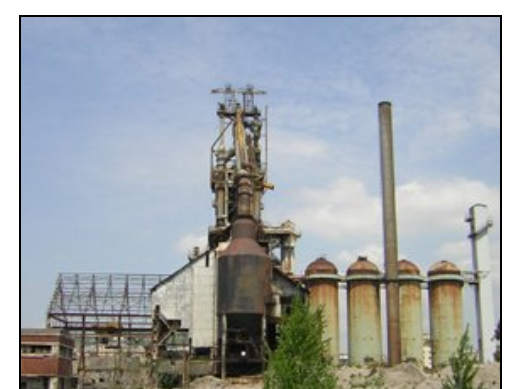

b.

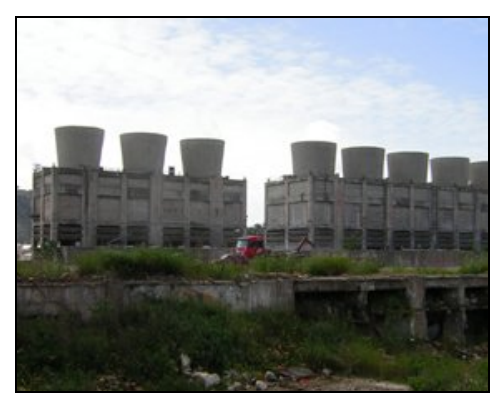

c.

34. Artefatos industriais que serão adaptados para novas funções no parque. a. Edifício da Aciaria construído na década de 1960, abrigará a Cidade da Música e um restaurante panorâmico; b. Alto-forno construído na década de 1950, futuro Museu do Trabalho; c. Central de resfriamento de água construída nos anos 1980, deverá transformar-se em Aquário e Centro de Exposições sobre o Mar. (BagnoliFutura)

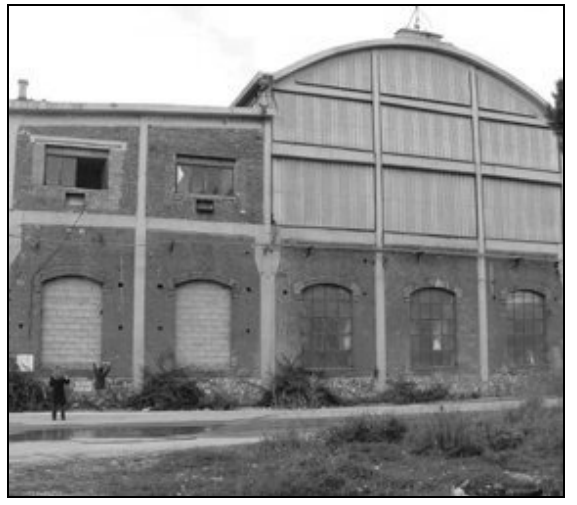

a.

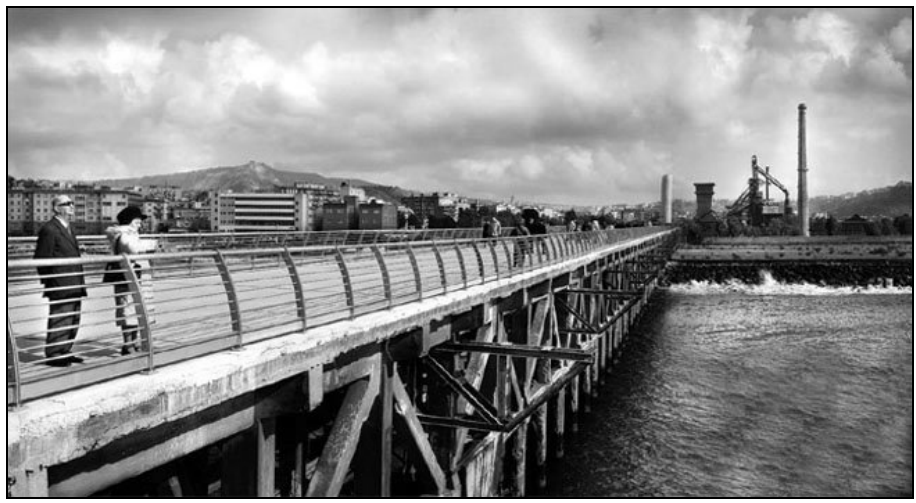

b.

35. a. Oficina mecânica construída em 1910. Será transformada em sede de um instituto de pesquisas;

b. Cais Norte recentemente recuperado como passeio público. Ao fundo, as grandes estruturas do sítio industrial marcam a paisagem, sobretudo a grande chaminé e o alto-forno. (BagnoliFutura)

Após a escolha dos 16 artefatos, foram definidas as diretrizes gerais para tratamento dos mesmos, classificando quais deveriam ser preservados integralmente e quais poderiam ter algumas partes desmontadas ou demolidas (principalmente no caso de grandes equipamentos). Entre os artefatos a serem preservados estão o Cais Norte, as instalações para triagem dos materiais fósseis, duas chaminés, a central termoelétrica, os sistemas de tratamento de água, entre outras. Cabe ainda ressaltar que, como previa o Plano Diretor, foram também desenvolvidos planos complementares para determinar quais os novos usos que esses artefatos deveriam receber. Dessa forma, procurou-se definir previamente quais artefatos seriam preservados como equipamentos públicos do parque e quais seriam confiados às funções geridas pela iniciativa privada. 
Um dos problemas do projeto de revitalização, apontado por Iaccarino, é a forma como as novas funções têm sido inseridas no bairro, sem buscar dialogar com as atividades já existentes, gerando prejuízos para a população local que gradativamente tem se afastado da área com a chegada dos grandes investimentos e o aumento dos preços dos imóveis. ${ }^{122}$ Essa questão possui grande pertinência pois a realidade urbana e social das áreas residenciais de Bagnoli e dos bairros adjacentes, está estreitamente relacionada às antigas atividades industriais ali sediadas, e configura, portanto, um importante elemento desse patrimônio. Cabe ressaltar, inclusive, que a desativação das indústrias de Bagnoli foi motivo de grande comoção no bairro, tanto devido ao receio dos problemas sociais a serem gerados pelo desemprego, como também por razões emotivas, já que uma significativa parcela da população da região nasceu e viveu nesse ambiente em grande parte moldado pela presença das fábricas. Para se ter uma idéia dessa dimensão simbólica, a desocupação industrial de Bagnoli chegou a ser tema de músicas populares ${ }^{123}$, e também de um romance do escritor napolitano Ermano Rea. No romance, a desocupação é o cenário para a narração de histórias pessoais de moradores da região cujas vidas são desarticuladas na medida em que a estruturas industriais vão sendo desmontadas. A desativação da fábrica representa, alegoricamente, a gradativa dissolução dos códigos sociais, das atividades tradicionais e das referências memoriais associadas ao bairro industrial. ${ }^{124}$ Não faria sentido, portanto, preservar testemunhos desse passado e destruir, ao mesmo tempo, o próprio contexto social que o faz ainda vivo.

As intervenções ainda estão em fase de implantação e precisaríamos acompanhar o andamento do processo para desenvolver análises mais criteriosas. Em 2002 foi criada a

\footnotetext{
${ }^{122}$ IACCARINO, Lucio. Ancora il caso Bagnoli: dalla pianificazione urbanistica ai paradossi istituzionali. Urbanistica Informazioni, anno XXXII, n.109, 2005, p.86.

${ }^{123}$ Trata-se da composição 'Vendo Bagnoli' do cantor napolitano Edoardo Bennato. A letra ironiza a transformação de Bagnoli em instrumento de lucro: "Ma che occasione, ma che affare / vendo Bagnoli chi la vuol comprare / colline verdi mare blu /avanti chi offre di più / vendo Bagnoli con le ciminiere / però sbrigatevi perché / è un'asta conto fino a tre!" (Optamos por não traduzir para não perder a sonoridade).

${ }^{124}$ REA, Ermano. La dismissione. Milano: BUR, 2002. Nessa passagem do romance, o narrador descreve a gradativa transformação das cotidianidades urbanas do bairro Bagnoli após o fechamento da siderúrgica: "Em seguida, a repentina mudança de cena. Repentina? Alguns dizem que aconteceu quase de um dia para o outro, após o fechamento a frio, em 91. Há quem diga, por outro lado, que foi um pouco por vez, como uma morte por hemorragia. Teriam desaparecido em primeiro lugar os vendedores ambulantes, em seguida os trabalhadores dos turnos, depois os empregados, depois os desocupados, depois as prostitutas. Então teriam começado a desligar as luzes dos primeiros estabelecimentos. Uma luz a menos por vez, a intervalos irregulares." Trad. nossa. "Poi, il repentino mutamento di scena. Repentino? C'è chi dice che avvenne quasi da un giorno all'altro, all'indomani della chiusura a freddo, nel'91. Chi dice invece che si produsse un po' alla volta, come una morte per dissanguamento. Sarebbero scomparsi innanzi tutto i venditori ambulanti, poi i turnisti, poi gli impiegati, por gli sfaccendati, poi le puttane. Poi avrebbero cominciato a spegnersi le luci dei primi esercizi. Una luce in meno ogni tanto, a intervelli irregolari."
} 
Bagnoli Futura, Sociedade de Transformação Urbana (STU) ${ }^{125}$ com a participação de diferentes esferas da administração pública (comune, região e província), que deverão atuar conjuntamente na execução das intervenções previstas pelo Plano Urbanístico Executivo Bagnoli-Coroglio. Um modelo de execução e gestão, portanto, diferente daquele proposto para a recuperação dos Mercados Gerais de Roma, em que a iniciativa privada lidera a condução dos objetivos do empreendimento.

A recuperação do Cais Norte foi concluída em 2005 e atualmente estão sendo executadas as obras da primeira fase de implantação do parque. $\mathrm{O}$ projeto do Parque Urbano de Bagnoli, vencedor de concurso, foi desenvolvido pelo escritório italiano Insula Arquitetura e Engenharia, com equipe coordenada pelo arquiteto Francesco Cellini. Pelo que pudemos observar nas imagens e descrições até o momento divulgadas, parece-nos que o projeto propõe intervenções criteriosas. Segundo a descrição textual do projeto, procurou-se criar novos espaços externos que dialogassem com as estruturas existentes de modo a permitir a leitura desses testemunhos e criar, ao mesmo tempo, um novo ambiente para abrigar as novas atividades. Além da valorização das estruturas industriais, buscou-se ainda evidenciar alguns traços dos antigos percursos produtivos. $\mathrm{O}$ grande edifício da aciaria atua como um 'ponto de força' na configuração do parque, em torno do qual as novas atividades se desenvolvem. Dessa forma, não foram propostas novas obras grandiosas ou espetaculares. As intervenções inserem-se de modo harmonioso e a grandiosidade coube aos imponentes remanescentes industriais que permanecem como personagens principais na configuração da paisagem. Somente no final das obras, contudo, poderemos desenvolver análises mais precisas.

\footnotetext{
125 A criação das Sociedades de Transformação Urbana (Società di Trasfomazione Urbana - STU) foi definida em lei de 1997 e disciplinada em 2000. Trata-se de um instrumento à disposição das administrações locais com o intuito de viabilizar a realização de intervenções em áreas urbanas consolidadas, previstas em planos urbanos vigentes. Depois de adquirir a área, cabe à STU a função de organizar as atividades de projeto, construção, gestão e comercialização das áreas construídas. No desenvolvimento de atividades de projeto e execução, a STU pode operar de duas formas: recorrendo ao seu próprio pessoal interno; ou buscando a colaboração externa.
} 
36a. Parque Urbano de Bagnoli. Projeto do escritório Insula Arquitetura e coordenado por Francesco Cellini. Em destaque, a primeira etapa das obras. As etapas de implantação do parque integram as diretrizes do PUE. (BagnoliFutura)
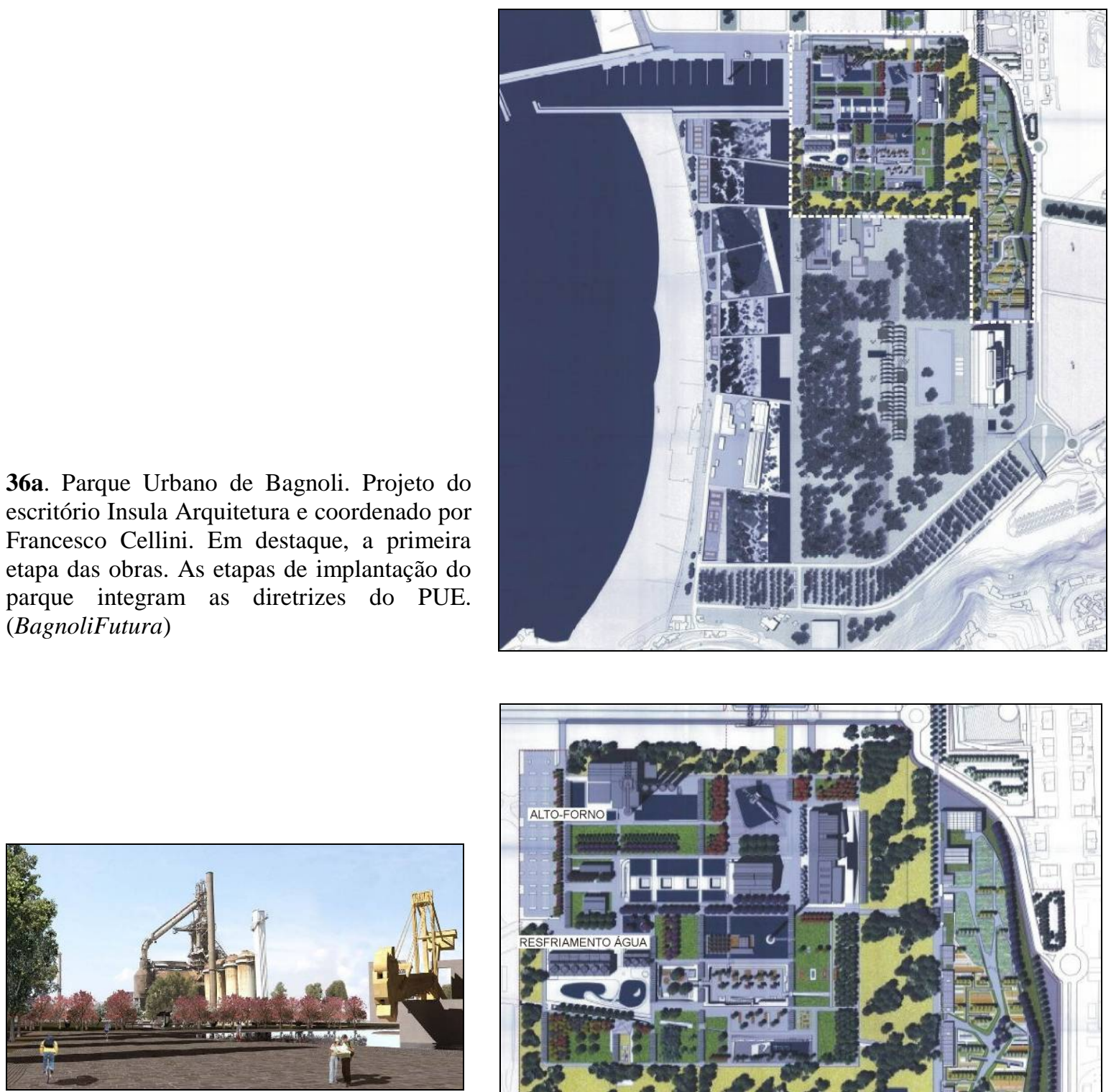

36c. Perspectiva eletrônica do parque. Ao fundo, as gigantescas estruturas do alto-forno. (BagnoliFutura)

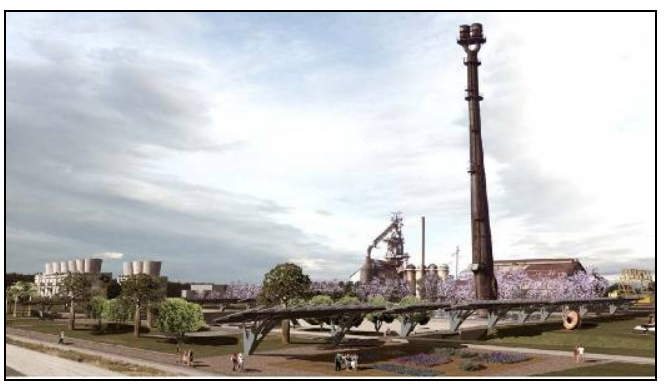

36d. Perspectiva eletrônica. À esquerda, a central de resfriamento de água. À direita, uma das chaminés. (BagnoliFutura)

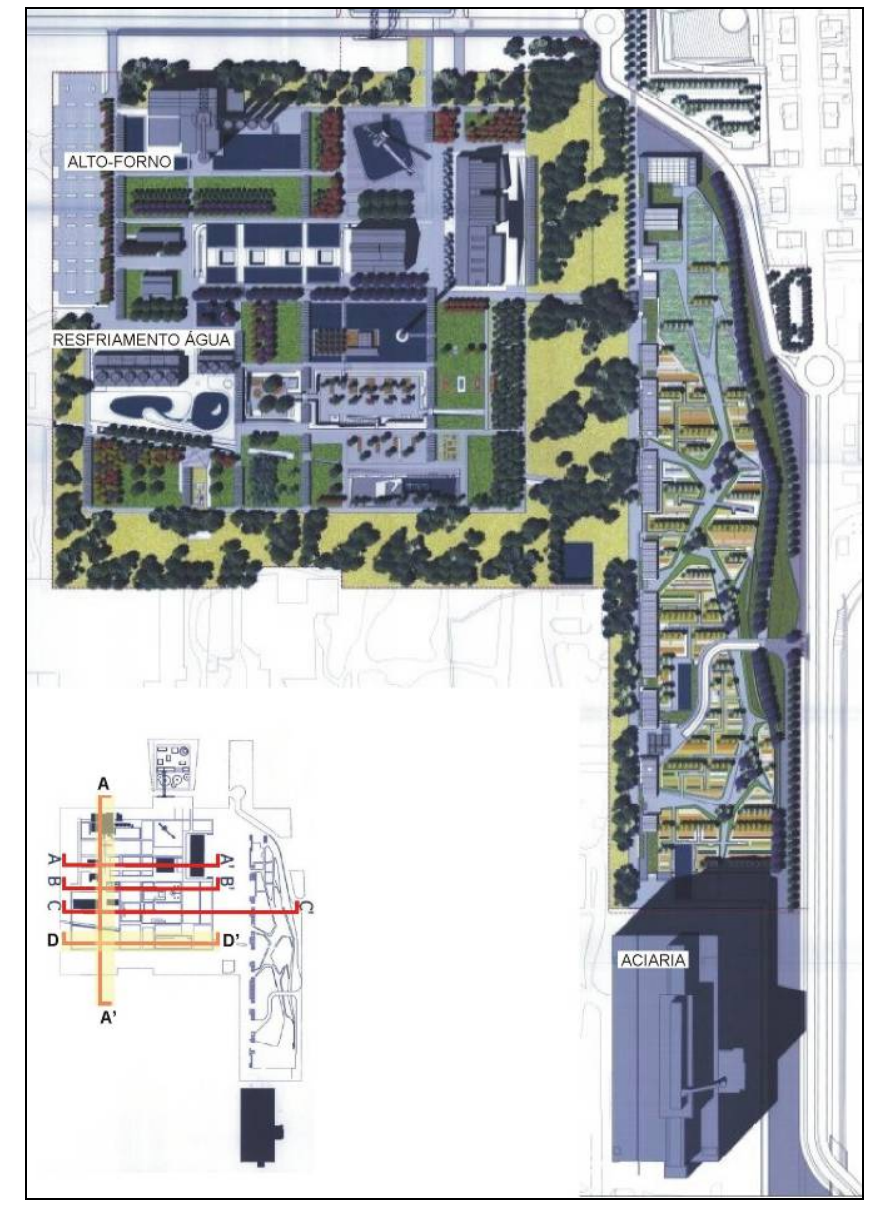

36b. Primeira etapa das obras. Os caminhos do parque procuram seguir a sequiência da produção siderúrgica, permitindo um percurso didático. Em destaque, alguns dos artefatos industriais preservados e integrados às novas funções. (BagnoliFutura) 


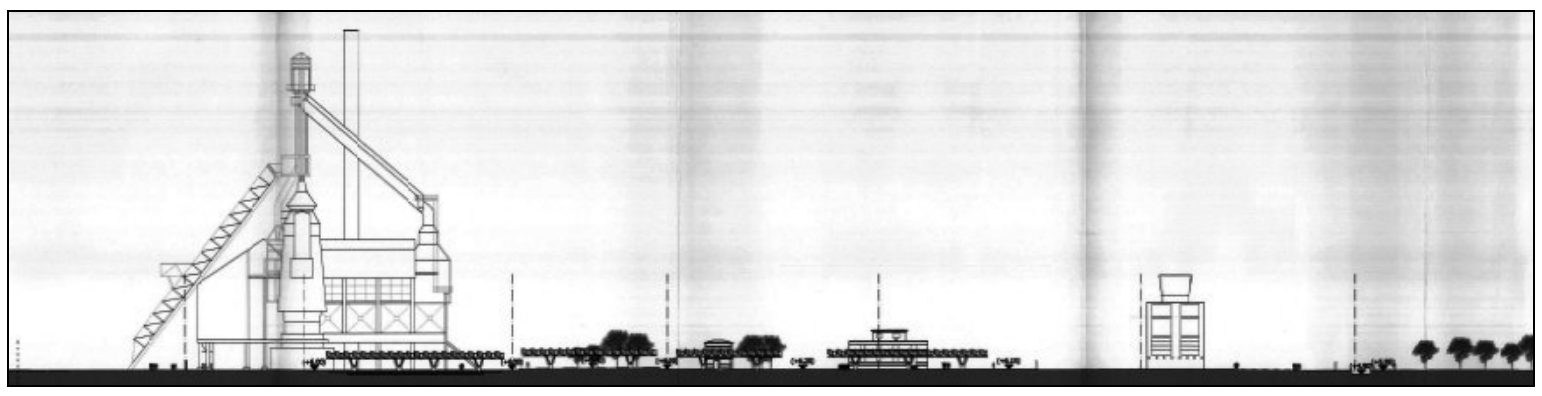

36e. Parque Urbano de Bagnoli. Corte AA'.

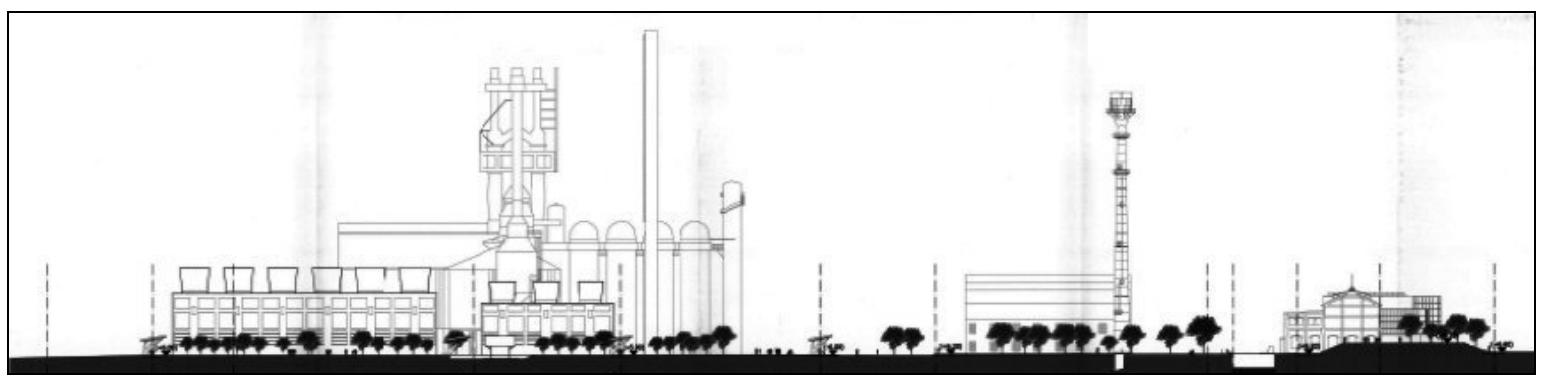

36f. Parque Urbano de Bagnoli. Corte DD'. (BagnoliFutura)

As propostas para Bagnoli nos remetem às operações realizadas na Alemanha entre os anos 1980 e 1990 num extenso perímetro que reúne vários sítios industriais, sobretudo vinculados à produção de carvão e à metalurgia, na região NordRheinWestfalen. Trata-se da região do Emscher Park, no vale do rio Ruhr. As atividades industriais no vale entraram em declínio nos anos 1980, gerando diversos problemas econômicos, sociais e ambientais na região industrial e arredores. A partir de então, iniciou-se a busca por alternativas para a revitalização do local e, em 1989, foi criado o grupo Internationale Bauausstellung Emscher Park que iniciou os programas para a instalação de um parque, abrangendo uma área de aproximadamente $800 \mathrm{~km}^{2}$.

As intervenções para criação do parque contaram com detalhada programação e a execução dos diversos projetos elaborados se estendeu por dez anos. Tratou-se de um projeto amplo, integrado, pensado previamente para se desenvolver num prazo longo e que envolveu a participação de várias esferas da administração pública, contando ainda com recursos da União Européia. Além do planejamento dos objetivos gerais a serem atingidos, foram desenvolvidos mais de cem projetos específicos que abarcaram não somente intervenções nos edifícios industriais desativados, mas também projetos urbanos e paisagísticos (incluindo trilhas para caminhada e ciclovias), projetos para exploração de fontes de energia alternativa, despoluição do local e do rio Emscher, instalação de infra- 
estrutura, recomposição das matas ciliares, construções residenciais e centros de pesquisa. Em síntese, uma série de intervenções integradas que buscaram recuperar a paisagem construída e natural. Os edifícios industriais foram adaptados para novos usos, sobretudo culturais, e algumas estruturas e equipamentos foram incorporados ao parque de modo criativo: um gasômetro foi convertido em espaços para exposições, um tanque de gás transformado em tanque para mergulho, antigas siderúrgicas abrigaram teatros, antigas fornalhas foram adaptadas como local para escaladas. A intervenção para a criação do parque foi pensada como um todo e procurou-se determinar os projetos pontuais a partir de uma coordenação prévia e de longa duração. Dessa forma, a análise dos artefatos industriais, considerados individualmente e em conjunto, permitiu a visualização de relações e articulações mais complexas, abarcando o espaço circundante, os bairros envolvidos e a própria cidade; um entendimento das relações entre as realidades que compunham aquele espaço (relações econômicas, políticas, sociais, urbanas) que permitiu fornecer as bases para um consistente plano de conjunto ${ }^{126}$. É um exemplo que merece ser acompanhado para se verificar o desenrolar dessas propostas no tempo e a condução futura dos projetos. Interessa-nos sobretudo destacar, que se tratava de uma área onde a questão da degradação abarcava não somente edifícios industriais obsoletos, mas toda uma realidade urbana envoltória e de grande dimensões. Situação que nos remete, indubitavelmente, à abordagem do problema de forma ampla, articulada e integrada ao planejamento urbano e regional, conduzindo à soluções complexas e de longa duração. A recorrência à soluções imediatistas, pontuais e desarticuladas, em casos como este, não permitem o desenvolvimento de um processo coerente de revitalização, não conduzem à um adequado tratamento do patrimônio urbano, e até mesmo podem gerar desequilíbrios ainda mais problemáticos para a região.

A partir das análises desenvolvidas nesse tópico, observamos que a intervenção no patrimônio urbano industrial requer uma compreensão apurada das especificidades dos artefatos envolvidos em diferentes escalas: as particularidades compositivas de cada edifício ou equipamento, suas relações com o sítio onde está inserido e as relações desse sítio com o bairro circundante e a própria cidade. A apreensão desse complexo sistema de

\footnotetext{
${ }^{126}$ A bibliografia sobre as intervenções realizadas no Vale do Ruhr é extensa. Neste breve comentário, buscamos infomações em: KÜHL, B. M., Preservação..., op. cit., pp. 108-109; KANIA, Hans. Zollverein XII, Zollverein Colliery and a $13 \mathrm{~km}^{2}$ Neighbouring Area Preserving a Large Scale Area inside the Ruhrgebiet. Patrimoine de l'industrie, n. 1, 1999-2000, pp. 25-30. Sugerimos ainda os artigos dos seguintes autores, para aprofundamentos: Corlay, Lambrecht, Ganser, Grohé, Minucci, Scognamiglio e Curreri, referências bibliográficas completas no final deste volume.
} 
relações deverá ser o primeiro passo para a concepção da intervenção como um todo articulado, um entendimento que naturalmente conduzirá à desejada integração interdisciplinar que temos buscado evidenciar. A apreensão dessas especificidades e relações, por sua vez, integra a imprescindível etapa de estudos preliminares, guiada pelas análises histórico-críticas, que antecedem qualquer operação de restauro. De posse desse conhecimento inicial e de criteriosa fundamentação teórica, a prática de intervenção, tanto no edifício isolado, como na área urbana como um todo, (considerando a inserção de novos usos, adaptações, remoções, novas construções), deverá ser conduzida segundo o juízo histórico-crítico.

\section{PRESERVAÇÃO DO PATRIMÔNIO URBANO-INDUSTRIAL PAULISTANO}

\section{A Operação Urbana diagonal Sul}

A exposição dos preceitos teóricos que regem a preservação e o restauro urbano e a observação dos principais entraves entre a teoria e a prática - principalmente no tratamento de sítios industriais de interesse cultural - , oferecem instrumentos para avaliarmos a condução da preservação do patrimônio urbano industrial paulistano, com enfoque para a Operação Urbana Diagonal Sul, objeto que nos impulsionou ao desenvolvimento de tais análises. A carência de sólidas fundamentações teóricas e a inobservância de diversos preceitos da teoria da preservação no tratamento do patrimônio industrial, questões que buscamos analisar no panorama italiano, também comparecem, sob diferentes aspectos, nas intervenções urbanas propostas ou efetivamente realizadas em nossa realidade cultural. Os percursos transcorridos pela citada operação urbana e a observação dos cenários propostos para o futuro tratamento deste perímetro evidenciam, mais uma vez, as rupturas entre a teoria e a prática.

A Operação Urbana Diagonal Sul (OUDS) abrange um extenso perímetro que percorre o eixo da Estrada de Ferro Santos-Jundiaí - a atual Linha 10 da CPTM, Companhia Paulista de Trens Metropolitanos - e seu entorno imediato, desde o bairro do Pari até a divisa com a cidade de São Caetano do Sul. ${ }^{127}$ Essa extensa faixa atravessa

${ }^{127}$ Conforme aludimos na introdução desta pesquisa, uma operação urbana é um recurso previsto em Lei federal e compreende um conjunto de intervenções e medidas coordenadas pelo Poder Público municipal 
vários bairros e abarca parcelas urbanas com características e paisagens diferenciadas. Tais bairros, no entanto, possuem uma particularidade comum: a presença histórica da atividade industrial como um importante elemento indutor de urbanização, notadamente a partir do início do século XX.

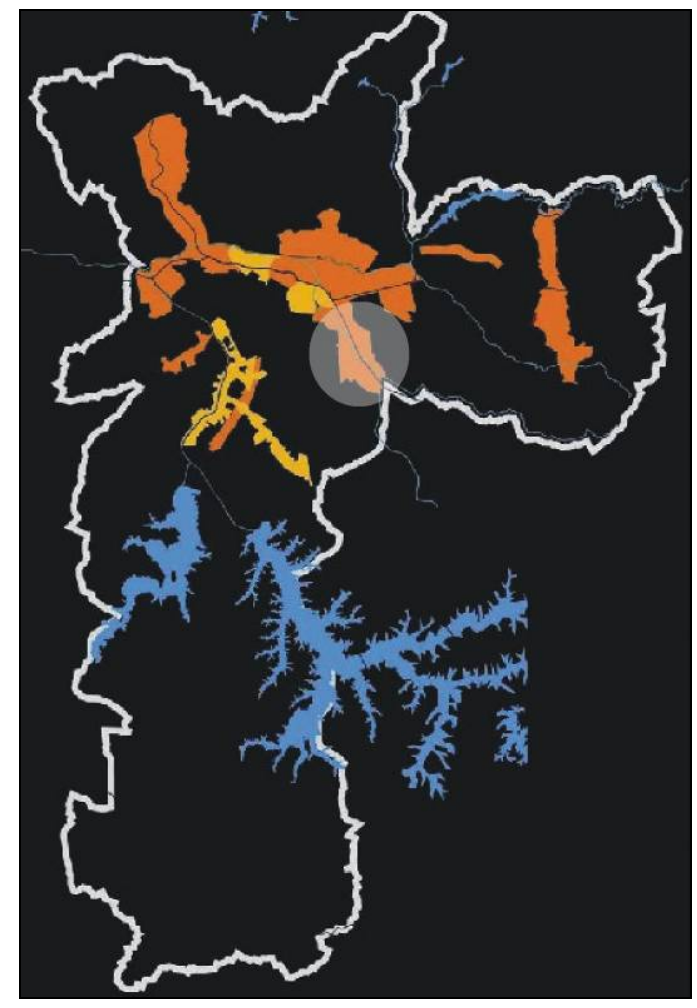

37a. Operações urbanas em São Paulo. Em amarelo, operações vigentes; em laranja, operações propostas no PDE 2002. Círculo em destaque: OUDS. (SEMPLA)

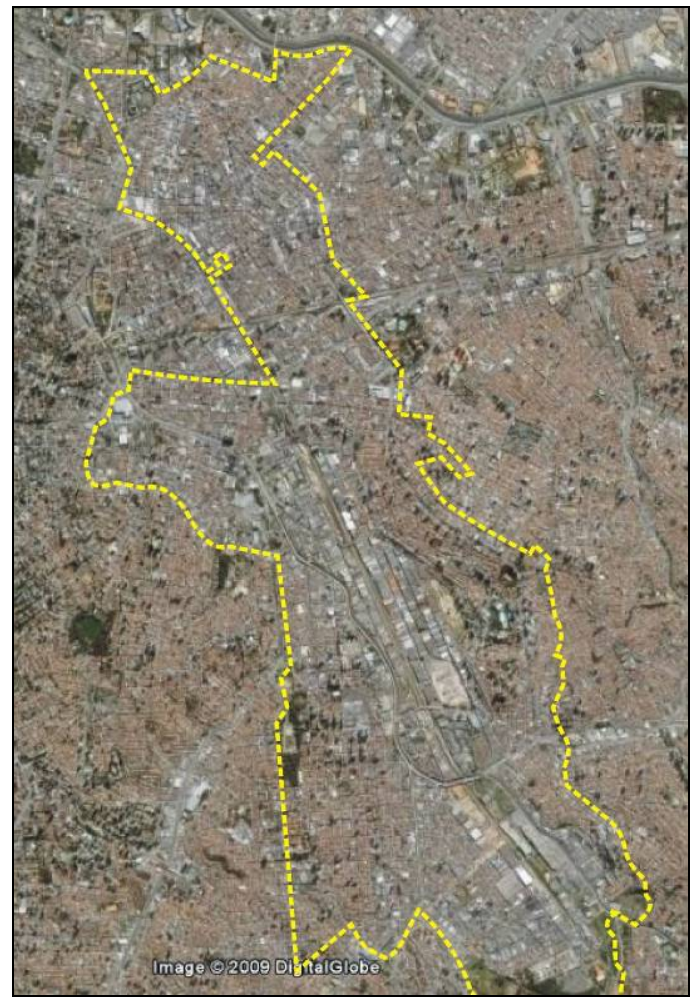

37b. Perímetro da Operação Urbana Diagonal Sul, São Paulo.

Grande parte do patrimônio industrial ali existente (englobando nesta asserção: edifícios fabris, armazéns, galpões, pátios ferroviários, vilas operárias e espaços envoltórios, etc) não está devidamente catalogado e sequer é conhecido convenientemente; numerosos edifícios e conjuntos arquitetônicos que configuram uma paisagem única sofrem a ação do tempo e da especulação imobiliária que descaracteriza o patrimônio urbano a cada novo empreendimento. O interesse municipal no desenvolvimento de projetos revitalizadores nessas áreas - e o risco iminente de destruição a que tais artefatos

com intuito de alavancar transformações urbanas estruturais, melhorias sociais e valorização ambiental. As áreas a serem transformadas devem ser previamente demarcadas em Lei municipal (em Plano Diretor), e os instrumentos urbanísticos a serem empregados devem ser determinados em Lei específica para cada Operação Urbana. BRASIL. Lei n. 10257, de 10 de julho de 2001. Estatuto da Cidade. 
estão submetidos -, levou-nos a instigar discussões sobre a maneira como intervenções dessa natureza são conduzidas, de que modo o patrimônio urbano deve ser considerado e qual a orientação teórico-prática que respalda tais iniciativas; questionamentos que temos tentado evidenciar nesta pesquisa. $\mathrm{O}$ aprofundamento do debate em torno dos critérios de atuação sobre áreas desta natureza é, portanto, discussão que deve ganhar espaço o quanto antes a fim de evitar a destruição de documentos únicos, simplesmente por desinformação ou negligência.

Além de um inestimável patrimônio histórico-documental, o eixo urbano considerado representa uma paisagem de grande representatividade em termos de desenho urbano e arquitetura, assim como configura um ambiente social próprio dos antigos bairros industriais e em grande parte ainda identificável e vivo. De fato, entre o final do século XIX e início do século XX, a presença da indústria na cidade de São Paulo promoveu a demarcação de territórios precisos e conferiu a determinados bairros paisagens e desenhos característicos da nova atividade. Nessa primeira etapa da industrialização paulistana, as fábricas localizavam-se predominantemente ao longo das vias férreas, regiões então consideradas propícias para as atividades fabris devido à topografia regular, aos baixos preços dos terrenos e às facilidades geradas pelo transporte ferroviário no escoamento e recebimento de produtos ${ }^{128}$. Diversos bairros industriais como o Brás, Belém, Pari, Mooca, Ipiranga e Vila Prudente, bairros presentes no perímetro considerado, ainda preservam parte desse parque industrial histórico; um extenso patrimônio urbano depositário de histórias e memórias que nos ajudam a compreender a formação e configuração da cidade contemporânea.

Com base na observação de plantas da cidade de São Paulo em 1914 e 1930, notamos que a configuração urbana de grande parte do perímetro da OUDS remonta ao início do século XX. As indústrias na região - demarcadas na planta de 1914 e em parte

\footnotetext{
${ }^{128}$ Sobre as origens e consolidação da atividade industrial na cidade de São Paulo e nos bairros em análise, consultar: LANGENBUCH, Juergen Richard. A Estruturação da Grande São Paulo - Estudo de geografia urbana. Rio de Janeiro: IBGE, 1971; ANDRADE, Margarida M. de. Bairros além Tamanduateí: O imigrante e a fábrica no Brás, Mooca e Belenzinho. Tese de doutorado. São Paulo, FFLCH-USP, 1990; AZEVEDO, Aroldo de (Org). A Cidade de São Paulo - Estudos de geografia Urbana. São Paulo: Editora Nacional, 1958; DEAN, Warren. A Industrialização de São Paulo (1880-1945). São Paulo, Rio de Janeiro: Difel, [s.d.]. TOLEDO, Benedito Lima de. São Paulo: três cidades em um século. São Paulo: Duas Cidades, 1983. Análises da ocupação industrial no bairro de Mooca e arredores foram previamente elaboradas em: RUFINONI, M. Preservação..., op. cit., pp.5-48.
} 
identificáveis na planta de 1930 a partir das grandes massas edificadas - são elementos que contribuíram decisivamente, portanto, na formulação e consolidação dessa paisagem.

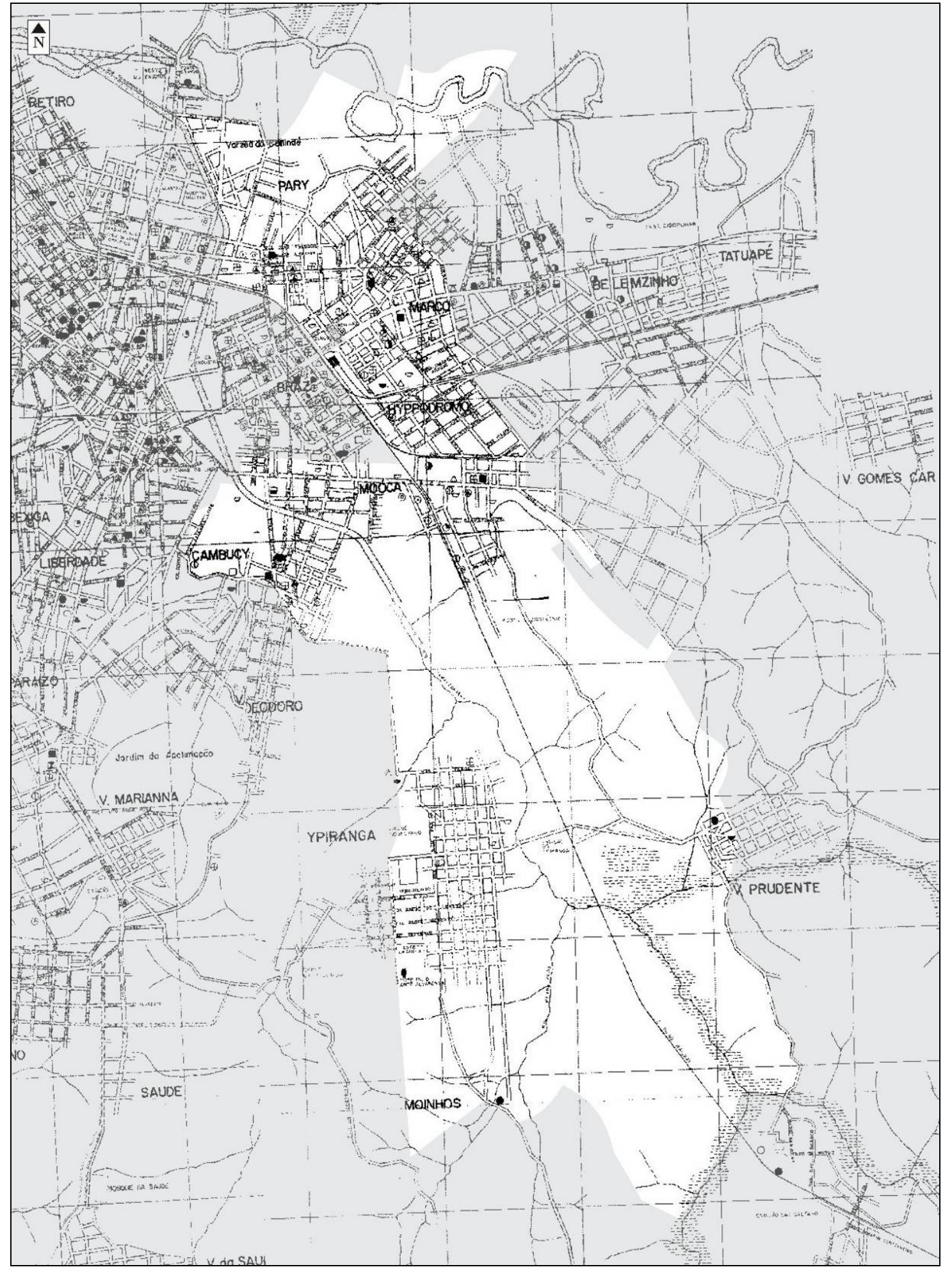

38. Sobreposição da OUDS sobre planta da cidade de São Paulo em 1914, com demarcação das principais fábricas catalogadas nesta data. Diversas vias que determinam o perímetro remontam ao início do século XX. Base cartográfica: Planta Geral da Cidade de São Paulo com Indicações Diversas. Comissão Geográfica e Geológica, eng. chefe João Pedro Cardoso, 1914, sem escala. (Memória Urbana) 




39. Sobreposição da OUDS sobre planta da cidade de São Paulo em 1930.

Urbanização consolidada em grande parte do perímetro. Base cartográfica:

Mapa Topográfico do Município de São Paulo - SARA Brasil, 1930, fl.IV. 


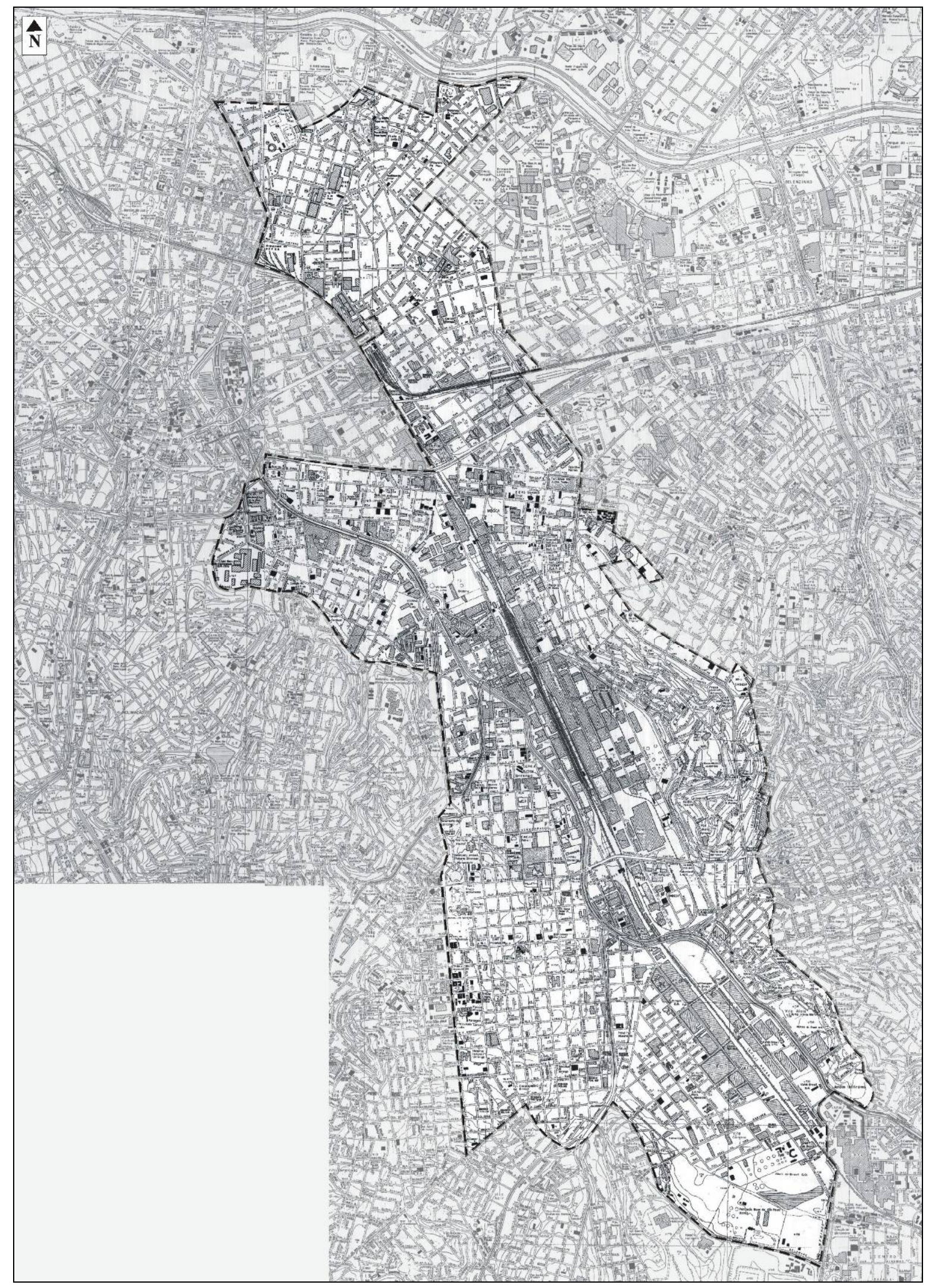

40. Delimitação da Operação Urbana Diagonal Sul. Base cartográfica: Levantamento Aerofotogramétrico da Cidade de São Paulo, Emplasa, 1981, sem escala. 
A partir da década de 1960, no entanto, a evasão das grandes indústrias para áreas afastadas dos centros urbanos ocasionou o paulatino abandono dos complexos produtivos mais antigos. Muitos edifícios fabris oriundos da primeira industrialização paulistana conjuntos de grande interesse histórico e estético - foram demolidos, abandonados ou passaram a abrigar outras funções, principalmente relacionadas ao setor terciário. Essa alteração do cenário econômico acabou impulsionando a degradação de vários sítios produtivos, pois muitos edifícios e espaços adjacentes de grandes dimensões não puderam ser absorvidos para novos usos. Por outro lado, como temos visto, essas amplas áreas desocupadas ou subutilizadas passaram a representar uma significativa reserva de terreno urbano ocioso e dotado de ampla infra-estrutura, uma grande oportunidade para a implementação de novos investimentos imobiliários. Cresce cada vez mais, portanto, a procura por antigas áreas fabris para a construção de grandes empreendimentos como conjuntos residenciais ou hipermercados. O potencial dessas regiões degradadas também tem despertado a atenção do poder público que manifestou - a partir da proposição da OUDS - , o interesse em conduzir a reutilização dessas áreas e alavancar projetos de reabilitação e valorização urbana, contexto em que o patrimônio industrial tem sido observado com certa atenção.

O Plano Diretor Estratégico de 2002 (PDE) demarcou o perímetro da Diagonal Sul como área de potencial interesse para o desenvolvimento de futura operação urbana. ${ }^{129}$ No desenvolvimento dos Planos Regionais Estratégicos, em 2003, as características associadas à conformação da paisagem e os valores de certos conjuntos urbanos do perímetro foram sensivelmente evidenciados, permitindo a proposição de medidas de preservação na redação final do Plano Diretor, votado em 2004. ${ }^{130}$.

Entre outras análises, nos levantamentos elaborados pelos Planos Regionais, a presença dos complexos fabris e a própria paisagem e morfologia característica da ocupação industrial foram consideradas com atenção. Com relação ao patrimônio urbano

\footnotetext{
${ }^{129}$ Segundo Pedro Sales, arquiteto da Secretaria de Planejamento da PMSP em entrevista concedida à autora desta tese em dezembro de 2008, a definição do perímetro da OUDS pautou-se pelos limites naturais do desenho urbano, relevo e morfologia: grandes eixos e avenidas, o rio Tietê (ao norte) e o limite de município (ao sul). Buscou-se demarcar a área de influência direta da ferrovia, ou seja, a parcela urbana estruturada e consolidada em torno da mesma. Observa-se, portanto, a preocupação com elementos da história urbana na delimitação do perímetro.

${ }^{130}$ SÃO PAULO (Cidade). Plano Diretor Estratégico do Município de São Paulo. Lei n n 13.430, de 13 de setembro de 2002. Os Planos Regionais objetivaram complementar e subsidiar as propostas enunciadas em 2002 a partir da análise pormenorizada das áreas encampadas por cada subprefeitura, fornecendo subsídios para a redação final do Plano Diretor, votado em 02 de julho de 2004.
} 
industrial, durante a elaboração dos diagnósticos, vários edifícios e sítios industriais foram sugeridos pela população como áreas de possível interesse para preservação. Foi ainda aventada a oportunidade de se criar um parque linear entre o viaduto São Carlos e a estação Mooca, iniciativa que revitalizaria os galpões industriais de interesse histórico como equipamentos do próprio parque e supriria a carência de áreas verdes e de lazer na região. Dentre os edifícios industriais elencados como de interesse para preservação, temos, nos bairros do Brás e Pari: o antigo Lanifício Paulista (hoje já demolido), a Fábrica Orion, o Gasômetro da Figueira, os conjuntos industriais das ruas Joli e Tiers e travessias da estrada de ferro na altura da estação Brás; na Mooca: o edifício da fiação do Cotonifício Crespi, a Tecelagem Labor, o Moinho Gamba (Santo Antônio) e o conjunto industrial da rua Borges de Figueiredo; e, no Belém, alguns conjuntos de casas e vilas julgadas representativas do caráter histórico e industrial do bairro. ${ }^{131} \mathrm{Na}$ elaboração final do Plano Diretor, algumas dessas indicações receberam um zoneamento específico: foram demarcadas como Zonas Especiais de Preservação Cultural (ZEPEC) e encaminhadas para estudos específicos para verificar a possibilidade de tombamento desses bens. Com este zoneamento, pretende-se estimular a preservação dos imóveis e sítios, bem como estudar a possível aplicação de instrumentos urbanísticos que orientem a reconversão de uso. Segundo o Plano Diretor,

\begin{abstract}
Zonas Especiais são porções do território com diferentes características ou com destinação específica e normas próprias de uso e ocupação do solo, [...] As Zonas de Preservação Cultural - ZEPEC são porções do território destinadas à preservação, recuperação e manutenção do patrimônio histórico, artístico e arqueológico, podendo se configurar como sítios, edifícios ou conjuntos urbanos. $\S 1^{\circ}$ - Os imóveis ou áreas tombadas ou preservadas por legislação Municipal, Estadual ou Federal, bem como os imóveis classificados como Z8-200 por Lei Municipal, enquadram-se como ZEPEC. $\S 2^{\circ}-$ Aplica-se às edificações particulares localizadas em ZEPEC a transferência do potencial construtivo [...]. ${ }^{132}$
\end{abstract}

O zoneamento ZEPEC define restrições na transformação do imóvel e busca ressarcir os proprietários por meio da transferência do direito de construir, ou seja, o potencial construtivo do lote demarcado com este zoneamento poderá ser transferido para outros terrenos. Trata-se de um instrumento que visa dinamizar o tratamento de áreas

\footnotetext{
${ }^{131}$ Dentre as Subprefeituras envolvidas na Diagonal Sul, apenas na Supbprefeitura Mooca (que inclui os bairros do Pari, Brás, Mooca, Belém, Tatuapé e Água Rasa) o Plano Regional chegou a indicar edifícios e sítios industriais para preservação. Nos Planos Regionais das Subprefeituras da Sé, Ipiranga e Vila Prudente não encontramos indicações semelhantes. Dados gerais sobre as análises desenvolvidas pelos Planos Regionais Estratégicos podem ser consultados no site da Secretaria Municipal de Planejamento da Prefeitura Municipal de São Paulo.

${ }^{132}$ SÃO PAULO (Cidade). Plano Diretor Estratégico..., op. cit., Art. 168.
} 
tombadas (ou em processo de tombamento) impedindo que as restrições impostas se transformem em motivo de 'congelamento' do bem. Com este instrumento, o proprietário de um imóvel situado em ZEPEC pode transferir para outros terrenos o potencial construtivo que não poderá ser explorado na área preservada. Os imóveis demarcados pelo Plano Diretor estão sendo analisados pelo DPH-CONPRESP e alguns entraram em processo de tombamento. Recentemente, proveniente de zoneamento ZEPEC, foram tombados vários edifícios que compõem um significativo conjunto industrial ao longo da rua Borges de Figueiredo, bem como definidos critérios específicos de ocupação no entorno imediato.

Outro importante instrumento urbanístico que chegou a ser aventado para certas parcelas da Diagonal Sul é o direito de preempção. Este instrumento, determinado pelo Estatuto da Cidade, permite ao poder público a prioridade de compra de um terreno no momento em que estiver à venda. Assim, a Prefeitura define no Plano Diretor as áreas onde pretende exercer o direito de preempção, geralmente porções consideradas estratégicas para futuros projetos de requalificação ou reestruturação urbana ${ }^{133}$. Na Diagonal Sul, uma grande extensão do eixo da via férrea e significativas parcelas urbanas envoltórias haviam sido demarcadas como preempção. Nas últimas revisões do Plano Diretor, contudo, a demarcação inicial sofreu grandes alterações.

Notamos, portanto, tanto pela delimitação das ZEPECs, como na demarcação de áreas de preempção (ainda que tenham sido suprimidas, posteriormente) que o patrimônio cultural da Diagonal tem sido observado com certa atenção e que existe a intenção da municipalidade em promover a sua preservação. Conforme temos tratado, no entanto, a grande extensão dessas áreas e a rapidez com que o mercado imobiliário tem avançado, dificultam sobremaneira a efetivação de um programa a longo prazo que permita o desenvolvimento de estudos detalhados e que conduza coerentemente quaisquer medidas de preservação e de intervenção.

\footnotetext{
${ }^{133}$ BRASIL. Lei n. 10257, de 10 de julho de 2001. Estatuto da Cidade. "Art. 25. O direito de preempção confere ao Poder Público municipal preferência para aquisição de imóvel urbano objeto de alienação onerosa entre particulares.§ $1^{\circ}$ Lei municipal, baseada no plano diretor, delimitará as áreas em que incidirá o direito de preempção [...] Art. 26. O direito de preempção será exercido sempre que o Poder Público necessitar de áreas para: [...] VI - criação de espaços públicos de lazer e áreas verdes; [...] VIII - proteção de áreas de interesse histórico, cultural ou paisagístico" (grifo nosso).
} 


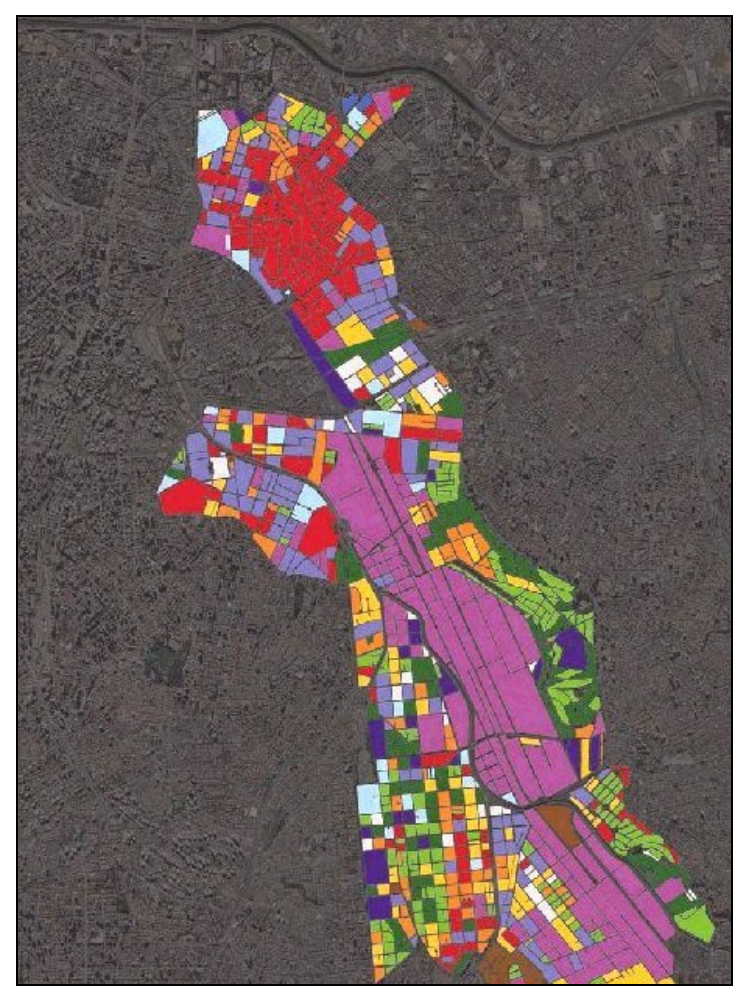

41. Levantamento do uso predominante por quadra. Em lilás, uso industrial; em vermelho, uso comercial; em tons de amarelo e verde, uso residencial e misto; em tons de azul, equipamentos públicos e institucionais. (SEMPLA)

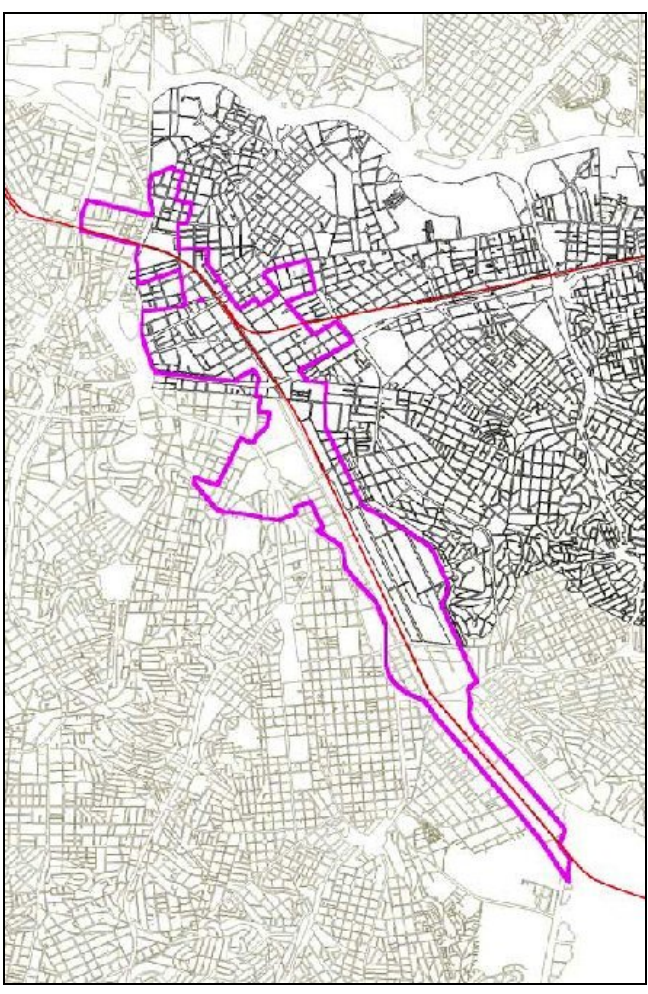

42. Proposta inicial de demarcação das áreas sujeitas ao direito de preempção, segundo o Plano Regional Mooca. As recentes revisões do Plano Diretor têm determinado alterações desse perímetro. (PREM)

Um primeiro passo para qualquer operação na área seria a elaboração de estudos detalhados sobre o perímetro da Diagonal Sul e de pesquisas aprofundadas sobre seu processo de urbanização, sobre as edificações existentes, suas características construtivas formais e técnicas, acompanhadas de estudos multidisciplinares que permitissem a apreensão das diversas e complexas relações materiais e imateriais que definem essa paisagem. Ao longo do extenso perímetro da operação urbana, observamos numerosos edifícios e sítios industriais, bem como áreas residenciais vinculadas à presença histórica das indústrias, que configuram um inestimável patrimônio urbano ainda não identificado e estudado convenientemente ${ }^{134}$. A realização desses estudos pormenorizados permitirá que apreendamos com clareza os elementos que definem essa paisagem, quais os edifícios e conjuntos que devem ser efetivamente preservados e de que maneira, segundo as

${ }^{134}$ Existem alguns levantamentos parciais, como o estudo realizado pela EMURB na década de 1970, Galpões Industriais Significativos. São Paulo: EMURB e o IGEPAC - Inventário Geral do Patrimônio Ambiental, Cultural e Urbano de São Paulo, elaborado pelo DPH na década de 1980, bem como pesquisas acadêmicas que têm se ampliados nos últimos anos, mas ainda assim há muito a ser estudado e atualizado. 
orientações teórico-críticas. Conhecimento prévio, portanto, imprescindível para a proposição e execução de quaisquer projetos de revitalização.

A permanência deste vasto patrimônio urbano configura-se como um acervo histórico documental pouco valorizado até o momento. Tomando de empréstimo a alegoria tantas vezes enunciada (a exemplo de Victor Hugo, Carlo Cattaneo, Charles Buls), a presença dessas estruturas e os percursos construtivos que orientaram a formação desse cenário configuram-se como um verdadeiro livro sobre nossa história urbana, arquitetônica, social. Um acervo documental não explorado e que pode nos revelar dados e eventos ainda pouco conhecidos, bem como lançar luzes para possíveis releituras historiográficas. Apenas do ponto de vista da arquitetura e do urbanismo, um breve levantamento das estruturas existentes na Diagonal e arredores trouxe à tona informações de grande interesse e até então inexploradas pelos estudos nesse campo. Além das características de traçado urbano, da composição dos conjuntos da chamada 'arquitetura menor', das residências em série e de projetos fabris anônimos de excepcional qualidade, diversos arquitetos e escritórios técnicos de grande importância na história da arquitetura brasileira contribuíram para a formação desse cenário construindo edifícios de inegável qualidade. Apesar de algumas edificações já terem sido demolidas, a presença desses projetos na Diagonal Sul evidencia relevantes caminhos interpretativos para os estudos sobre a arquitetura brasileira. A própria contribuição de renomados arquitetos na formação dos bairros industriais e operários é um tema praticamente inexplorado e o acervo arquitetônico da Diagonal representa, nesse sentido, um importante ponto de partida.

Dentre os projetos identificados nesse breve levantamento, cabe ressaltar a atuação do Escritório Técnico Ramos de Azevedo, autor do projeto dos Armazéns Ernesto de Castro, construídos na Mooca por volta de 1918, na rua André de Leão, e ainda hoje utilizados como depósitos. ${ }^{135}$ Também atribuído ao Escritório, temos ainda o edifício da Companhia Nacional de Tecidos de Juta Sant'Anna, construído no Brás por volta de $1890^{136}$ e o projeto de ampliação (tipografia e garagem) da Companhia Fazenda BelémMooca $^{137}$.

\footnotetext{
${ }^{135}$ AZEVEDO, Ramos e SEVERO, Ricardo. Projecto de prolongamento dos Armazéns de Ernesto de Castro \& Co. São Paulo/SP, 1918. (Arquivo Histórico Municipal Washington Luis, acervo de manuscritos AHMWL).

${ }^{136}$ AZEVEDO, Francisco de Paula Ramos (1851-1928). Edifício Industrial da Companhia Nacional de Tecidos Sant'Anna da Juta. São Paulo/SP, [1891?]. (Acervo de Projetos de Arquitetura da Biblioteca FAUUSP - APA-FAUUSP). Sobre a Companhia de Juta Sant'Anna e seus edifícios, consultar: BANDEIRA
} 


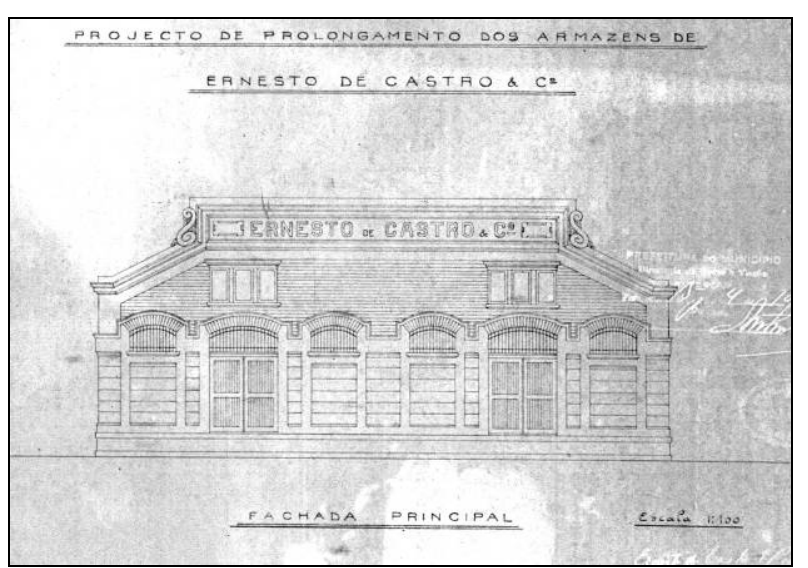

43a. Projeto de ampliação dos Armazéns Ernesto de Castro, elevação principal. (AHMWL)

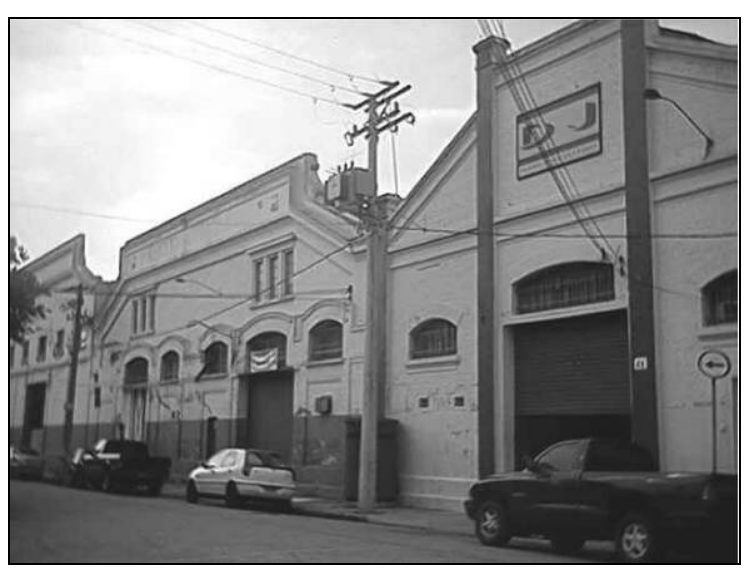

43b. Armazéns Ernesto de Castro, vista da rua André de Leão, 2003. (foto da autora)

Destacam-se ainda a Fábrica de Calçados Clark construída na Mooca em 1909, hoje demolida, sobre a qual existe um projeto atribuído a Samuel das Neves; ${ }^{138}$ os edifícios da São Paulo Alpargatas, um projetado por Julio Michele e outro pelo Escritório Scott \& Urner, ${ }^{139}$ que hoje abrigam uma universidade e o edifício da fiação do Cotonifício Crespi, construído na década de 1920 pelo arquiteto italiano Giovanni Battista Bianchi e recentemente descaracterizado para a instalação de um hipermercado, conforme aludimos anteriormente. Um conjunto arquitetônico de grande interesse são os Armazéns de Elias Calfat, hoje conhecidos como Armazéns Piratininga, construídos na rua da Mooca entre 1916 e 1918 e de autoria de Victor Dubugras. Trata-se de um conjunto formado por quinze galpões e anexos. Os galpões apresentam técnicas construtivas muito empregadas em edifícios industriais naquela data, como a alvenaria estrutural de tijolos e os pilares de ferro fundido sustentando tesouras de madeira. Apresenta ainda recursos interessantes como a adoção de lanternins e de venezianas para ventilação nas aberturas do frontão, numa perfeita assimilação entre desenho e funcionalidade. O conjunto de armazéns foi desocupado recentemente e seu futuro é incerto. ${ }^{140}$

JR., A.F. A Indústria no Estado de São Paulo em 1901. São Paulo: Typ. do Diário Oficial, 1901; PINTO, Alfredo Moreira. A cidade de São Paulo em 1900. São Paulo: Governo do Estado, 1979, p.208.

137 AZEVEDO, Francisco de Paula Ramos (1851-1928). Edifício Industrial da Companhia Fazenda BelémMooca: Projeto de Aumento da Tipografia e da Nova Garagem à rua Borges de Figueiredo esquina com a rua Monsenhor Felippo. São Paulo/SP, [s.d.]. (APA-FAUUSP).

${ }^{138}$ NEVES, Samuel das. Fábrica de Calçados Clark, à rua da Mooca, 321. São Paulo/SP, 1909. (APAFAUUSP).

${ }^{139}$ Cf.: SALMONI, Anita e Debenedetti, Emma. Arquitetura Italiana em São Paulo. São Paulo: Perspectiva, 1981; Alpargatas: oitenta anos de nossa história. São Paulo: Mouro Ivan Marketing Editorial, 1987, p.19.

${ }^{140}$ DUBUGRAS, Victor. Construção de dois armazéns. São Paulo/SP, 1916; Reforma de um armazém. São Paulo/SP, 1918. (AHMWL). Os armazéns de Dubugras são analisados em: RUFINONI, M. Traços 


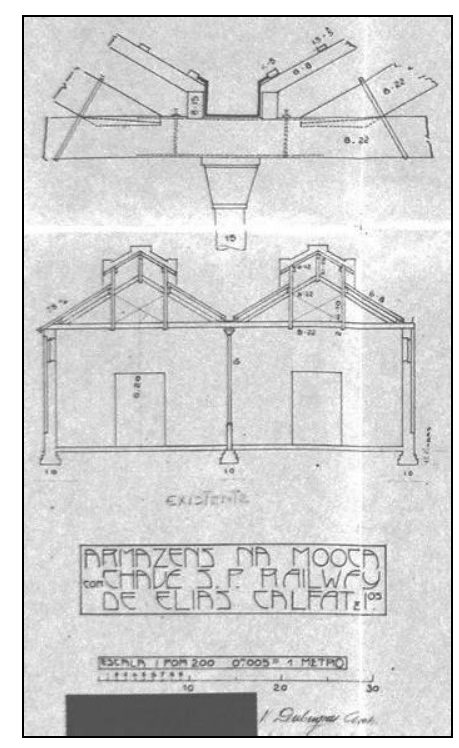

a.

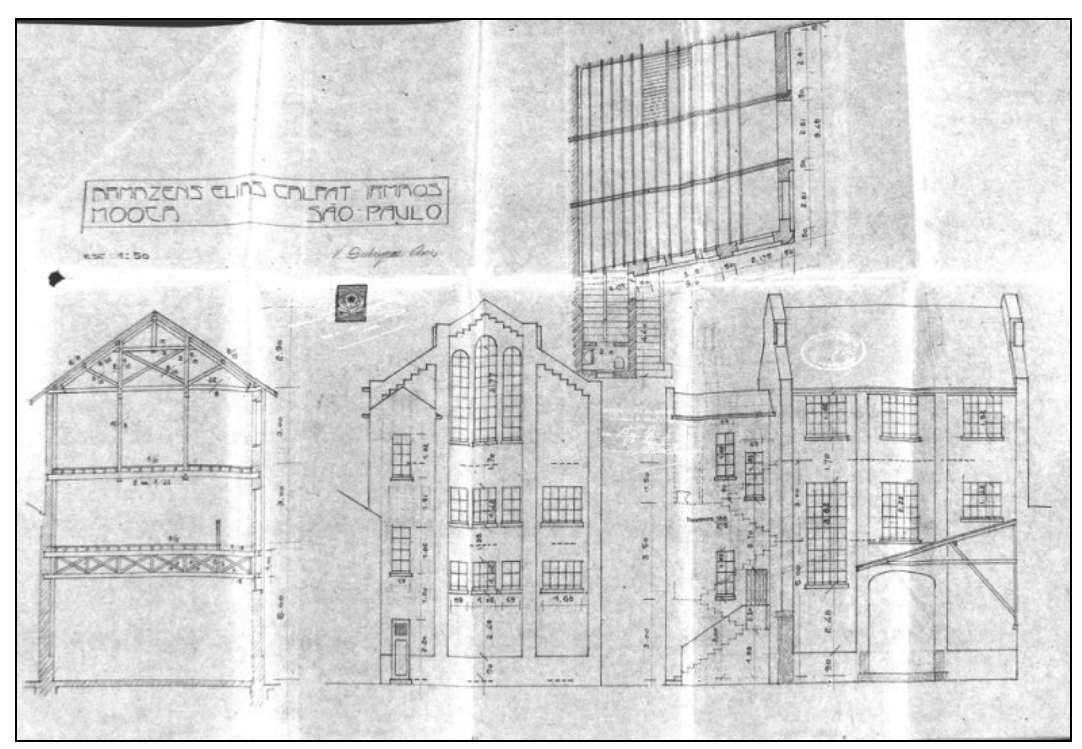

b.

44. Armazéns de Elias Calfat (Armazéns Piratininga). Projeto de Victor Dubugras. a. Planta de 1916, corte e detalhe estrutural; b. Planta de 1918, elevações e corte. (AHMWL)

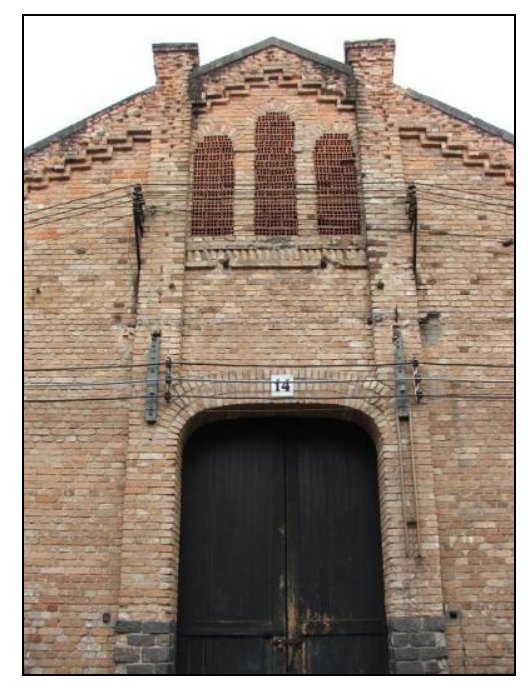

c.

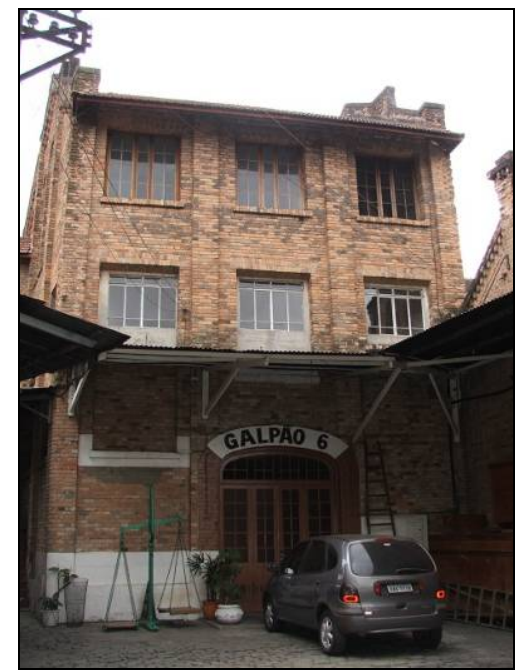

d.

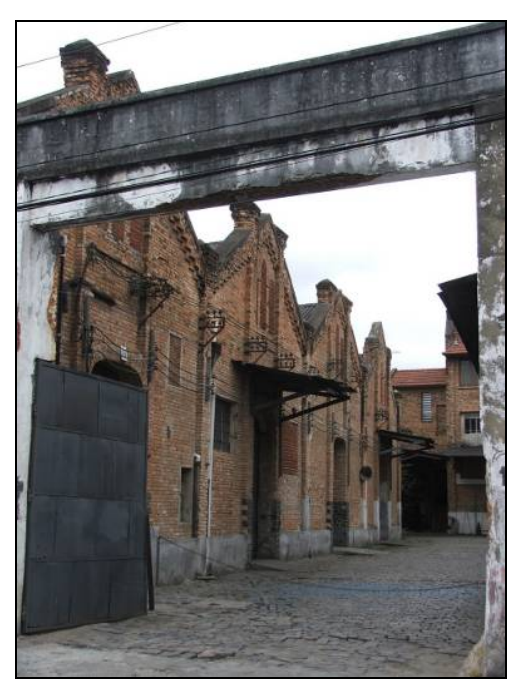

e.

Elevações segundo projeto de 1918. Acesso ao conjunto industrial, via interna, 2005. (fotos da autora)

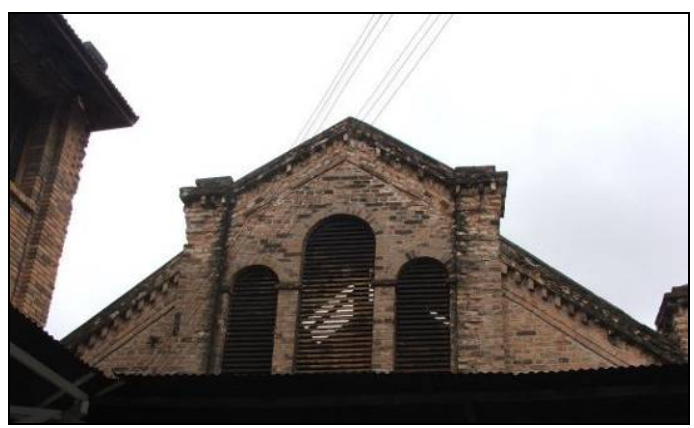

f.

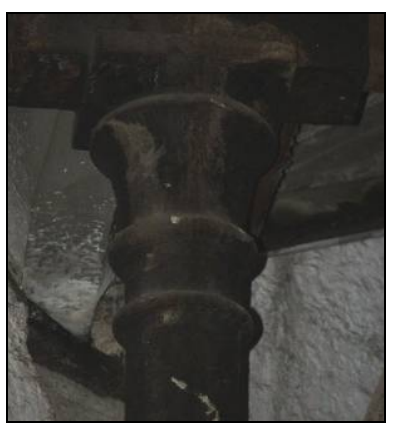

g. f. Detalhe das venezianas nas aberturas do frontão, 2005.

g. Detalhe da estrutura de ferro fundido, 2005.

modernos: o resgate de uma obra de Victor Dubugras. In: Anais do III Seminário Docomomo Estado de São Paulo: Permanência e Transitoriedade do Modernismo Paulista. São Paulo: Univ. Mackenzie, 2005. 
Atribuídos ao Escritório Ramos de Azevedo, Severo \& Villares, destacam-se os edifícios da Tecelagem de Seda Ítalo-Brasileira, construída no Brás em 1936, na rua Joli $^{141}$; da Fábrica de Papel das Indústrias Reunidas Francisco Matarazzo, construída no Belenzinho, em $1938^{142}$ e do conjunto industrial da Ford Motors Company, construído na Vila Prudente, na década de 1950 e recentemente demolido. Acredita-se que os terrenos da Ford serão utilizados para a construção de um shopping center $^{143}$.

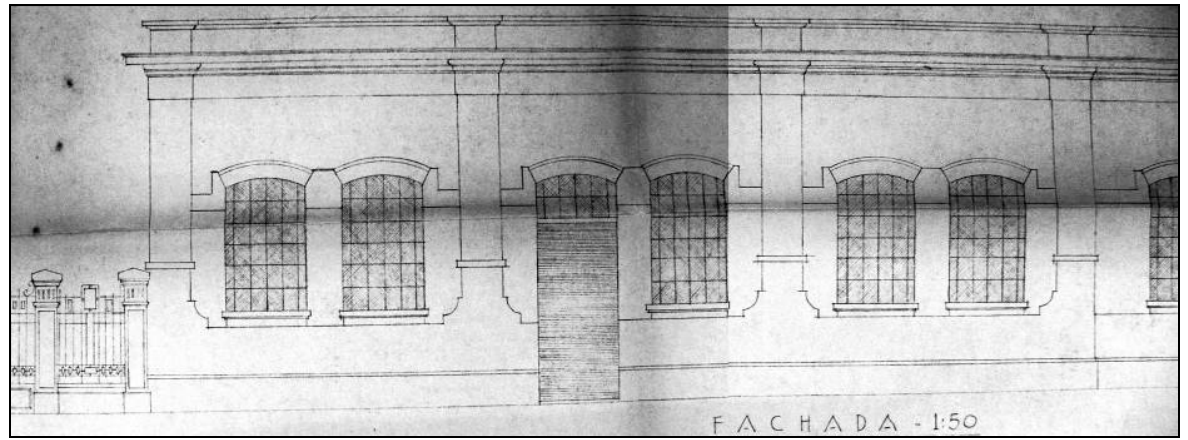

45a. Tecelagem de Seda Ítalo-Brasileira. Edifício do refeitório e almoxarifado, 1936. (APA-FAUUSP)

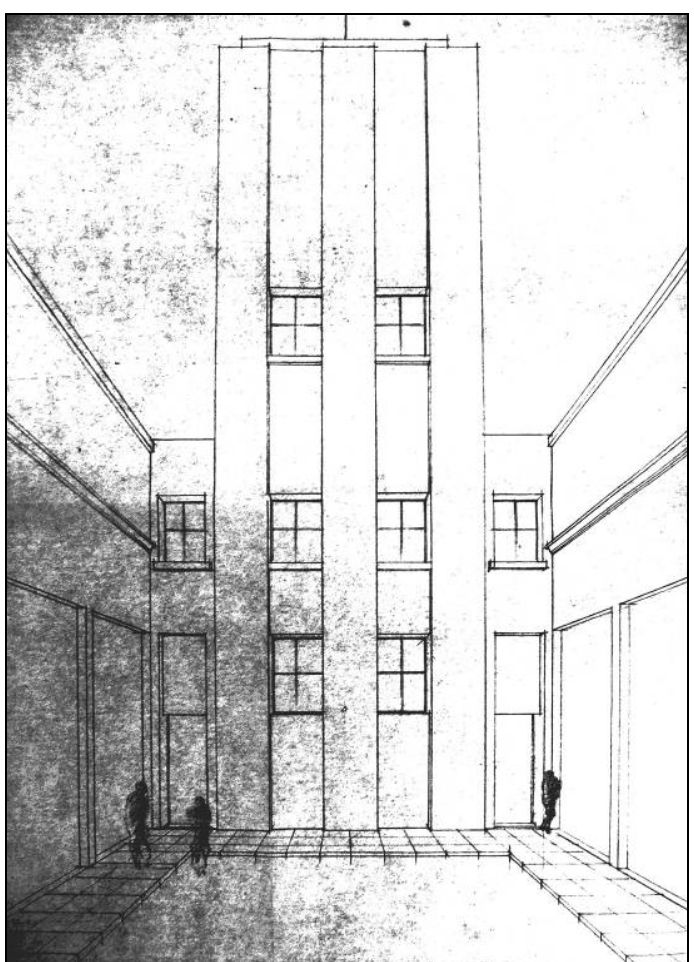

45b. Tecelagem de Seda Ítalo-Brasileira. Perspectiva do reservatório, 1936. (APA-FAUUSP)
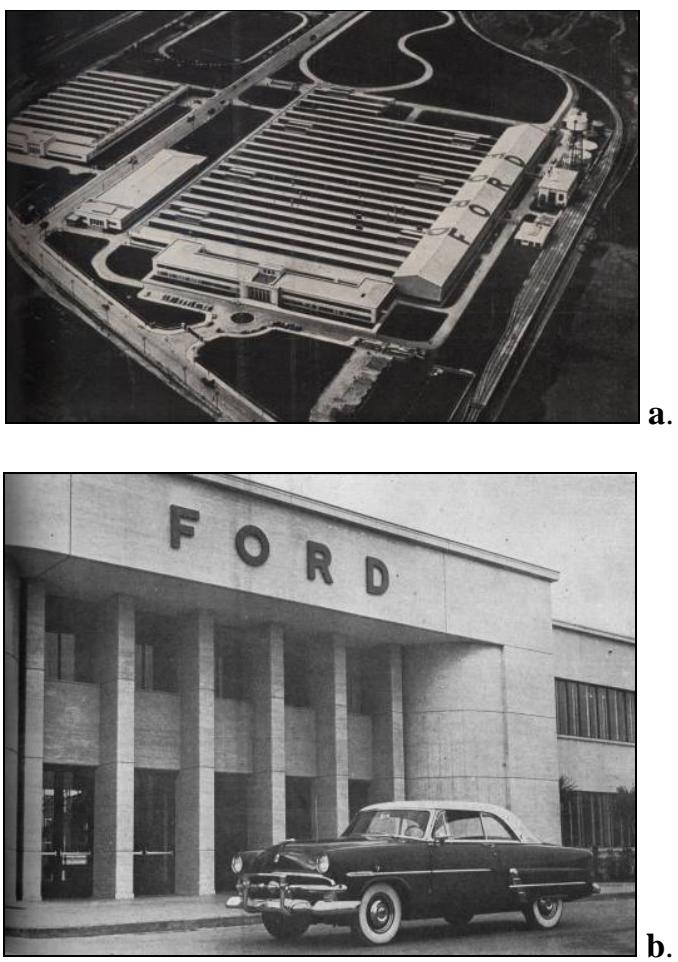

46. Ford Motors Company.

a. Vista geral; b. Acesso principal (Habitat, n.11)

${ }^{141}$ ESCRITÓRIO Técnico 'Ramos de Azevedo', Severo \& Villares. Fábrica da Tecelagem de Seda ÍtaloBrasileira, à rua Joly, 39. São Paulo/SP, 1936. (APA-FAUSP).

142 ESCRITÓRIO Técnico 'Ramos de Azevedo', Severo \& Villares. Fábrica de Papel de Propriedade das Indústrias R. F. Matarazzo S/A., situada no Belenzinho. São Paulo/SP, 1938. (APA-FAUUSP).

${ }^{143}$ Revista Habitat, n. 11, 1953, pp.109-115; Revista Habitat, n. 6, 1952, pp.100-103. 
A arquitetura moderna não deixou de ser representada. Destacamos, nesse sentido, quatro projetos de Rino Levi: a Cia Jardim de Cafés Finos (e armazéns adjacentes para estocagem de café e produção de massas alimentícias, projetados para João Marino e Bruno Mencarini) ${ }^{144}$ e a Arno Indústria e Comércio ${ }^{145}$, construída na avenida que hoje recebe seu nome e ainda em funcionamento, ambas na Mooca; a Fábrica de Brinquedos Estrela, na rua Joaquim Carlos, no Belém, hoje ocupada por uma Faculdade ${ }^{146}$ e um projeto para a Fábrica de Chapéus de Dante Ramenzoni, no Cambuci, já demolida ${ }^{147}$.

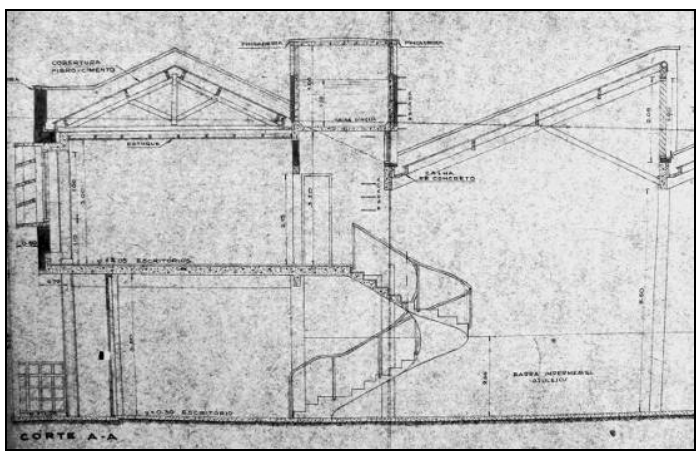

47a. Projeto de armazéns em terreno adjacente à Cia. Jardim de Cafés Finos, 1943-44. (APA-FAUUSP)

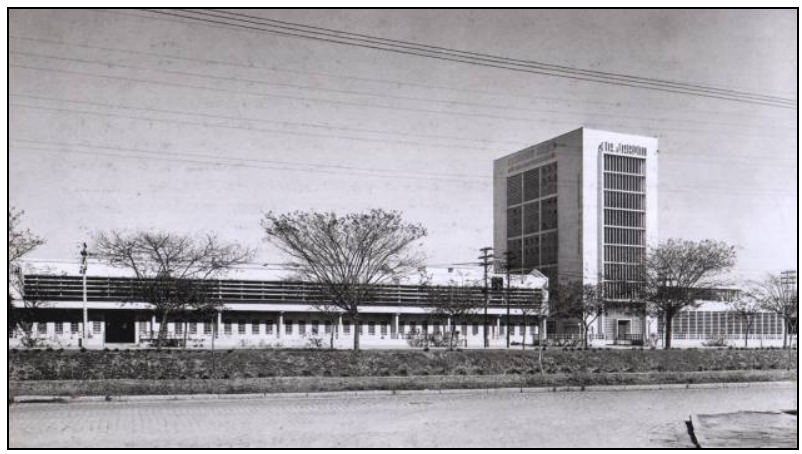

47b. Companhia Jardim de Cafés Finos, 1943. Vista da avenida do Estado antes da construção da via elevada. (GUERRA, A., op. cit.)

47c. Companhia Jardim de Cafés Finos, 1943. (GUERRA, A., op. cit.)

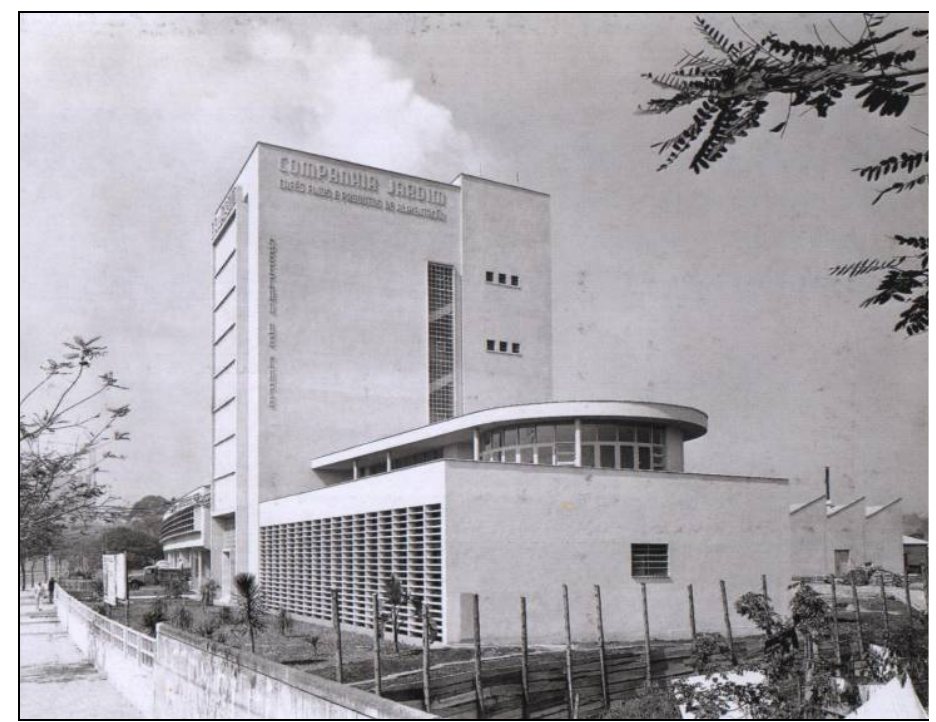

${ }^{144}$ GUERRA, Abílio (Org.). Rino Levi: arquitetura e cidade. São Paulo: R. Guerra, 2001, pp. 122-123; LEVI, Rino. Armazéns à avenida do Estado de propriedade dos Srs. João Marino e Bruno Mencarini. São Paulo/SP, 1943-1944. (APA-FAUUSP).

${ }^{145}$ LEVI, Rino. Arno S/A. Indústria e Comércio. Construção de Escritórios e Fábrica à av. do Café. São Paulo/SP, 1950-1953. (APA-FAUUSP). Projeto publicado na Revista Habitat, n.10, 1953, pp.24-25.

146 Projeto publicado na Revista Habitat, n.9, 1953, pp.103-105; LEVI, Rino. Manufatura de Brinquedos Estrela S/A. Projeto de ampliação da fábrica e do depósito. São Paulo/SP, 1949-1958. (APA-FAUUSP).

${ }^{147}$ LEVI, Rino. Fábrica de Dante Ramenzoni e Cia. Ltda., a rua Lavapés, 192 e 716, esquina com rua Scuvero. São Paulo/SP, 1936. (APA-FAUUSP). 


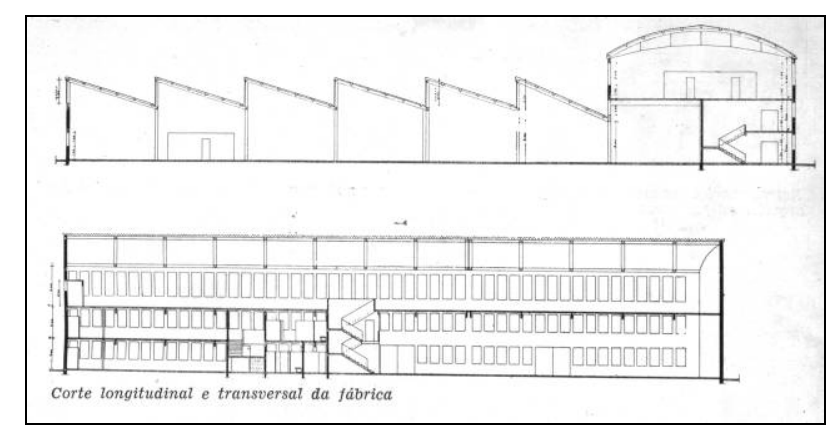

48a. Arno Indústria e Comércio, corte longitudinal e transversal, 1953 (Habitat, n.10).
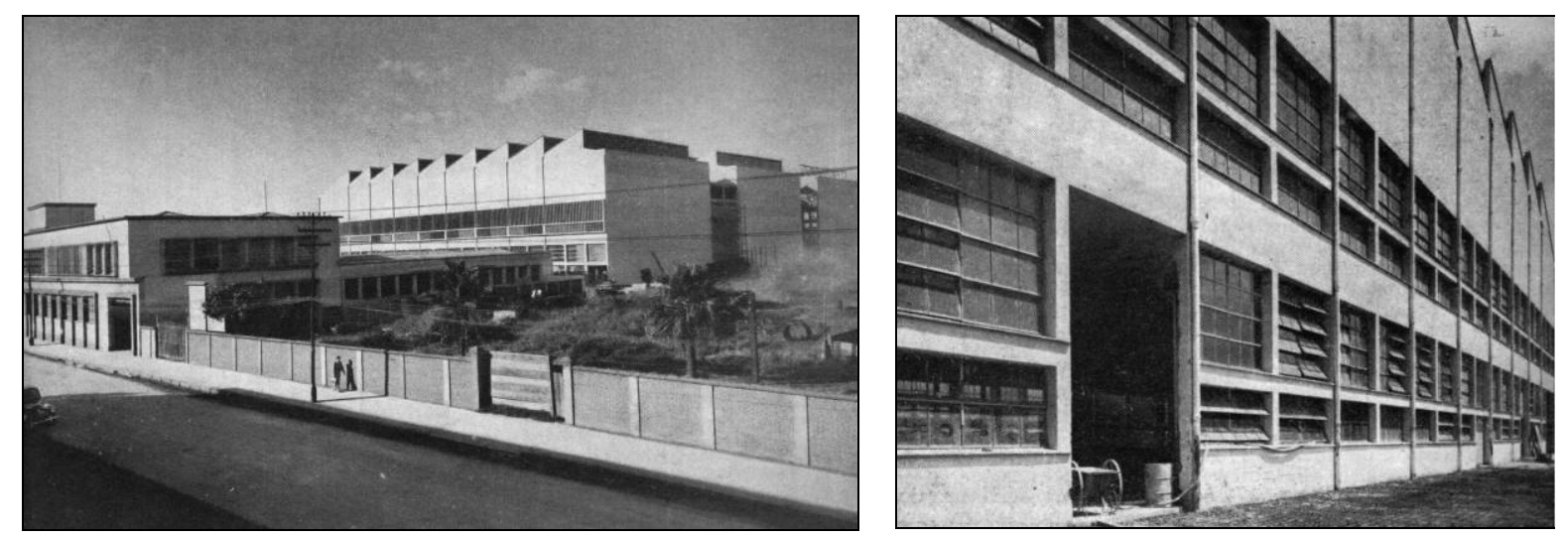

49. Manufatura de Brinquedos Estrela, vista geral do conjunto arquitetônico e detalhe da fachada, década de 1950. (Habitat, n.9)

Destacam-se ainda o edifício para a Lion Engenharia e Importação, na Praça Alberto Lion, desenvolvido em 1954 pelo escritório Charles Bosworth Sociedade Civil de Engenharia $^{148}$ e o projeto de Vilanova Artigas para a Companhia União de Refinadores, na rua Borges de Figueiredo, não construído. ${ }^{149}$ Além do conjunto de residências econômicas projetado por Gregori Warchavchik na rua Barão de Jaguara, de 1929.

Durante a primeira metade do século XX, portanto, ao lado dos numerosos projetos anônimos - edifícios industriais e residenciais que compõem a chamada 'arquitetura menor' e que apresentam, em muitos casos, excepcionais qualidades compositivas - , observamos a contribuição de renomados arquitetos e escritórios técnicos na configuração e consolidação desse patrimônio urbano. Um vasto acervo arquitetônico ainda não convenientemente estudado e que vem sendo destruído com grande rapidez.

\footnotetext{
${ }^{148}$ Revista Habitat, n.19, 1954, pp.26-27.

149 ARTIGAS, João Batista Vilanova. Edifício Comercial para a Cia. União dos Refinadores, à rua Borges de Figueiredo, 237 com rua Guaratinguetá, Mooca. São Paulo/SP, 1943-44. (APA-FAUUSP).
} 


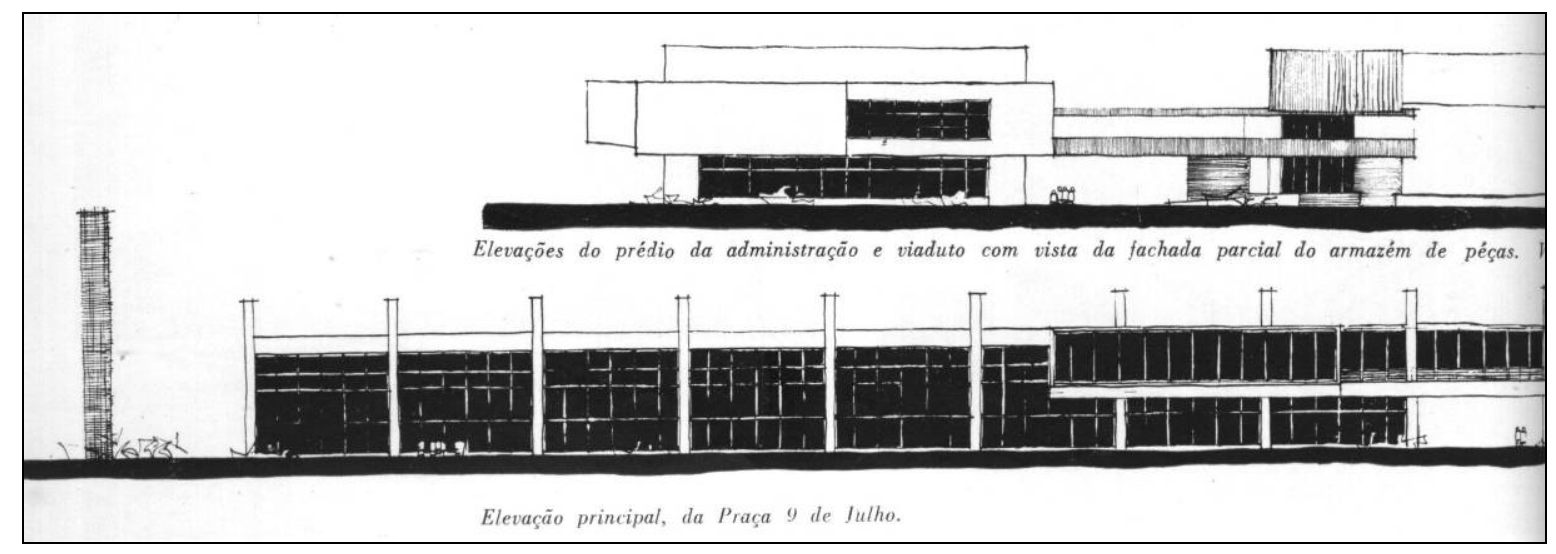

a.

50. Lion S.A. Engenharia e Importação, 1954.

a. Elevação do prédio da administração e do armazém de peças e elevação principal; b. Perspectiva do projeto aprovado. (Habitat, n.19)
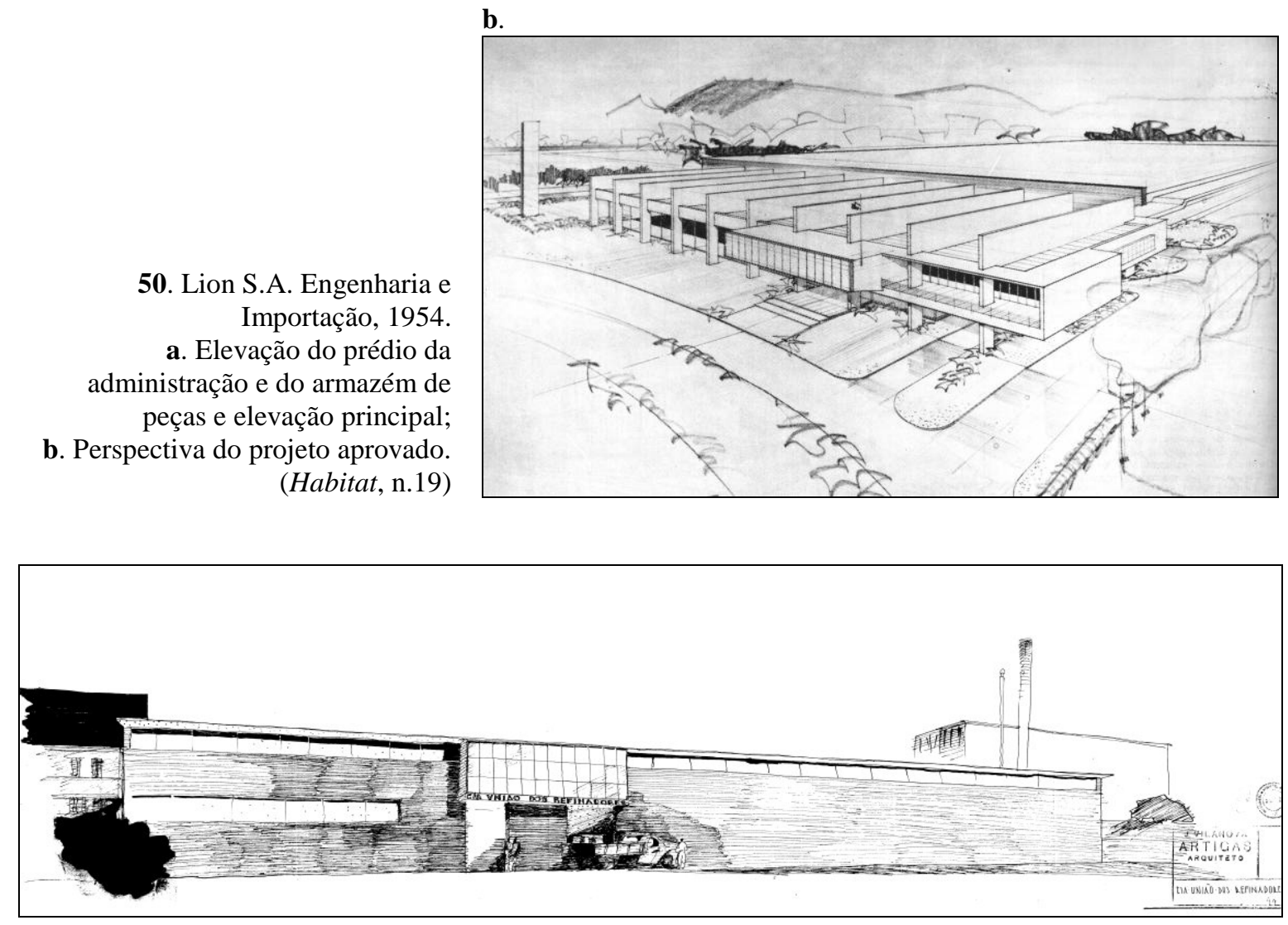

51. Projeto de Vilanova Artigas para a Cia. União de Refinadores, 1943-44. (APA-FAUUSP)

Na Diagonal Sul e arredores são poucos os edifícios e sítios industriais efetivamente protegidos por Lei. São tombados os edifícios da Estação do Brás e a Vila Maria Zélia, em nível estadual e municipal (tombamento ex officio). Em nível municipal, além do Moinho Matarazzo e da Tecelagem Mariangela, protegidos na década de $1990^{150}$, foram tombados em 2007, a partir de estudos impulsionados pelo zoneamento ZEPEC,

\footnotetext{
${ }^{150}$ Tombamento do Moinho Matarazzo e da Fábrica Mariangela (CONPRESP, Res. 38/92); Vila Maria Zélia (CONDEPHAAT Res. SC 43/92 e CONPRESP Res. 39/92); Remanescentes da Estação do Brás (CONDEPHAAT Res. 22/82 e CONPRESP 5/91).
} 
uma série de galpões na rua Borges de Figueiredo, na Mooca. Além dos demais edifícios e sítios em ZEPEC que estão sendo estudados pelo DPH há, ainda, outros pedidos encaminhados e processos de tombamento em análise, como a solicitação datada de 2006 que sugere a proteção de diversos galpões - inclusive dos armazéns de Victor Dubugras e o processo de tombamento da Companhia Antarctica Paulista, atualmente em estudo. Os mapas a seguir oferecem um panorama geral dos conjuntos industriais identificados até o momento e dos edifícios tombados, em análise ou já demolidos. Para complementar a visualização dos mapas, o Anexo I traz uma seqüência de fotos de alguns desses imóveis.

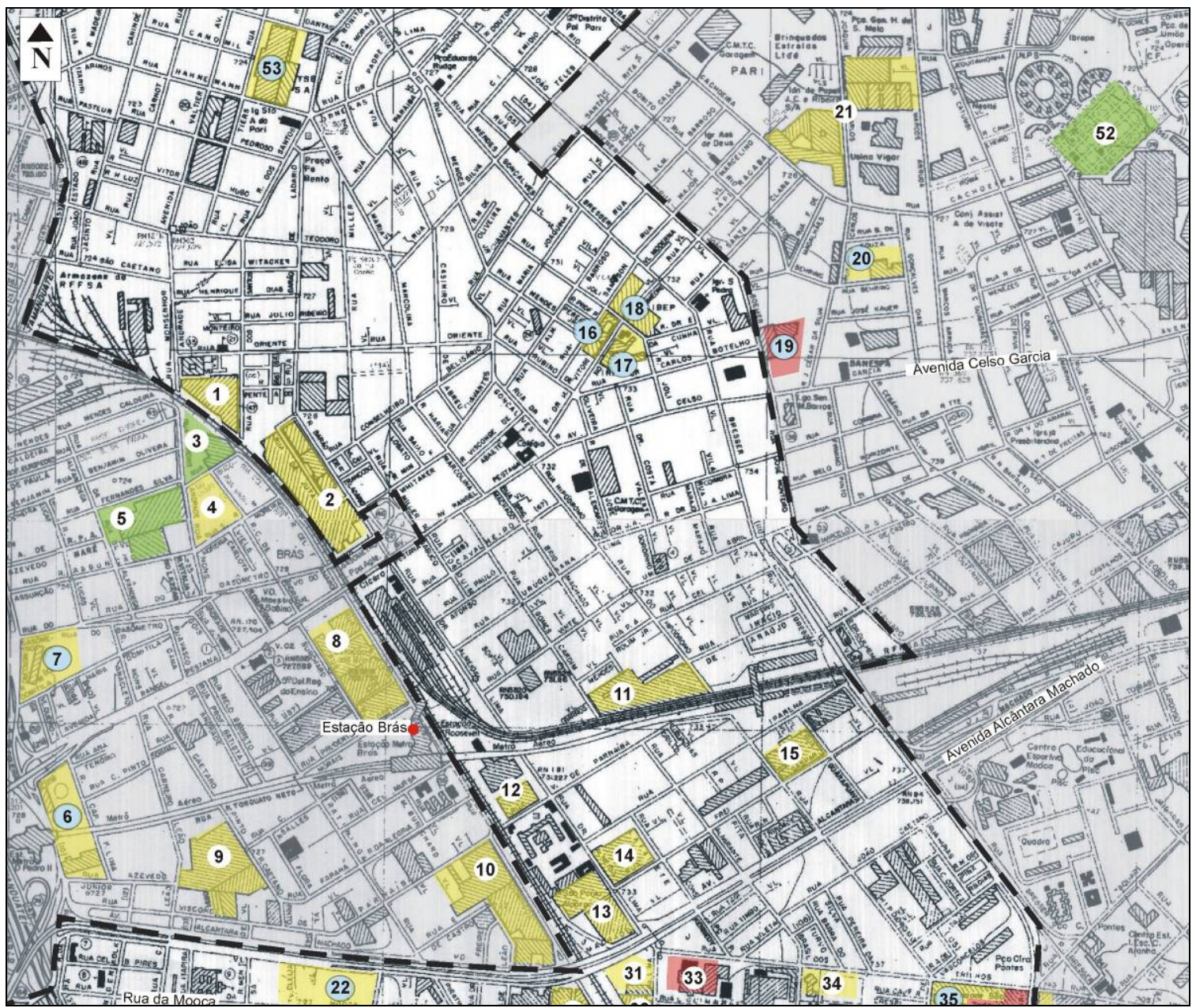
Edifícios e Sítios Industriais identificados até o momento:
11 - Companhia Paulista de Leite
12 - Depósitos da Estrada de Ferro Central do Brasil
01 - Centro de Abastecimento da Grande SP - CEAGESP 13 - São Paulo Alpargatas
02 - Remanescentes do Conjunto Industrial da rua da Juta
14 - São Paulo Alpargatas
03 - Moinho Matarazzo
04 - Remanescentes do conjunto industrial da rua Flórida
15 - Antiga Indústria de Papéis Gordinho \& Braune Co.
16 - Depósitos das I.R.F.M. (Conjunto da rua Joli)
17 - I.R.F.M. Administração (Conjunto da rua Joli)
05 - I.R.F. Matarazzo, Tecelagem Mariangela
06 - Gasômetro da Figueira
07 - Casa das Retortas
18 - Antiga Tecelagem Matarazzo (Conjunto da rua Joli)
08 - Remanescentes dos Armazéns da Estrada de Ferro
19 - Lanifício Paulista (demolido)
20 - Orion, Indústria de Artefatos de Borracha
21 - Fábrica de Brinquedos Estrela
09 - I.R.F.M., Indústria Metalúrgica
10 - Conjunto de Galpões da rua André de Leão
22 - Tecelagem Labor

52a. Edifícios e sítios industriais identificados até o momento nos bairros do Pari e Brás. Demarcação baseada no estudo EMURB e em levantamentos de campo realizados pela autora entre 2001 e 2008. Base cartográfica: Levantamento Aerofotogramétrico, Emplasa, 1981, sem escala. 


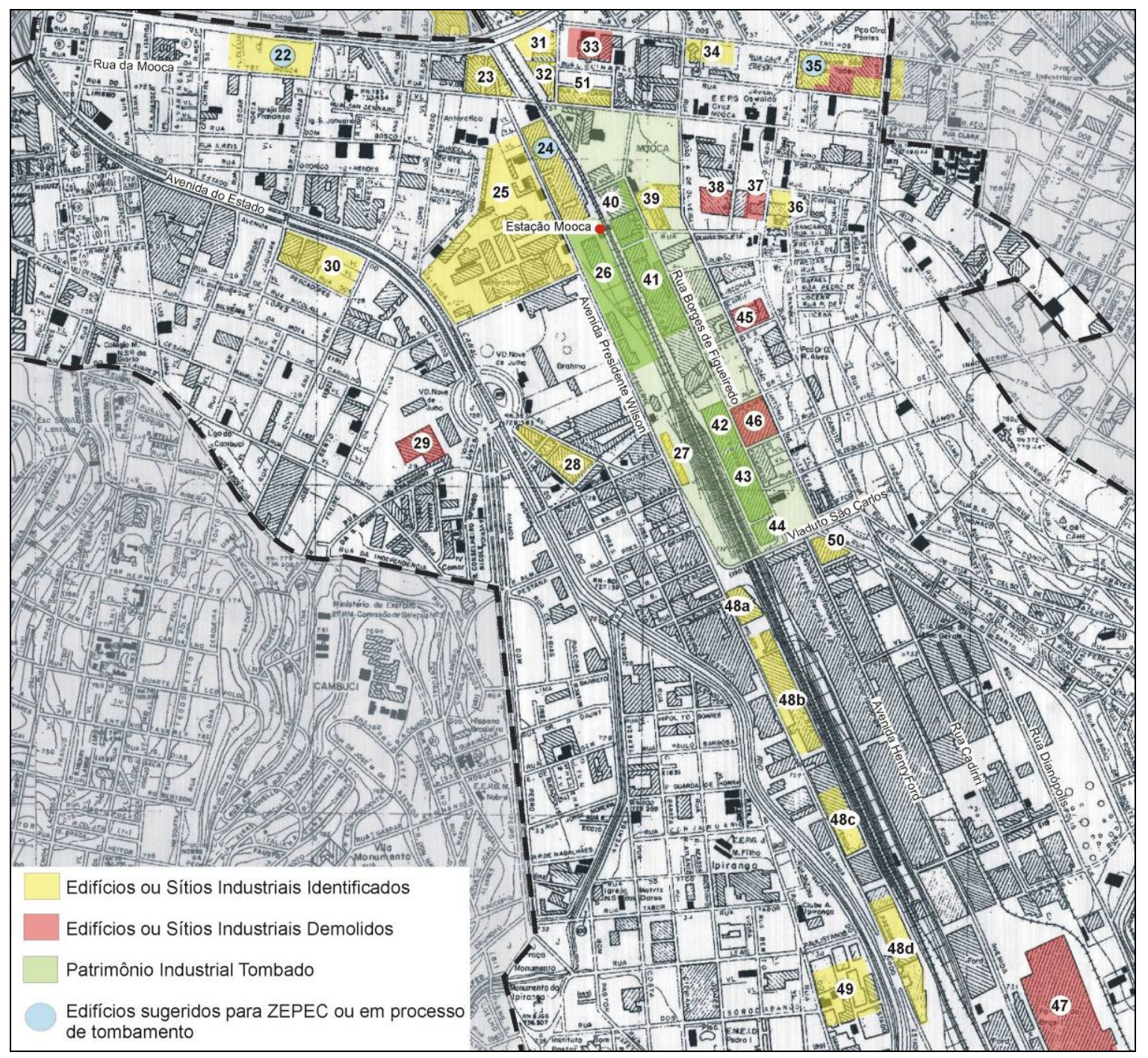

Edifícios e Sítios Industriais identificados até o momento:

23 - Armazéns Gerais Piratininga (armazéns de Elias Calfat)

38 - Fábrica de Estopa Paulista (demolido)

39 - Companhia União de Refinadores

40 - Oficinas da Sociedade Anônima Casa Vanorden

41 - Grandes Moinhos Minetti Gamba

25 - Sítio Industrial da Cia. Antárctica Paulista

26 - Conjunto de Armazéns da antiga São Paulo Railway

27 - Armazéns Gerais da Estrada de Ferro

28 - Indústria de Eletrodomésticos Arno

29 - Lion S.A. Engenharia e Importação (demolido)

30 - Companhia Jardim de Cafés Finos

42 - Conjunto de Galpões e Armazéns

43 - Conjunto de Depósitos para Café - CEAGESP

44 - Sociedade Técnica Bremensis e Schimidt Trost.

45 - Cia. Metalúrgica Paulista (demolido)

46 - Metalúrgica Piratininga (demolido)

47 - Ford Motors Company (demolido)

48 - Seqüência de Galpões da avenida Presidente Wilson

49 - Fábrica de Linhas Corrente

50 - Fábrica de Eletrodomésticos Continental

51 - Galpão entre rua da Mooca e rua Nilo Peçanha

52 - Vila Maria Zélia

53 - Conjunto Industrial da rua Tiers

52b. Edifícios e sítios industriais identificados até o momento no bairro da Mooca e parte da Vila Prudente e Ipiranga. Fotos de alguns desses edifícios seguem no Anexo I desta tese.

O recente tombamento do conjunto industrial da rua Borges de Figueiredo significou uma importante conquista para a preservação do patrimônio urbano industrial da cidade de São Paulo. Procurou-se proteger não apenas edifícios isolados, mas todo um conjunto arquitetônico homogêneo e representativo de etapas decisivas na formação urbana 
do bairro e da própria cidade. Foram tombados o conjunto de galpões das Oficinas Vanorden; o Moinho Minetti Gamba (incluindo edifícios de produção de óleo, sabão e glicerina, os moinhos de trigo e arroz e espaços internos); conjunto de depósitos para armazenagem de café posteriormente adquiridos pela CEAGESP; conjunto arquitetônico da Sociedade Técnica Bremensis e Schmidt Trost (também conhecido como Cooperativa Banco do Brasil) e os armazéns da antiga São Paulo Railway. ${ }^{151} \mathrm{O}$ tombamento abrange o perímetro formado pelas ruas Borges de Figueiredo, Monsenhor João Felipo, avenida Presidente Wilson e viaduto São Carlos e determina, ainda, restrições de gabarito no entorno. As alturas das novas construções deverão ser estudadas caso a caso, não ultrapassando, porém, 25m nas áreas adjacentes aos imóveis tombados e 30m nos quarteirões entre a rua Borges de Figueiredo e a rua João Antonio de Oliveira, que também não poderão ser remembrados, conforme mapa abaixo.

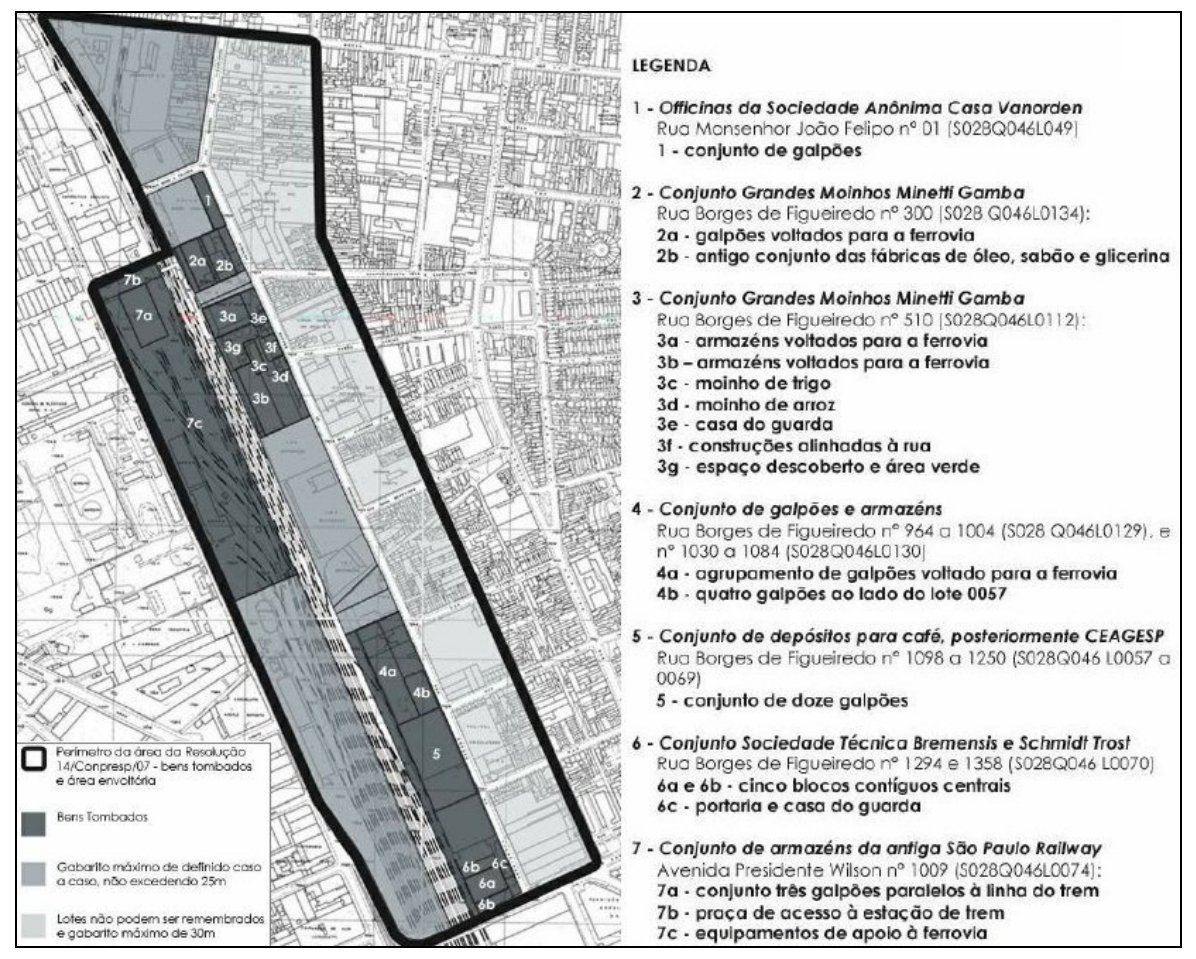

53. Rua Borges de Figueiredo. Mapa anexo à Resolução de Tombamento. (CONPRESP. Res. 14/07)

\footnotetext{
${ }^{151}$ CONPRESP. Res. 14/2007. Há ainda processo de tombamento aberto para os edifícios da Companhia Antarctica Paulista (Res. 09/07); para a chaminé remanescente da Companhia União de Refinadores, conjunto industrial em desativação (Res.07/08), ambos em nível municipal; e para o conjunto industrial da rua Joli, no Brás, em nível estadual. Para informações detalhadas sobre os edifícios tombados na rua Borges de Figueiredo, consultar: SMC/DPH. Estudo para o tombamento do Patrimônio Industrial na orla ferroviária em torno da Estação da Mooca. Pesquisa desenvolvida por Ana Clara Giannecchini, Dalva Thomaz e Valdir Arruda. São Paulo, 2007.
} 

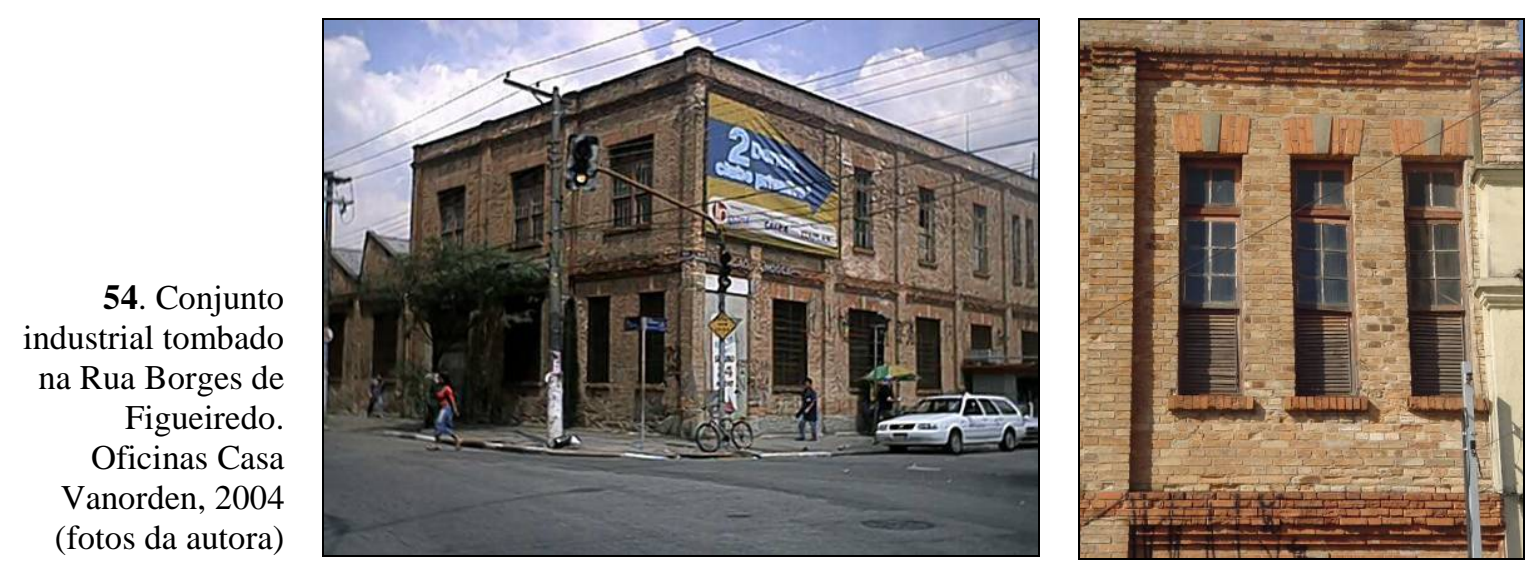

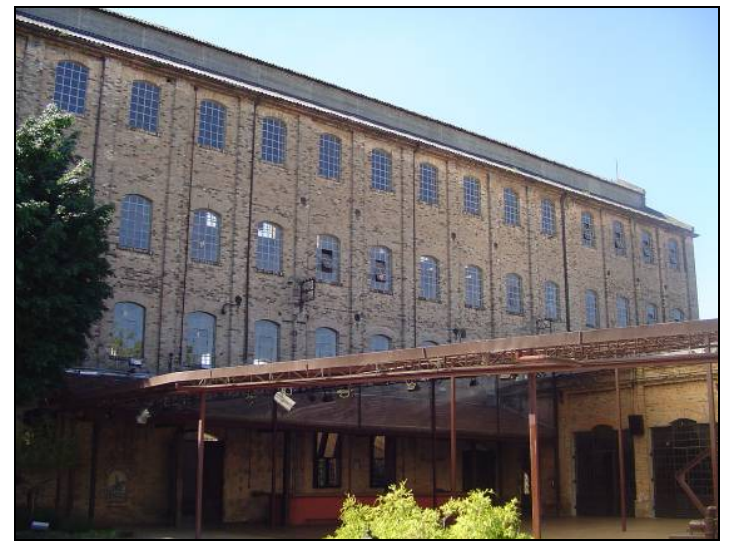

55. Conjunto industrial Grandes Moinhos Minetti Gamba, 2004.

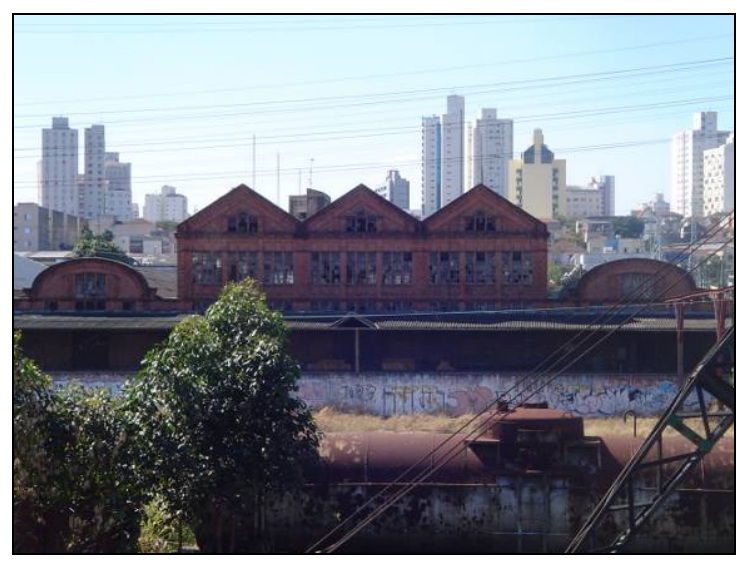

57. Conjunto arquitetônico da Sociedade Técnica Bremensis e Schmidt Trost, 2004.

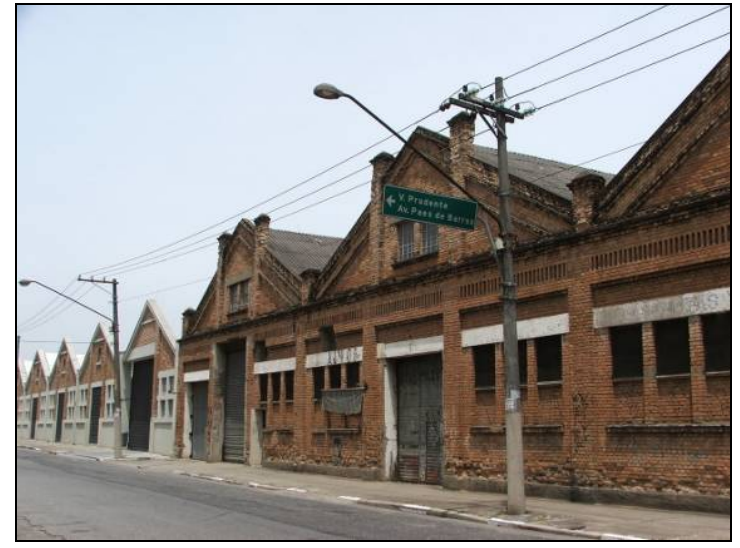

56. Conjunto de galpões da rua Borges de Figueiredo, 2008.

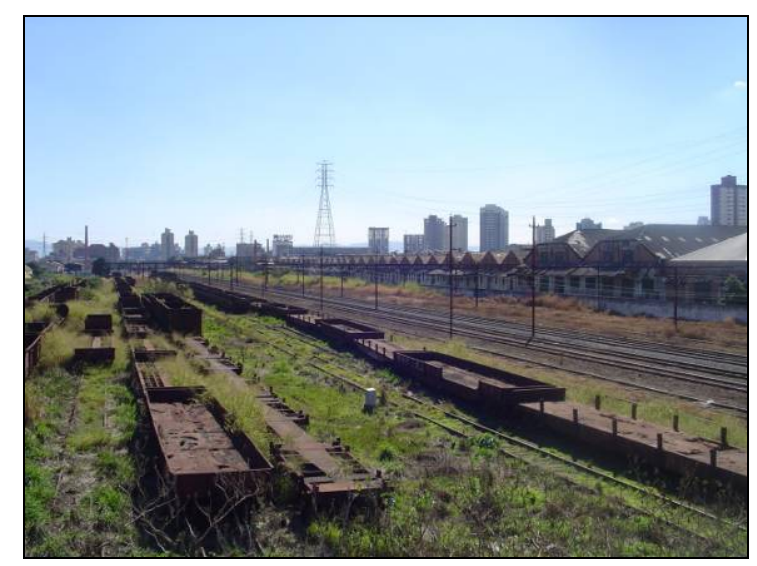

58. Vista do conjunto de galpões da rua Borges de Figueiredo a partir da via férrea, 2004.

O tombamento desse extenso conjunto industrial e as restrições construtivas no entorno foram motivo de muita polêmica, sobretudo por parte de empreendedores imobiliários que já planejavam investimentos na área. Na rua Borges de Figueiredo, pouco antes do tombamento, todo o quarteirão formado pelas ruas Visconde de Inhomerim, João 
Antonio de Oliveira e Doutor Eduardo Gonçalves - local onde se localizava a antiga Metalúrgica Piratininga - foi demolido para a construção de torres residenciais que devem ser inauguradas em breve. Em 2007, quando então corria o processo de tombamento, alguns galpões localizados na rua Borges de Figueiredo chegaram a ser demolidos internamente, mesmo estando protegidos pelo zoneamento ZEPEC. Atitudes que evidenciam as dificuldades políticas e econômicas envolvidas na proteção do patrimônio urbano de origem industrial.

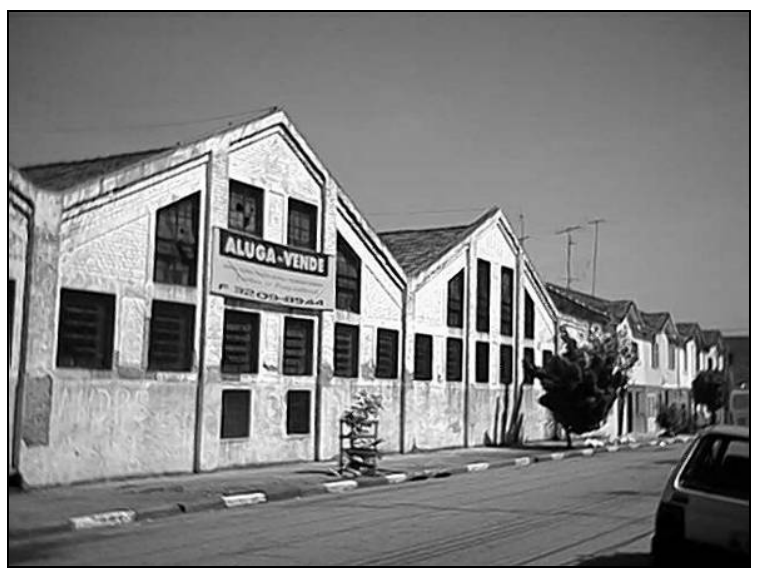

59. Rua João Antônio de Oliveira em 2003. Metalúrgica Piratininga e residências adjacentes demolidas em 2006. (Fotos da autora)

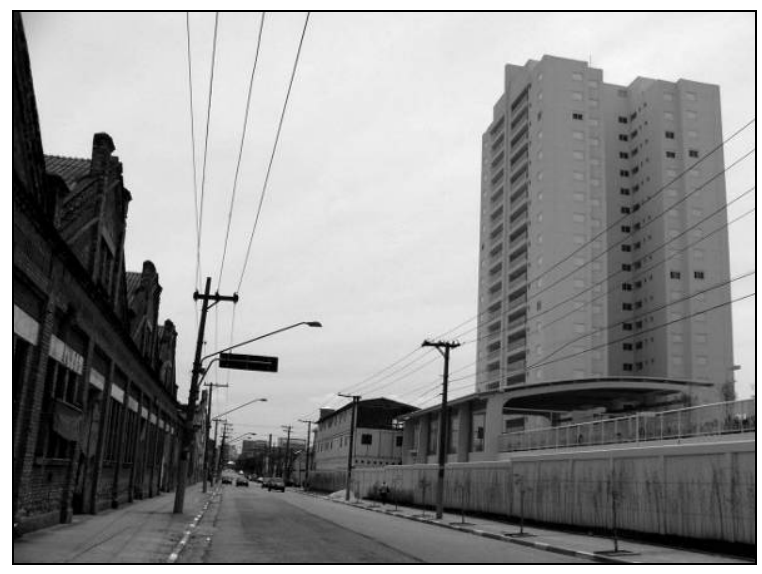

60. Rua Borges de Figueiredo. À esquerda, galpões industriais tombados em 2007. À direita, edifício construído no local da antiga Metalúrgica, 2008.

Esses edifícios e sítios têm sido destruídos com grande rapidez para ceder espaço a novas obras construídas segundo visões projetuais restritas e até mesmo tacanhas. São raras as reflexões de projeto que buscam uma ocupação diferenciada, um diálogo com o preexistente ou que integram as características peculiares do bairro como uma importante condicionante de partido. Pelo contrário, todos os bairros da cidade são construídos segundo o mesmo padrão e as mesmas estratégias de venda. No caso das torres construídas sobre os escombros da Piratininga, trata-se de um projeto desprovido de quaisquer referências locais e desproporcional em relação às escalas, urbanidades e paisagens preexistentes; qualidades, aliás, utilizadas para vender o empreendimento: um "bairro distante da inquietação paulistana [onde] ainda é possível passar por ruas pequenas de paralelepípedos margeadas por árvores, ver crianças brincando em praças com balanço e gangorra, tijolinhos aparentes nas fachadas de algumas casas", ${ }^{152}$ um conjunto de

152 Dizeres extraídos do material de venda do empreendimento Stupendo Mooca, as torres residenciais construídas nos terrenos da antiga Metalúrgica Piratininga. A rapidez na reocupação desses lotes e a busca 
elementos materiais e imateriais que esses mesmos empreendimentos vêm dissolvendo pouco a pouco. A descaracterização da paisagem também se observa com nitidez na inserção de várias torres residenciais no terreno de uma antiga fábrica de estopas situada na rua Marina Crespi, a poucas quadras do exemplo anterior. Da antiga fábrica restou somente a fachada principal transformada em pórtico de acesso do conjunto residencial.

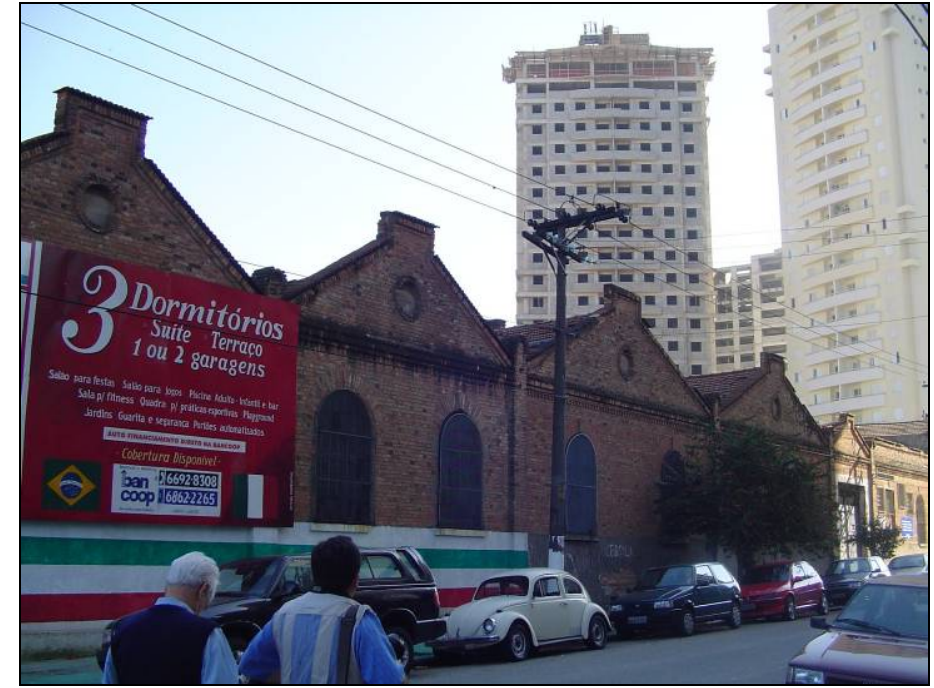

61a. Fábrica de Estopas na rua Marina Crespi, construída na década de 1910. Situação em 2004. (fotos da autora)

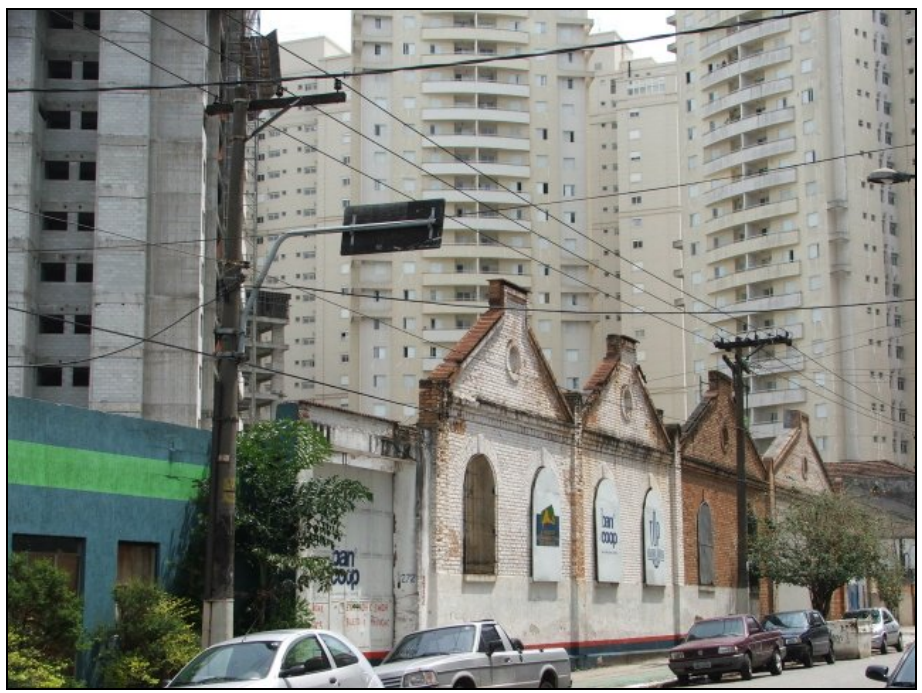

61c. Situação em 2008.Torres residenciais já construídas. Parte da fachada foi mantida como pórtico de acesso.

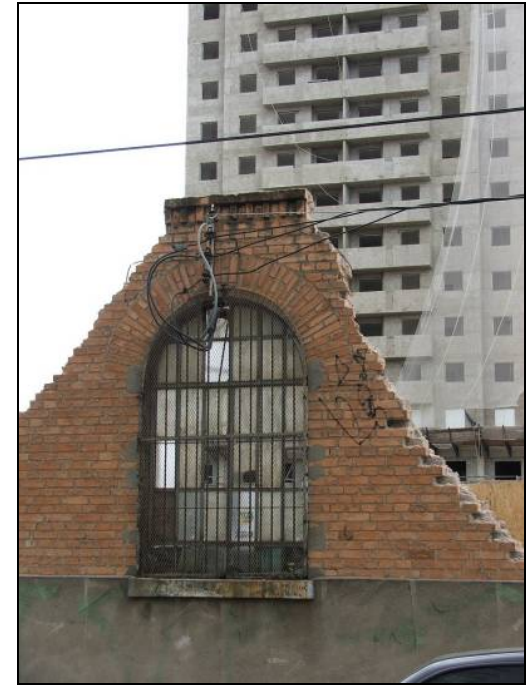

61b. Demolição, entre 2004 e 2005.

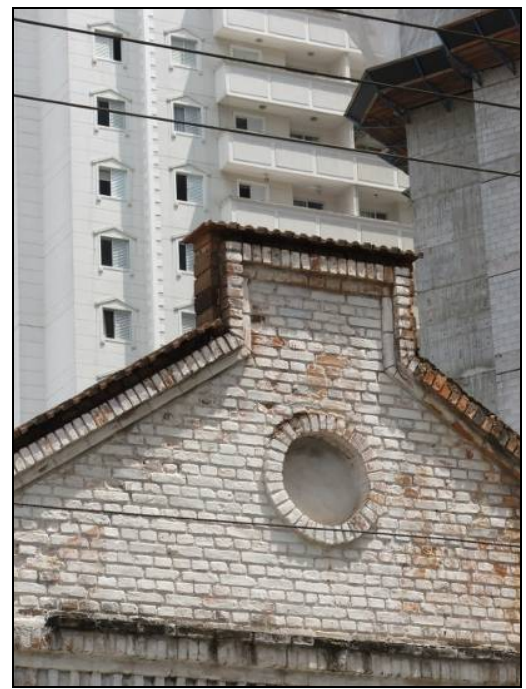

61d. Detalhe de um dos frontões remanescentes.

pelo máximo lucro possui faces ainda mais perversas: segundo informações obtidas na Secretaria Municipal de Planejamento, o subsolo desses terrenos está contaminado com resíduos químicos provenientes da antiga atividade industrial (segundo laudo elaborado por empresa especializada) e, mesmo assim, a obra foi levada adiante sem a necessária descontaminação do solo. 


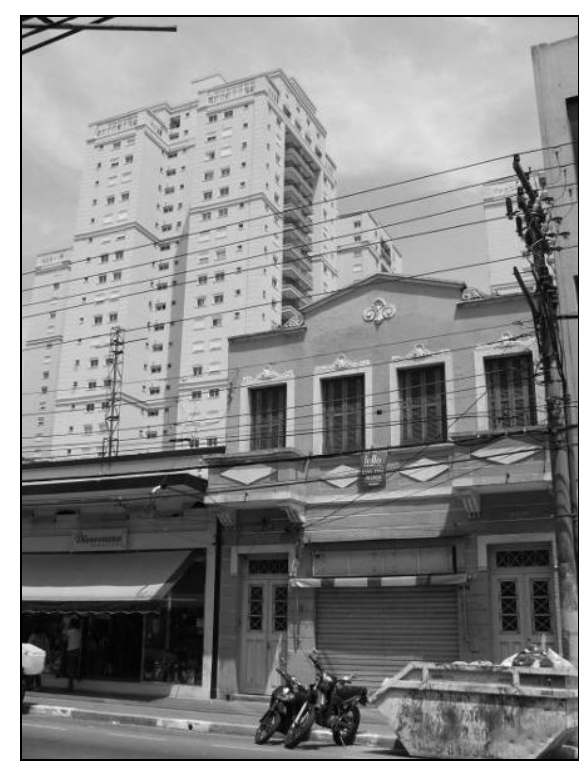

61e. Descaracterização da paisagem. Vista da rua da Mooca, 2008. (fotos da autora)

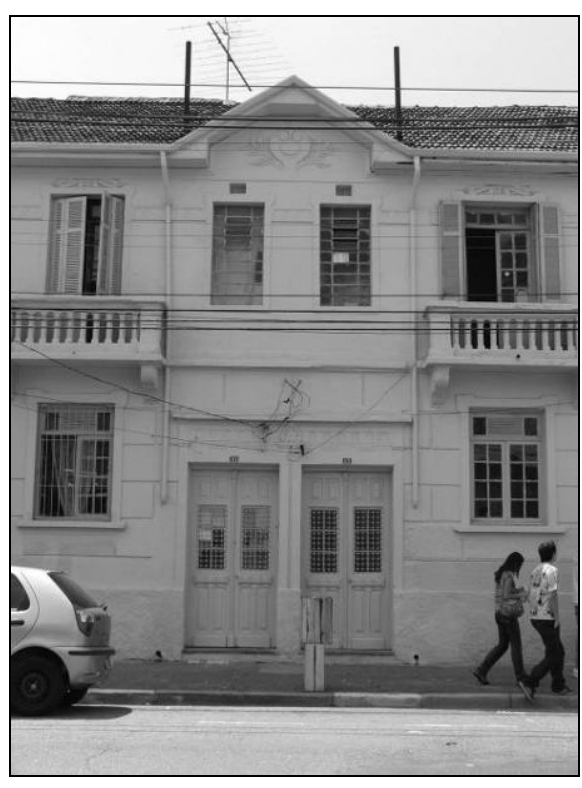

61f. Aspectos da paisagem local. Residências nas imediações da rua Marina Crespi, 2008.

Obras semelhantes ameaçam ainda diversos outros edifícios e sítios industriais na Diagonal Sul. O conjunto arquitetônico do Moinho Gamba, tombado em 2007, é um deles. Há uma proposta para construção de torres residenciais que prevê a demolição de todo o conjunto arquitetônico e a conservação apenas do edifício central do Moinho, considerado um elemento suficiente para testemunhar o antigo uso. Na Vila Prudente, além dos galpões ao longo da rua Guamiranga que deverão ceder espaço para ampliação do Shopping Central Plaza, localizado na avenida do Estado, foram demolidos diversos armazéns situados na avenida Presidente Wilson, na altura da estação de trem Tamanduateí - uma área imensa sobre a qual não havia qualquer documentação ou levantamento - para a construção do pátio de manobras do futuro metrô.

Uma das obras mais polêmicas, contudo, foi a demolição de grande parte do conjunto arquitetônico do Cotonifício Crespi, conforme aludimos no início deste capítulo. O edifício, construído na década de 1920 com o intuito de abrigar todas as etapas da fiação, ficou desocupado por um longo período até que, em 2004, foi alugado por um importante grupo de comércio varejista para a instalação de um hipermercado, novo uso que abarcaria também outros edifícios fabris do mesmo complexo. O conjunto arquitetônico original ocupava todo o quarteirão e era formado por diversas edificações que abrigavam etapas específicas da produção e que foram sendo construídas gradativamente, conforme o crescimento da empresa e as inovações tecnológicas, desde 1897, ano de sua fundação, até 
meados da década de 1960. Dessa forma, além de permitir a leitura dos processos produtivos, o conjunto reunia edifícios construídos em momentos distintos, evidenciando a adoção de diferentes linguagens formais e técnicas construtivas ao longo do tempo. $\mathrm{O}$ edifício principal do complexo apresenta um sistema construtivo de grande interesse. Trata-se de uma estrutura metálica autônoma com vedação de tijolos aparentes que desenvolve as funções fabris em vários pavimentos, solução pouco usual entre os edifícios industriais construídos no início do século XX, em São Paulo. A adaptação para novo uso, no entanto, não buscou preservar e valorizar tais especificidades. As primeiras propostas apresentadas, que previam a manutenção de apenas duas fachadas desse edifício, demolindo-se todo o restante, não foram aprovadas pelo Departamento do Patrimônio Histórico, chamado à discussão pois o edifício usufrui de zoneamento ZEPEC. Em síntese, após grande polêmica e contando até mesmo com a intervenção do Ministério Público, o projeto finalmente aprovado e construído manteve as fachadas e parte da estrutura metálica original; o restante, o 'miolo' do edifício, foi inteiramente removido, sendo construído no espaço resultante um novo edifício seguindo o padrão de todas as lojas do grupo. Boa parte do conjunto industrial adjacente foi totalmente demolida para dar lugar aos estacionamentos do hipermercado. Uma solução absolutamente desrespeitosa, em que não foram observadas as qualidades compositivas do conjunto industrial e de seus edifícios, tratados como meros 'contentores' para o novo uso. ${ }^{153}$

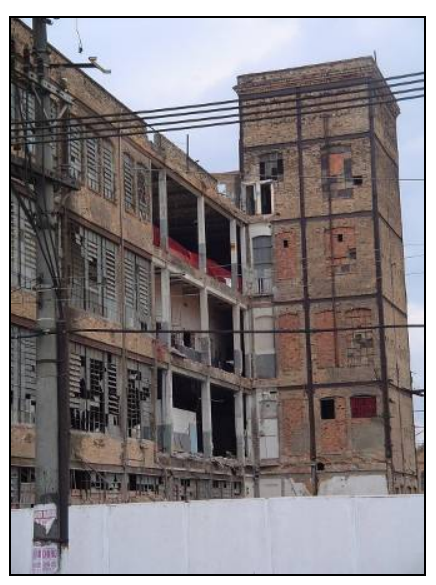

a.

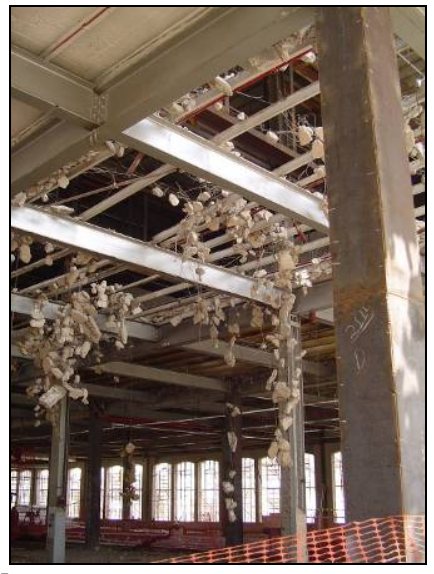

b.

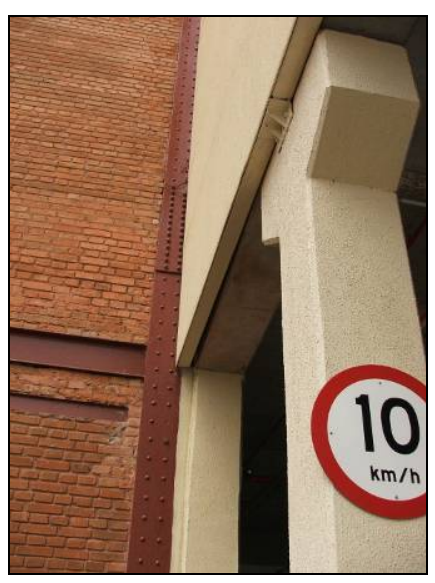

c.

62. Cotonifício Crespi. Obras de adaptação para o novo uso.

a. Demolições no edifício da fiação; b. Demolição das lajes do primeiro pavimento; c. Após o término das obras. Junção entre a estrutura de aço original e a nova construção de pré-moldados de concreto.

${ }^{153}$ RUFINONI, M. Patrimônio industrial ameaçado..., op. cit., pp.73-88; KÜHL, B. M., Preservação..., op. cit., pp.171-175. 


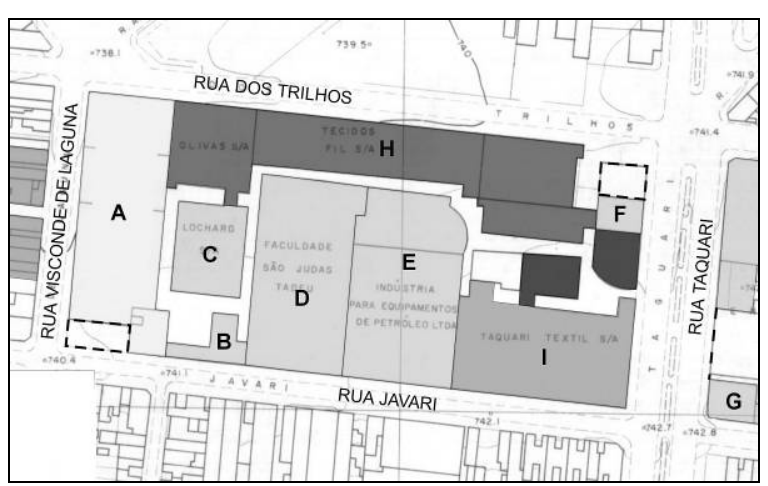

62d. Conjunto arquitetônico do Cotonifício Crespi. Situação em 2001.

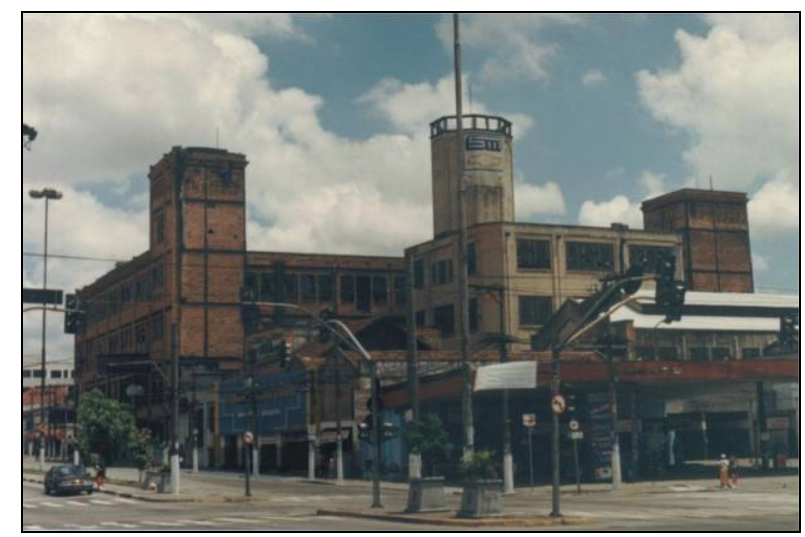

62f. Vista da esquina entre a rua dos Trilhos e a rua Taquari. Situação em 2001.

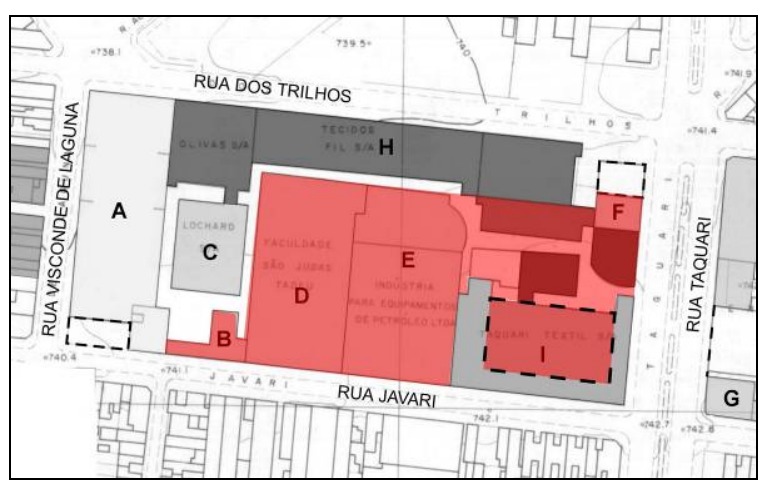

62e. Situação em 2004, após as demolições para a inserção do hipermercado

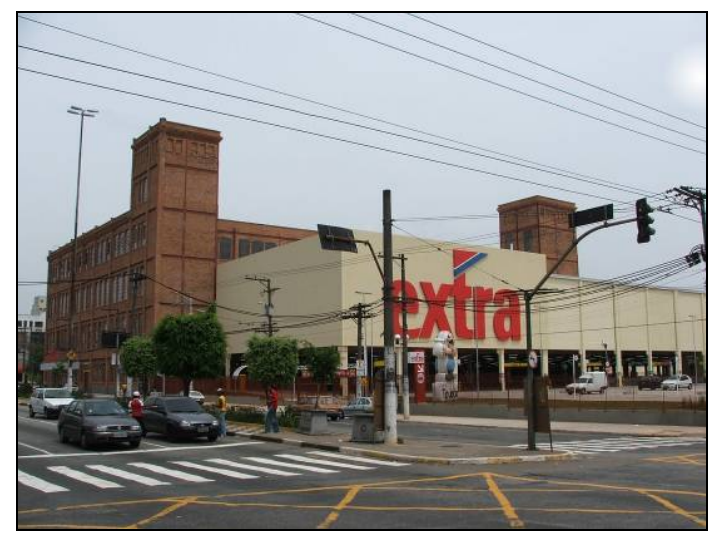

62g. Mesmo ângulo. Situação após o término das obras, em 2004.

Esse breve panorama da descaracterização da área evidencia uma série de problemas na preservação efetiva desse patrimônio. Como vimos, até mesmo edifícios em zoneamento ZEPEC, ou mesmo já tombados, vêm sofrendo com reformas aleatórias, desprovidas de qualquer fundamentação criteriosa. A tutela do patrimônio urbano é sempre algo difícil e controverso, pois o tombamento de extensas áreas, como observamos no caso da rua Borges de Figueiredo, esbarra em poderosos interesses e na mentalidade largamente difundida de que tombar significa 'congelar'. Assim, defender a manutenção do patrimônio urbano industrial torna-se uma tarefa quase impossível: por um lado, certos edifícios isolados não justificam a proteção legal e, por esse motivo, pouco a pouco os galpões e armazéns vão sendo demolidos e substituídos pela verticalização descaracterizadora; por outro lado, buscar a preservação de perímetros significativos acirra ainda mais a avidez do mercado imobiliário, fato que nos leva até mesmo a refletir se o conjunto industrial da Borges de Figueiredo não acabará se tornando a única parcela representativa preservada em conjunto. 
Um possível caminho para sugerir novos moldes de tutela e intervenção poderia se configurar, nesse sentido, a partir dos instrumentos urbanísticos a serem propostos pela operação urbana. Se a preservação e o restauro do patrimônio urbano industrial integrarem, de fato, o escopo dos temas a serem abordados pela Diagonal Sul, conforme as diretrizes de Amsterdã, a operação poderia configurar-se como um programa a longo prazo voltado para a condução de um criterioso processo de requalificação, utilizando a abertura jurídica que lhe é própria para a proposição de novos instrumentos de tutela, preservação e intervenção devidamente estudados para atender às particularidades do contexto em pauta. O percurso traçado até o momento pela operação urbana, contudo, não tem seguido nessa direção.

Segundo Pedro Sales, ${ }^{154}$ a operação urbana Diagonal Sul inicialmente integrava o escopo dos programas de intervenção a serem financiados pelo BID - Banco Interamericano de Desenvolvimento, programa que hoje se restringe às atuações em andamento na área da Luz. O projeto inicial apresentado para o BID era bem mais extenso e abrangia várias áreas da cidade, inclusive a OUDS. Para subsidiar as futuras intervenções na Diagonal, nessa primeira programação da operação urbana era prevista uma etapa inicial composta por sete estudos de viabilidade e pesquisas interdisciplinares sobre a situação preexistente - planejamento da infra-estrutura viária e transportes, mapeamento das indústrias em atividade, análise imobiliária, estudos voltados à melhoria da qualidade ambiental, localização das áreas contaminadas, etc. - e, também, a realização de um inventário detalhado dos bens culturais, arquitetônicos e urbanos, dos bairros da Mooca, Ipiranga e Vila Prudente. ${ }^{155}$ Esses estudos seriam financiados pelo BID e deveriam fundamentar o prosseguimento das propostas. No entanto, entre 2004 e 2005, após mudanças de governo e redefinição de prioridades, a Prefeitura optou por interromper o andamento dessa programação inicial (que previa um prazo extenso e várias etapas de projeto e execução) e aplicar o financiamento internacional em uma única área, no bairro

\footnotetext{
154 Dados obtidos em entrevista com o arquiteto Pedro Sales, da SEMPLA - Secretaria Municipal de Planejamento, em entrevista concedida à autora desta pesquisa em dezembro de 2008.

155 A primeira etapa previa a realização de sete estudos preliminares que subsidiariam o prosseguimento das propostas: 1. Estudo de melhoria da qualidade da água do Tamanduateí; 2. Geo-referenciamento das informações da PAEP - Pesquisa da Atividade Econômica Paulista, entre 1996/2001; 3. Inventário dos bens culturais: Mooca, Ipiranga, Vila Prudente; 4. Mapeamento de áreas com problemas de contaminação: subsolo, solo, água; 5. Levantamento e análise imobiliária; 6. Planejamento da infra-estrutura viária e de transporte; 7. Plano-Referência de Intervenção e Ordenação Urbanística. SALES, Pedro M. R. Operações Urbanas em São Paulo: crítica, plano e projetos. Parte 5: Operação Urbana Digonal Sul. Arquitextos Vitruvius, n.315, junho 2005.
} 
da Luz, talvez com o intuito de promover obras mais imediatas e de maior impacto frente à opinião pública.

Quanto à OUDS, por determinação política, os sete estudos iniciais foram reduzidos à quatro: inventário dos bens culturais, mapeamento da localização industrial, planejamento viário e contaminação do solo. Não há, contudo, qualquer previsão para iniciar a elaboração desses estudos - agora sem o financiamento do BID - e a programação de toda a operação urbana por ora está suspensa. Essa situação é preocupante pois, como vimos, a atividade imobiliária em várias áreas da Diagonal tem crescido muito, provocando a rápida descaracterização de paisagens históricas de grande interesse. Com a incidência de diretrizes criteriosas de desenvolvimento, advindas de uma operação urbana que considerasse a valorização do patrimônio urbano cultural (como sugeria a proposição dos estudos preliminares), poderia ser possível redirecionar esse cenário de transformações para soluções menos destrutivas do que aquelas promovidas pela livre especulação, como vem acontecendo.

Os objetivos dos estudos preliminares propostos indicam que a programação inicial da operação urbana considerava com atenção as preexistências industriais. Segundo Sales, além do inventário propriamente dito, o mapeamento da atividade industrial seria também um estudo de grande interesse para a visualização das estruturas existentes e condução de estudos mais aprofundados sobre eventuais exemplares significativos. Conforme temos abordado, as informações sobre os sítios industriais da Diagonal são escassas, inexistem levantamentos precisos e atualizados e muitos desses sítios são inacessíveis, fechados por grandes muros. Além disso, a grande extensão da área e dos próprios sítios dificulta sobremaneira a pesquisa caso a caso. $\mathrm{O}$ mapeamento seria desenvolvido a partir do cruzamento entre estudos cartográficos e os dados do SEADE Fundação Sistema Estadual de Análise de Dados, que mantém informações atualizadas sobre as indústrias em funcionamento, desativações, localização, setores produtivos, etc. ${ }^{156}$ Nessa etapa de definição dos estudos preliminares houve interesse da equipe envolvida em buscar a colaboração interdisciplinar. A Secretaria de Planejamento esteve em contato direto com o Departamento do Patrimônio Histórico e chegou-se a traçar em conjunto as diretrizes gerais para a realização desses estudos, inventários, levantamentos históricos e

\footnotetext{
${ }^{156}$ Segundo Sales, esses dados foram reunidos pelo SEADE a partir do desenvolvimento do PAEP - Pesquisa da Atividade Econômica Paulista, entre os anos 1996 a 2001. Não foi possível elaborar esse mapeamento industrial conforme previsto inicialmente, mas no momento a SEMPLA vem realizando estudo semelhante a partir de outra base de dados.
} 
documentais. Assim, observamos que a integração entre os departamentos acontece na esfera técnica a partir do interesse dos profissionais diretamente envolvidos nas propostas. Os setores administrativos que efetivamente decidem, no entanto, dificilmente vislumbram a complexidade envolvida na condução desses projetos urbanos, notadamente em áreas de interesse cultural, e acabam por privilegiar ações de maior visibilidade política, sem as articulações e integrações necessárias, conforme temos buscado demonstrar.

Para cada operação urbana uma Lei específica é redigida. Para a Diagonal Sul, no entanto, ainda não há tal definição legislativa pois o andamento do processo foi suspenso. Como princípio fundamental de uma operação urbana, as áreas abarcadas deverão usufruir de parâmetros diferenciados de ocupação e adensamento, como por exemplo, o emprego da outorga onerosa acima dos índices normalmente praticados ${ }^{157}$. Assim, a ampliação do potencial construtivo é empregada com o intuito de incentivar investimentos na área a partir da possibilidade de se construir mais do que o zoneamento originalmente permitiria $^{158}$. Segundo Sales, na OUDS esse instrumento não surtiria efeito pois os lotes são suficientemente grandes e os índices aplicados permitem o adensamento (fato, aliás, que ameaça a preservação do patrimônio). Uma possível alternativa seria o emprego do Land Readjustement, instrumento urbanístico pautado pelo rearranjo da matriz fundiária e incentivo à implementação de melhorias, ou seja, o proprietário de um grande lote cede uma parte de seu terreno ao promotor das melhorias (instalação de infra-estrutura, implementação de novos usos, empreendimentos, etc.), que tanto pode ser o poder público como a iniciativa privada, e, em troca, usufrui, na parte restante, da valorização promovida por tais transformações ${ }^{159}$. No primeiro caso, trata-se de solo criado e o proprietário é envolvido por adesão; no segundo caso, trata-se de desenvolvimento local a partir da implementação de melhorias como meio de valorização urbana e a participação é

\footnotetext{
${ }^{157}$ Segundo o Plano Diretor, "Outorga Onerosa é a concessão, pelo Poder Público, de potencial construtivo adicional acima do resultante da aplicação do Coeficiente de Aproveitamento Básico, até o limite estabelecido pelo Coeficiente de Aproveitamento Máximo, de alteração de uso e parâmetros urbanísticos, mediante pagamento de contrapartida financeira".

${ }^{158} \mathrm{O}$ detalhamento desses instrumentos e os índices a serem aplicados são determinados em Lei específica para cada operação urbana. Para se ter uma idéia, consideremos um caso hipotético onde adotou-se a concessão onerosa do direito de construir do seguinte modo: partindo de uma taxa base $=1$ (pode-se construir uma vez a área do terreno), para casos fora de operação urbana, o proprietário pode construir até 2,5 vezes a área do terreno desde que pague ao poder público uma taxa que incide sobre a diferença de 1,5 construído a mais; em casos abarcados por uma operação urbana, pode-se construir ainda mais (e a quantidade é definida em Lei), por exemplo, até 4 vezes a área do terreno, e sobre a diferença de 3 deverá ser paga uma taxa que vai para o fundo da operação urbana. É um instrumento, portanto, que objetiva incentivar o investimento privado em determinadas áreas para induzir a requalificação urbana.

${ }^{159}$ Sobre esse instrumento urbanístico e estudos sobre a viabilidade e oportunidade de empregá-lo na cidade de São Paulo, consultar: MONTANDON, Daniel Todtmann e SOUZA, Felipe Francisco de. Land Readjustement e Operações Urbanas Consorciadas. São Paulo: Romano Guerra, 2007.
} 
compulsória. A determinação de qual instrumento será aplicado em uma área de operação urbana é definida em uma lei específica para cada operação. Segundo Pedro Sales, é possível que, ao ser reativada a OUDS, essa segunda opção seja adotada. Com relação à áreas urbanas de interesse cultural existentes na Diagonal, contudo, a aplicação deste instrumento, caso seja escolhido, implicará a necessidade da elaboração de criteriosos estudos. A concessão de parte dos lotes para outro proprietário, no caso de sítios industriais cuja configuração original deva ser preservada, deverá ser considerada de maneira cautelosa, atentando para que não resulte no parcelamento de lotes historicamente determinados, desconfigurando a composição original desses sítios e do próprio tecido urbano. Por outro lado, as melhorias a serem implementadas, também deverão atentar para os usos compatíveis e serem desenvolvidas como projetos de restauro urbano, o que, infelizmente, não acreditamos que ocorra.

Esse ceticismo tem um motivo claro. Além das novas construções realizadas pela especulação imobiliária que, como vimos, vêm alterando a paisagem industrial consolidada dos bairros históricos, fato agravado pela dificuldade de se defender a preservação de um conjunto urbano significativo, deparamo-nos, ainda, com as grandes propostas revitalizadoras para a área advindas de discussões acadêmicas ou grupos de profissionais que, mais uma vez, evidenciam a inobservância dos valores de conjunto desse patrimônio, de sua especificidades compositivas e relações com o entorno, em diferentes escalas, responsáveis pela configuração dessa paisagem.

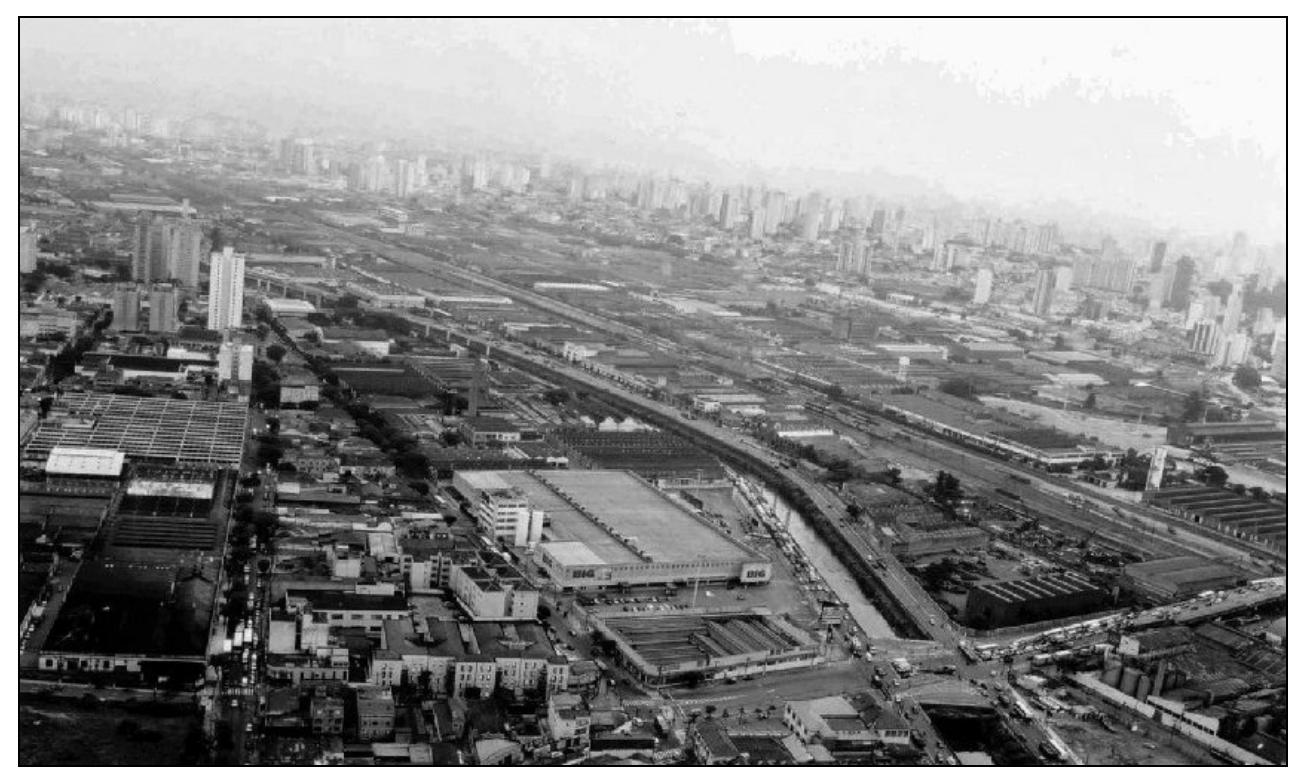

63. Vista do eixo industrial ao longo da estrada de ferro. Em primeiro plano, cruzamento entre o viaduto Pacheco Chaves, início da rua dos Patriotas e a avenida do Estado, Ipiranga. (SEMPLA) 
Propostas desse tipo têm sido aventadas para trechos do perímetro da Diagonal Sul desde a década de 1970. Naquele momento, os eixos ferroviários e as áreas subutilizadas em seu entorno (sítios industriais então em processo de desativação, pátios de manobras, áreas de depósito de mercadorias, etc.) foram abordados como elementos potencialmente reestruturadores dos sistemas de transporte em nível metropolitano e regional. Diante da desconcentração industrial que então se acentuava, esses sítios de grandes dimensões e em gradativa desocupação começaram a despertar a atenção como reserva de espaço propícia para o desenvolvimento de reordenações urbanas em grande escala. Na proposta dos 'corredores metropolitanos', essa reordenação espacial envolveria a implementação de transporte de massa de qualidade (recuperando e promovendo inovações tecnológicas no sistema ferroviário), políticas de assentamento populacional, novos direcionamentos para a atividade industrial e produção de espaços urbanos associados às novas tendências funcionais que tais corredores deveriam abrigar. As áreas envoltórias desses eixos estratégicos, portanto, desempenhariam a função de abrigar novas atividades (terciárias, industriais de menor porte, usos associados ao lazer) e promover a gradativa transformação da paisagem. O eixo urbano ao longo da ferrovia Santos-Jundiaí, área abarcada pela Diagonal Sul, era um dos corredores propostos. Em um cenário de buscas por respostas para a fruição do transporte e de diretrizes de urbanização numa cidade que crescia vertiginosamente, a proposta dos 'corredores' vislumbrava nessas áreas uma forma de promover reformas estruturais em âmbito metropolitano e regional. Assim, o estudo defendia a reordenação dos eixos de transporte e do tráfego como um instrumento indutor da reestruturação funcional da cidade: os corredores adotariam o "sistema de transporte como o elemento estrutural-chave ao redor do qual a região [seria] organizada espacialmente [...] e recupera[ria] o uso da ferrovia para o transporte urbano [de modo também] a enfatizar a estrutura histórica criada ao longo das ferrovias". ${ }^{160}$

Não obstante o caráter técnico do estudo - voltado aos sistemas de transporte, sistema viário, diretrizes de crescimento urbano, etc. -, e os próprios limites interpretativos daquele momento histórico, quando, no cenário brasileiro, talvez fosse ainda prematuro pensar em termos de valorização do patrimônio urbano industrial, a abordagem da pesquisa evidencia formas específicas de apropriação do espaço urbano que ainda hoje permanecem

\footnotetext{
${ }^{160}$ CAMPOS Filho, Cândido Malta. Um Desenho para São Paulo: o corredor metropolitano como estrutura urbana aberta para a grande São Paulo. Tese de Doutorado. São Paulo: FAUUSP, 1972, pp.16,20-22. O estudo propunha três grandes corredores: corredor Leste-Oeste, ao longo do rio Tietê; corredor Norte-Sul, ao longo do Rio Pinheiros; Corredor Sudeste-Noroeste, ao longo do rio Tamanduateí e um quarto corredor de menores dimensões, o corredor do Espigão Central.
} 
em muitos contextos. Apesar de não desenvolver o tema sobre as diretrizes arquitetônicas e urbanas para a reocupação dessas áreas, a pesquisa traz uma série de croquis de possíveis cenários para a ocupação desses corredores, que revelam a predileção pela inserção maciça do novo, pelas grandes obras alheias ao preexistente, postura recorrente na atualidade, sobretudo no tratamento de áreas industriais. Mesmo reconhecendo a aparente prematuridade da apreensão do patrimônio urbano nos anos 1970, tal perspectiva não se justifica completamente, pois a Carta de Veneza, bem como os questionamentos que a delinearam, já eram conhecidos naquela data.

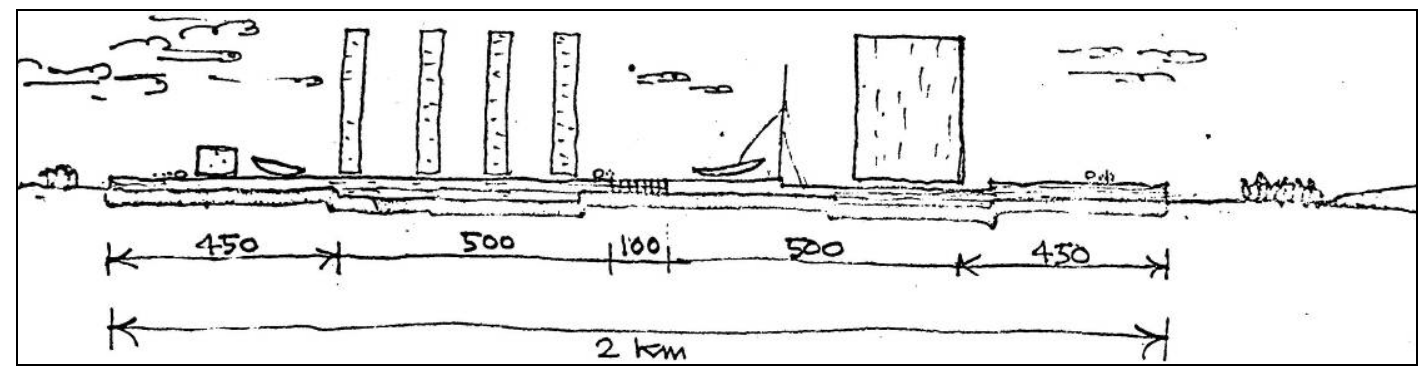

a.

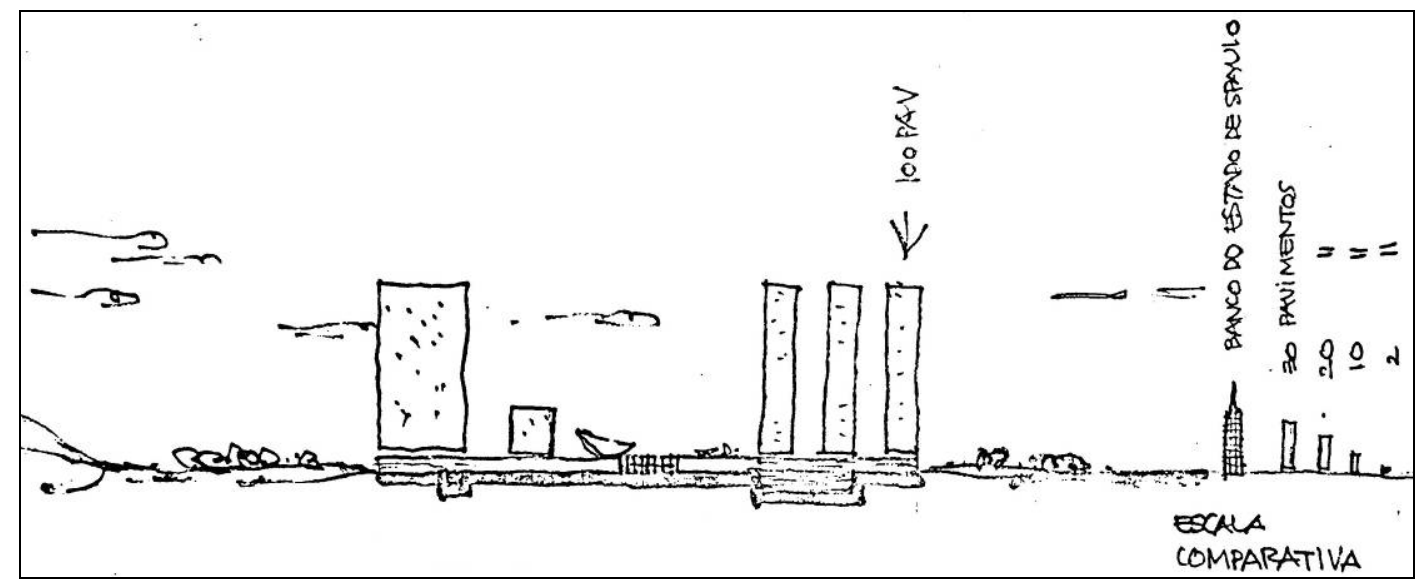

64. Possíveis cenários para a nova ocupação dos corredores metropolitanos. Desenhos da década de 1970 (CAMPOS, Filho., op. cit.)

Outro projeto pautado pela tábula rasa das estruturas existentes em áreas industriais foi a proposta, apresentada em 1999, pelo Grupo Brasilinvest e Fundação Maharishi, para implantação da São Paulo Tower, no bairro do Pari (área não encampada pela Diagonal Sul, mas uma seqüência natural das parcelas urbanas adjacentes). O projeto previa a construção de um megaedifício multifuncional de 108 andares, 510 metros de altura e aproximadamente 400 metros de base. O edifício concentraria em seu interior boa parte das funções de uma cidade: hotel, centro de convenções, shopping, escolas, 
residências e até mesmo hospitais. $\mathrm{O}$ empreendimento inseria-se de modo absolutamente abrupto e desrespeitoso em uma região consolidada da cidade e provocaria transformações radicais no tecido urbano, não somente devido às maciças demolições, mas também devido às escalas desproporcionais da intervenção e dos volumes gigantescos a serem criados. Sem contar, é claro, no perigoso precedente que a aceitação de um projeto desse porte e imposto dessa maneira poderia representar para a futura condução dos rumos da cidade. Dissemos 'imposto', pois o projeto chegou pronto dos Estados Unidos: um volume trapezoidal desprovido de qualquer mérito arquitetônico ou funcional e que agredia não somente a imagem da cidade e do tecido urbano dilacerado, mas também a própria cultura brasileira. Para sua implantação seriam demolidas todas as edificações existentes em um perímetro de 1.325 milhão de metros quadrados nos bairros do Brás e Pari, incluindo proximidades de bens tombados, como o antigo Moinho Matarazzo e a Tecelagem Mariangela. Toda a zona cerealista seria removida e, no caso de edifícios com algum valor, como a Igreja São Vito, chegaram a ser aventadas soluções bastante inusitadas como a sua demolição e reconstrução em outro lugar, já que se tratava de um edifício 'histórico'. ${ }^{161}$

Como não poderia deixar de ser, o projeto provocou muita polêmica. Alguns arquitetos e urbanistas chegaram a encarar a proposta como uma oportunidade para implementar soluções associadas à idéia do corredor metropolitano. O megaprojeto impulsionaria a realização de melhorias do sistema ferroviário e incentivaria a reocupação das áreas ao longo da ferrovia criando um eixo revitalizado desde São Paulo até a cidade de Santo André.

As características da arquitetura proposta e a total inadequação ao contexto, contudo, foram criticados veementemente. O partido arquitetônico chegou pronto, poderia ser implantado em São Paulo ou em qualquer cidade do mundo. Assim, não se buscou qualquer informação prévia, nenhuma relação com o preexistente ou mesmo com a cultural local, para conduzir sua criação. ${ }^{162}$

\footnotetext{
${ }^{161}$ Para dados gerais sobre o projeto e suas soluções complementares, consultar os artigos publicados na Revista Projeto Design, n.237 e n.238, 1999.

${ }^{162}$ Segundo os dados divulgados em revistas especializadas, a forma trapezoidal seria baseada em preceitos da milenar doutrina védica que expressa as crenças do hinduísmo. Além da imagem infame, o processo projetual pauta-se pela proposição de formas 'estilísticas' e, ainda mais, provenientes de uma cultura fora do contexto. Como afirma Paulos Bastos, "construir em forma védica é como construir um pagode tibetano, caso o dinheiro fosse do Dalai Lama.”. Na cobertura do edifício, inclusive, estava prevista uma grande escultura védica, um "captador de energia cósmica". Seria uma proposta hilária, se não fosse trágica. São Paulo Tower: na hora das adaptações, polêmica permanece. Projeto Design, n.238, dez. 1999, p.21.
} 


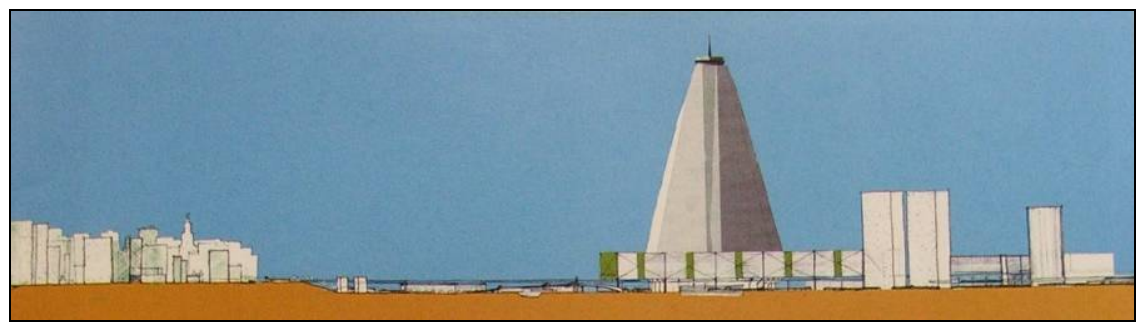

a.

65. São Paulo Tower, edifício de 108 andares que seria implantado no bairro do Pari.

Proposta de 1999.

(Projeto, n.237 e 238)

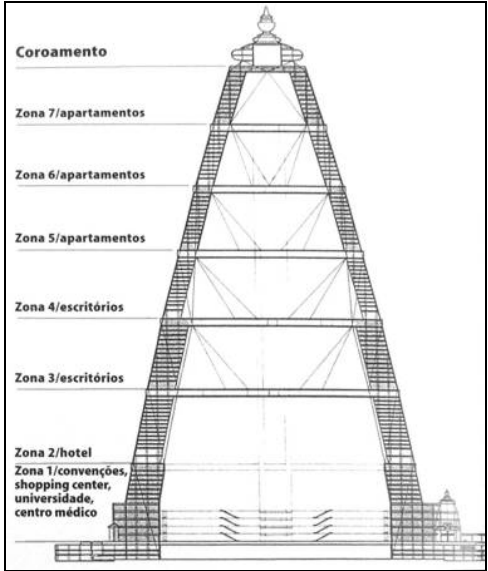

b.

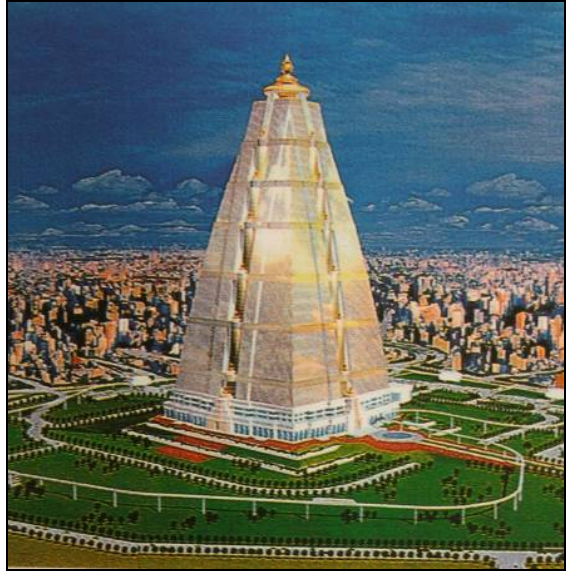

c.

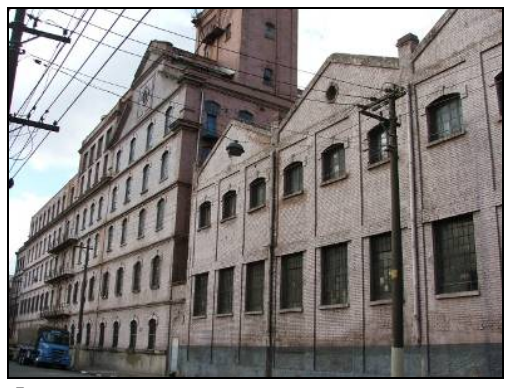

d.

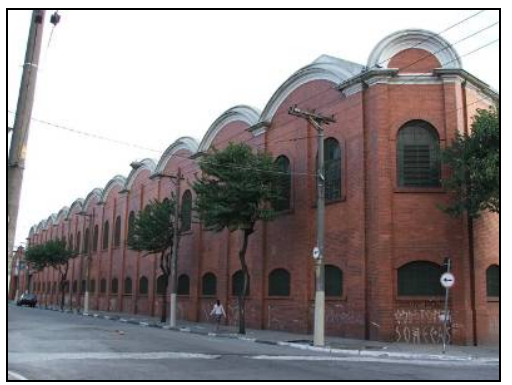

e.

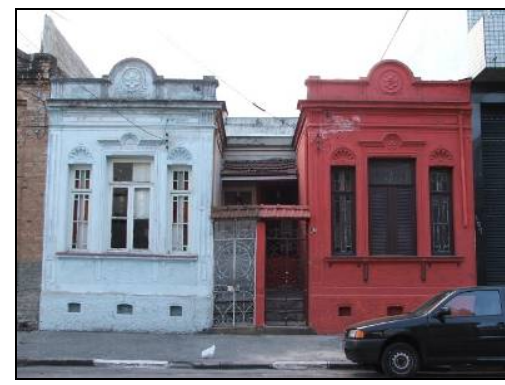

f.

65. Arredores da São Paulo Tower, aspectos da paisagem preexistente. Da esquerda para a direita: Moinho Matarazzo, Tecelagem Mariangela e residências tradicionais do bairro, 2006. (Fotos da autora)

A inserção de uma estrutura tão gigantesca faria todo o entorno (remanescente) insignificante, "elementos de nossa memória cultural como o Mercado Municipal, o Palácio das Indústrias, a Casa das Retortas e a Igreja de São Vito [se tornariam] um rodapé do edifício". Toda uma paisagem urbana de inestimável valor cultural seria destruída e condenada em favor da "apoteose da idéia de shopping", de um projeto concebido como "uma ilha da fantasia, que volta as costas para a cidade". ${ }^{163}$

\footnotetext{
${ }^{163}$ Paulo Bastos em entrevista à Projeto Design. Sim e não à São Paulo Tower. Projeto Design, n.237, nov. 1999 , p. 25. Muitos arquitetos criticaram veementemente a proposta e enfatizaram a necessidade de atentar para os bens culturais, arquitetônicos e urbanos, existentes na área. São Paulo Tower..., op. cit., p.22.
} 
A proposta, felizmente não levada a cabo, evidencia muitos dos pontos que temos procurado discutir. Os antigos sítios industriais, como a região escolhida para implantação da Torre, são encarados como meros lotes degradados prontos para receber novos usos, um terreno livre para experiências arquitetônicas e urbanísticas fantasiosas. E nesse caso, nem mesmo a qualidade do projeto poderia servir de argumento para a destruição do preexistente. O patrimônio urbano industrial seria condenado, não em nome da proposição de uma nova arquitetura, imagem de nossa época, uma tentativa projetual de promover o diálogo antigo-novo; e sim, em nome da inserção de um projeto importado, fruto de empreendimentos econômicos agressivos a serem implantados em qualquer cidade 'terra de ninguém'. Não só a arquitetura proposta (em termos formais, funcionais, técnicos, urbanos e simbólicos) não justificaria a destruição do preexistente, como o próprio modelo de desenvolvimento apresentado vai na contracorrente de grande parte dos atuais estudos no campo do urbanismo.

Em propostas bem mais recentes, permanece ainda a tendência predominante dos grandes projetos urbanos revitalizadores, pautados pela criação de novas estruturas e traçados, como a intervenção de revitalização de um trecho da Diagonal Sul apresentada na Conferência Urban Age ${ }^{164}$, no final de 2008. No projeto, concebido como um conjunto de possíveis soluções e idéias projetuais para a atuação em áreas degradadas, a parcela da Diagonal Sul então considerada foi abordada como um exemplo de intervenção urbana renovadora e sustentável. O perímetro escolhido - entre os viadutos Grande São Paulo e São Carlos, com a possibilidade de expandir-se até as proximidades da divisa com São Caetano do Sul - é descrito como um cenário de "descontinuidades territoriais", áreas abandonadas e vazios urbanos, que oferecem uma grande oportunidade para novos projetos contemporâneos "dinâmicos, flexíveis e estratégicos". De modo esquemático, nos limites de uma apresentação de idéias para um encontro científico, foram considerados vários itens envolvidos na intervenção: instrumentos jurídicos e administrativos para viabilização das obras, necessidade de promover parcerias público-privadas para a elaboração e execução dos projetos, exploração dos instrumentos urbanísticos associados às operações urbanas, cálculos aproximados das metragens a serem construídas, modernização do sistema ferroviário, descontaminação dos terrenos.

\footnotetext{
${ }^{164}$ Proposta apresentada pelos arquitetos Bernd Rieger, Carlos Leite, Eduardo Della Manna. Diagonal Sul Strategic Proposal. In: Urban Age South American Conference. São Paulo, 3-5 dec. 2008.
} 


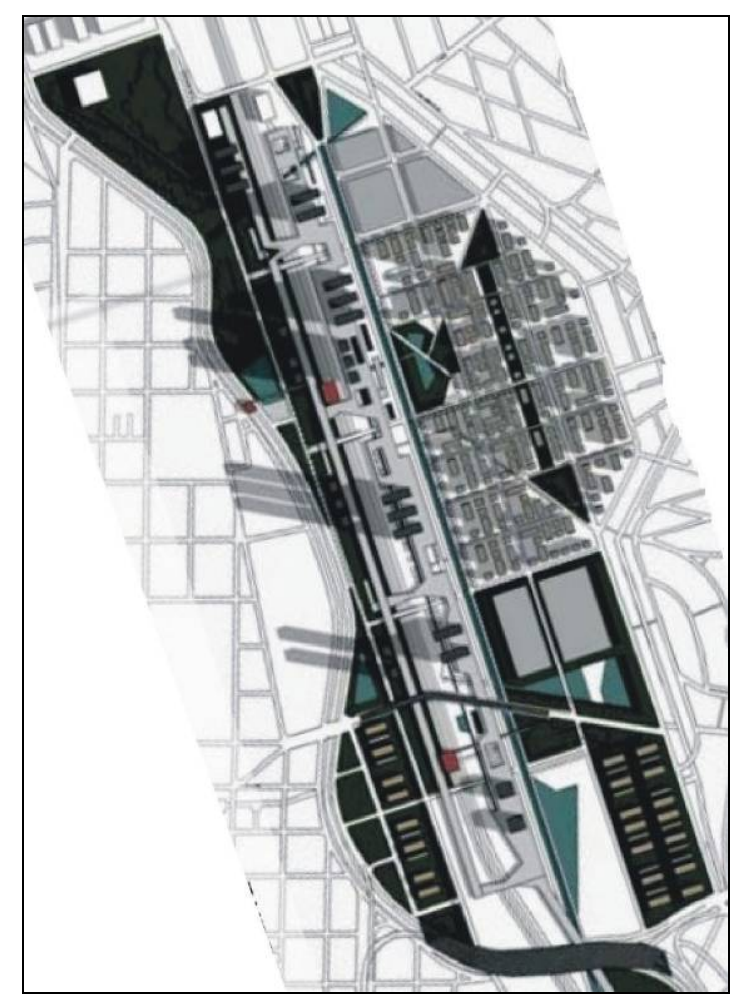

a.
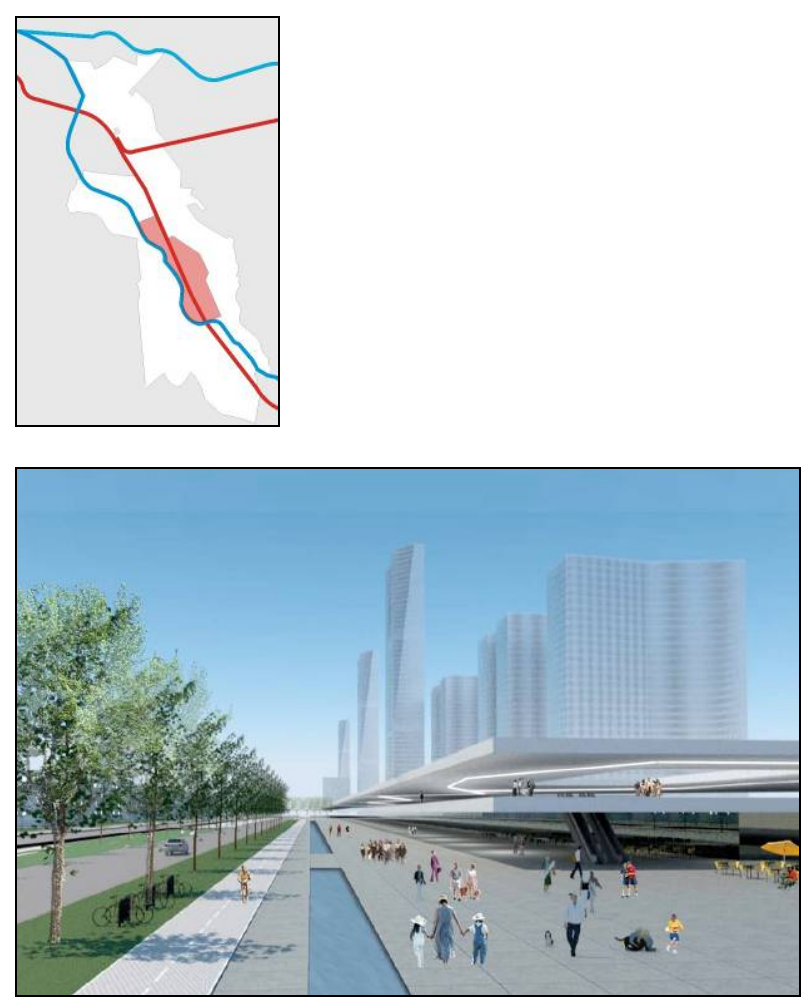

b.

66. Proposta de revitalização de um trecho da Diagonal Sul entre os viadutos Grande São Paulo e São Carlos.

a. Plano geral. Áreas verdes, reparcelamento de lotes e ocupação das margens ferroviárias;

b. Perspectiva eletrônica: marquise e torres de 200m de altura. (RIEGER, B. et al., op. cit.)

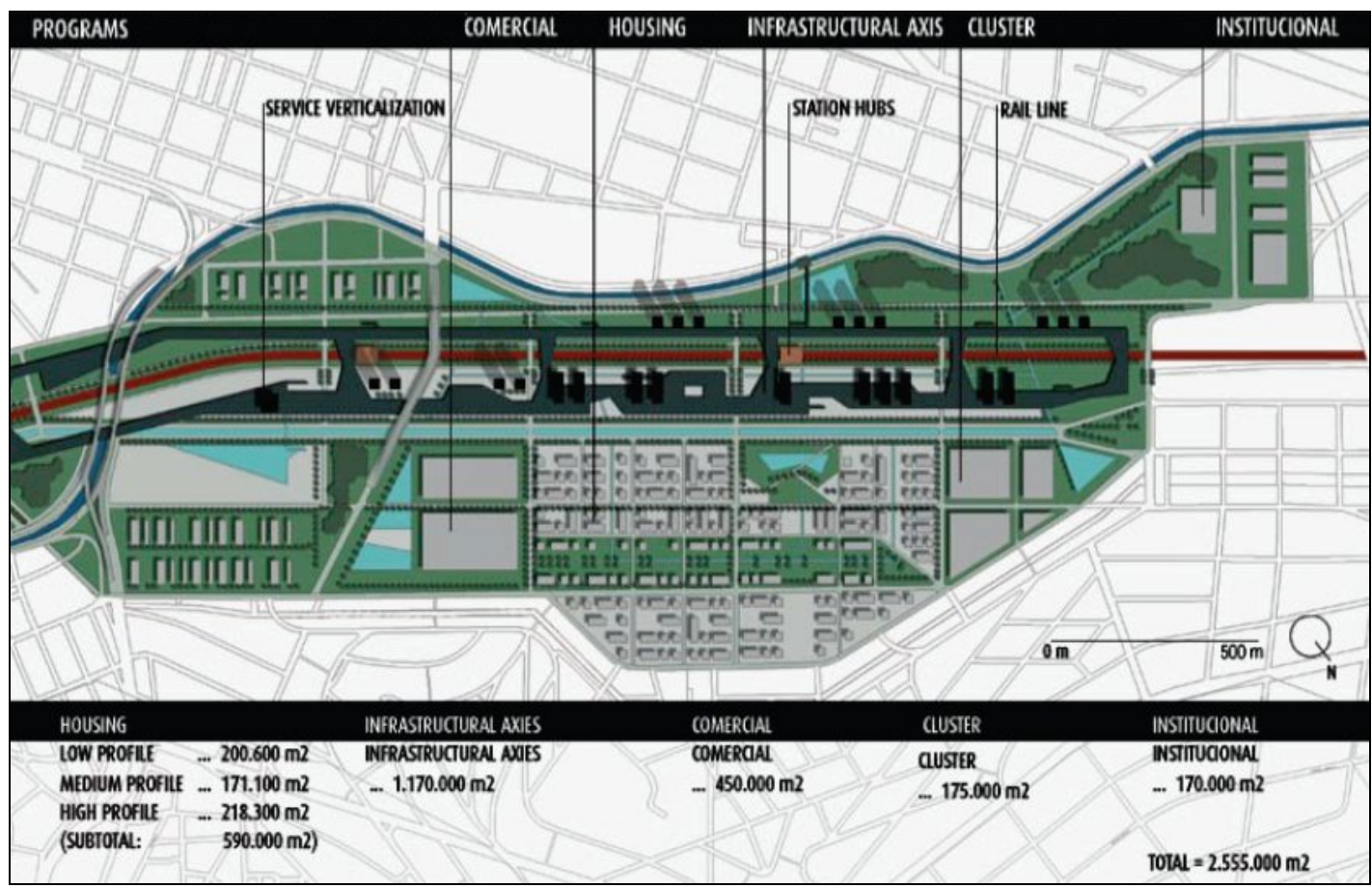

66c. Detalhamento da proposta. 
A intervenção propriamente dita é apresentada como a criação de uma "nova cidade": grande parte do traçado urbano foi redesenhado com o reparcelamento dos extensos lotes industriais da avenida Henry Ford e das ruas Cadiriri e Dianópolis. O tecido resultante dessa operação foi destinado à diversificação de usos, sendo grande parte da área destinada à construção de edifícios residenciais. No local da antiga Fábrica da Ford, demolida recentemente, foi proposta a inserção de edifícios de uso comercial. No espaço longitudinal entre a via férrea e a avenida Henry Ford, todos os galpões industriais seriam demolidos e a faixa 'livre' seria destinada à construção de torres de 200 metros de altura e, no nível do pedestre, haveria espaços públicos cobertos por uma imensa marquise. Foi proposta ainda uma espécie de espelho d'água com o intuito de "reintegrar a cidade e a água". Entre a avenida dos Estados e a ferrovia foi ainda proposta uma extensa área verde.

Na exposição dos objetivos do projeto, a nova arquitetura é chamada a enfrentar a reabilitação de espaços degradados: "o desafio da arquitetura contemporânea é trabalhar na cidade existente, em vez de substituí-la e negá-la”. No entanto, a intervenção caminha no sentido inverso, pauta-se pela remodelação e substituição e não pela apreensão, interpretação e integração com o preexistente. Assim, a paisagem predominantemente industrial, marcada pela horizontalidade, baixa densidade construtiva, grandes lotes, edifícios e parcelamentos característicos, foi apagada para a criação gratuita de uma nova imagem. A questão do patrimônio urbano e o estudo sobre os sítios industriais e seu possível interesse para preservação, não foi citada. Mesmo sem um levantamento detalhado do patrimônio urbano da área, ainda a ser elaborado, identificamos em uma rápida análise a demolição de significativos conjuntos industriais, datados do início do século, ao longo da avenida Presidente Wilson.

Outra proposta para a Diagonal Sul foi apresentada recentemente, em 2006, na Mostra Coletivo Arquitetura Paulista Contemporânea. O projeto demonstra sensibilidade para com a paisagem local e as características históricas da região e sugere a atenção aos sítios industriais existentes. A intervenção foi apresentada como uma oportunidade de promover uma nova ocupação que permita explorar a infra-estrutura subutilizada mas, ao mesmo tempo, preservar os diversos estratos de formação da cidade, configurando-se como uma contraposição projetual à transformação em curso, que segrega e apaga esses testemunhos. Assim, propõe preservar os traços da formação urbana de São Paulo, 
inclusive a leitura da geografia definida pelas várzeas dos rios Tamanduateí e Ipiranga, várzeas que concentraram, originalmente, a instalação de muitas indústrias.

A descrição do projeto é sucinta, limitada à apresentação em uma mostra de arquitetura $^{165}$. Compreende o eixo entre o viaduto Grande São Paulo e a rua da Mooca e propõe, em síntese, a instalação de um parque linear ao longo da ferrovia - solução já aventada pelos planos regionais - , a preservação de alguns sítios industriais, o parcelamento de grandes glebas e criação de novos arruamentos, construção de espaços públicos e de lazer, áreas para esportes, transposições da ferrovia, do rio e áreas destinadas à habitação. Foram ainda propostas três grandes torres e um grande espelho d'água linear acompanhando a via férrea, um elemento, na prática, dificilmente exeqüível. Alguns conjuntos industriais ao longo do eixo ferroviário foram preservados e, aparentemente, seriam encampados pelas atividades do parque linear. Apesar da sensibilidade para com o patrimônio industrial e da proposição de novas arquiteturas de modo mais cauteloso, propostas dessa natureza, baseadas em desenhos e volumes pouco precisos, podem ser perigosas. As extensas áreas que seriam reparceladas não foram, ainda, convenientemente estudadas, desconhecemos suas particularidades, seus edifícios, não possuímos dados históricos e documentais suficientes para selecionar, com cuidado, o quê e de maneira deverá ser preservado. Além do desenho de uma nova malha retilínea, apagando o tecido histórico original e característico da ocupação industrial, a intervenção não esclarece como seria a orientação de ocupação dessas novas glebas (volumes, densidades, etc.), algo que poderá alterar completamente a paisagem do bairro. Propor grandes transformações em áreas urbanas de interesse cultural sem um entendimento preciso das preexistências - de quais elementos deverão ser preservados e de que modo, conforme criteriosas análises histórico-críticas, pode ter um efeito perverso e reduzir a preservação a poucos edifícios isolados e descontextualizados.

Finalmente, em tempos recentes, tem-se aventado a possibilidade de contratar um projeto externo, de algum grande escritório internacional. Novamente sem a realização de qualquer estudo prévio. ${ }^{166}$

${ }^{165}$ Projeto apresentado pelo escritório Una Arquitetura. Projeto de Reurbanização Mooca / Ipiranga. NOBRE, Ana Luiza et al. Coletivo: 36 projetos de arquitetura paulista contemporânea. São Paulo: CosacNaify, 2006, pp.224-228.

${ }^{166}$ Discussões em andamento na Secretaria de Planejamento, segundo Sales. 


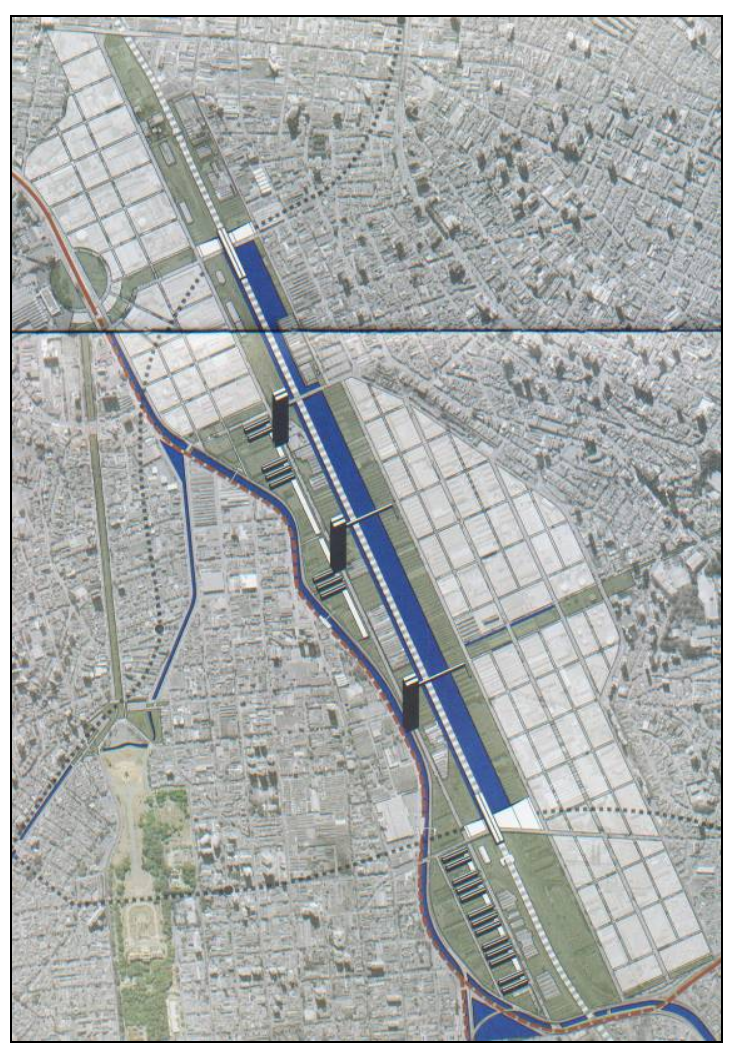

a.
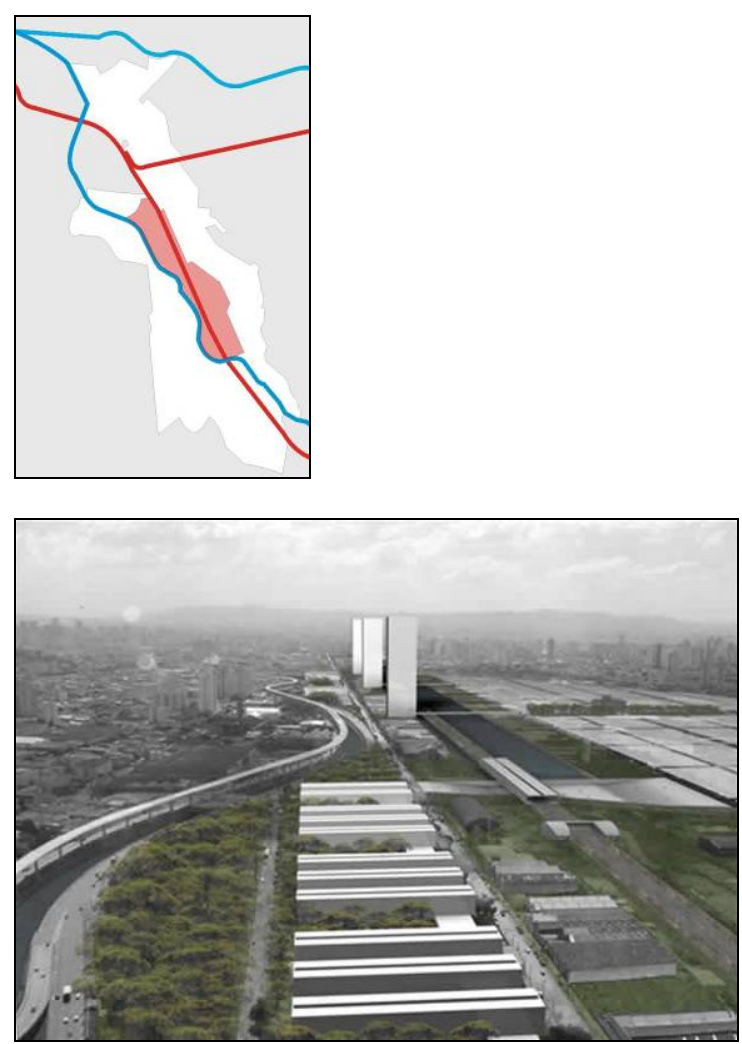

b.

67. Projeto de Reurbanização Mooca / Ipiranga, entre o viaduto Grande São Paulo e a rua da Mooca. a. Plano geral; b. Perspectiva eletrônica. (NOBRE, A. L. et al., op. cit.)

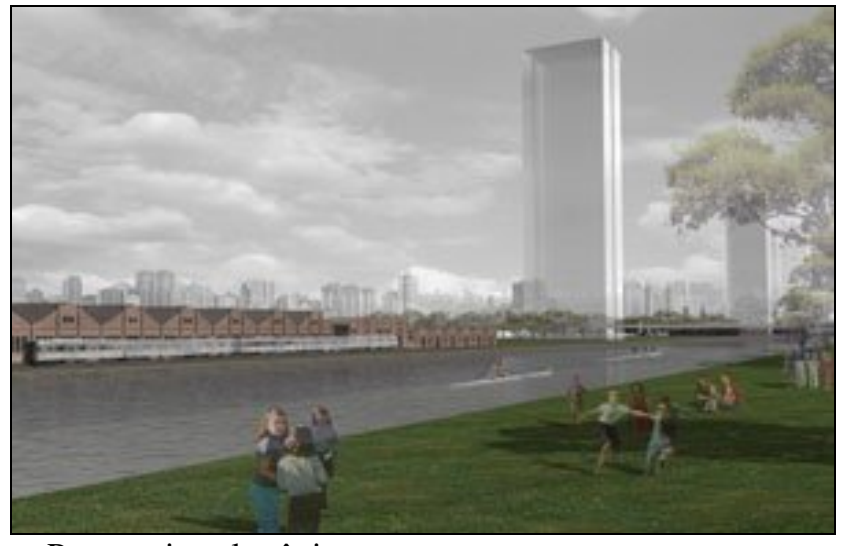

c. Perspectiva eletrônica.

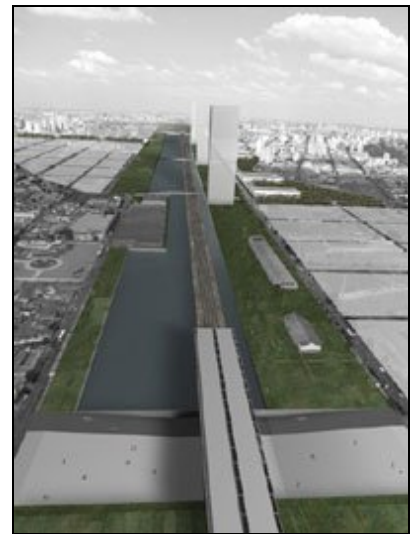

d. Perspectiva eletrônica.

Essas propostas pautadas por modelos de desenvolvimento que ignoram as preexistências e seus possíveis valores culturais, idéias tão comuns em nossa predominante cultura de projeto, remetem-nos aos dizeres de Miarelli Mariani, segundo o qual as destruições mais profundas do patrimônio urbano não foram provocadas por guerras ou desastres naturais, mas sim, pelos chamados fenômenos de desenvolvimento, aos quais geralmente assistimos sem grandes contestações: 
É possível constatar que as lacerações mais profundas às estruturas territoriais e urbanas não foram provocadas por guerras ou abalos sísmicos, que sem dúvida produziram danos enormes, mas sim por fenômenos de 'desenvolvimento' dos quais freqüentemente nos vangloriamos. Ou seja, por intervenções ligadas à lógicas setoriais e baseadas em parâmetros próprios da 'contemporaneidade' mais efêmera, que destruíram valores e equilíbrios seculares. ${ }^{167}$

Em muitos casos, como na cidade de São Paulo, os sítios industriais representam um patrimônio urbano em escala única, uma estratificação histórica de grandes dimensões e em grande parte ainda preservada, apesar das descaracterizações. E é a preservação desta característica particular, a escala urbana, justamente um dos itens mais difíceis de se tutelar e restaurar. Nesse contexto, o reconhecimento dos valores associados aos sítios industriais e a apreensão dessas especificidades de escala e composição, são temas que precisam ganhar espaço para que possamos vislumbrar caminhos criteriosos para as intervenções de preservação ou requalificação nesse patrimônio; caminhos pautados pela larga experiência teórica e prática que circunscreveu a atual teoria da preservação e de acordo, conseqüentemente, com os preceitos ditados pelos documentos internacionais. Esse percurso inevitavelmente deverá passar pelo entendimento claro do próprio conceito de patrimônio urbano e das responsabilidades envolvidas no tratamento dessas áreas especiais. De posse desse entendimento, poderíamos esperar novos cenários para o tratamento de áreas urbanas de interesse cultural, como acreditava Bonelli: "Quando vermos os arquitetos recusarem as tarefas profissionais que impliquem destruições dos ambientes antigos, a ruína dos monumentos e alterações da paisagem, uma nova época se iniciará. Este dia certamente ainda está distante, mas estamos certos de que chegará". ${ }^{168}$ Passaram-se cinqüenta anos, aguardemos um pouco mais.

\footnotetext{
${ }^{167}$ MIARELLI MARIANI, G. Sul recupero dei centri storici: uno schematico sguardo d'insieme. In: Centri storici..., op. cit., pp. 62-63. Trad. nossa. "È possibile constatare che le lacerazione più profonde alle strutture territoriale ed urbane non sono state provocate da guerre o sismi, che pure hanno prodotto danni ingentissimi, ma da fenomeni di 'sviluppo' di cui spesso persino ci vantiamo. Cioè da interventi, legati a logiche settoriali e basati su parametri propri della 'contemporaneità' più effimera, che hanno distrutto valori ed equilibri secolari."

168 BONELLI, Renato. Il rapporto antico-nuovo nei suoi aspetti generali. In: Attualità urbanistica del monumento e dell'ambiente antico. Milano: Görlich, Centro Studi della Triennale di Milano, 1957, p.57. Trad. nossa. "Quando vedremo gli architetti rifiutare gli incarichi professionale che comportano le distruzione degli ambienti antichi, la rovina dei monumenti e l'alterazione del paesaggio, una nuova epoca sarà cominciata. Quel giorno è certamente ancora lontano, ma noi siamo certi che verrà."
} 


\section{CONSIDERAÇÕES FINAIS}

\section{UMA TENTATIVA DE SÍNTESE: AQUISIÇÃo DE CONCEITOS E DIFUSÃO DE UMA PRÁTICA}

O reconhecimento dos valores históricos e estéticos de certos conjuntos arquitetônicos - e de ambientes urbanos inteiros - , e a sua identificação como artefatos patrimoniais autônomos e possuidores de qualidades compositivas físicas e extra-físicas próprias são temas e aquisições conceituais que remontam ao início do século XX e que ao longo de décadas de debates vêm recebendo a atenção de diversos estudiosos. Nesse percurso, os aprofundamentos teóricos nos permitiram compreender a estrutura urbana e territorial como um conjunto orgânico formado tanto pelos monumentos ditos 'excepcionais', como também pela arquitetura comum, pelos conjuntos construídos dotados de expressividades compositivas e figurativas formadas pela integração mútua entre vários componentes. Como bem observou Miarelli Mariani, avançamos da concepção de ambiente urbano como conjunto de formas para aquela de ambiente como conjunto de elementos e de condições, realidade na qual "cada um desses elementos é aquilo que é somente em virtude de sua relação e na sua relação com todos os outros componentes da estrutura". 169

Essa gradativa extensão do conceito de monumento a inteiros espaços construídos - artefatos complexos e em constante mutação -, levantou e ainda levanta uma série de problemas técnicos, críticos e interpretativos. Além da necessidade de cunhar novos instrumentos urbanísticos e métodos de planejamento urbano e territorial; a própria dimensão atribuída à produção arquitetônica precisou ser reinterpretada, uma vez que, considerando áreas urbanas de interesse cultural, onde quer que se construa se está atuando, de fato, sobre uma preexistência 'monumental'. E o projeto passa a assumir, portanto, uma nova conotação; passa inevitavelmente a requerer a adoção de métodos e instrumentos pertinentes ao restauro. ${ }^{170}$

$\mathrm{Na}$ esteira das aquisições conceituais relativas às especificidades do patrimônio urbano, a gradativa extensão do reconhecimento de atributos culturais a uma vasta gama de

\footnotetext{
${ }^{169}$ MIARELLI MARIANI, G. Riflessioni su un vecchio tema: il nuovo nella città storica. Restauro, n.164, 2003, p.33.

${ }^{170}$ CARBONARA, G. Avvicinamento al Restauro. Napoli: Liguori, 1997, pp.423-424.
} 
artefatos abriu caminho para a valorização de edifícios e sítios provenientes do processo de industrialização. Tais artefatos passam então a ser reconhecidos e estudados tanto por seus inequívocos valores documentais, como também pelo papel crucial que desempenharam na formação de extensas paisagens urbanas e na configuração de cotidianidades geradas e alimentadas pelas atividades produtivas. Essa noção de paisagem fez ainda emergir a identificação de valores estéticos não necessariamente reconhecíveis em obras arquitetônicas industriais isoladas, mas habilmente observados na composição dos conjuntos arquitetônicos produtivos, nos quais as modestas construções, chaminés, estruturas e espaços adjacentes, elementos compositivos 'não-excepcionais', desenhavam uma figuratividade própria, historicizada e irreproduzível ${ }^{171}$. Os sítios industriais portanto, assumem o caráter de sítio urbano representativo, ou seja, de patrimônio urbano, conforme as enunciações da Carta de Veneza e, como tal, igualmente solicitam o emprego de critérios de análise, tutela e intervenção pautados pela teoria do restauro.

Logo, a intervenção em sítios urbanos de interesse cultural, e em sítios industriais nesse contexto, abarca uma série de questões que precisam ser devidamente observadas. Primeiramente, o patrimônio urbano, assim identificado, é antes de tudo um bem cultural, um monumento que deve ser apreendido, interpretado e tratado conforme as premissas do juízo histórico-crítico ${ }^{172}$. A clareza de sua caracterização como bem cultural pressupõe a compreensão das responsabilidades envolvidas em quaisquer operações de conservação ou intervenção, ou seja, são testemunhos únicos, portadores de valores documentais, estéticos, memoriais e simbólicos que interessam e concernem à coletividade; são artefatos cuja transformação, portanto, só pode ocorrer com base em amplo conhecimento, rigorosos critérios e coerente fundamentação teórico-crítica. De posse desta proposição elementar, devemos atentar para as especificidades de escala, composição e dinâmica evolutiva dos sítios urbanos que inevitavelmente requerem, como temos tratado, a aproximação interdisciplinar, teórica e prática, entre projeto arquitetônico, restauro e urbanismo. Dessa forma, em diferentes escalas de projeto, o processo de transformação e 'inovação' deve ser

\footnotetext{
${ }^{171}$ COSSONS, Neil. The BP Book of Industrial Archaeology. London: David \& Charles, 1978, pp.22, 424425.

${ }^{172}$ Como observara Brandi, a preservação e o restauro dos chamados 'monumentos coletivos' deve seguir os mesmos princípios adotados para os monumentos 'individuais'. "Os critérios e bases [para uma intervenção], do ponto de vista da obra de arte, e portanto do centro histórico como obra de arte, serão os mesmos, baseados sobre a composição da instância histórica e daquela estética." Trad. nossa. "I criteri di basi, dal punto di vista dell'opera d'arte, e quindi del centro storico come opera d'arte, saranno gli stessi, imperniati sulla composizione della istanza storica e di quella estetica." BRANDI, C. Prima di tutto un problema di impostazione teorica. Italia Nostra, n.128, 1975, p.7. Cf.: BRANDI, C. Teoria da restauração. Trad. B. M. Kühl. Cotia, São Paulo: Ateliê, 2004, p.133 et seq.
} 
objeto de atenta avaliação e acurada definição projetual; deve ser tratado, portanto, como um problema de restauro que convoca a participação e contribuição de outras disciplinas. ${ }^{173}$ Dadas as particulares exigências de preservação dos sítios urbanos e dos sítios industriais, sobretudo devido à escala e às especificidades compositivas, tais ações devem ainda integrar o escopo de trabalho de planos urbanos de maior abrangência - não como um problema secundário e sim como uma das premissas da intervenção ou como um dos temas a serem observados frente às previsões de desenvolvimento. De modo análogo, assim como as diretrizes urbanísticas devem respeitar as especificidades do patrimônio urbano, também os projetos arquitetônicos não podem se esquivar dessa premissa. Tais temas reivindicam um esforço interpretativo e operacional interdisciplinar; ou seja, requerem a busca por uma forma de pensar e de projetar que atente adequadamente para os diversos vetores envolvidos de modo a não permitir a perda, ao longo do processo, do objetivo fundamental de qualquer intervenção em um bem cultural: a sua preservação e a transmissão de seus essenciais valores para o futuro. Em síntese, devemos ter clareza sobre o que se preserva, por que se preserva e de que maneira fazê-lo. Conceitos aparentemente básicos, mas muitas vezes desconsiderados na prática corrente de intervenção em bens culturais; principalmente em áreas urbanas e de modo ainda mais evidente em sítios industriais.

Uma parcela significativa das intervenções em edifícios e sítios industriais de interesse cultural tem acontecido absolutamente à margem das discussões e prerrogativas aqui apresentadas que, como vimos, contam com longa ascendência investigativa. Desprovidas de fundamentos teóricos ou referindo-se aos mesmos de modo equivocado, as mais variadas espécies de intervenções - as famosas operações prefixadas pelo "re", "regurgitações lexicais" segundo Miarelli Mariani ${ }^{174}$ - , têm sido adotadas de modo indiscriminado no tratamento deste patrimônio e provocado penosas destruições. Temas amplamente debatidos como a integração interdisciplinar, a necessidade de abordar o tema no âmbito do planejamento urbano, a questão do encontro antigo-novo e até mesmo o correto entendimento dos moventes culturais da preservação e do restauro, não têm sido, portanto, devidamente depurados e considerados na atuação prática em áreas urbanas de interesse cultural. Atitudes que evidenciam perigosas falhas interpretativas ou mesmo o desconhecimento de princípios básicos da preservação há muito tempo consolidados.

\footnotetext{
${ }^{173}$ CARBONARA, G. La reintegrazione dell'immagine. Roma: Bulzoni, 1975, pp.161-163.

${ }^{174}$ MIARELLI MARIANI, G. Riflessioni..., op. cit., p.33.
} 
Esses princípios conceituais não surgiram do nada, foram adquiridos, construídos - como vimos ao longo desta pesquisa -, em décadas de discussões teóricas e experiências práticas. Processo que, como ressalta Kühl, não foi linear, nem tampouco isento de contradições e polêmicas. E foi justamente a pluralidade de proposições e de experimentos que permitiu o aprofundamento contínuo do debate, da reflexão crítica, e o paulatino amadurecimento de uma série de conceitos e preceitos de grande consistência que constituem uma verdadeira conquista cultural ${ }^{175}$. A apreensão dos valores do ambiente construído e a própria 'invenção' do patrimônio urbano, usando as palavras de Choay ${ }^{176}$, são temas desse percurso investigativo, são aquisições conceituais oriundas desse debate e alimentadas pelas buscas cognitivas sobre o próprio organismo urbano; estudos que contribuíram para o delineamento da disciplina do urbanismo. A abrangência e a pertinência dos preceitos adquiridos nesse percurso foram devidamente contempladas na elaboração dos documentos internacionais analisados, notadamente a Carta de Veneza, a Declaração de Amsterdã e a Carta de Washington, textos que nos fornecem bases conceituais e operacionais sólidas e ainda bastante atuais; diretrizes gerais com as quais as novas questões, notadamente aquelas advindas da expansão do conceito de patrimônio cultural, deveriam dialogar.

No entanto, mesmo os princípios fundamentais do restauro moderno - a questão da 'retrabalhabilidade', da distingüibilidade e da mínima intervenção; ou ainda as orientações acerca da conservação integrada e a necessidade de buscar métodos de estudo, proposta e projeto a partir de esforços interdisciplinares - , questões tratadas em décadas de debates, não têm sido devidamente contempladas na elaboração de projetos de intervenção no patrimônio urbano. $\mathrm{O}$ fato nos remete a intrigantes indagações: por que tais prerrogativas não tem sido devidamente consideradas na prática? Qual a real aplicabilidade dos preceitos ditados pelos documentos internacionais? Uma possível resposta logo vem à tona: a despeito de qualquer conhecimento teórico e técnico, a pressão de prioridades econômicas ou políticas freqüentemente tem tomado a dianteira na condução de uma significativa parcela desses projetos. Certamente as questões econômicas envolvidas em intervenções no patrimônio urbano, como as chamadas 'reabilitações' de áreas desocupadas e degradadas, situação na qual se encontra grande parte dos sítios industriais,

\footnotetext{
175 KÜHL, Beatriz Mugayar. Preservação da arquitetura industrial em São Paulo: questões teóricas [Relatório Científico]. São Paulo: FAUUSP, Fapesp, 2005, p.236.

${ }^{176}$ CHOAY, F. A alegoria do patrimônio. São Paulo: Estação Liberdade, Unesp: 2001, pp.175-203.
} 
possuem grande influência e não podem ser negligenciadas. Mas o retorno econômico não poderia ser encarado como uma conseqüência natural de uma intervenção bem sucedida? De posse dos conhecimentos adquiridos, e contando com a participação interdisciplinar, não deveria ser possível desenvolver projetos criteriosos de restauro urbano que garantissem a valorização e preservação de estruturas históricas e vislumbrassem melhorias para as áreas envolvidas gerando, conseqüentemente, retornos financeiros? Algo distinto, portanto, de querer obter os maiores lucros possíveis, realidade infelizmente observada em muitas das atuais operações. Seguindo esse raciocínio, as questões econômicas (e também políticas, dentro de certos limites), não deveriam assumir o equivocado posto de objetivo do restauro e sim serem abordadas como mais um dado de projeto a ser considerado na condução do restauro que permaneceria pautado pelas prioridades da esfera cultural. A priorização econômica que tanto nos aflige configura-se, portanto, como um dos graves sintomas de um problema maior.

$\mathrm{Na}$ verdade, a questão que intentamos ressaltar é que os conceitos adquiridos no campo da preservação e do restauro não estão suficientemente integrados à nossa 'cultura de projeto'. Observa-se em grande parte das intervenções em bens culturais, sobretudo sobre o patrimônio urbano, a predominância de discursos projetuais frágeis e a debilidade na busca de soluções que efetivamente dialoguem com as aquisições conceituais aqui expostas. Uma grande distância, portanto, entre a teoria e a prática. Essa fragilidade se manifesta tanto no reconhecimento de valores e no correto entendimento do que seja um bem cultural, quanto na própria compreensão do que é o restauro e de quais são suas premissas, ou seja, as velhas questões sobre o quê, por que e como preservar, tão trabalhadas pela teoria do restauro, e que parecem ainda estar distantes do discurso prático.

Observa-se atualmente um distanciamento perigoso entre a preservação do patrimônio e a cultura de projeto e de planejamento urbano, ou seja, a preservação e o restauro têm se afastado cada vez mais da produção arquitetônica e urbanística. Na contramão das diretrizes de Amsterdã, em vez de convergir, os campos disciplinares se têm isolado em nichos profissionais idealizados que atuam sobre as preexistências patrimoniais cada qual segundo suas próprias (e desconexas) orientações. Frisamos 'idealizados' pois este isolamento é absolutamente inconcebível frente à discussão teórica que circunscreveu a 'invenção' do patrimônio urbano e as diretrizes de preservação do mesmo, segundo as quais, inevitavelmente, a colaboração interdisciplinar faz-se necessária. 
Interdisciplinaridade que não significa apenas a garantia da fruição do trinômio arquitetura-restauro-urbanismo, mas também a absorção das imprescindíveis contribuições que alimentam esses mesmos campos disciplinares: a história, a estética, a sociologia, etc.

Poderíamos indagar-nos se essa dificuldade de pensar e projetar de modo interdisciplinar não derivaria, em certos contextos, de um entendimento equivocado da produção arquitetônica e urbana como objetos herméticos e isolados (e por vezes até mesmo como meros instrumentos para a promoção individual do arquiteto, como destacara Bonelli na década de 1950) ${ }^{177}$. Essa noção equivocada poderia explicar o desinteresse pelas preexistências históricas e a esquiva em aproximar-se da teoria do restauro na busca por soluções projetuais complexas e respeitosas, apoiando-se na crença de que a grandiosidade de um projeto excepcional resolveria adequadamente a questão de modo mais imediato e com maior visibilidade. Essa indagação remete-nos à necessidade de aprofundar o debate sobre as prioridades e os caminhos geralmente trilhados ao longo da formação profissional e as possíveis alternativas para abrir os horizontes e permitir uma maior pluralidade nas formas de pensar a arquitetura. Nesse sentido, a reinterpretação de certas prerrogativas projetuais alimentadas sobretudo pelo movimento moderno, poderia permitir a aproximação entre as disciplinas a partir de um entendimento mais completo do fazer arquitetônico e de uma compreensão mais atenta dos diversos elementos que compõem o espaço construído; ou ainda, procurar olhar para a cidade e para o objeto arquitetônico como um elemento de um sistema e não como o objeto em si mesmo.

O distanciamento entre o discurso, a prática e os verdadeiros moventes da preservação - seja por desconhecimento, comodismo, negligência ou inépcia - abre caminho para a priorização de outros objetivos na elaboração de projetos de intervenção em áreas urbanas de interesse cultural. $\mathrm{Na}$ balança dos interesses econômicos, políticos e especulativos, proliferam as intervenções de cunho midiático, exemplificadas pelo desejo da municipalidade romana de 'internacionalizar' a cidade a partir da promoção de projetos arquitetônicos estratégicos elaborados por arquitetos de renome, ocasião em que as 'áreas desocupadas', principalmente industriais, configuram-se como uma importante reserva de terreno livre. Apesar do otimismo de estudiosos como De Fusco que classifica certas iniciativas projetuais grandiosas como uma positiva 'especulação arquitetônica', sinal de uma nova tendência construtiva impulsionada pelas exigências práticas de se construir

\footnotetext{
177 BONELLI, Renato. Il rapporto antico-nuovo nei suoi aspetti storici generali. In: Attualità urbanistica del
} monumento e dell'ambiente antico. Milano: Görlich, Centro Studi della Triennale di Milano, 1957, p.57. 
sobre o construído ${ }^{178}$, não podemos nos esquecer do rigor necessário ao intervir sobre o 'construído' de interesse patrimonial. Em outras palavras, a nova 'tendência' pode manifestar-se, mas quando atuar sobre preexistências de interesse cultural deverá pautar-se pelo rigor de um projeto de restauro, pelas premissas histórico-críticas. Lembrando ainda os dizeres de Racheli, a discussão sobre a qualidade projetual não faz mais sentido quando a nova arquitetura é construída sobre os escombros de um passado que não se soube identificar, compreender e valorizar ${ }^{179}$.

Como observa Kühl, restauros bem sucedidos geralmente nos passam despercebidos. Não por serem miméticos ou 'imitarem' as preexistências, mas por se inserirem de modo harmônico e respeitoso junto às estruturas que requerem a preservação ${ }^{180}$. Isso também não significa que o projeto deva ser insípido ou invisível. Como vimos, devemos evitar certas confusões na abordagem da questão sobre a qualidade projetual e sobre a inserção do novo em ambientes históricos. Entre aqueles que defendem a inconciliabilidade entre o novo e o antigo e aqueles que, ao contrário, julgam necessário o diálogo com a arquitetura de nossa época, despontam posições radicais de ambos os lados. Devemos ser cautelosos. Nem o novo é completamente nocivo, nem é, por outro lado, a solução milagrosa para qualquer intervenção, sobretudo no patrimônio urbano, podendo lançar-nos aos citados projetos 'espetáculo'. O problema é que, mais uma vez, frequientemente a questão afasta-se do campo do restauro e repousa na suposta autonomia da arquitetura do novo, a velha separação já citada por Ranellucci entre os arquitetos 'criadores' e os 'restauradores', 181 .

Quando diversos autores sugerem a 'qualidade projetual' ou a 'criatividade arquitetônica' como resposta à polêmica sobre o encontro entre o antigo e o novo, não pretenderam defender a inserção sem critérios de quaisquer estruturas espetaculares ou a tábula rasa sobre o preexistente em nome de uma reconstrução de boa qualidade. Quando se trata de áreas de interesse cultural, de patrimônio urbano, como são os sítios industriais ora tratados, a qualidade da intervenção não pode ser entendida como a qualidade de um projeto considerado individualmente, ou seja, a intenção projetual, estética ou funcional

\footnotetext{
${ }^{178}$ DE FUSCO, Renato. Dov'era ma non com'era: il patrimonio architettonico e l'occupazione. Firenze: Alinea, 1999, pp.44-45.

179 RACHELI, Alberto. Il quartiere Ostiense-Marconi nel nuovo Piano Regolatore. Roma Moderna e Contemporanea, anno XII, n.1-2, 2004, p. 257.

${ }^{180}$ KÜHL, B. M. Preservação..., op. cit., pp. 229-230.

${ }^{181}$ RANELLUCCI, S. Restauro Urbano: teoria e prassi. Torino: UTET, 2003, p. 267.
} 
das quatro paredes que definem uma nova arquitetura ou dos elementos que delimitam um novo espaço urbano. $\mathrm{Na}$ intervenção sobre o patrimônio urbano, assim como em monumentos considerados individualmente, a criatividade e a qualidade projetual remetem indubitavelmente à abordagem histórico-crítica.

Equívocos semelhantes perambulam em torno das preexistências industriais da Diagonal Sul, em São Paulo. Em diferentes momentos nos últimos anos, notadamente após a década de 1970 quando se inicia o processo de desocupação industrial, surgiram propostas de diferentes cenários para uma nova ocupação dessas áreas industriais. Propostas que apresentam em comum a inobservância dos valores históricos, estéticos e memoriais dessa paisagem. O patrimônio urbano da Diagonal Sul, área que reserva especificidades materiais e imateriais ainda pouco estudadas, além das características de traçado urbano que condicionaram os modos de ocupação da região, da presença da indústria na configuração das urbanidades locais e de uma paisagem histórica única, apresenta ainda outra importante particularidade que lança luzes sobre os diversos percursos traçados pela história da arquitetura brasileira: ao lado de diversas vilas operárias e edifícios produtivos anônimos, exemplares da chamada 'arquitetura menor' que compõe a 'literatura arquitetônica' da região, desfilam ainda representativos exemplares de 'antigos grandes nomes' da arquitetura brasileira: residências de Warchavichik, edifícios industriais e galpões de Ramos de Azevedo, Samuel das Neves e Victor Dubugras, e os projetos modernos de Severo e Villares, Rino Levi e talvez outros mais. A falta de um levantamento preciso dessas preexistências por si só já seria um bom motivo para evitarmos quaisquer propostas apressadas de intervenção, ainda mais de projetos 'grandiosos' ou novas versões da velha tábula rasa.

$\mathrm{Na}$ maioria das propostas de reabilitação voltadas às áreas da Diagonal Sul, independentemente da qualidade propositiva em termos de flexibilização do tráfego, adensamento habitacional, diversificação de usos e tantos outros temas que sempre vêm à tona diante das chamadas áreas degradadas, praticamente inexiste a preocupação real com a preservação do patrimônio urbano-industrial existente, ou seja, são propostas que partem da 'arquitetura' isoladamente, do 'urbanismo' isoladamente, e não buscam qualquer diálogo com a preservação e o restauro. Ou as preexistências industriais e o próprio conjunto urbano não são devidamente entendidos como artefatos de interesse cultural, ou a cultura de projeto predominante não nos permite um cenário de soluções integradas e não 
busca visualizar todos os importantes aspectos envolvidos em uma área de visíveis complexidades. Parece-nos faltar, portanto, uma compreensão do projeto, do fazer arquitetura, como um processo dinâmico e multifacetado que contemple as especificidades do fazer urbanismo e do fazer restauro em um mesmo pensamento, como um projeto articulado, o velho trinômio que desde a década de 1950 se busca consolidar.

Devemos ter em mente que a questão da preservação urbana - e da tutela dos sítios industriais da Diagonal Sul nesse contexto -, não diz respeito às especialidades profissionais isoladas: arquitetos preocupados com a valorização das preexistências; 'outros' arquitetos desejosos de uma fatia de um mercado imobiliário em ascensão; urbanistas preocupados com as possibilidades de desenvolvimento e profissionais diversos envolvidos com os recursos e lucros advindos de quaisquer operações imobiliárias. A questão da preservação e do restauro urbano diz respeito à própria produção da cidade contemporânea e deve abarcar, portanto, o entendimento de que a atuação sobre a cidade de hoje se dá muito mais pela inserção em tecidos construídos e consolidados do que pela produção de objetos excepcionais, ou a substituição indiscriminada do antigo pelo novo.

Na Diagonal Sul, uma intervenção que vislumbre adequadamente a preservação do patrimônio industrial, contudo, só seria possível após um aprofundado estudo da área que contemplasse diversas frentes de análises: o estudo do processo histórico de formação e transformação urbana, dos aspectos formativos e compositivos do tecido urbano, das massas construídas e dos espaços adjacentes, inventários do patrimônio existente, bem como análises multidisciplinares diversas. Dessa forma, desde o 'corredor metropolitano' da década de 1970, passando pela espantosa São Paulo Tower na década de 1990, pelas recentes propostas pontuais apresentadas em concursos de projetos e, mais uma vez, pela intenção de convocar alguma 'estrela' nacional ou internacional para resolver a questão, continuamos a observar uma contínua seqüência de projetos pautados pelo imediatismo e pelo retorno econômico e/ou midiático. Propostas que vislumbram na grandiosidade projetual a possibilidade de resolver a degradação de áreas subutilizadas a partir da gradativa valorização imobiliária do entorno. Valorização que, nesse caso, significa demolir velhas indústrias para ceder espaço a novos empreendimentos. No caso específico das áreas industriais, a dificuldade de reconhecer os seus valores e a grande dimensão dessas estruturas contribui para a proliferação de intervenções que sequer mascaram 
supostos critérios de restauro, as áreas são sumariamente consideradas como refugo urbano e pratica-se a tábula rasa sem grandes questionamentos.

Apesar de evidenciar a interpretação equivocada do tema, felizmente até o momento os citados projetos grandiosos têm ficado no papel. Além das chamadas intervenções de cunho midiático, contudo, lutamos cotidianamente com propostas bem menos ousadas, mas tão destrutivas quanto as primeiras. Na ausência de uma política contundente de tutela para o patrimônio urbano, tema controverso em nossa realidade já que o tombamento agride incisivamente os poderes do mercado imobiliário, prosseguem as descaracterizações do conjunto arquitetônico a partir da demolição de edifícios industriais isolados para ceder espaço a novos empreendimentos. A tutela desses edifícios considerados isoladamente é algo polêmico e difícil de justificar pois geralmente são construções sem evidentes valores individuais, edificações cuja importância reside na composição desse conjunto que vem se dissolvendo. Nesses novos empreendimentos, contudo, as questões em torno da qualidade projetual ou da harmonia entre o antigo e o novo, como temos tratado, parecem temas distantes e até mesmo surreais. Os novos projetos construídos na Diagonal Sul sobre os escombros do patrimônio industrial são edifícios unicamente voltados ao mercado, sem qualquer pretensão estética, e que paulatinamente vêm alterando a paisagem industrial, promovendo a verticalização e a supressão das tradicionais urbanidades locais através da transformação de antigos bairros operários em sucessivos condomínios residenciais fechados entre quatro grandes muros. Tem-se demolido preexistências que compõem uma paisagem histórica única para substituí-las por projetos de cunho mercadológico nos quais a questão do encontro antigonovo nem mesmo faz sentido, pois o novo poucas vezes pode receber o nome de 'arquitetura'. Projetos que, curiosamente, vendem o sossego do bairro operário como um atrativo, vendem aquilo que destroem.

Outra questão problemática com relação ao patrimônio industrial é a tendência ao isolamento que se tem observado em certos estudos sobre o tema. É claro que esse patrimônio possui particularidades que requerem esforços interpretativos para adequarmos os pressupostos teóricos às suas específicas necessidades, sobretudo com a conjugação dos fatores urbanísticos. Como patrimônio cultural, contudo, a abordagem da preservação dos remanescentes industriais não pode ocorrer de forma isolada, como uma espécie de 
'restauro a parte' ${ }^{182}$. Ao contrário, deve-se necessariamente buscar a teoria da preservação e do restauro dos bens culturais, conforme buscamos mostrar, e não se encerrar em um campo de estudos isolado e reinventar a roda ao discutir tópicos de uma suposta preservação sem se referir à teoria em pauta. Apesar das especificidades desse patrimônio - as características especiais que outras categorias de artefatos igualmente possuem -, não podemos esquecer que existem objetivos, métodos e preceitos teóricos comuns a todo o campo da preservação dos bens culturais. $\mathrm{O}$ tratamento do patrimônio industrial - desafio interpretativo advindo da expansão do conceito de patrimônio -, não pode, paradoxalmente, voltar as costas ao próprio percurso conceitual que abrira caminho para a sua valorização.

$\mathrm{Na}$ atuação em edifícios e sítios industriais de interesse cultural tem-se evitado a discussão sobre as formas de intervir em bens culturais. O tema geralmente é tratado como uma reforma comum, como uma intervenção urbana revitalizadora para uma região em desuso. Dessa forma, a intervenção sobre bens recentemente encampados pela expansão da noção de patrimônio a preservar, como os artefatos industriais, tende a um tratamento cada vez mais desvinculado do campo cultural e dos princípios da preservação, como se retornássemos à concepção do restauro como um ato essencialmente ditado por razões práticas, desconsiderando ao menos dois séculos de experiências e aquisições teóricas. Trata-se da fragilidade do discurso prático conforme buscamos evidenciar: os moventes culturais da preservação e as bases histórico-críticas do restauro parecem ser temas alheios ao discurso desses projetos. Grande parte desses profissionais, portanto, ignoram o debate sobre a preservação e suas teorias e por vezes nem mesmo conhecem a própria existência do campo disciplinar. ${ }^{183}$

Cabe ainda ressaltar que a preservação desses bens não significa, como defendem alguns, o 'congelamento' da cidade, a 'mumificação' de parcelas estratégicas para o desenvolvimento urbano. Como esclareceu Miarelli Mariani, um dos desafios do restauro urbano, de posse dos conceitos adquiridos e da compreensão dos valores inerentes às paisagens urbanas, é justamente permitir a relação dialética entre conservação e desenvolvimento. Tarefa que certamente não é simples, nem possui um manual, mas que

\footnotetext{
182 Situação também observada no tratamento de outras 'categorias' de artefatos, como o tratamento da arquitetura moderna, por exemplo, muitas vezes equivocadamente encarado como um 'restauro a parte', fora do âmbito da preservação dos bens culturais. VARAGNOLI, Claudio. Un restauro a parte? Palladio, v.12, n.22, 1998 apud KÜHL, B. M. Preservação..., op. cit., p.6.

${ }^{183}$ KÜHL, B. M. Preservação..., op. cit., p.234.
} 
demanda a congregação de diferentes disciplinas, adequadamente interligadas, na busca pela interpretação dos pressupostos teóricos e por uma consciente aplicação na prática de intervenção. Momento metodológico, inclusive, que demanda uma articulação com as políticas urbanas de tutela e de planejamento urbano - seja partindo de diretrizes gerais para a atuação pontual, ou da experimentação pontual que se articula com o todo, como deseja De Fusco -, a questão é, nas diferentes escalas de atuação, desenvolver métodos coerentes com as prerrogativas teóricas e atentos às especificidades a serem preservadas. Como exposto ao longo desta pesquisa, diferentes correntes interpretativas sugerem modos de interpretar e de intervir no patrimônio construído e as soluções adotadas, ainda que amplamente fundamentadas de acordo com os pressupostos teóricos que as orientaram, são sempre soluções de pertinência relativa, sujeitas à discussão. O campo da preservação e do restauro, como qualquer campo disciplinar intimamente relacionado às transformações da sociedade, é um campo dinâmico, cujos debates estão em contínuo desenvolvimento e aprofundamento. Isso não pode significar, contudo, que as aquisições teóricas amplamente debatidas em séculos de discussões devam ser 'reinventadas' a cada novo desafio.

No caso específico dos sítios industriais, como a Diagonal Sul, devemos considerar primeiramente um adequado e aprofundado conhecimento do patrimônio existente, de suas particularidades compositivas materiais e imateriais, para que possamos apreender a inteireza dos conjuntos construídos e os elementos formadores que devem ser preservados. Não defendemos que tudo deva ser tutelado indiscriminadamente; diante de tão extensas e complexas preexistências industriais é inevitável realizar uma seleção. Mas essas escolhas deverão pautar-se pelo conhecimento amplo desse território e pelas próprias análises histórico-críticas que instrumentalizam a apreensão das qualidades de conjunto. $\mathrm{O}$ que não podemos permitir é que a 'seleção' seja, na verdade, a tutela daquilo que 'sobrou'; que as escolhas ocorram pela ação do mercado imobiliário e não pelas determinações de uma criteriosa análise, conforme temos tratado.

Diante das propostas fugidias e evasivas com relação à teoria aqui apresentada, devemos buscar o aprofundamento do debate sobre o caráter cultural e social da preservação e do restauro. As bases da teoria da restauração que hoje conhecemos, apesar das crescentes contribuições e discussões, estão lançadas há muitas décadas. Temas que tomaram grande repercussão nesta pesquisa: a integração entre arquitetura, restauro e urbanismo; a prioridade do caráter cultural do restauro; a ameaça dos poderes 
especulativos e econômicos; estão em pauta há anos, intensificando-se sobretudo a partir de 1950, e os meios de enfrentamento vêm sendo discutidos desde aquela época. Os temas acordados na Carta de Veneza, e nas cartas posteriores, como a questão da conservação integrada, tão importante para a polêmica preservação dos sítios industriais, não são novidades, são premissas operativas aceitas desde a década de 1970 e com longa ascendência teórica, como vimos. Como ressalta Cervellati, talvez seja o momento de olharmos para trás, de buscarmos a retomada desse percurso e uma reflexão crítica que nos permita compreender em que momento perdemos os liames entre a teoria e a prática, refletir sobre "como reafirmar a salvaguarda daquilo que defendemos com paixão por tantos anos", e reelaborar os porquês da preservação e os seus vínculos com a cultura e a sociedade, o "porquê e para quem conservar". ${ }^{184}$

Não nos falta, portanto, base teórica; falta-nos sim disposição interpretativa para depurar esses preceitos, aplicá-los à nossa realidade e buscar soluções, que nunca serão simples ou manualísticas, mas que permitirão o desenvolvimento de formas de se relacionar com o patrimônio urbano, assegurando a sua transmissão ao futuro. Os mecanismos até então discutidos, considerando as variedades interpretativas de cada vertente teórica, oferecem-nos instrumentos e caminhos seguros para o enfrentamento dos problemas pertinentes à preservação e intervenção de modo consciente e responsável, ainda que o contínuo alargamento dos bens considerados de interesse cultural continue a suscitar um sempre renovado esforço de análise e interpretação, como bem observara Carbonara. E foi justamente esse esforço, voltado para a interpretação dos instrumentos do restauro e a sua aplicação para o patrimônio urbano industrial, que procuramos desenvolver nesta tese.

Resta-nos ressaltar que o caminho para a preservação do patrimônio urbano - e dos remanescentes cada vez mais ameaçados de nosso passado industrial - deve buscar uma retomada do entendimento da preservação e do restauro como atos críticos e como ações pautadas pelo reconhecimento das especificidades do artefato cultural. Como ato crítico, as intervenções devem estar baseadas em análises meticulosas do preexistente, em criterioso juízo histórico-crítico que nos guiará na proposição de soluções projetuais conscientes e fundamentadas. A preservação urbana objetiva a harmoniosa relação entre o

${ }^{184}$ CERVELLATI, P. L. Nessun'alternativa alla conservazione integrata. Italia Nostra, n. 206, 1981, pp. 17 20. Trad. nossa. "[...] si sente l'esigenza di una riflessione per tentare di capire dove e quando ci siamo sbagliati: dove e come si può riaffermare la salvaguardia di ciò che abbiamo difeso con passione per tanti anni, $[\ldots]$ perché e per chi conservare." 
patrimônio construído, o conjunto das especificidades materiais e imateriais que configuram a cidade, e a vida contemporânea. Vida esta que, por sua vez, também é história. Garantir a transmissão desse patrimônio ao futuro, a partir do respeito pelas estratificações históricas e da relação cotidiana com as linguagens construtivas moldadas ao longo do tempo, significa, portanto, buscar uma nova forma de compreender e respeitar a própria cidade, suas preexistências, coexistências e transformações. 


\begin{abstract}
ANEXO
OPERAÇÃO URBANA DIAGONAL SUL

LEVANTAMENTO FOTOGRÁFICO PARCIAL
\end{abstract}


ANEXO I - LEVANTAMENTo Fotográfico PARCIAL

\section{Operação Urbana Diagonal Sul: Trecho Brás - Pari}

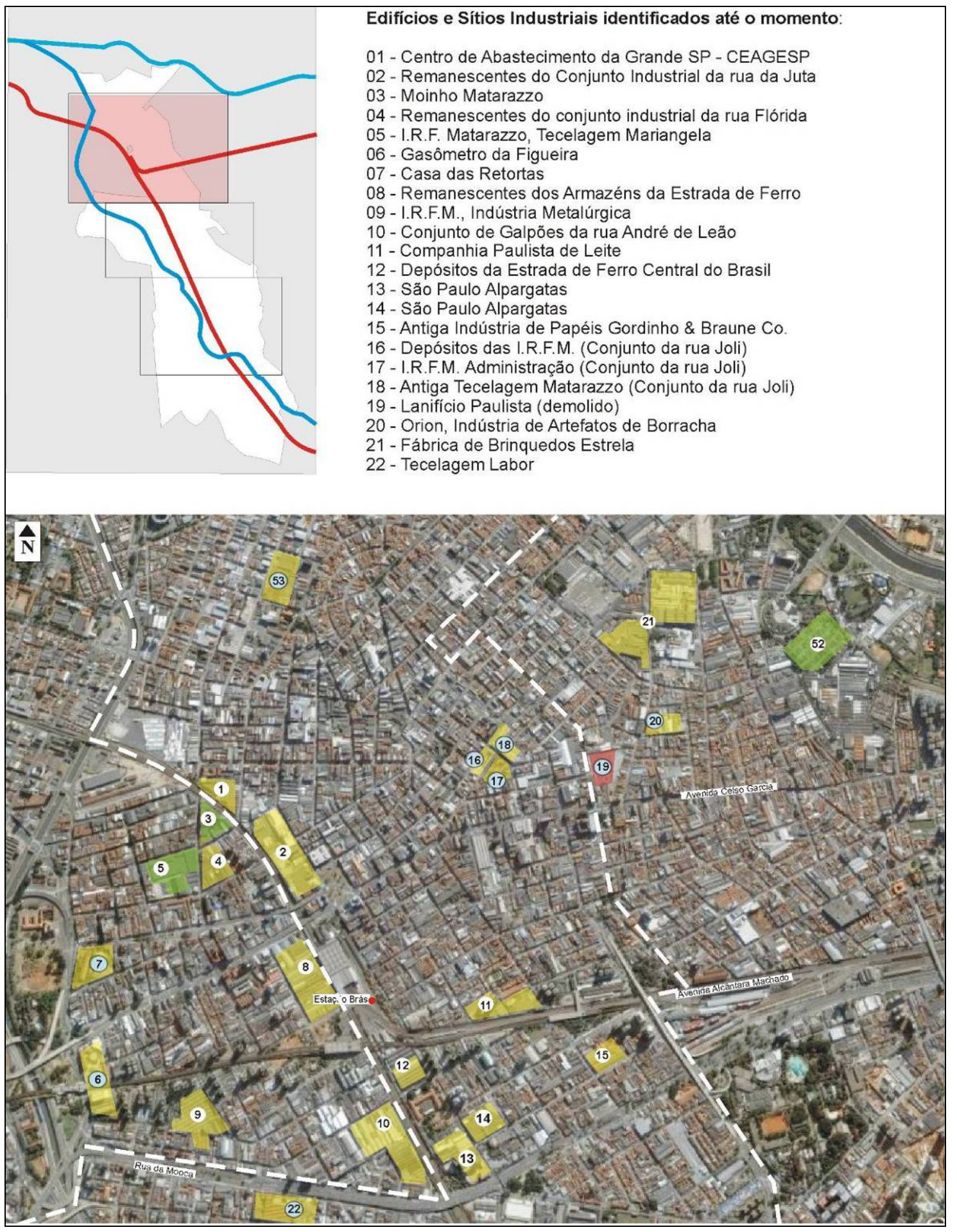




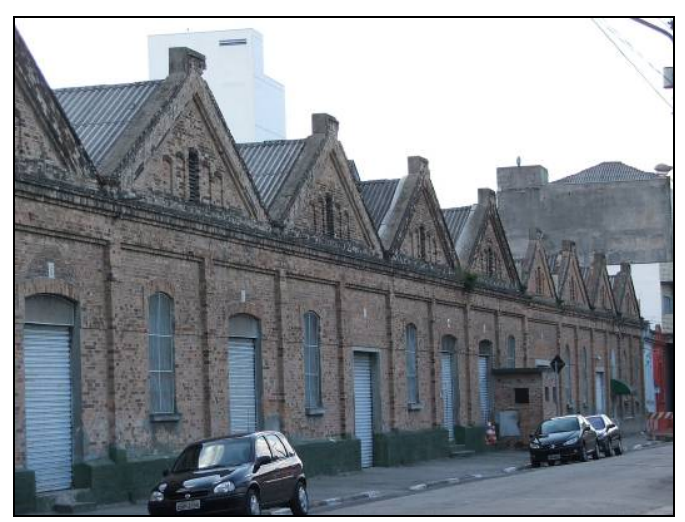

n.01. Centro de Abastecimento da Grande São Paulo, Depósito CEAGESP, 2006. (Fotos da autora)

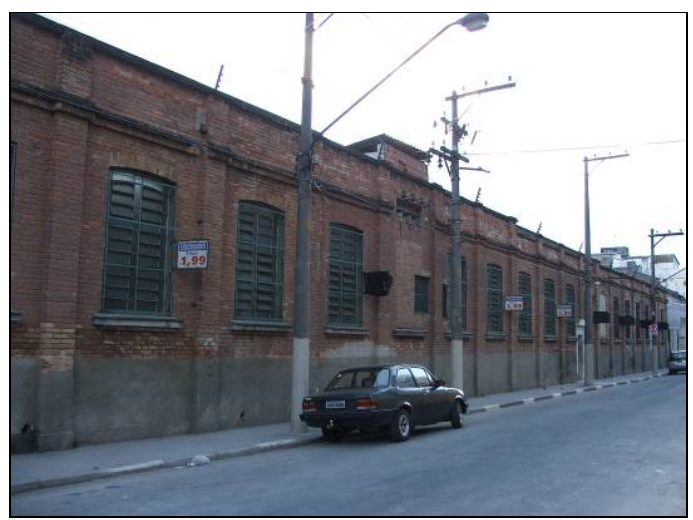

n.02. Remanescentes do conjunto industrial da rua da Juta, 2006.

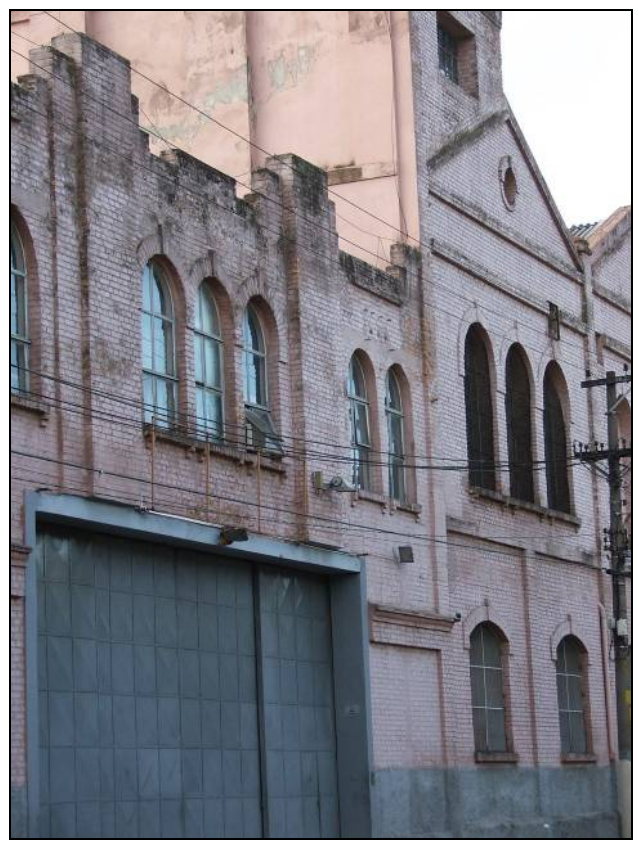

n.03. Moinho Matarazzo. Vista da rua Monsenhor de Andrade, 2006

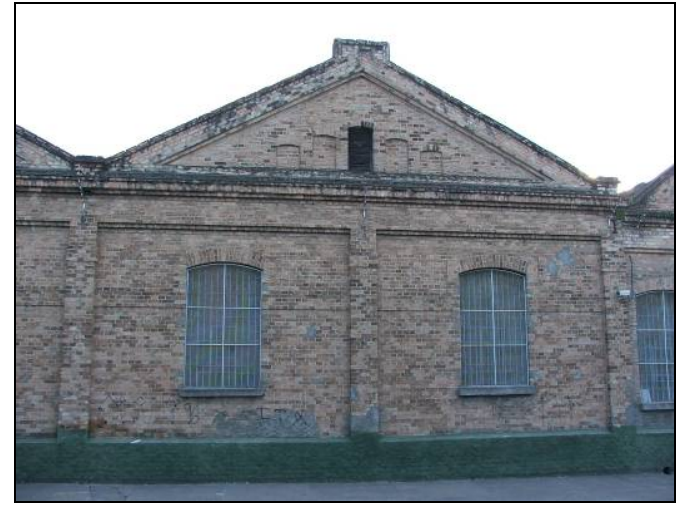

n.01. Depósito CEAGESP, detalhe. Vista da rua Rodrigues dos Santos. 2006

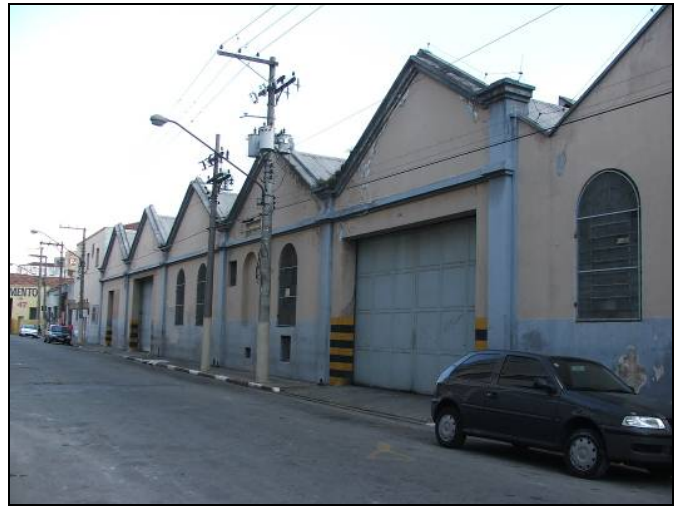

n.02. Remanescentes do conjunto industrial da rua da Juta, 2006.

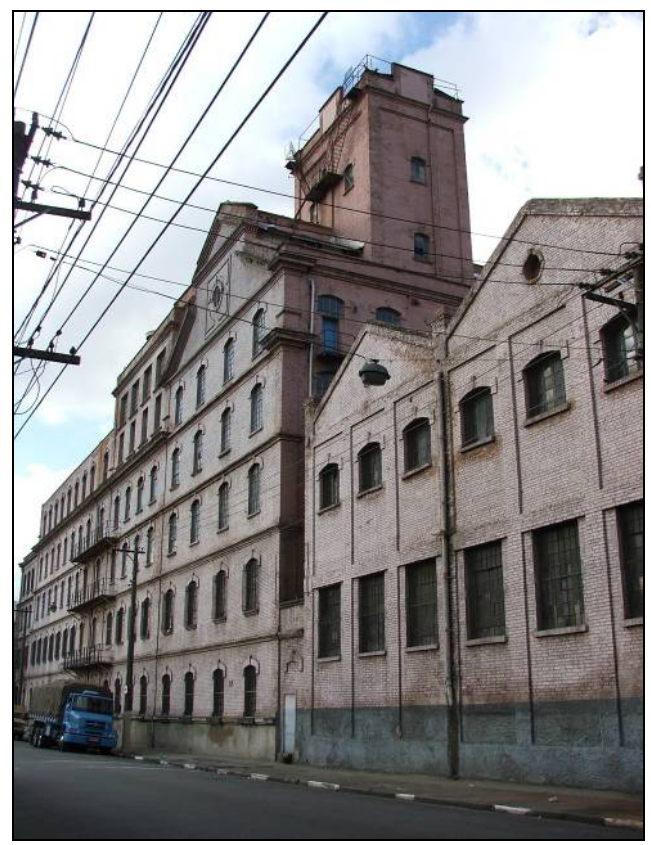

n.03. Moinho Matarazzo. Vista da rua Monsenhor de Andrade, 2006 


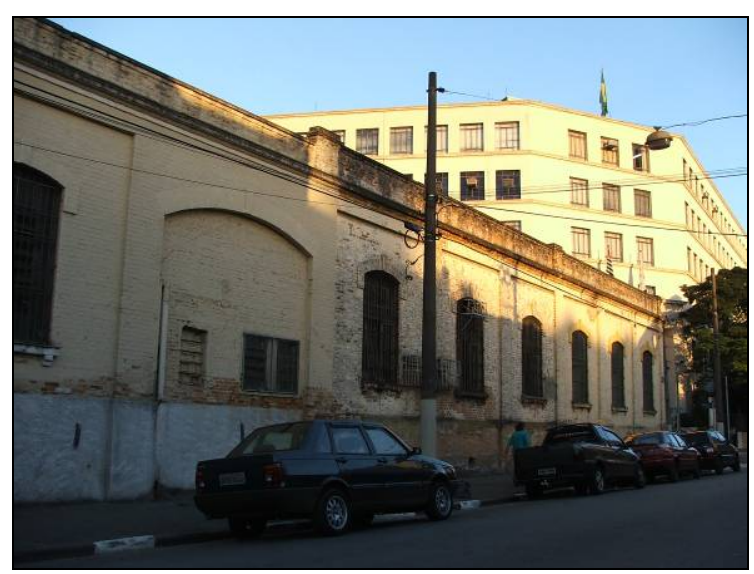

n.4. Remanescentes do conjunto industrial da rua Flórida. Vista da rua Monsenhor de Andrade, 2006.

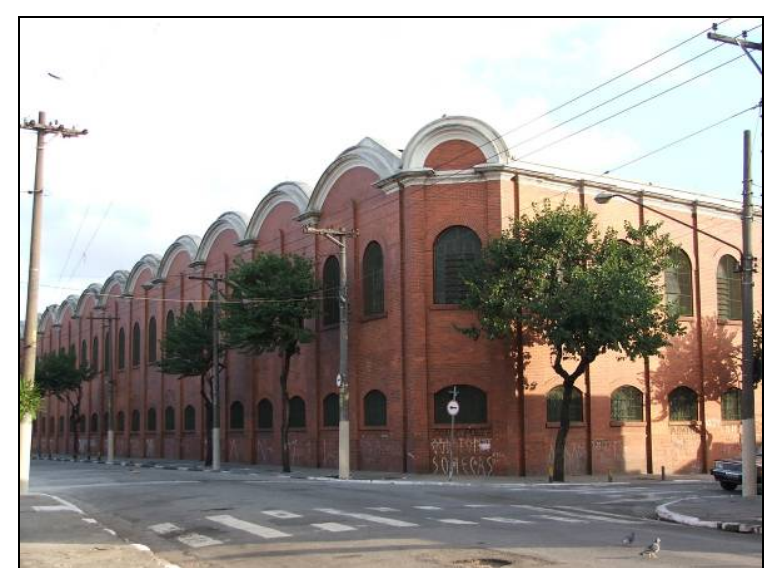

n.5. Tecelagem Mariângela. Esquina entre as ruas Monsenhor de Andrade e Fernandes Silva, 2006.

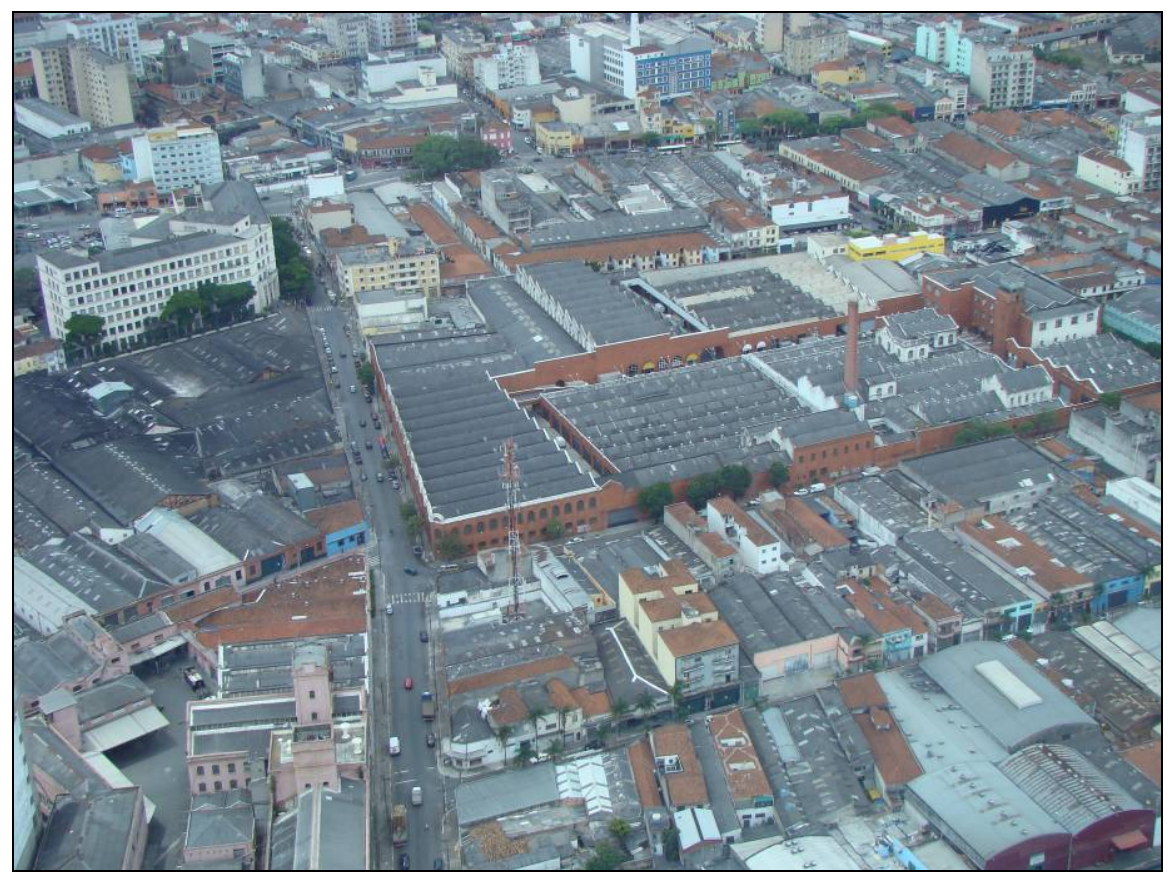

Moinho Matarazzo e Tecelagem Mariangela (Foto Pedro Sales)

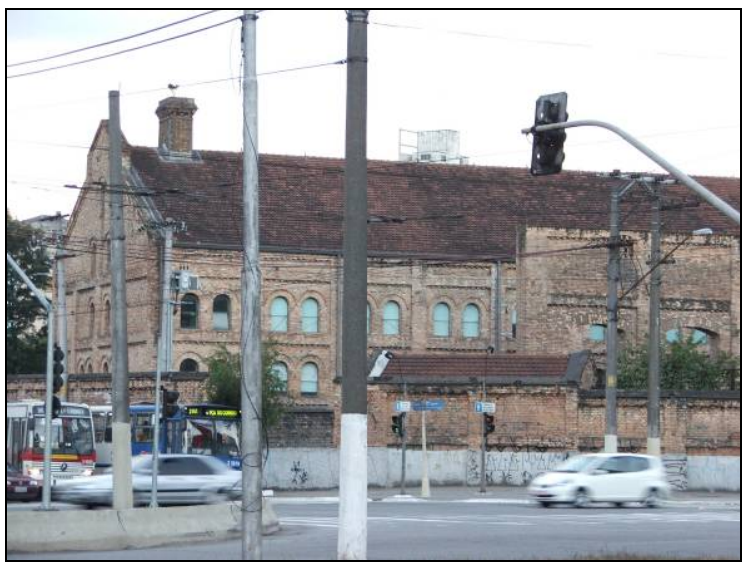

n.7. Casa das Retortas, 2006

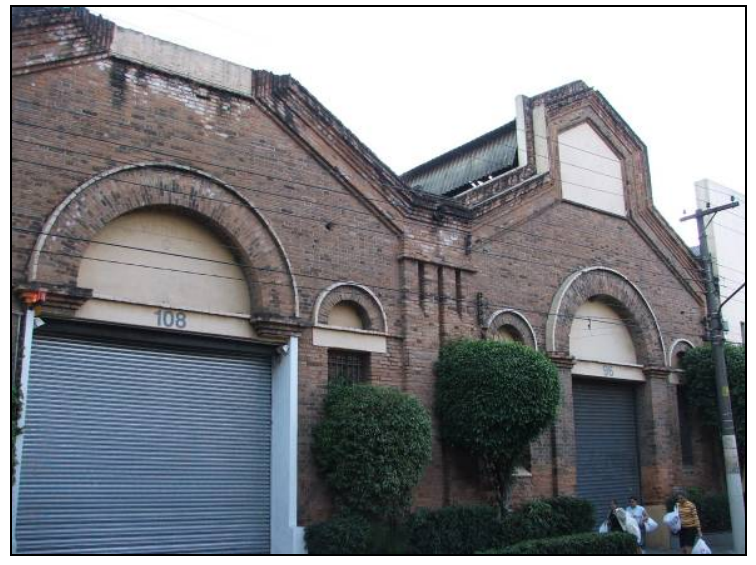

n.8. Remanescentes dos armazéns da estrada de ferro. Rua Domingos Paiva, 2006 


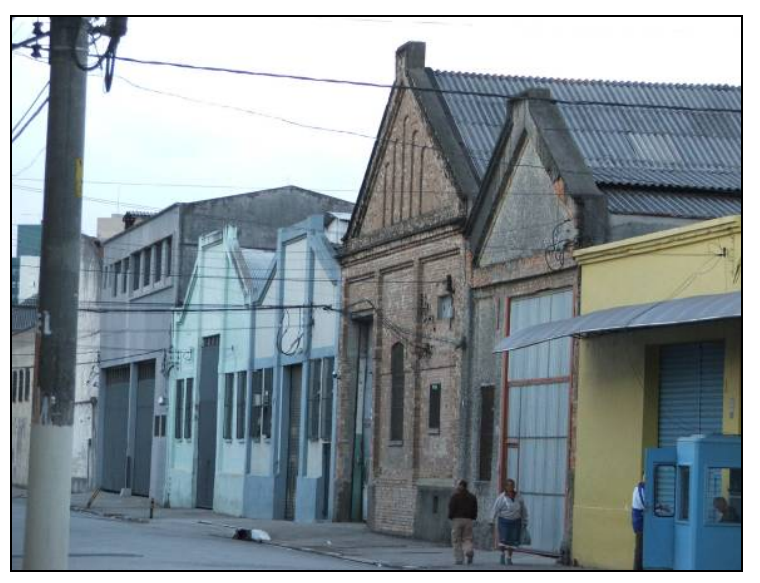

n.8. Remanescentes dos armazéns estrada de ferro. Rua Martin Buchard, 2006.

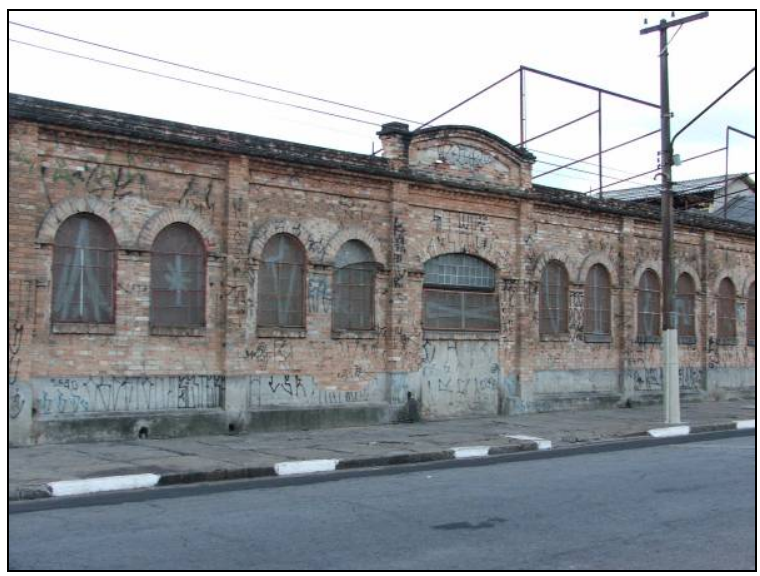

n.8. Remanescentes dos armazéns estrada de ferro. Rua Martin Buchard, 2006.

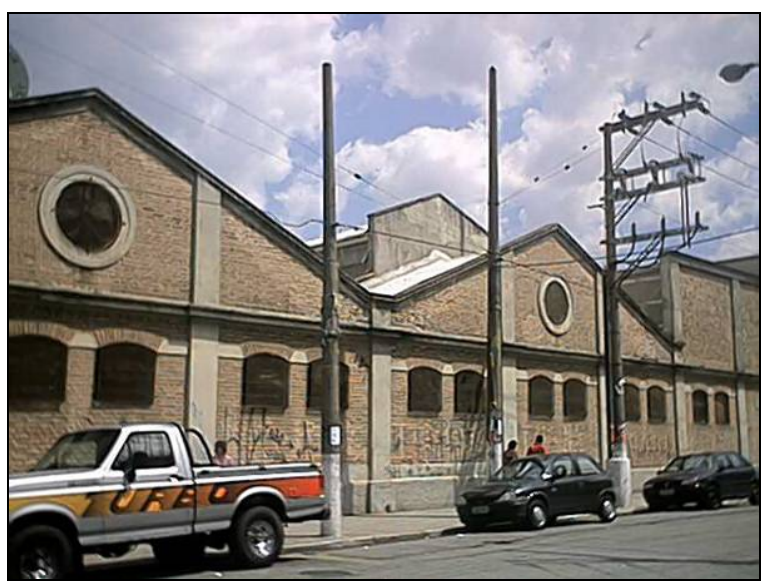

n.13. São Paulo Alpargatas, rua Almeida Lima, lado par, 2002.

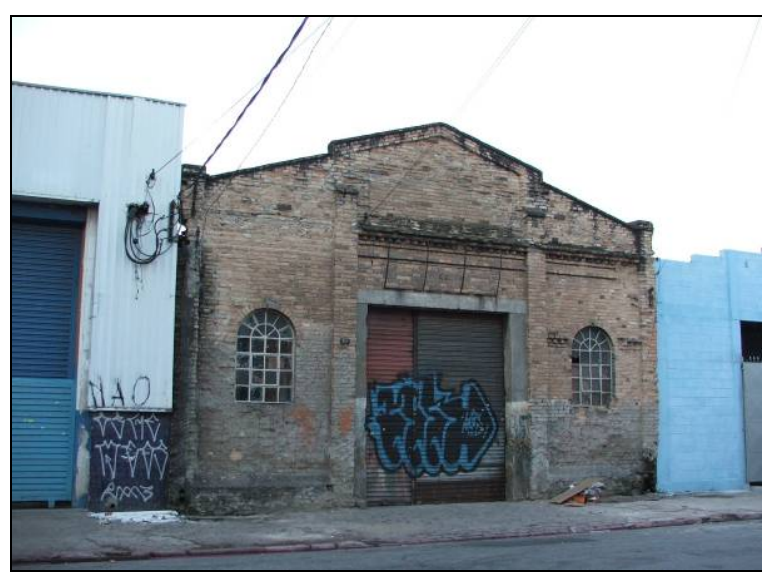

n.8. Remanescentes dos armazéns estrada de ferro. Rua Martin Buchard, 2006.

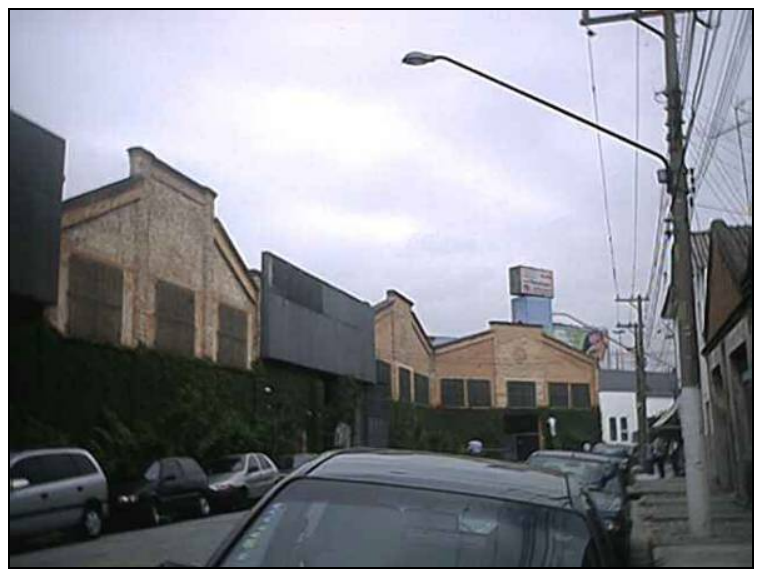

n.10. Galpões da rua André de Leão, ao lado dos armazéns Ernesto de Castro, 2002.

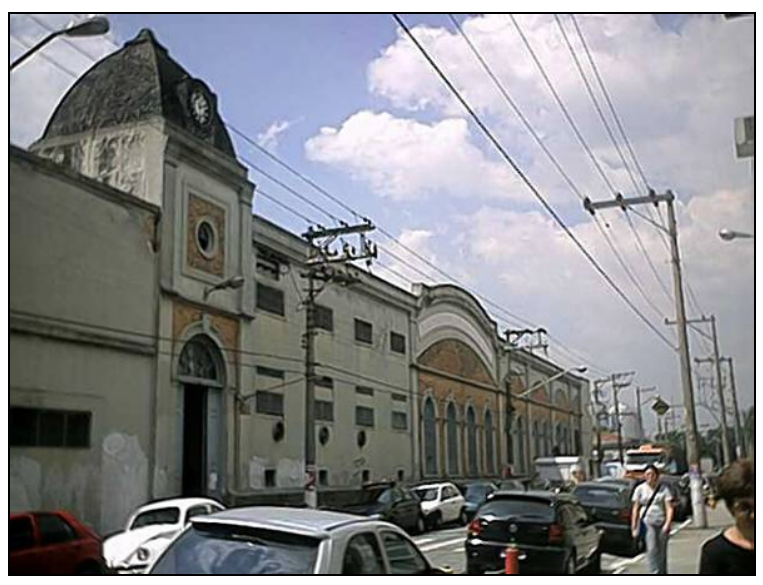

n.14. São Paulo Alpargatas, rua Almeida Lima, lado ímpar, 2002. 


\section{Operação Urbana Diagonal Sul: Trecho MoOca}

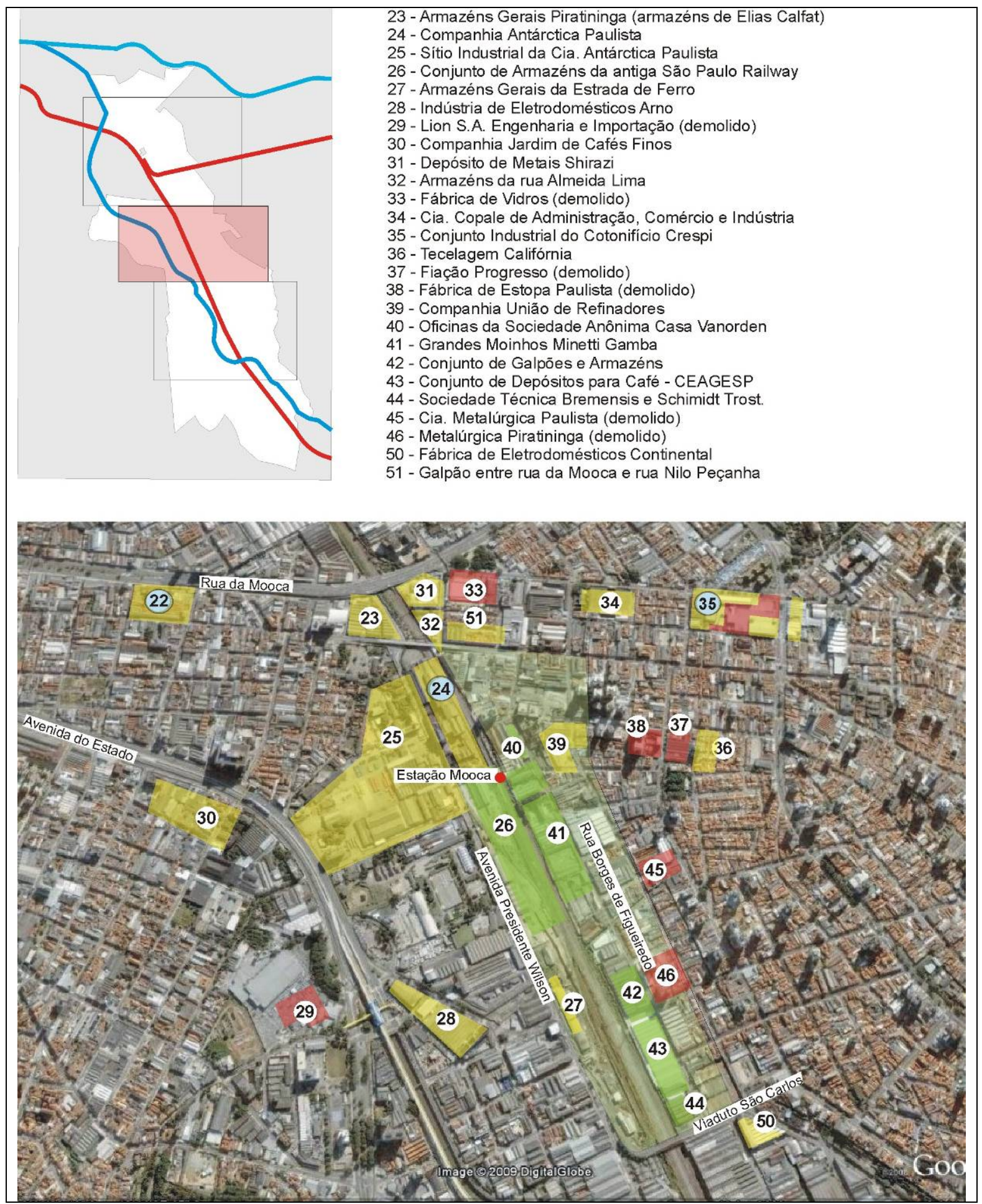




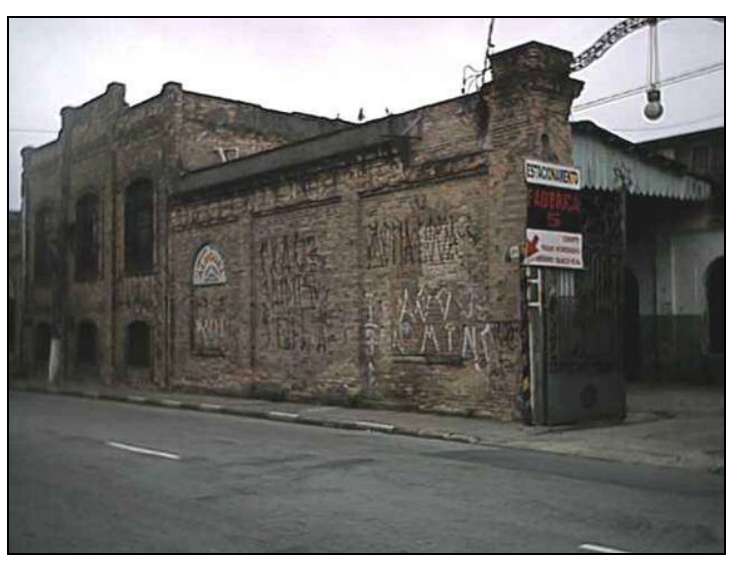

n.22. Tecelagem Labor, rua da Mooca, 2002.

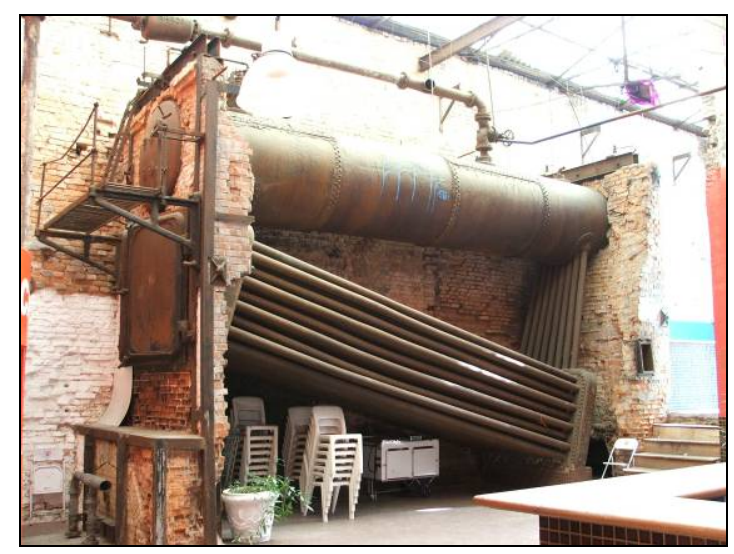

n.22. Tecelagem Labor, equipamento industrial abandonado, 2005.

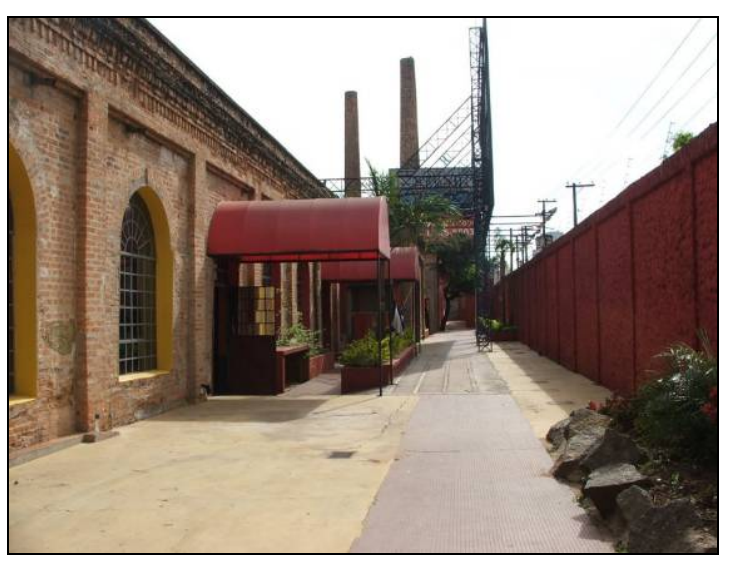

n.22. Tecelagem Labor. Via interna, 2005.

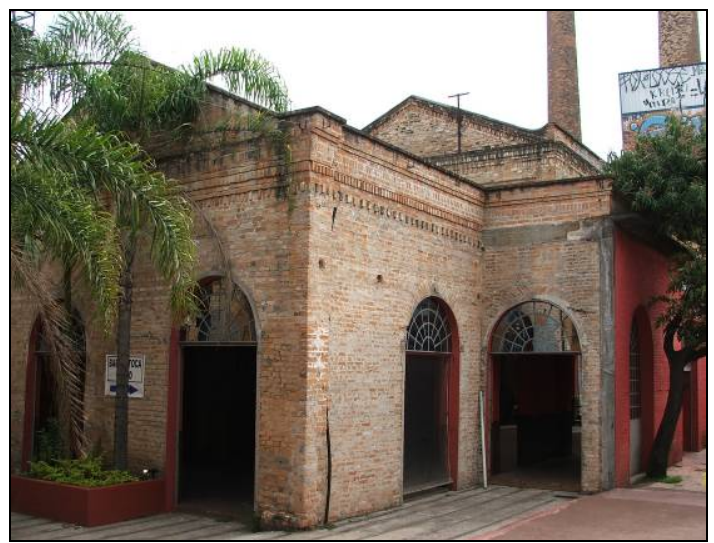

n.22. Tecelagem Labor, espaços internos do sítio industrial, 2005.
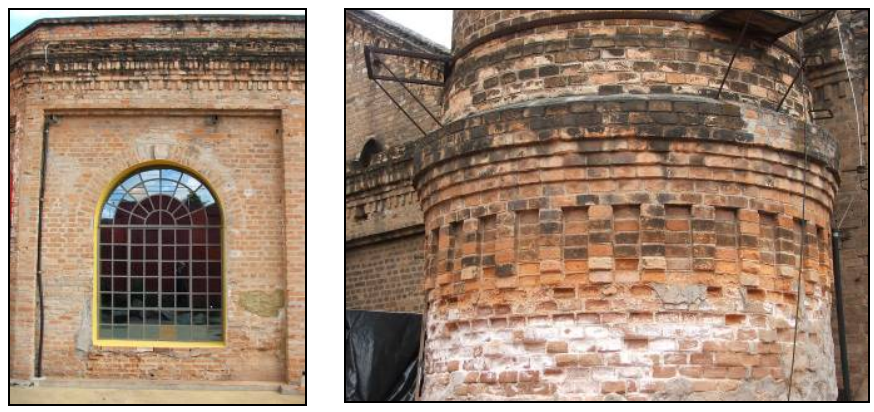

n.22. Detalhes construtivos

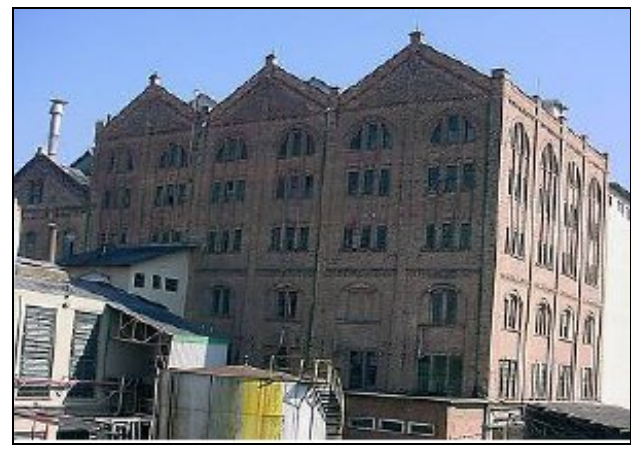

n.24. Companhia Antárctica Paulista, 2003.

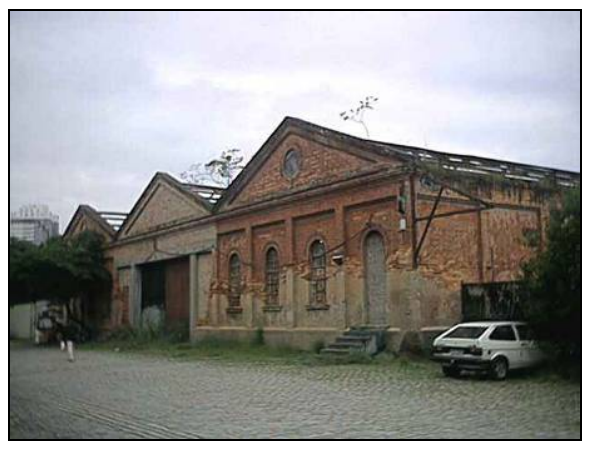

n.26. Armazém da SPR - São Paulo Railway, 2002 


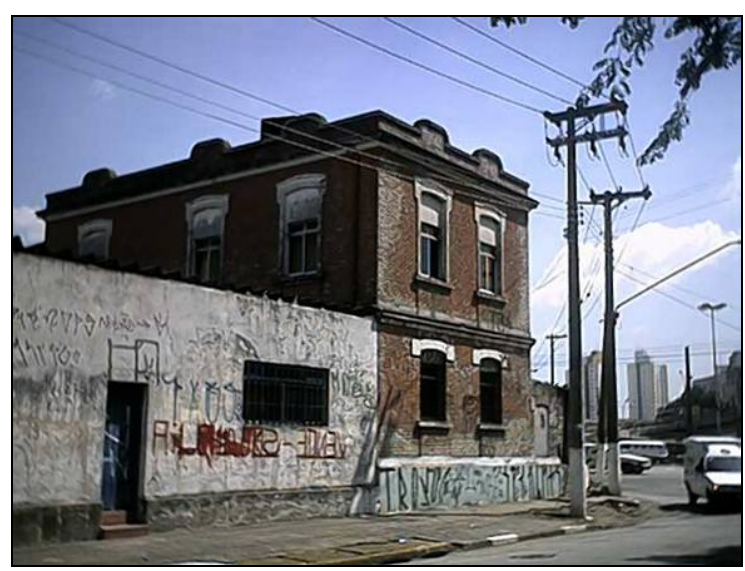

n.31. Depósito de Metais Shirazi, 2002.

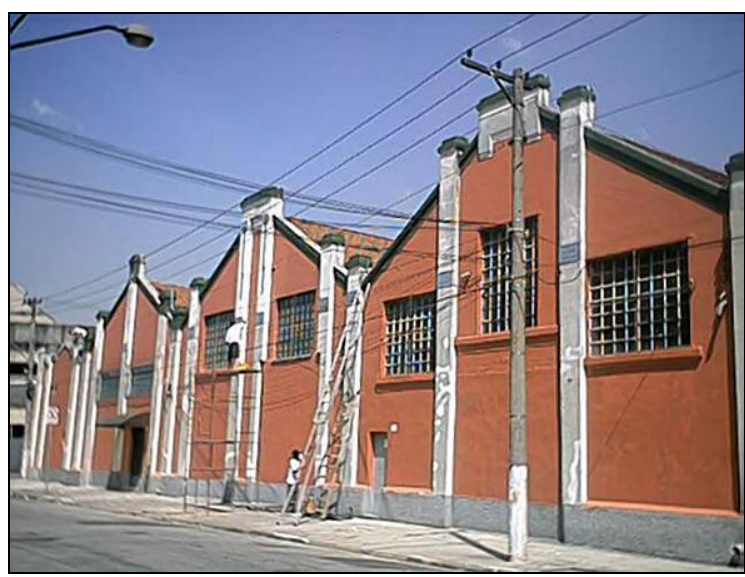

n.32. Armazéns da rua Almeida Lima, 2002.

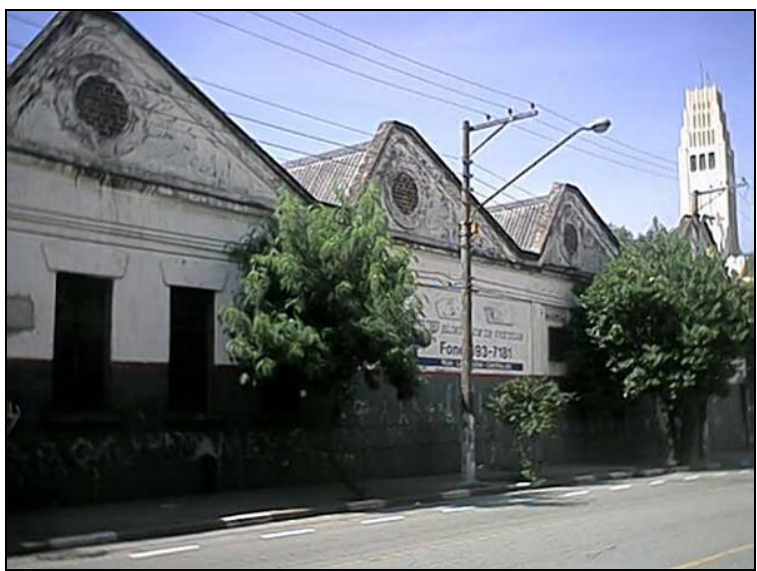

n.36. Tecelagem Califórnia, rua Orville Derby, 2002.

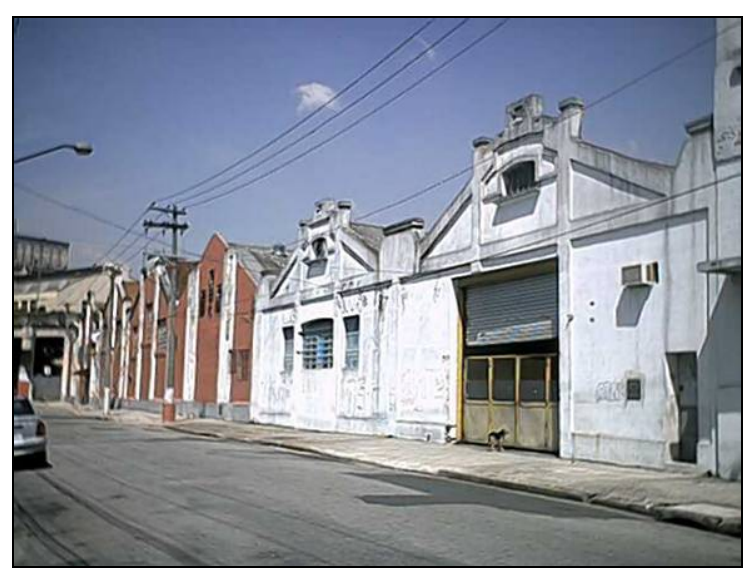

n.32. Armazéns da rua Almeida Lima, 2002.

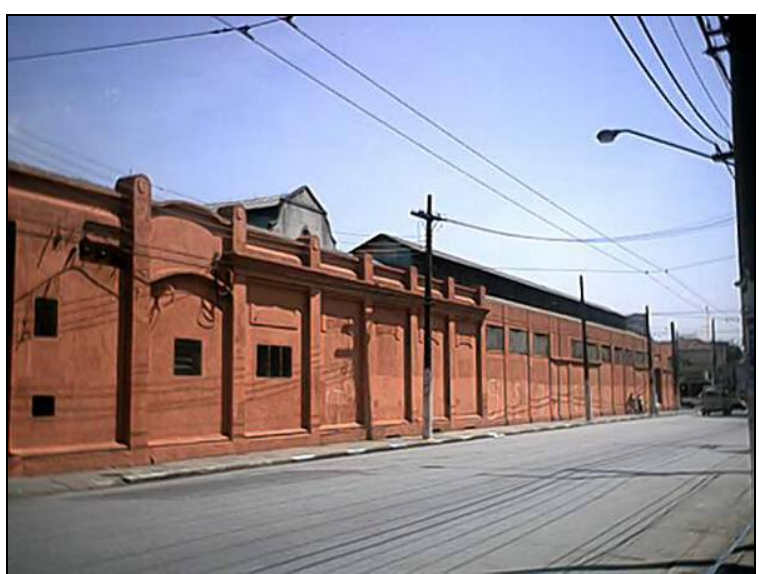

n.34. Cia Copale de Administração, Comercio e Indústria. Rua João Antônio de Oliveira, 2002

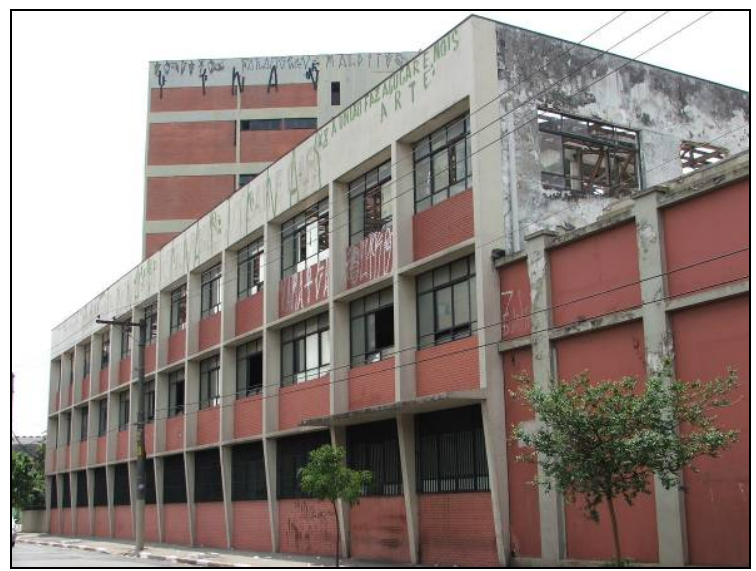

n.39. Companhia União de Refinadores, rua Borges de Figueiredo, 2008. 
Ao centro, conjunto industrial da Companhia Antarctica Paulista, 2008.

(Fotos Pedro Sales)

Ao fundo, conjunto de galpões da rua Borges de Figueiredo, vista a partir da via férrea, 2008

Galpões ao longo da via férrea: Grandes Moinhos Minetti Gamba e armazéns da rua Borges de Figueiredo, 2008.
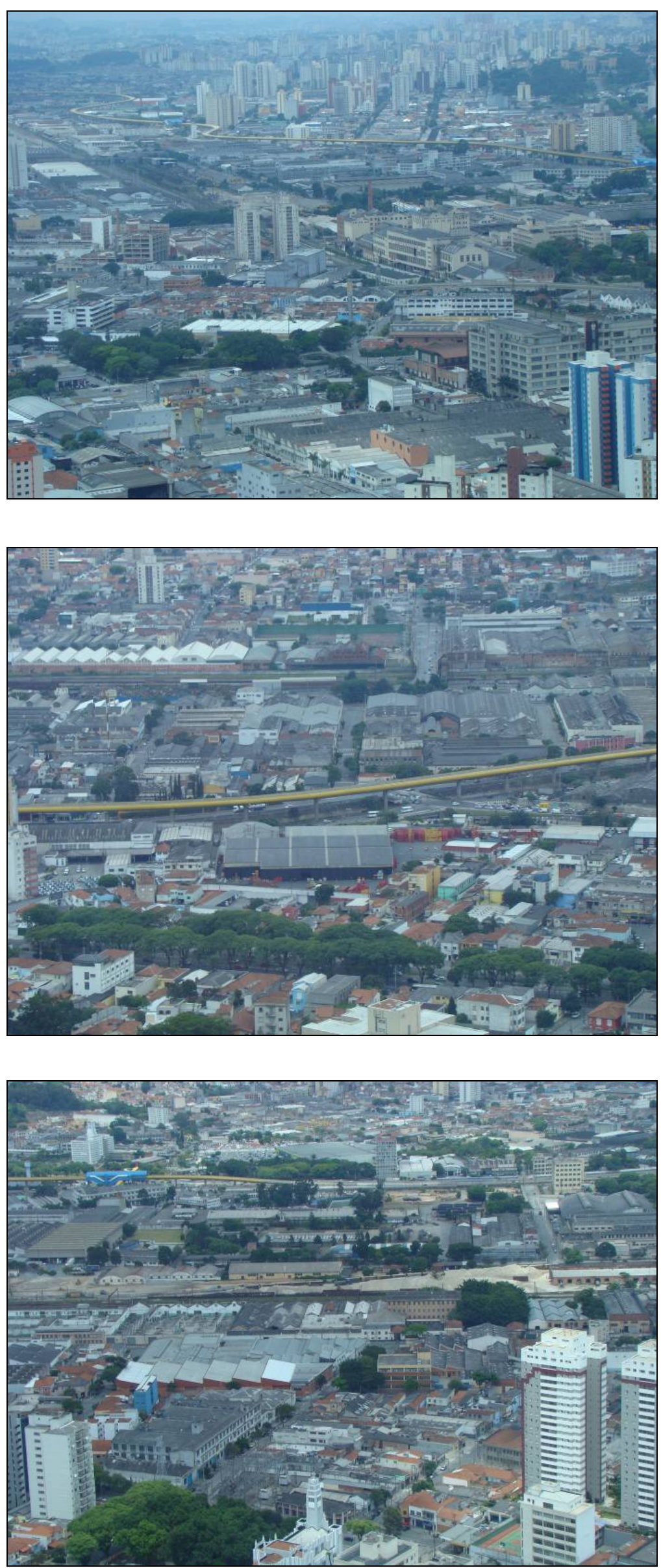
Operação Urbana Diagonal Sul: Trecho Vila Prudente - IPIRANGa

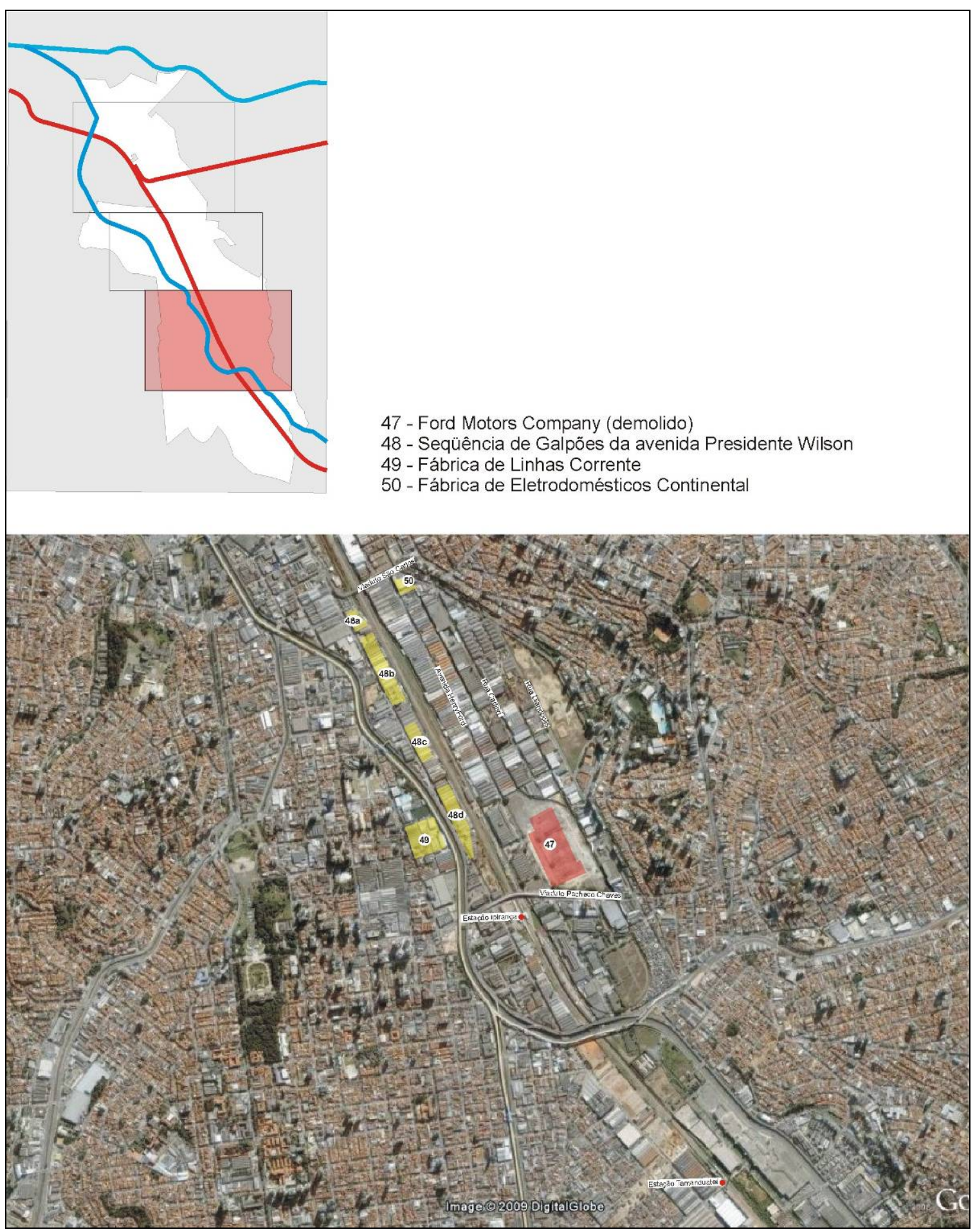


Ao fundo, faixa de terra batida após a demolição de vários galpões na altura da estação Tamanduateí, 2008. (Fotos Pedro Sales)

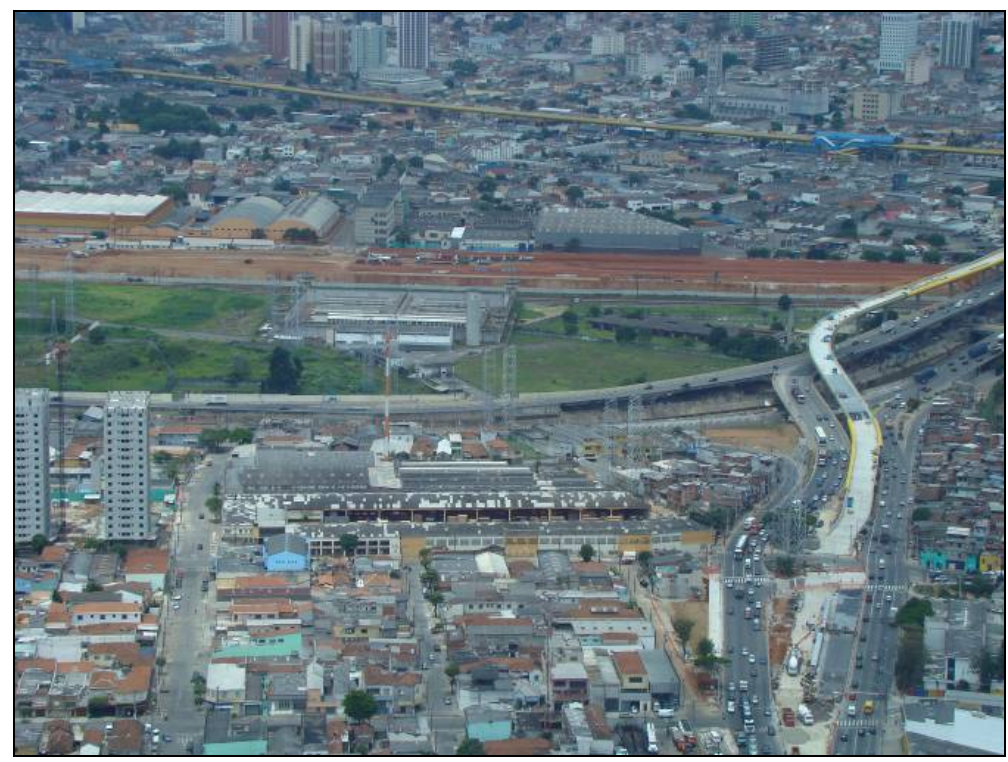

Vista do conjunto de galpões entre as ruas Dianópolis, Cadiriri e Henry Ford. Ao fundo, o bairro do Ipiranga, 2008.

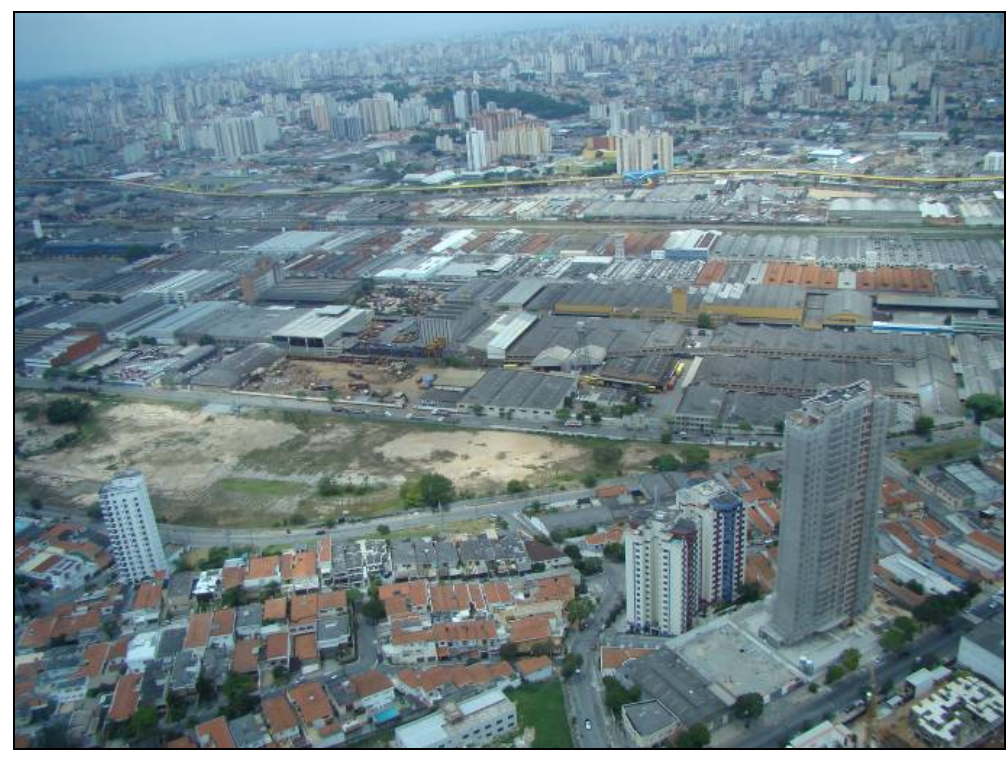

Amplo terreno liberado após a recente demolição da Ford Motors Company, 2008.

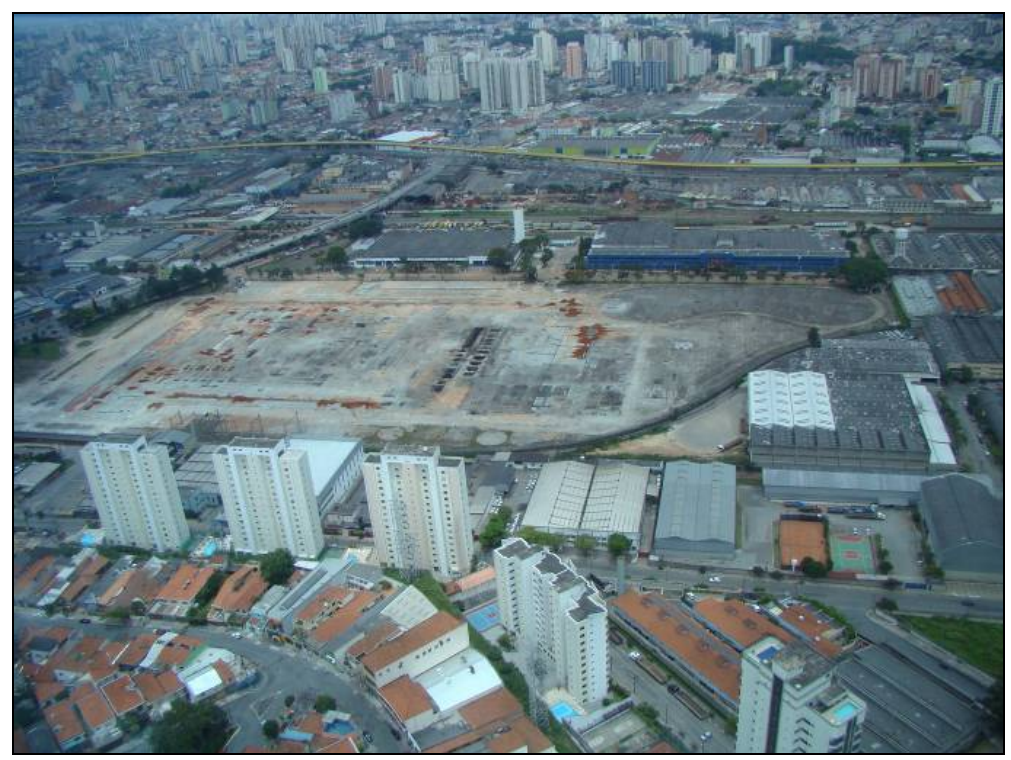




\section{REFERÊNCIAS BIBLIOGRÁFICAS}

Actas del Congreso Internacional Puesta en Valor del Patrimonio Industrial: Sitios, Museos y Casos. Santiago de Chile: TICCIH, 2006.

AGUILAR, Inmaculada. Restauración del património arquitectónico industrial. In: Preservación de la arquitectura industrial en Iberoamérica y España. S.l.: Instituto Andaluz del Patrimonio Historico, 2001, pp.160-203.

ALBERTI, Leon Battista. L'Architettura [De Re Aedificatoria]. [Testo latino e traduzione a cura di Giovanni Orlandi. Introduzione e note di Paolo Portoghesi]. Milano: Polifilo, 1966.

Alpargatas: oitenta anos de nossa história. São Paulo: Mouro Ivan Marketing Editorial, 1987.

ANDALORO, Maria (Org.). La teoria del restauro nel novecento da Riegl a Brandi. Firenze: Nardini, 2006.

ANDRADE, Antonio Luiz Dias de. Um estado completo que pode jamais ter existido. Tese de Doutorado. São Paulo: FAUUSP, 1993.

ANDRADE, Mário de. Anteprojeto para criação do Serviço do Patrimônio Artístico Nacional [1936]. In: CAVALCANTI, Lauro (Org.). Modernistas na repartição. Rio de Janeiro: UFRJ/Minc/IPHAN, 2000.

ANDRADE, Margarida Maria de. Bairros além Tamanduateí: O imigrante e a fábrica no Brás, Mooca e Belenzinho. Tese de doutorado. São Paulo: FFLCH-USP, 1990.

ANDRADE, Rodrigo Melo Franco de. Brasil: monumentos históricos e arqueológicos. México: Instituto Pan-americano de Geografia e História, 1952.

ANDRIEUX, Jean-Yves. Le Patrimoine Industriel, (Que sais-je?). Paris: PUF, 1992.

ALEXANDER, Christopher. Ensayo sobre la Sintesis de la Forma [1966]. Buenos Aires: Infinito, 1969.

ANNONI, Ambrogio. Scienza ed arte del restauro architettonico. idee ed esempi. Milano: FRAMAR, 1946.

ARANTES, Antonio Augusto (Org.). Produzindo o Passado: Estratégias de Construção do Patrimônio Cultural. São Paulo: Brasiliense, 1994.

ARATA, G. U. Ricostruzioni e restauri. Milano: Ulrico Hoepli, 1942.

Archeologia industriale a Roma. Roma: Sugarco, 1989.

ARCHIBUGI, Franco. Il nuovo Piano regolatore di Roma (2001): un piano senza strategia. In: Rome: a new planning strategy. London, New York: Routledge, 2005.

ARCHICOLLEGIO. Gli architetti moderni e l'incontro tra antico e nuovo. Convegno di Venezia 23-25 aprile 1965. Bergamo: Collegio Architetti Bergamo, n.7-8, speciale dicembre 1965.

ARGAN, Giulio Carlo. Urbanistica e architettura. Le arti, 1939.

. Il governo dei beni culturali. Storia dell'Arte, n. 19, 1973, pp. 189-191.

La città nel pensiero de Leon Battista Alberti. Rassegna di Architettura e Urbanistica, n. 73,74,75, 1991, p. 173-179.

ARGAN, Giulio Carlo e FAGIOLO, Maurizio. Guia de História da Arte. Trad. M. L. Gonçalves de Azevedo. Lisboa: Estampa, 1994.

Atti del Convegno Internazionale 'La Città di Domani: strategie, programmi, progetti di riqualificazione urbana'. Bologna, Ferrara: Facoltà di Architettura di Ferrara, Regione Emilia Romagna, 2000. 
Atti del Seminario Internazionale 'L'Associazione artistica tra i cultori di architettura e Gustavo Giovannoni'. Roma 19-20 novembre 1987. Bolletino del Centro di Studi per la Storia dell'Architettura, n.36, 1990.

Atti del Seminario Internazionale 'Città in Trasformazione: Le aree dismesse nella riqualificazione della città europea'. Roma 18-19 giugno 1993. Roma: Dipartimento di Pianificazione Territoriale e Urbanistica, Università degli Studi di Roma La Sapienza, 1993.

Atti della giornata di studi sul tema: Restauro Urbano. Che fare?[QUASAR, n.23]. Firenze: Facoltà di Architettura dell'Università degli Studi di Firenze, n.23, 2000.

Attualità urbanistica del monumento e dell'ambiente antico. Milano: Görlich, Centro Studi della Triennale di Milano, 1957.

AYMONINO, Carlo. Il significato della città [1975]. Venezia: Marsilio, 2000.

AZEVEDO, Aroldo de (Org). A Cidade de São Paulo - Estudos de geografia Urbana. São Paulo: Editora Nacional, 1958.

BANDEIRA JR., A.F. A Indústria no Estado de São Paulo em 1901. São Paulo: Typ. do Diário Oficial, 1901.

BANDINELLI, Ranuccio Bianchi. Come non ricostruire Firenze demolita. Il Ponte, vol.1, n. II, 1945, pp. 114-118.

BARBACCI, Alfredo. Sul restauro dei monumenti e del loro ambiente. In: PEROGALLI, Carlo (Org.). Architettura e restauro: esempi di restauro eseguiti nel dopoguerra. Milano: Görlich, 1955.

BARBUY, Heloísa. A conformação dos ecomuseus: elementos para compreensão e análise. Anais do Museu Paulista, 1995, v.3, pp. 209-236

BARTHÉLEMY, Jean. De la Charte de Venise a celle des Villes Historiques. Restauro, n. 131132, pp. 109-116, 1995.

Noveau rôle pour l'urbaniste? Restauro, n.144, pp.17-22, 1998.

BAUMEISTER, Reinhard. Stadt-erweiterungen in technischer baupolizeilicher und wirthschaftlicher beziehung. Berlin: Korn, 1876.

BELLINI, Amedeo. Note indicative per una possibile gestione integrata della tutela dei beni architettonici. Restauro, anno XVIII, n. 104-105, 1989, pp. 43-53.

. Riflessione sull'attualità di Ruskin. Restauro, n. 71-72, 1984, pp. 63-84.

BENEDETTI, Sandro. La cultura del restauro nel 'recupero' dei centri storici. Storia Architettura, anno V, n. 1, gennaio-giugno, 1982, pp. 89-104.

BENEVOLO, Leonardo. L'esigenza di conservare gli ambienti antichi non significa bloccare ogni iniziativa. L'Architettura Cronache e Storia, anno III, n.21, luglio 1957, pp. 182-185.

La conservazione dei centri antichi e del paesaggio come problema urbanistico. Ulisse, anno XI, fasc. XXVII, 1957, pp. 1445-1453.

. Storia dell'architettura del Rinascimento. Roma: Laterza, 2002.

. História da Arquitetura Moderna. São Paulo: Perspectiva, 2001.

BERGERON, Louis. TICCIH et L'Ecomusée du Creusot-Montceau les Mines: les cheminements d'une convergence. Patrimoine de l'Industrie, 1999, n.1, pp.7-13.

BIANCHETTI, Cristina. Arte urbana e memoria disciplinare. In: SMETS, M. Charles Buls: I principi dell'arte urbana. Roma: Officina, 1999.

BIANCHETTI, Daniela. Aree industriali dismesse: primi percorsi di ricerca. Urbanistica, n.81, 1985, pp.82-85.

BIGNAMI, Sabrina. La normativa italiana per l'archeologia industriale. Recupero $e$ Conservazione, n.36, 2000, pp. 52-53. 
BISIO, Lidia e BOBBIO, Roberto. Gestione dei grandi eventi e strategie di riqualificazione urbana a Genova. In: IMBESI, Paola Nicoletta (Org.). Governare $i$ grandi eventi, l'effetto pulsar e la pianificazione urbanistica. Roma: Gangemi, 2004.

BOITO, Camillo. La nuova piazza del Duomo a Milano. In: Il nuovo e l'antico in architettura. Milano: Jaca Book, 1988

BOITO, Camillo. Os restauradores. Trad. Beatriz Mugayar Kühl. Cotia: Ateliê, 2002.

BONDONIO, Andrea; CALLEGARI, Guido; FRANCO, Cristina; GIBELLO, Luca. Stop \& Go: il riuso delle aree industriali dismesse in Italia, trenta casi studio. Firenze: Alinea, 2005.

BONELLI, Renato. Architettura e restauro. Venezia: Neri Pozza, 1959.

. Il rapporto antico-nuovo nei suoi aspetti storici generali. In: Attualità urbanistica del monumento e dell'ambiente antico. Milano: Görlich, Centro Studi della Triennale di Milano, 1957, pp. 55-57.

La cultura italiana e la tutela dei centri storici. Enciclopedia '75, s.d., pp. 399-402.

. Scritti dul Restauro e sulla Critica Architettonica. Roma, Bonsignori, 1995.

. Viollet-Le-Duc: fra teoria dell'architettura e restauro dei monumenti. Restauro, n.5657-58, 1981, pp. 172-185.

BONICELLI, Enrico. L'architettura industriale nei suoi elementi costruttivi e nella sua composizione. Torino: Unione Tipografico-Editrice Torinese, 1930.

BORSI, Franco. Problemi del patrimonio architettonico industriale. Bollettino della Biblioteca della Facoltà di Architettura dell'Università di Roma, n.19-20, dicembre 1978, pp.7-8. Introduzione all'Archeologia Industriale. Roma: Officina, 1978.

BOSCARINO, Salvatore. Il restauro architettonico ed il tema della rifunzionalizzazione degli edifici. Storia Architettura, ano XI, n.1-2, 1988, pp. 23-34.

BOSCARINO, Salvatore; CARBONARA, Giovanni et al. Il progetto di restauro. Interpretazione critica del testo architettonico. Trento: Comitato Giuseppe Gerola, 1988.

BORNHEIM, G. Introdução à leitura de Winckelmann. In: WINCKELMANN, J. J. Reflexões sobre a arte antiga. Tradução de Herbert Caro e Leonardo Tochtrop. Porto Alegre: Editora Movimento, UFRS, 1975.

BRANDI, Cesare. Teoria da restauração. Trad. Beatriz Mugayar Kühl. Cotia, São Paulo: Ateliê, 2004.

. Il patrimonio insidiato [a cura di Massimiliano Capati]. Roma: Editori Riuniti, 2001.

Il Restauro. Teoria e Pratica. Roma: Editori Riuniti, 1994.

Prima di tutto un problema di impostazione teorica. Italia Nostra, anno XVII, n.128, settembre 1975, pp. 7-8.

Processo all'architettura moderna. L'Architettura Cronache e Storia, anno II, n.11, settembre 1956, pp. 356-360.

. Terre d'Italia. Milano: Bompiani, 2006.

Struttura e architettura. Torino: Giulio Einaudi, 1967.

BRUNO, Ernani Silva. História e tradições da cidade de São Paulo. São Paulo: José Olympio, 1954, v. I,II e III.

BRUSCHI, Arnaldo. Osservazioni sulla teoria architettonica rinascimentale nella formulazione albertiana. Quaderni dell'Istituto di Storia dell'Architettura, serie VI-VII-VIII, n.31-38, 1961, pp. 115-130.

BUCCI, Carlo Alberto. Ostiense, il tesoro dei mercati, scoperte centinaia di anfore. La Repubblica. Roma, 14 dic. 2007. 
BUCHANAN, R. A. Industrial Archaeology in Britain [1972] Harmondsworth: Penguin, 1974.

The Definition of Industrial Archeology. In: L'Etude et la Mise en Valeur du Patrimoine Industriel, 4eme Confèrence Internationale, Lyon-Grenoble, September 1981. Paris: CNRS, 1985, pp. 104-108.

BULS, Charles. La restauration des monuments anciens. Bruxelles: Weissenbruch, 1903. Le nationalisme dans l'art. S.1.: s.n, s.d.

Estetica delle città. Trad. Maria Pasolini. In: SMETS, Marcel. Charles Buls: I principi dell'arte urbana (appendice). Roma: Officina, 1999.

CACCIA, Aristide, Costruzione, trasformazione ed ampliamento delle città, compilato sulla traccia dello Städtebau di J. Stübben: ad uso degli ingegneri, architetti, uffici tecnici ed amministrazioni municipali. Milano: Hoepli, 1915.

CALABI, Donatella. L'arte urbana in Europa: alcuni categorie concettuali nelle parole dei suoi teorici. In: SPAGNESI, Gianfranco (Org.). L'Architettura delle Trasformazioni Urbane 1890-1940, Atti del XXIV Congresso di Storia dell'Architettura. Roma: Centro di Studi per la Storia dell'Architettura, 1992.

O papel de Paris na urbanística italiana do século XIX: o mito da modernização. In: SALGUEIRO, Heliana Angotti (Org.). Cidades capitais do século XIX. São Paulo: Edusp, 2001

CAMBEDDA, Anna. Il mattatoio e le grotte del monte a Testaccio. In: Architettura e urbanistica: uso e trasformazione della città storica. Venezia: Marsilio, pp. 448-454, 1984.

CAMPOS Filho, Cândido Malta. Um Desenho para São Paulo: o corredor metropolitano como estrutura urbana aberta para a grande São Paulo. Tese de Doutorado. São Paulo: FAUUSP, 1972.

CAMPOS Neto, Cândido Malta. Os rumos da cidade: urbanismo e modernização em São Paulo. São Paulo: Senac, 2002.

CAMPITELLI, Alberta e TOLOMEO, Maria Grazia. Servizi generali e industrie private sulla via Ostiense. In: Architettura e urbanistica: uso e trasformazione della città storica. Venezia: Marsilio, pp. 455-462, 1984.

CANCIANI, Marco (org.). Piano di assetto per l'attuazione del progetto urbano Ostiense-Marconi. Roma: Kappa, 2004.

CANIGGIA, Gianfranco. Saverio Muratori e il progetto di tessuto. Storia Architettura, anno VII, n. 1-2, gennaio-dicembre, 1984, pp. 31-38.

CAPASSO, Tiziana. Il dibattito sulla salvaguardia dei centri storici dagli anni sessanta ad oggi. Restauro, n. 144, pp. 71-98, 1998.

CARDILLO, Enrico. Napoli: l'occasione post-industriale. Da Nitti al piano strategico. Napoli: Guida, 2006.

CARBONARA, Giovanni. Avvicinamento al Restauro. Teoria, Storia, Monumenti. Napoli: Liguori, 1997. . (Org.). Trattato di restauro architettonico. Torino: Utet, 1996. Architettura e restauro oggi a confronto. Palladio, n.35, pp. 99-128, 2005. . I Trent'anni di una buona Carta del Restauro. Restauro, anno XXIV, n. 131-132, pp. 5760, 1995.

La reintegrazione dell'immagine. Problemi di restauro dei monumenti. Roma: Bulzoni, 1976.

. Equivoci di lessico... Paesaggio Urbano, Anno I, gennaio-febbraio 1990, pp.22-28. 
Brandi e il restauro architettonico oggi. In: ANDALORO, M. (Org.) La teoria del restauro nel novecento da Riegl a Brandi. Firenze: Nardini, 2006.

. Restauro fra conservazione e ripristino: note sui più attuali orientamenti di metodo. Palladio, n.6, 1990, pp. 43-76.

Spunti di riflessione sulla salvaguardia dei centri storici. Restauro, n. 144, pp. 38-45, 1998.

CARBONI, Massimo. Cesare Brandi. Teoria e esperienza dell'arte. Roma: Editori Riuniti, 1992.

CARTA, Mino. Histórias da Mooca. Rio de Janeiro: Berlendis \& Vertecchia, 1982.

Carta de Nizhny Tagil para o Patrimônio Industrial. Nizhny Tagil: TICCIH, 2004.

Carta Italiana del Restauro 1932. Consiglio Superiore per le antichità e belle arti. Norme per il restauro dei monumenti.

Cartas Patrimoniais. Rio de Janeiro: IPHAN, 2000.

Carta 1987 della Conservazione e del Restauro degli oggetti d'Arte e di Cultura. Arte Documento Rivista di Storia e Tutela dei Beni Culturali, 1988, n. 1, pp.91-106.

CARVALHO, Maria Cristina Wolff. Ramos de Azevedo. São Paulo: Edusp, 1996.

CASIELLO, Stella (Org.). La cultura del Restauro, teorie e fondatori. Venezia: Marsilio, 1996.

CATTANEO, Carlo. Scritti storici e geografici. Firenze: F. Le Monnier, 1957

Sulla piazza del Duomo di Milano. In: Scritti su Milano e la Lombardia. Milano: Rizzoli, 1990.

CAVALCANTI, Lauro (Org.). Modernistas na repartição. Rio de Janeiro: UFRJ/Minc/IPHAN, 2000.

CECCARONI, Marco. Genova 1992: La scoperta del Porto Vecchio. Spazio \& Società, anno XV, n.58, 1992.

CEDERNA, Antonio; MANIERI ELIA, Mario. Orientamenti critici sulla salvaguardia dei centri storici. Urbanistica, n. 32, 1960, pp. 69-71.

CERDÁ, Ildefonso. La théorie générale de l'urbanisation [1867]. Paris: Editions du Seuil, 1979.

CERRI, Maria Grazia e BERTOLOZZI, Carla (Org.). Il Restauro Architettonico per le Grandi Fabbriche. Torino, 1989.

CERVELLATI, Pier Luigi. L'Arte di curare la città. Bologna: Mulino, 2000.

. Nessun'alternativa alla conservazione integrata. Italia Nostra, anno XXV, n. 206, 1981, pp. 17-20.

CESARI, Carlo. Considerazioni sul problema della conservazione integrata. Roma: ICCROM, 1984.

. Housing problems and historic centres. Roma: ICCROM, s.d.

Ipotesi di strumentazione progettuale per gli interventi di conservazione di sistemi urbani storici. Roma: ICCROM, 1982.

CESCHI, Carlo. Teoria e Storia del Restauro. Roma: Bulzoni, 1970.

CHIRICI, Cesare. Il problema del restauro. Milano: Ceschina, 1971.

CHOAY, Françoise. Introduction. In: GIOVANNONI, Gustavo. L'urbanisme face aux villes anciennes. Paris: Éditions du Seuil, 1998.

CHOAY, Françoise. A Alegoria do Patrimônio. Trad. Luciano Vieira Machado. São Paulo: Estação Liberdade, Unesp, 2001. L'orizzonte del posturbano. Roma: Officina, 1982. 
O Urbanismo: utopias e realidades, uma antologia. Trad. Dafne N. Rodrigues. São Paulo: Perspectiva, 2003.

. Pour une antropologie de l'espace. Paris: Éditions du Seuil, 2006.

COLLINS, George R. Camillo Sitte and the birth of modern city planning. New York: Random House, [1965].

COLQUHOUN, Alan. Thoughts on Riegl. Oppositions, 1982, n. 25, pp. 79-83.

Compendio delle norme tecniche di attuazione del PRG vigente: aggiornate al 31.03.2005. Roma: Comune di Roma, 2005.

Congrès sur le Patrimoine Architectural Européen, Amsterdam, 21-25 octobre 1975. Amsterdam: Conseil d'Europe, 1975.

CONNER, Patrick R. M. Pugin and Ruskin. Journal of the Warburg and Courtauld Institutes, v. 41, 1978, pp. 344-350.

Convention for the Protection of Cultural Property in the Event of Armed Conflict with Regulations for the Execution of the Convention. The Hague, Unesco, 1954.

CORBOZ, André. Esquisse d'une metodologie de la reanimation: batiments anciens et fonctions actuelles. Restauro, n. 36, 1978, pp. 55-73.

CORDARO, Michele. Sull'inutilità di una nuova carta del restauro. Restauro \& Città, n. 11-12, 1989, pp. 97-101.

CORDEIRO, José Manuel Lopes. Sauvagarde, réutilisation ou muséalisation du patrimoine industriel dans le banlieues: le cas de Porto. Patrimoine de l'industrie, n. 1, 1999.

CORLAY, Lysian et LAMBRECHT, Maren. Un exemple dans la Ruhr: l'IBA Emscher Park. Patrimoine Industriel, n.31, pp. 16-18.

COSSONS, N. Cossons. The BP Book of Industrial Archaeology [1975]. London: David \& Charles, 1978

CRISTALLINI, Elisabetta. Ragghianti, Zevi e il dibattito sulla tutela del patrimonio artistico negli anni della ricostruzione. In: ANDALORO, M. (Org.) La teoria del restauro nel novecento da Riegl a Brandi. Firenze: Nardini, 2006.

CROCE, B. A poesia: introdução à crítica e história da poesia e da literatura [1946]. Trad. Flávio Loureiro Chaves. Porto Alegre: Faculdade de Filosofia, 1967.

CUPELLONI, Luciano (Org.). Il Mattatoio di Testaccio a Roma. Roma: Gangemi, 2001.

CURRERI, Massimiliano. Per ridure l'energia grigia. Il riuso di un'ex miniera nell'Emscher Park. Spazio \& Società, anno XXII, n. 91, 2000, pp. 48-53.

CYRINO, Fábio R. Pedro. Ferro e Argila - A História da Implantação e Consolidação da Empresa 'The San Paulo (Brazilian) Railway Company Ltd. através da análise de sua Arquitetura. Dissertação de Mestrado. São Paulo: FAU-USP, 2000.

DANSERO, Egidio; GIAIMO, Carolina; SPAZIANTE, Agata. Se i vuoti si riempiono. Aree industriali dismesse: temi e ricerche. Firenze: Alinea, 2001.

DAUMAS, Maurice. L'archéologie industrielle en France. Paris: Laffont, 1980.

DEAN, Warren. A Industrialização de São Paulo (1880-1945). São Paulo, Rio de Janeiro: Difel, [s.d.].

DE ANGELIS D'OSSAT, Guglielmo. Sul Restauro dei monumenti architettonici. Concetti, operatività, didattica. Roma, Bonsignori, 1995.

DE FUSCO, Renato. Dov'era ma non com'era: il patrimonio architettonico e l'occupazione. Firenze: Alinea, 1999.

Roberto Pane teorico del restauro. In: CASIELLO, S. (Org.). La cultura del Restauro, teorie e fondatori. Venezia: Marsilio, 1996. 
Storia dell'architettura contemporanea. Roma: Laterza, 2000.

DELEUZE, Gilles. Relação das faculdades na crítica do juízo. In: A Filosofia Crítica de Kant. Trad. Germiniano Franco. Lisboa: Edições 70, 1994.

DE ROUX, Emmanuel. Patrimoine industriel. Paris: Scala, 2000.

DEZZI BARDESCHI, Marco. Considerazioni sul futuro del costruito urbano, alla luce delle ultime proposte (e dimenticanze) legislative. Restauro, n. 144, pp. 46-55, 1998.

. Restauro: punto e da capo. Milano: FrancoAngeli, 1991.

Conservare, non restaurare. Hugo, Ruskin, Boito, Dehio e dintorni. Breve storia e suggerimenti per la conservazione in questo nuovo millenio. Restauro, n.164, pp. 69108, 2003.

Dall'archeologia al patrimonio industriale: un passaggio obbligato. 'ANAГKH, n.24, dicembre 1998, pp. 2-3;108.

DI STEFANO, Roberto. Considerazioni sul restauro urbanistico. Restauro, anno XVII, n.98-100, 1988, pp. 161-179.

Verso una nuova economia della conservazione del patrimonio. Restauro, 65-66-67, 1983, pp. 110-117.

- Architettura contemporanea per la conservazione integrata. Restauro, anno XVIII, n.102, 1989, pp. 86-95.

John Ruskin, interprete dell'architettura e del restauro. Napoli: Edizione Scientifiche Italiane, 1983.

DRAGOTTO, Marina e GARGIULO, Carmela (org.). Aree dismesse e città: Esperienze di metodo, effetti di qualità. Milano: Franco Angeli, 2003.

DVOŘÁK, Max. Catechismo per la tutela dei monumenti (1916) [Estratto della Rivista Paragone n.257, Inserto Redazionale]. Italia Nostra, pp. 1-38, Maggio, 1972.

ELIA, Barbara. Strumenti urbanistici e conoscenza dell'edificio: preliminare per il progetto di recupero, un esempio nel quartiere Ostiense. Roma Moderna e Contemporanea, anno VIII, n.1-2, 2000, pp. 331-341.

Pianificazioni ed attuazioni passate e presenti per il quartiere Ostiense. Roma Moderna e Contemporanea, anno XII, n.1-2, 2004, pp.247-252.

EMILIANI, Andrea. Dal museo al territorio, 1967-1974. Bologna: Alfa, 1974.

Fabbriche della conoscenza: Roma Tre nel territorio e nella riqualificazione dell'area Ostiense. Roma: Università degli Studi Roma Tre, 2001.

FIENGO, Giuseppe. Il contributo di Roberto Pane al dibattito sulla tutela ed il restauro dei centri storici. In: FIENGO, G. e GUERRIERO, L. (Org.). Monumenti e ambienti protagonisti del restauro del dopoguerra: atti del seminario nazionale. Napoli: Arte Tip., 2004.

FONSECA, Maria Cecília Londres. O patrimônio em processo: trajetória da política federal de preservação no Brasil. Rio de Janeiro: UFRJ/Minc/IPHAN, 2005.

FORTE, Francesco. Il contributo delle theorie del piano e per il piano alla definizione delle politiche per la conservazione integrata ed il recupero. Restauro, n. 53-54, 1981.

Regional development strategies and the integrated conservation. Restauro, n.65-66-67, 1983, pp.118-155.

FREESTONE, Robert (Org.). Urban Planning in a Changing World: The Twentieth Century Experience. London: Taylor \& Francis, 2000.

GABRIELLI, Bruno. La rinascita di Genova. Urbanistica Dossier INU, anno VIII, n.74, 2005, pp. 33-35. 
GANSER, Karl; KRAU, Ingrid e NOELBEL, Walter A. Una IBA a scala territoriale nella Ruhr. Casabella, anno LIII, n.563, pp. 50-60, dicembre 1989.

GARANO, Stefano (org.). La riqualificazione delle periferie nella città europea: politiche, strumenti, esperienze in Francia, Inghilterra e nella Repubblica Federale Tedesca. Roma: Kappa, 1990.

GAZANEO, J. Verso il Recupero del Patrimonio Archeologico Industriale. In: GENOVESE, R. A. Archeologia Industriale in Campania alla fine del XIX secolo. [S.I]: [s.n], 1983

GAZZOLA, P. L'evoluzione del concetto di restauro prima e dopo la Carta di Venezia. Bollettino del Centro Internazionale di Studi di Architettura Andrea Palladio, 1978, pp. 239-254.

GENOVA: Come utilizzare il porto storico. Italia Nostra, anno XXX, n.241,1986, pp. 15-17.

GENOVESE, Rosa Anna. Architettura e città antiche: conoscenza e valorizzazione. Restauro, anno XIV, n-79, maggio-luglio 1985, pp. 95-99. . Presentazione. Restauro, anno XIV, n.82, novembre-dicembre 1985, pp. 5-12.

GIAMBRUNO, Mariacristina. L'opera di Charles Buls: dall'estetica delle città al restauro dei monumenti. 'Ananke, nuova serie, N. 31, 2001, p. 46-52.

GIANNÌ, Roberto. Il centro storico e le aree ex industriali. Spazio \& Società, anno XVIII, n.69, 1995.

GIANNINI, Alessandro. L'ambiente, l'architettura e Saverio Muratori. Storia Architettura, anno VII, n. 1-2, gennaio-dicembre, 1984, pp. 39-50.

GIOVANNONI, Gustavo. Lo sviluppo storico del Piano Regolatore della città di Roma e il suo significato nella moderna urbanistica. In: XII Congresso Internazionale dell'Abitazione e dei Piani Regolatore. Roma: s.n., 1929, v.1, pp. 5-19.

Vecchie città ed edilizia nuova. Torino: Utet, 1931.

- La restauration des monuments en Italie. In: La Conférence d'Athènes sur la Conservation Artistique et Historique des Monuments (1931). [édition établie par Françoise Choay]. Besançon: Éditions de l'imprimeur, 2002, pp.57-60.

La Conferenza Internazionale di Atene pel Restauro dei Monumenti. Bollettino d'Arte del Ministero dell'Educazione Nazionale, anno X, fasc. IX, 1932, pp. 3-15.

. La urbanistica e la deurbanizzazione. Roma: Società Italiana per il Progresso delle Scienze, 1936.

Il restauro dei monumenti. Roma: Cremonese, s.d. [1939?]

Restauro dei monumenti e urbanistica. Le Arti, 1942, pp. 33-39.

GIRARD, Luigi Fusco. Alcuni aspetti economici della conservazione dei beni culturali immobiliari. Restauro, n. 53-54, 1981, pp. 103-133.

L'utilità dei beni culturali nella città moderna. Restauro, anno XXIV, n. 131-132, 1005, pp. 71-80.

GIRARD, Luigi Fusco e CERRETA, Maria. Il patrimonio culturale: strategie di conservazione integrata e valutazione. Economia della Cultura, anno XI, n.2, 2001, pp. 175-185.

GIULIANI, Aldo. Monumenti, Centri Storici, Ambiente. Milano: Tamburi, 1966.

GONÇALVES, José Reginaldo Santos. A retórica da perda. Rio de Janeiro: UFRJ/MinC/IPHAN, 2002

GOZE, Maurice. La ville patrimoine et l'habitat ancien: le synchrétisme des politiques publiques. In: LAMY, Y. (Org.). L'alchimie du patrimoine. Bordeaux: MSHA, 1996.

GRASSI, Liliana. Momenti e problemi di storia del restauro. In: Restauro architettonico. Milano: Cesare Tamburini, 1961. 
GROHÉ, Tomas. L'exposition internationale d'architecture de L'Emscher Park: un projet ecologique pour la reconversion de la Ruhr. Les Annales de la Recherche Urbaine, n.52, pp. 33-40, 1991-1992.

GUERRA, Abílio (Org.). Rino Levi: arquitetura e cidade. São Paulo: R. Guerra, 2001.

GURRIERI, Francesco. Dal restauro dei monumenti al restauro del territorio. Firenze: Sansoni, 1983.

GURRIERI, Francesco; VAN RIEL, Silvio e SEMPRINI, Mario Paolo. Il restauro del paesaggio: dalla tutela delle bellezze naturali e panoramiche alla governance territoriale / paesaggistica. Firenze: Alinea, Associazione ARSPAT, 2005.

HAUSSMANN, Baron. Mémoires. Paris: Éditions du Seuil, 2000.

HUDSON, Kenneth. Industrial Archaeology: an introduction [1963]. London: Baker, 1966. . World Industrial Archaeology. London: Cambridge University Press, 1979. The Archaeology of Industry. New York: Charles S. Sons, 1976. Handbook for Industrial Archaeologists. London: Baker, 1967.

HUGO, Victor. Guerre aux démolisseurs. In: HUGO, Victor. Notre-Dame de Paris. Paris: Gallimard, 2002, pp. 648-661. . Notre-Dame de Paris [1831]. Paris: Gallimard, 2002.

IACCARINO, Lucio. Ancora il caso Bagnoli: dalla pianificazione urbanistica ai paradossi istituzionali. Urbanistica Informazioni, anno XXXII, n.109, 2005, pp. 84-86.

Il quadrante Ostiense tra Otto e Novecento. Roma moderna e contemporanea (numero monografico), anno XII, n.1-2, genaio-agosto 2004.

Il Monumento per l'uomo. Atti del II Congresso Internazionale del Restauro. Venezia 25-31 maggio 1964. Padova: ICOMOS, Marsilio, 1971.

Industria e città. I luoghi della produzione fra archeologia e recupero. Roma moderna $e$ contemporanea (numero monografico), anno VIII, n.1-2, gennaio-agosto 2000.

INNOCENTI, Raimondo e PALOSCIA, Raffaele (org.). La riqualificazione delle aree metropolitane. Milano: Franco Angeli, 1990.

Istruzioni per il Restauro dei Monumenti, Ministero della Pubblica Istruzione,1938.

JACOBS, Jane. Morte e vida de grandes cidades [1961]. São Paulo: Martins Fontes, 2000.

JOKILEHTO, Jukka. A History of Architectural Conservation [1999]. Oxford: ButterworthHeinemann, 2006.

L'approccio al restauro ed il pluralismo culturale, riflessione nell' ambito internazionale. Restauro, anno XXIV, n. 131-132, pp. 155-165, 1995.

JUDITH, Alfrey; PUTNAM, Tim. The industrial heritage: managing resources and uses. London, New York: Routledge, 1992.

KANIA, Hans. Zollverein XII, Zollverein Colliery and a $13 \mathrm{~km}^{2}$ Neighbouring Area Preserving a Large Scale Area inside the Ruhrgebiet. Patrimoine de l'industrie, n. 1, 1999-2000, pp. 25-30.

KARRER, Francesco; MOSCATO, Mara; RICCI, Manuela e SEGNALINI, Ornella. Il rinnovo urbano, programmi integrati di riqualificazione e di recupero urbano: valutazione $e$ prospettive. Roma: Carocci, 1998.

KÜHL, Beatriz Mugayar. Arquitetura do ferro e arquitetura ferroviária em São Paulo. São Paulo: Ateliê, Fapesp, Secretaria da Cultura,1998.

Preservação da arquitetura industrial em São Paulo: questões teóricas. Relatório Científico. São Paulo: FAUUSP, Fapesp, 2005. 
Quatremère de Quincy e os verbetes Restauração, Restaurar, Restituição e Ruína. Rotunda, n.2, 2003.

. Questões teóricas relativas à preservação da arquitetura industrial. Desígnio Revista de História da Arquitetura e do Urbanismo, n. 1, março 2004, pp. 103-104.

Cesare Brandi e a teoria da restauração. Pós Revista do Programa de Pós Graduação em Arquitetura e Urbanismo da FAUUSP, v.21, 2007, pp. 198-211.

La Conservation des Monuments d'Art e d'Histoire. Paris: Office International des Musées, 1933.

La Conférence d'Athènes sur la Conservation Artistique et Historique des Monuments (1931). [édition établie par Françoise Choay]. Besançon: Éditions de l'imprimeur, 2002.

LANÇA, Antonio. Preservação do patrimônio urbano paulista. Tese de Doutorado. São Paulo: FAUUSP, 2005.

LA REGINA, Francesco. Il Restauro dell'architettura, l'architettura del restauro. Napoli: Liguori, 2004.

William Morris e l'anti-restauration movement. Restauro, n. 13-14, 1974, pp. 77-149.

LAGUNES, Maria Margarita Segarra (org.). Manutenzione e recupero nella città storica: 'L'inserzione del nuovo nel vecchio' a trenta anni da Cesare Brandi. Atti del IV Convegno Nazionale, Roma 4-8 giugno 2001. Roma: Gangemi, 2004.

LAMAS, José M. R. G. Morfologia urbana e desenho da cidade. Porto: FCG / FCT, 2004.

LAUMON, Annete. Tribulations d'une expression en France. In: L'Etude et la Mise en Valeur du Patrimoine Industriel, Confèrence Internationale, Lyon-Grenoble, September 1981. Paris: CNRS, 1985, pp. 109-111.

BERENSON, Bernardo. Come ricostruire la Firenze demolita. Il Ponte, vol.1, n.I, 1945, pp. 33-38.

LANGENBUCH, Juergen Richard. A Estruturação da Grande São Paulo - Estudo de geografia urbana. Rio de Janeiro: IBGE, 1971.

LASCO, Antonio. Roma tra Rinascimento e antichità. In: MARTA, Roberto. Il Rinascimento a Roma fra Leon Battista Alberti e Donato Bramante. Roma: Elio de Rosa, 2004.

LE CORBUSIER. Urbanisme. Paris: Crès, 1923.

LICHFIELD, Nathaniel. Economics in planning for integrated conservation. Restauro, n.65-66-67, 1983, pp. 163-175.

LICHFIELD, Nathaniel; LICHFIELD, Dalia, et al. Verso una $\mathrm{n}$ integrata per la coservazione dei beni culturali in campania. Restauro, n. 53-54, 1981, pp. 11-67.

LIMA, Heitor Ferreira. Evolução Industrial de São Paulo. São Paulo: Martins, 1954.

LOEWEN, Andrea Buchidid. A concepção de cidade em Leon Battista Alberti. Dissertação de Mestrado. São Paulo: FAU Puccamp, 1999.

LUMIA, Chiara. A proposito del restauro e della conservazione. Roma: Gangemi, 2003.

LYNCH, Kevin. A imagem da cidade [1960]. São Paulo: Martins Fontes, 1997.

MAJOR, Kenneth J. Fieldwork in Industrial Archaeology. London: B. T. Batsford, 1975.

MARAMOTTI POLITI, Anna Lucia. La materia del restauro. Milano: Franco Angeli, 1993.

MARCELLONI, Maurizio. Dal recupero edilizio alla riqualificazione urbana. Urbanistica, n. 93, Novembre 1988, pp. 6-20.

Roma: Recenti esperienze di sostituzione. In: DRAGOTTO, Marina e GARGIULO, Carmela (Org.). Aree dismesse e città: esperienze di metodo, effetti di qualità. Milano: FrancoAngeli, 2003.

MARCONI, Paolo. Restauro urbano e restauro architettonico. In: Architettura e urbanistica: uso e trasformazione della città storica. Venezia: Marsilio, 1984, pp. 51-55. 
Il restauro e l'architetto: teoria e pratica in due secoli di dibattito. Venezia: Marsilio, 1993.

MARINO, Bianca Gioia. William Morris: la tutela dei monumenti come problema sociale. Napoli: Edizione Scientifiche Italiane, 1993.

MARTA, Roberto. Il Rinascimento a Roma fra Leon Battista Alberti e Donato Bramante: Analisi delle forme costruttive. Roma: Elio de Rosa, 2004.

MARTINS, Antonio Egydio. São Paulo Antigo (1554 a 1910). São Paulo: Typographia do Diário Official, 1912, v. II.

MATOS, Odilon Nogueira de. Café e Ferrovias. São Paulo, Arquivo do Estado, 1981.

MATTEUCCI, Mario. Il problema della tutela dei monumenti e dell'ambiente artistico considerato sul piano internazionale. In: Attualità urbanistica del monumento e dell'ambiente antico. Milano: Görlich, Centro Studi della Triennale di Milano, 1957, pp. 43-44.

MEC/SPHAN. Restauração e revitalização de núcleos históricos: análise frente a experiência francesa. Brasília: FPM, 1980.

Proteção e Revitalização do Patrimônio Cultural no Brasil: uma Trajetória. Brasília, 1980.

MELIS, Armando. Ancora di urbanistica e vecchi centri. Urbanistica, anno X, n.4-5, luglio-ottobre 1941, pp.23-24.

Memória Urbana: a Grande São Paulo até 1940. São Paulo: Arquivo do Estado, Imprensa Oficial, 2001.

MENESES, Ulpiano Bezerra. Patrimônio, Preservação e História da Energia. In: Anais do $1^{o}$ Seminário Nacional de História e Energia. São Paulo: DPH, 1988, pp. 68-73.

Patrimônio Industrial e Museus: um Campo Problemático. Memória da Eletricidade, Boletim n. 06, São Paulo, 1988.

MEYER, Regina M. Prosperi. Urbanismo à procura do espaço perdido. Revista USP, n. 5, Dossiê Cidades, 1990.

MIARELLI MARIANI, Gaetano. I restauri di Pierre Prunet: un pretesto per parlare di architettura. Palladio, n.27, 2000, pp.65-67.

- Restauro architettonico oggi: alcuni considerazioni. Beni culturali tutela $e$ valorizzazione, anno IV, n.1, 1996, pp. 40-47.

Centro storico. Un nodo ancora da sciogliere. Palladio, anno XXVIII, fasc. 1-4. 1979, pp. 133-142.

Esiste il restauro? Storia Architettura, anno II, n.2, 1975, pp.4-9.

. Qualche pensiero effimero sul restauro dei monumenti architettonici. Storia Architettura, ano XI, n.1-2, 1988, pp. 15-22.

Riflessioni su un vecchio tema: il nuovo nella città storica. Restauro, n.164, 2003, pp. 11-48.

Centri Storici: alcune definizioni [1980]. In: Centri Storici: note sul tema. Roma: Bonsignori

$\mathrm{Su}$ alcune attuali difficoltà del recupero urbano e territoriale. In: Atti del Convegno Nazionale: una normativa e un Centro regionale per il recupero dei centri storici calabresi. Rivista semestrale del Dipartimento Patrimonio Architettonico e Urbanistico: Storia Cultura e Progetto, anno I, n.1. Catanzaro: Rubbetino, 1991.

. Centri Storici: note sul tema. Roma: Bonsignori, 1993.

MINUCCI, Fabio. Le regione industrializzate tra declino e innovazione. Il caso della Ruhr in un contesto europeo. Milano: Franco Angeli, 1996. 
MIRANDA, Rosana Helena. Mooca: Lugar de Fazer Casa. Tese de Doutorado. São Paulo: FAUUSP, 2002.

MONTANDON, Daniel Todtmann e SOUZA, Felipe Francisco de. Land Readjustement $e$ Operações Urbanas Consorciadas. São Paulo: Romano Guerra, 2007.

Monuments et sites d'art et d'histoire et fouilles archeologiques: problemes actuels. Paris: UNESCO, 1950.

MOROZZO, M. Donatella. Tipologia edilizia, tipologia architettonica: Genova, Marsiglia, Firenze, Roma. Genova: Edizioni Culturali Internazionali, 1988.

MORSE, R. Formação Histórica de São Paulo. São Paulo: Difusão Européia do Livro, 1970.

MORRIS, William. The Society for the Protection of Ancient Buildings [1877]. In: Repair, not Restoration. London: The S.P.A.B., 1977.

MURATORE, Giorgio. Il territorio dell'archeologia industriale come luogo del progetto. In: DE RUBERTIS, Roberto; SOLETTI, Adriana (Org.). De vulgari architectura: indagine sui luoghi urbani irrisolti. Roma: Officina, 2000.

MURATORI, Saverio. Studi per una operante storia urbana di Venezia. Venezia: Istituto Poligrafico dello Stato, s.d.

Commento al III tema: metodologia della storia dell'urbanistica. In: Atti del VII Congresso Nazionale di Storia dell'architettura. Palermo 24-30 settembro 1950. Palermo: Comitato presso la Soprintendenza ai Monumenti, 1956, pp. 357-361.

NICODEMI, Giorgio. L'environnement des monuments. In: La Conférence d'Athènes sur la Conservation Artistique et Historique des Monuments (1931) [Èdition établie par Françoise Choay]. Besançon: Éditions de l'imprimeur, 2002.

NATOLI, Marina (Org.). L'archeologia industriale nel Lazio. Storia e recupero. Roma: Palombi, 1999.

NERI, Maria Luisa. Sviluppo produttivo ed espansione urbana. Roma Moderna e Contemporânea, anno VIII, n.1/2, 2000, pp.83-141.

NOBRE, Ana Luiza et al. Coletivo: 36 projetos de arquitetura paulista contemporânea. São Paulo: CosacNaify, 2006.

Norme tecniche di attuazione: delibera di adozione del Consiglio Comunale n.33 del 19/20 marzo 2003. Roma: Comune di Roma, 2003.

ONESTI, Carlo Calzecchi. Urbanistica e Monumenti. Costruzioni Casabella, anno XVI, n.165, 1941, pp. 2-7.

PANE, Andrea. Dal monumento all'ambiente urbano: la teoria del diradamento edilizio. In: CASIELLO, Stella (Org.). La cultura del restauro: teorie e fondatori. Venezia: Marsilio, 1996, pp. 293-314.

PANE, Roberto. Attualità dell'ambiente antico. Firenze: La Nuova Italia, 1967.

. Attualità e dialettica del restauro [antologia a cura di Mauro Civita]. Chieti: Marino Solfanelli, 1987.

Restauro dei monumenti e conservazione dell'ambiente antico. In: Attualità urbanistica del monumento e dell'ambiente antico. Milano: Görlich, Centro Studi della Triennale di Milano, 1957, pp. 7-18.

Restauro e problemi d'ambiente. In: PEROGALLI, Carlo (org.). Architettura e restauro: esempi di restauro eseguiti nel dopoguerra. Milano: Görlich, 1955.

PANELL, J. P. M. The Techniques of Industrial Archaeology [1966]. London: David \& Charles, 1974.

PAOLI, Célia Maria. São Paulo operária e suas imagens (1900-1940). Espaço \& Debates, n.33, 1991, pp. 27-41. 
PAPINI, Roberto. Quattro domande agli urbanisti. In: Attualità urbanistica del monumento $e$ dell'ambiente antico. Milano: Görlich, Centro Studi della Triennale di Milano, 1957, pp. 99-100.

PARISELLA, Antonio. Il futuro del passato industriale. Roma Moderna e Contemporanea, anno VIII, n.1-2, 2000, pp.37-81.

PENTEADO, Jacob. Belenzinho 1910: retrato de uma época. São Paulo: Carrenho, 2003.

PETRELli, M. Alois Riegl. In: CASIELlO, Stella (Org.). La cultura del Restauro, teorie e fondatori. Venezia: Marsilio, 1996.

PETRONE, Pasquale. As indústrias paulistanas e os fatores de sua expansão. Boletim Paulista de Geografia, 1953, pp. 26-37.

PEVSNER, Nikolaus. Os Pioneiros do Desenho Moderno. São Paulo: Martins Fontes, 1980

PHILIPPOT, Paul. Saggi sul restauro e dintorni: antologia. Roma: Bonsignori, 1998.

Piano Esecutivo Urbanistico di Coroglio-Bagnoli (PUE). Napoli: Comune di Napoli, 2000-2003.

Piazza del Duomo di Milano. Storia, problemi, progetti, Milano: Mazzotta 1982.

PICA, Agnoldomenico. Attualitá del restauro. I monumenti antichi sul tavolo dell'urbanista. Costruzioni, anno XVI, n. 182, 1943, pp.3-10.

Difficile convivenze. In: Attualità urbanistica del monumento e dell'ambiente antico. Milano: Görlich, Centro Studi della Triennale di Milano, 1957, pp. 30-34.

PICCINATO, Giorgio. All cities are historic (but some more so than others). In: Managing historic cities. Krakòw: International Cultural Centre Krakòw, 1993, pp. 49-53.

. La costruzione dell'urbanistica: Germania 1871-1914. Roma: Officina, 1974.

PICCINATO, Luigi. Sistemazione delle città a carattere storico per adattarle alle esigenze della vita moderna. In: XII Congresso Internazionale dell'Abitazione e dei Piani Regolatore. Roma: s.n., 1929, v.1, pp. 343-355.

PIGAFETTA, Giorgio. Saverio Muratori architetto: teoria e progetti. Venezia: Marsilio, 1990.

PINHEIRO, M. L. B. William Morris e a SPAB. Rotunda, n.3, out. 2004, pp. 22-35.

PINON, Pierre. Atlas de Paris Haussmannien. Paris: Parigramme, 2002.

PINTO, Alfredo Moreira. A cidade de São Paulo em 1900. São Paulo: Governo do Estado, 1979.

POLEGGI, Ennio. Waterfront o riva? Progetti per il porto antico. In: ROCCA, Alessandro e SAMBONET, Guia (Org.). La città dipinta: Genova '92. Milano: Electa, 1991.

Preservación de la Arquitectura Industrial en Iberoamérica y España. S.l.: Instituto Andaluz del Patrimonio Histórico, 2001.

PUTZU, M. Giovanna. Progetto archeologico, progetto architettonico. Arkos, 2003, n. 1, pp. 18-25.

QUARONI, Ludovico. Per difendere il patrimonio artistico antico non possiamo aspettare... L'Architettura Cronache e Storia, n.22, agosto 1957.

QUARONI, Ludovico; DELLI SANTI, Gianfilippo; ROGERS, N. Ernesto. La difesa e il rinnovamento del paesaggio urbano e rurale. L'Architettura Cronache e Storia, anno III, n.22, agosto 1957, pp. 255-259.

RACHELI, Alberto M. Antico e moderno nei centri storici: restauro urbano e architettura. Roma: Gangemi, 2003.

Conservare innovando o progettare distruggendo? Roma Moderna e Contemporânea, anno VIII, n.1/2, 2000, pp. 13-36.

Il quartiere Ostiense-Marconi nel nuovo Piano Regolare. Roma Moderna $e$ Contemporânea, anno XII, n.1/2, 2004, pp.256-160. 
RAGGHIANTI, Carlo Ludovico. Nota sull'urbanistica. Costruzioni Casabella, anno XVI, n.166, 1941, pp. 2-5.

RAISTRICK, A. Industrial Archaeology: an Historic Survey. Frogmore: St. Albans, Paladin, 1973

RANELLUCCI, Sandro. Restauro Urbano: teoria e prassi. Torino: UTET, 2003.

. Le teorie del restauro urbano e la musealizzazione dei centri storici. Opus: Quaderno di Storia dell'Architettura e Restauro, n.3, 1993, pp. 229-272.

REA, Ermano. La dismissione. Milano: BUR, 2002.

REALE, Ebe. Brás, Pinheiros, Jardins: três bairros, três mundos. São Paulo: Pioneira, Edusp, 1982.

RÉAU, Louis (org). L’oeuvre du Baron Haussmann, Préfet de la Seine (1853-1870). Paris: PUF, 1954.

REIS FILHO, Nestor Goulart. São Paulo e outras cidades: produção Social e degradação dos espaços urbanos. São Paulo: Hucitec, 1994. Quadro da Arquitetura no Brasil. São Paulo: Perspectiva, 1970.

Restauro. La legge 457/78 ed i centri storici. Napoli: Edizione Scientifiche Italiane, anno VIII, n. $41,1979$.

Restauro. Patrimonio architettonico industriale. Roma: Arte, anno VII, n. 38-39, 1978.

Revista Habitat, n. 6 (1952), 9, 10, 11 (1953), 19 (1954).

Revista Projeto Design, n.237 e 238, 1999.

RIEGER, Bernd; LEITE, Carlos e DELLA MANNA, Eduardo. Diagonal Sul Strategic Proposal. In: Urban Age South American Conference. São Paulo, 3-5 dec. 2008.

RIEGL, Aloïs. Le culte moderne des monuments, son essence et sa genèse [1903]. Trad. Daniel Wieczorek. Paris: Seuil, 1984

ROCCHI, Giuseppe. Camillo Boito e le prime proposte normative del restauro. Restauro, 1974, n.15.

ROGERS, E. N. Il problema del costruire nelle preesistenze ambientali non riguarda soltanto $\mathrm{i}$ valori emergenti monumentali ma implica la responsabilità di tutti gli interventi architettonici. L'Architettura Cronache e Storia, n.22, agosto 1957, pp.255-256.

Roma: L'architettura del lavoro. Ipotesi di recupero funzionale del patrimonio edilizio non residenziale. Roma: CRESME, Mediocredito del Lazio, 1987.

ROMEO, Ippolita. La centrale termoelettrica Montemartini. Patrimoine de l'industrie, n. 6, 2001, pp. 89-98.

RONCAYOLLO, Marcel; PAQUOT, Thierry. Villes \& Civilisation Urbaine, XVIIIe-XXe siècle. Paris: Larousse, 1992.

ROSSI, Fabio. Il futuro di Roma nel segno dei grandi architetti. Il Messaggero. Roma, 03 ago. 2005.

ROUX, Emmanuel de. Patrimoine Industriel. Paris: Scala, 2000.

RUFINONI, M. Preservação do patrimônio industrial na cidade de São Paulo: o bairro da Mooca. Dissertação de Mestrado. São Paulo: FAUUSP, 2004

Patrimônio industrial ameaçado: o Cotonifício Rodolfo Crespi. Arqueologia Industrial, v.1, n.1-2, 2005, pp.73-88.

Traços modernos: o resgate de uma obra de Victor Dubugras. In: Anais do III Seminário Docomomo Estado de São Paulo: Permanência e Transitoriedade do Modernismo Paulista. São Paulo: Univ. Mackenzie, 2005. 
RUSKIN, John. Le sette lampade dell'architettura [1849]. [Traduzione Renzo Massimo Pivetti]. Milano: Jaca Book, 1993, 3.ed.

The seven lamps of architecture [1849]. New York: Wiley, 1865.

Economia politica dell'arte. Trad. Lucio Angelini. Torino: Bollati Boringhieri, 1991.

Lectures on Art [1870]. London: G. Allen, 1890.

The study of architecture. Boston: D. Estes, [1890?].

RUSSO, Michelangelo. Aree dismesse: forma e risorsa della 'città esistente'. Napoli: Edizioni Scientifiche Italiane, 1998.

Napoli: scenari futuri. La difficile condivisione. Il Giornale dell'Architettura, n.47, gennaio 2007

SAES, Flávio Azevedo Marques. As Ferrovias de São Paulo 1870-1940. São Paulo: Hucitec, 1981.

SAINT-HILAIRE, Auguste de. Viagem à província de São Paulo. São Paulo: Edusp, Itatiaia, 1976.

SALES, Pedro M. R. Operações Urbanas em São Paulo: crítica, plano e projetos. Parte 5: Operação Urbana Digonal Sul. Arquitextos Vitruvius, n.315, junho 2005.

SALGUEIRO, Heliana Angotti (Org.). Cidades capitais do século XIX. São Paulo: Edusp, 2001.

SALMONI, Anita e Debenedetti, Emma. Arquitetura Italiana em São Paulo. São Paulo: Perspectiva, 1981.

SAMPAIO, Maria Ruth Amaral. O papel da iniciativa privada na formação da periferia paulistana. Revista Espaço \& Debates, n.37, 1994, pp. 19-33.

SANT'ANNA, Marcia. Da cidade-monumento à cidade-documento: a trajetória da norma de preservação de áreas urbanas no Brasil (1927-1990). Dissertação de Mestrado. Salvador: UFBA, 1995.

SANT’ANNA, Nuto. São Paulo histórico: aspectos, lendas e costumes. São Paulo: Departamento de Cultura, 1944.

SANTORO, Lucio. Restauro dei monumenti e tutela ambientale dei centri antichi. Cava dei Tirreni: Di Mauro, 1970.

SCARROCCHIA, Sandro. Alois Riegl: teoria e prassi della conservazione dei monumenti. Bologna: Accademia Clementina di Bologna, 1995

La ricezione della teoria della conservazione di Riegl fino all'apparizione della teoria di Brandi. In: ANDALORO, Maria (Org.). La teoria del restauro nel novecento da Riegl a Brandi. Firenze: Nardini, 2006.

SCOGNAMIGLIO, Marina. Due interventi di trasformazione nella Ruhr. L'Industria delle Costruzioni, anno XXXVII, n.373, settembre-ottobre 2003, pp. 62-69.

SETTE, Maria Piera. Profilo Storico. In: CARBONARA, Giovanni (org.). Trattato di Restauro Architettonico (4 vols). Torino: Utet, 1996, vol 1. pp. 111-299.

. (Org.). Gustavo Giovannoni: riflessioni agli albori del XXI secolo. Giornata di Studio dedicata a Gaetano Miarelli Mariani (1928-2002). Roma: Bonsignori, 2005.

SIMÕES Jr., José Geraldo. A urbanística germânica (1870-1914): Internacionalização de uma prática e referência para o urbanismo brasileiro. Arquitextos Vitruvius, n. 097.03, 2008

SITTE, Camillo. A construção das cidades segundo seus princípios artísticos [1889]. Trad. Ricardo Ferreira Henrique. São Paulo: Ática, 1992

SMETS, Marcel. Charles Buls et l'amorce d'une nouvelle politique urbaine a la fin du $19^{\mathrm{eme}}$ siècle . In: SPAGNESI, Gianfranco (Org.). L'Architettura delle Trasformazioni Urbane 18901940, Atti del XXIV Congresso di Storia dell'Architettura, Roma 10-12 gennaio 1991. Roma: Centro di Studi per la Storia dell'Architettura, 1992. 
Charles Buls: I principi dell'arte urbana (edizione italiana a cura di Cristina Bianchetti). Roma: Officina, 1999.

SOUCY, Claude. La tutela delle città storiche in Francia: un bilancio della legge Malraux. Restauro, anno XVIII, n.102, marzo-aprile 1989, pp. 5-47.

SPAZIANTE, Agata; CIOCCHETTI, Angelica. La riconversione delle aree dismesse: la valutazione, i risultati. Milano: Franco Angeli, 2006.

STANGHERLIN, Bernardino. L'ex area industriale di Bagnoli: la bonifica degli impianti dismessi e il piano di risanamento ambientale. Recuperare l'edilizia, anno 3, n.13, 2000, pp. 2229.

STAZIO, Attilio. Taranto: faire revivre un patrimoine negligé. In: Patrimoine architectural: un atout pour réussir la ville. Conférence internationale, Halifax (Royaume-Uni), 24-27 octobre 1988. Strasbourg: Conseil d'Europe, 1989.

STORELLI, Grazia. Museo in doppia esposizione, l'ex-centrale elettrica Montemartini. Recupero e Conservazione, n. 38, pp. 55-66, 2001.

STRATTON, Michael (org.). Industrial buildings. Conservation and regeneration. London: Spon, 2000.

STÜBBEN, Joseph. Der Städtebau (Handbuch Der Architektur). Darmstadt: Bergsträsser, 1890.

TERRANOVA, Antonino. L'alternativa c'è ed è progettuale. Italia Nostra, anno XXVII, n.220, marzo-aprile 1983, pp.58-63.

TERRANOVA, Antonino e FALINI, Paola. Strumenti urbanistici e normative per i centri storici: le tendenze emergenti. Restauro \& Città, n. 11-12, 1989, pp. 140-153.

TOLEDO, Benedito Lima de. São Paulo: três cidades em um século. São Paulo: Duas Cidades, 1983.

. Prestes Maia e as origens do urbanismo moderno em São Paulo. São Paulo: Empresa das Artes, 1996.

TORSELLO, B. Paolo. La materia del restauro. Venezia: Marsilio, 1988.

Figure di pietra: l'architettura e il restauro. Venezia: Marsilio, 2006.

TORRES, Maria Celestina T. Mendes. O Bairro do Brás. São Paulo: PMSP, Secretaria da Educação e Cultura, 1981.

TRAVAGLINI, Carlo M. Archeologia industriale e paesaggi urbani. Città e Storia, n. I-2, 2006, pp. 614-619.

VARAGNOLI, Claudio. Un restauro a parte? Palladio Rivista di Storia dell'Architettura e Restauro, n.22, luglio-dicembre 1998, pp. 111-115.

VIDLER, Anthony. The 'Art' of History. Monumental Aesthetics from Winckelmann to Quatremère de Quincy. Oppositions, 1982, n. 25 p. 53-67.

VIOLLET-LE-DUC, Eugène Emmanuel. Restauração. Trad. Beatriz Mugayar Kühl. São Paulo: Ateliê, 2000.

. Entretiens sur l'Architecture [1863-1872]. Bruxelles, Liège: P. Mardaga, 1986.

Dictionnaire Raisonné de l'Architecture Française du XI au XVI Siècle [1854-1868]. Paris: Librairies-Imprimeries Réunies, s.d.

VITOR, Manuel. São Paulo de Antigamente. São Paulo: Secretaria da Cultura e Tecnologia de São Paulo, 1976.

WARREN, David. British policies for integrated urban conservation. Restauro, n.65-66-67, 1983, pp. 273-286.

WIECZOREK, Daniel. Camillo Sitte et les débuts de l'urbanisme moderne. Bruxelles: Pierre Mardaga, [1981]. 
XII Congresso Internazionale dell'Abitazione e dei Piani Regolatore. Roma: Federazione Internazionale dell' Abitazione e dei Piani Regolatore, 1929.

XIII International TICCIH Congress, industrial heritage and urban transformation productive territories and industrial landscape. Terni-Roma, 2006.

ZANCHETI, Silvio Mendes (org.). Gestão do Patrimônio Cultural Integrado. Recife: Ed. Universitária da UFPE, 2002.

ZEVI, Bruno. Contro ogni teoria dell'ambientamento. L'Architettura Cronache e Storia, anno XI, n.4, agosto 1965, pp. 212-213.

. Visione prospettica e spazio-temporalità nell'architettura moderna. L'Architettura Cronache e Storia, anno II, n.11, settembre 1956, pp. 322-323.

ZUCCONI, Guido (Org.). Dal capitello alla città. Milano: Jaca Book, 1997.

. (Org.). Camillo Sitte e i suoi interpreti. Milano: FrancoAngeli, 1992.

LEGISLAÇÃo, RElatóRIOS E PUBLICAÇÕES DA AdMINISTRAÇÃo PÚBliCA

BRASIL. Constituição da República Federativa do Brasil de 1988.

. Lei n. 10257, de 10 de julho de 2001. Estatuto da Cidade.

. Decreto-lei n. 25, de 30 de novembro de 1937.

SÃO PAULO (Estado). Decreto n. 13.426 de 16 de março de 1979.

. Decreto n. 48.137 de 07 de outubro de 2003.

CONDEPHAAT. Resoluções: 22/82 e SC 43/92.

. CONDEPHAAT. Inventário dos Bens Tombados pelo Governo do Estado: Relatório de Gestão. São Paulo, 1980.

SÃO PAULO (Cidade). Lei $n^{\circ} .13430$, de 13 de setembro de 2002. Plano Diretor Estratégico do Município de São Paulo.

. Lei n. 8.328 de 03de dezembro de 1975.

Plano Regional Estratégico da Subprefeitura Mooca - relatório final. São Paulo: SEMPLA, Instituto Polis, 2003, v.1,2.

. Galpões Industriais Significativos. São Paulo: EMURB, [197-?].

. IGEPAC - Inventário Geral do Patrimônio Ambiental, Cultural e Urbano de São Paulo. São Paulo: SMC/DPH, 1987.

Cadastro de Referências Urbanas: Zona Leste. São Paulo: SEMPLA / PMSP, 1985.

. SMC / CONPRESP. Resoluções: 5/91; 38/92; 39/92; 10/95; 09/07; 14/07; 07/08.

. SMC / DPH. Estudo para o tombamento do Patrimônio Industrial na orla ferroviária em torno da Estação da Mooca. [Pesquisa desenvolvida por Ana Clara Giannecchini, Dalva Thomaz e Valdir Arruda]. São Paulo: DPH, 2007.

. Mapa Topográfico do Município de São Paulo - SARA Brasil, 1930. Escala 1:20000.

. Levantamento Aerofotogramétrico, Emplasa, 1981. Escala 1:10000. 


\section{Arquivo Histórico Municipal Washington Luis:}

AZEVEDO, Ramos e SEVERO, Ricardo. Projecto de prolongamento dos Armazéns de Ernesto de Castro \& Co. São Paulo/SP, 1918.

DUBUGRAS, Victor. Construção de dois armazéns. São Paulo/SP, 1916.

Reforma de um armazém. São Paulo/SP, 1918.

\section{Acervo de Projetos de Arquitetura da Biblioteca FAUUSP:}

ARTIGAS, João Batista Vilanova. Edifício Comercial para a Cia. União dos Refinadores, à rua Borges de Figueiredo, 237 com rua Guaratinguetá, Mooca. São Paulo/SP, 1943-44.

AZEVEDO, Francisco de Paula Ramos (1851-1928). Edifício Industrial da Companhia Nacional de Tecidos Sant'Anna da Juta. São Paulo/SP, [1891?].

- Edifício Industrial da Companhia Fazenda Belém-Mooca: Projeto de Aumento da Tipografia e da Nova Garagem à rua Borges de Figueiredo esquina com a rua Monsenhor Felippo. São Paulo/SP, [s.d.].

ESCRITÓRIO Técnico 'Ramos de Azevedo', Severo \& Villares. Fábrica da Tecelagem de Seda Ítalo-Brasileira, à rua Joly, 39. São Paulo/SP, 1936.

Fábrica de Papel de Propriedade das Indústrias R. F. Matarazzo S/A., situada no Belenzinho. São Paulo/SP, 1938.

LEVI, Rino. Armazéns à avenida do Estado de propriedade dos Srs. João Marino e Bruno Mencarini. São Paulo/SP, 1943-1944.

Arno S/A. Indústria e Comércio. Construção de Escritórios e Fábrica à av. do Café. São Paulo/SP, 1950-1953.

Manufatura de Brinquedos Estrela S/A. Projeto de ampliação da fábrica e do depósito. São Paulo/SP, 1949-1958.

Fábrica de Dante Ramenzoni e Cia. Ltda., a rua Lavapés, 192 e 716, esquina com rua Scuvero. São Paulo/SP, 1936.

NEVES, Samuel das. Fábrica de Calçados Clark, à rua da Mooca, 321. São Paulo/SP, 1909. 


\section{Bibliotecas da Universidade de São Paulo - USP}

FAU - Faculdade de Arquitetura e Urbanismo

FFLCH - Faculdade de Filosofia, Letras e Ciências Humanas

POLI - Escola Politécnica

IEB - Instituto de Estudos Brasileiros

MAE - Museu de Arqueologia e Etnologia

\section{Bibliotecas e Acervos da Administração Pública}

SMC / DPH - Secretaria Municipal da Cultura, Departamento do Patrimônio Histórico Arquivo Histórico Municipal Washington Luis - Acervo de Manuscritos

EMURB - Empresa Municipal de Urbanização

SEMPLA - Secretaria Municipal de Planejamento

SMGP - Secretaria Municipal de Gestão Pública - Arquivo Municipal de Processos

CONDEPHAAT - Conselho de Defesa do Patrimônio Histórico, Arqueológico e Turístico do Estado de São Paulo

\section{Bibliotecas da 'Università degli Studi di Roma La Sapienza'}

Faculdade de Arquitetura:

Biblioteca Centrale

Dip. di Storia dell'Architettura, Restauro e Conservazione dei Beni Architettonici DIPTU - Dip. di Pianificazione Territoriale e Urbanistica

ITACA - Dip. Innovazione Tecnologica dell'Architettura e Cultura dell' Ambiente

CAVEA - Dip. di Caratteri dell'Architettura, Valutazione e Ambiente

Faculdade de Engenharia:

Dip. Architettura e Urbanistica per l'Ingegneria

Biblioteca Centrale 'G. Boaga'

\section{Biblioteca da 'Università degli Studi di Genova'}

Faculdade de Arquitetura:

Dip. di Storia e Progetto dell'Architettura, del Territorio e del Paesaggio

Biblioteca do ICCROM, International Centre for the Study of the Preservation and Restoration of Cultural Property 